
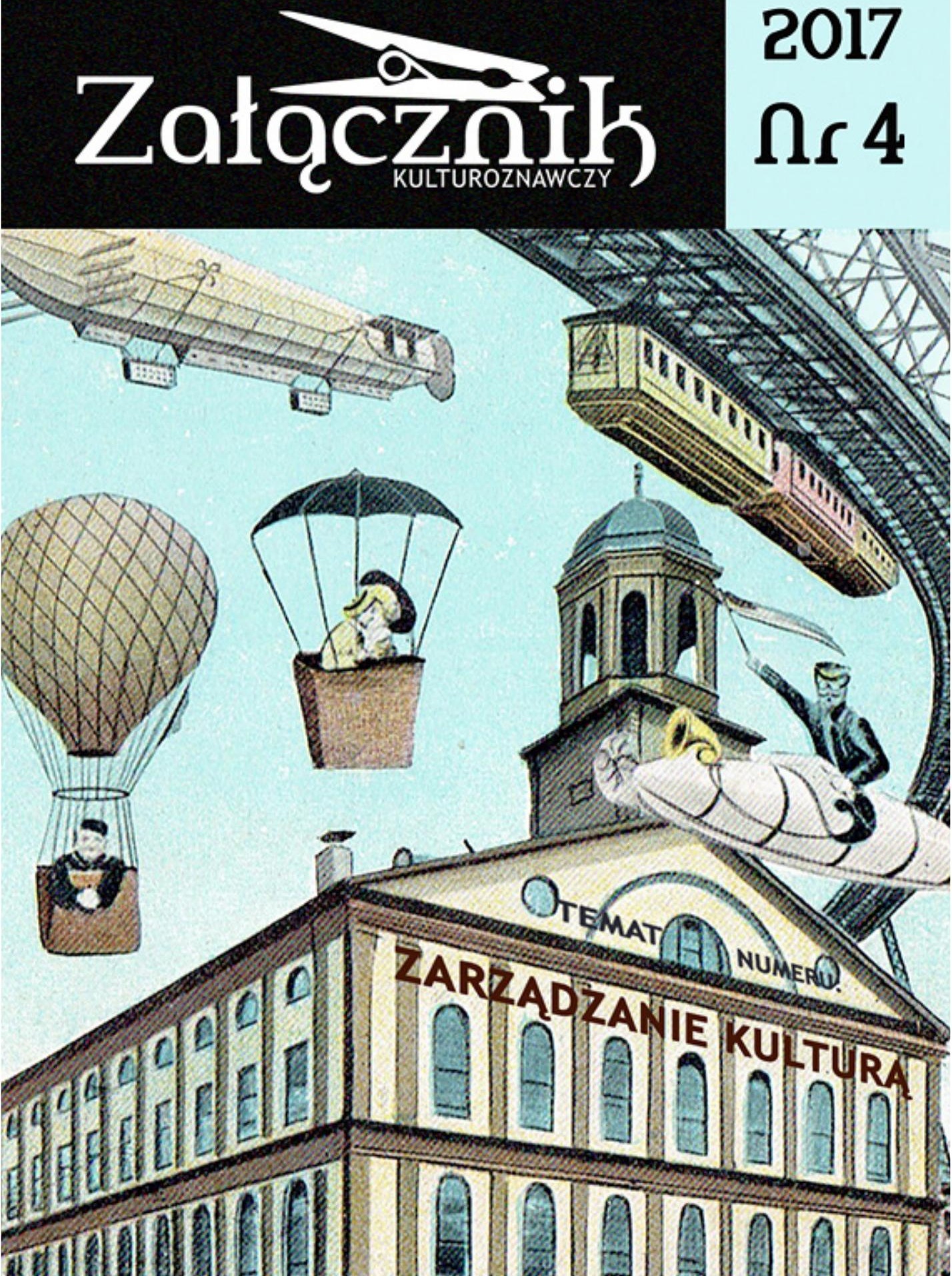
REDAKTOR NACZELNA (EDITOR-IN-CHIEF):

dr hab. Brygida Pawłowska-Jądrzyk, prof. UKSW

ZASTĘPCA REDAKTORA NACZELNEGO

(DEPUTY EDITOR IN-CHIEF):

dr Piotr Jakubowski

SEKRETARZ REDAKCJI

(MANAGING EDITOR):

mgr Dorota Dąbrowska

ASYSTENT SEKRETARZA (ASSISTANT):

mgr Katarzyna Gołos

REDAKTOR JĘZYKOWY

(LINGUISTIC EDITOR):

dr Piotr Jakubowski

KONCEPCJA I REDAKCJA

DZIAŁU TEMATYCZNEGO NUMERU:

(THE IDEA AND SUBSTANTIVE EDITING

OF THE THEMATIC SECTION):

dr Anna Wróblewska, mgr Kama Pawlicka

RADA NAUKOWA (ADVISORY BOARD):

dr hab. Tomasz Chachulski, prof. UKSW

dr hab. Anna Czajka-Cunico, prof. UKSW

dr hab. Dorota Kielak, prof. UKSW

prof. dr Luca Lecis, Università degli Studi di Cagliari

prof. dr hab. Mieczysław Mejor, IBL PAN

dr Alberto Pirni, Scuola Superiore Sant Anna, Pisa

prof. dr Bernd-Juergen Warneken,

Empirische Kulturwissenschaften,

Ludwig-Uhland-Institut, Tübingen

dr hab. Jan Zieliński, prof. UKSW

KOREKTA I WERYFIKACJA PRZEKŁADÓW

(PROOF-READER):

dr Małgorzata Ciunovič

PROJEKT OKŁADKI (COVER DESIGN):

dr Agnieszka Smaga

PROJEKT LOGO (LOGO DESIGN):

mgr Marek Ostrowski

SKŁAD:

Maciej Faliński

Strona internetowa: www.zalacznik.uksw.edu.pl

Email: zalacznikkulturoznawczy@gmail.com
LISTA RECENZENTÓW:

dr hab. Marcin Adamczak, UAM

dr hab. Maciej Aleksandrowicz, prof. ASP

dr hab. Dariusz Brzostek, UMK

prof. Ewa Chruściel, Colby-Sawyer College

prof. dr hab. Teresa Dobrzyńska, IBL PAN

dr hab. Katarzyna Flader-Rzeszowska, UKSW

dr Małgorzata Grzywacz, UAM

dr hab. Elżbieta Janus, prof. UKSW

dr Jakub Jernajczyk, ASP we Wrocławiu

dr hab. Rafał Kasprzak, prof. SGH

dr hab. Krzysztof Koehler, prof. UKSW

dr hab. Jacek Kopciński, prof. UKSW

dr Rafał Koschany, UAM

dr Agnieszka Kramkowska-Dąbrowska, IBL PAN

prof. Raya Kuncheva, IL BAN (Sofia)

prof. dr hab. Arkadiusz Lewicki, UWr

dr hab. Piotr Majewski, prof. UKSW

dr hab. Żaneta Nalewajk-Turecka, UW

dr Anna Pięcińska, US

prof. dr hab. Maria Romanowska, SGGW

dr hab. Agnieszka Sopińska, prof. SGH

dr Paweł Stangret, UKSW

dr hab. Katarzyna Taras, UKSW

prof. Massimo Tria, University of Cagliari

dr Mateusz Werner, UKSW

dr Łukasz Wróblewski, WSB w Dąbrowie Gór-

niczej

dr hab. Małgorzata Wrześniak, prof. UKSW

\section{ISSN 2392-2338}

Redakcja informuje, że wersją pierwotną „Załącznika Kulturoznawczego” jest wersja elektro-

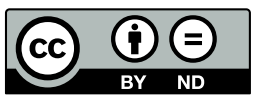
niczna (online).

Zwracamy uwagę, że materiał ilustracyjny publikujemy na prawach cytatu, nie jest on objęty formułą Creative Commons. Uznanie autorstwa-Bez utworów zależnych 3.0 Polska https://creativecommons.org/licenses/by-nc-nd/3.0/pl/ 


\section{SPIS TREŚCI}

Słowo od redakcji

\section{DOCIEKANIA KULTUROLOGICZNE}

Magdalena Danielewiczowa

Do czego konieczny jest jezzyk?

Co jest konieczne $w$ jezzyku?

\section{TEMAT NUMERU: ZARZĄDZANIE KULTURA}

Wokół zarzadzania kultura. Rezultaty badania ankietowego

oprac. Patryk Dziurski, Kama Pawlicka, Anna Wróblewska

Krzysztof Stachowiak

Pośrednicy kulturowi i ich rola w gospodarce kreatywnei

Patryk Dziurski

Strategie (nie)instytucji kultury.

Studium przypadku Zamku Cieszyn

Agnieszka Praga

Zarzadzanie strategiczne muzeum martyrologicznym i miejscem pamięci na przykładzie Państwowego Muzeum Auschwitz-Birkenau w Oświęcimiu

Ewa Frączek-Biłat

Samopublikowanie prac naukowych i literatury pięknej

Małgorzata Oszup-Rawicz

Sztuka kulinarna jako nowy przemyst kreatywny

Łukasz Bańburski

Telewizyjne kanały tematyczne w Polsce w kontekście przemian technologicznych i dominacji nowych mediów 


\section{VARIA}

Monika Kostaszuk-Romanowska

Teatr na wodzie. Wodny żywioł

we współczesnym teatrze polskim

201

Małgorzata Wrześniak

Historia jednego motywu -

rzecz o zwiazkach biżuterii z architektura

Agnieszka Smaga

Comparative Analysis of Media.

The Transformation of Relations between

Script and Image - from Analogue Media

to Interactive Environment

\section{INTERPRETACJE}

Jacek Kopciński

Faust/yna. W promieniach Artura Pałygi

Brygida Pawłowska-Jądrzyk

Between Job and Homo Sovieticus: Sergei Bondarchuk's

Fate of a Man as a Masterpiece of Propaganda Cinema

Jan Zieliński

Romans z zegarmistrzem

\section{FOTOESEJ I OKOLICE}

Weronika Kobylińska-Bunsch

Od konkretu rzeczywistości do pogranicza realności refleksja wokół wczesnych prac Stefana Wojneckiego

Stanisław Baj

Maluje rzeke Bug

Piotr Jakubowski

Etyka przeróbki. Internetowe reanimacje Omrana Daqneesha 
z prof. Teresą Kostkiewiczową rozmawia Magdalena Abramczyk

Żyjemy w świecie rozsypanym

z Grzegorzem Miecugowem rozmawia Łukasz Bańburski

\section{KOMENTARZE. OPINIE. GLOSY}

Agnieszka Wnuk

Humaniści i teoria. Na marginesie książki

Edwarda Kasperskiego Metody i metodologia

Brian R. Banks

Promenade Abroad with Bruno Schulz

\section{ANEKS}

Maciej Woźniak

Muzyka jako środek narracji

w wybranych filmach Michaela Hanekego

401 



\section{Stowo od Redakcji}

Główne pole tematyczne czwartego numeru „Załącznika Kulturoznawczego”, który mamy przyjemność oddać w Państwa ręce, wyznacza stosunkowo młoda (sub)dyscyplina badawcza, jaką jest zarządzanie kulturą. Koncepcja tegorocznego wydania powstała we współpracy z Zakładem Zarządzania Kulturą (Instytut Filologii Klasycznej i Kulturoznawstwa WNH UKSW), reprezentowanym przez dr Annę Wróblewską i mgr Kamę Pawlicką.

Okres transformacji oraz początek XXI wieku przyniosły istotne zmiany w zarządzaniu i funkcjonowaniu przemysłów kultury w Polsce. Zmieniły się realia rynkowe, które przed artystami postawiły zadania związane między innymi z wypracowaniem nowych modeli zarządzania instytucjami kultury - publicznymi bądź prywatnymi, nastawionymi na zysk lub non-profit - ze zdobywaniem funduszy na ich działalność oraz wychodzeniem naprzeciw potrzebom odbiorców-klientów. Dziełami artystów zaczęli zarządzać wyspecjalizowani menadżerowie, których zadaniem pozostaje, mówiąc w dużym skrócie, promocja dóbr kultury.

Niniejsza publikacja stanowi głos w niezwykle potrzebnej dyskusji o wielowymiarowości zarządzania kulturą, a także o nowych zjawiskach i przemianach zachodzących w przemysłach kultury. Warte szczególnej uwagi są $\mathrm{w}$ tym aspekcie wyniki ankiety badawczej przeprowadzonej wśród naukowców i menadżerów kultury, która poświęcona została próbie przyporządkowania zarządzania kulturą - balansującego między naukami ekonomicznymi a humanistycznymi - do aktualnie obowiązującego podziału na obszary nauki i dyscypliny badawcze, a także rozpoznania szans i wyzwań stojących przed ciągle kształtującą się refleksją nad tym obszarem tematycznym.

Poszczególne artykuły zamieszczone w tej części dotyczą najciekawszych $-\mathrm{z}$ badawczego, choć nie tylko, punktu widzenia - trendów w zarządzaniu, takich jak pośrednictwo kulturowe (Krzysztof Stachowiak), self-publishing (Ewa Frączek-Biłat), charakterystyka strategii organizacji sektorów kultury (Patryk Dziurski) oraz zarządzanie strategiczne muzeum martyrologicznym i miejscem pamięci (Agnieszka Praga). W sekcji tej znalazły się także artykuły, które bazują na wybranych pracach dyplomowych studentów specjalizacji Zarządzanie Kulturą prowadzonej na rodzimym kierunku kulturoznawstwo, podejmujące tematy sztuki kulinarnej jako 
przemysłu kreatywnego (Małgorzata Oszup-Rawicz) oraz rozwoju telewizyjnych kanałów tematycznych w Polsce (Łukasz Bańburski). W nawiązaniu do ostatniego z wymienionych artykułów, w dziale Wywiady prezentujemy ponadto rozmowę z Grzegorzem Miecugowem - zmarłym w 2017 roku znanym dziennikarzem i dyrektorem kanału informacyjnego TVN24. To wyjątkowa refleksja na temat rynku telewizyjnego, przemian postaw odbiorców, nowych kanałów komunikacji i dynamicznie zmieniającego się świata współczesnych mediów.

W otwierającym numer dziale Dociekania kulturologiczne zamieszczamy, lingwistycznie ukierunkowany, artykuł Magdaleny Danielewiczowej. Autorka stawia w nim tezę, że między mową ludzką a kodami zwierzęcymi istnieje przepaść, której nie sposób „zasypać” objaśnieniami o charakterze ewolucjonistycznym, i przywołuje argumenty wybitnych uczonych opowiadających się za prymatem języka w stosunku do wszelkich innych systemów semiotycznych, które tworzą przestrzeń kultury.

W sekcji Varia tym razem publikujemy artykuły poświęcone, dość nieoczywistym w danych kontekstach, połączeniom, relacjom czy odwołaniom. Monika Kostaszuk-Romanowska bada sposoby i funkcje wykorzystania zarówno naturalnych, jak i specjalnie na tę okoliczność wytworzonych zbiorników wodnych w spektaklach teatralnych, Małgorzata Wrześniak inspiracje architektoniczne w sztuce jubilerskiej, Agnieszka Smaga zaś związki słowa i obrazu w procesie projektowania graficznego za pomocą narzędzi cyfrowych.

Nowym pomysłem, który zamierzamy kontynuować także w kolejnych numerach czasopisma, jest wprowadzenie działu Interpretacje, dedykowanego odczytaniom wybranych utworów literackich, filmowych, teatralnych etc. W tym numerze zachęcamy do lektury intrygujących przykładów close reading, do jakich niewątpliwie zaliczyć należy artykuł Jacka Kopcińskiego poświęcony monodramowi Artura Pałygi W promieniach, a także anglojęzyczną rozprawę Brygidy Pawłowskiej-Jądrzyk, w której autorka omawia transsemiotyczne gry znaczeniowe czyniące z Losu człowieka Siergieja Bondarczuka arcydzieło kina propagandowego.

Tradycyjnie już publikujemy również fotoeseje, konsekwentnie próbując odpowiedzieć na pytanie o możliwość ukonstytuowania się tego gatunku jako pełnoprawnej formy wypowiedzi o charakterze naukowym. (Powyższa idea była $z$ inicjatywy Redakcji szerzej rozpatrywana w wydanej w serii 
Biblioteka „Załącznika Kulturoznawczego” książce Fotoesej - testowanie granic gatunk $u^{1}$ ). Dominantą dwóch pierwszych zamieszczonych „foto-tekstów" jest ich artystyczne ukierunkowanie: Weronika Kobylińska-Bunch osadza spuściznę fotograficzną Stefana Wojneckiego na tle tradycji awangardowych, dowodząc, że wybitny poznański artysta twórczo reinterpretował w swych wczesnych dziełach pluralistyczny język obrazowania, a ponadto tworzył unikatową dla medium fotografii ikonografię cierpienia. Natomiast Stanisław Baj opowiada - w rejestrze na poły technicznym, na poły medytacyjnym - o zmaganiach twórczych artysty $\mathrm{z}$ odzwierciedleniem na płótnie estetycznego fenomenu płynącej rzeki. Część tę kończy kontynuacja opublikowanego w zeszłym numerze „Załącznika...” fotoeseju Piotra Jakubowskiego - tym razem autor przeprowadza krytyczną analizę przeróbek kolejnego „ikonicznego" obrazu ukazującego cierpienia ofiar konfliktów zbrojnych na Bliskim Wschodzie, a mianowicie fotografii przedstawiającej Omrana Daqneesha, osadzając swą refleksję w kontekście etycznej odpowiedzialności twórców.

W dziale Wywiady oprócz wspomnianej już rozmowy z Grzegorzem Miecugowem publikujemy „wywołaną opowieść” zasłużonej polskiej literaturoznawczyni Profesor Teresy Kostkiewiczowej, dotyczącą Jej kolei życia i drogi naukowej, a zwieńczoną refleksją nad aktualną kondycją humanistyki.

Sekcję Komentarze. Opinie. Glosy otwierają uwagi Agnieszki Wnuk zainspirowane książką Edwarda Kasperskiego Metody i metodologia, następnie zaś zamieszczamy artykuł brytyjskiego krytyka literackiego Briana R. Banksa dotyczący zagranicznej recepcji twórczości Brunona Schulza oraz licznych kontrowersji, których źródłem są biografie pisarza.

W Aneksie tradycyjnie publikujemy wybraną pracę dyplomową - tym razem autorstwa nie tylko absolwenta kulturoznawstwa UKSW, ale też poety i felietonisty Macieja Woźniaka, poświęconą wykorzystaniu muzyki w wybranych filmach Michaela Hanekego.

${ }^{1}$ Fotoesej - testowanie granic gatunku, red. B. Pawłowska-Jądrzyk, M. Jewdokimow, Warszawa 2016. 
Tegoroczny numer czasopisma powstawał $\mathrm{w}$ atmosferze niepewności i niepokoju związanego $\mathrm{z}$ informacjami o planach wykreślenia kulturoznawstwa z listy dyscyplin naukowych w ramach nowej ustawy o szkolnictwie wyższym. Redakcja „Załącznika Kulturoznawczego” pragnie wspierać wysiłek badaczy, którego zwieńczeniem, a zarazem otwarciem drogi do prowadzenia instytucjonalnie ugruntowanych badań, było powołanie Polskiego Towarzystwa Kulturoznawczego (2001), utworzenie Komitetu Nauk o Kulturze PAN (2003), a wreszcie uzyskanie w tym samym roku odrębności dyscyplinarnej. Mamy nadzieję, że kulturoznawstwo przetrwa doraźne reorganizacje instytucjonalnego pola produkcji wiedzy, zachowując swoją rozpoznawalną „tożsamość w różnorodności”, której przykładem w mikroskali może być chociażby kształt niniejszego numeru „Załącznika Kulturoznawczego".

Redakcja 
ZalǫcZnIil

Uznanie autorstwa-Użycie niekomercyjne-Bez utworów zależnych

\section{DO CZEGO KONIECZNY JEST JĘZYK? CO JEST KONIECZNE W JĘZYKU?}

MAGDALENA DANIELEWICZOWA

Wydział Neofilologii, Uniwersytet Warszawski

Faculty of Modern Languages, University of Warsaw

m.m.danielewicz@uw.edu.pl

W artykule tym chciałabym zarysować odpowiedzi na dwa tytułowe pytania, które pozostają ze sobą w bezpośrednim i ścisłym związku. Zacznę od zajęcia stanowiska w sprawie relacji między językiem naturalnym a kodami zwierzęcymi z jednej strony i innymi zjawiskami zaliczanymi do sfery kultury - z drugiej, by następnie przejść do wskazania i krótkiego omówienia tych własności języka, które decydują o jego istocie, są konstytutywne i niezbywalne, które właśnie sprawiają, że, po pierwsze, różne zestawy sygnałów, jakie wysyłają do siebie w obrębie określonych gatunków zwierzęta, oddziela od ludzkiej mowy nie zaledwie płynna granica, ale prawdziwa przepaść, po drugie natomiast - język jest wśród innych systemów znakowych instytucją szczególną i wyróżnioną.

\section{WŁADZA JEZZYKOWA JAKO ZJAWISKO SWOIŚCIE LUDZKIE}

Już na samym wstępie odrzucam dominujące we współczesnej antropologii, neurobiologii czy prymatologii stanowisko, jakoby języki, jakimi posługują się obecnie różne społeczności ludzkie, były produktem ewolucyjnego przekształcenia i rozwoju bądź to rozmaitych pohukiwań (w teoriach wokalnych), bądź to ekspresywnych gestów (w teoriach gesturalnych) wyżej zorganizowanych małp, w szczególności szympansów i orangutanów, których kod genetyczny, jak twierdzą specjaliści, w ponad dziewięćdziesięciu procentach jest zgodny z kodem ludzkim ${ }^{1}$. Tym samych kwestionuję również istnienie

${ }^{1}$ Na temat różnych ewolucyjnych teorii dotyczących glottogenezy zob. na przykład: R. Leakey, Pochodzenie człowieka, tłum. Z. Skrok, Warszawa 1995, s. 63-189; 
w dziejach istot mówiących protojęzyka, którego miałyby używać od 4 do 1,5 miliona lat temu austrolopiteki lub znacznie później (ewolucjoniści nie są co do tych datowań zgodni), bo dopiero w okresie paleolitu - to znaczy około 35 tysięcy lat temu - hominidzi, a który miałby być ogniwem łączącym zwierzęce sygnały i język ludzki. Rozmaite opisy takiego protojęzyka, głoszące na przykład, że pierwotnie składał się on wyłącznie z nazw indywiduów i zdarzeń, ale nie zawierał określeń relacji ${ }^{2}$, albo też ustanawiające kolejność pojawiania się w różnych okresach poszczególnych pojęć, także semantycznie prostych i uniwersalnych ${ }^{3}$, są nienaukowe w tym sensie, że niemożliwe do sfalsyfikowania. Również swoboda w przesuwaniu, bez jakichkolwiek argumentów lingwistycznych, prapoczątków mowy o milion lat do tyłu lub o parędziesiąt tysięcy lat do przodu musi budzić poważne wątpliwości. Nie ma, niestety, bezpośredniego przejścia od obserwacji dotyczących pozostałości materialnych w postaci czaszek, szkieletów, prymitywnych narzędzi i tym podobnych artefaktów, do wniosków na temat zjawiska całkowicie pozbawionego cech fizykalnych, jakim jest język.

Poważny wgląd w strukturę ludzkiej mowy pozwolił językoznawcom XX i XXI wieku opisać jej konieczne, definicyjne własności, a tym samym odkryć rządzące nią mechanizmy. Albo pewien kod jest w ten mechanizm wyposażony, a wtedy automatycznie uznamy go za język taki, jak nasz, albo jest tej maszynerii pozbawiony i żadne ulepszenia w postaci dodawania doń

S. Pinker, Język jest instynktem ludzkim, przeł. J. i M. Jannaszowie, [w:] Trzecia kultura, red. J. Brockman, Warszawa 1996; J. Aitchison, Ziarna mowy. Początki i rozwój języka, tłum. M. Sykurska-Derwojed, Warszawa 2002; P. Żywiczyński, S. Wacewicz, Ewolucja języka. W stronę hipotez gesturalnych, Lublin 2015.

2 Taka teza została zgłoszona w pracy W. Calvina i D. Bickertona, Lingua ex Machina. Reconciling Darwin and Chomsky with the Human Brain, Cambridge 2001.

C. Goddard, A. Wierzbicka, H. Fabréga Jr. w artykule Evolutionary semantics: using NSM to model stages in human cognitive evolution, „Language Sciences” 2013, No. 42, s. 60-79, wyróżniają sześć takich etapów kształtowania się NSM, czyli naturalnego metajęzyka semantycznego. Pierwsze pojęcia, a mianowicie 'ręce', 'nogi', 'głowa', 'twarz', miały rzekomo pojawić się na drugim etapie rozwoju hominidów, około 4-3 milionów lat temu, w związku przyjęciem przez nich postawy wyprostowanej. 
nowych elementów czy nawet całych ich zestawów niczego tu nie zmienią. Przywołajmy w tym miejscu znamienny cytat z Wilhelma Humboldta, który w Über das vergleichende Sprachstudium, 13 uznał mowę za zjawisko bezpośrednio tkwiące w człowieku:

[...] nic nie pomoże, jeśli na jej wynalezienie poświęcimy tysiąclecia i jeszcze tysiąclecia. [...] Aby człowiek naprawdę rozumiał choćby jedno jedyne słowo, nie jako zwykły impuls zmysłowy, lecz jako artykułowany, oznaczający pojęcie dźwięk, musi już mowa tkwić w nim całkowicie: w całym swym uwikłaniu .

Racjonalne stanowisko w sprawie genezy mowy zajmował Ferdynand de Saussure ${ }^{5}$, uważany za ojca współczesnej lingwistyki. Wyznawał on mianowicie paradoksalną zasadę jednoczesnej zmienności i niezmienności języka w czasie oraz zmienności i niezmienności języka w przestrzeni. Uważał, że ten, kto chce się czegoś dowiedzieć o źródłach danego idiomu, powinien badać jego stan współczesny; podkreślał tym samym, że język naszych najodleglejszych nawet przodków nie różnił się niczym zasadniczym od języka, którym różne społeczności ludzkie posługują się obecnie, a to dlatego, że zarówno w czasie, jak i w przestrzeni, o ile nie dojdzie w nim do jakiegoś gwałtownego zaburzenia, zachowuje on ciągłość, choć jednocześnie podlega stałym przekształceniom. Projektowane przez genewskiego uczonego językoznawstwo ogólne miało potwierdzić, iż istota zjawisk językowych:

jest - po pierwsze - wszędzie taka sama, a po drugie, że zawsze była taka sama, tak mianowicie, że błędem jest sądzić, iżby problem pochodzenia języka miał być czymś innym niż ten, który dotyczy jego przekształceń. Byłby to inny problem, gdybyśmy założyli, że w mowie ludzkiej działały kiedyś odmienne siły, których nie możemy sobie wyobrazić na podstawie tego, co się dzieje, kiedy mówimy, również dzisiaj; ale takie założenie jest w tym samym stopniu arbitralne, co nieprawdziwe - zmierza ono do przypisania

${ }^{4}$ Cyt. za: M. Scheler, Pisma $z$ antropologii filozoficznej i teorii wiedzy, tłum. i oprac. S. Czerniak, A. Węgrzecki, Warszawa 1987, s. 3-42 (kursywa oryginalna).

5 F. de Saussure, Szkice zjęzykoznawstwa ogólnego, tłum. M. Danielewiczowa, Warszawa 2004, s. 142-167. 
ludom pierwotnym władz i zmysłów zasadniczo różnych od tych, które my mamy $[\ldots]^{6}$.

Uderzająco podobne do tez de Saussure’a są myśli Johna Lyonsa, brytyjskiego językoznawcy, młodszego od genewczyka o blisko osiemdziesiąt lat, który w punkcie 1.7 (pod znaczącym tytułem Nie ma żadnych prymitywnych języków) swej znanej pracy Language and Linguistics. An Introduction pisze:

Nadal dosyć często słyszy się laików mówiących o prymitywnych językach, a nawet powielających zdyskredytowany mit, jakoby istniały jakieś ludy, których język składa się z paruset wyrazów uzupełnionych gestami. Prawda jest taka, że każdy z dotychczas badanych języków - niezależnie od tego, jak prymitywne bądź niecywilizowane pod innymi względami mogłoby się nam wydawać społeczeństwo, które go używa - po dogłębnej analizie okazał się złożonym i wysoce rozwiniętym systemem komunikacyjnym. Cała hipoteza ewolucji kulturowej od barbarzyństwa do cywilizacji jest sama w sobie mocno wątpliwa. Ale nie do lingwisty należy wypowiadanie opinii na temat jej prawdziwości. Jest on natomiast w stanie stwierdzić, że nie odkryto dotychczas żadnego związku między poszczególnymi etapami rozwoju kulturowego, przez które przeszły społeczeństwa, a typami języka używanego w tych stadiach kulturowego rozwoju. Nie istnieje, na przykład, nic takiego jak typ języka epoki kamienia lub też, biorąc pod uwagę ogólną strukturę gramatyczną, typ języka, który charakteryzowałby społeczeństwa trudniące się zbieractwem czy pasterstwem $\mathrm{z}$ jednej strony i współczesne uprzemysłowione społeczeństwa $\mathrm{z}$ drugiej strony. [...] W ciągu dziewiętnastego wieku lingwiści zaczęli zdawać sobie sprawę z tego, że jakkolwiek daleko wstecz usiłowano prześledzić historię danych języków w tekstach, które dotrwały do naszych czasów, niemożliwe było dostrzeżenie w nich jakichkolwiek śladów ewolucyjnego rozwoju od bardziej prymitywnego do bardziej zaawansowanego stanu?

Na zakończenie tego fragmentu mojego opracowania przywołam jeszcze stanowisko Andrzeja Bogusławskiego i Ewy Drzazgowskiej - autorów

6 Ibidem, s. 155.

7 J. Lyons, Language and Linguistics. An Introduction, Cambridge 1981, s. 27-29. Powyższy cytat podaję w poprawionym przez siebie pod względem redakcyjnym tłumaczeniu, które można znaleźć na stronie internetowej: http://potop-exodus.w.interiowo.pl/babel/lingwisci.html [dostęp: 17.10.16]. 
dwutomowego dzieła poświęconego historii myśli lingwistycznej, którzy fizjologiczne rozważania na temat pochodzenia języka, mieszczące się w nurcie post- lub neodarwinistycznym, określają mianem domysłów mających „charakter niepoważnych anegdot lub źle ukierunkowanych spekulacji” i przyjmują w swej pracy strategię wypracowaną przez Société de Linguistique de Paris. Towarzystwo to w 1866 roku zakazało jakiejkolwiek debaty na temat początków języka, uznawszy te kwestie za niepoważny problem, który przyciąga głównie szaleńców i fantastów.

\section{JEZYYK - WARUNEK KONIECZNY KULTURY}

$\mathrm{W}$ różnych podręcznikach, a od czasu do czasu również w autorskich monografiach mających poważniejszy charakter naukowy, można niekiedy przeczytać, że język jest co prawda swoistym, ale też jednym $\mathrm{z}$ wielu elementów kultury, obok instytucji czy osiągnięć, takich na przykład jak taniec, malarstwo, rzemiosło czy moda. Taki obraz wyłania się w szczególności z rozważań poświęconych rozmaitym typologiom znaków, dla których niemal powszechną praktyką jest traktowanie wyrażeń językowych jako pewnego podtypu dzielonej kategorii, znajdującej się na tym samym poziomie, co oznaki czy indeksy (takie jak trop zwierzęcia na śniegu), ikony (w rodzaju czyjejś karykatury), czy też symbole (jakimi są na przykład biała bądź czerwona flaga wywieszone na plaży) $)^{9}$ W pewnym stopniu za przedstawiony wyżej stan rzeczy odpowiada propagatorska siła ujęcia utrwalonego w Kursie językoznawstwa ogólnego ${ }^{10}$, w którym to dziele semiologia, czyli projektowana nauka o znakach, miała być częścią psychologii ogólnej i zajmować

8 A. Bogusławski, E. Drzazgowska, Język $w$ refleksji teoretycznej. Przekroje historyczne, t. I-II, Warszawa 2016, s. 28.

9 Por. na przykład: B. Bojar, Zarys językoznawstwa dla studentów bibliotekoznawstwa i informacji naukowej, Warszawa 1991, s. 31; I. Bobrowski, Zaproszenie do językoznawstwa, Kraków 1998, s. 43-44; E. Łuczyński, J. Maćkowiak, Językoznawstwo ogólne. Wybrane zagadnienia, Gdańsk 1999, s. 10-12; R. Przybylska, Wstęp do nauki o języku polskim. Podręcznik dla szkół wyższych, Kraków 2003, s. 12-18; R. Grzegorczykowa, Wstęp do językoznawstwa, Warszawa 2007, s. 15-21.

10 F. de Saussure, Kurs językoznawstwa ogólnego, tłum. K. Kasprzyk, Warszawa 2002. 
się, obok języka naturalnego, również innymi systemami znaków ${ }^{11}$. Choć w przywołanym dziele zaznaczone zostało, że nowej dyscyplinie powinna patronować lingwistka, ponieważ języki, jakimi posługują się ludzie, są kodami najpowszechniejszymi i najbardziej złożonymi ${ }^{12}$, w świadomości znacznej części odbiorców Kursu... pozostało przede wszystkim dowartościowanie, na równi z ludzką mową, innych systemów semiotycznych.

Oryginalne pisma F. de Saussure’a nie zostawiają wątpliwości co do tego, że uczony uważał język naturalny za instytucję wśród innych wyróżnioną, o takim mianowicie charakterze, że wszystkie ,inne ludzkie ustanowienia, z wyjątkiem pisma, mogą nas jedynie co do jej prawdziwej istoty mylić, o ile na nasze nieszczęście zaufamy ich analogii”. Dodawał przy tym, że ktokolwiek postawi nogę na gruncie języka, zostanie pozbawiony jakichkolwiek zestawień i porównań „ze zjawiskami niebieskimi i ziemskimi”. Język bowiem to jedyny system semiologiczny, który „musi się zmierzyć z doświadczeniem czasu"13, choćby dlatego, że stanowi przedmiot międzypokoleniowej transmisji.

Claude Lévi-Strauss, badacz - jak wiadomo - zainspirowany myślą de Saussure'a, w wywiadzie z Georges'em Charbonnierem podkreślał, że linię demarkacyjną między naturą a kulturą wyznacza nie tyle obecność narzędzi, na co często zwracają uwagę antropolodzy, ile mowa artykułowana. Język bowiem jest:

[...] najdoskonalszym ze wszystkich przejawów porządku kulturowego i jeśli chcemy zrozumieć, czym jest sztuka, religia, prawo, a może nawet i kuchnia lub zasady uprzejmości, należy je rozumieć jako kody utworzone przez artykulację znaków, według modelu lingwistycznego porozumiewania się ${ }^{14}$.

W podobny sposób na temat stosunku między językiem a innymi kodami kultury wypowiadał się Roman Jakobson, który badaczom różnych systemów porozumiewania się zalecał, by nie zapominali, że:

${ }^{11}$ Ibidem, s. 44.

12 Ibidem, s. 92.

13 F. de Saussure, Szkice..., op. cit., s. 199, 206 i 242.

14 G. Charbonnier, Rozmowy z Claude Lévi-Straussem, tłum. J. Trznadel, Warszawa 2000, s. 141. 
[...] dla całej ludzkości język jest głównym środkiem komunikacji oraz że tę hierarchię chwytów komunikacji z konieczności odbijają wszystkie inne, wtórne typy komunikatów ludzkich. W różny sposób są one zależne od języka, mianowicie od jego wcześniejszego przyswojenia oraz od jawnych i ukrytych językowych wypowiedzi, które towarzyszą wszelkim innym komunikatom lub je interpretują ${ }^{15}$.

Jeszcze bardziej dobitnie, bo w sposób czysto formalny, kwestię relacji między językiem naturalnym a innymi systemami semiotycznymi stawia Andrzej Bogusławski. Autor ten w paru swoich opracowaniach ${ }^{16}$ zaprezentował wywód wykluczający istnienie części wspólnych między tym, co idiomatycznie ludzie nazywają znakami, a wyrażeniami językowymi, które w mowie zwykłych użytkowników znakami nazywane nigdy nie są. Sformułował również tezę, że między znakami (takimi na przykład, jak gwizdek oznaczający odjazd pociągu) a wyrażeniami językowymi zachodzi implikacja jednostronna, w tym sensie, że znak, w potocznym sensie tego słowa, jest ustanawiany na mocy użycia języka, nie odwrotnie. Co więcej, funkcję znaków mogą pełnić również elementy izolowane, takie jak na przykład czarna chorągiew zawieszona na bramie uniwersyteckiej, sygnalizująca pogrzeb jednego z profesorów, podczas gdy wyrażenia językowe swe istnienie zawdzięczają jedynie opozycjom, w jakie wchodzą z innymi jednostkami. W takiej perspektywie uogólnienie, które obejmowałoby wyrażenia językowe i znaki jako klasy stojące obok siebie, jak również redukowanie tych pierwszych do drugich, prowadzi nieuchronnie do regresu nieskończonego. $\mathrm{Z}$ formalnego rozumowania Bogusławskiego jednoznacznie wynika, że warunkiem koniecznym ustanowienia przez człowieka jakiegokolwiek zjawiska czy kodu kulturowego, a także zinterpretowania dowolnego faktu czy stanu rzeczy w kategoriach znaku, czyli uruchomienia dowolnego procesu semiozy, jest wyposażenie w język.

15 R. Jakobson, Język a inne systemy komunikacji, tłum. A. Tanalska, [w:] idem, W poszukiwaniu istoty języka. Wybór pism, t. I, red. M.R. Mayenowa, Warszawa 1989, s. 61.

${ }_{16}$ Zob. na przykład: A. Bogusławski, Język $i$ świat znaków, „Przegląd Humanistyczny" 1988, nr 12, s. 133-168; idem, Słowo i znak, [w:] Znaki czy nie znaki?, red. M. Guławska-Gawkowska, G.M. Zeldowicz, Warszawa, 2013, s. 9-19; A. Bogusławski, E. Drzazgowska, op. cit., t. I, s. 18-20. 
Po tych rozważaniach, mających na celu przypomnienie rzeczywistej, bo podyktowanej względami logicznymi zależności między zdolnością mowy a wszystkimi innymi władzami i osiągnięciami człowieka, przechodzę do omówienia podstawowych własności, które są w języku niezbywalne, a tym samym pozwalają odróżnić tę instytucję nie tylko od kodów zwierzęcych, lecz także od w tórnych w stosunku do niej i na niej ufundowanych systemów semiotycznych, za pomocą których ludzie organizują swą kulturową przestrzeń. Trzeba przy tym odróżnić tak zwane uniwersalia językowe, to znaczy cechy, które występują we wszystkich bez wyjątku ludzkich idiomach ${ }^{17}$, od tych lingwistycznych własności, które są zdeterminowane logicznie. Tylko te drugie będą dalej przedmiotem mojego zainteresowania. Przywołane zbiory nie mają identycznych zakresów. Dla przykładu, wszystkie języki posługują się jako nośnikiem znaczenia dźwiękiem, który nie tylko nie stanowi w procesie komunikacji elementu koniecznego, lecz, co więcej, przy pewnym rozumieniu tego problemu, jest całkowicie obcy naturze języka ${ }^{18}$. Chodzi mianowicie o to, że w języku (langue) - rozumianym jako z natury bezcielesny, będący dobrem wspólnym i systemem opozycji - nie ma miejsca na jednostkowe zjawiska fizykalne. Te mogą być obserwowane jedynie w indywidualnym akcie mowy (parole), będącym przejawem woli mówiącego. Dźwięk jest, co prawda, najwygodniejszym środkiem przekazywania sensów, ale nie należy zapominać, że na przykład osoby niesłyszące z powodzeniem posługują się inną, a mianowicie manualno-przestrzenną formą wyrazu.

\section{PODWÓJNE ROZCZŁONKOWANIE JĘZYKA}

Niezbywalną cechą języka naturalnego jest jego podwójne rozczłonkowanie lub - jak czasami się to określa - podwójna artykulacja (od lac. articulus 'cząstka'). Własność ta, powiązana logicznie z kwestią linearności wyrażeń językowych, sprowadza się do tego, że z potoku mowy można wydobywać jednostki dwojakiego rodzaju: po pierwsze takie, które są bilateralne, $w$ tym sensie, że mają zarówno płaszczyznę wyrażenia, jak i płaszczyznę treści; po drugie takie, które służą do rozróżniania znaczeń, pełnią więc funkcje

${ }_{17}$ Listę takich uniwersaliów podał na przykład Charles Hockett w artykule: Zagadnienie uniwersaliów w języku, tłum. H. Kurkowska, [w:] Językoznawstwo strukturalne, red. A. Weinsberg, H. Kurkowska, Warszawa 1979, s. 209-228.

18 Por. F. de Saussure, Szkice..., op. cit., s. 41-45. 
diakrytyczne, ale same w sobie znaczenia nie mają. Problem podwójnego rozczłonkowania najdobitniej sformułowany został w ważnej wypowiedzi francuskiego strukturalisty André Martineta z 1960 roku $^{19}$.

Produkty pierwszego (przede wszystkim w sensie hierarchii ważności) podziału łączy wspólna cecha znaczącości, a różni to, że mogą one należeć do różnych podsystemów czy też reprezentować różne rangi wyrażeń. Na przykład w wypowiedzeniu: Oto nasza pływalnia wyodrębnić można segment zdaniotwórczy oto, dystrybucyjnie odpowiadający czasownikowi $\mathrm{w}$ formie finitywnej, i grupę imienną nasza pływalnia. Oba te ciągi mają charakter bilateralny. Można również rozpatrywaną całość podzielić od razu na elementy prostsze, to znaczy na formy wyrazowe: oto, nasza, pływalnia, reprezentujące poziom jednostek leksykalnych. Można w końcu, nie odchodząc wciąż od formuły pierwszego rozczłonkowania, wskazać $\mathrm{w}$ analizowanym przykładzie minimalne jednostki znaczące: oto, nasz-, $-a$, pływ-, -alń, - $a$, będące aktualizacjami odpowiednich morfemów ${ }^{20}$ rdzennych (/oto/, /nasz/, /pływ/), słowotwórczych (/alń/) i gramatycznych (/a/). $\mathrm{W}$ drugim rozczłonkowaniu sekwencję rozwijającą się na linii czasu (w wypowiedzi ustnej) lub w przestrzeni (w tekście pisanym) dzielimy na jednostki unilateralne, to znaczy głoski: $o, t, o, n, a, \check{s}, a, p, \ell, y, w, a, l, \grave{n}, a$, stanowiące realizacje określonych fonemów (w tekście pisanym reprezentowane są one przez odpowiednie litery lub połączenia liter).

Podwójna artykulacja wypowiedzi, a co za tym idzie: również języka, zapewnia systemowi kombinatoryczność i, w konsekwencji, ekonomiczność, a jego użytkownikowi pozwala minimalizować wysiłek związany z zapamiętywaniem ogromu znaczeń i opozycji, w jakie znaczenia te wchodzą. Ze stosunkowo niewielkiej liczby cząstek znaczących skonstruowane są w języku naturalnym miliony jednostek leksykalnych; zaledwie parę dziesiątków fonemów tworzy z kolei płaszczyznę wyrażenia wszystkich jego elementów

19 Chodzi o I rozdział książki A. Martineta: Éléments de linguistique générale, Paris 1960, s. 17-22. Zob. polskie wydanie pod tytułem: Podstawy lingwistyki funkcjonalnej, wybór i tłum. L. Zawadowski Warszawa 1970, s. 18-24; lub przedruk: [Podwójne rozczłonkowanie języka], [w:] Semiotyka dziś i wczoraj, red. L. Koj, J. Pelc, Wrocław 1991, s. 342-345.

20 Martinet we wspomnianym wyżej opracowaniu posługuje się w tym miejscu terminem 'monem'. 
dwustronnych. Jakobson w przywoływanym już wcześniej artykule podkreśla, że „bogaty repertuar elementów znaczących (słów i morfemów) jest możliwy dzięki istnieniu ich składników wyłącznie różnicujących (fonemów, cech dystynktywnych), a więc produktów drugiego rozczłonkowania"21.

Taka podwójna struktura, konieczny rys ludzkiej mowy, nie występuje w żadnym innym systemie semiotycznym.

\section{DWUKLASOWOŚĆ JĘZYKA}

Ustanowienie, które pretenduje do miana języka naturalnego, musi ponadto obejmować dwie klasy jednostek, to znaczy, z jednej strony, wyrażenia składające się na jego słownik, $\mathrm{z}$ drugiej zaś - jednostki operacyjne ${ }^{22}$ tworzące jego gramatykę. Takie wyposażenie zapewnia kodowi generatywnośći kreatywność. Dzięki tej cesze mówiącym dana jest możliwość przechodzenia od langue - systemu elementów zmagazynowanych w zbiorowej pamięci danej wspólnoty etnicznej, z której każdy jej uczestnik czerpie - do parole, to znaczy indywidualnych wypowiedzi stanowiących linearne układy elementów wybranych ze słownika i ukształtowanych gramatycznie na mocy jednostkowej decyzji nadawcy. Odwołując się do terminologii de Saussure'owskiej, można by tu również mówić o przechodzeniu od porządków asocjacyjnych (czy paradygmatycznych) do związków o charakterze syntagmatycznym. Jakobson z kolei ująłby to w kategoriach poruszania się między osią wyboru a osią kombinacji.

Dwuklasowość języka sprawia, że nie jesteśmy skazani na to, by posługiwać się gotowymi zdaniami, których klasa musiałaby być zamknięta, choć odpowiednio duża. W praktyce trudno nawet taką sytuację sobie wyobrazić. Omawiana cecha daje użytkownikom języka możliwość posługiwania się ogromną co prawda, ale skończoną liczbą elementów, do tworzenia nieskończonej liczby wypowiedzi, z których każda jest aktem niepowtarzalnym i twórczym, niezależnie od tego, czy chodzi o strofę autorskiego poematu, czy też, dajmy na to, o najzwyklejszą odpowiedź na pytanie.

${ }^{21}$ R. Jakobson, op. cit., s. 73.

${ }^{22} \mathrm{Na}$ temat operacyjnych jednostek języka zob. więcej w: A. Bogusławski, Towards an Operational Grammar, „Studia Semiotyczne” 1978, nr 8, s. 29-90, pol. przekład: Preliminaria gramatyki operacyjnej, tłum. R. Gozdawa-Gołębiowski, „Polonica” 1989, nr 13, s. 163-223. 


\section{PROPORCJONALNOŚĆ}

Odpowiednich jednostek leksykalnych i operacyjnych musi być w języku naturalnym tyle, by gwarantowało to jego proporcjonalność. Mechanizm ludzkiej mowy sprowadza się bowiem do układów proporcjonalnych. Cechę tę na gruncie filozofii i lingwistyki akcentowało od czasów starożytnych wielu autorów ${ }^{23}$. Szczególne miejsce w tym gronie zajmuje de Saussure, który twierdził, że język to nic innego, jak tylko stosunki stosunków, że są w nim wyłącznie opozycje, a więc różnice i tożsamości, że jest on formą, a nie substancją, że ma charakter algebraiczny. Wyrażał przekonanie, że pewnego dnia zostanie rozpoznane, iż wielkości językowe i stosunki między nimi „są w sposób regularny wyrażalne, z samej ich natury, w formułach matematycznych" ${ }^{24}$. Niezależnie od de Saussure’a i w sposób bardziej od niego precyzyjny istotę językowych tożsamości ujmował Ludwig Wittgenstein w Traktacie logiczno-filozoficznym ${ }^{25}$ i w Philosophische Grammatik ${ }^{26}$. W polskim językoznawstwie teoretycznym na tę konstytutywną cechę języka wielokrotnie $z$ wielkim naciskiem zwracał uwagę A. Bogusławski ${ }^{27}$.

Prawda o tym, że w języku wszystko zasadza się na proporcjach, daje o sobie znać w różnych odsłonach na każdym kroku: w historii dowolnego idiomu, w jego codziennym funkcjonowaniu, w rozwoju mowy najmłodszych członków danej wspólnoty. Weźmy dowolny przykład: polskie czytać do czytał ma się tak, jak biegać do biegał, jak chwytać do chwytał czy śpiewać do śpiewał. Między takimi analogicznymi formami istnieją w języku, jak mówił o tym Jerzy Kuryłowicz, distances égales - równe odległości ${ }^{28}$. Nazwy

${ }^{23}$ Obszerne omówienie sposobów traktowania analogii i proporcji w dziejach myśli lingwistycznej oraz filozoficznej znaleźć można w opracowaniu A. Bogusławskiego i E. Drzazgowskiej (op. cit., t. I, s. 356-367).

24 F. de Saussure, Szkice..., op. cit, s. 195.

25 L. Wittgenstein, Tractatus logico-philosophicus, tłum. B. Wolniewicz, Warszawa 2006, tezy: 3.141, 4.03, 4.032.

26 L. Wittgenstein, Philosophische Grammatik, hrsg. von Rush Rhees, Frankfurt am Main 1989, s. 297, 315-318.

27 Zob. przede wszystkim: A. Bogusławski, O proporcjonalności w języku i jej warunkach, [w:] Jęzkoznawstwo diachroniczne i synchroniczne, red. J. Sambor, J. Linde-Usiekniewicz, R. Huszcza, Warszawa 1993, s. 59-76.

28 J. Kuryłowicz, La nature des procčs dits «analogiques», Kraków 1949. 
tadowarka czy niszczarka utworzone zostały zgodnie z regularnym wzorcem istniejącym w polszczyźnie, a mianowicie tematowi odpowiedniego czasownika towarzyszy tu przyrostek -arka, co poświadczają liczne czwórki, szóstki, ósemki itd. proporcjonalne, a więc: spawać : spawarka, wiercić : wiertarka, zamrażać : zamrażarka, suszyć : suszarka, ładować : ładowarka, niszczyć : niszczarka. Upowszechniające się nazwy żeńskie w rodzaju filozofka czy geolożka również powoływane są do istnienia zgodnie z proporcjonalnym modelem, utrwalonym w świadomości mówiących. Wszystkie innowacje, zarówno te mieszczące się w normie, jak i pozanormatywne, mają charakter analogiczny. Polacy używają niepoprawnego bezokolicznika *wziaść, bo noszą w pamięci wyrażenia przasść, siąść czy trząść. Dzieci francuskie, jak pokazywał de Saussure, posługują się w miejsce oczekiwanego je viendrai błędną formą czasu przyszłego je *venirai, urobioną od czasownika venir, dlatego że jest to forma spełniająca narzucającą się proporcję, jedną z tych, które język wdrukowuje w ludzki umysł, a więc w tym wypadku: punir : punirai, partir : partirai, finir : finirai, mentir : mentirai itd. Znana z laciny klasycznej forma honor wyparła dawniejszy nominativus honos, bo znowu zadziałało tu prawo równania: victor $:$ victorem $=$ orator $:$ oratorem $=x$ : honorem, z czego wynika, że na miejsce $x$ powinno wejść wyrażenie honor ${ }^{29}$, nawet jeśli jest to wyrównanie analogiczne, a nie proporcja w ścisłym tego słowa znaczeniu ${ }^{30}$.

Systemowość języka, w podręcznikach akademickich definiowana często w upraszczający i naiwny sposób, nie da się dobrze uchwycić i adekwatnie przybliżyć bez koniecznego powiązania jej z zasadą proporcjonalności. Jak już była o tym wcześniej mowa, nie ma w języku naturalnym elementów izolowanych. Okoliczność ta odróżnia jego jednostki od znaków należących do innych sfer kultury. Proporcjonalność języka wyklucza też jakiekolwiek analogie $z$ sygnałami zwierzęcymi, bo w przeciwnym razie trzeba by przyjąć, że zwierzęta, podobnie jak ludzie, są zdolne do ujmowania świata w kategoriach różnic i tożsamości, a co za tym idzie - również do aktywności tak

${ }^{29}$ Jest to przykład dobrze znany z Kursu językoznawstwa ogólnego (op. cit., s. 189).

30 Słowa orator i victor mają jednak inne niż honor zakończenia, a ponadto oznaczają osoby, a nie abstrakcyjne pojęcia. 
wyszukanych, jak tworzenie neologizmów, zabawy językowe czy skomplikowane operacje logiczne.

Świadomość istnienia w danym systemie układów proporcjonalnych sprawia, że posługujący się nim ludzie postrzegają konkretne wypowiedzi nie jako pasmo niezróżnicowanych dźwięków (jak ma to na przykład miejsce w wypadku odgłosów wydawanych przez zwierzęta, niepodzielnych na segmenty funkcjonalne), ale jako ciąg, w którym następującym po sobie porcjom brzmienia odpowiadają stosowne porcje znaczeń. Wyodrębnione na mocy różnic i tożsamości wyrażenia to byty konkretne języka, tworzące jego podsystem leksykalny i morfologiczny ${ }^{31}$.

$\mathrm{Na}$ wstępie tego fragmentu mojej wypowiedzi zaznaczyłam, że w każdym języku naturalnym musi się znaleźć taka liczba elementów, jaka gwarantować będzie spełnienie zasady proporcjonalności. De Saussure, który tak odkrywczo uchwycił istotę mechanizmu mownego, sprowadzając go do układów algebraicznych, mylił się jednak, twierdząc, że do zaistnienia języka wystarczą jedynie dwie formy (na przykład $b a$ i la), zdolne do uporządkowania wszystkich koniecznych w nim znaczeń po stronie jednej bądź drugiej z nich ${ }^{32}$. Odpowiednich form i związanych $\mathrm{z}$ nimi znaczeń musi być co najmniej cztery, bo dopiero w takich warunkach można mówić o czwórce proporcjonalnej ${ }^{33}$.

${ }^{31} \mathrm{Na}$ temat adekwatnej delimitacji ciągu wypowiedzeniowego zob. np. F. de Saussure, Kurs..., op. cit., s. 125-129; A. Bogusławski, O zasadach rejestracji jednostek języka, „Poradnik Językowy” 1976, nr 8, s. 356-364; idem, Jednostki języka a produkty językowe. Problem tzw. orzeczeń peryfrastycznych, [w:] Z zagadnień słownictwa współczesnego języka polskiego, red. M. Szymczak, Wrocław 1978, s. 17-30; idem, Jeszcze o delimitacji bilateralnych wielkości językowych, [w:] Symbolae Slavisticae. Dedykowane Pani Profesor Hannie Popowskiej-Taborskiej, red. E. Rzetelska-Feleszko, Warszawa 1996, s. 47-56.

32 F. de Saussure, Szkice..., op. cit. s. 95.

33 Na ten temat zob. więcej w artykule: A. Bogusławski, An Example of Non-Existence of What Fails to Meet the Proportionality Requirement, [w:] Language, Science and Culture: Essays in Honour of Professor Jerzy Bańczerowski on the Occasion of His 70th Birthday, red. P. Łobacz, P. Nowak, W. Zabrocki, Poznań 2009, s. 85-90. 


\section{ŚRODKI W JEZZYKU NIEZBĘDNE}

W ostatniej części tego artykułu chcę powiedzieć kilka słów o wyposażeniu języka w wyrażenia, które są niezbędne do zbudowania jakiejkolwiek wypowiedzi, oraz w inne konieczne do tego celu środki wyrazu.

\section{WYRAŻENIA PREDYKATYWNE I REFERENCJALNE}

Na mówienie - jak przenikliwie pokazał to John L. Austin, reprezentant brytyjskiego nurtu filozofii analitycznej - składa się bardzo wiele różnych czynności. Dwie z nich są jednak absolutnie podstawowe, a chodzi mianowicie, po pierwsze, o akt referencji, czyli odesłania tego, co się mówi, do odpowiednich przedmiotów w świecie, i po drugie - o akt predykacji (lub orzekania), czyli przypisania danemu przedmiotowi odpowiedniej wiązki $\operatorname{cech}^{34}$. Mówienie to, innymi słowy, wskazywanie obiektów w świecie i charakteryzowanie ich pod pewnym względem. I tak na przykład w zdaniu: Janek pracuje wskazujemy wiadomą osobę, której na imię Janek, i orzekamy o niej, że w momencie mówienia pracuje. Do każdorazowego spełnienia tych dwóch czynności konieczne są wyspecjalizowane środki językowe. Z jednej strony, mówiący musi dysponować wyrażeniami referencjalnymi lub indeksalnymi, takimi jak imiona własne, różnego rodzaju zaimki czy rodzajniki, które pozwalają mówić nie tylko o tym, co pozostaje w zasięgu palca wskazującego, z drugiej zaś - niezależnymi od tamtych wyrażeniami predykatywnymi, należącymi do rozmaitych części mowy. Z łatwością można sobie wyobrazić język, w którym nie byłoby pewnej klasy predykatów, na przykład tego, co nazywamy rzeczownikami, albo tego, czemu przypisujemy nazwę czasownika, a tym bardziej tego, co określamy mianem spójnika, ale rozróżnienie między indeksami a orzecznikami musi być zachowane pod groźbą zachwiania istotą zdarzenia mownego. I nic nie szkodzi, że nie ma w języku czystych indeksów - takich, które byłyby całkiem wolne od treści predykatywnych, bo nawet imiona własne nie są pozbawione elementarnego znaczenia; ważna jest dominacja jednej z tych funkcji, tworząca wyrazistą opozycję.

34 Por. J.L. Austin, Jak działać słowami, [w:] idem: Mówienie i poznawanie. Rozprawy i wykłady filozoficzne, tłum. B. Chwedeńczuk, Warszawa 1993, s. 640-644. 


\section{WYRAŻENIA Z POZIOMU PRZEDMIOTOWEGO I METAPRZEDMIOTOWEGO}

W każdym języku, obok wyrażeń służących do reprezentowania zjawisk należących do rzeczywistości pozajęzykowej, muszą też istnieć środki służące do mówienia o mówieniu, to znaczy odsyłające do innych wyrażeń tego samego systemu językowego ${ }^{35}$. Jest to znowu jedna $\mathrm{z}$ tych cech, których próżno by szukać w kodach zwierzęcych. Wyżej zorganizowane małpy zdolne są z pewnością do tego, by sygnalizować opiekunowi chęć uzyskania pożywienia, ale nie mogą wysyłać komunikatów na temat tych właśnie sygnałów. Jest to związane $\mathrm{z}$ faktem, który w swej teorii lingwistycznej akcentuje A. Bogusławski, a mianowicie że zwierzęta, podobnie jak ludzie, wiedzą różne rzeczy o świecie, ale nie mogą nic wiedzieć o własnej wiedzy, brak im bowiem autorefleksji.

W języku naturalnym możliwy jest nie tylko namysł nad systemem jako całością (taki charakter ma mój artykuł), nad tym czy innym elementem kodu (np. Słowo „kot” jest jednosylabowe) lub nad zrealizowanymi w nim wypowiedziami (np. „Słowo »kot « jest jednosylabowe” - to dobry przykład metawypowiedzi). Wskazane wyżej operacje dokonywane są w parole za pomocą niespecyficznych narzędzi, ale i w samym języku (langue) znajdujemy elementy wyspecjalizowane do pełnienia funkcji metatekstowych. W repertuarze jego środków ważne miejsce zajmują bowiem takie, które pod względem semantycznym są ściągniętymi do postaci jednostki leksykalnej komentarzami na temat spełnianych aktualnie czynności mownych. W polszczyźnie taką rolę mają do odegrania partykuły typu: raczej, chyba, może, bynajmniej nie ${ }^{36}$, czy też bardziej przejrzysty metatekst w rodzaju: krótko mówiąc, innymi słowy, by tak rzec i wyrażenia tym podobne.

Impuls do rozpoczęcia badań nad metajęzykiem na gruncie lingwistyki dały osiągnięcia wybitnych filozofów XX wieku, a w szczególności Alfreda Tarskiego, który wypracowując swą teorię prawdy, założył, że znajomość

35 Ta własność języka została dostrzeżona już w starożytnych Indiach, około 500 lat p.n.e. Na temat historii rozważań o metajęzyku zob. A. Bogusławski, E. Drzazgowska, op. cit., t. II, s. 486-522.

36 Trzy ostatnie partykuły w przywołanym szeregu to na przykład króciutkie opowieści o tym, że wiedza mówiącego jest niedostateczna, by pod asercją głosić to, co po nich następuje. 
danego języka naturalnego implikuje znajomość jego metajęzyka, a ta z kolei znajomość metametajęzyka itd., to znaczy zdolność odnoszenia się do wyrażeń jako do tego, o czym mowa, oraz przekładania wyrażeń z poziomu przedmiotowego na wyrażenia metapoziomu z zachowaniem ich znaczenia ${ }^{37}$.

\section{3. ŚRODKI SŁUŻĄCE DO PRZEKAZYWANIA WIEDZY I KOMUNIKOWANIA PRAWDY}

Podstawową funkcją języka jest funkcja określana mianem symbolicznej, reprezentatywnej bądź referencjalnej. Jednostki znaczące mają bowiem zdolność reprezentowania odpowiednich obiektów w rzeczywistości pozajęzykowej i językowej, a także wszelkich relacji między tymi obiektami. Poszczególne realizacje systemu w postaci konkretnych wypowiedzi pełnią natomiast przede wszystkim funkcję poznawczą. Głównym sensem użycia języka w indywidualnym akcie mowy jest bowiem przekazanie odbiorcy pewnej porcji wiedzy. Komunikacja językowa to w pierwszym rzędzie dzielenie się ze współrozmówcami wiedzą. Takie efekty, jak manifestowanie swoich stanów emocjonalnych, wywieranie presji na odbiorcę, osiąganie celów fatycznych czy poetyckich - wszystko to są rzeczy wtórne i nadbudowane nad aspektami poznawczymi.

Badania nad rekonstrukcją systemu pojęć prostych i uniwersalnych, prowadzone w różnych ośrodkach naukowych na materiale języków różniących się w sposób zasadniczy strukturą, dostarczają przekonujących argumentów na rzecz tezy, że jednym $z$ bazowych indefinibiliów jest pojęcie związane z polskim czasownikiem wiedzieć, $\dot{z} e_{-}, \mathrm{z}$ francuskim savoir que_, $\mathrm{z}$ angielskim know that_, z rosyjskim znat' čto_itd. Bogusławski, który problematyce kognitywnej w języku naturalnym poświęcił swoje najważniejsze prace ${ }^{38}$, zwraca uwagę nie tylko na eksplanacyjną moc pojęcia wiedzy (będącą refleksem tego, że jest ono składnikiem ogromnej większości pojęć złożonych występujących w poszczególnych językach), lecz także na fakt,

37 Zob. np. A. Tarski, Pisma logiczno-filozoficzne, t. 1: Prawda, Warszawa 1995, s. 292-332.

38 Mam tu przede wszystkim na myśli dwie obszerne monografie tego autora, a mianowicie: Science as Linguistic Activity, Linguistics as Scientific Activity (Warszawa 1998) i A Study in the Linguistics-Philosophy Interface (Warszawa 2007). 
że każde sensownie użyte zdanie oznajmujące ma implikację epistemiczną. Znaczy to tyle, że z użytego zdania $p$ logicznie wynika, iż ktoś wie, że p.

Co więcej, w każdym zdaniu oznajmującym wypowiedzianym pod asercją, to znaczy na serio, z przeżyciem pewności, w takim, które można zreferować za pomocą akcentowanej frazy ktoś powiedziat, $\dot{z} e_{-}$, zawarte jest tak zwane truth-claim, czyli swoiste nastawanie nadawcy na prawdziwość spełnianego przezeń wypowiedzenia. Ten bardzo ważny element nie ma swoich wykładników segmentalnych, zasadniczą rolę odgrywają tu środki prozodyczne, związane przede wszystkim z intonacją kadencji. Implikacja epistemiczna i truth-claim sprawiają, że mówienie, które nie dotykałoby wiedzy i prawdy - to rzecz po prostu niemożliwa.

W artykule pod znaczącym tytułem Veredicum laudare necesse est, vitam sustinere non est necesse ${ }^{39}$ Bogusławski zwraca uwagę na to, że prawda zajmuje w języku szczególne miejsce. Jest ona logicznie wyróżniona w stosunku do dobra (a więc też takich cnót, jak życzliwość, miłosierdzie, wielkoduszność), a także w stosunku do piękna. Swoją tezę opiera on na obserwacji, popartej wywodem logicznym, że całkowita i ostateczna aprobata dla świadomie głoszonej nieprawdy jest wewnętrznie sprzeczna, podczas gdy taka sama aprobata dla prawdy nigdy sprzeczna nie jest. Ktokolwiek bowiem aprobuje mówienie przez inną osobę rzeczy, które są całkowicie nieprawdziwe, nie może jednocześnie nie odnosić się z aprobatą do tego, co z jego punktu widzenia jest prawdziwe, a mianowicie do własnej pozytywnej oceny owych fałszów. Inne wartości i antywartości takiej asymetrii nie wykazują.

Lingwistyczny prymat prawdy przed dobrem i pięknem potwierdzają dane płynące $\mathrm{z}$ różnych języków. Przekonujące przykłady Bogusławskiego dają świadectwo temu, że prawda wykazuje uderzającą niezależność od innych wartości. Zdanie: Byłoby to piękne/dobre, gdyby było prawdziwe jest nie tylko całkowicie akceptowalne, ale - co więcej - często używane, podczas gdy wypowiedzenie: ${ }^{\star} B y ł o b y$ to prawdziwe, gdyby było piękne/dobre musi być uznane za nieakceptowalne.

Świadome pogwałcenie przez mówiącego prawdziwości wypowiedzi skutkuje wytworzeniem się niewłaściwego i szkodliwego obrazu odpowiedniego

39 A. Bogusławski, Veredicum laudare necesse est, vitam sustinere non est necesse, "Journal of Pragmatics” 2005, No. 37, s. 411-431; przedruk w: idem, Roztrząsania nadlingwistyczne, Warszawa 2011, s. 51-74. 
fragmentu rzeczywistości w umyśle odbiorcy, co z kolei grozi gotowością tegoż do działania w nieadekwatny sposób; konsekwencje fałszu są więc zarówno z praktycznego, jak i aksjologicznego punktu widzenia daleko idące. Całkowite zerwanie z prawdziwością w komunikacji ludzkiej, a w efekcie załamanie się wzajemnego zaufania, prowadziłoby do podkopania fundamentów języka, a ostatecznie - do anihilacji życia społecznego. Z pewnością dlatego właśnie nie istnieje taki system etyczny, w którym wybór między mówieniem prawdy i nieprawdy byłby rzeczą obojętną.

\section{PODSUMOWANIE}

W tej krótkiej wypowiedzi mogłam zasygnalizować jedynie wybrane problemy związane ze sprawą konieczności w języku naturalnym. Podsumowując swoje rozważania, raz jeszcze chcę podkreślić, że jest on taką instytucją, której nie da się zestawić z żadnym innym systemem komunikacyjnym czy to w porządku natury, czy też w dziedzinie kultury. Banalne i - wydawałoby się - czysto strukturalne własności języka wyprowadzają nas od razu nieuchronnie w sferę podstawowych zagadnień ontologicznych, epistemologicznych i aksjologicznych.

\section{Bibliografia:}

John L. Austin, Jak działać słowami, [w:] idem, Mówienie i poznawanie. Rozprawy i wykłady filozoficzne, tłum. B. Chwedeńczuk, PWN, Warszawa 1993.

Jean Aitchison, Ziarna mowy. Początki i rozwój języka, tłum. M. Sykurska-Derwojed, PWN, Warszawa 2002.

Ireneusz Bobrowski, Zaproszenie do językoznawstwa, Wyd. Instytutu Języka Polskiego PAN, Kraków 1998.

Andrzej Bogusławski, O zasadach rejestracji jednostek języka, „Poradnik Językowy” 1976, nr 8, s. 356-364.

Andrzej Bogusławski, Jednostki języka a produkty językowe. Problem tzw. orzeczeń peryfrastycznych, [w:] Z zagadnień słownictwa współczesnego języka polskiego, red. M. Szymczak, Ossolineum, Wrocław 1978, s. 17-30.

Andrzej Bogusławski, Towards an operational grammar, "Studia Semiotyczne” 1978, nr 8, 29-90, pol. przekład: Preliminaria gramatyki operacyjnej, tłum. R. Gozdawa-Gołębiowski, „Polonica” 1989, nr 13, s. 163-223. 
Andrzej Bogusławski, Język i świat znaków, „Przegląd Humanistyczny” 1988, nr 12, s. 133-168; przedruk w: idem, Sprawy słowa / Word Matters, Veda, Warszawa 1944, s. 22-48.

Andrzej Bogusławski, O proporcjonalności w języku i jej warunkach, [w:] Językoznawstwo diachroniczne i synchroniczne, red. J. Sambor, J. Linde-Usiekniewicz, R. Huszcza, Wydawnictwo UW, Warszawa 1993, s. 59-76.

Andrzej Bogusławski, Jeszcze o delimitacji bilateralnych wielkości językowych, [w:] Symbolae Slavisticae. Dedykowane Pani Profesor Hannie Popowskiej-Taborskiej, red. E. Rzetelska-Feleszko, Slawistyczny Ośrodek Wydawniczy, Warszawa 1996, s. 47-56.

Andrzej Bogusławski, Science as Linguistic Activity, Linguistics as Scientific Activity, Katedra Lingwistyki Formalnej UW, Warszawa 1998.

Andrzej Bogusławski, Veredicum laudare necesse est, vitam sustinere non est necesse, „Journal of Pragmatics” 2005, nr 37, s. 411-431; przedruk w: idem, Roztrzasania nadlingwistyczne, Bel STUDIO, Warszawa 2011, s. 51-74.

Andrzej Bogusławski, A Study in the Linguistics-Philosophy Interface, Katedra Lingwistyki Formalnej UW, Warszawa 2007.

Andrzej Bogusławski, An Example of Non-Existence of What Fails to Meet the Proportionality Requirement, [w:] Language, Science and Culture: Essays in Honour of Professor Jerzy Bańczerowski on the Occasion of His 70th Birthday, red. P. Łobacz, P. Nowak, W. Zabrocki, Wydawnictwo Naukowe UAM, Poznań 2009, s. 85-90.

Andrzej Bogusławski, Słowo i znak, [w:] Znaki czy nie znaki?, red. M. Guławska-Gniewkowska, G.M. Zeldowicz, Instytut Lingwistyki Stosowanej, Warszawa, 2013, s. 9-19.

Andrzej Bogusławski, Ewa Drzazgowska, Język w refleksji teoretycznej. Przekroje historyczne, t. I-II, Katedra Lingwistyki Formalnej UW, Warszawa 2016.

Bożenna Bojar, Zarys językoznawstwa dla studentów bibliotekoznawstwa i informacji naukowej, Wydawnictwo UW, Warszawa 1991.

Georges Charbonnier, Rozmowy z Claude Lévi-Straussem, tłum. J. Trznadel, Czytelnik, Warszawa 2000.

William H. Calvin, Derek Bickerton, Lingua ex Machina. Reconciling Darwin and Chomsky with the Human Brain, MIT Press, Cambridge 2001.

Magdalena Danielewiczowa, Dosięgnąć przedmiotu. Rzecz o Ferdynandzie de Saussurze, Wydawnictwo UW, Warszawa 2016. 
Cliff Goddard, Anna Wierzbicka, Horacio Fabréga Jr., Evolutionary Semantics:

Using NSM to Model Stages in Human Cognitive Evolution, „Language Sciences" 2013, No. 42, s. 60-79.

Renata Grzegorczykowa, Wstęp do językoznawstwa, PWN, Warszawa 2007.

Charles F. Hockett, Zagadnienie uniwersaliów w języku, tłum. H. Kurkowska,

[w:] Językoznawstwo strukturalne, red. A. Weinsberg, H. Kurkowska, PWN, Warszawa 1979, s. 209-228.

Roman Jakobson, Język a inne systemy komunikacji, przeł. A. Tanalska, [w:] idem

W poszukiwaniu istoty języka. Wybór pism, red. M.R. Mayenowa, t. I, PWN, Warszawa 1989, s. 59-74.

Jerzy Kuryłowicz, La nature des pročcs dits «analogiques», SPAU, Kraków 1949.

Richard Leakey, Pochodzenie człowieka, tłum. Z. Skrok, CIS, MOST, Warszawa 1995.

John Lyons, Language and Linguistics. An Introduction, CUP, Cambridge 1981. Edward Łuczyński, Jolanta Maćkowiak, Językoznawstwo ogólne. Wybrane zagadnienia, Wydawnictwo UG, Gdańsk 1999.

André Martinet, Éléments de linguistique générale, Armand Colin, Paris 1960; pol. wydanie: Podstawy lingwistyki funkcjonalnej, wybór i tłum. L. Zawadowski, PWN, Warszawa 1970, s. 18-24; lub przedruk: [Podwójne rozczłonkowanie języka], [w:] Semiotyka dziś i wczoraj, red. L. Koj, J. Pelc, Ossolineum, Wrocław 1991, s. 342-345.

Ferdynand de Saussure, Kurs językoznawstwa ogólnego, tłum. K. Kasprzyk, PWN, Warszawa 2002.

Ferdinand de Saussure, Szkice zjęzykoznawstwa ogólnego, przeł. M. Danielewiczowa, Dialog, Warszawa 2004.

Steven Pinker, Język jest instynktem ludzkim, tłum. J. i M. Jannaszowie, [w:] Trzecia kultura, red. J. Brockman, CIS, Warszawa 1996.

Renata Przybylska, Wstęp do nauki o języku polskim. Podręcznik dla szkół wyższych, Wydawnictwo Literackie, Kraków 2003.

Max Scheler, Pisma $z$ antropologii filozoficznej i teorii wiedzy, tłum. i oprac.

S. Czerniak, Węgrzecki, PWN, Warszawa 1987.

Alfred Tarski, Pisma logiczno-filozoficzne, t. 1: Prawda, Wydawnictwo Naukowe PWN, Warszawa 1995.

Ludwig Wittgenstein, Philosophische Grammatik, hrsg. von R. Rhees, Suhrkamp, Frankfurt am Main 1989. 
Ludwig Wittgenstein, Tractatus logico-philosophicus, tłum. B. Wolniewicz, PWN, Warszawa 2006.

Przemysław Żywiczyński, Sławomir Wacewicz, Ewolucja języka. W stronę hipotez gesturalnych, Wydawnictwo UMK, Lublin 2015.

\section{What is Language Necessary for? What is Necessary in the Language Itself?}

The article attempts to answer two closely interrelated questions: What is a natural language necessary for and, on the other hand, what is necessary in the language itself? In the first part the author puts forward a thesis that there is a gulf between human speech and animal codes - a gulf which cannot be filled with explanations of evolutionary nature. She also invokes a series of ideas of distinguished scholars who advocate the logical primacy of language in relation to all other semiotic systems that create the space of culture. In the second part of the article, the inalienable properties of language are discussed, those that determine its essence and, at the same time, the uniqueness with respect to both the animal signals and all other sign systems. These features include: double demarcation, duality, proportionality, the possession of reference and predictive expressions, metalinguistic and metatextual tools, as well as tools for communicating the truth and knowledge of the world.

Keywords: linguistics, semiotics, natural language, animal codes, inalienable features of human language 

ZatącZnil

\section{WOKÓŁ ZARZĄDZANIA KULTURA. REZULTATY BADANIA ANKIETOWEGO}

OPRACOWANIE:

PATRYK DZIURSKI

Kolegium Zarządzania i Finansów, Szkoła Główna Handlowa w Warszawie Collegium of Management and Finance, SGH Warsaw School of Economics pd54550@sgh.waw.pl

KAMA PAWLICKA

ANNA WRÓBLEWSKA
Wydział Nauk Humanistycznych UKSW

Faculty of Humanities, Cardinal Stefan Wyszyński University in Warsaw kamapawlicka@hotmail.com

Wydział Nauk Humanistycznych UKSW

Faculty of Humanities, Cardinal Stefan Wyszyński University in Warsaw annadorotawroblewska@gmail.com

\section{WPROWADZENIE}

Kultura fascynowała wielu badawczy od stuleci, ale dopiero w drugiej połowie XX wieku zainteresowali się nią ekonomiści ${ }^{1}$. Obecnie obszar badawczy, jakim jest ekonomia kultury, stanowi część ekonomii, a na całym świecie powstają publikacje dotyczące ekonomicznych aspektów kultury². Współcześnie wydaje się, że obok ekonomii kultury wykształca się nowy obszar - zarządzanie kulturą, cieszące się zainteresowaniem wielu badaczy oraz wymagające zdefiniowania i opisania zarówno pod względem zakresu znaczeniowego, jak i odpowiednich metodologii badawczych.

Wiosną 2017 roku przeprowadziliśmy ankietę wśród badaczy zajmujących się szeroko rozumianymi sektorami kreatywnymi, a także wśród

1 R. Kasprzak, Przemysty kreatywne w Polsce: uwarunkowania i perspektywy, Warszawa 2013, s. 29; K. Stachowiak, Problemy metodologiczne badania sektora kreatywnego, „Rozwój Regionalny i Polityka Regionalna” 2015, nr 30, s. 14-16.

2 Zob. np. U. Grzelońska, Ekonomiczna strona kultury, Warszawa 2016; D. Ilczuk, Ekonomika kultury, Warszawa 2012; D. Throsby, Ekonomia i kultura, tłum. O. Siara, Warszawa 2010; R. Towse, Ekonomia kultury. Kompendium, tłum. Ł. Skrok, H. Dębowski, K.L. Pogorzelski, Warszawa 2011. 
menedżerów, często łączących doświadczenie w tej materii z praktyką akademicką. Na naszą prośbę odpowiedziało dwadzieścia osób. Wyniki tego - w gruncie rzeczy autorefleksyjnego - badania prezentujemy poniżej. Subiektywne podejście respondentów do problemów, różnorodność stanowisk, a w wielu punktach także ich zbieżność, tworzą fundament, na którym można budować poszukiwania badawcze w tym obszarze i odnaleźć, wciąż liczne, biały plamy.

Zdecydowaliśmy się zadać naszym respondentom następujące pytania: Czy Pana/i zdaniem zarządzanie kulturą należy do nauk ekonomicznych, czy też jest subdyscypliną kulturoznawstwa? Co wyróżnia zarządzanie kulturą na tle innych nauk? Który obszar zarządzania kulturą i jakie zagadnienia należy rozwinąć: obszar przedmiotowy (np. teoria zarządzania, zarządzanie strategiczne, zarządzanie kapitałem ludzkim, przywództwo, marketing i inne) czy obszar podmiotowy (np. sektory kreatywne, sektory kultury, rynek audiowizualny, teatry i inne)? Czy modele i metody zarządzania mogą zostać zastosowane w zarządzaniu kulturą? Jeśli tak, to jakie? Czy może Pan/i wskazać metody i modele z zakresu kulturoznawstwa, które można zastosować w zarządzaniu kulturą? Czy Pana/i zdaniem można mówić w Polsce o istnieniu środowiska badaczy zarządzania kulturą? Proszę wskazać liczące się ośrodki. Czy istnieje współpraca między ośrodkami naukowymi oraz między ośrodkami naukowymi a instytucjami kultury? Czy wytwarzają się kanały komunikacji (publikacje, konferencje, nieformalne grupy)? ${ }^{3}$

W odpowiedzi na temat aplikacji teorii zarządzania do domeny kultury dr Agata Siwiak (UAM), która jest akademiczką oraz aktywną kuratorką i producentką, stwierdziła:

Bardzo cenię tę bizawodowość. Kiedy czytam artykuły dotyczące zarządzania w kulturze, to miewam często wrażenie, że brakuje w nich podstaw praktycznych. Wierzę, że badaczom zarządzania pomogłaby możliwość wglądu w procesy produkcji sztuki. Mam poczucie, że zarządzanie kulturą wciąż traktuje się jako wyizolowaną naukę - brakuje interdyscyplinarności, poszukiwań wędrujących wzdłuż i wszerz zarządzania, estetyki, teorii sztuki,

3 W artykule tym nie zostały ujęte odpowiedzi na jedno pytanie (na temat szans i barier w zarządzaniu kulturą), które odnosi się do innego obszaru badań. 
socjologii, antropologii, co przekłada się na lukę w badaniach jakościowych. Brakuje języka, który łączyłby wszystkie te przestrzenie.

Natomiast prof. Mieczysław Morawski (UE we Wrocławiu) stwierdził, że:

Mamy tu do czynienia z próbą połączenia dwóch żywiołów. Z jednej strony kultura, splatająca zdarzenia, procesy i przedsięwzięcia oparte na oryginalności, wyjątkowości i niepowtarzalności, twórczej odwadze i przełamywaniu różnych tabu, generująca wartości filozoficzne, ekspresywne, estetyczne, edukacyjne i inne, których percepcja uzależniona jest od indywidualnych preferencji i wrażliwości. Zarządzanie to drugi żywioł, oferujący zbiór sprawdzonych, wielokrotnie wykorzystywanych narzędzi działania, których stosowanie sprzyja osiąganiu sukcesów w realizacji celów. Dzięki zarządzaniu - w rozumieniu naukowych koncepcji i metod menedżerskich oraz praktycznych, sprawdzonych dyrektyw postępowania - przedsięwzięcia kreowane, wzbogacane i realizowane w domenie kultury mają większą szansę na wielowymiarowy sukces, $w$ tym komercyjny, ekonomiczno-finansowy, organizacyjny, marketingowy. Specyfiki połączenia obu tak różnych żywiołów można upatrywać właśnie w kategoriach paradoksów i sprzeczności, we współistnieniu różnych dopuszczalnych alternatyw działania na styku oryginalnej sztuki i racjonalnego zarządzania. To z kolei powinno się przekładać na niezwykłą kreatywność zarządzania kulturą, w której każdy projekt oferujący widzom/słuchaczom/czytelnikom wartości oparte na przeżyciach i odpowiadające przedsięwzięciu narzędzia finansowe, organizacyjne czy marketingowe tworzyć będzie innowacyjne rozwiązania. Daje to wyobrażenie o wielu potencjalnych problemach i procesach badawczych, które mogą być realizowane przez heterogeniczne zespoły badawcze, składające się z przedstawicieli różnych nauk. Generalizując, paradoksy i sprzeczności wnoszone przez odmiennie konstytuowane: kulturę i zarządzanie, kreatywność i innowacyjność wynikającą z planowania i realizacji projektów, różne tradycje i paradygmaty naukowe osób angażujących się w zarządzanie kulturą - wszystko to może decydować o jego odmienności i specyfice.

\section{ZARZĄDZANIE KULTURĄ WOBEC PODZIAŁU NAUK I DYSCYPLIN}

Czy zarządzanie kulturą przynależy do nauk ekonomicznych, czy do kulturoznawstwa? Nawet pobieżna analiza odpowiedzi na tak sformułowane pytanie nie daje jednoznacznej odpowiedzi. Część z ankietowanych uważa, że 
zarządzanie kulturą należy do nauk ekonomicznych, w szczególności nauk o zarządzaniu, część natomiast, że jest częścią kulturoznawstwa, a pozostali wskazują na jego interdyscyplinarny czy multidyscyplinarny charakter. Powyższy problem następująco opisuje prof. Urszula Grzelońska (PAN):

Jeśli godzimy się ze stanowiskiem, że zarządzanie należy do dziedziny nauk ekonomicznych, to musimy konsekwentnie zgodzić się, że zarządzanie kulturą również należy do tej dziedziny, i to bez względu na to, czy mówimy o zarządzaniu kulturą, czy w kulturze, czy o zarządzaniu instytucjami kultury. [...] O ile kulturoznawstwo jako przedmiot edukacji jest stosunkowo dobrze zakorzenione w Polsce, to jako przedmiot badań charakteryzuje się ciągle różnymi niekonsekwencjami, będącymi skutkiem tworzenia go na zasadzie „zszywania” wielu problemów rozpatrywanych do niedawna oddzielnie, w ramach różnych dyscyplin naukowych, i stąd nie mam wątpliwości, że w jego ramach może pomieścić się także zarządzanie kulturą.

Pokrywa się to z opinią dra hab. Konrada Klejsy (UŁ), który wskazuje, że: Polskie kulturoznawstwa to z jednej strony filozofia kultury, z drugiej zaś określenie „ramowe”, pod którym kryją się bądź studia nad kulturami świata („kulturoznawstwo bliskowschodnie” itp.), bądź subdyscypliny dotyczące poszczególnych rodzajów twórczości artystycznej, takie jak filmoznawstwo czy teatrologia.

Dr Łukasz Wróblewski (WSB Dąbrowa Górnicza) stwierdza natomiast, że:

Sektor kultury jest wewnętrznie bardzo zróżnicowany. W jego ramach działają zarówno publiczne, jak i prywatne instytucje, instytucje niedochodowe oraz instytucje zorientowane na zysk, instytucje o orientacji produktowej oraz rynkowej, instytucje kreacji i upowszechniania dzieł sztuki. Wszystko to sprawia, że trudno znaleźć tu wspólny mianownik - uniwersalne narzędzia, metody czy strategie, które mogą mieć zastosowanie we wszystkich podmiotach sektora kultury. Ponadto ciągle panuje sytuacja braku porozumienia w podstawowych kwestiach teoretycznych i metodologicznych, dająca o sobie znać choćby w zróżnicowanym sposobie rozumienia głównych pojęć służących do opisu rzeczywistości społeczno-kulturowej, występujących w niej zjawisk i procesów. 


\section{PROBLEMY DEFINICYJNE}

Kwestią problematyczną w dyskusji nad zarządzaniem kulturą jest to, co prof. Tadeusz Stryjakiewicz (UAM) trafnie określił jako „brak precyzji pojęciowej”, a co może odnosić się także do zadanych przez nas pytań:

Czy mówimy o zarządzaniu kulturą, czy o zarządzaniu w kulturze; lub: czy zarządzanie kulturą traktujemy jako naukę, czy jako wiedzę praktyczną? Jeśli chodzi o zarządzanie instytucjami i organizacjami kultury, wówczas to, co w ankiecie nazwane jest „zarządzaniem kulturą”, bardziej związane jest $\mathrm{z}$ naukami ekonomicznymi (a nawet ekonomiczno-prawnymi), jeśli zaś chodzi o kulturę jako sferę życia i aktywności człowieka, wówczas zwiększa się rola kulturoznawstwa.

W podobnym tonie wypowiedział się dr Krzysztof Stachowiak (UAM), który wskazał, że: „przede wszystkim należy odróżnić zarządzanie kulturą od nauki o zarządzaniu kulturą. W pierwszym przypadku mamy do czynienia z działaniami związanymi z kierowaniem organizacjami kultury (teatry, muzea, galerie sztuki itp.), a w drugim - z dziedziną wiedzy, której przedmiotem zainteresowania są te działania”. Dr Katarzyna Plebańczyk (UJ) zwróciła natomiast uwagę, że:

Odpowiedź na pytanie o definicję zarządzania w kulturze wymaga sprecyzowanego podejścia do pojęcia „kultura”. Od lat 90. w Polsce, a trochę wcześniej i poza Polską, świat nauki, ale i polityki oraz praktyków zarządzania dyskutuje o tym, co jest kulturą. Prowadzi nas to do ustalenia, że konieczne jest stosowanie definicji indywidualnych, przyjmowanych na potrzeby konkretnych działań (Raport KEA z 2004 r. o znaczeniu gospodarczym sektora kultury jest tego najlepszym dowodem, gdyż na jego potrzeby została przyjęta definicja, która wzbudziła spore kontrowersje wśród m.in. ekonomistów kultury). Kiedy mówimy o kulturze, a w konsekwencji o zarządzaniu kulturą, zawsze musimy doprecyzować, co właściwie mamy na myśli, inaczej bowiem pojęcie to odniesiemy do sfery publicznego, instytucjonalnego funkcjonowania kultury, inaczej do sektora pozarządowego, a jeszcze inaczej do biznesu. Kulturą zarządza się z poziomu polityki, ale także $\mathrm{z}$ poziomu organizacji (instytucji, firmy), i stosowane tu narzędzia różnią się między sobą, a czasami są podobne tylko z pozoru (np. różne rozumienie zarządzania strategicznego).

Brak precyzji pojęciowej powoduje chaos definicyjny. Wydaje się jednak, że nie jest to niepokojący fakt, gdyż, jakkolwiek nazywane, zarządzanie 
kulturą jest młodą subdyscypliną naukową. Korzystając z propozycji P. Hirscha oraz D. Levina ${ }^{4}$, można stwierdzić, że obszar zarządzania kulturą znajduje się obecnie w fazie wschodzącego zainteresowania (emerging excitement), a w przyszłości wejdzie w fazę weryfikowania wyzwań (validity challenge), następnie zaś w fazę porządkowania typologii (tidying up with typologies). W początkowych fazach rozwoju obszaru badawczego nieprecyzyjność oraz nadmiar stosowanych pojęć jest stanem naturalnym, wraz $z$ rozwojem natomiast zmniejsza się chaos definicyjny oraz wykształcają się paradygmaty, a badacze tworzą nowe teorie.

\section{PRZYNALEŻNOŚĆ DYSCYPLINARNA ZARZĄDZANIA KULTURA}

Cześć ekspertów jednoznacznie wskazała, że zarządzanie kulturą przynależy do nauk ekonomicznych, w szczególności do nauk o zarządzaniu. Mieczysław Morawski stwierdził, iż:

Wszędzie tam, gdzie podejmuje się próby zarządzania, również zarządzania kulturą, mamy do czynienia z pierwiastkiem racjonalności. Oznacza to przede wszystkim działanie przemyślane, zaplanowane, $\mathrm{z}$ zestawem celów podstawowych i pośrednich, głównych i ubocznych, strategicznych i taktycznych, z przewidzianymi potrzebami w zakresie zasobów ludzkich, finansowych, materialnych, $\mathrm{z}$ ustalonym harmonogramem czynności, przygotowanymi i opanowanymi metodami działania itd. Zarządzać znaczy: postępować w sposób efektywny, uwzględniający bilans efektów i nakładów, łączący w jedną zintegrowaną całość wszystkie potrzebne i dostępne elementy służące realizacji założonych celów. Jeśli zatem zarządzanie kulturą jest zbiorem działań nastawionych na realizację przyjętych wcześniej celów w sposób maksymalnie efektywny, uwzględniający racjonalne wykorzystanie ludzi, zasobów i metod - to na pewno mieści się ono w obrębie nauk ekonomicznych i menedżerskich.

4 P. Hirsch, D. Levin, Umbrella Advocates Versus Validity Police: A Life-Cycle Model, „Organizational Science” 1999, Vol. 10, No. 2, s. 200-203, [cyt. za:] G.F. Lowe, Introduction: What's So Special About Media Management, [w:] Managing Media Firms and Industries. What's So Special About Media Management, red. G.F. Lowe, Ch. Brown, New York - Dordrecht - London 2016, s. 3-4. 
Podobnie wypowiedziała się dr Anna Janowska (SGH w Warszawie), która wskazała, że zarządzanie kulturą należy:

do szeroko rozumianych nauk ekonomicznych (nauk o zarządzaniu), dlatego że używane są tu metody i modele specyficzne dla tych nauk. Wyjątkowy jest przedmiot - kultura, co stawia całe zagadnienie trochę pomiędzy dyscyplinami. Trzeba bowiem znać specyfikę funkcjonowania sektorów kultury, aby nimi właściwie zarządzać, np. wiedzieć, na czym polega proces twórczy, praca artystów, co wyróżnia produkty kultury spośród innych produktów itd.

Badaczka zwróciła także uwagę na trzy specyficzne aspekty zarządzania kulturą:

1. Praca twórcza oraz produkcja dóbr kultury nie podlegają niektórym prawom ekonomicznym, np. nie sprawdza się prawo malejącej użyteczności krańcowej, działa efekt Baumola 5 .

2. Bardzo ważną rolę odgrywają tutaj efekty zewnętrzne, wpływające na budowanie kapitału kulturowego oraz społecznego ludzi, a także na ogólny dobrobyt. Dlatego zarządzania kulturą nie należy prowadzić tak, jak zarządzania jakąkolwiek działalnością biznesową, komercyjną.

3. Artyści pracują inaczej niż pracownicy pozostałych sektorów gospodarki, ważne są tutaj: proces twórczy i jego efekt, kwestia czasu pracy i czasu wolnego, wynagrodzenia za pracę itd.

Do specyfiki zarządzania zasobami ludzkim w sektorach kultury nawiązał także Łukasz Wróblewski:

${ }^{5}$ Badaczka powołuje się w tym miejscu na słynną pracę Williama Baumola i Williama Bowena Performing Arts: The Economic Dilemma, która ukazała się w 1966 roku i trwale zmieniła stosunek ekonomistów do kultury. Rezultatem badań autorów nad teatrami było m.in. odkrycie tak zwanego efektu Baumola, inaczej nazywanego „chorobą kosztów”. Efekt ten podważa klasyczną tezę ekonomiczną, zgodnie z którą poziom dochodów warunkowany jest produktywnością określonej branży. W przypadku branż kulturalnych postęp technologiczny nie prowadzi do wzrostu produktywności, czyli spadku kosztów. Płace i koszty rosną tam szybciej niż wydajność, co musi prowadzić do deficytu. Produktywność teatru pozostaje bowiem na podobnym poziomie (przyp. red.). 
Jeszcze kilkadziesiąt lat temu wielki talent i mistrzowska sztuka stawiały wielu artystów występujących na scenie jak gdyby ponad prawami obowiązującymi ludzi innych profesji. Przywileje te artyści często wykorzystywali, tyranizując niemiłosiernie dyrekcje filharmonii, teatrów operowych, teatrów dramatycznych, impresariów, a nawet i twórców sztuki. Mimo że w XXI wieku sytuacja diametralnie się zmieniła, to jednak współpraca $\mathrm{z}$ artystami ciągle zasadniczo różni się od pracy z ludźmi wszystkich innych profesji. Jak twierdzi R. Bing ${ }^{6}$, pracownicy administracyjni też niewątpliwie mają swoje ambicje, ale nie muszą co dzień rzucać wszystkiego na szalę, co wieczór walczyć o swoją egzystencję. Dlatego też artyści to ludzie wyjątkowi wrażliwi i drażliwi, nerwowi i cokolwiek zwariowani.

Do zarządzania zasobami ludzkimi odniosła się także Katarzyna Plebańczyk, której zdaniem: „zarządzanie kulturą mieści się w nurcie zarządzania w naukach humanistycznych, co oznacza, że skupia się na zarządzaniu ludźmi, przez ludzi i dla ludzi”. Łukasz Wróblewski wskazał natomiast, że:

Zarządzanie w kulturze ma oczywiście wiele cech wspólnych z tym, które wykształciło się w przedsiębiorstwach, ale wiele też takich, które spotykamy tylko w sektorze kultury. Jest to widoczne chociażby w działaniach marketingowych instytucji kultury, które ze względu na bardzo specyficzny produkt przybierają dużo oryginalnych cech. Dla przykładu, cena w organizacjach biznesowych jest jednym $\mathrm{z}$ najbardziej elastycznych instrumentów marketingu mix $^{7}$, a jej kształtowanie dzisiaj nie nastręcza menedżerom zbyt wielu problemów - w przeciwieństwie od rynku dóbr i usług kultury, gdzie cena jest jednym z najtrudniejszych do ustalenia składników marketingu. Trudność sprawia ustalenie ogólnych zasad, na podstawie których ustalano by ceny na usługi kultury. Duże zróżnicowanie usług, konkurencja oraz różnorodne uregulowania zewnętrzne (chociażby zapisy mówiące o powszechnym dostępie do kultury) ograniczają swobodę w kreowaniu strategii cenowej.

${ }^{6}$ R. Bing, 5000 wieczorów w operze, tłum. W. Kalinowski, Warszawa 1982, s. 34-35.

7 Marketing mix to zespół instrumentów służących do oddziaływania na rynek. To popularna kompozycja teoretyczna związana z marketingiem. Składa się z czterech elementów: ceny, produkcji, miejsca i promocji (przyp. red.). 
Na odmienność zarządzania kulturą zwróciła także uwagę Urszula Grzelońska, podkreślając różnicę między pracą w „zwykłej” gospodarce a pracą w kulturze, pracą artystów:

Jednym z głównych zadań w zarządzaniu firmą wytwarzająca rzeczy powtarzalne jest wypracowanie w ludziach motywacji, która pozwoli im wykonywać setki powtarzalnych czynności, nie umierając przy tym ze znudzenia. W ludziach pracujących twórczo, a taka jest praca w kulturze, nie trzeba budować takiej motywacji, oni ją mają wrodzoną! Zawsze znajdzie się mnóstwo ludzi, którzy z entuzjazmem będą tworzyć. W kulturze widzianej oczami ekonomisty i zarządzającego nie ma problemu z podażą. Jest natomiast problem z popytem na wytwory twórców, na dobra kultury. Dlatego marketing dóbr kultury wymaga gruntownego wzmocnienia w porównaniu z marketingiem powtarzalnych przedmiotów i usług, których użyteczność nie budzi na ogół niczyich wątpliwości.

Badaczka dostrzega ponadto różnicę w skali wytwórstwa zwykłych dóbr i dóbr kultury:

Gdy szuka się rynku dla miliona słoików kawy, w cenie jednego słoika łatwo zmieścić dziesięć groszy na marketing, który wymaga nakładów finansowych w kwocie stu tysięcy złotych. Przedstawienie teatralne robi się dla powiedzmy - dwudziestu tysięcy osób, i uzyskanie stu tysięcy złotych na marketing tegoż przedstawienia wymagałoby zmieszczenia pięciu złotych w cenie biletu, a o to już trudniej.

Dr Patrycja Klimas (UE w Katowicach), która uznaje zarządzanie kulturą za obszar nauk o zarządzaniu, stwierdza ponadto, że:

Na tle innych obszarów zarządzania [zarządzanie kulturą - przyp. red.] wyróżnia się np. znacznym udziałem kapitału publicznego (co wpływa na konkurencyjność), koniecznością rozpatrzenia nie tylko płatnych, ale także bezpłatnych modeli biznesu, ponadprzeciętną rolą zarządzania projektami, deficytem wyspecjalizowanej kadry menadżerskiej.

Prof. Dorota Ilczuk (Uniwersytet SWPS), której habilitacja, jak sama przyznaje, jako pierwsza w Polsce usytuowana była w nurcie zarządzania w naukach humanistycznych, uważa, iż: 
Absolwent wyłącznie ogólnego zarządzania zazwyczaj jest beznadziejnym menedżerem kultury, słabo rozumiejącym specyfikę zarządzania w tym obszarze. [...] Jeśli oficjalnie został w nauce wydzielony taki nurt zarządzania, oznacza to, że zarządzanie w kulturze wymaga innych kompetencji, odmiennych sposobów przekazywania wiedzy. Różni się więc od zarządzania wykładanego na wydziałach ekonomicznych szkół wyższych.

Obecnie w Polsce nauki o zarządzaniu stanowią dyscyplinę naukową w zakresie dwóch dziedzin - nauk ekonomicznych, ale także nauk humanistycznych (na Uniwersytecie Jagiellońskim). Wedle wcześniej obowiązującej klasyfikacji zarządzanie należało wyłącznie do nauk ekonomicznych. Oznacza to, być może, że od pytania o miejsce zarządzania kulturą w obszarze kulturoznawstwa właściwsze byłoby pytanie szersze - o to, jakie aspekty zarządzania kulturą sytuują je w obszarze nauk humanistycznych.

Do specyfiki zarządzania kulturą nawiązał Tadeusz Stryjakiewicz, który stwierdził, że:

[jego] wyróżnikiem jest dualny charakter procesu zarządzania kulturą, związany z jednej strony z jego wymiarem ekonomicznym (gdzie z powodzeniem można wprowadzać rozwiązania oparte na ekonomicznych teoriach zarządzania), z drugiej - z wymiarem humanistycznym i społecznym (gdzie wiele działań, np. sam proces tworzenia, $z$ trudem poddaje się „zarządzaniu”).

Krzysztof Stachowiak również zwrócił uwagę na cechujący zarządzanie kulturą dualizm ekonomiczno-kulturowy, co oznacza, że badane zjawiska przejawiają, w zależności od sytuacji, własności ekonomiczne lub kulturowe.

Ma to doniosłe konsekwencje metodologiczne i wskazuje na interdyscyplinarność tej dziedziny wiedzy. Wynika to ze specyfiki przedmiotu tego zarządzania, czyli kultury. Procesy ekonomiczne i kulturowe mają odmienną naturę. Zarządzanie kulturą (oraz nauka o nim) z jednej strony zakorzenione jest w teoriach zarządzania, a $\mathrm{z}$ drugiej - powinno uwzględniać specyfikę działalności kulturalnej (np. muzeów, teatrów, galerii sztuki) oraz wytworów kultury. Styk procesów kulturowych i ekonomicznych sprawia, że zjawiska będące przedmiotem zainteresowania zarządzania kulturą mają dualny charakter. [...] Zarządzanie kulturą musi uwzględniać tę dwoistość. W przeciwnym razie kierowanie organizacjami kultury nie będzie efektywne. Nauka o zarządzaniu kulturą również musi brać to pod uwagę, ponieważ bez tego obraz badanych zjawisk będzie niepełny lub niewłaściwy. 
W naukach o zarządzaniu wyróżnia się dwadzieścia jeden subdyscyplin. Biorąc pod uwagę kryterium typów organizacji, można wyróżnić zarządzanie organizacjami gospodarczymi oraz zarządzanie publiczne i $\mathrm{NGO}^{8}$. Druga z subdyscyplin została wyodrębniona właśnie ze względu na specyfikę zarządzania organizacjami publicznymi. Prof. Alina Kozarkiewicz (AGH) stwierdziła, że:

Trudno wskazać metody lub modele zarządzania, które nie mogą być stosowane w zarządzaniu kulturą, zwłaszcza że zarządzanie kulturą to zarządzanie w sferze publicznej (zarządzanie publiczne), ale także zarządzanie w organizacjach komercyjnych, działających w oparciu o finansowanie przez udziałowców (prywatnych właścicieli, a czasami samych twórców czy też przez akcjonariuszy).

Iwona Haberny (Agencja Promocyjna OKO) dzieli zarządzanie kulturą na dwa nurty:

1. Zarządzanie „przemysłami kreatywnymi”, czyli tym, co w zamierzeniu ma przynosić zysk: I tutaj mają zastosowanie normalne zasady rynkowe i system zarządzania (a także marketingu i promocji) obowiązujące w każdym innym biznesie. Łącznie z tym, że wartości artystyczne często ustępują wobec zysku - rynek bestsellerów (książka, film, muzyka) miewa niewiele wspólnego z prawdziwą sztuka i kulturą. Potrzebny jest dobry, utalentowany manager (może być - a nawet lepiej, gdy jest - zupełnie niezwiązany z kulturą), który potrafi zatrudnić odpowiednie osoby i bez emocji zarządzać nimi i całą firma.

2. Zarządzanie instytucjami kultury: w tym wypadku chodzi nie o zysk, ale o stworzenie warunków, w których kultura (twórcy i ich publiczność) może się najpełniej rozwijać. [...] Potrzebna jest tu osobna refleksja teoretyczna, która pozwoli ustalić priorytety, kryteria i długofalowe cele. Natomiast wdrażanie tego wymaga otwarcia się na wiedzę już wypracowaną (zarządzanie, marketing, promocja - tutaj nie widzę powodu, by wyważać otwarte drzwi i tworzyć nowe teorie na potrzeby kultury).

8 S. Cyfert, W. Dyduch, D. Latusek-Jurczak, J. Niemczyk, A. Sopińska, Subdyscypliny w naukach o zarządzaniu - logika wyodrębniania, identyfikacja modelu koncepcyjnego oraz zawartość tematyczna, „Organizacja i Kierowanie” 2014, nr 1(161), s. 40. 
Podobnie sprawę przedstawia też prof. Piotr Majewski (UKSW, Dyrektor Instytutu Muzealnictwa i Ochrony Zbiorów).

Zgodnie z przytoczonym wcześniej podziałem na subdyscypliny w naukach o zarządzaniu, zarządzanie kulturą znajduje się zarówno w obszarze zarządzania organizacjami gospodarczym (np. zarządzanie teatrami działającymi na zasadach komercyjnych), jak i w obszarze zarządzania publicznego i NGO (np. działania instytucji kultury finansowanych publicznie). Kwestią otwartą pozostaje pytanie, czy nie uprawnia to do wydzielenia oddzielnej subdyscypliny w naukach o zarządzaniu, jaką byłoby zarządzanie w kulturze?

Większość ekspertów wskazała, że modele i metody zarządzania stosowane w organizacjach gospodarczych są i mogą być wykorzystywane w zarządzaniu kulturą, ale powinny zostać dostosowane do specyfikacji organizacji z sektorów kultury. Dr Mateusz Lewandowski (UJ) stwierdził, że:

$\mathrm{W}$ pierwszej kolejności należy stosować modele zarządzania w organizacjach biznesowych dla tych podmiotów, które w kulturze działają czysto komercyjnie, a modele zarządzania publicznego dla podmiotów sektora publicznego, a więc instytucji kultury. Analogicznie w przypadku organizacji pozarządowych. Kluczowe jest jednak działanie w ramach tak zwanego współrządzenia (governance) i szukanie rozwiązań hybrydowych oraz wypracowywanie metod dedykowanych sektorowi kultury.

Łukasz Wróblewski wskazał, że „zarządzanie w kulturze wymaga spojrzenia holistycznego. Wymaga rozwiązań, metod oraz narzędzi badawczych bardziej wyrafinowanych niż te, które dają odpowiedzi wyłącznie zerojedynkowe”. Mateusz Lewandowski zwrócił natomiast uwagę, iż:

Kluczowe jest zachowanie zdrowego rozsądku i krytycznego myślenia $\mathrm{w}$ dostosowywaniu: czasem oznacza to wprowadzenie kosmetycznych zmian, a czasem daleko idących modyfikacji. Nie zawsze dostosowanie modelu i metod zarządzania przełoży się na oczekiwane rezultaty i ma sens. Przykładowo, zarządzanie jakością i ISO ${ }^{9}$ sprawdzi się bardziej w bibliotece niż w teatrze, ale czy konkretna biblioteka jest gotowa do poniesienia

${ }^{9}$ ISO - termin z zakresu zarządzania jakością. Normy z rodziny ISO 9000 dotyczą zarządzania jakością, czyli podejmowania działań z zakresu kierowania organizacją i nadzorowania jakością w organizacji (przyp. red.). 
nakładów na wdrożenie takiego rozwiązania i czy będzie w stanie skonsumować rezultaty tej metody, to osobna kwestia.

Maciej Dominiak (menedżer kultury współpracujący z UKSW) podkreślił jednak, iż:

Teoria zarządzania jest uniwersalna, w podstawowych aspektach opiera się po prostu na zasadach ludzkiej percepcji, ludzkich emocji, elementarnych regułach porządkujących otaczającą nas rzeczywistość. Specyfika zarządzania w kulturze polega na „przetworzeniu” teorii zarządzania w sposób uwzględniający specyfikę i unikalność działalności kulturalnej, specyfikę i unikalność „produktów kultury” oraz specyfikę potrzeb odbiorców. Jeśli przeanalizujemy np. zagadnienia związane $\mathrm{z}$ teorią zarządzania zespołem ludzkim, to fundament teoretyczny pozostanie ten sam, ale na poziomie szczegółowym teoria będzie wymagała precyzyjnego dostosowania do specyfiki branży artystycznej i całej bogatej sfery złożonych relacji, np. na linii "pion artystyczny” - „pion organizacyjny”, w przypadku których „standardowe" teorie zarządzania nie znajdą zastosowania”.

Paweł Płoski (Teatr Narodowy w Warszawie) słusznie więc zauważył, że:

Należy zwrócić uwagę na sposoby dostosowywania tychże [modeli i metod przyp. red.] do interesującego nas obszaru. Dostosowywanie powinno odbywać się z poszanowaniem, ale przede wszystkim zrozumieniem obszaru, do którego mają być „aplikowane”. Pamiętam kursy zarządzania kryzysowego w kulturze, gdzie przykładem kryzysu było reagowanie na złą recenzję po przedstawieniu. Trenerka zdaje się nigdy w teatrze nie pracowała, więc wymyśliła przykład „na sucho”. Nie muszę dodawać, jaką wartość przedstawiało to ćwiczenie. (Wszelkie znane mi próby reagowania na tego typu teksty kończyły się porażką instytucji i „moralnym zwycięstwem” krytyka). Zatem w zarządzaniu kulturą dobrze jest pilnować się, by nowa metoda stanowiła pomoc we wskazywaniu i rozwiązywaniu problemów, a nie skrywaniu ich pod "profesjonalnym nazewnictwem”.

Podobnie wypowiedział się także Mieczysław Morawski, który stwierdził, że po dokonaniu potrzebnych dopasowań nie ma:

przeszkód w stosowaniu rozwiązań menedżerskich w działalności teatralnej, filmowej, wystawienniczej, festiwalowej czy muzealnej. W każdej organizacji 
i przedsięwzięciu liczy się racjonalne podejście do finansów, organizacji pracy, zatrudnienia, marketingu, logistyki. Konieczna jest strategia i ustalony model działania (biznesu). Po drugiej stronie jest wymagający, coraz bardziej obyty, dobrze poinformowany, wykształcony i często wrażliwy klient, który oczekuje doznań i przeżyć wyjątkowych; nawet jeśli ulotnych, to do głębi poruszających. Tenże klient oczekuje jednakże, iż wartości artystyczne otrzyma w rozsądnej cenie, w komfortowych warunkach, na najwyższym poziomie profesjonalnej sztuki, wcześniej łatwo się o ich miejscu i czasie ekspozycji dowiadując i odpowiednio łatwo rezerwując i płacąc na przyszłe doznania.

Katarzyna Plebańczyk dodała, że w zarządzaniu kulturą używa się:

instrumentów i narzędzi charakterystycznych dla zarządzania w ogóle, ale w zależności od formy prowadzonej działalności jedne będą wykorzystywane intensywniej bądź zostaną zaadaptowane. Dobrym przykładem jest tu dobór narzędzi i instrumentów zarządzania w kontekście celów działalności. Każda instytucja/organizacja przeprowadzi kalkulację zysków i strat, ale np. teatr publiczny zdefiniuje je w innych kategoriach niż wydawnictwo. Dla teatru ważniejszy będzie zysk niematerialny (choć finansowy jest nie bez znaczenia), rozwój artystyczny, szansa promocji zespołu, artystów czy wpisanie się w modny ostatnio w Polsce audience development. Dla wydawnictwa istotny jest zysk finansowy, ale w zależności od profilu firmy - także dbanie o wizerunek. Wydaje się, że aspekt humanistyczny (przez ludzi i dla ludzi) ma tu znaczenie największe i jest czynnikiem odróżniającym [zarządzanie kulturą - przyp. red.] od zarządzania ekonomicznego, nastawionego na zysk, najczęściej rozumiany w kategoriach finansowych.

\section{PRZYNALEŻNOŚĆ DO KULTUROZNAWSTWA?}

Wśród ankietowanych ekspertów znacznie mniej było tych, którzy uznali, że zarządzanie kulturą przynależy do kulturoznawstwa. Piotr Majewski stwierdził, iż:

Bez wątpienia sfera „ekonomii” jest przedmiotem zarządzania. Zarządzanie, tak w wymiarze instytucjonalnym, jak również indywidualnym, ma swoje konsekwencje, by tak rzecz, „kosztotwórcze”. Świadomość faktu, iż nasze wybory, nasze decyzje przybierają także formę excelowych tabel z kosztorysem, jest rudymentem, zwłaszcza praktycznego parania się zarządzaniem. 
Kto nie ma poczucia odpowiedzialności za pieniądz publiczny, kto nie ma wiedzy - a przynajmniej potrzeby jej zdobycia - na temat zamówień publicznych czy podatku VAT, niech nie ryzykuje losów powierzonej mu instytucji i ludzi, zostając jej szefem. Z pewnością więc nauki ekonomiczne są ważnym aspektem zarządzania kulturą. Ale właśnie w takim porządku, nie na odwrót. „Budżetowanie” nie jest bowiem celem samym w sobie; ono jest ramą dla realizacji misji czy zadań statutowych, na które składają się poszczególne projekty uszeregowane w długo-, średnio- i krótkoterminowe szeregi „strategii” i „polityk”. Zarządzanie, zwłaszcza w instytucjach kultury, to myślenie o celach, myślenie o zmianie, to ambicja kreowania i inspirowania ludzkich postaw i zachowań w skali społecznej; to działalność twórcza, która, jeśli mówimy o aspektach finansowych, musi zawierać w sobie prawo do błędu i prawo do autokorekty (co w żadnym stopniu nie oznacza przyzwolenia na intencjonalne omijanie prawa).

W związku z tym badacz (a jednocześnie praktyk, szef instytucji kultury) lokuje zarządzanie kulturą w dyscyplinarnych ramach kulturoznawstwa:

Na tym rozdrożu nauk i wartości, gdzie podążać można w jednym kierunku, nie gubiąc innych, korzystając z bogactwa synergii i interdyscyplinarności, pozostając otwartym na spełnienie intelektualne, twórcze, niekoniecznie „ekonomiczne”. Bo zarówno zarządzanie kulturą, jak i sama kultura to kategorie non profit, nie zaś nastawione na zysk; choć liczą się z „groszem”, nie stawiają go w centrum świata wartości.

\section{ZARZĄDZANIE KULTURA JAKO OBSZAR INTERDYSCYPLINARNY}

Część respondentów wskazała, że zarządzanie kulturą nie należy ani do nauk o zarządzaniu, ani do kulturoznawstwa. Dobrze obrazuje to opinia dra hab. Marcina Adamczaka (UAM), który uważa, że „czasy współczesne są okresem zacierania granic między dyscyplinami, nie podjąłbym się zatem próby określania tutaj wyraźnej przynależności”. K. Klejsa stwierdził natomiast, że: „Zarządzanie kulturą z pewnością nie jest osobną dyscypliną, tak jak nie jest nią, powiedzmy, historia filmu polskiego. Powiedziałbym, iż zarządzanie kulturą to interdyscyplinarne studia humanistyczno-ekonomiczne". Koresponduje to z uwagą Macieja Dominiaka: 
Zarządzanie kulturą traktowałbym raczej jako pewnego rodzaju metadyscyplinę, wykorzystującą zarówno elementy nauk ekonomicznych (w kontekście aspektów finansowo-administracyjnych), humanistycznych (stanowiących w procesie zarządzania przedmiot realizowanych działań - np. poszczególne dziedziny sztuki), jak i nauk technicznych (np. działania związane z koordynacją techniczną, posługiwaniem się nowymi technologiami itp.). Myślę, że wspomniana powyżej multidyscyplinarność sprawia, że dziedzina ta bazuje na dokonaniach innych dyscyplin nauki, czerpie z ich podstaw teoretycznych i przetwarza wiedzę na potrzeby procesu zarządzania przedsięwzięciami kulturalnymi, uwzględniając ich specyfikę i unikalność.

Podobnie wypowiada się mgr Joanna Śmietanka (UWR):

Zarządzanie kulturą, jako przynależną do obszaru nauk humanistycznych dziedzinę interdyscyplinarną, umiejscawiać należy w obrębie nauki o zarządzaniu, z elementami kulturoznawstwa, literaturoznawstwa, historii sztuki, a także nauk społecznych, takich jak nauka o mediach, nauka o poznaniu i komunikacji, psychologia czy socjologia (jeśli wliczymy w to zarządzanie w obrębie socjologii kultury, obejmujące zarządzanie relacjami pomiędzy społeczeństwem a kulturą). Wśród zagadnień związanych z zarządzaniem kulturą odnaleźć można również zagadnienia z zakresu prawa (np. w przypadku imprez masowych ${ }^{10}$ ), dziedzin nauk filmowych, sztuk plastycznych, muzycznych oraz teatralnych. Interdyscyplinarne podejście do zarządzania kulturą pozwala na wykorzystanie wiedzy z innych dziedzin, która wydaje się niezbędna do prawidłowego rozumienia mechanizmów zachodzących w managemencie kultury. Mowa tu głównie o kulturoznawstwie, nauce o mediach, nauce o poznaniu i komunikacji, a także psychologii.

Alina Kozarkiewicz widzi specyfikę zarządzania kulturą w wielowymiarowości i interdyscyplinarności. Interdyscyplinarność wyraża się w badaniach na styku nauk ekonomicznych, humanistycznych i społecznych: ekonomii, nauk o zarządzaniu, socjologii, filozofii i kulturoznawstwa. Natomiast wielowymiarowość polega na kompleksowości tematyki badawczej i wielości paradygmatów charakterystycznych dla nauk społecznych.

10 Ustawa o bezpieczeństwie imprez masowych z 2009 roku oraz Ustawa z dnia 11 września 2015 roku o zmianie Ustawy o bezpieczeństwie imprez masowych oraz niektórych innych ustaw. 


\section{Mateusz Lewandowski uważa, że:}

Każda sfera działalności kulturalnej ma swoją specyfikę, która determinuje metody i modele zarządzania. Na przykład galerie działające na rynku sztuki, biblioteki, agencje eventowe, muzea, domy kultury i opery - wszystko to są zupełnie różne byty. Ich specyfika wymaga szczegółowej wiedzy, która w zarządzaniu kulturą nie jest podawana studentom. Ponadto ważne są kontakty w środowisku - to jest bariera dla studentów, którzy chcą działać, a nie mogą, chyba że sami mają takie kontakty. Reasumując, uważam, że większa specjalizacja jest istotna dla rozwoju zarządzania kulturą.

Podobnie wypowiedziała się dr Marzenna Wiśniewska (UMK), która wskazała, że „zarządzanie kulturą, osadzone głównie w naukach humanistycznych i społecznych, stanowi dobrą platformę do wymiany badawczej $\mathrm{z}$ reprezentantami nauk ścisłych/technicznych, np. w zakresie informatyki - perspektywa ta cały czas wydaje się jeszcze mało zagospodarowana”. Krzysztof Stachowiak również zwrócił uwagę na multidyscyplinarny charakter zarządzania kulturą:

Składają się nie przede wszystkim badania: ekonomiczne (zwłaszcza z obszaru nauki o zarządzaniu, ale także ekonomii oraz finansów), kulturoznawcze, socjologiczne, filozoficzne, związane ze sztuką (estetyka); ale nie brak także szeregu innych dyscyplin. Multidyscyplinarność (wielodyscyplinarność) występuje wtedy, gdy pole badawcze zawiera pewną sumę składników różnych dyscyplin, które zachowują swoją indywidualność. Nauka o zarządzaniu kulturą nie nabrała jeszcze interdyscyplinarnego charakteru, a z całą pewnością nie stanowi odrębnej dyscypliny. Interdyscyplinarność stanowi bowiem wyższy poziom multidyscyplinarności, na którym różne dyscypliny dążą do uzyskania zintegrowanego ujęcia i wyników, które nie będą już tylko sumą poszczególnych rezultatów.

W zarządzaniu kulturą sięga się po dorobek wielu różnych nauk i dyscyplin naukowych. Tym samym trudno jest jednoznacznie przypisać zarządzanie kulturą do określonego obszaru. Można odnieść wrażenie, że to, co najciekawsze, powstaje na styku wielu różnych obszarów badawczych, a nie w ramach sztywno określonych specjalizacji. Sprawia to, że w zarządzaniu kulturą powinniśmy sięgać do dorobku różnych dyscyplin, aby dążyć do powstania interdyscyplinarnego obszaru badawczego, w ramach którego 
badania będą prowadzone przez naukowców z różnych specjalizacji. Warto w tej sytuacji przy toczyć wypowiedź Marzenny Wiśniewskiej, która zwróciła uwagę, że „jedną ze znamiennych tendencji we współczesnych badaniach naukowych jest przekraczanie granic między dyscyplinami, co skutkuje zarówno poszerzaniem ujęć metodologicznych, jak i tworzeniem interdyscyplinarnych zespołów badawczych”. Jak wynika z naszych doświadczeń, a także z wyników ankiety, zarządzenie kulturą zarówno w praktyce, jak i badaniach w największym stopniu sięga do dorobku z zakresu szeroko rozumianej teorii zarządzania. Jest to zgodne z opinią Macieja Dominiaka, który zauważył, iż:

Zarządzanie kulturą to w sensie ogólnym wciąż element dziedziny zwanej zarządzaniem, z tą różnicą, że uwzględniający specyfikę unikalnej materii, jaką jest kultura, uwzględniający jej „niemierzalność”, pozaekonomiczne walory i czynniki, które budują wartość kultury w oparciu o zupełnie inne wskaźniki niż np. w standardowym obiegu komercyjnym, bazującym na wyprodukowaniu prostego produktu zaspokajającego proste potrzeby klienta.

\section{„BIAŁE PLAMY”}

Szczególnie istotne w kontekście celów niniejszej ankiety było pytanie o to, który obszar zarządzania kulturą należy rozwinąć: obszar przedmiotowy (np. teorię zarządzania, zarządzanie strategiczne, zarządzanie kapitałem ludzkim, przywództwo, marketing i inne) czy obszar podmiotowy (np. sektory kreatywne, sektory kultury, rynek audiowizualny, teatry i inne). Tu odpowiedzi się powtarzają - poniżej prezentujemy tylko wybrane z nich i jak łatwo zauważyć, wyczuwa się deficyt w obu omawianych obszarach.

Tadeusz Stryjakiewicz uważa, że:

W obszarze przedmiotowym należy przede wszystkim zdefiniować specyfikę zarządzania kulturą w kontekście dotychczasowego dorobku nauk o zarządzaniu i kulturoznawstwa oraz wskazać „luki poznawcze”. Natomiast w obszarze podmiotowym wielkim wyzwaniem wydają się te segmenty kultury, na które najsilniej wpływają przemiany związane z nowymi technologiami informacyjno-komunikacyjnymi (ICT), np. miejsce bibliotek w dobie rozpowszechniania się e-booków, rynek audiowizualny itp. 
Dr Kamila Lewandowska (Akademia Teatralna im. Aleksandra Zelwerowicza w Warszawie) natomiast stwierdza, iż:

Powinniśmy zacząć od pytania: czym ma zajmować się obszar nauk zwany zarządzaniem kulturą? Większość publikacji dostępnych na polskim rynku podchodzi do tematu przez pryzmat zarządzania instytucjami. Autorzy bazują na schematach zarządzania strategicznego (misja/wizja/cele strategiczne - analiza SWOT - plany strategiczne itp.). Moim zdaniem są to schematy już mocno przestarzałe i warto by poszukać nowych rozwiązań. Przede wszystkim należy uwzględnić to, że większość praktyków kultury nie jest i nigdy nie będzie dyrektorami instytucji. Rozwój wiedzy o zarządzaniu instytucjami jest na pewno potrzebny, np. należałoby poświęcić więcej uwagi komunikacji wewnętrznej w organizacjach. A jednak na największy deficyt wiedzy mogą obecnie narzekać pracownicy bardziej „elastycznych” form działalności kulturalnej, takich jak małe teatry niepubliczne, niezależne zespoły itp.

„Zdecydowanie należałoby rozwinąć obszary z zakresu zarządzania strategicznego - mam tu na myśli przede wszystkim wdrożenie modelowych procesów zarządzania, które umożliwią osiąganie przez ośrodki kultury swoich celów w sposób skuteczny i efektywny" - stwierdza Joanna Śmietanka. Piotr Majewski z kolei uważa, iż:

Ze wskazanego obszaru [przedmiotowego - przyp. red.] rozwinięcia wymaga przede wszystkim zarządzanie strategiczne. Pytanie o strategię to pytanie o cel: w wymiarze wspólnotowym, indywidualnym, państwowym, instytucjonalnym etc. To pytanie o udzielenie odpowiedzi, która nie może być obciążona detalem (wszak większość z tych detali zmienna jest i nieprzewidywalna...). Pytanie o strategię to odpowiedź na potrzebę i umiejętność formułowania rudymentarnych założeń, które w sposób naturalny „toną” w codzienności krótkoterminowych wyzwań, okiełznanych przymusem „responsywności” ludzi itd. Zarządzanie strategiczne to także umiejętność zerwania tych pęt.

„Warto rozwijać zarządzanie strategiczne, zarządzanie kapitałem ludzkim, ale też - co mocno podkreślamy - komunikację wartości” - stwierdzili eksperci związani z instytucją kultury Zamek Cieszyn. „Zarówno naukowcy, jak i przedstawiciele praktyki są zgodni, że należy dążyć do adaptacji metod i technik zarządzania na potrzeby różnych podmiotów sektora kultury, 
$\mathrm{w}$ tym również publicznych instytucji kultury. W tym kontekście jedną z ważniejszych koncepcji zarządzania w kulturze jest zarządzanie strategiczne, gdzie stan wiedzy ciągle jest jeszcze niepełny” - podkreśla Łukasz Wróblewski, i dodaje:

Luka ta jest widoczna między innymi w kluczowej sferze zarządzania strategicznego, jaką jest marketing strategiczny, a w konsekwencji ma przełożenie na jedno z najważniejszych narzędzi marketingu strategicznego, czyli na strategię marketingową. Dotyczy ona [luka - przyp. red.] chociażby procedur wdrażania strategii marketingowej oraz metod pomiaru, które umożliwiłyby skuteczną kontrolę jej realizacji w podmiotach kultury. W związku $\mathrm{z}$ tym faktem $\mathrm{w}$ polskich podmiotach sektora kultury obserwuje się problem zarówno o charakterze teoretycznym, jak i metodycznym, związany z określeniem stopnia i zakresu wdrożenia strategii marketingowej czy odpowiednią procedurą umożliwiającą przeprowadzenie kontroli jej realizacji. Wynika to głównie z faktu, że dotychczasowe badania, dotyczące strategii marketingowych instytucji kultury w Polsce, koncentrują się na pewnych ich elementach czy procedurach, jak np. identyfikacja potrzeb, preferencji i zachowań konsumentów na rynku dóbr i usług kultury, segmentacja rynku, strategiczne planowanie marketingowe, możliwości wykorzystania strategii marketingowych, analizy działań marketingowych czy też stopnia ich intensywności i częstotliwości. Bardzo rzadko podnoszony jest natomiast problem dotyczący stopnia i zakresu wdrożenia strategii marketingowej, procedur kontroli realizacji strategii czy głównych problemów jej implementacji.

\section{Joanna Śmietanka wskazuje jednak, iż:}

W obszarze marketingu chyba już wszystko zostało powiedziane, chociaż przydatne wydaje się opracowanie i wdrożenie nowoczesnych technik promocji do ośrodków kulturalnych „starej daty”. Można odnieść wrażenie, że tylko część projektów, jak np. eventy muzyczne, czerpie z dostępnego dziś całego wachlarza metod dotarcia do widza. W tyle wciąż pozostają muzea, filharmonie i wiele innych ośrodków kulturalnych.

Wiele uwagi badacze i eksperci poświęcają zagadnieniom związanym z managementem, zarządzaniem zasobami ludzkimi, kształceniem menedżerów, liderów itd. Dorota Ilczuk uważa, iż w sferze dydaktyki należy zwrócić większą uwagę na psychologiczne uwarunkowania menedżerów, 
na możliwości wykorzystania psychologii i psychologii społecznej do nauki skutecznego zarządzania:

Peter Drucker [jeden z najważniejszych teoretyków zarządzania XX wieku przyp. red.] powtarzał zawsze, że w zarządzaniu najważniejsi są ludzie. Należałoby więc przyjrzeć się, na ile menedżerowie, zarządcy, agenci, producenci przygotowani są emocjonalnie i psychicznie do wykonywania swoich funkcji. $Z$ drugiej strony, nie ma w tym nic nowego - założenie, że w procesach zarządzania kluczowe funkcje pełnią ludzie, jest jedną z pierwotnych tez tej dziedziny wiedzy. Na stare koncepcje nakładane są często nowe nazwy.

„W jakieś mierze czynnik ludzki powinien odgrywać pierwszorzędne znaczenie ze względu na konieczność działań oryginalnych, pionierskich, często odważnych i dalekowzrocznych” - uważa Mieczysław Morawski. Dlatego też nacisk należy położyć na „zagadnienia związane z przywództwem, kształtowaniem cech liderów kreatywnych zespołów i projektów, problematykę profilu kompetencyjnego osób inicjujących i prowadzących przedsięwzięcia kulturalne, oddziaływanie lidera na współpracowników itd.”.

Piotr Majewski dodaje:

Odwołam się do potrzeb najbliższego mi sektora kultury - sektora muzealnego. Jakkolwiek wzrasta systematycznie oferta kształcenia (w tym uniwersytecka) dla kadry zarządzającej wszystkich szczebli, tak się jednak składa (tu polecam prześledzenie karier zawodowych osób „sprawujących władzę” w polskim muzealnictwie), że większość dyrektorów (i coraz więcej dyrektorek) to swoiste „samorodki”, ludzie budujący swą zawodową pozycję przez drogi (a czasem bezdroża) praktyki, z ciągle zbyt małą podbudową teoretyczną. Moje osobiste doświadczenie ten model potwierdza. Ciągle w Polsce jeszcze zbyt często najpierw się szefem zostaje, a potem do tej roli dopiero dorasta (zwłaszcza w wymiarze wiedzy teoretycznej) albo... nie dorasta. Jest więc ten przeze mnie wskazany obszar podmiotowy ciągle odkrywaną dziedziną.

Alina Kozarkiewicz stwierdza natomiast, że:

Wydaje się, że trudno pominąć którykolwiek z wymienionych powyżej obszarów [przedmiotowy i podmiotowy - przyp. red.]. Inne potencjalnie ważne obszary to zarządzanie projektami - działalność wielu instytucji 
kultury to działalność projektowa. Można uzupełnić listę obszarów i zagadnień o takie istotne aktualnie problemy, jak dostęp do kultury, digitalizacja, kultura w sieci, uczestnictwo w kulturze w czasach zmian demograficznych i różnorodności.

„Ważne są procesy finansowe, jak choćby pozyskiwanie środków finansowych, ich efektywne wykorzystanie, identyfikowanie źródeł - donatorów, sponsorów, kredytodawców - uważa Mieczysław Morawski. - Nie można również pominąć równie kluczowych zagadnień własności intelektualnej i praw autorskich”. Konrad Klejsa dodaje do tego: zamówienia publiczne, prawo pracy i prawo podatkowe. Alina Janowska stwierdza natomiast, że:

Ważne są tutaj aspekty finansowania kultury, szczególnie w otoczeniu cyfrowym (erozja prawa autorskiego), mierzenia efektów działalności kulturalnej (nie tylko komercyjnych, finansowych, ale i pozafinansowych). Istotne są prace nad sytuacją artystów, specyfiką ich zawodu, co wiąże się ze sprawą zabezpieczeń finansowych, statusu na rynku pracy itd. W Polsce wciąż brakuje badań sektorów kreatywnych i sektorów kultury; są to obszary niedoceniane przez „poważnych” badaczy zajmujących się np. rynkami finansowymi czy też tradycyjnymi obszarami gospodarki.

W podobnym tonie wypowiada się Mateusz Lewandowski: „Przekornie powiedziałbym, że [rozwinąć należy - przyp. red.] zarządzanie efektywnością (performance management). Debata nad efektami funkcjonowania podmiotów sektora kultury jest niezwykle ważna i ciągle brakuje dobrych opracowań i sensownych rozwiązań”. W przypadku obszaru podmiotowego badacz wymienia sieci, partnerstwa oraz centra aktywności lokalnej.

„Jeśli chodzi o obszar podmiotowy, brakuje mi pogłębionych analiz sektora audiowizualnego. Stosunkowo wiele badań dotyczy kinematografii, niewiele zaś - telewizji i sektora gier" - stwierdza Konrad Klejsa. Marcin Adamczak dodaje natomiast, że:

Bardzo potrzebne byłyby szeroko zakrojone, a jednocześnie wnikliwe, komparatystyczne badania rynku audiowizualnego i przemysłów kreatywnych w różnych krajach, nie tylko europejskich. W ten sposób można porównać skuteczność poszczególnych architektur instytucjonalnych, systemów 
wsparcia i finansowania oraz ich zależność od otoczenia społecznego, rynkowego i rzeczywistości kulturowej.

Na jeszcze inny, rzadko analizowany obszar wskazał Paweł Płoski: „W obszarze podmiotowym wciąż ogromnym materiałem do zagospodarowania są historyczne ujęcia zarządzania kulturą - przede wszystkim funkcjonowanie instytucji kultury w PRL-u i jego skutki w ich współczesnej pracy”. Dorota Ilczuk z kolei zwróciła uwagę na praktyczny aspekt zarządzania kulturą:

$\mathrm{Z}$ naukowego punktu widzenia najciekawsze jest dla mnie łączenie nauki $\mathrm{z}$ aplikacyjnością. Wiedza nie może być odcięta od rzeczywistości. Lubię wiedzieć, że moja praca przekłada się na rozwiązania praktyczne, tak jak było to $\mathrm{np}$. w przypadku opracowania systemu zasilenia finansowania kultury z Totolotka ${ }^{11}$. Możliwość praktycznego zastosowania badań daje uczucie spełnienia.

Krzysztof Stachowiak ujął temat dość szeroko:

Jeśli przyjmiemy, że nauka o zarządzaniu kulturą jest specjalnością nauk o zarządzaniu, to z pewnością rozwój teorii zarządzania w odniesieniu do kultury powinien być priorytetem. Jeśli przyjąć, że nauka o zarządzaniu kulturą jest pewną wyodrębniającą się dziedziną wiedzy, to kluczowe wydaje się określenie jej specyfiki. Aby stała się ona względnie jednorodną dziedziną wiedzy (lub nawet dyscypliną naukową), powinna zmierzać w kierunku interdyscyplinarności, a potem ewentualnego usamodzielnienia (chodzi o samodzielność metodologiczną, a nie instytucjonalną). [...] W związku z tym należy rozwijać zagadnienia teoretyczne, czerpiąc w pierwszych etapach z już ugruntowanych dyscyplin (np. nauki o zarządzaniu, kulturoznawstwa). Równolegle należałoby próbować określić dziedzinę badań, a także ich zakres przedmiotowy, i rozwijać badania empiryczne. Przykładowo, przedmiotem badań może być sektor kultury rozumiany jako ta część szeroko pojętej kultury, której celem jest generowanie nie tylko wartości kulturowych, ale także wartości ekonomicznych. Przedmiotem mogą być organizacje kultury i procesy w nich zachodzące (np. jak zorganizowana jest

${ }^{11}$ D. Ilczuk odwołuje się do stworzonego z jej udziałem systemu finansowania przedsięwzięć i inwestycji kulturalnych z loterii narodowej. Totalizator Sportowy ma obowiązek przekazywać pewne środki pozyskane $\mathrm{z}$ dopłat do gier na polską kulturę, kierując je do Funduszu Promocji Kultury (przyp. red.). 
działalność kulturalna). Problematyką badawczą może być np. efektywność takich organizacji kulturalnych. To wszystko wymaga pogłębionej refleksji i możliwie szerokiej dyskusji.

\section{KULTUROZNAWSTWO JAKO INSPIRACJA DLA ZARZĄDZANIA KULTURĄ?}

Zadaliśmy naszym respondentom pytanie o to, jakie metody i modele z zakresu kulturoznawstwa mogą mieć zastosowanie w specyficznym obszarze badawczym, jakim jest zarządzanie kulturą. Joanna Śmietanka stwierdziła, iż:

Współczesna refleksja kulturoznawcza rozszerza koncepcję samej kultury, która - poza rozumieniem kultury jako zbioru ludzkich wytworów, zainteresowaniem obszarami kultury wysokiej oraz popularnej - zawiera w sobie również całokształt zwyczajów i norm panujących w danej społeczności, w tym również media, konsumpcjonizm czy zjawiska dnia codziennego, takie jak np. moda. Antropologiczne pojmowanie kultury, zachowania i indywidualne preferencje uczestników kultury, sposoby jej doświadczania, konsumpcja mediów, historia myśli o kulturze, teorie kultury - wszystko to znajduje dziś uzasadnienie w obszarze zarządzania kulturą. Teoria zarządzania kulturą czerpie z badań przedmiotowych związanych z elementami (wytworami) kultury stworzonymi przez człowieka - mogą to być analizy konkretnych ośrodków kultury w celu rozpoznania sytuacji zastanej, i tym samym możliwości proponowania rozwiązań (w formie strategii zarządzania). Zastosowanie znajdują tu obserwacje, wywiady, metody socjometryczne z zakresu wiedzy o muzyce, literaturze, plastyce, filmie, teatrze czy komunikacji.

W podobnym tonie wypowiadają się Konrad Klejsa, który zwraca uwagę na znaczenie wywiadu pogłębionego i historii mówionej, oraz Marzenna Wiśniewska, która przywołuje w tym kontekście antropologię kultury, performatykę czy metody wizualne w badaniach jakościowych. Ponadto Paweł Płoski wyróżnia oryginalne metody badania kultury produkcji rozwinięte przez Marcina Adamczaka oraz badania gdańskich socjologów kultury, którzy pod auspicjami Instytutu Kultury Miejskiej przygotowują kolejne raporty dotyczące szeroko rozumianego uczestnictwa w kulturze. Przywołany powyżej Marcin Adamczak odwołuje się natomiast do badań produkcyjnych rozwijanych przede wszystkim przez Johna T. Caldwella. 


\section{ARCHIPELAGI}

Jako że zarządzanie kulturą, jak to zostało powyżej podkreślone, stanowi wciąż nowy obszar badawczy, zdecydowaliśmy się zadać pytanie, czy można obecnie mówić już o środowisku zarządzania kulturą i o znaczących ośrodkach rozwoju tych studiów.

Paweł Płoski uważa - a jego pogląd zdaje się potwierdzać więcej respondentów - iż współpraca ta, choć istnieje, ma wymiar personalny - opiera się na relacjach, kontaktach, spotkaniach: „Mam wrażenie rozproszenia. Zamiast ośrodków mamy wiele osób. »Żyjemy na archipelagach « - by użyć słów poety". Tadeusz Stryjakiewicz zwrócił natomiast uwagę na lokalny charakter tych kontaktów.

Większość osób, które wzięły udział w ankiecie, zdecydowanie podkreśliła znaczenie budowania środowiska badaczy i nawiązywanie współpracy między nimi, jednocześnie ubolewając nad niewystarczającym stanem rozwinięcia tych relacji.

„Król” jest jeden - Instytut Kultury Uniwersytetu Jagiellońskiego, który od lat wydaje cenione czasopismo „Zarządzanie w Kulturze”. „Przoduje ośrodek krakowski, szkoła zarządzania w kulturze stworzona przez profesora Emila Orzechowskiego. W tym wypadku można mówić o konkretnym środowisku badaczy powiązanych $\mathrm{z}$ ośrodkiem Uniwersytetu Jagiellońskiego” - stwierdza Dorota Ilczuk, a wtóruje jej Paweł Płoski: „Ani w Warszawie, ani w Poznaniu, ani w Gdańsku nie nastąpiło jeszcze takie skonsolidowanie sił, z jakim mamy do czynienia w przypadku Krakowa”. „W skali kraju środowisko badaczy jest zatomizowane. Nie znamy się - mówi Dorota Ilczuk. - Paradoksem jest, że kolegów zajmujących się tą dziedziną spotykałam zazwyczaj na konferencjach zagranicznych. Zrozumiałam wówczas, jak potrzebne jest stworzenie mechanizmu wymiany, wspólnej platformy porozumienia”. Dlatego też w maju 2016 roku Doota Ilczuk zainicjowała utworzenie nieformalnej sieci ekonomistów, teoretyków i praktyków zarządzania kulturą oraz ich przyjaciół. Zainteresowanie tą inicjatywą jest bardzo duże.

Na konieczność poszerzenia sieci współpracy zwrócił uwagę także Piotr Majewski: „Na pewno niewystarczająca jest współpraca między ośrodkami naukowymi a instytucjami kultury jako takimi. A nic przecież tak dobrze nie kształtuje wiedzy o zarządzaniu, jak umiejętne łączenie teorii z praktyką, korzystanie $\mathrm{z}$ wiedzy ludzi, którzy smak praktyki poznali, często 
odkrywając teorię w terminie późniejszym, czy też - polegając na intuicji jedynie...”. Dobrym przykładem jest tutaj znowu Kraków. Jak stwierdza Alina Kozarkiewicz, w ramach współpracy instytucji kultury i uczelni w Krakowie tworzone są inicjatywy badawcze dotyczące kultury (np. diagnozy), wspierane przez instytucje samorządowe (np. Małopolski Instytut Kultury). Istnieją również fundacje wspierające taką współpracę.

Krzysztof Stachowiak uważa, że być może nie należy jeszcze mówić o środowisku, ale o ośrodkach skupionych wokół konkretnych osób. Poza najważniejszym ośrodkiem krakowskim badacz wymienia takie uczelnie, jak: Uniwersytet Ekonomiczny w Krakowie, Szkoła Główna Handlowa w Warszawie, Uniwersytet Kardynała Stefana Wyszyńskiego w Warszawie, Uniwersytet Warszawski, a także Uniwersytet im. Adama Mickiewicza w Poznaniu, Uniwersytet Wrocławski, Uniwersytet Śląski i Uniwersytet Ekonomiczny w Katowicach. Wypowiedź Konrada Klejsy skłania, by dodać do tej listy jego rodzimy Uniwersytet Łódzki. Z kolei Joanna Śmietanka zwraca uwagę na znaczenia działalności Narodowego Centrum Kultury w Warszawie, w którym „zadaniem statutowym jest podejmowanie działań na rzecz rozwoju kultury w Polsce, między innymi poprzez edukację kulturalną oraz zwiększanie zainteresowania kulturą i sztuką, rozwój i profesjonalizację sektora kultury, promocję polskiego dziedzictwa narodowego oraz podtrzymywanie i upowszechnianie tradycji narodowej i państwowej”.

Urszula Grzelońska przy pracy nad książką Ekonomiczna strona kultury korzystała z lektury prac np. socjologa kultury prof. Mariana Golki oraz kulturoznawcy prof. Jacka Sójki (obaj z Uniwersytetu im. Adama Mickiewicza). Badaczka podkreśliła również dorobek prof. Doroty Ilczuk związanej z kulturoznawstwem na Uniwersytecie Humanistycznym SWPS. Z kolei Agata Siwiak zwróciła uwagę na dorobek zespołu kierowanego przez prof. Jerzego Hausnera w Katedrze Gospodarki i Administracji Publicznej na Uniwersytecie Ekonomicznym w Krakowie (to zresztą, obok ośrodka z Uniwersytetu Jagiellońskiego, jeden z pionierów polskiego zarządzania kulturą):

Ja sama staram się skupiać na tym, co robię na mojej uczelni - w Instytucie Teatru i Sztuki Mediów UAM - czyli też działam w pewnej izolacji. Na UAM prowadzę specjalizację dla kuratorów i producentów teatralnych, której finałem jest Festiwal Nowa Siła Kuratorska, w ramach którego studenci 
rokrocznie przygotowują autorskie projekty artystyczne. Programują je na poziomie artystycznym i produkują: zdobywają środki finansowe, pieniądze, sieciują instytucje kultury, pozyskują partnerów i mecenasów. [...] Zarządzanie kulturą jest dyscypliną, którą warto badać przez praktykę.

Łukasz Wróblewski wspomina o działalności Wyższej Szkoły Biznesu w Dąbrowie Górniczej (WSB): uczelnia ta jest organizatorem cyklicznej Międzynarodowej Konferencji Naukowej „Współczesne problemy zarządzania i marketingu w instytucjach kultury", prowadzi również regularne badania w sektorze kultury na pograniczu polsko-czeskim. Marzenna Wiśniewska dodaje do tej listy Instytut Kultury Współczesnej UŁ oraz Wydział Humanistyczny UMCS w Lublinie. Jej zdaniem trudno jest jednak mówić w Polsce o środowisku badaczy zarządzania kulturą, gdyż jest to dyscyplina stosunkowo młoda i mało skonsolidowana w ośrodkach badawczych:

Zarządzaniem kulturą zajmują się badacze różnych dyscyplin i dla wielu $\mathrm{z}$ nich nie jest to główny nurt badań, ale dziedzina towarzysząca - dzieje się tak zarówno wtedy, gdy podstawowym obszarem badacza są nauki spoleczne, jak i w przypadku nauk humanistycznych (np. kulturoznawstwa). Brakuje w Polsce konferencji, sesji, programów, projektów, które umożliwiłyby spotkania i wymianę myśli oraz doświadczeń badaczy podejmujących zagadnienia związane z zarządzaniem kulturą.

$\mathrm{Na}$ bardzo ciekawy, niejako psychologiczny aspekt współpracy między badaczami zwrócił uwagę Konrad Klejsa, który zauważył, że „środowiska "znawców kultury« oraz osób chcących uchodzić za "ekspertów od zarządzania« są rozłączne, zbyt rzadko się zazębiają, a gdy na siebie natrafią, niekiedy trudno im się porozumieć”. Badacz podaje też jednak przykład z własnego doświadczenia, który pokazuje, ile można „ugrać” na współdziałaniu w tej dziedzinie: „Całkiem niedawno moja koleżanka z łódzkiego Instytutu Kultury Współczesnej oraz jej kolega z Instytutu Ekonomii napisali wspólnie artykuł o crowdfundingu i został on opublikowany w »topowym« czasopiśmie międzynarodowym z ministerialnej listy A. I tego rodzaju inicjatywy - wspólne, kulturoznawców i ekonomistów lub prawników - mają według mnie przyszłość". 


\section{Z PUNKTU WIDZENIA PRAKTYKA}

Niezaprzeczalną wartością ankiety okazało się włączenie do rozmowy praktyków, którzy na co dzień, czasami intuicyjnie, starają się dostosować dostępne narzędzia i modele do codziennego zarządzania instytucją kultury, projektem, organizacją. Interesujące jest podejście do zarządzania przedstawione przez Iwonę Haberny, która twierdzi, że:

Chodzi o stworzenie warunków, w których kultura (twórcy i ich publiczność) może się najpełniej rozwijać. [...]. Potrzebna jest osobna refleksja teoretyczna, która pozwoli ustalić priorytety, kryteria i długofalowe cele. Natomiast wdrażanie tego wymaga otwarcia się na wiedzę już wypracowaną - zarządzanie, marketing, promocję. W tym wypadku nie widzę powodu, by wyważać otwarte drzwi i tworzyć nowe teorie na potrzeby kultury.

Ida Bocian (Teatr Gdynia Główna) zauważyła natomiast, że „metody działania (nawet zarządzania) należy dostosowywać na bieżąco do wyznaczonych celów, zespołu ludzkiego, z którym mam pracować, struktury, w którą wchodzę (jako pracownik i zarządzający), a w szczególności - potrzeb odbiorców naszych działań. To oczywiście wymaga od zarządzającego elastyczności, ale również zaryzykowania i pewnych założeń wstępnych, których skuteczność możemy w trakcie realizacji zadań sprawdzać”. Kamila Lewandowska $z$ kolei podkreśliła konieczność „dostosowania” klasycznych metod zarządzania do działalności kulturalnej:

Wiele prac poświęconych zarządzaniu lub marketingowi kultury opiera się na (zbyt) dosłownym zapożyczaniu rozwiązań z zarządzania biznesowego. Publikacje te są ciężko przyswajalne dla studentów i mało przydatne dla praktyków. Udane publikacje/szkolenia/zajęcia powinny raczej opierać się na pogłębionej analizie ciekawych przypadków (case studies), a w mniejszym stopniu na modelach, diagramach i definicjach w formie bullet points. Dobrych wzorców dostarczają kraje anglosaskie, gdzie nauczanie zarządzania opiera się na analizie przypadków.

Joanna Śmietanka puentuje: „Pamiętać należy przy tym, że zarządzanie kulturą nie tworzy kultury, ale ją umożliwia. Polega przede wszystkim na dostarczaniu dóbr kulturalnych poprzez umiejętne zarządzanie tworami kultury, ale też ośrodkami, w których one powstają". 


\section{ZAKOŃCZENIE}

Na koniec warto przywołać refleksję Urszuli Grzelońskiej, która zwróciła uwagę na ścisły związek między zarządzania kulturąa a życiem:

Najważniejszą sprawą zarządzania w kulturze w dzisiejszych czasach jest odpowiednie umotywowanie ludzi - odbiorców kultury, nie tylko aby chcieli korzystać z obecnych i dawniej wytworzonych dóbr kultury, ale też aby zechcieli płacić za wytworzenie i ochronę dziedzictwa kulturowego, i to płacić nie tylko za bilety wstępu do instytucji kulturalnych, ale aby poczuwali się do obowiązku filantropii na rzecz kultury. Uczenie zarządzania w kulturze to, moim zdaniem, uczenie ludzi, jak fachowo organizować sponsoring różnych działań kulturalnych wśród różnych grup społecznych i dochodowych, a nie tylko szukać sponsorów w grupie kilku banków i firm przetwarzających ropę naftową. Rozważenie różnych możliwych teoretycznie sposobów organizowania i finansowania działalności kulturalnej uczy, że polegając tylko na rynku i na państwie, w żadnym kraju nie osiągnie się satysfakcjonującej intensywności życia kulturalnego, spełniającego oczekiwania każdego odbiorcy.

Autorefleksyjną dyskusję na temat zarządzania w kulturze zamyka dłuższa wypowiedź prof. Emila Orzechowskiego, twórcy słynnego krakowskiego ośrodka i jednego z polskich pionierów zarządzania kulturą.

Emil Orzechowski (UJ)

\section{Zarządzanie kulturą a zarządzanie w kulturze}

Małe, niepozorne „a”, lecz wielką różnicę czyni. Tak mi się przynajmniej wydaje, choć refleksji na ten temat w polskiej literaturze nie znajduję. Moim zdaniem „zarządzanie kulturą” to sfera polityczna, „zarządzanie w kulturze” to pragmatyka sektora kultury. Jest to ważne, wręcz zasadnicze rozróżnienie kompetencji, a zatem i zakresów odpowiedzialności. Rzecz jasna, aby móc sensownie rozmawiać o tych kwestiach, należy najpierw uzgodnić zakres pojęcia zasadniczego - „kultura”. Do wyboru jest tu albo lapidarne, lecz wartościujące określenie Karola Wojtyły, zgodnie z którym „kulturą godzi nazywać się to wszystko, co przyczynia się pozytywnie do rozwoju człowieka"12, albo chłodna, technokratyczna, amerykańska definicja przyjęta

12 Konstytucja duszpasterska o Kościele w świecie współczesnym „Gaudium et spes”, [w:] Sobór Watykański II. Konstytucje, dekrety, deklaracje, Poznań 2002, nr 53. 
i popularyzowana u nas przez Piotra Sztompkę, która mówi, że kultura obejmuje „wszystko, co ludzie czynią, myślą i posiadają jako członkowie społeczności”'13 (kultura symboliczna, materialna, normatywna). Definicja ta pozwala na domniemanie, że cała ta sfera podlega wpływom politycznym, a jej możliwości określa to, co w teorii zarządzania Ricky W. Griffin nazywa otoczeniem ogólnym w wymiarze prawno-politycznym, socjokulturowym, międzynarodowym etc. ${ }^{14}$ Jej zastosowanie w kategoriach zarządzania w kulturze umożliwia ważne dopełnienie Antoniny Kłoskowskiej, która dostrzega „instytucjonalny układ kultury [...] w ramach określonych specjalnymi regułami formalnie zorganizowanych instytucji, na przykład szkół, kościołów, teatrów, filharmonii, domów kultury"15. Jednak i ona dodaje, że „ten układ podlega zwykle kontroli szerszych organizacji wchodzących w skład socjetarnej kultury, jest przedmiotem wpływów polityki kulturalnej lub pluralistycznych polityk kulturalnych"16. Z takiego ujęcia wynika, że między zarządzaniem kulturą (polityką kulturalną) a zarządzaniem w kulturze nie powinno być niejasności, a już szczególnie sprzeczności - to drugie powinno logicznie i harmonijnie wynikać z pierwszego. Czy tak jest u nas istotnie?

Nie jest, bo „państwo polskie mózgu jest pozbawione” (Jerzy Hausner ${ }^{17}$ ) i nie ma żadnej racjonalnie wypracowanej polityki kulturalnej. Prezes Polskiej Akademii Nauk, prof. Michał Kleiber, skomentował sytuację nie mniej drastycznie: „Polska jest rzadkim przykładem cywilizowanego kraju, w którym nie istnieje ośrodek studiów strategicznych [...]. Politycy nie są zainteresowani niezależnymi ekspertyzami, bo obawiają się, że mogą krępować swobodę ich działania"18.

Zasady polityki kulturalnej muszą być oparte na gruntownej znajomości faktów - faktów zinterpretowanych przez wnikliwych analityków, których opracowania zrecenzują wybitni eksperci, tak akademicy, jak i praktycy, a następnie zostaną one poddane publicznej dyskusji i uchwalone przez Sejm

13 P. Sztompka, Socjologia: analiza społeczeństwa, Kraków 2002, s. 233.

14 R.W. Griffin, Podstawy zarządzania organizacjami, tłum. M. Rusiński, Warszawa 2004, s. 77.

15 A. Kłoskowska, Społeczne ramy kultury. Monografia socjologiczna, Warszawa 1972, s. 41.

${ }^{16}$ Ibidem.

17 Cyt. za: E. Bendyk, Gdzie Tusk ma mózg?, „Polityka”, www.polityka.pl/ tygodnikpolityka/kraj/1536403,1,gdzie-jest-mozg-polskiego-panstwa.read [dostęp: 8.11.17].

18 Ibidem. 
czy przyjęte przez Rząd. Aby dokument taki mógł powstać, potrzebne jest prowadzenie systematycznych badań. Jak je zorganizować? - podpowiedzi udziela Mark J. Schuster w książce Informacja w polityce kulturalnej, będącej przeglądem chyba wszystkich istotnych światowych wzorców. Jakie będą tego konsekwencje? - niesłychanie ważne, gdyż polityka kulturalna to, moim zdaniem, nic innego jak odpowiednik misji w procesach zarządzania. A wiadomo, że od misji wszystko się zaczyna. Misja wskazuje wartości, krąg odbiorców, sposoby działania. Misja integruje, wskazuje na wyjątkowe walory oferty. Państwa, w których takie studia były i są prowadzone, dopracowały się precyzyjnych nazw resortów, w jakich mieści się kultura, i, co ciekawe, chyba nigdzie nie występuje ona bez partnera, którym może być sport, turystyka, często edukacja, a nawet i rynek pracy (sic!). W Polsce nazwa ministerstwa ulega zmianie, kiedy tak sobie wymyśli dany minister lub - co gorsze - jego partia. Co jednak znaczy obecny „partner” kultury „dziedzictwo narodowe” - dalibóg, nie wiem. Nie sądzę też, by twórca tego dopełnienia, Kazimierz Michał Ujazdowski, miał na uwadze te wartości (i metody ich implementacji), jakim hołduje dziś minister Piotr Gliński. Ale skoro wiemy, że „dziedzictwo narodowe” oznaczać może bardzo różne wartości, przyzwoitość nakazuje, aby je dookreślić. M.J. Schuster pisze wprost: „Jest, czy też i nie, politycznie poprawne używanie słów »polityka kulturalna« w uładzonym towarzystwie, każde społeczeństwo ma jakąś i powinno to być oczywistością, że mamy możność oceniać, jak ona funkcjonuje”, i niejako ostrzega: „Polityka może być wyłożona klarownie [explicit], i w takim przypadku może być wyczytana w istniejących dokumentach, albo też może być ukryta [implicit], a wówczas można o niej wnioskować na podstawie oświadczeń i działań” ${ }^{\prime 19}$. Zapewne wielka musiała być frustracja i konfuzja znakomitego skądinąd dziennikarza „Polityki”, który napisał kilkanaście lat temu: „na rynku, gdzie znalazła się w ostatniej dekadzie także kultura, nikt nie pyta przecież o idee”, i jeszcze, co gorsza, dodał: „Rząd obiecuje, że zadba o pieniądze, ale przecież na tym - na szczęście - kończy się dzisiaj polityka kulturalna państwa”20. Co więcej, w tym samym numerze „Polityki” jego nie mniej znakomity kolega w artykule pod wymownym tytułem Nie porzucaj mnie rozpaczliwie błagał o regulacje, które spowodują, że „bogaci

19 M.J. Schuster, Informacja w polityce kulturalnej. Infrastruktura informacyjna i badawcza, tłum. M. Król, Kraków 2007, s. X.

20 Z. Pietrasik, Rząd założy kabarety, „Polityka”, https://archiwum.polityka. $\mathrm{pl} / \mathrm{art} / \mathrm{rzad}-\mathrm{zalozy}-\mathrm{kabaret}, 373328 . \mathrm{html}$, [dostęp: 15.11.17]. 
i twórczy znów padną sobie w ramiona”21. Jak to możliwe przy braku polityki kulturalnej - doprawdy, nie wiadomo... Amerykanie, którzy też nie mają polityki kulturalnej wyrażonej explicite, de facto realizują ją bez deklaracji i na swój pragmatyczny sposób: poprzez regulacje podatkowe, sprzyjanie fundacjom i wszelkim inicjatywom obywatelskim.

$\mathrm{Z}$ tego, co napisałem, wynika jeden wniosek: polityka kulturalna jest zarządzaniem kulturą, i z niej dopiero wyprowadzone mogą być sposoby zarządzania w kulturze. Jasno pisze o tym Schuster: „Dopiero wówczas, gdy zasady polityki kulturalnej są określone, potrzeba planowania staje się oczywista. Plany obejmują strategię, zestaw działań, które pozwolą nam na przejście z miejsca, w którym jesteśmy, na miejsce, w którym chcielibyśmy być. Plan opiera się na możliwie najlepszym rozpoznaniu tego, jaki rodzaj działań jest najlepszy dla osiągnięcia zakładanych celów przy najsprawniejszym wykorzystaniu dostępnych zasobów"22.

Zarządzanie, rzecz jasna, miało i ma na celu realizację misji w sposób „sprawny i skuteczny” (R.W. Griffin) ${ }^{23}$. Mimo że - podobnie jak kultura obecne było od zawsze, zaczęło być traktowane serio dopiero wówczas, gdy i maszyna, i wykorzystanie jej możliwości stały się - z punktu widzenia rentowności - ważniejsze od człowieka. Kwestia, jak sprawić, by człowiek nadążał za maszyną, była główną troską klasyków zarządzania. W ten sposób zarządzanie trafiło w zazdrosne ręce wąsko patrzących ekonomistów, zysk li tylko materialny mających na uwadze. Trzeba było wielu lat, by nieco inne spojrzenie zostało potraktowane serio. To nowe spojrzenie to myśli Petera Druckera, który w roku 1969 napisał: „Zarządzanie będzie musiało być traktowane jako "nauka ścisła» $\mathrm{i}$ »humanistyka« [science and humanity]", i objaśniał to w ten sposób: „Zarządzanie jest również kulturą i systemem wartości i przekonań. Jest też środkiem, za pomocą którego dane społeczeństwo uruchamia swoje własne wartości i przekonania. Zarządzanie może być uznawane za pomost między cywilizacją [...] i kulturą, która wyraża rozmaite tradycje, wartości, wierzenia i dziedzictwo. Zarządzanie musi stać się instrumentem, za pomocą którego różnorodność kulturowa będzie służyć wspólnym celom ludzkości”. Badacz konkludował, że „jeśli zarządzanie nie zdoła uruchomić specyficznego dziedzictwa kultury danego kraju i narodu,

${ }^{21}$ P. Sarzyński, Nie porzucaj mnie, „Polityka”, https://archiwum.polityka.pl/ art/nie-porzucaj-mnie,375622.html [dostęp: 8.11.17].

22 M.J. Schuster, op. cit., s. X.

${ }^{23}$ R.W. Griffin, op. cit., s. 6. 
nie zaistnieje rozwój społeczny i ekonomiczny"24. Trzeba było wielu lat, by Lawrence E. Harrison i Samuel Huntington wydali zbiorową pracę pod tytułem Kultura ma znaczenie ze znaczącym podtytułem: Jak wartości wpływaja na rozwój społeczeństw ${ }^{25}$.

W Polsce myślom takim przebić się nie było - a i nadal nie jest - łatwo, mimo oryginalnego wkładu do nauki światowej takich myślicieli, jak Florian Znaniecki czy Tadeusz Kotarbiński. Historia pierwszego w Polsce kierunku studiów z zakresu zarządzania kulturą dostarcza tu aż nadto wiele wymownych przekładów. Początkowo był to kierunek Zarządzanie i marketing, skąd został „przegoniony” decyzją Polskiej Komisji Akredytacyjnej, złożonej z samych ekonomistów. Potem był kierunek Sprawy publiczne - zgodnie z sugestią autorytetów z zakresu administracji. Hubert Izdebski i Michał Kulesza pisali: „wymogi ekonomiki, techniki i zarządzania nie są w stanie całkowicie wyeliminować ani odrębności narodowych, wynikających z tradycji historycznych, ani też faktu, że zarządzanie publiczne uwikłane jest zawsze w materie władzy publicznej, a »interes publiczny« nie zawsze daje się pogodzić z ogólnymi kryteriami efektywnościowymi”"26. Zarządzanie kulturą nie mieściło się jednak i w tym obszarze, bo kultura spełnia się we wszystkich sektorach, także prywatnym (rynek książki, dzieł sztuki). Potem było kulturoznawstwo, „śmietnik” o elitarnych ambicjach - dość powiedzieć, że na samym Uniwersytecie Jagiellońskim jest około trzydziestu kulturoznawstw, a próby ich sensownego zreformowania w kierunku scalenia są skazane na porażkę. Na zarządzanie kulturą/w kulturze nie było tam, zdaniem kulturoznawczych autorytetów, miejsca. A szkoda, bo wszystkimi procesami, jakimi zajmuje się kulturoznawstwo, także się zarządza, a im sprawniej i skuteczniej, tym lepsze są efekty. Ostatecznie - od czasu reformy kształtowania programów studiów - kierunek ten ma nazwę Zarządzanie kulturą i mediami, która definiuje pole akademickich zainteresowań tej nowej dyscypliny naukowej.

Oczywistością jest, że nie ma nauki bez metodologii. Tu tropy wskazywali nam ci, którzy byli pionierami na tym polu. Nieprzypadkowo pierwszym przetłumaczonym na polski i przez nas wydanym podręcznikiem

${ }^{24}$ P.F. Drucker, Management's New Role, „Harvard Business Revue” 1969, November-December, s. 49-54.

${ }^{25}$ L. Harrison, S. Huntington, Kultura ma znaczenie. Jak wartości wptywaja na rozwój społeczeństw, tłum. S. Dymczyk, Poznań 2003.

${ }^{26} \mathrm{H}$. Izdebski, M. Kulesza, Administracja publiczna. Zagadnienia ogólne, Warszawa 2004, s. 298. 
była książka Giepa Hagoorta Przedsiębiorczość w kulturze ${ }^{27}$, potem prace Petera Bendixena ${ }^{28}$, Marka J. Schustera i in. Wielki materiał do przemyślenia przyniosły wykłady ambasadorów na temat polityki kulturalnej ich kraju. Owocem poszukiwań i testowania metodologii były kolejne prace doktorskie, habilitacyjne czy tak zwane profesorskie, najczęściej wydawane we własnej serii „Biblioteka Zarządzania w Kulturze”. Jej funkcję spełniają dziś wydawnictwa między innymi Narodowego Instytutu Kultury, dysponującego środkami nieporównanie większymi niźli uniwersytet. Co jest przy tym ważne, może i najważniejsze, to fakt, że w owe metodologiczne poszukiwania włączyło się już wielu ekonomistów. Nowe impulsy dały prace Doroty Ilczuk $^{29}$, Łukasza Sułkowskiego ${ }^{30}$ i wielu innych, natomiast ostatnio wiele w tej materii uczyniła Monika Kostera, publikując między innymi Manifest humanistyczny o zrównoważone zarządzanie, w którym dobitnie zaznaczyła: „Nadszedł dla nas, zwykłych ludzi, czas, żeby odzyskać zarządzanie”, co $\mathrm{w}$ tym przypadku wskazuje na proces prowadzony $\mathrm{z}$ myślą o poszukiwaniu zarządzania humanistycznego i zarządzania w humanistyce ${ }^{31}$.

Nie ma nauki bez prowadzenia badań i upowszechniania ich wyników. Powołaliśmy zatem na UJ dwa czasopisma naukowe: „Zarządzanie w Kulturze” oraz międzynarodowe „Culture Management”, a także serię wydawniczą „Biblioteka Zarządzania w Kulturze”, w której wyszło wiele prac tłumaczonych i sporo oryginalnych, pionierskich w Polsce. Było to wszystko możliwe wyłącznie dzięki pełnej zaufania dla inicjatorów zarządzania w naukach humanistycznych decyzji Centralnej Komisji ds. Stopni i Tytułów Naukowych uznającej prawo Wydziału Zarządzania i Komunikacji Społecznej UJ do nadawania stopni i tytułów w zakresie nauki humanistyczne, dyscyplina: zarządzanie.

Wydaje się, że na poziomie najogólniejszym kwestie sporne wokół ulokowania zarządzania kulturą/w kulturze w sieci akademickich dziedzin załatwia, a tym samym i wszystkie spory likwiduje, ujęcie św. Tomasza z Akwinu, przypomniane przez Jana Pawła II na spotkaniu z rektorami

${ }^{27}$ G. Hagoort, Przedsiębiorczość w kulturze. Wprowadzenie do zagadnień zarządzania w kulturze, tłum. B. Bezemer-Szefke, E. Orzechowski, Kraków 1996. ${ }_{28}$ P. Bendixen, Wprowadzenie do ekonomiki kultury i sztuki, tłum. K.D. Kopeć, Kraków 2001.

29 D. Ilczuk, op. cit.

30 Ł. Sułkowski, Kulturowa zmienność organizacji, Warszawa 2002.

${ }_{31}$ M. Kostera, Manifest humanistyczny o zrównoważone zarządzanie, [w:] Zarządzanie. Kultura - media - dziedzictwo, Kraków 2013, s. 14. 
polskich uniwersytetów: „Genus humanum arte et ratione vivit: arte et ratione”32. Zamiast alternatywy mamy tu spójnik „i” - to wielka różnica. Jan Paweł II objaśniał to w sposób następujący: „A więc nauka, człowiek żyje nauką! Nauką, czyli poszukiwaniem prawdy o samym sobie i świecie otaczającym, wreszcie o Bogu. Człowiek jest nie tylko twórcą kultury, ale żyje kulturą i żyje poprzez swoją kulturę. To samo należy powiedzieć o narodzie. Także naród żyje kulturą i żyje poprzez swoją kulturę. Ona jest fundamentem jego duchowej suwerenności”. Oddając te kwestie pod rozwagę i opiekę uczonych, ostrzegał: „Sytuacja demokracji i wolności wymaga od środowisk akademickich wiele inicjatywy, wiele przedsiębiorczości, rzec można, i poczucia odpowiedzialności. Wymaga także czujności, ażeby wolności, z takim trudem i za taką cenę odzyskanej, nie tracić pod wpływem rozmaitych presji czy manipulacji, od których nie są wolne również współczesne demokracje”. Nazwał je po imieniu: „Obecnie pojawiają się nowe trudności i nowe zagrożenia. Jednym $\mathrm{z}$ nich w systemie liberalnej demokracji i wolnego rynku jest postawa skrajnego utylitaryzmu. Szerzy się bowiem sposób myślenia, który kryterium korzyści ekonomiczne uważa za normę najważniejszą i aplikuje ją do wszystkich dziedzin życia - także do sfery kultury i nauki”33.

Warto zauważyć, że R. Griffin, autor jednego z najbardziej popularnych akademickich podręczników na temat zarządzania - Podstawy zarządzania organizacjami - uważał podobnie, skoro we wstępie do swego dzieła stwierdził, że największymi menedżerami tego świata są: papież (gdy pisał te słowa, był nim Jan Paweł II) oraz prezydent Stanów Zjednoczonych ${ }^{34}$. Podobne uprawnienia, w stosownej skali, przypisywał dyrektorowi muzeum sztuki, prezesowi piłkarskiego klubu etc. To, że zajął się potem zarządzaniem zorientowanym na zysk ekonomiczny, nie zmieniło jego zasadniczego przekonania, że ogólne reguły zarządzania dotyczą instytucji i organizacji wszelkiego rodzaju. Jedyne, co je różni, to misja i zawarte w niej wartości, a także fakt, że dla różnego kręgu organizacji najważniejsze będą różne rodzaje zasobów; w sferze kultury nie są to zasoby materialne, lecz ludzie.

W latach ostatnich pojawiły się też i inne zagrożenia, których nawet święty nie był w stanie przewidzieć. W ich kontekście menedżer kultury

32 Wystąpienie ojca świętego Jana Pawła II podczas spotkania z rektorami polskich uniwersytetów, które odbyło się 4 stycznia 1996 roku w Watykanie. https:/w2.vatican.va/content/john-paul-ii/pl/speeches/1996/january/documents/ hf_jp-ii_spe_19960104_rettori-polonia.pdf [dostęp: 8.11.2017].

33 Ibidem.

34 R.W. Griffin, op. cit, s. 7. 
musi pamiętać o słowach Władysława Stróżewskiego, który definiuje dwa pojęcia kluczowe, niesłychanie dziś ważne przy budowaniu misji (polityki kulturalnej): „etyka obywatelska” $\mathrm{i}$ „etyka obywatela”35. Pierwsza z nich jest „etyką powinności, etyką obowiązku” ${ }^{6}$ i „dotyczy wszystkich obywateli, przede wszystkich jednak tych, którzy pretendują do podjęcia władzy"37. Z kolei „etyka obywatela to etyka odpowiedzialności”38. Stróżewski dodaje: „Punktem odniesienia etyki obywatelskiej jest państwo i jego prawa. Punktem odniesienia etyki obywatela jest ojczyzna"39, i wzmacnia to stwierdzenie cytatem z Cypriana Kamila Norwida: „Ojczyzna to wielki zbiorowy obowiązek". Ironią losu jest to, że pochodzi on z tekstu Memoriał o młodej emigracji.

W „Polityce” Jan Hartman pisze: „Każdy patrzy wszak tylko, gdzie by tu wyjechać albo załapać się na stypendium lub grant" ${ }^{\text {"40 }}$, a Włodzimierz Borodziej dodaje: „W Polsce nie idea europejska ma poparcie większości, lecz europejskie subwencje [...]. A gdy subwencje się skończą, to niech się rozleci. Usunięcie europejskich flag przez Beatę Szydło było wyraźnym sygnałem. Europa to subwencje i jak najmniej zobowiązań. W najlepszym razie strefa wolnego handlu"41. A więc jednak święty przewidział - przed tym właśnie nas ostrzegał.

\section{Bibliografia}

Peter Bendixen, Wprowadzenie do ekonomiki kultury i sztuki, tłum. K.D. Kopeć, Wydawnictwo UJ, Kraków 2001.

Rudolf Bing, 5000 wieczorów w operze, tłum. W. Kalinowski, PIW, Warszawa 1982. Szymon Cyfert, Wojciech Dyduch, Dominika Latusek-Jurczak, Jerzy Niemczyk, Agnieszka Sopińska, Subdyscypliny w naukach o zarządzaniu - logika

35 W. Stróżewski, O wielkości. Szkice z filozofii człowieka, Kraków 2002, s. 228.

36 Ibidem.

37 Ibidem.

38 Ibidem, s. 232.

39 Ibidem, s. 236.

40 J. Hartman, Inteligencja 2.0, „Polityka” 2016, nr 3049, s. 95.

41 A. Krzemiński, Pawie narodów, [Rozmowa z prof. W. Borodziejem], „Polityka”, https://archiwum.polityka.pl/art/pawie-narodow,449841.html [dostęp: 12.11.17]. 
wyodrębniania, identyfikacja modelu koncepcyjnego oraz zawartość tematyczna, „Organizacja i Kierowanie” 2014, nr 1(161), s. 37-48.

Peter F. Drucker, Management's New Role, „Harvard Business Revue” 1969, November-December, s. 49-54.

RickyW. Griffin, Podstawy zarządzania organizacjami, tłum. M. Rusiński, Wydawnictwo Naukowe PWN, Warszawa 2004.

Urszula Grzelońska, Ekonomiczna strona kultury, Wydawnictwo Key Text, Warszawa 2016;

Giep Hagoort, Przedsiębiorczość w kulturze. Wprowadzenie do zagadnień zarzadzania w kulturze, tłum. B. Bezemer-Szefke, E. Orzechowski, Wydawnictwo UJ, Kraków 1996.

Lawrence E. Harrison, Samuel P. Huntington Kultura ma znaczenie. Jak wartości wpływaja na rozwój społeczeństw, tłum. S. Dymczyk, Zysk i S-ka, Poznań 2003.

Dorota Ilczuk, Ekonomika kultury, Wydawnictwo Naukowe PWN, Warszawa 2012. Hubert Izdebski, Michał Kulesza, Administracja publiczna. Zagadnienia ogólne, „Liber”, Warszawa 2004.

Rafał Kasprzak, Przemysty kreatywne w Polsce: uwarunkowania i perspektywy, Kamon Consulting, Warszawa 2013.

Antonina Kłoskowska, Społeczne ramy kultury. Monografia socjologiczna, PWN, Warszawa 1972

Konstytucja duszpasterska o Kościele w świecie wspótczesnym „Gaudium et spes”, [w:] Sobór Watykański II. Konstytucje, dekrety, deklaracje, Pallotinum, Poznań 2002, nr 53

Monika Kostera, Manifest humanistyczny o zrównoważone zarządzanie, [w:] Zarządzanie. Kultura - media - dziedzictwo, Attyka, Kraków 2013, s. 9-14.

Gregory Ferrell Lowe, Introduction: What's So Special About Media Management, [w:] Managing Media Firms and Industries. What's So Special About Media Management, red. G.F. Lowe, Ch. Brown, Springer, New York - Dordrecht London 2016, s. 3-4.

Mark Davidson J. Schuster, Informacja w polityce kulturalnej. Infrastruktura informacyjna i badawcza, tłum. M. Król, Wydawnictwo UJ, Kraków 2007.

Krzysztof Stachowiak, Problemy metodologiczne badania sektora kreatywnego, „Rozwój Regionalny i Polityka Regionalna” 2015, nr 30, s. 14-16.

Władysław Stróżewski, O wielkości. Szkice z filozofii człowieka, Znak, Kraków 2002. 
Łukasz Sułkowski, Kulturowa zmienność organizacji, Polskie Wydawnictwo Ekonomiczne, Warszawa 2002.

Piotr Sztompka, Socjologia: analiza społeczeństwa, Znak, Kraków 2002.

David Throsby, Ekonomia i kultura, tłum. O. Siara, Narodowe Centrum Kultury, Warszawa 2010.

Ruth Towse, Ekonomia kultury. Kompendium, tłum. Ł. Skrok, H. Dębowski, K.L. Pogorzelski, Narodowe Centrum Kultury, Warszawa 2011.

\section{Around Cultural Management. The Outcome of the Research Survey}

In the spring of 2017 we conducted a survey among researchers in the broadly understood creative sectors, and among managers, often combining experience in this field with academic practice. We asked, among other things, about the cultural management, the specificity of this research area, and the most important environments dealing with this subject. Twenty people responded to our request. The results of this - in fact, self-reflective - research is presented below. Subjective attitude of the respondents to the problems, diversity of positions, and in many points also their convergence form the foundation on which to build research exploration in this area and find, still numerous, white spots.

Keywords: cultural management, culture studies, economy of the culture, interdisciplinary approach, creative industries 


\section{POŚREDNICY KULTUROWI I ICH ROLA W GOSPODARCE KREATYWNEJ}

KRZYSZTOF STACHOWIAK

Instytut Geografii Społeczno-Ekonomicznej i Gospodarki Przestrzennej UAM

Institute of Socio-Economic Geography and Spatial Management, Adam Mickiewicz University in Poznań

krst@amu.edu.pl

\section{WPROWADZENIE - PODMIOTY GOSPODARKI KREATYWNEJ}

Gospodarka kreatywna jest tą częścią systemu gospodarczego, której rozwój dokonuje się pod dominującym wpływem kultury i jej zasobów. Dobra powstające w takiej gospodarce, które można określić jako dobra kreatywne, charakteryzują się relatywnie wysoką wartością kulturową, ale także posiadają zdolność generowania wartości ekonomicznej. To oznacza, że mogą być nabywane i sprzedawane na rynku. Dlatego też działalności, które prowadzą do wytwarzania takich dóbr, określa się mianem sektora kreatywnego, sektora kultury, przemysłów kreatywnych lub przemysłów kultury¹. Jest to wynik postępującej od połowy XX wieku ekonomizacji kultury, która polega na tym, że zjawiskom kulturalnym przypisuje się również znaczenie gospodarcze.

Gospodarka kreatywna jest sferą powstającą na styku dwóch części społeczeństwa - gospodarki i kultury. Obie te części mają zgoła odmienną naturę, co sprawia, że zjawiska zachodzące w ich obrębie mają dualny charakter. Artysta, z punktu widzenia kultury, jest twórcą dzieł sztuki, a więc przedmiotów o szczególnych walorach estetycznych i artystycznych. Z punktu widzenia gospodarki - jest on przedsiębiorcą lub pracownikiem,

${ }^{1} \mathrm{~W}$ sprawie relacji między tymi pojęciami i dyskusji terminologicznej zob. K. Stachowiak, Problemy metodologiczne badania sektora kreatywnego, „Rozwój Regionalny i Polityka Regionalna” 2015, nr 30. 
który wytwarza określone dobra, trafiające następnie na rynek i nabywane przez konsumentów. Jest on zatem jednocześnie elementem kultury danego społeczeństwa oraz częścią jego systemu gospodarczego. W zależności od sytuacji przejawia inne cechy. To sprawia, że gospodarka kreatywna charakteryzuje się dualizmem ekonomiczno-kulturowym ${ }^{2}$, dlatego też elementy tej gospodarki przejawiają, w zależności od sytuacji, własności ekonomiczne lub kulturowe.

W gospodarce kreatywnej funkcjonują podmioty, które - niezależnie od ich formy organizacyjnej - są aktywnymi uczestnikami procesów gospodarczych, a ich decyzje i działania wywołują skutki ekonomiczne. Dualistyczny, ekonomiczno-kulturowy charakter gospodarki kreatywnej sprawia, że podmioty te funkcjonują również w sferze kultury. David Throsby do głównych kategorii podmiotów w gospodarce kreatywnej zalicza między innymi: pracowników kultury (zarówno twórców, jak i personel pomocniczy lub administracyjny), firmy prywatne (nastawione na zysk), prywatne organizacje nienastawione na zysk (non-profit), publiczne instytucje kultury, szkoły artystyczne, agencje rządowe i samorządowe związane z kulturą czy organizacje międzynarodowe, takie jak UNESCO, a także konsumentów lub odbiorców kultury ${ }^{3}$. W zależności od struktury gospodarki danego regionu czy kraju, a także od specyfiki kultury, wyżej wymienione podmioty będą odgrywać różną rolę. W rozwiniętych gospodarczo i instytucjonalnie krajach pomiędzy twórcami a odbiorcami tworzy się cały system złożonych powiązań, w których pośredniczą organizacje pozarządowe, firmy prywatne czy też instytucje kultury. Mogą one też pełnić odmienne role, na przykład instytucje kultury mogą pełnić rolę redystrybucyjną, gdy decydują o tym, na które przedsięwzięcia kulturalne zostaną przeznaczone środki publiczne (tak jak robi to Polski Instytut Sztuki Filmowej w przypadku kinematografii). To stawia je jednak w roli producenta - dokonują one alokacji środków, oceniając przy tym wartość kulturową przedsięwzięcia. W niektórych przypadkach instytucje kultury mogą pełnić rolę twórców, jeśli angażują się w proces twórczy. Wydaje się zatem, że zamiast tworzyć listę wszelkich możliwych rodzajów podmiotów, lepiej jest określić je przez pryzmat roli,

2 K. Stachowiak, Gospodarka kreatywna i mechanizmy jej funkcjonowania. Perspektywa geograficzno-ekonomiczna, Poznań 2017.

3 D. Thorsby, The Economics of Cultural Policy, New York 2010, s. 23-24. 
jaką pełnią. Ta bowiem pozwala wyznaczyć ich miejsce w gospodarce. Zatem z punktu widzenia głównych procesów gospodarczych, a więc produkcji, konsumpcji i dystrybucji, a także ze względu na rolę w wytwarzaniu i przekazywaniu wartości kulturowej i ekonomicznej, głównymi rodzajami podmiotów w gospodarce kreatywnej są: (1) twórcy i producenci, (2) odbiorcy oraz (3) pośrednicy kulturowi. O ile dwie pierwsze grupy podmiotów były przedmiotem wielu badań, to znaczenie pośredników kulturowych zostało dostrzeżone względnie niedawno. Im zostanie zatem poświęcona uwaga w niniejszym artykule. Przedstawię główne ujęcia mówiące o tym, kim są pośrednicy kulturowi, a następnie ukażę ich rolę jako selekcjonerów (gatekeepers) w gospodarce kreatywnej.

\section{KIM SĄ POŚREDNICY KULTUROWI? PRZEGLĄD GŁÓWNYCH UJĘĆ}

Pośrednicy kulturowi są specyficzną i niezwykle istotną kategorią podmiotów w gospodarce kreatywnej. Pełnią oni kluczową rolę, zwłaszcza w rozpowszechnianiu dóbr kreatywnych, oraz stanowią swego rodzaju pomost pomiędzy twórcami i producentami a odbiorcami i konsumentami. Pomost ten ma jednak dość swoisty charakter. W tradycyjnej gospodarce główną rolą pośredników jest kojarzenie sprzedających i kupujących. Pośrednicy wiązani są najczęściej z takimi formami działalności, jak agencje zatrudnienia, pośrednictwo finansowe, ubezpieczeniowe czy obrót nieruchomościami. Pośrednicy kulturowi natomiast nie tylko biorą udział w kojarzeniu sprzedających z kupującymi, przez co ułatwiają obieg dóbr, ale ponadto są zaangażowani w kształtowanie ostatecznej wartości dobra. Chodzi tu przede wszystkim o jego wartość kulturową, która jest sumą wartości semiotycznych (w tym symbolicznych), estetycznych, artystycznych, historycznych i autentyczności ${ }^{4}$. Pośrednicy kulturowi są więc ogniwem w łańcuchu wartości, który dodaje coś do już istniejącego dobra. Trudno ich jednoznacznie przyporządkować do któregoś z głównych procesów zachodzących w gospodarce - choć pośredniczą między twórcami a odbiorcami, a więc odgrywają rolę w dystrybucji dóbr kreatywnych, to ich działania obejmują bardzo często sferę produkcyjną, a nawet i konsumpcyjną. Sytuacji nie ułatwia

4 Por. D. Throsby, Ekonomia i kultura, tłum. O. Siara, Warszawa 2010, s. 39-40. 
fakt, że pojęcie „pośrednicy kulturowi” jest nie do końca określone: w literaturze pojawia się ono w trzech głównych znaczeniach, jako: (1) jednostki lub grupy pełniące rolę medium pomiędzy kulturami, (2) zbiór profesji, których zadaniem jest transfer wartości kulturowych w społeczeństwie, (3) jednostki lub grupy zaangażowane w transfer dóbr kreatywnych i wartości kulturowych pomiędzy twórcami a odbiorcami.

W pierwszym $\mathrm{z}$ wymienionych znaczeń pośrednik kulturowy stanowi łączące ogniwo lub medium pomiędzy różnymi grupami kulturowymi, na przykład między kulturami narodowymi, grupami etnicznymi itp. Rola pośredniczenia związana jest z przenoszeniem treści lub wartości kulturowych z jednej kultury na inną. Taki pośrednik zna i rozumie oba konteksty kulturowe i w pewnym sensie tłumaczy jedne treści na drugie. Przykładem może być imigrant, który przebywa w innej niż swoja rodzima kulturze na tyle długo, że swobodnie posługuje się językiem oraz szeregiem innych kodów kulturowych. Wartości i postawy charakterystyczne dla rodzimej kultury są dzięki temu transferowane do miejsca aktualnego pobytu, a więc do innej kultury. Analogicznie transfer ten może odbywać się w drugą stronę - imigranci tacy przyjmują pewne wartości i postawy od otoczenia, w którym przebywają. David B. Ruderman i Giuseppe Veltri analizowali w ten sposób rolę żydowskich intelektualistów w kształtowaniu się renesansu we Włoszech ${ }^{5}$. Pojęcie pośredników kulturowych w tym znaczeniu jest jednak stosunkowo rzadko używane w badaniach społecznych ${ }^{6}$.

Drugie znaczenie tegoż pojęcia związane jest z pracami Pierre’a Bourdieu, a zwłaszcza z jego dziełem Dystynkcja. Społeczna krytyka władzy sądzenia. Zawiera ono fragmenty omawiające nowe profesje, które pojawiły się w społeczeństwach XX-wiecznych, a ich zadaniem była mediacja między wytworami sztuki i kultury a masami, w trakcie której zmianie ulega forma i ranga społeczna tych wytworów. Choć nie sposób w kilku zdaniach streścić złożonej koncepcji Bourdieu, to główne przesłanie Dystynkcji można sprowadzić do twierdzenia, że uczestnictwo

5 Cultural Intermediaries: Jewish Intellectuals in Early Modern Italy, ed. D.B. Ruderman, G. Veltri, Philadelphia 2004.

6 V. Durrer, S. Miles, New Perspectives on the Role of Cultural Intermediaries in Social Inclusion in the UK, „Consumption Markets and Culture” 2009, Vol. 12, No. 3. 
w kulturze jest uwikłane w różnice między klasami społecznymi, a zatem występuje zbieżność uwarstwienia społecznego i kulturowego, w związku z czym zróżnicowanie społeczne pokrywa się z wyborami kulturowymi ${ }^{7}$. Naturalnymi konsumentami kultury wysokiej są elity społeczne, natomiast klasy niżej usytuowane pozostają w kręgu oddziaływania kultury wytwarzanej na skalę masową. „Powoduje to, że określona ranga społeczna znajduje swe odzwierciedlenie w kulturowej wartości konsumowanych dóbr i podejmowanych praktyk. Pozycja w hierarchii społecznej pozostaje zatem w ścisłym związku z pozycją hierarchicznie uporządkowanych pod względem prawomocności wyborów kulturowych"8. W takiej sytuacji dość widoczne są również zależności między „kapitałem edukacyjnym” a „kapitałem kulturowym”. Ci, którzy odwiedzają muzea i galerie sztuki lub potrafią rozpoznać klasycznych kompozytorów - a więc są w stanie właściwie odebrać i uczestniczyć w „kulturze prawomocnej” - mają najczęściej lepsze wykształcenie. Stanowią oni mniejszość, i w konsekwencji większa część społeczeństwa nie jest w stanie w owej kulturze partycypować. W związku z tym w drugiej połowie XX wieku pojawiły się nowe zawody - w tym pośrednicy kulturowi - będące częścią „nowego drobnomieszczaństwa”. Pozwalają one na tworzenie „kultury średniej”, która, najogólniej rzecz ujmując, jest spopularyzowaną i uproszczoną wersją „kultury prawomocnej”, dostępnej dzięki tym procesom dla liczniejszej publiczności. „Kultura średnia zawdzięcza część swojego powabu wszystkim odniesieniom do kultury prawomocnej, które zawiera i które skłaniają i dają podstawę do utożsamiania jej z tamtą kulturą"'. Takie odniesienia to przystępne adaptacje filmowe klasycznych dzieł literackich, popularne aranżacje muzyki klasycznej, „pozornie wyrafinowane orkiestracje ludowych przyśpiewek” czy wokalne interpretacje klasycznych dzieł. Bourdieu następująco wyjaśnia, w jaki sposób taka kultura jest tworzona i rozpowszechniana:

7 P. Bourdieu, Dystynkcja. Społeczna krytyka władzy sądzenia, tłum. P.P. Bilot, Warszawa 2000.

8 K. Strzyczkowski, Szlachectwo nie zobowiazuje. Zmiany we wzorach konsumpcji kulturowej, „Ruch Prawniczy, Ekonomiczny i Socjologiczny” 2009, z. 1, s. 196.

9 P. Bourdieu, op. cit., s. 396. 
Nowi pośrednicy kulturowi (do najbardziej typowych należą redaktorzy programów kulturalnych w radiu lub telewizji, krytycy z dzienników i tygodników „dbających o poziom” oraz wszyscy dziennikarze-pisarze i pisarze-dziennikarze), stawiając czoło podwójnej konkurencji producentów, czyli auctores, i prawomocnych komentatorów, czyli lectores - w starciu z którymi nie mieliby szans, gdyby nie dysponowali specyficzną mocą, jaką gwarantuje opanowanie mass mediów - wymyślili całą serię gatunków pośrednich między kulturą prawomocną a produktami masowymi („felietony”, „eseje”, „świadectwa" itd. $)^{10}$.

Jak widać, pośrednicy kulturowi mają tu zupełnie inny charakter niż w pierwszym znaczeniu tego pojęcia. Po pierwsze, kultura prawomocna, o której tu mowa, związana jest z działalnością artystyczną i sztuką, jak na przykład literatura, muzyka czy sztuki sceniczne. Po drugie, mediacja ma charakter jednokierunkowy - od kultury prawomocnej do określonych odbiorców, nie odwrotnie. Po trzecie, istnieje istotna różnica w wielkości „populacji”, między którymi usytuowani są pośrednicy, bowiem Bourdieu często wskazuje na masowe media i masową produkcję. Zatem pośrednicy kulturowi „tłumaczą” w relacji niewielu-do-wielu: od niewielkiej grupy twórców do znacznie większej rzeszy odbiorców. Przy okazji Bourdieu podaje konkretne zawody, które zaliczane są do kategorii pośredników kulturowych, pisząc, że:

Nowe drobnomieszczaństwo spełnia się w zawodach prezentacji i reprezentacji (takich jak przedstawiciele handlowi, specjaliści od reklamy, public relations, mody, dekoracji itd.) oraz we wszelkich instytucjach sprzedaży dóbr i usług symbolicznych, czy będą to zawody z zakresu pomocy medyczno-społecznej (tacy jak doradcy do spraw małżeńskich, seksuolodzy, dietetycy, doradcy z poradni zawodowych i dziecięcych itd.), czy też produkcji i animacji kultury (animatorzy kulturalni, pedagodzy, reżyserzy oraz prezenterzy radiowi i telewizyjni, dziennikarze w czasopismach itd.), których szybko przybywało w ciągu ostatnich lat ${ }^{11}$.

Nazywa ich też „handlarzami potrzeb, sprzedawcami dóbr i usług symbolicznych, którzy sprzedają zawsze samych siebie jako typowych

10 Ibidem, s. 397.

${ }^{11}$ Ibidem, s. 439. 
reprezentantów i gwarantów wartości swoich produktów, i tak skutecznie pełnią funkcję reprezentacji tylko dlatego, że prezentują dobrze i wierzą w wartość tego, co prezentują i reprezentują"12.

Jennifer Smith Maguire i Julian Matthews zwracają uwagę, że choć pojęcie pośredników kulturowych odgrywa relatywnie niewielką rolę w analizach Bourdieu, to zyskało ono wagę w anglosaskich koncepcjach socjologicznych ${ }^{13}$. Rozszerzono w nich znacznie zakres pojęcia, co przyczyniło się do wyłonienia trzeciego znaczenia pośredników kulturowych, zgodnie $\mathrm{z}$ którym są to podmioty zaangażowane w transfer wartości kulturowych, zwłaszcza pomiędzy twórcami a odbiorcami, ale także w wewnętrznym polu samych twórców lub samych odbiorców. Owo rozszerzenie zakresu sprawiło, że pojęcie pośredników kulturowych stało się - według Davida Hesmondhalgha - jednym $\mathrm{z}$ bardziej niejasnych ${ }^{14}$, tym bardziej że wynikało ono z dość luźnych, a czasem niewłaściwych interpretacji idei Bourdieu ${ }^{15}$. Można też powiedzieć, że uległo ono dekontekstualizacji, w efekcie czego $\mathrm{w}$ użyciu pozostał sam termin, a jego oryginalne znaczenie zostało zmienione lub zastąpione nowym. Dla wielu badaczy może mieć to uzasadnienie praktyczne, ponieważ kategoria pośredników kulturowych jest użyteczna analitycznie, a przez nadanie jej zmienionego lub nowego znaczenia pozwala na zdystansowanie się od lewicująco-krytycznej proweniencji myśli Bourdieu. Według Hesmondhalgha to nowe znaczenie uformowało się na początku lat 90. XX wieku. W znanej i wpływowej w kręgach anglojęzycznych pracy na temat sfery produkcyjnej w kulturze - Production of Culture / Cultures of Production pod redakcją Paula du Gaya - jeden z jej autorów, Sean Nixon, określił mianem pośredników kulturowych praktycznie wszystkie podmioty włączone w obieg wartości i dóbr kulturowych: są nimi wszystkie te osoby lub organizacje, które przenoszą znaki i ich znaczenia, lub szerzej:

12 Ibidem, s. 446.

13 J. Smith Maguire, J. Matthews, Bourdieu on Cultural Intermediaries, [w:] The Cultural Intermediaries Reader, red. J.S. Maguire, J. Matthews, London 2014.

14 D. Hesmondhalgh, The Cultural Industries. Sage, London 2002, s. 53.

15 Ibidem, s. 54; K. Negus, The Work of Cultural Intermediaries and the Enduring Distance between Production and Consumption, „Cultural Studies” 2002, Vol. 16, No. 4, s. 502. 
wartość kulturową, z jednego miejsca w drugie ${ }^{16}$. Dla Nixona, podobnie zresztą jak dla Bourdieu, najbardziej reprezentatywnym przykładem pośrednictwa kulturowego jest branża reklamowa, której znaczenie i udział w rynku globalnym istotnie wzrosły w XX wieku. Reklama jest tą częścią komunikacji, która ma dostarczać informacji w formie perswazyjnej na temat dóbr dla potencjalnych odbiorców lub klientów. Operuje w tym celu szerokim zestawem znaków i kodów kulturowych, często mocno uwikłanych w sieci znaczeniowe funkcjonujące w społeczeństwie. Jest przy tym łącznikiem między sprzedającym a potencjalnym kupującym. Jak widać, w odróżnieniu od poprzednich dwóch znaczeń, takie pośrednictwo kulturowe nie jest ani pomostem między kulturami, ani też między kulturą prawomocną a popularną, ale stanowi raczej kanał transmisji niemal każdej z możliwych form kulturowych. Ze względu na nader szeroki zakres pojęcia pośrednika kulturowego Hesmondhalgh sugeruje, żeby porzucić używanie tego niejasnego terminu na rzecz bardziej konkretnych określeń, takich jak „menedżer kreatywny”, „twórca symboli” lub „kreatywny praktyk”.17.

Niezależnie od problemów z klarownością pojęcia, trudno kwestionować rolę pośredników kulturowych we współczesnej gospodarce kreatywnej. W pracy na temat roli przedsiębiorczości w sektorze kultury ${ }^{18}$ Charlie Leadbeater i Kate Oakley w następujący sposób charakteryzują znaczenie pośredników kulturowych dla gospodarki kreatywnej:

Są oni niezbędni do tego, aby wypełnić „dziurę” w strukturze sektora kreatywnego. Pośrednicy kulturowi odkrywają i promują talenty, wprowadzają do obiegu idee i trendy, kontaktują ludzi ze sobą, organizują wydarzenia oraz umożliwiają dostęp do rynku. Pośrednicy kulturowi są często twórcami, którzy zostawili działalność twórczą za sobą i poszli dalej w innym kierunku. Są nimi piosenkarze, którzy zostali menedżerami; aktorzy, którzy zostali łowcami

${ }^{16}$ S. Nixon, Circulating Culture, [w:] Production of Culture / Cultures of Production, red. P. du Gay, London 1997, s. 181.

17 D. Hesmondhalgh, op. cit., s. 53.

18 Warto nadmienić, że praca ta miała istotny wpływ na kształtowanie się polityki rozwoju sektora kreatywnego w Wielkiej Brytanii pod koniec lat 90., a w szczególności na raporty i dokumenty opracowywane przez brytyjskie Ministerstwo Kultury, Mediów i Sportu (DCMS), które później stały się wzorem dla podobnych opracowań w innych krajach. 
talentów; twórcy programów telewizyjnych, którzy zostali redaktorami w wydawnictwach. Są niczym olej w trybach sektora kreatywnego. W Dolinie Krzemowej tę rolę [...] odgrywa kapitał wysokiego ryzyka. Pośrednicy kulturowi są co prawda mniej sformalizowani i mniej wpływowi niż ich odpowiednicy z Doliny Krzemowej, jednak podobnie jak oni sprawiają, że wszystko się kręci. W gruncie rzeczy to oni umieszczają lokalne talenty na szerszym, komercyjnym rynku. Aby sektor kreatywny mógł skutecznie się rozwijać, potrzebuje nie tylko zdolnych twórców, ale również skutecznych pośredników. Promowanie tych pośredników powinno być celem polityki publicznej ${ }^{19}$.

Widać tu rolę pośredników kulturowych jako połączeń w łańcuchu produkcji kulturowej, ze znacznym podkreśleniem ich znaczenia gospodarczego i możliwości generowania wartości ekonomicznych dzięki ich działalności. Znaczenie pośredników polega zatem na dostarczaniu środków, za pomocą których można tworzyć dobra rynkowe z działalności kulturowej. Łączą oni zatem artefakty kulturowe z rynkiem, co oznacza, że wytwory kultury mogą być kupowane i sprzedawane oraz mogą przynosić zysk ich twórcom. Jednakże, co bardzo ważne, pośrednicy kulturowi nie pełnią tylko prostej, logistycznej roli dostarczycieli produktów na rynek. Biorą oni bowiem udział nie tyle w obiegu dóbr, ile wartości kulturowych - bazują na semiotycznych kodach kulturowych, nierzadko modyfikując je i dostosowując do wymagań rynku. Zatem to kompetencje kulturowe, jak i znajomość realiów ekonomicznych pozwalają im odgrywać tę gospodarczą rolę.

Znaczenie pośredników kulturowych dla gospodarki kreatywnej oraz specyfika ich działania były przedmiotem licznych badań, z których każde podkreślało ich fundamentalny charakter dla obiegu wartości kulturowych i dóbr kreatywnych ${ }^{20}$. Chris Gibson uważa, że także nauka i uczeni pełnią

${ }_{19}$ Charles Webster Leadbeater, Kate Oakley, The Independents: Britain's New Cultural Entrepreneurs, London 1999, s. 45.

20 K. Negus, op. cit.; D. Wright, Mediating Production and Consumption: Cultural Capital and 'Cultural Workers', „The British Journal of Sociology” 2005, Vol. 56, No. 1; L. De Propris, S. Mwaura, Demystifying Cultural Intermediaries: Who Are They, What Do They Do and Where Can They Be Found in England?, Discussion Paper 2013-07, Birmingham 2013; J. Smith Maguire, J. Matthews, op. cit.; D. Jakob, B. van Heur, Taking Matters into Third Hands: Intermediaries and the Organization of the Creative Economy, „Regional Studies” 2015, Vol. 49, No. 3; J. O'Connor, Intermediaries and 
rolę pośredników kulturowych - badając sektor kreatywny i procesy w nim zachodzące, wytwarzają wiedzę, która potem jest transferowana do społeczeństwa poprzez publikacje czy wykłady. Ponadto pełnią oni również często rolę ekspertów, pomagając kształtować politykę publiczną. W tym edukacyjnym i eksperckim wymiarze stają się „promotorami” gospodarki kreatywnej ${ }^{21}$. Zatem w tym sensie również i ten tekst oraz jego autor pełnią rolę pośrednika kulturowego.

Norma Rantisi i Deborah Leslie wskazują ponadto, że edukacja w ogóle ma charakter pośredniczący i pozwala nie tylko funkcjonować gospodarce kreatywnej, ale i ją rozwijać. System szkolnictwa artystycznego jest przecież istotnym ogniwem w obiegu nie tylko wiedzy, ale i wartości kulturowych ${ }^{22}$. $\mathrm{W}$ rozwiniętych społeczeństwach ma on rozbudowany i wyspecjalizowany charakter. Przykładowo w kanadyjskim Montrealu funkcjonuje od 1981 roku Narodowa Szkoła Cyrkowa (École Nationale de Cirque), która ma status państwowej szkoły wyższej. Montrealska szkoła jest zapleczem dla rozwiniętej w tym mieście sztuki cyrkowej, a zwłaszcza dla światowej sławy przedsięwzięcia - Cirque du Soleil, powstałego w 1984 roku. Cirque du Soleil jest specyficznym połączeniem sztuki ulicznej i biznesu. O skali przedsięwzięcia niech świadczy fakt, że przy tworzeniu widowisk pracuje ponad cztery tysiące osób z ponad czterdziestu krajów, przychody przekraczają 810 milionów USD rocznie, a marża (zysk) jest szacowana na ponad 20 procent $^{23}$. W Polsce również funkcjonuje podobna szkoła artystyczna - Państwowa Szkoła Sztuki Cyrkowej w Julinku, nieopodal Warszawy, która kontynuuje tradycje szkoły cyrkowej założonej w latach 60. XX wieku.

Imaginaries in the Cultural and Creative Industries, „Regional Studies” 2015, Vol. 49, No. 3; C. Taylor, Between Culture, Policy and Industry: Modalities of Intermediation in the Creative Economy, „Regional Studies” 2015, Vol. 49, No. 3.

${ }^{21}$ Ch. Gibson, Negotiating Regional Creative Economies: Academics as Expert Intermediaries Advocating Progressive Alternatives, „Regional Studies” 2015, Vol. 49, No. 3, s. 477.

${ }^{22}$ N. Rantisi, D. Leslie, Significance of Higher Educational Institutions as Cultural Intermediaries: The Case of the École Nationale de Cirque in Montreal, Canada, „Regional Studies” 2015, Vol. 49, No. 3.

${ }_{23}$ G. Collins, Run Away to the Circus? No Need. It's Staying Here, „The New York Times" 28.04.2009 r., s. C1. 
Obok edukacji rolę pośredników kulturowych pełnią całe branże kreatywne, takie jak reklama ${ }^{24}$ czy branża medialna $^{25}$, lub jej części, jak dziennikarstwo ${ }^{26}$. Ale też w konkretnych działalnościach kreatywnych wiele osób lub organizacji realizuje funkcje pośrednictwa kulturowego, czego przykładem są: agencje talentów w branżach filmowej, muzycznej lub w sztukach scenicznych $^{27}$, regionalne komisje filmowe w branży filmowej ${ }^{28}$, niezależni rzemieślnicy artystyczni ${ }^{29}$, projektanci mody ${ }^{30}$ czy wzornictwa przemysłowego ${ }^{31}$. Pośrednicy kulturowi są kluczowymi ogniwami w branżach o wysoce rozwiniętych i złożonych sieciach produkcji, takich jak branża filmowa ${ }^{32}$

${ }^{24}$ L. McFall, What About the Old Cultural Intermediaries? An Historical Review of Advertising Producers, „Cultural Studies” 2002, Vol. 16, No. 4; C. Hodges, „PRP Culture": A Framework for Exploring Public Relations Practitioners as Cultural Intermediaries, „Journal of Communication Management” 2006, Vol. 10, No. 1; L. Moor, Branding Consultants as Cultural Intermediaries, "The Sociological Review” 2008, Vol. 56, No. 3.

25 D. Hesmondhalgh, Bourdieu, the Media and Cultural Production, „Media, Culture \& Society" 2006, Vol. 28, No. 2; J.S. Maguire, J. Matthews, Cultural Intermediaries and the Media, „Sociology Compass” 2010, Vol. 4, No. 7.

${ }^{26}$ K. Negus, The Production of Culture, [w:] Production of Culture / Cultures of Production, op. cit.

27 F. Martel, Mainstream. Co podoba się wszędzie na świecie, tłum. K. Sikorska, Warszawa 2010, s. 114-122.

28 P. Foster, St. Manning, D. Terkla, The Rise of Hollywood East: Regional Film Offices as Intermediaries in Film and Television Production Clusters, „Regional Studies" 2015, Vol. 49, No. 3.

${ }_{29}$ B. Shultz, The Work Behind the Scenes: The New Intermediaries of the Indie Crafts Business, „Regional Studies” 2015, Vol. 49, No. 3.

${ }_{30}$ L. Skov, Hong Kong Fashion Designers as Cultural Intermediaries: Out of Global Garment Production. „Cultural Studies” 2002, Vol. 16, No. 4.

31 T. Vinodrai, Constructing the Creative Economy: Design, Intermediaries and Institutions in Toronto and Copenhagen. „Regional Studies” 2015, Vol. 49, No. 3.

32 A.J. Scott, On Hollywood: The Place, the Industry, Princeton 2005; L. De Propris, L. Hypponen, Creative Clusters and Governance: The Dominance of the Hollywood Film Cluster, [w:] Creative Cities, Creative Clusters and Local Economic Development, red. P. Cooke, L. Lazzeretti, Cheltenham 2007. 
oraz muzyczna ${ }^{33}$. Co interesujące, w tej ostatniej, pomimo rosnącej digitalizacji produkcji muzycznej i popularności wirtualnych pośredników, takich jak YouTube, to raczej realni niż wirtualni pośrednicy okazują się istotni, jeśli myśli się o przynajmniej minimalnym powodzeniu komercyjnym ${ }^{34}$. Niektórzy autorzy wskazują na to, że nawet konsumenci mogą pełnić rolę pośredniczącą. Przykładem jest tu japońska manga, której fani podejmują się tłumaczenia, redakcji i rozpowszechniania tej formy komiksu poza Japonią, bez oficjalnej zgody właścicieli praw autorskich ${ }^{35}$. Zasadne staje się zatem pytanie, które stawiają Maguire i Matthews: czy aby wszyscy nie jesteśmy już pośrednikami kulturowymi?

Pozytywna odpowiedź na powyższe pytanie skutkować będzie nadmiernym rozszerzeniem rozumienia tego, kim są pośrednicy kulturowi. W związku z tym proponuję uściślenie tego pojęcia i ograniczenie go do dwojakiego pojmowania:

1) Pośrednictwo kulturowe jako rola, która polega na pośredniczeniu w obiegu wartości kulturowej (szersze ujęcie). Ta wartość związana jest $\mathrm{z}$ dobrami kreatywnymi, w związku z czym często jest to pośrednictwo w obiegu dóbr. Podmioty pełniące rolę pośredniczącą nie muszą być (i często nie są) w tym pośrednictwie wyspecjalizowane. Role pośrednictwa kulturowego polegają zatem na: (a) kojarzeniu twórców (sprzedających) i odbiorców (kupujących), (b) przekazywaniu wartości kulturowej lub (c) modyfikacji wartości kulturowej. Należy zwrócić uwagę, że rola pośrednictwa kulturowego może mieć zarówno intencjonalny, jak i przypadkowy charakter. Metaforycznie można ją porównać do roli pszczoły, która zbiera pyłek z jednych roślin, przenosi je na inne i je zapyla. O ile pszczoły robią to wyłącznie instynktownie, o tyle działania pośredników kulturowych są często celowe.

33 P. Gałuszka, Biznes muzyczny. Ekonomiczne i marketingowe aspekty fonografii, Warszawa 2009; A. Watson, Cultural Production in and beyond the Recording Studio, London 2015.

34 B.J. Hracs, Cultural Intermediaries in the Digital Age: The Case of Independent Musicians and Managers in Toronto, „Regional Studies” 2015, Vol. 49, No. 3.

35 H.-K. Lee, Cultural Consumers as "New Cultural Intermediaries”: Manga Scanlators, „Arts Marketing: An International Journal” 2012, Vol. 2, No. 2. 
2) Pośrednik kulturowy jako wyspecjalizowany podmiot (węższe ujęcie) - może być nią jednostka (osoba) lub organizacja (np. firma, organizacja pozarządowa) wyspecjalizowana w takiej działalności, dla której pośrednictwo kulturowe jest jednym z głównych obszarów działania lub który stanowi dla niej źródło utrzymania bądź dochodu.

Tak określeni pośrednicy mogą działać we wszystkich głównych procesach gospodarczych (produkcja, dystrybucja, konsumpcja), przy czym ich główna rola związana jest z produkcją i dystrybucją. Działalność pośredników kulturowych może mieć charakter rynkowy, gdy jest to działalność nastawiona na zysk (np. agencje talentów), lub nierynkowy - w przypadku gdy ma ona charakter autoteliczny, związany z realizacją misji społecznych lub innych wartości ogólnych (np. szkoły artystyczne, fani).

\section{POŚREDNICY KULTUROWI JAKO SELEKCJONERZY (GATEKEEPERS)}

Pojęcie selekcji (gatekeeping) funkcjonuje w naukach społecznych od końca lat 40. XX wieku, kiedy to psycholog społeczny Kurt Lewin uznał na podstawie swoich badań, że we wszelkich sytuacjach społecznych przepływ informacji jest zawsze nierównomierny i niecałkowity ${ }^{36}$. Przepływ ten reguluje cała seria barier, nazywanych bramami (gates), które są kontrolowane przez określone jednostki lub organizacje pełniące rolę selekcjonerów (gatekeepers), przepuszczających pewne informacje, a zatrzymujących inne. $\mathrm{W}$ tym rozumieniu selekcja jest więc procesem zmniejszania ogromnej ilości informacji i przekształcania ich w ograniczoną liczbę wiadomości, które docierają do odbiorców w procesie komunikacji społecznej ${ }^{37}$. W dużych i rozwiniętych społeczeństwach komunikacja kulturowa opiera się w znacznym stopniu na różnego rodzaju mediach, przez co są one centralną częścią współczesnego życia publicznego. Proces selekcji nie tylko określa, które informacje zostaną przekazane odbiorcom, ale także to, jaka jest ich treść. Ponieważ kultura symboliczna w przeważającej mierze ma charakter semiotyczny i związana jest $\mathrm{z}$ tworzeniem, przekazywaniem, odbiorem i interpretacją różnych treści, można proces selekcji takich treści określić

36 T. Goban-Klas, Media i komunikowanie masowe. Teorie i analizy prasy, radia, telewizji i Internetu, Warszawa 2001 s. 58-59.

37 P.J. Shoemaker, T.P. Vos, Gatekeeping Theory, New York 2009, s. 1. 
mianem selekcji kulturowej. Obejmuje ona filtrowanie i przekształcanie treści oraz ich przesyłanie za pomocą odpowiednich mediów lub kanałów.

W odniesieniu do sektora kultury, a zwłaszcza kultury popularnej, Paul Hirsch zaproponował model produkcji kulturowej, w którym przedstawił między innymi działanie mechanizmu selekcji ${ }^{38}$. Model Hirscha oparty był o jego pionierskie prace dotyczące struktury produkcji w branży muzycznej, w których analizował proces filtrowania i wyboru piosenek lub płyt odnoszących następnie sukces komercyjny ${ }^{39}$ - prace te były później inspiracją w badaniach nad ekonomiką sektora kultury i sektora kreatywnego ${ }^{40}$. Podejście Hirscha czerpało również z rozwijającego się w tym czasie systemowego ujęcia w teorii organizacji i ukazywało produkcję kulturową jako proces, w trakcie którego z ogólnej liczby twórców w kolejnych etapach zostają wybierani nieliczni, których dzieła trafiają w efekcie do konsumentów (ryc. 1). $\mathrm{Na}$ pierwszym etapie pośrednicy kulturowi to osoby lub firmy zajmujące się wyszukiwaniem utalentowanych artystów lub obiecujących twórców i starające się określić ich potencjał kreatywny. Takimi pośrednikami są na przykład agencje talentów, wydawnictwa, wytwórnie płytowe. Oferują one twórcom wsparcie finansowe, pomoc techniczną, sieci dystrybucji i inne zasoby, które posiadają po to, aby wytworzyć określony produkt i dostarczyć go na rynek. Rolę takich selekcjonerów pełnią nawet programy telewizyjne w rodzaju „Mam talent!”.

W kolejnym etapie pojawiają się konsumenci pośredni (surrogate consumers), którzy nabywają gotowy produkt (piosenkę, film lub program telewizyjny), a potem udostępniają go końcowemu odbiorcy. Do tej grupy można zaliczyć stacje radiowe i telewizyjne, wydawnictwa prasy itp. Konsumenci pośredni również dokonują selekcji, tym razem wśród gotowych produktów,

38 P.M. Hirsch, Processing Fads and Fashions: An Organization-Set Analysis of Cultural Industry Systems, „American Journal of Sociology” 1972, Vol. 77, No. 4.

39 P.M. Hirsch, The Structure of the Popular Music Industry: The Filtering Process by which Records are Preselected for Public Consumption, Institute for Social Research, Ann Arbor 1969.

${ }^{40}$ Zob. np. R.E. Caves, Organization of Arts and Entertainment Industries, [w:], Handbook of the Economics of Art and Culture, vol. 1, red. V.A. Ginsburgh, D. Throsby, Amsterdam 2006. Autor szeroko omawia ekonomiczną rolę selekcjonerów w sektorze kreatywnym. 


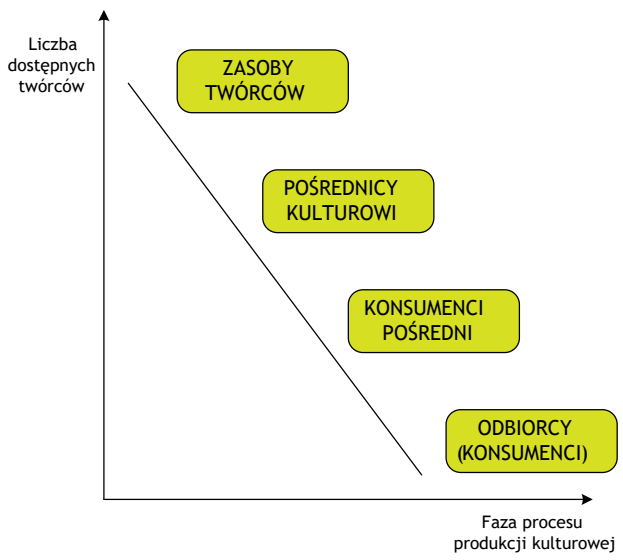

Ryc. 1. Model selekcji kulturowej Hirscha

Źródło: opracowanie własne na podstawie: P.M. Hirsch, Processing Fads and Fashions: An Organization-Set Analysis of Cultural Industry Systems, „American Journal of Sociology"1972, Vol. 77, No. 4.

i udostępniają je do przekazu liczniejszej publiczności. Nie wytwarzają oni zatem dóbr, ale poprzez selekcję wpływają na wartość określonego dobra, tworząc systemy ocen, takie jak listy przebojów, recenzje itp. Odgrywają więc niemałą rolę w łańcuchu wartości dodanej, decydując niekiedy o ewentualnym sukcesie rynkowym lub też porażce danego dobra kreatywnego, albo też wzmacniając pozycję danego dobra, na przykład poprzez częstą emisję piosenki czy filmu. Pełnią oni zatem istotną rolę w ustalaniu końcowej wartości kulturowej dobra kreatywnego, a także wydatnie wpływają na trwałość dóbr kreatywnych ${ }^{41}$. Niekiedy to nie podmioty, ale wydarzenia mają selekcyjny charakter, na co wskazują badania funkcjonowania takich wydarzeń, jak festiwale czy targi, które pełnią rolę „bram” na drodze od twórcy do odbiorcy ${ }^{42}$.

Pomimo szeregu zmian organizacyjnych i technologicznych, jakie zaszły na przełomie wieków w branży muzycznej i innych branżach kreatywnych, model Hirscha jest ciągle aktualny, co pokazał między innymi w swojej

41 Ibidem, s. 274.

42 B. Moeran, J.S. Pedersen, Negotiating Values in the Creative Industries: Fairs, Festivals and Competitive Events, Cambridge University Press, Cambridge 2011. 
pracy Gabriel Rossman. Badał on, w jaki sposób piosenki rozprzestrzeniają się w społeczeństwie (na zasadzie analogii do procesu dyfuzji innowacji), jak zyskują popularność i jaką rolę w tym wszystkim odgrywa radio. Jeden z ważniejszych wniosków z tych badań sprowadza się do wykazania, że pomimo dynamicznego rozwoju mediów cyfrowych w pierwszej dekadzie XXI wieku, tradycyjne radio ciągle pełni kluczową rolę dla muzyków $\mathrm{w}$ ich drodze do komercyjnego sukcesu. Bardzo dobrze przy tym widać rolę mechanizmu selekcji kulturowej, który okazuje się kluczowy dla całej rynkowej branży muzycznej. Rossman zwraca przy tym uwagę, że w produkcji kulturowej owa selekcja ma często charakter bardzo intensywnego odsiewu. Niewielka frakcja aktywnych twórców zostaje zauważona przez pośredników kulturowych, a z grupy tych, którym to się uda, nieliczni są promowani przez konsumentów pośrednich. Lecz nawet z tych, którzy przejdą i ten etap, bardzo niewielu odnosi duży sukces wśród końcowych odbiorców, co zresztą sugerował już Hirsch i co ilustruje stromość linii na zamieszczonej rycinie ${ }^{43}$.

Mechanizm selekcji sprawia, że podmioty, jakimi są selekcjonerzy kulturowi, pełnią kluczową rolę w gospodarce kreatywnej, decydując o tym, które dobra kreatywne zostaną upublicznione i trafią do odbiorców. Z ekonomicznego punktu widzenia selekcjonerzy obniżają koszty transakcyjne związane $\mathrm{z}$ dostępem do informacji na temat jakości dobra oraz jego oceny. Redukują oni również ryzyko i niepewność pojawiające się w różnych etapach łańcucha wartości, związane z oceną tego, który z pomysłów lub realizacji ma szansę na komercyjny sukces ${ }^{44}$. Selekcjonerem, w przypadku branży sztuk plastycznych, może być menedżer galerii sztuki, który decyduje o wystawieniu dzieł wybranych przez siebie artystów. Tę samą rolę pełni również redaktor naczelny w przypadku branży mediów, wybierając artykuły do najnowszego numeru gazety lub wydania programu informacyjnego w radiu lub telewizji. Podobną rolę mogą pełnić nie tylko jednostki, ale również wyspecjalizowane organizacje, takie jak na przykład agencje talentów. Należy mieć jednak na uwadze, że obecnie rola selekcjonerów w branżach kreatywnych zmienia

${ }^{43}$ G. Rossman, Climbing the Charts: What Radio Airplay Tells Us about the Diffusion of Innovation, Princeton 2012.

44 UNDP/UNCTAD, Creative Economy. Report 2010, Geneva - New York 2010, s. 85 . 
się ze względu na rozwój Internetu i mediów cyfrowych, dzięki którym twórcy mają możliwość natychmiastowego publikowania swych dzieł bez udziału pośredników. Służy do tego zestaw różnych narzędzi, jak portale społecznościowe (np. Facebook), portale wideo (np. YouTube), internetowe galerie sztuki (np. Digart) czy blogi ${ }^{45}$. Zarówno intuicja, jak i niektóre głosy w dyskusji ${ }^{46}$ sugerują, że rola mechanizmu selekcji będzie się zmniejszać wraz z upowszechnieniem się Internetu w nowoczesnym społeczeństwie informacyjnym. W myśl tej sugestii Internet pozwala na nieograniczone, bezkosztowe i niemal natychmiastowe udostępnianie dzieł i równie szeroki do nich dostęp. Nie potrzeba zatem podmiotów, które będą wybierały, jakie treści mają znaleźć się w obiegu - to twórcy i odbiorcy sami o tym zadecydują. Tymczasem doświadczenie na to nie wskazuje, a mechanizm selekcji - zamiast zanikać - ciągle jest obecny, choć ewoluuje. Wynikiem owej ewolucji jest wyłanianie się nowego rodzaju selekcji - selekcji technologicznej, która funkcjonuje obok selekcji tradycyjnej. Rolę bramy stanowią w takim przypadku nie bezpośrednio ludzie lub organizacje, ale narzędzia technologiczne, takie jak wyszukiwarki indeksujące treści dostępne za pośrednictwem Internetu. One determinują to, które informacje i w jakiej formie do nas trafiają. Należy przy tym pamiętać, że technologie te są wytworem działalności człowieka i realizują określone przez niego cele. Jak trafnie zauważa Magdalena Szpunar:

Wyszukiwarki kierują się logiką, którą predefiniują jej twórcy. Jest to logika odwołująca się do porządku komercyjnego, zaś rzetelne prezentowanie informacji staje się wtórne wobec generowania zysków. Przypomnijmy, iż wedle badań aż 73\% ankietowanych deklaruje, iż informacje, które wyłuskują dla nich szperacze, są dokładne i wiarygodne, a 66\% uważa, że wyszukiwarki są rzetelnym i obiektywnym źródłem informacji ${ }^{47}$.

45 S. Szultka, Klastry w sektorach kreatywnych - motory rozwoju miast i regionów, Warszawa 2012, s. 44.

${ }^{46}$ P.J. Shoemaker, T.P. Vos, op. cit.; P.-J. Benghozi, Th. Paris, The Cultural Economy in the Digital Age: A Revolution in Intermediation?, „City, Culture and Society" 2016, Vol. 7, No. 2.

${ }^{47}$ M. Szpunar, Wokół koncepcji gatekeepingu. Od gatekeepingu tradycyjnego do technologicznego, [w:] Idee i myśliciele. Medialne i społeczne aspekty filozofi, Kraków 2013, s. 61. 
Według Richarda E. Cavesa selekcjonerzy kulturowi są krytycznym elementem łańcucha wartości w wytwarzaniu prostych dóbr kreatywnych. Wytwarzanie tego rodzaju dóbr angażuje często jednego twórcę i jednego pośrednika kulturowego, który dostosowuje dzieło do wymagań rynku, a potem dystrybuuje dobro do odbiorców, czasem przy pomocy innych pośredników. Ta pozornie prosta relacja niesie jednak ze sobą, według Cavesa, spore wyzwania organizacyjne. Wynika to z trzech powodów. Po pierwsze, na rynku jest wielu twórców, co sprawia, że często mamy do czynienia z ich nadpodażą. Pośrednik kulturowy musi więc pełnić rolę selekcjonera, wybierając jednych i odrzucając innych. Po drugie, łączenie efektów twórczego wkładu artysty z działaniami ekonomicznymi selekcjonera może przybierać różne formy organizacyjne. Podmiot pełniący rolę pośrednika kulturowego może tylko reprezentować twórcę, ale może zawiązać z nim spółkę, przez co uzyska większy wpływ na końcowy kształt dzieła oraz może otrzymać dodatkowe prawa, na przykład do dystrybucji. Wreszcie też może sam zatrudnić artystę i mieć już znaczną kontrolę nad całym procesem twórczym i jego efektami. Po trzecie, lokalizacja działalności kreatywnych ma tendencję do skupiania się. Te tendencje aglomeracyjne zależą jednak od tego, jak relacje między artystą a pośrednikiem kulturowym (selekcjonerem) są zorganizowane i zarządzane. Mechanizm selekcji jest zatem uwikłany w procesy lokalizacyjne ${ }^{48}$.

Ten ostatni element - lokalizacyjny aspekt mechanizmu selekcji kulturowej - wskazuje na konsekwencje przestrzenne procesów funkcjonowania gospodarki kreatywnej. Jak się bowiem okazuje, bliskość geograficzna odgrywa kluczową rolę w budowaniu pozycji twórców, która potem decyduje o ich komercyjnym sukcesie. Chodzi tu przy tym o bliskość względem selekcjonerów oraz społecznych sieci łączących ze sobą twórców i producentów. Elizabeth Currid-Halkett pokazała empirycznie, jaką rolę odgrywa bliskość geograficzna dla procesów budowy reputacji w klastrach kreatywnych Nowego Jorku. Według tej autorki, twórcy doświadczają warunków wysokiej niepewności, zarówno jeśli chodzi o stabilność pracy, jak i przewidywalność popytu na ich dzieła. W tej sytuacji bliskość geograficzna selekcjonerów kulturowych odgrywa kluczową rolę i staje się jednym z głównych czynników

48 R.E. Caves, Organization of Arts and Entertainment Industries, [w:], Handbook of the Economics of Art and Culture, op. cit., s. 537-538. 
lokalizacji w ich otoczeniu - stają się oni swego rodzaju magnesami przyciągającymi twórców. Skoro wartość kulturowa i ekonomiczna dóbr kreatywnych jest przedmiotem ciągłych negocjacji, co jest wynikiem działania mechanizmu obiegu wartości, a jednocześnie selekcjonerzy w dużym stopniu ustalają tę wartość, nie jest zaskakujące, że dla twórców kontakt z takimi selekcjonerami jest decydujący. Co więcej, dzięki tym kontaktom twórcy wspinają się w hierarchii uznania i popularności, co jest kluczowe zarówno dla artystycznego, jak i komercyjnego sukcesu. Selekcjonerzy, pełniąc również rolę swoistych filtrów informacji, mają ogromny wpływ na to, co i jak mówi się o danym twórcy. Według Currid-Halkett, selekcjonerzy kształtują tak zwany lokalny gwar (buzz), a więc obieg plotek, nieformalnych informacji, które składają się na medialny obraz artysty ${ }^{49}$. Również Gina Neff, Elizabeth Wissinger i Sarah Zukin, które badały twórców i pracowników branży mody oraz nowych mediów, podkreślają wagę kontaktów z selekcjonerami kulturowymi. Co najważniejsze, zwracają one uwagę na to, że tymczasowość pracy i efemeryczny charakter reputacji artystycznej czyni te kontakty wręcz przymusowymi dla pracowników kreatywnych. Te czynniki stają się elementami doprowadzającymi do powstawania klastrów kreatywnych. Składają się one bowiem na korzyści aglomeracji związane z tworzeniem więzów zaufania i akumulacji kapitału społecznego ${ }^{50}$. Poza nimi w takich skupieniach występują jeszcze trzy innego rodzaju korzyści. Są to: istnienie wyspecjalizowanego rynku pracy, przepływy wiedzy oraz działanie dużej liczby instytucji otoczenia biznesu ${ }^{51}$. Mechanizm selekcji kulturowej ma więc klastrotwórczy charakter. Potwierdzają to między innymi badania przeprowadzone przez Barbarę Heebels i Irinę van Aalst w dwóch klastrach kreatywnych Berlina: w dzielnicach Prenzlauer Berg i Kreuzberg. Zlokalizowani tam przedsiębiorcy i twórcy podkreślali szczególną rolę selekcjonerów kulturowych w początkowych etapach rozwoju ich działalności. Kontakty z nimi i ich bliskość przestrzenna pozwalały na

49 E. Currid-Halkett, The Warhol Economy: How Fashion, Art, and Music Drive New York City. Princeton University Press, Princeton 2007, s. 130-132.

${ }^{50}$ G. Neff, E. Wissinger, S. Zukin, Entrepreneurial Labor among Cultural Producers: „Cool” Jobs in „Hot” Industries, „Social Semiotics” 2005, Vol. 15, No. 3. 51 K. Stachowiak, P. Tomczak, Przestrzenny wymiar sektora kreatywnego, Poznań 2015 s. 67-70. 
rozwój sieci społecznych oraz na budowę reputacji i marki w miejskich społecznościach kreatywnych. To dzięki obecności selekcjonerów coraz to nowi twórcy byli przyciągani do tych obszarów, co w efekcie spowodowało przekształcenie ich w klaster ${ }^{52}$. Pośrednio mechanizm selekcji ma wpływ także na innowacyjność skupienia, ponieważ selekcja pełni ważną rolę w procesie dyfuzji innowacji ${ }^{53}$. Mechanizm selekcji determinuje, które innowacje zostaną rozprzestrzenione, a które nie. Należy zaznaczyć, że w gospodarce kreatywnej obok klasycznych innowacji produktowych, technologicznych, organizacyjnych lub procesowych, występują również „miękkie innowacje”, a więc na przykład innowacje estetyczne, semiotyczne lub artystyczne ${ }^{54}$. Już Hirsch wskazywał na selekcyjną rolę mediów masowych i nazywał je „instytucjonalnymi regulatorami innowacji"55.

\section{PODSUMOWANIE}

Pośrednicy kulturowi są specyficzną dla gospodarki kreatywnej grupą podmiotów. Ich specyfika polega między innymi na tym, że często współuczestniczą w wytwarzaniu dóbr. Ten udział rzadko jest jednak bezpośredni. Dobra kreatywne powstają jako efekt działalności pojedynczych twórców lub ich grup, a przykładami owych dóbr mogą być: piosenka, powieść, wiersz, obraz, rzeźba czy znak graficzny. Ich wartość jest przede wszystkim funkcją wiedzy, umiejętności, kompetencji, talentu i kreatywności twórców, które stanowią zasoby ich kapitału kulturowego. Wielkość tego kapitału zależy w dużej mierze od edukacji artystycznej lub specjalistycznej. Twórcy z odpowiednim wykształceniem trafiają na rynek, na którym oni lub ich wytwory są zauważane przez tak zwanych pośredników kulturowych. Należą do nich między innymi: agencje talentów, galerie sztuki czy marszandzi, którzy pomagają twórcy zdobyć odpowiednią reputację, dzięki

52 B. Heebels, I. van Alst, Creative Clusters in Berlin: Entrepreneurship and the Quality of Place in Prenzlauer Berg and Kreuzberg, „Geografiska Annaler: Series B, Human Geography” 2010, Vol. 92, No. 4.

53 E.M. Rogers, Diffusion of Innovations, New York 1983, s. 144-145.

54 P. Stoneman, Soft Innovation: Economics, Product Aesthetics, and the Creative Industries, Oxford 2010.

55 P.M. Hirsch, Processing Fads and Fashions: An Organization-Set Analysis of Cultural Industry Systems, „American Journal of Sociology” 1972, Vol. 77, No. 4. 
której rynkowa wartość produkowanych przez niego dóbr będzie wyższa. Oni też często pomagają dystrybuować dobra wytworzone przez twórców. Dlatego też kwalifikacje takich pośredników kulturowych są nie mniej istotne niż kwalifikacje twórców. Zajmują się oni selekcją i często decydują o tym, którzy twórcy lub które wytwory trafią do szerszego obiegu. A od tego zależy często sukces komercyjny na rynku.

\section{Bibliografia}

Pierre-Jean Benghozi, Thomas Paris, The Cultural Economy in the Digital Age: A Revolution in Intermediation?, „City, Culture and Society” 2016, Vol. 7, No. 2, s. 75-80.

Pierre Bourdieu, Dystynkcja. Społeczna krytyka władzy sq̨dzenia, tłum. P.P. Bilot, Wydawnictwo Naukowe „Scholar”, Warszawa 2000.

Richard E. Caves, Creative Industries: Contracts between Art and Commerce, Harvard University Press, Cambridge 2000.

Richard E. Caves, Organization of Arts and Entertainment Industries, [w:], Handbook of the Economics of Art and Culture, vol. 1, red. V.A. Ginsburgh, D. Throsby, Elsevier, Amsterdam 2006, s. 533-566.

Glenn Collins, Run Away to the Circus? No Need. It's Staying Here, „The New York Times" 28.04.2009 r., s. C1.

Elizabeth Currid-Halkett, The Warhol Economy: How Fashion, Art, and Music Drive New York City, Princeton University Press, Princeton 2007.

Lisa De Propris, Laura Hypponen, Creative Clusters and Governance: The Dominance of the Hollywood Film Cluster, [w:] Creative Cities, Creative Clusters and Local Economic Development, red. P. Cooke, L. Lazzeretti, Edward Elgar, Cheltenham 2007, s. 258-286.

Lisa De Propris, Samuel Mwaura, Demystifying Cultural Intermediaries: Who Are They, What Do They Do and Where Can They Be Found in England?, Discussion Paper 2013-07, University of Birmingham, Birmingham 2013.

Victoria Durrer, Steve Miles, New Perspectives on the Role of Cultural Intermediaries in Social Inclusion in the UK, „Consumption Markets and Culture” 2009, Vol. 12, No. 3, s. 225-241.

Pacey Foster, Stephan Manning, David Terkla, The Rise of Hollywood East: Regional Film Offices as Intermediaries in Film and Television Production Clusters, „Regional Studies” 2015, Vol. 49, No. 3, s. 433-450. 
Patryk Gałuszka, Biznes muzyczny. Ekonomiczne i marketingowe aspekty fonografi, Wydawnictwo Placet, Warszawa 2009.

Chris Gibson, Negotiating Regional Creative Economies: Academics as Expert Intermediaries Advocating Progressive Alternatives, „Regional Studies” 2015, Vol. 49, No. 3, s. 476-479.

Tomasz Goban-Klas, Media i komunikowanie masowe. Teorie i analizy prasy, radia, telewizji i Internetu, PWN, Warszawa 2001.

Barbara Heebels, Irina van Aalst, Creative Clusters in Berlin: Entrepreneurship and the Quality of Place in Prenzlauer Berg and Kreuzberg, „Geografiska Annaler: Series B, Human Geography” 2010, Vol. 92, No. 4, s. 347-363.

David Hesmondhalgh, The Cultural Industries, Sage, London 2002.

David Hesmondhalgh, Bourdieu, the Media and Cultural Production, „Media, Culture \& Society" 2006, Vol. 28, No. 2, s. 211-231.

Paul M. Hirsch, The Structure of the Popular Music Industry: The Filtering Process by which Records are Preselected for Public Consumption, Institute for Social Research, University of Michigan, Ann Arbor 1969.

Paul M. Hirsch, Processing Fads and Fashions: An Organization-Set Analysis of Cultural Industry Systems, „American Journal of Sociology” 1972, Vol. 77, No. 4, s. 639-659.

Caroline Hodges, „PRP Culture”: A Framework for Exploring Public Relations Practitioners as Cultural Intermediaries, „Journal of Communication Management" 2006, Vol. 10, No. 1, s. 80-93.

Brian J. Hracs, Cultural Intermediaries in the Digital Age: The Case of Independent Musicians and Managers in Toronto, „Regional Studies” 2015, Vol. 49, No. 3 , s. $461-475$.

Doreen Jakob, Baas van Heur, Taking Matters into Third Hands: Intermediaries and the Organization of the Creative Economy, „Regional Studies” 2015, Vol. 49, No. 3, s. 357-361.

Charles Webster Leadbeater, Kate Oakley, The Independents: Britain's New Cultural Entrepreneurs, Demos, London 1999.

Hye-Kyung Lee, Cultural Consumers as „New Cultural Intermediaries”: Manga Scanlators, „Arts Marketing: An International Journal” 2012, Vol. 2, No. 2 , s. 131-143.

Jennifer Smith Maguire, Julian Matthews, Cultural Intermediaries and the Media, „Sociology Compass” 2010, Vol. 4, No. 7, s. 405-416. 
Jennifer Smith Maguire, Julian Matthews, Are We All Cultural Intermediaries Now? An Introduction to Cultural Intermediaries in Context, „European Journal of Cultural Studies" 2012, Vol. 15, No. 5, s. 551-562.

Jennifer Smith Maguire, Julian Matthews, Bourdieu on Cultural Intermediaries, [w:] The Cultural Intermediaries Reader, red. J.S. Maguire, J. Matthews, Sage, London 2014, s. 15-24.

Frédéric Martel, Mainstream. Co podoba się wszędzie na świecie, tłum. K. Sikorska, Wydawnictwo Czarna Owca, Warszawa 2010.

Liz McFall, What About the Old Cultural Intermediaries? An Historical Review of Advertising Producers, „Cultural Studies” 2002, Vol. 16, No. 4, s. 532-552.

Brian Moeran, Jesper Standgaard Pedersen, Negotiating Values in the Creative Industries: Fairs, Festivals and Competitive Events, Cambridge University Press, Cambridge 2011.

Liz Moor, Branding Consultants as Cultural Intermediaries, „The Sociological Review" 2008, Vol. 56, No. 3, s. 408-428.

Gina Neff, Elizabeth Wissinger, Sarah Zukin, Entrepreneurial Labor among Cultural Producers: „Cool” Jobs in „Hot” Industries, „Social Semiotics” 2005, Vol. 15, No. 3, s. 307-334.

Keith Negus, The Production of Culture, [w:] Production of Culture/Cultures of Production, red. P. du Gay, Sage, London 1997, s. 67-104.

Keith Negus, The Work of Cultural Intermediaries and the Enduring Distance between Production and Consumption, „Cultural Studies” 2002, Vol. 16, No. 4, s. 501-515.

Sean Nixon, Circulating Culture, [w:] Production of Culture/Cultures of Production, red. P. du Gay, Sage, London 1997, s. 177-220.

Justin O'Connor, Intermediaries and Imaginaries in the Cultural and Creative Industries, „Regional Studies” 2015, Vol. 49, No. 3, s. 374-387.

Norma Rantisi, Deborah Leslie, Significance of Higher Educational Institutions as Cultural Intermediaries: The Case of the École Nationale de Cirque in Montreal, Canada, „Regional Studies” 2015, Vol. 49, No. 3, s. 404-417.

Everett M. Rogers, Diffusion of Innovations, Free Press, New York 1983.

Gabriel Rossman, Climbing the Charts: What Radio Airplay Tells Us about the Diffusion of Innovation, Princeton University Press, Princeton 2012.

David B. Ruderman, Giuseppe Veltri (red.), Cultural Intermediaries: Jewish Intellectuals in Early Modern Italy, University of Pennsylvania Press, Philadelphia 2004. 
Allen J. Scott, On Hollywood: The Place, the Industry, Princeton University Press, Princeton 2005.

Pamela J. Shoemaker, Timothy P. Vos, Gatekeeping Theory, Routledge, New York 2009.

Benjamin Shultz, The Work Behind the Scenes: The New Intermediaries of the Indie Crafts Business, „Regional Studies” 2015, Vol. 49, No. 3, s. 451-460.

Lise Skov, Hong Kong Fashion Designers as Cultural Intermediaries: Out of Global Garment Production, „Cultural Studies” 2002, Vol. 16, No. 4, s. 553-569.

Krzysztof Stachowiak, Problemy metodologiczne badania sektora kreatywnego, „Rozwój Regionalny i Polityka Regionalna” 2015, nr 30, s. 9-46.

Krzysztof Stachowiak, Gospodarka kreatywna i mechanizmy jej funkcjonowania.

Perspektywa geograficzno-ekonomiczna, Wydawnictwo Naukowe UAM, Poznań 2017.

Krzysztof Stachowiak, Paulina Tomczak, Przestrzenny wymiar sektora kreatywnego, Bogucki Wydawnictwo Naukowe, Poznań 2015.

Paul Stoneman, Soft Innovation: Economics, Product Aesthetics, and the Creative Industries, Oxford University Press, Oxford 2010.

Konstanty Strzyczkowski, Szlachectwo nie zobowiąuje. Zmiany we wzorach konsumpcji kulturowej, „Ruch Prawniczy, Ekonomiczny i Socjologiczny” 2009, z. 1, s. 195-219.

Magdalena Szpunar, Wokół koncepcji gatekeepingu. Od gatekeepingu tradycyjnego do technologicznego, [w:] Idee i myśliciele. Medialne i społeczne aspekty filo$z o f i$, red. S.I. Fiut, Uczelniane Wydawnictwo Naukowo-Dydaktyczne AGH im. S. Staszica, Kraków 2013, s. 52-61.

Stanisław Szultka (red.), Klastry w sektorach kreatywnych - motory rozwoju miast i regionów, Polska Agencja Rozwoju Przedsiębiorczości, Warszawa 2012.

Calvin Taylor, Between Culture, Policy and Industry: Modalities of Intermediation in the Creative Economy, „Regional Studies” 2015, Vol. 49, No. 3, s. 362-373.

David Throsby, The Economics of Cultural Policy, Cambridge University Press, New York 20102.

David Throsby, Ekonomia i kultura, tłum. O. Siara, Narodowe Centrum Kultury, Warszawa 2010.

UNDP/UNCTAD, Creative Economy. Report 2010, Geneva - New York 2010.

Tara Vinodrai, Constructing the Creative Economy: Design, Intermediaries and Institutions in Toronto and Copenhagen, „Regional Studies” 2015, Vol. 49, No. 3, s. 418-432. 
Allan Watson, Cultural Production in and beyond the Recording Studio, Routledge, London 2015.

David Wright, Mediating Production and Consumption: Cultural Capital and 'Cultural Workers', „The British Journal of Sociology” 2005, Vol. 56, No. 1, s. 105-121.

\section{Cultural Intermediaries and Their Role in the Creative Economy}

The paper presents the role that cultural intermediaries play in creative economy. Cultural intermediaries are a specific and very important category of subjects in the creative economy. They play a key role especially in the dissemination of creative goods. They also serve as intermediaries between creators and producers. However, they are not only involved in connecting sellers with buyers, but are also involved in shaping the final value of goods. Therefore, cultural intermediaries can play a threefold role in the creative economy. They can be: (1) individuals or groups acting as a medium between cultures; (2) a collection of professions to transfer cultural values to society; (3) individuals or groups involved in the transfer of creative and cultural goods, cultural values between creators and audience.

Keywords: cultural intermediaries, creative economy, creative industries 



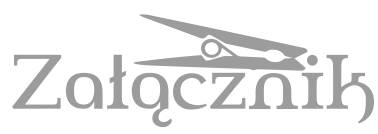

\section{STRATEGIE (NIE)INSTYTUCJI KULTURY. STUDIUM PRZYPADKU ZAMKU CIESZYN}

PATRYK DZIURSKI

\begin{abstract}
Kolegium Zarządzania i Finansów, Szkoła Główna Handlowa w Warszawie

Collegium of Management and Finance, SGH Warsaw School of Economics pd54550@sgh.waw.pl
\end{abstract}

\section{WPROWADZENIE}

Strategie organizacji sektorów kultury są mało eksploatowanym tematem rozważań naukowych, ale liczba publikacji na ten temat stale wzrasta. Związane jest to zapewne ze wzrostem znaczenia sektorów kultury, a szerzej - także sektorów kreatywnych, w gospodarce oraz społeczeństwie. $\mathrm{W}$ naukach społecznych kultura oraz kreatywność postrzegane są coraz częściej jako trzon współczesnego rozwoju. Temat strategii w tychże sektorach jest szczególnie interesujący, gdyż organizacje w nich działające różnią się od przedsiębiorstw ${ }^{1}$. Powoduje to, że wszelkie badania, zarówno teoretyczne, jak i empiryczne, są niezwykle potrzebne, ponieważ pozwalają lepiej poznać specyfikę zarządzania organizacjami z sektorów kultury i kreatywnych, a przez to uchwycić pełen obraz obszaru badawczego. Celem niniejszego artykułu jest więc charakterystyka strategii organizacji z sektorów kultury na przykładzie (nie)instytucji kultury - Zamku Cieszyn, który łączy w sobie najlepsze elementy organizacji niedziałających dla zysku z elementami tych, które nastawione są na zysk. Studium przypadku poprzedza opis strategii organizacji oraz charakterystyka strategii organizacji w sektorach kultury.

Artykuł ma charakter teoretyczno-empiryczny. Na podstawie krytycznej analizy literatury rozwijam oraz uzupełniam propozycje teoretyczne, które następnie weryfikuję w studium przypadku. Narzędziami wykorzystanymi

1 Przedsiębiorstwo, czyli zorganizowany zespół składników niematerialnych i materialnych przeznaczonych do prowadzenia działalności gospodarczej. 
w opracowaniu studium przypadku są: wywiad pogłębiony częściowo ustrukturyzowany, analiza materiałów udostępnionych przez badaną organizację oraz informacji ogólnodostępnych.

\section{STRATEGIE ORGANIZACJI - WPROWADZENIE}

Strategia to bodajże najczęściej używane pojęcie w kontekście zarządzania organizacjami. Przyjmuje się, że realizacja celów oraz rozwój organizacji są utrudnione bez dobrze opracowanej strategii. W literaturze przedmiotu trudno jednak znaleźć jednoznaczną odpowiedź na pytanie, czym jest strategia. Krzysztof Obłój pisze, że „teoria strategii jest niczym dywan utkany z momentami przeciwstawnych - a w pewnych aspektach komplementarnych - głównych koncepcji”", do których można zaliczyć: teorię planistyczną, ewolucyjną, pozycyjną i zasobową ${ }^{3}$.

Planistyczna teoria strategii zakłada, że kadra menedżerska jest władna w swobodny i racjonalny sposób kształtować plan strategiczny ${ }^{4}$. Strategię rozumie się więc jako zbiór decyzji planistycznych, podejmowanych w oparciu o szczegółową analizę otoczenia organizacji oraz jej mocnych i słabych stron (klasycznym narzędziem teorii planistycznej jest analiza SWOT ${ }^{5}$ ), które to decyzje mają zapewnić osiągnięcie przyjętych celów ${ }^{6}$. W opozycji do teorii planistycznej powstała teoria ewolucyjna. Przyjmuje się w niej, że tworzenie strategii jest niesformalizowanym procesem poszukiwania

2 K. Obłój, Strategia organizacji, wyd. III, Warszawa 2014, s. 24.

3 Por. G. Gierszewska, M. Romanowska, Analiza strategiczna przedsiębiorstwa, wyd. V, Warszawa 2017, s. 12-15; A. Sopińska, Wiedza jako strategiczny zasób przedsiębiorstwa. Analiza i pomiar kapitału intelektualnego przedsiębiorstwa, Warszawa 2010, s. 24-57; M. Romanowska, Planowanie strategiczne w przedsiębiorstwie, wyd. II, Warszawa 2009, s. 11-13; E. Stańczyk-Hugiet, Paradygmat relacji - czy to nowa jakość w zarządzaniu?, „Studia i Prace Kolegium Zarządzania i Finansów” 2012, nr 116, s. 164.

4 K. Obłój, op. cit., s. 24.

5 Analiza SWOT - nazwa jest akronimem od słów w języku angielskim określających element składowe analizy: Strengths (mocne strony), Weaknesses (słabe strony), Opportunities (szanse) i Threats (zagrożenia). Analiza SWOT polega na analizie mocnych i słabych stron organizacji oraz szans i zagrożeń związanych $\mathrm{z}$ otoczeniem.

${ }^{6}$ M. Romanowska, Planowanie strategiczne..., op. cit., s. 12. 
wzorca, który wyłania się z eksploatacji nowych opcji i powielania utrwalonych rozwiązań7. Strategia wyłania się wraz z upływem czasu i stanowi połączenie zamierzonych planów i wprowadzonych zmian ${ }^{8}$. Ważna jest umiejętność uczenia się oraz doskonalenia, gdyż tylko wtedy organizacja może osiągnąć sukces?.

Kolejna koncepcja to teoria pozycyjna, w której strategia powiązana jest $\mathrm{z}$ pozycją organizacji w otoczeniu konkurencyjnym ${ }^{10}$, co determinuje korzyści strategiczne, jakie mogą zostać przez nią osiągnięte ${ }^{11}$. Uwaga koncentruje się tu na tworzeniu strategii konkurencji, a nie wytyczaniu kierunków i tempa rozwoju organizacji. Strategia jest tworzona z perspektywy otoczenia konkurencyjnego, a nie zasobów wewnętrznych organizacji. Ta druga perspektywa charakteryzuje teorię zasobową, w której przyjmuje się, że sukces organizacji zależy od jakości zgromadzonych przez nią zasobów, szczególnie tych o charakterze niematerialnym ${ }^{12}$. Posiadane przez organizację zasoby są ważniejsze niż uwarunkowania sektorowe ${ }^{13}$. Maria Romanowska wskazuje jednak, że sukces organizacji nie zależy od posiadanych zasobów, ale od umiejętności zarządzania nimi. Autorka wskazuje cztery modelowe strategie zasobowe ${ }^{14}$ :

- „bogaty dyletant”, czyli organizacja, która posiada własne zasoby, ale nie umie nimi zarządzać;

- „władca skarbów”, czyli organizacja, która posiada własne zasoby oraz umiejętnie nimi zarządza;

7 K. Obłój, op. cit., s. 25.

8 E. Stańczyk-Hugiet, op. cit., s. 164.

9 M. Romanowska, Planowanie strategiczne... op. cit., s. 12.

10 Otoczenie konkurencyjne składa się ze wszystkich podmiotów, które mają z organizacją powiązania kooperacyjne lub konkurencyjne, czyli istniejący i potencjalni konkurenci, dostawcy, odbiorcy oraz producenci substytutów.

11 E. Stańczyk-Hugiet, op. cit., s. 164.

12 M. Romanowska, Planowanie strategiczne..., op. cit., s. 12-13.

13 K. Obłój, op. cit., s. 25.

14 M. Romanowska, Dostosowanie strategii przedsiębiorstwa do jego zasobów, [w:] Zarządzanie strategiczne. Ujęcie zasobowe, red. R. Krupski, Wałbrzych 2006, s. 93-96. 
- „chłopiec na posyłki”, czyli organizacja, która nie posiada własnych zasobów ani nie ma umiejętności korzystania i zarządzania zasobami cudzymi;

- „architekt biznesu”, czyli organizacja, która nie ma własnych zasobów, ale ma rozwinięte umiejętności korzystania i zarządzania zasobami cudzymi.

W opinii M. Romanowskiej, „można odnieść sukces, nie posiadając zasobów (»architekt biznesu«), ale nie można odnieść sukcesu, nie posiadając umiejętności zarządzania zasobami, nawet jeżeli te zasoby są obfite (»bogaty dyletant«)”15. Ważny jest dostęp do zasobów oraz umiejętność zarządzania nimi, a nie samo ich posiadanie. $Z$ tego względu strategia organizacji powinna być także postrzegana z perspektywy sieci ${ }^{16}$. Organizacje powinny utrzymywać i rozwijać relacje z innymi organizacjami i osobami, aby tworzyć, chronić i przechwytywać wytworzone wartości ${ }^{17}$. Relacje są ważnym źródłem przewagi konkurencyjnej w dynamicznie zmieniającym się świecie. Adam M. Brandenburger oraz Barry J. Nalebuff wyróżniają dwie strategie w zależności od zaangażowania organizacji w sieci relacji: strategię niezależności oraz uwikłania w sieć kooperacyjną ${ }^{18}$. Pierwsza $\mathrm{z}$ nich oznacza, że organizacja nie nawiązuje relacji z innymi organizacjami ani osobami. Druga natomiast, że organizacja nawiązuje różnorodne relacje i poprzez współpracę podnosi własną konkurencyjność w stosunku do organizacji, które nie są uczestnikami sieci.

Każda z przedstawionych teorii ma swoich zwolenników, krytyków, założenia, skrzynkę narzędziową oraz ograniczenia. Przedstawione teorie częściowo są sprzeczne, ale częściowo się uzupełniają. Uważam, że w praktyce bardzo ciężko wskazać tylko jedną teorię, zgodnie z którą organizacja postrzega swoją strategię. W organizacjach dominuje zazwyczaj jedno podejście, które łączone jest mniej lub bardziej świadomie z innymi (np.

15 Ibidem, s. 96.

16 E. Stańczyk-Hugiet, op. cit., s. 166.

17 D. Lewicka, A. Zakrzewska-Bielawska, Rola zaufania $w$ relacyjnej orientacji przedsiębiorstwa, [w:] Meandry teorii i praktyki zarządzania, red. G. Osbert-Pociecha, S. Nowosielski, Wrocław 2016, s. 109.

18 A.M. Brandenburger, B.J. Nalebuff, Co-Opetition, New York - London Toronto - Sydney - Auckland 1996. 
dominujące może być rozumienie strategii zgodnie $\mathrm{z}$ teorią ewolucyjną, ale $\mathrm{w}$ jej tworzeniu wykorzystuje się także elementy $\mathrm{z}$ teorii zasobowej). Uogólniając, można wskazać trzy podejścia do tworzenia strategii w organizacji. Pierwsze podejście - „od zewnątrz do wewnątrz” - oznacza, że strategia ukierunkowana jest rynkowo. To szanse i zagrożenia znajdujące się w otoczeniu organizacji determinują jej cele i strategie. W drugim podejściu - „od wewnątrz do zewnątrz” - przyjmuje się odwrotną perspektywę. Strategię determinują tu zasoby, które organizacja posiada lub ma do nich dostęp. W tym przypadku to mocne i słabe strony organizacji określają jej cele oraz strategie. Trzecie podejście integruje dwa poprzednie, gdyż strategia jest wypadkową posiadanych przez organizacje mocnych i słabych stron oraz szans i zagrożeń związanych $\mathrm{z}$ otoczeniem.

W tradycyjnym ujęciu strategia to efekt prac, które poprzedza analiza strategiczna oraz projektowanie strategii. Przygotowany dokument jest następnie przekazywany do realizacji, a zmiana strategii następuję dopiero w następnym okresie, który kolejny raz poprzedzają analizy strategiczne oraz projektowanie strategii. W nowoczesnym ujęciu strategia rozumiana jest jako ciągły i dynamiczny proces, który nigdy się nie kończy. Strategia to dynamiczny proces pokonywania trudności, jakie organizacja napotyka na drodze swojego rozwoju ${ }^{19}$.

\section{STRATEGIE ORGANIZACJI Z SEKTORÓW KULTURY}

$\mathrm{W}$ teorii zarządzania jednym z podstawowych pojęć jest organizacja, czyli "grupa ludzi, którzy współpracują ze sobą w sposób uporządkowany i skoordynowany, aby osiągnąć pewien zestaw celów"20. Stosując jeden z najprostszych podziałów, można wyróżnić organizacje działające dla zysku oraz organizacje niedziałające dla zysku. Celem organizacji działających dla zysku jest maksymalizacja wartości, a wypracowany zysk jest dzielony między właścicieli lub reinwestowany w dalszy rozwój organizacji, co ma zapewnić wzrost jej wartości w przyszłości. Natomiast celem organizacji niedziałających dla zysku jest realizacji misji oraz wytwarzanie produktów niekomercyjnych. Generowanie zysku nie jest celem, co nie oznacza, że nie

19 M. Romanowska, Planowanie strategiczne..., op. cit., s. 17, 19.

20 R.W. Griffin, Podstawy zarządzania organizacjami, wyd. II, tłum. M. Rusiński, Warszawa 2014, s. 5. 
może być on wypracowywany przez tego typu organizacje. Wygenerowany zysk nie jest dzielony między właścicieli, ale reinwestowany w rozwój organizacji. Heerad Sabeti zwraca jednak uwagę, że taki podział jest zbytnim uproszczeniem, gdyż współcześnie coraz trudniej przydzielić organizacje do określonego typu ${ }^{21}$. W obszarze kultury przykładów nie trzeba długo szukać. Warto zwrócić uwagę na opracowanie Towarzystwa Inicjatyw Twórczych $\mathrm{E}_{\ell}^{22}$ oraz książkę Kultura i rozwój. Analizy, rekomendacje, studia przypadków ${ }^{23}$. W obydwu pracach zwraca się uwagę na inicjatywy kulturalne / nieinstytucje kultury, które często nie wchodzą w sferę formalnej kultury, a nie można ich określić jako organizacji niedziałających dla zysku, przez co są trudne do uchwycenia i wymykają się wszelkim klasyfikacjom. Jednocześnie inicjatywny te mają wpływ na ład instytucjonalny w kulturze oraz rozwój społeczno-gospodarczy. Oznacza to, że powstają organizacje hybrydowe, które H. Sabeti nazywa przedsiębiorstwami nastawionym na korzyści niematerialne (for-benefit enterprises) ${ }^{24}$, a Justyna Szumniak-Samolej - przedsięwzięciami zbudowanymi wokół misji społecznej i/lub środowiskowej ${ }^{25}$. Organizacje hybrydowe łączą elementy charakterystyczne dla organizacji działających dla zysku (np. nacisk położony na efektywność działania) z elementami charakterystycznymi dla organizacji niedziałających dla zysku (np. koncentracja na realizacji misji). W sektorach kultury działają wszystkie trzy rodzaje organizacji - niedziałające dla zysku, hybrydowe

${ }^{21}$ H. Sabeti, Przedsiębiorstwo nastawione na korzyści niematerialne, „Harvard Business Review” 2012, nr 5, s. 67-74.

${ }^{22}$ M. Kubecka, M. Białek-Graczyk, Jaskółki. Nowe zjawiska w warszawskich instytucjach i nieinstytucjach kultury, 2016, http://nck.pl/media/attachments/317271/ Jask\%C3\%B3\%C5\%82ki.\%20Nowe\%20zjawiska\%20w\%20warszawskich\%20instytucjach\%20i\%20nieinstytucjach\%20kultury.pdf [dostęp: 2.02.17].

${ }_{23}$ Por. Kultura i rozwój. Analizy, rekomendacje, studia przypadku, red. J. Hausner, I. Jasińska, M. Lewicki, I. Stokfiszewski, Warszawa 2016.

${ }^{24}$ H. Sabeti, op. cit., s. 67-74.

25 J. Szumniak-Samolej, Innowacyjne przedsięwzięcia nawiąujące do idei społecznej odpowiedzialności biznesu na rynku polskim, [w:] Badania młodych naukowców $w$ dziedzinie nauk ekonomicznych a praktyka gospodarcza, red. M. Wolański, Warszawa 2015, s. 369-378; eadem, Polskie przedsiębiorstwa oparte na misji społecznej: modele biznesowe, motywacje, wyzwania, [w:] Wkład nauk ekonomicznych w budowę kapitału społecznego, red. M. Menkes, Warszawa 2016, s. 171-186. 
oraz działające dla zysku, choć trzeci typ jest najrzadziej spotykany. Opis strategii organizacji z sektorów kultury - jeśli wziąć pod uwagę powyższe uwarunkowania - jest interesującym tematem, który wymaga pogłębienia zarówno teoretycznego, jak i empirycznego.

Strategie organizacji z sektorów kultury stają się tematem rozważań coraz większej liczby naukowców i praktyków, ale w dalszym ciągu jest to obszar stosunkowo słabo rozwinięty. Mateusz Lewandowski zwraca uwagę na fakt, że metody i narzędzia zaczerpnięte $\mathrm{z}$ obszaru zarządzania strategicznego są coraz powszechniej stosowane w polskich instytucjach kultury $^{26}$. Instrumentarium zarządzania strategicznego wykorzystuje się także do opisu charakterystyki sektorów kultury (również w pracach naukowych), czego przykład stanowi praca Anny Wróblewskiej na temat sektora produkcji filmów fabularnych w Polsce ${ }^{27}$.

M. Lewandowski, wskazując obszary, w których prowadzane są badania dotyczące zarządzania strategicznego w polskich instytucjach kultury, wymienia kolejno: (1) tworzenie misji oraz proces zarządzania strategicznego $\mathrm{w}$ muzeach, (2) podejście do strategii i zarządzania strategicznego z perspektywy praktyków zarządzających instytucjami kultury, (3) strategie marketingowe w sektorze sztuki i filharmonii, a także (4) typologie strategii oraz charakterystykę procesu zarządzania strategicznego w instytucjach kultury ${ }^{28}$. Ostatni obszar jest tematem rozważań Lidii Varbanovej, która na podstawie gruntownej analizy literatury przedmiotu zaproponowała typologie różnych strategii organizacji w sektorach kultury, wyróżniając: główne strategie organizacji, strategie produktowo-rynkowe (programowo-rynkowe) oraz strategie konkurencji ${ }^{29}$ (tabela 1). Strategie ogólne określają kierunki rozwoju organizacji i dotyczą całej organizacji. Strategie produktowo-rynkowe (programowo-rynkowe) wskazują na ścieżki rozwoju pro-

26 M. Lewandowski, Czynniki utrudniające samodzielne opracowywanie planów strategicznych przez pracowników instytucji kultury, [w:] Zarządzanie w instytucjach kultury, red. Ł. Wróblewski, Warszawa 2014, s. 62.

27 A. Wróblewska, Kinematografia jako przemyst kultury. Uwarunkowania i tendencje rozwoju branży filmowej w Polsce, Warszawa 2013, s. 242-265.

28 M. Lewandowski, op. cit., s. 62-63.

29 L. Varbanova, Zarządzanie strategiczne w kulturze, tłum. T. Piwowarczyk, Warszawa 2015 [e-book]. 
duktów (programów) i rynków. Organizacja może koncentrować się na obecnych rynkach i produktach (programach), stosując strategie penetracji, lub może rozwijać nowe produkty (programy) i/lub rynki. Natomiast celem strategii konkurencji jest tworzenie, wzmacnianie i utrzymywanie przewagi konkurencyjnej, czyli osiągniecie przez organizacje lepszej pozycji w sektorze w porównaniu $z$ innymi podmiotami. Należy wskazać, że organizacje powinny posiadać i realizować każdy typ strategii oraz mogą realizować kilka strategii równocześnie. Przykładowo organizacja może realizować zarówno strategie innowacji, jak i strategie tworzenia sieci kontraktów (strategie ogólne) oraz strategie przywództwa kosztowego w jednym sektorze, strategie przywództwa jakościowego natomiast w innym (strategie konkurencji).

Tabela 1. Typologia strategii organizacji w sektorach kultury

\begin{tabular}{|c|c|c|}
\hline 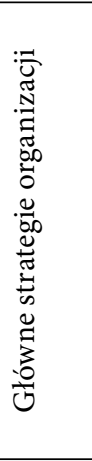 & $\begin{array}{l}\text { Strategie określające } \\
\text { kierunki, w jakich podążać } \\
\text { będzie organizacja }\end{array}$ & $\begin{array}{l}\text { strategia innowacji } \\
\text { strategia wydzielenia (outsourcingu) } \\
\text { strategia prywatyzacji } \\
\text { strategia budowania potencjału } \\
\text { strategia przetrwania } \\
\text { strategia likwidacji } \\
\text { strategia integracji } \\
\text { strategia partnerstwa } \\
\text { strategia klastrów kreatywnych } \\
\text { strategia koprodukcji } \\
\text { strategia tworzenia sieci kontraktów } \\
\text { strategia lobbingowa }\end{array}$ \\
\hline 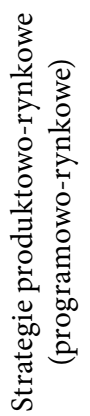 & $\begin{array}{l}\text { Strategie rozwoju, które } \\
\text { obarczone są różnym } \\
\text { ryzykiem }\end{array}$ & $\begin{array}{l}\text { strategia penetracji rynku } \\
\text { strategia rozwoju rynku } \\
\text { strategia rozwoju produktu (programu) } \\
\text { strategia dywersyfikacji }\end{array}$ \\
\hline
\end{tabular}




\begin{tabular}{|c|c|c|}
\hline 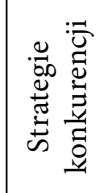 & $\begin{array}{l}\text { Strategie, które mają na } \\
\text { celu osiągniecie, wzmac- } \\
\text { nianie oraz utrzymanie } \\
\text { przewagi konkurencyjnej }\end{array}$ & $\begin{array}{l}\text { strategia przywództwa kosztowego } \\
\text { strategie dyferencjacji (zróżnicowania, } \\
\text { przywództwa jakościowego) } \\
\text { strategia koncentracji } \\
\text { strategia zintegrowana }\end{array}$ \\
\hline
\end{tabular}

Źródło: opracowanie własne na podstawie: L. Varbanova, Zarządzanie strategiczne w kulturze, tłum. T. Piwowarczyk, Warszawa 2015 [e-book].

W swojej pracy L. Varbanova definiuje także strategie organizacji z sektorów kultury jako: „system podejść, metod i narzędzi oceny i wyboru opcji prowadzących do realizowania misji i osiągnięcia długoterminowych celów w najskuteczniejszy sposób, przy uwzględnieniu wpływów zewnętrznych i wewnętrznych oraz zasobów i zdolności organizacji, jak również potencjału innowacyjności, przedsiębiorczości i kreatywności”30. W zaproponowanej definicji strategia postrzegana jest jako wypadkowa uwarunkowań zewnętrznych oraz mocnych i słabych stron organizacji. Posiadanie i realizowanie strategii jest kluczowe, aby osiągać założone cele oraz w pełni wykorzystać potencjał wewnętrzny organizacji.

Chis Bilton, badacz operujący pojęciem kreatywnej strategii, wyróżnia trzy podejścia do jej tworzenia: (1) model „heroiczny” ('heroic' model), (2) adhokrację (adhocracy) oraz (3) posthokrację (posthocracy). W „heroicznym" modelu kreatywnej strategii najważniejsze miejsce zajmuje lider. To on w oparciu o swoje doświadczenie, umiejętność analizy trendów rynkowych oraz kreatywność identyfikuje unikalną przewagę konkurencyjną oraz tworzy strategię. W adhokracji, zgodnie z założeniami teorii ewolucyjnej, strategia tworzona jest kolektywnie i przyrostowo, a przyszła strategia wyłania się z aktualnych działań ${ }^{31}$. W świecie chaosu oraz dominacji pozornie niepowiązanych ze sobą wydarzeń kluczowa jest umiejętność rozpoznawania słabych sygnałów oraz „niewidzialnych” prawidłowości, a porządek wyłania się z pozornie przypadkowych i niezorganizowanych interakcji ${ }^{32}$. Adhokracja

30 Ibidem.

31 C. Bilton, Management and Creativity. From Creative Industries to Creative Management, Oxford - Carlton 2007, s. 91 i n.

32 J. Hartley, J. Potts, S. Cunningham, T. Flew, M. Keane, J. Banks, Key Concepts in Creative Industries, Los Angeles - London - New Delhi - Singapore - Washington (DC) 2013, s. 28-29. 
w zarządzaniu strategicznym nie oznacza tylko prostego akceptowania chaosu i niepewności, ale odwołuje się do oddolnego (bottom-up) procesu tworzenia strategii, co oznacza, że wyłania się z działań i decyzji operacyjnych. Trzecim z podejść jest posthokracja, gdzie nieprzewidywalność otoczenia jest tak duża, że planowanie staje się niemożliwe. Podstawą podjęcia decyzji są emocje, ego oraz osobowość decydenta, a ich racjonalność określana jest expost ${ }^{33}$. Typy wskazane przez C. Biltona znajdują potwierdzenie w słowach Martyny Śliwy, która wskazuje, że w polskich instytucjach kultury podejście do strategii jest różnorodne: „od tradycyjnego, w myśl którego przywódca podejmuje większość decyzji i kieruje zespołem tak, aby realizował on jego wizję strategiczną, po styl oparty na budowaniu wizji strategicznej instytucji w dialogu z pracownikami i pozostawienie zespołowi znacznej wolności twórczej”" ${ }^{34}$. Podejście tradycyjne odpowiada „heroicznemu” modelowi kreatywnej strategii, natomiast drugie z nich - adhokracji. M. Śliwa wskazuje także, że nie istnieje jedna ogólna strategia realizowana przez wszystkie instytucje kultury w Polsce, gdyż każda z nich tworzy własną strategię, uwzględniając uwarunkowania otoczenia oraz swoje słabe i mocne strony ${ }^{35}$, co potwierdza wcześniejsze rozważania o różnych strategiach oraz jest spójne $z$ definicją strategii organizacji z sektorów kultury zaproponowaną przez L. Varbanovą.

Martyna Śliwa zaznacza ponadto, że zarządzający polskimi instytucjami kultury borykają się z dużą nieprzewidywalnością otoczenia ${ }^{36}$ oraz mają

${ }_{33}$ C. Bilton, op. cit., s. 91 i n.

${ }^{34}$ M. Śliwa, Stratedzy i strategie polskich instytucji kultury: podsumowanie, [w:] Strategie dla kultury. Kultura dla rozwoju. Zarzadzanie strategiczne instytucja kultury, red. M. Śliwa, Kraków 2011, s. 211.

35 Ibidem, s. 212.

36 Niepewność otoczenia jest stosunkowo szczegółowo opisana w literaturze przedmiotu. W związku z czym, biorąc pod uwagę także ograniczenia długości artykułu, zdecydowałem się pominąć opis tej sytuacji. Zainteresowanych czytelników zachęcam do zapoznania się z następującymi pracami: G. Bērziņš, Strategic Management in Creative Industry Organizations: Specifics in Strategic Decision Making, „Management of Organizations: Systematic Research” 2012, No. 62, s. 10-11; R.E. Caves, Creative Industries. Contracts Between Art and Commerce, Cambridge Massachusetts - London 2000, s. 2-3; D. Hesmondhalgh, The Cultural Industries, 
ograniczony wpływ na część decyzji podejmowanych w szeroko rozumianej sferze publicznej, które bezpośrednio dotyczą ich organizacji ${ }^{37}$. Organizacje działające w sferze publicznej, w tym także w sektorach kultury, mają narzuconą realizację misji publicznej, co wpływa na ich cele oraz strategie. Sprawia to, że cele organizacji niedziałających dla zysku są inne niż cele organizacji działających dla zysku, a przez to i sposoby ich osiągania będą się różnić. Dodatkowo, nierzadko władza na różnych szczeblach, pośrednio oraz bezpośrednio, wyraża swoje oczekiwania względem organizacji oraz sposobu realizacji misji publicznej. Otoczenie w sektorach kultury jest zatem złożone, a dla funkcjonowania organizacji w nich działających duże znaczenie mają czynniki polityczne. Władze centrale i samorządowe mają zasadniczy wpływ na kierunki polityki kulturalnej oraz ład instytucjonalny w sektorach kultury, przez co silnie oddziałują na cele organizacji. Nasuwa się więc pytanie, w jakim stopniu organizacje z sektorów kultury określają samodzielnie misje i cele? Jest to trudne do stwierdzenia, ale nie wydaje się jednak nadużyciem wskazanie, że organizacje z sektorów kultury są przynajmniej częściowo „ubezwłasnowolnione” w podejmowaniu decyzji strategicznych ${ }^{38}$ (np. ograniczenia prawne dotyczące prowadzenia działalności gospodarczej lub odmienne zamierzenia właścicieli). Kwestią utrudniającą tworzenie oraz realizowanie strategii jest także konieczność godzenia celów różnych grup interesariuszy (czyli osób indywidualnych, grup lub organizacji działających wewnątrz organizacji lub poza nią), których interesy są związane z zarządzaniem organizacją i mogą wpływać na jej działanie w sposób bezpośredni lub pośredni. Interesariusze wpływają na organizację, ale również są pod jej wpływem $^{39}$. W przypadku organizacji z sektorów kultury liczba interesariuszy

ed. III, Los Angeles - London - New Delhi - Singapore - Washington (DC) 2013, s. 26-28.

${ }^{37}$ M. Śliwa, op. cit., s. 212.

38 W tym miejscu warto zwrócić uwagę, że w przypadku niektórych organizacji działających dla zysku możliwość podejmowania decyzji strategicznych jest także ograniczona. Przykład stanowią spółki-córki, które są całkowicie zależne od spółek-matek. Strategie są tworzone przez spółkę-matkę, a zadaniem spółek-córek jest ich realizacja.

39 P. Wachowiak, Wrażliwość społeczna przedsiębiorstwa. Analiza i pomiar, Warszawa 2013, s. 46. 
jest o wiele większa niż w przypadku organizacji działających dla zysku ${ }^{40}$, a zaspokajanie ich potrzeb stanowi o wiele trudniejsze zadanie ${ }^{41}$. Różne grupy interesariuszy zgłaszają różne interesy, które często są sprzeczne, a zadaniem zarządzających organizacją jest takie przygotowanie i realizowanie strategii, aby zaspokoić aspiracje każdej z grup. Zarządzający muszą więc balansować pomiędzy różnymi interesami i wybierać rozwiązania kompromisowe, co również ogranicza swobodę podejmowania decyzji strategicznych.

\section{ZAMEK CIESZYN - STRATEGIA INNOWACYJNEJ (NIE)INSTYTUCJI KULTURY ${ }^{42}$}

Zamek Cieszyn powstał w 2005 roku $^{43}$ jako jednostka budżetowa miasta, ale od 2011 roku jest samorządową instytucją kultury prowadzoną wspólnie przez Miasto Cieszyn oraz Województwo Śląskie. Cel Zamku Cieszyn stanowi „rozwój innowacyjnej przedsiębiorczości poprzez wykorzystanie wzornictwa”, które jest postrzegane jako skuteczne narzędzie „podnoszenia konkurencyjności firm, instytucji, miast i regionów”44. Tak obrany cel sprawia, że Zamek Cieszyn koncentruje się na działaniu w trzech obszarach: designu, przedsiębiorczości oraz turystyki. Oferta w obszarze designu kierowana jest głównie do projektantów i obejmuje: warsztaty i szkolenia, doradztwo dla zakładających działalność gospodarczą oraz doradztwo/po-

40 Por. Ł. Gaweł, Zarządzanie strategiczne szlakiem dziedzictwa kulturalnego w świetle koncepcji stakeholders, „Turystyka Kulturowa” 2012, nr 10, s. 33-40.

${ }^{41}$ Por. W. Williams, D. Lewis, Strategic Management Tools and Public Sector Management, „Public Management Review” 2008, Vol. 10, No. 5, s. 655-660.

${ }^{42}$ Studium przypadku zostało przygotowane na podstawie wywiadów z pracownikami Zamku Cieszyn, udostępnionych przez nich materiałów oraz ogólnodostępnych informacji. Wywiady zostały przeprowadzone przez Patryka Dziurskiego (Szkoła Główna Handlowa w Warszawie, Instytut Zarządzania) i Mikołaja Lewickiego (Uniwersytet Warszawski, Instytut Socjologii) w okresie czerwiec-lipiec 2015 roku na potrzeby projektu badawczego pt. Kultura i rozwój finansowanego z Programu Ministra Kultury i Dziedzictwa Narodowego 2015 Obserwatorium Kultury.

${ }^{43}$ Do 2011 roku Zamek Cieszyn nosił nazwę: Śląski Zamek Sztuki i Przedsiębiorczości.

44 Projektujemy możliwości, http://www.zamekcieszyn.pl/pl/artykul/projektujemy-mozliwosci-199 [dostęp: 30.01.17]. 
moc przy wdrożeniach. W obszarze przedsiębiorczości oferta kierowana jest do biznesu i obejmuje: szkolenia prowadzone przez pracowników Zamku, szkolenia dostosowane do potrzeb klienta, prowadzone przez zewnętrznych ekspertów, doradztwo/pomoc przy wdrożeniach oraz organizowanie imprez firmowych. Dodatkowo obie grupy mają możliwość wynajmu powierzchni wystawienniczych i lokali. Zamek Cieszyn organizuje także wyjazdy na targi i festiwale designu. Ofertę w obszarze turystyki stanowi wynajem pokoi gościnnych, zwiedzanie wzgórza zamkowego, organizowanie warsztatów tradycyjnego i artystycznego rzemiosła oraz organizacja imprez ${ }^{45}$. Usługi oferowane przez Zamek Cieszyn są częściowo bezpłatne, częściowo natomiast świadczone na zasadach komercyjnych. Na budżet Zamku Cieszyn składa się dotacja z Urzędu Miasta i Województwa Śląskiego ( $1 / 3$ budżetu), finansowanie zewnętrzne (np. projekty unijne; $1 / 3$ budżetu) oraz przychody z działalności gospodarczej ( $1 / 3$ budżetu).

Zamek Cieszyn łączy w sobie tradycję i nowoczesność. Poprzez swoją nazwę i położenie na wzgórzu zamkowym bezpośrednio nawiązuje do tradycji oraz historii, pośrednio natomiast - poprzez ochronę i promocję tradycyjnego rzemiosła. Z drugiej strony, działalność Zamku Cieszyn jest zwrócona ku nowoczesnemu projektowaniu. Wytycza on kierunki rozwoju designu w Polsce poprzez promowanie projektowania usług, przestrzeni publicznej oraz zmian społecznych. Ewa Gołębiowska, dyrektor Zamku Cieszyn, zwraca uwagę, że „splecenie historii, tradycji, tożsamości z wzornictwem i nowoczesnymi technologiami” stanowi o sile Zamku ${ }^{46}$.

Zamek Cieszyn jest samorządową instytucją kultury, ale po zapoznaniu się z jego działalnością trudno go uznać za instytucję typową. Jedna z respondentek stwierdza: ,jesteśmy taką nietypową instytucją kultury” (respondentka 1). Ta sama osoba wskazuje, że razem z ekipą chcieliby zostać nazwani ,inspirującym miejscem”, a nie traktowani jak tradycyjna instytucja czy dom kultury. W materiałach prasowych można znaleźć informację, że pracownicy Zamku Cieszyn określają go mianem „firmy”, co oznacza,

${ }^{45}$ http://www.zamekcieszyn.pl/pl/artykul/oferta-200 [dostęp: 30.01.17].

46 E. Gołębiowska, Pomiędzy kultura i przedsiębiorczościa, tradycją i innowacyjnościa. Przykład: Zamek Cieszyn - centrum wzornictwa, instytucja kultury rozwijająca przedsiębiorczość, [w:] Strategie dla kultury..., op. cit., s. 157. 
że istnieje „określony cel, wspólnota działania, wizja, [...] strategia tego działania. [...] Mówimy o firmie niekoniecznie w sensie określania celu jako działalności gospodarczej nastawionej na zysk, ale skuteczności działania w konkretnie określonym celu" (respondentka 1). Inna z respondentek dodaje, że „my [pracownicy Zamku Cieszyn - przyp. P.D.] mamy zawsze gdzieś z tyłu głowy misję. Możemy czasem zrobić coś, co nie do końca jest opłacalne w sensie finansowym [...]; są działania, które dopiero za jakiś czas przynoszą pewne owoce i nie zawsze stricte finansowe, czasem zmianę mentalności, przygotowanie do wprowadzenia jakichś innych rozwiązań" (respondentka 2). Zamek Cieszyn łączy działalność służącą realizacji misji publicznej z działalnością gospodarczą, jest więc organizacją hybrydową, która spaja w sobie najlepsze elementy organizacji działających i niedziałających dla zysku.

Strategia w Zamku Cieszyn postrzegana jest jako dynamiczny proces pokonywania trudności na drodze rozwoju (ujęcie nowoczesne). Jego pracownicy wskazują na liczne problemy, które muszą być rozwiązywane, aby można było realizować projekty i się rozwijać. Zwraca się także uwagę na trudność w planowaniu długookresowym, szczególnie w aspekcie finansowym, co utrudnia działanie i zarządzanie całą organizacją. Ewa Gołębiowska jest bez wątpienia silnym liderem, ale - jak sama deklaruje w jednym $\mathrm{z}$ wywiadów ${ }^{47}$ - proces tworzenia, realizowania i nawet kontroli realizacji strategii odbywa się przy dużym udziale pracowników.

W Zamku Cieszyn strategia częściowo postrzega jest przez pryzmat teorii zasobowej, dlatego też podczas tworzenia strategii stosuje się podejście od wewnątrz do zewnątrz. Ważne są wszelkie rodzaje zasobów: zarówno materialne (zasoby finansowe i budynki), jak i niematerialne (wiedza i umiejętności, relacje, reputacja i wizerunek, silna marka oraz sprawny system zarządzania). Większa waga przypisywana jest jednak zasobom niematerialnym, szczególnie wiedzy i umiejętnościom oraz relacjom. Dyrektor Zamku Cieszyn wskazuje, że „instytucji jest potrzebny dobry, silny trzon, stały zespół”48. Potwierdza to także jedna z respondentek, mówiąc: „musimy mieć załogę, najważniejsze jest, żeby dobrać zespół i żeby ten zespół kształcić i związać" (respondentka 1).

47 Ibidem, s. 150.

48 Ibidem, s. 151. 
Ważnym niematerialnym zasobem Zamku Cieszyn są relacje, które były tworzone i wykorzystywane jeszcze przed jego powstaniem oraz w czasie jego działalności. W wywiadach podkreślono, że to dzięki pomocy i zaangażowaniu osób z Urzędu Miasta Cieszyn oraz Urzędu Marszałkowskiego możliwe było powstanie Zamku Cieszyn. Już po powstaniu natomiast intensywnie wykorzystywano różne relacje, aby pozyskać wiedzę i umiejętności potrzebne do realizacji przyjętej misji, co jest praktykowane do dziś (np. wykorzystywanie zewnętrznych ekspertów). Należy jednak zwrócić uwagę, że obecnie zespół Zamku Cieszyn posiada dużą wiedzę i umiejętności, które umożliwiają rozwój usług szkoleniowych i doradczych. Dodatkowo Zamek Cieszyn pełni rolę animatora współpracy, co oznacza, że jego działania umożliwiają tworzenie oraz wzmacnianie relacji między innymi osobami i organizacjami. Przykładowe inicjatywy tego typu to: Klub Przedsiębiorcy, Śląski Klaster Dizajnu oraz śniadania biznesowe. Duża sieciowość Zamku wykorzystywana jest także w codziennej działalności, aby pomóc przedsiębiorcom, projektantom oraz innym centrom designu, na co wskazuje jedna z respondentek: „zawsze można [do nas - przyp. P.D.] zadzwonić i się zapytać, gdzie są specjaliści do tego czy tamtego. Jak możemy pomóc, to przekazujemy telefony, namiary" (respondentka 1). Oznacza to, że Zamek Cieszyn realizuje strategię nazwaną przez Brandenburgera i Nalebuffa strategią uwikłania w sieć kooperacyjną lub strategię tworzenia sieci kontaktów z typologii zaproponowanej przez Varbanovą. Zamek Cieszyn tworzy różnorodne relacje, które wykorzystuje na drodze rozwoju oraz udostępnia innym partnerom.

Określenie strategii zasobowej Zamku Cieszyn jest trudnym zadaniem. Z jednej strony, posiada on własne zasoby (materialne, w postaci budynków oraz środków finansowych, oraz niematerialne, w postaci wiedzy, umiejętności i relacji), ale - z drugiej strony - z sukcesem korzysta $\mathrm{z}$ zasobów cudzych (głównie niematerialnych, w postaci wiedzy i umiejętności). Oznacza to, że Zamek Cieszyn posiada dobrze rozwiniętą umiejętność zarządzania zasobami nie tylko własnymi, ale także obcymi. Jego strategia zasobowa mieści się więc pomiędzy strategią „władcy skarbów” a strategią „architekta biznesu", ale w mojej opinii bliżej jest mu do pierwszej z wymienionych opcji.

Wydaje się także, że Zamek Cieszyn stosuje strategię innowacji, która w jego przypadku polega na poszerzaniu zakresu projektowania (nie tylko projektowanie produktów, ale także usług, przestrzeni publicznej oraz 
zmiany społecznej), co pozytywnie oddziałuje na wzrost efektywności. Wydaje się, że strategią produktowo-rynkową dla Zamku Cieszyn jest strategia rozwoju produktu. Oznacza to, że wprowadza on nowe produkty na dotychczasowych rynkach swojego działania.

Ostatnią kwestią, którą chciałbym poruszyć, jest wpływ interesariuszy na tworzenie oraz realizację strategii. Zamek Cieszyn musi radzić sobie z oczekiwaniami różnych interesariuszy. Przykładowo, sprzeczne interesy zgłaszają właściciele Zamku - władze wojewódzkie chcą zwiększyć obecność Zamku poza Śląskiem Cieszyńskim, natomiast władze miejsce oczekują większej obecności Zamku w Cieszynie ${ }^{49}$. Tworzenie oraz realizacja strategii przy tak sprzecznych oczekiwaniach jest niezwykle trudnym zadaniem, a do tego dochodzą jeszcze oczekiwania innych grup: środowiska designu, mieszkańców Cieszyna, przedsiębiorców, partnerów i pracowników, które są różne i mogą być wzajemnie sprzeczne. Strategia jest tworzona i realizowana w wyniku kompromisu, a nie na podstawie swobodnych decyzji pracowników Zamku Cieszyn, co potwierdza moje wcześniejsze uwagi.

\section{PODSUMOWANIE}

Powyższe rozważania skłaniają mnie do sformułowania dwóch wniosków. Po pierwsze, tworzenie oraz realizacja strategii są trudnymi zadaniami w organizacjach z sektorów kultury. Daleki byłbym jednak od stwierdzenia, że jest to proces trudniejszy niż w organizacjach działających dla zysku. Proces zarządzania strategicznego ma swoją specyfikę w każdym typie organizacji, a przed osobami tworzącymi oraz realizującymi strategię stoją odmienne wyzwania. Skłania mnie to do sformułowania drugiego wniosku, zgodnie z którym na proces tworzenia i realizacji strategii w organizacjach z sektorów kultury największy wpływ mają następujące czynniki: cele organizacji (odmienne od celów organizacji działających dla zysku), konieczność zarządzania sprzecznymi aktywnościami, takimi jak eksploracja i eksploatacja ${ }^{50}$,

${ }^{49}$ Por. P. Dziurski, Design jako źródło zmian społecznych. Studium przypadku Zamku Cieszyn, [w:] Kultura i rozwój. Analizy..., op. cit., s. 425-430.

${ }^{50}$ Kwestia zarządzania sprzecznymi aktywnościami, takimi jak eksploracja i eksploatacja, nie była poruszana w artykule, ale uważam, że jest to codzienne wyzwanie w sektorach kultury oraz kreatywnych, a przez to wpływa na proces tworzenia i realizacji strategii. Por. E.R.W. Knight, W.S. Harvey, Managing 
konieczność godzenia oczekiwań różnych grup interesariuszy, nieprzewidywalność otoczenia oraz czynniki polityczne.

Badania dotyczące strategii organizacji z sektorów kultury powinny być w dalszym ciągu prowadzone, gdyż ten obszar badawczy jest wciąż słabo odkryty. Uważam jednak, że w przyszłości powinny koncentrować się one nie tylko na strategii, ale na całym procesie zarządzania strategicznego, gdyż pozwoli to na uchwycenie pełnego obrazu rzeczywistości. Dodatkowo, wydaje się pożądane, żeby w przyszłych badaniach naukowcy wzięli pod uwagę wskazane przeze mnie uwarunkowania, aby potwierdzić ich słuszność, odrzucić je lub uzupełnić.

\section{Bibliografia}

Chris Bilton, Management and Creativity. From Creative Industries to Creative Management, Blackwell Publishing, Malden - Oxford - Carlton 2007.

Adam M. Brandenburger, Barry J. Nalebuff, Co-Opetition, Currency/Doubleday, New York - London - Toronto - Sydney - Auckland 1996.

Gundars Bērziņš, Strategic Management in Creative Industry Organizations: Specifics in Strategic Decision Making, „Management of Organizations: Systematic Research" 2012, no. 62.

Richard E. Caves, Creative Industries. Contracts Between Art and Commerce, Harvard University Press, Cambridge (MA) - London 2000.

Łukasz Gaweł, Zarzadzanie strategiczne szlakiem dziedzictwa kulturalnego w świetle koncepcji stakeholders, „Turystyka Kulturowa” 2012, nr 10.

Grażyna Gierszewska, Maria Romanowska, Analiza strategiczna przedsiębiorstwa, wyd. V, PWE, Warszawa 2017.

Ricky W. Griffin, Podstawy zarzadzania organizacjami, wyd. II, tłum. M. Rusiński, PWN, Warszawa 2014.

John Hartley, Jason Potts, Stuart Cunningham, Terry Flew, Michael Keane, John Banks, Key Concepts in Creative Industries, Sage, Los Angeles - London New Delhi - Singapore - Washington (DC) 2013.

Exploration and Exploitation Paradoxes in Creative Organizations, „Management Decision” 2015, Vol. 53, No. 4, s. 809-827; Y. Wu, S. Wu, Managing Ambidexterity in Creative Industries: A Survey, „Journal of Business Research” 2016, Vol. 69, No. 7, s. 2388-2396. 
David Hesmondhalgh, The Cultural Industries, wyd. III, Sage, Los Angeles - London - New Delhi - Singapore - Washington (DC) 2013.

Eric R. W. Knight, Will S. Harvey, Managing Exploration and Exploitation Paradoxes in Creative Organizations, „Management Decision” 2015, Vol. 53, No. 4.

Kultura i rozwój. Analizy, rekomendacje, studia przypadku, red. J. Hausner, I. Jasińska, M. Lewicki, I. Stokfiszewski, Krytyka Polityczna, Warszawa 2016. Mateusz Lewandowski, Czynniki utrudniajace samodzielne opracowywanie planów strategicznych przez pracowników instytucji kultury, [w:] Zarządzanie w instytucjach kultury, red. Ł. Wróblewski, CeDeWu.pl, Warszawa 2014.

Dagmara Lewicka, Agnieszka Zakrzewska-Bielawska, Rola zaufania w relacyjnej orientacji przedsiębiorstwa, [w:] Meandry teorii i praktyki zarządzania, red. G. Osbert-Pociecha, S. Nowosielski, Wydawnictwo UE we Wrocławiu, Wrocław 2016.

Krzystof Obłój, Strategia organizacji, wyd. III, PWE, Warszawa 2014.

Maria Romanowska, Dostosowanie strategii przedsiębiorstwa do jego zasobów, [w:] Zarzadzanie strategiczne. Ujęcie zasobowe, red. R. Krupski, Wałbrzyska Wyższa Szkoła Zarządzania i Przedsiębiorczości, Wałbrzych 2006.

Maria Romanowska, Planowanie strategiczne w przedsiębiorstwie, wyd. II, PWE, Warszawa 2009.

Heerad Sabeti, Przedsiębiorstwo nastawione na korzyści niematerialne, „Harvard Business Review" 2012, No. 5.

Agnieszka Sopińska, Wiedza jako strategiczny zasób przedsiębiorstwa. Analiza i pomiar kapitału intelektualnego przedsiębiorstwa, Oficyna wydawnicza SGH w Warszawie, Warszawa 2010.

Ewa Stańczyk-Hugiet, Paradygmat relacji - czy to nowa jakość w zarządzaniu?, „Studia i Prace Kolegium Zarządzania i Finansów” 2012, nr 116.

Strategie dla kultury. Kultura dla rozwoju. Zarządzanie strategiczne instytucja kultury, red. M. Śliwa, Małopolski Instytut Kultury, Kraków 2011.

Justyna Szumniak-Samolej, Innowacyjne przedsięwzięcia nawiązujace do idei społecznej odpowiedzialności biznesu na rynku polskim, [w]: Badania młodych naukowców $w$ dziedzinie nauk ekonomicznych a praktyka gospodarcza, red. M. Wolański, Oficyna Wydawnicza SGH w Warszawie, Warszawa 2015.

Justyna Szumniak-Samolej, Polskie przedsiębiorstwa oparte na misji społecznej: modele biznesowe, motywacje, wyzwania, [w:] Wkład nauk ekonomicznych w budowę kapitału społecznego, red. M. Menkes, Oficyna Wydawnicza SGH w Warszawie, Warszawa 2016. 
Lidia Varbanova, Zarzadzanie strategiczne $w$ kulturze, tłum. T. Piwowarczyk, Narodowe Centrum Kultury, Warszawa 2015.

Piotr Wachowiak, Wrażliwość społeczna przedsiębiorstwa. Analiza i pomiar, Oficyna Wydawnicza SGH, Warszawa 2013.

Wil Williams, Duncan Lewis, Strategic Management Tools and Public Sector Management, „Public Management Review” 2008, Vol. 10, No. 5.

Anna Wróblewska, Kinematografia jako przemysł kultury. Uwarunkowania i tendencje rozwoju branży filmowej w Polsce, Wydawnictwo Naukowe UKSW, Warszawa 2013.

Yuanyuan Wu, Shikui Wu, Managing Ambidexterity in Creative Industries: A Survey, „Journal of Business Research” 2016, Vol. 69, No. 7.

\section{Źródła internetowe}

http://www.zamekcieszyn.pl/pl/artykul/oferta-200.

Magdalena Kubecka, Marta Białek-Graczyk, Jaskółki. Nowe zjawiska w warszawskich instytucjach i nieinstytucjach kultury, 2016, http://nck.pl/media/attachments/317271/Jask\%C3\%B3\%C5\%82ki.\%20Nowe\%20zjawiska\%20w\%20 warszawskich\%20instytucjach\%20i\%20nieinstytucjach\%20kultury.pdf.

Projektujemy możliwości, http://www.zamekcieszyn.pl/pl/artykul/projektujemy -mozliwosci-199.

\section{Cultural (No)institutions' Strategies. Case Study of Zamek Cieszyn}

The aim of the article is to characterize the strategies of organizations in cultural industries, and as an exemplification one of cultural (no)institutions (Zamek Cieszyn) was chosen. Zamek Cieszyn is an unusual institution, because it combines the best elements from for-profit organizations with those from non-profit organizations. It is an example of good practise of managing an organisation in cultural industries. The author applies an appropriate methodology. The research method is a critical analysis of academic literature (a desk research) and a case study method. In the article, the author develops and supplements theoretical proposals, which are empirically verified in the case study. To sum up, creating and realizing strategies in organisations in cultural industries is a difficult task, since it is affected by the following factors: organizations' goals that are different from the goals in for-profit organizations, the necessity to manage conflicting activities; the 
need to reconcile different expectations of stakeholders; the unpredictability of the environment and influence of political factors.

Keywords: cultural industries, strategy, cultural institution, strategic management 


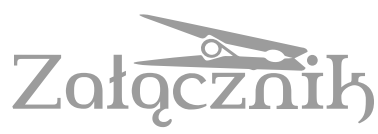

\section{ZARZAৃDZANIE STRATEGICZNE MUZEUM MARTYROLOGICZNYM I MIEJSCEM PAMIĘCI NA PRZYKŁADZIE PAŃSTWOWEGO MUZEUM AUSCHWITZ-BIRKENAU W OŚWIĘCIMIU}

AgNIESZKA PRAGA

Instytut Nauk Historycznych UKSW

Institute of Historical Sciences UKSW

praga.agnieszka@gmail.com

„Zarządzanie miejscami pamięci” jest terminem młodym, który nie we wszystkich kręgach akademickich spotyka się z pozytywnym przyjęciem. Wątpliwości związane z zasadnością używania określenia „zarządzanie pamięcią i miejscami pamięci” mogą wynikać ze skojarzeń z zarządzaniem traumą, co z oczywistych względów jest nie do przyjęcia. W dyskursie nad miejscami pamięci ${ }^{1}$, w szczególności powstałymi na terenie byłych obozów koncentracyjnych, podkreśla się przede wszystkim ich ponadczasowe znaczenie - będąc symbolem Zagłady, stanowią one jednocześnie ostrzeżenie przed kolejnymi aktami ludobójstwa, nasilającym się ekstremizmem, obojętnością na tragedię krajów ogarniętych wojną. Zagadnienia miejsc pamięci są w głównej mierze podejmowane z punktu widzenia ich znaczenia edukacyjnego - tak zwanej pedagogiki miejsc pamięci. Nie należy jednak zapominać, że miejsce pamięci, stanowiące nieodłączny element kształtowania tożsamości zbiorowej, osadzone jest przecież w realnej przestrzeni i nierzadko związane z konkretnymi pozostałościami materialnymi. Alicja Kędziora z Instytutu Kultury Uniwersytetu Jagiellońskiego podkreśla, że zarządzanie pamięcią sprowadza się do zarządzania miejscami pamięci; nie tylko niematerialnym dziedzictwem kulturowym, ale również jego materialnym wymiarem ulokowanym w określonej „kulturowej przestrzeni

1 Pojęcie „miejsca pamięci” (lieux de mémoire) wprowadził w 1984 roku francuski historyk Pierre Nora. Używali go również m.in. Hagen Schulze, Etienne Francis, Jan i Alaida Assmannowie czy Andrzej Szpociński. 
umuzealnionej” spełniającej funkcję pamiętania o przeszłości: „Miejsca pamięci nie istnieją w próżni, [ale] w określonych warunkach społeczno -ekonomicznych współtworzą przestrzeń kulturową i tylko jako takie mogą zostać w pełni odebrane i zrozumiane"2. Dlatego też tak istotne jest rozpatrywanie miejsc pamięci również pod kątem zarządzania nimi w ten sposób, by nałożone nań funkcje mogły zostać w pełni zrealizowane. Zarządzanie miejscami pamięci związane jest z zarządzaniem muzeami czy instytucjami kultury w ogóle. Ze względu na specyfikę miejsc pamięci po byłych obozach koncentracyjnych i zagłady administrowanie nimi rozszerzone jest dodatkowo na działania utrwalające wymiar autentyzmu przestrzeni poobozowych. Jak pisze A. Kędziora: „Epoka rozliczeń z przeszłością spowodowała eskalację znaczeń omawianego terminu ["miejsce pamięci“ - przyp. A.P.], a jego niezwykła kariera każe się zastanowić nad korzyściami płynącymi z użycia go także w dyscyplinie tak młodej, jaką jest zarządzanie kulturą"3. Andrzej Szpociński stawia tezę, że źródłem tak dużego powodzenia terminu „miejsca pamięci” jest uwrażliwienie kultury naszych czasów, również w jej historycznym aspekcie, na wymiar przestrzenno-wizualny ${ }^{4}$.

Państwowe Muzeum Auschwitz-Birkenau (PMA-B) jest szczególnym miejscem pamięci. O jego wyjątkowym charakterze świadczy między innymi wpisanie w 1979 roku terenu po byłym niemieckim obozie koncentracyjnym i zagłady na Listę Światowego Dziedzictwa UNESCO. Z tego miejsca pamięci płynie przesłanie dzięki autentyzmowi, zachowaniu pozostałości po byłym obozie - dzięki temu ludzkość może skonfrontować się ze swą własną historią, tożsamością i teraźniejszością. W sprawozdaniu PMA-B za rok 2016 znajdujemy informację o kolejnej rekordowej liczbie odwiedzających Miejsce Pamięci i Muzeum Auschwitz-Birkenau: 2053000 osób 5 .

2 Zob. A. Kędziora, Miejsca pamięci w zarządzaniu pamięcia o artyście, „Zarządzanie w Kulturze” 2012, nr 13, z. 2, s. 106-108.

3 Ibidem, s. 110.

4 Zob. A. Szpociński, Miejsca pamięci (lieux de mémoire), „Teksty Drugie” 2008, nr 4, s. 11.

5 P. Sawicki, Ponad 2 miliony odwiedzających Miejsce Pamięci Auschwitz-Birkenau w 2016 r., „Oś - Oświęcim - Ludzie - Historia - Kultura” 2017, nr 105 (styczeń), s. 2. 
Wyk. 1. Frekwencja w latach 2001-2016

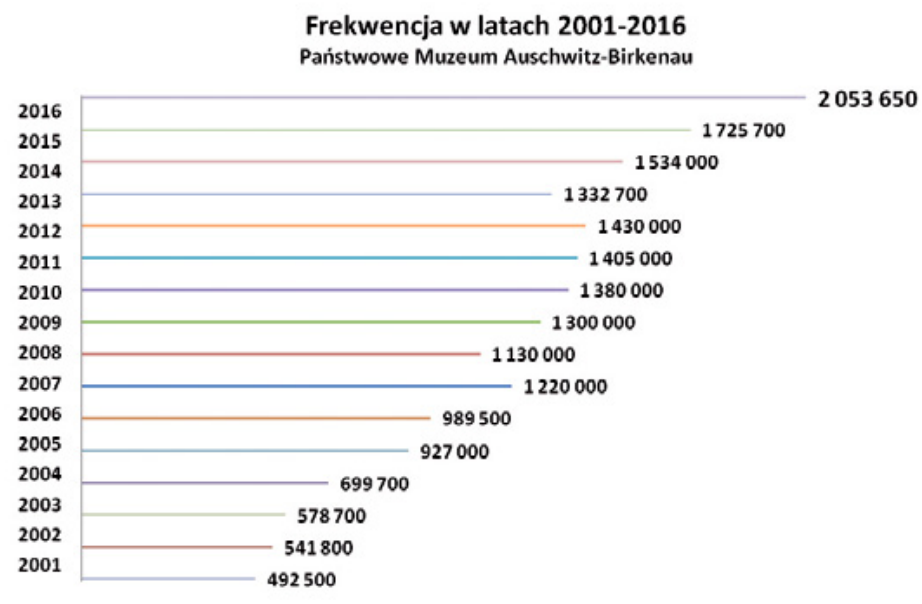

Źródło: Sprawozdanie Państwowego Muzeum Auschwitz-Birkenau w Oświęcimiu za rok 2016

W związku z dużą frekwencją Muzeum wprowadziło obowiązkową rezerwację internetową dla grup zorganizowanych oraz osób indywidualnych ${ }^{6}$. Tego typu system nie pozwala biurom turystycznym na organizowanie wejść na teren Muzeum w najbardziej obleganych godzinach. Wizyty rozłożone są na wszystkie dostępne godziny, również popołudniowe. System rezerwacji jest na bieżąco analizowany i ulepszany. Obecnie terminy wizyt można rezerwować nawet z rocznym wyprzedzeniem. Od marca 2017 roku teren byłego obozu będzie udostępniony zwiedzającym już od godziny 7.307. Ponadto odwiedzający mogą liczyć na 286 edukatorów-przewodników, władających łącznie dziewiętnastoma językami. Warto podkreślić, że żadne muzeum na świecie nie zatrudnia przewodników mówiących w tak wielu językach ${ }^{8}$. W czym tkwi „sekret” PMA-B? Czy uznanie miejsca pamięci za światowy symbol Zagłady wystarczy, by odnieść sukces frekwencyjny?

${ }^{6}$ visit.auschwitz.org [dostęp: 28.02.17].

7 P. Sawicki, op. cit., s. 3.

$8 \mathrm{http}$ //auschwitz.org/muzeum/aktualnosci/nowy-system-rezerwacji-online -w-muzeum-auschwitz,1673.html [dostęp: 28.02.17]. 
W jaki sposób udało się logistycznie zapanować nad jednym z największych na świecie obiektów chronionych Konwencją UNESCO?

Zgodnie z wywodzącą się z ekonomii koncepcją zasobów i kompetencji (wprowadzoną do literatury przez Edith Penrose ${ }^{9}$ ) wszelkie strategie budowane przez organizacje i instytucje powinny opierać się na wewnętrznych atutach tychże instytucji. Według tej koncepcji, bazowanie na atutach charakterystycznych dla danej instytucji gwarantuje jej przetrwanie w dłuższym okresie $^{10}$. W przypadku PMA-B nie trzeba daleko szukać owego „gwaranta istnienia instytucji”. Potężnym jego atutem jest przede wszystkim autentyzm miejsca pamięci - obecność infrastruktury poobozowej. Można przewrotnie stwierdzić, że w takim układzie wszelkie miejsca pamięci mają zagwarantowaną „dobrą pozycję” ze względu na swą historyczną lokalizację. Faktem jest, że ze wszystkich miejsc pamięci po byłych obozach koncentracyjnych i zagłady na terenie dawnego KL Auschwitz-Birkenau pozostało najwięcej obiektów z lat funkcjonowania obozu - jest to miejsce najmniej dotknięte upływem czasu i ingerencją ludzką. Inną trudnością zarządzania pamięcią związaną z infrastrukturą obozową i specyfiką miejsc pamięci będących jednocześnie cmentarzyskami - jest estetyka przestrzeni, pytanie o zasadność eksponowania treści i artefaktów przy pomocy nośników wykraczających poza granicę autentyzmu (technologie multimedialne). Międzynarodowych interesariuszy niełatwo przekonać o znaczeniu osobistej konfrontacji człowieka $\mathrm{z}$ terenem, na którym współczesność nie odcisnęła swego wpływu. Piotr M.A. Cywiński, dyrektor PMA-B, przytacza kilka przykładów:

Niektórzy widzą w Auschwitz miejsce, w którym powinny zaistnieć multimedia, interaktywność, atrakcje. Inni chcą więcej rekonstrukcji, ktoś kiedyś proponował oryginalnej wielkości lalki, np. esesmanów z psami czy też stojących na wieżyczkach i oślepiających przechodzących snopem światła. Propozycji takich jest multum. Pytaniem jest, czym jest Auschwitz dzisiaj [...]. Pamięć jest czynnikiem ponadczasowym, jednakże gdy jest przeżywana w autentycznym Miejscu. Zrozumienie i świadomość mają szansę osiągnąć [tu] niepowtarzalnie więcej niż przed ekranem telewizora lub nad

9 Zob. E. Penrose, The Theory of the Growth of the Firm, Oxford 1959.

10 Zob. M. Śliwa, Zarzadzanie strategiczne organizacja, [w:] Strategie dla kultury. Kultura dla rozwoju. Zarządzanie strategiczne instytucja kultury, red. M. Śliwa, Kraków 2011, s. 17. 
kartą książki. Autentyzm jest zatem tym, co należy chronić i ukazywać. Tę ochronę i to ukazywanie uważam za najważniejsze zadanie osób mających Auschwitz dzisiaj w swej opiece. Autentyzm jest paradygmatem Miejsca Pamięci. Każdego ${ }^{11}$.

Konkretne i konsekwentne stanowisko dyrektora Cywińskiego skłania, by zagadnienie zachowania autentyzmu miejsca pamięci włączyć w szerszy plan strategii, których elementem jest również wypracowanie tożsamości instytucji kultury:

Instytucja kultury przede wszystkim powinna mieć określoną, wypracowaną z jej interesariuszami tożsamość, tzn. wiedzieć, czego chce, w jaki sposób działa, i wokół tej tożsamości budować też sieć relacji z publicznością i lokalnym środowiskiem. [...] Idealnie byłoby, gdyby instytucja kultury dawała zarówno poczucie zakorzeniania, jak i możliwości przebudowania tożsamości tak, by korespondowała ona ze zmianami otaczającego nas świata. Stanowi to, oczywiście, ogromne wyzwanie dla instytucji kultury ${ }^{12}$.

Podsumowując, należałoby połączyć owe „poczucie zakorzenienia” właśnie z koncepcją zachowania autentyzmu miejsca pamięci, jeśli zaś chodzi o „przebudowę tożsamości” na miarę współczesności i zmian w otaczającym świecie - bez wątpienia można wskazać na koncepcję nowej wystawy głównej PMA-B ${ }^{13}$, wypracowywaną w ciągu dwóch i pół roku w sposób bardzo wnikliwy, z pomocą wielu ekspertów i z wykorzystaniem wiedzy na temat charakterystyki odwiedzających. Nowa wystawa będzie otwierana dla zwiedzających w trzech częściach w latach 2021-2025. Tak długi czas realizacji spowodowany jest wdrażaniem kolejnych punktów harmonogramu etapami, aby nie musieć ograniczać możliwości zwiedzania instytucji. Wedle przyjętych założeń, wystawa nie może mieć charakteru wyłącznie edukacyjnego

11 P.M.A. Cywiński, Epitafium... i inne spisane niepokoje, Oświęcim 2012, s. 90-97.

${ }_{12}$ M. Krajewski, Instytucje kultury a uczestnicy kultury. Nowe relacje, [w:] Strategie dla kultury..., op. cit., s. 34-35.

${ }_{13}$ Jej pierwsze ogólne założenia koncepcyjne zostały opracowane przez prof. Wacława Długoborskiego oraz starszych kustoszy Teresę Świebocką i Teresę Zbrzeską. W lipcu 2007 projekt został przyjęty przez Międzynarodową Radę Oświęcimską. 
i historycznego, dlatego powołano (co jest warte podkreślenia, ponieważ nie w każdym muzeum dostrzega się konieczność tego typu współpracy) interdyscyplinarny zespół zadaniowy Nowej Wystawy Głównej, w skład którego wchodzą m.in. edukator, historyk, dokumentalista, architekci ${ }^{14}$. Szczególnie istotna dla sprawnego zarządzania instytucją kultury jest zauważalna w Miejscu Pamięci i Muzeum Auschwitz-Birkenau umiejętność współpracy ludzi różnych specjalności przy jednym projekcie. Katarzyna Barańska, podejmując problematykę zarządzania z perspektywy humanistycznej, zwraca uwagę, że zazwyczaj zespół pracowników instytucji kultury boryka się z wewnętrznymi trudnościami: „Wymiana myśli teoretycznej oraz doświadczeń z zakresu tzw. dobrych praktyk przeważnie odbywa się "we własnym gronie« - osobno organizowane są konferencje dla konserwatorów, edukatorów czy kustoszy. Każdy boi się wyjść poza swoją specjalność lub dopuścić do niej kogoś z zewnątrz »branży«"15.

Według rekomendowanego schematu organizacyjnego placówek muzealnych:

[...] bez względu na rodzaj sprawowanego nadzoru struktura funkcjonowania współczesnego muzeum powinna być oparta na tzw. sześcianie zadań, na który składa się współpraca trzech pionów muzeum: opieki nad zbiorami (kuratoria, konserwacja, dokumentacja); realizacji programów-projektów (organizacja wystaw, projektowanie, edukacja, wydawnictwa, public relations, marketing); administracji (kadry, dział finansowy i księgowy, obsługa prawna, dział rozwoju, inwestycji i remontów, ochrona, dział obsługi zwiedzających i korzystających ze zbiorów, utrzymanie porządku). Każdy $\mathrm{z}$ trzech pionów muzeum powinien być kierowany przez specjalistę $\mathrm{w}$ danym zakresie: muzeologa, specjalistę co najmniej II stopnia; muzeologa z dodatkowym wykształceniem w zakresie edukacji, PR lub marketingu; specjalistę ds. zarządzania z wykształceniem ekonomicznym, prawnym lub technicznym ${ }^{16}$.

${ }^{14}$ Informacje uzyskane dzięki uprzejmości Alicji Białeckiej, pełnomocnika ds. Nowej Wystawy Głównej PMA-B.

${ }^{15} \mathrm{~K}$. Barańska, Muzeum w sieci znaczeń. Zarzadzanie z perspektywy nauk humanistycznych, Kraków 2013, s. 212.

16 D. Folga-Januszewska, Muzea w Polsce 1989-2008. Stan, zachodzace zmiany i kierunki rozwoju muzeów $w$ Europie oraz rekomendacje dla muzeów w Polsce, Warszawa 2008, s. 37. 
Współpraca między tymi pionami jest niezbędna, nie mogą one działać na zasadzie odrębnych jednostek. Dział administracji odpowiadający m.in. za inwestycje i remonty nie powinien funkcjonować niezależnie, ponieważ jego działania bezpośrednio dotyczą również filaru odpowiedzialnego za opiekę nad zbiorami.

Mieczysław Porębski wskazywał, że „muzeum idealne jest przede wszystkim dobrze zorganizowane". Wyjaśniał, że niezwykle istotne jest zachowanie odpowiednich proporcji $\mathrm{w}$ realizacji zadań między pracownikami merytorycznymi a administracyjnymi i technicznymi. Barańska rozwija tę myśl i dodaje, że w strategii zarządzania każdym projektem należy zwracać uwagę nie tylko na właściwe przydzielanie zadań i rozliczanie efektów pracy, ale w równej mierze trzeba budować zespół pracowniczy, który opiera się na wielu specjalnościach (merytorycznych, konserwatorskich, edukacyjnych) ${ }^{17}$. Dobrym przykładem realizacji tych postulatów są zespoły powoływane w Państwowym Muzeum Auschwitz-Birkenau m.in. przy realizacji Nowej Wystawy Głównej, jak również przy Globalnym Planie Konserwacji i Zachowania Miejsca Pamięci Auschwitz-Birkenau. Do realizacji projektu powołano trzydziestoosobowy „team”: konserwatorów zabytków, inżynierów budownictwa różnych specjalności, rzemieślników, chemików, prawników, finansistów, księgowych ${ }^{18}$. Dowodzi to dojrzałości przy planowaniu strategii realizowania kluczowych projektów w oparciu o interdyscyplinarny zespół ekspercki.

Jednym z głównych filarów planu strategicznego PMA-B jest także ochrona zbiorów i konserwacja architektonicznych pozostałości poobozowych. Wiele placówek sporządza plan strategii dotyczącej zbiorów. Plan strategiczny obejmuje tylko główne punkty, jak charakterystyka zbiorów, inwentaryzacja i dokumentacja, badania, zachowanie zbiorów i zarządzanie nimi oraz tworzenie nowych kolekcji. Uwagę kieruje się przede wszystkim w stronę takich zagadnień, jak:

- zakres zbiorów muzeum;

- trzon zbiorów;

- odpowiedź na pytanie, jaką funkcję spełniają zbiory wobec publiczności;

17 Zob. K. Barańska, op. cit., s. 167, 211-212.

18 Informacje uzyskane dzięki uprzejmości Anny Łopuskiej z Działu Konserwacji PMA-B, koordynatorki Globalnego Planu Konserwacji. 
- odpowiedź na pytanie, pod jakim względem zbiory te różnią się od kolekcji innych muzeów ${ }^{19}$.

Strategia konserwacji obiektów nieruchomych PMA-B jest tak rozbudowana, że zasługuje na odrębną analizę. Pozostając przy zagadnieniach związanych konkretnie z zarządzaniem projektami, bez wątpienia należy wspomnieć o bezprecedensowym przedsięwzięciu, jakim jest ustanowiony w 2009 roku Globalny Plan Konserwacji i Zachowania Miejsca Pamięci Auschwitz-Birkenau ${ }^{20}$ oraz Kapitał Wieczysty Fundacji Auschwitz-Birkenau, rozszerzony w kolejnych latach o osiemnaście Filarów Pamięci. Fundacja Auschwitz-Birkenau ${ }^{21}$ współpracuje $\mathrm{z}$ trzydziestoma sześcioma państwami, dwoma miastami ${ }^{22}$ oraz darczyńcami indywidualnymi. W 2016 roku działalność fundraisingową Fundacji wspomógł Ronald S. Lauder ${ }^{23}$, powołując do życia Auschwitz-Birkenau Foundation Committee. W każdym sprawozdaniu rocznym PMA-B można odnaleźć konkretne kwoty przeznaczone na wyszczególnione zadania zaplanowane na dany rok, co jest przykładem transparentności przepływu środków finansowych. Jest to pierwsza na świecie tego typu instytucja, która wypracowała tak doskonały projekt ochrony dziedzictwa, włączający również inne kraje i indywidualne osoby z całego świata. Aby zrozumieć skalę przedsięwzięcia, należy pamiętać, że obszar ochronny obejmuje około dwadzieścia hektarów byłego obozu Auschwitz I oraz 171 hektarów Birkenau. Na terenie tym znajduje się 155 budynków, 300 ruin (m.in. komór gazowych i krematoriów, relikty po barakach), sieci kanalizacji i rowy melioracyjne, drogi, trzynaście kilometrów ogrodzenia

19 Nowoczesne zarzadzanie muzeum. Wspótpraca polsko-holenderska $w$ ramach projektu MATRA 1999-2007, red. J. Czaj, B. Ziemnicka-Darnowska, P. Pawlina, Warszawa 2017, s. 39-40.

20 Jego realizację rozpoczęto w czerwcu 2012 roku.

${ }^{21}$ Fundacja Auschwitz-Birkenau powstała w 2009 roku, by zarządzać Kapitałem Wieczystym. Roczne odsetki z Funduszu wynoszą 4-5 milionów euro, co pozwala na realizację założeń konserwacyjnych.

${ }^{22}$ www.fundacja.auschwitz.org/index.php/darczyncy/panstwa [dostęp: 28.02.17].

${ }^{23}$ Ronald S. Lauder - amerykański biznesmen i filantrop, przewodniczący Światowego Kongresu Żydów i założyciel Fundacji Laudera, od 2012 roku członek Międzynarodowej Rady Oświęcimskiej. 
z ponad trzema tysiącami słupów betonowych oraz - znajdujące się na ekspozycji i w magazynach - tysiące poobozowych obiektów ruchomych i archiwalia ${ }^{24}$. Stałej konserwacji poddawana jest również zieleń niska i drzewostany, m.in. dwadzieścia hektarów lasu.

Nie trzeba przekonywać o niedofinansowaniu polskich muzeów. Szczególnie boleśnie odczuwają to muzea na terenie byłych obozów koncentracyjnych i zagłady, których obszar jest dużo bardziej rozległy niż typowych muzeów historycznych. W cytowanej już książce Nowoczesne zarządzanie muzeum Herman Aarts i Kees Plaisier przedstawiają definicję muzeum jako przedsiębiorstwa:

Muzeum to instytucja niedochodowa, ale prowadzona jak przedsiębiorstwo, które dostarcza takich produktów, jak wystawy czy projekty dla szkół. Produkty przedsiębiorstwa sprzedawane są w celu wypracowania zysku, podstawą zaś finansowania muzeum jest dotacja z budżetu państwa. Wpływy od klientów, czyli osób odwiedzających placówkę, pokrywają jedynie niewielką część kosztów eksploatacji. Państwo dotuje muzea w ramach polityki kulturalnej, ukierunkowanej na podkreślenie ich uczestnictwa w kulturze i roli w zachowaniu dziedzictwa kulturowego ${ }^{25}$.

Definicja ta nie do końca współgra z PMA-B, które będąc muzeum martyrologicznym, nie może pobierać opłat od odwiedzających za możliwość wejścia na teren poobozowy, więc nie możemy w tym wypadku mówić o typowych „wpływach od klientów”. Poniżej przedstawiona została tabela ukazująca źródła finansowania PMA-B w poszczególnych latach, począwszy od 2006 roku, kiedy po raz pierwszy Muzeum udostępniło opinii publicznej sprawozdanie ze swej działalności. W 2006 roku dotacja Ministerstwa Kultury i Dziedzictwa Narodowego (na wydatki bieżące i wydatki majątkowe) w wysokości 10,3 mln zł nieznacznie przewyższała sumę przychodów własnych Muzeum (10,2 mln zł). Co ciekawe, z upływem lat przychody własne Muzeum (59,2 \%) przewyższyły ponad dwukrotnie dotacje z MKiDN (25,6\%).

${ }^{24}$ www.fundacja.auschwitz.org/index.php/aktualnosci/32-globalny-plan-konserwacji-rozpoczety [dostęp: 28.02.17].

${ }^{25}$ Nowoczesne zarzadzanie muzeum..., op. cit., s. 16. 
Wyk. 2. Źródła finansowania Państwowego Muzeum Auschwitz-Birkenau

\begin{tabular}{|c|c|c|c|c|c|c|c|c|c|c|c|}
\hline & 2006 & 2007 & 2008 & 2009 & 2010 & 2011 & 2012 & 2013 & 2014 & 2015 & 2016 \\
\hline $\begin{array}{l}\text { Przychody wła- } \\
\text { sne Muzeum }\end{array}$ & $\begin{array}{l}10,2 \\
\mathrm{mln}\end{array}$ & $\begin{array}{l}11,5 \\
\mathrm{mln}\end{array}$ & $\begin{array}{c}13 \\
\mathrm{mln}\end{array}$ & $\begin{array}{l}16,2 \\
\mathrm{mln}\end{array}$ & $\begin{array}{l}20,2 \\
\operatorname{mln}\end{array}$ & $\begin{array}{l}22,3 \\
\mathrm{mln}\end{array}$ & $\begin{array}{l}24,8 \\
\mathrm{mln}\end{array}$ & $\begin{array}{l}26,7 \\
\operatorname{mln}\end{array}$ & $\begin{array}{l}28,6 \\
\mathrm{mln}\end{array}$ & $\begin{array}{l}33,4 \\
\mathrm{mln}\end{array}$ & $\begin{array}{l}39,5 \\
\mathrm{mln}\end{array}$ \\
\hline $\begin{array}{l}\text { Dotacja } \\
\text { Ministerstwa } \\
\text { Kultury } \\
\text { i Dziedzictwa } \\
\text { Narodowego }\end{array}$ & $\begin{array}{l}10,3 \\
\text { mln }\end{array}$ & $\begin{array}{c}11 \\
\mathrm{mln}\end{array}$ & $\begin{array}{l}12,7 \\
\mathrm{mln}\end{array}$ & $\begin{array}{l}11,6 \\
\mathrm{mln}\end{array}$ & $\begin{array}{l}11,2 \\
\mathrm{mln}\end{array}$ & $\begin{array}{c}11 \\
\mathrm{mln}\end{array}$ & $\begin{array}{l}15,7 \\
\mathrm{mln}\end{array}$ & $\begin{array}{l}15,3 \\
\operatorname{mln}\end{array}$ & $\begin{array}{l}14,7 \\
\text { mln }\end{array}$ & $\begin{array}{l}16,7 \\
\mathrm{mln}\end{array}$ & $\begin{array}{l}17,1 \\
\mathrm{mln}\end{array}$ \\
\hline $\begin{array}{l}\text { Środki celowe } \\
\text { Ministra } \\
\text { Kultury } \\
\text { i Dziedzictwa } \\
\text { Narodowego }\end{array}$ & - & - & - & - & $\begin{array}{l}9,6 \\
\mathrm{mln}\end{array}$ & $\begin{array}{l}4,2 \\
\mathrm{mln}\end{array}$ & $\begin{array}{l}0,7 \\
\mathrm{mln}\end{array}$ & $3 \mathrm{mln}$ & $\begin{array}{c}4,1 \\
\mathrm{mln}\end{array}$ & $\begin{array}{c}3,9 \\
\mathrm{mln}\end{array}$ & $\begin{array}{l}2,5 \\
\operatorname{mln}\end{array}$ \\
\hline $\begin{array}{l}\text { Fundusze } \\
\text { pozyskane } \\
\text { z zagranicy }\end{array}$ & $\begin{array}{l}266 \\
\text { tys. }\end{array}$ & $\begin{array}{l}754 \\
\text { tys. }\end{array}$ & $\begin{array}{c}1,5 \\
\operatorname{mln}\end{array}$ & $\begin{array}{l}600 \\
\text { tys. }\end{array}$ & $\begin{array}{l}400 \\
\text { tys. }\end{array}$ & - & - & - & -1 & $\begin{array}{c}2,4 \\
\mathrm{mln}\end{array}$ & - \\
\hline $\begin{array}{l}\text { Dotacja } \\
\text { w ramach } \\
\text { Europejskiego } \\
\text { Programu } \\
\text { Operacyjnego } \\
\text { Infrastruktura } \\
\text { i Środowisko } \\
\end{array}$ & - & - & - & $\begin{array}{c}2,5 \\
\operatorname{mln}\end{array}$ & $\begin{array}{c}3,1 \\
\mathrm{mln}\end{array}$ & $\begin{array}{l}1,2 \\
\mathrm{mln}\end{array}$ & $\begin{array}{c}6,5 \\
\mathrm{mln}\end{array}$ & $\begin{array}{l}1,9 \\
\operatorname{mln}\end{array}$ & $\begin{array}{c}2,2 \\
\operatorname{mln}\end{array}$ & - & - \\
\hline $\begin{array}{l}\text { Programy } \\
\text { unijne }\end{array}$ & - & - & - & - & - & $\begin{array}{c}6,9 \\
\mathrm{mln}\end{array}$ & $\begin{array}{l}4,1 \\
\mathrm{mln}\end{array}$ & $\begin{array}{c}4,2 \\
\mathrm{mln}\end{array}$ & - & - & $\begin{array}{l}1,3 \\
\mathrm{mln}\end{array}$ \\
\hline $\begin{array}{l}\text { Fundacja } \\
\text { Pamięci Ofiar } \\
\text { Obozu Zagłady } \\
\text { Auschwitz- } \\
\text {-Birkenau } \\
\text { w Oświęcimiu }\end{array}$ & - & - & - & $\begin{array}{l}100 \\
\text { tys. }\end{array}$ & $\begin{array}{l}600 \\
\text { tys. }\end{array}$ & $\begin{array}{l}300 \\
\text { tys. }\end{array}$ & $\begin{array}{c}1,8 \\
\mathrm{mln}\end{array}$ & $\begin{array}{c}2,1 \\
\operatorname{mln}\end{array}$ & $\begin{array}{c}2,2 \\
\mathrm{mln}\end{array}$ & $\begin{array}{l}79 \\
\text { tys. }\end{array}$ & $\begin{array}{l}32 \\
\text { tys. }\end{array}$ \\
\hline $\begin{array}{l}\text { Volkswagen } \\
\text { / Między- } \\
\text { narodowy } \\
\text { Komitet } \\
\text { Oświęcimski }\end{array}$ & - & - & - & - & - & - & - & - & $\begin{array}{c}1,2 \\
\operatorname{mln}\end{array}$ & $\begin{array}{c}0,3 \\
\mathrm{mln}\end{array}$ & - \\
\hline $\begin{array}{l}\text { Fundacja } \\
\text { Auschwitz- } \\
\text { Birkenau }\end{array}$ & - & - & - & - & - & - & - & - & - & $\begin{array}{c}5,2 \\
\mathrm{mln}\end{array}$ & $\begin{array}{l}5,9 \\
\mathrm{mln}\end{array}$ \\
\hline NIMOZ & - & 1- & - & - & - & - & - & I & - & $\begin{array}{l}15 \\
\text { tys. }\end{array}$ & - \\
\hline
\end{tabular}

Źródło: Opracowanie własne na podstawie danych statystycznych dostępnych $w$ corocznym sprawozdaniu PMA-B (okres 2006-2016) 
Istotnym elementem strategii zarządzania są również partnerstwa strategiczne, umiejętna współpraca i utrzymywanie kontaktu z instytucjami międzynarodowymi, krajowymi i lokalnymi czy administracją publiczną (szeroki zakres współpracy ukazuje powyższa tabela źródeł finansowania). PMA-B w ciągu wieloletniej działalności w sposób znaczący rozbudowało ten typ kanału komunikacyjnego, wymiany doświadczeń i wsparcia międzyorganizacyjnego. Na szczególną uwagę zasługuje m.in. Międzynarodowa Rada Oświęcimska przy Premierze RP (MRO), powołana w 1990 roku decyzją Ministra Kultury i Sztuki. MRO stanowi międzynarodowy organ opiniodawczo-doradczy składający się z wielu ekspertów i autorytetów; jest doskonałą przestrzenią dla wymiany myśli, doświadczeń i propozycji. Podczas posiedzeń MRO nigdy nie zabrakło miejsca dla przedstawicieli pozostałych miejsc pamięci - m.in. Płaszowa, Sobiboru, Majdanka, Treblinki czy Stutthofu. Poza MRO przy Muzeum funkcjonuje również Rada Muzeum, Rada Fundacji Auschwitz-Birkenau oraz Rada Międzynarodowego Centrum Edukacji o Auschwitz i Holocauście. W moim odczuciu, sukces PMA-B polega m.in. właśnie na budowaniu trwałych i owocnych relacji z instytucjami, autorytetami i ekspertami, dzięki czemu siła przekazu jest jeszcze mocniejsza, a zasięg oddziaływania na świecie wciąż się poszerza. Jest to również dowód na skuteczność strategii zarządzania opartej na współdziałaniu w zespole.

Budowanie skutecznej komunikacji zewnętrznej w instytucjach kultury jest możliwe dzięki stosowaniu następujących zasad:

- prostoty przekazu;

- konkretności (fakty, wydarzenia, które odwiedzający mogą bezpośrednio odnieść do własnego życia);

- wiarygodności;

- emocjonalności (nostalgia, wspomnienia, utożsamienie);

- opowieści ${ }^{26}$.

Dokumentem łączącym wszystkie te punkty jest wspomniane już wcześniej roczne sprawozdanie, prezentujące najważniejsze wydarzenia, plany, badania, bieżące zadania czy statystykę odwiedzających począwszy od 2006 roku. Sprawozdanie wzbogacone zostało przejrzystymi raportami

26 R. Stocki, Dialog strategiczny w instytucji kultury. Przykład: Wawel i przewodnicy, [w:] Strategie dla kultury..., s. 170-172. 
dotyczącymi finansowania Muzeum oraz działalności Fundacji Auschwitz-Birkenau. Jest ono również ukłonem w stronę pracowników Muzeum podkreśla ich pracę na rzecz ochrony dziedzictwa: „Ten raport to opowieść o ludziach, którzy wybrali swoją własną odpowiedź na te pytania. Oddali swój czas, swoje siły, emocje i nadzieje, aby odpowiedzialnie zająć się na co dzień tym przerażającym Miejscem Prawdy"27.

Katarzyna Barańska w pracy Muzeum w sieci znaczeń. Zarządzanie zperspektywy nauk humanistycznych zauważa, że w minionych latach wiele muzeów decydowało się umieścić na stronach internetowych swoich placówek strategię działania czy misję. Niestety, specjalistyczny charakter tych informacji oraz specyficzny język powodują, że odbiorca nie uzyskuje interesujących wiadomości odnoszących się do aktywności danej placówki ${ }^{28}$. Natomiast pojawienie się sprawozdania PMA-B spotkało się z wielkim zainteresowaniem w Polsce i na świecie. W związku z tym Muzeum w każdym wydaniu postanowiło zaprezentować tak zwane międzynarodowe głosy poparcia, świadczące o potrzebie istnienia dokumentu dostępnego dla wszystkich i jednocześnie utwierdzającego przedstawicieli i pracowników Muzeum w przekonaniu, że wraz z kierunkiem, w jakim podążają, mają wokół siebie coraz więcej międzynarodowego wsparcia. „Jestem przekonany, że informowanie w takiej formie także społeczeństw poza granicami Polski o działalności instytucji muzealnej przyczyni się do umocnienia pamięci o tragedii i ofiarach II wojny światowej w skali międzynarodowej"29 - stwierdził Tomas Bertelman, ambasador Szwecji. W podobnym tonie wypowiedział się Pascala Couchepin, ówczesny prezydent Konfederacji Szwajcarskiej: „Zauważyłem z satysfakcją stabilny wzrost liczby odwiedzających, jak również rozwój projektów edukacyjnych i postęp badań naukowych. Poza tym fakt, że przygotowują Państwo w tej chwili nową wystawę główną, pokazuje, że Muzeum jest ciągle przygotowane na podejmowanie nowych wyzwań" ${ }^{\prime 30}$.

27 Sprawozdania Państwowego Muzeum Auschwitz-Birkenau w Oświęcimiu za rok 2014, s. 4.

${ }_{28}$ K. Barańska, op. cit., s. 209.

${ }_{29}$ Sprawozdanie Państwowego Muzeum Auschwitz-Birkenau w Oświęcimiu za rok 2007, s. 5 .

30 Sprawozdanie Państwowego Muzeum Auschwitz-Birkenau w Oświęcimiu za rok 2008, s. 7. 
Jaki był pierwotny cel cyklicznego wydawania raportu? Dyrektor Muzeum, Piotr M.A. Cywiński, w sprawozdaniu za rok 2006 napisał:

Pierwszy raz w historii instytucji opiekującej się jednym z najważniejszych miejsc na ziemi przedstawiam Wam, w tej formie, roczny raport $\mathrm{z}$ naszej działalności. Głównymi naszymi zadaniami są oczywiście ochrona i konserwacja reliktów poobozowych, prowadzenie badań naukowych, rozwój programów edukacyjnych. Potrzeby są olbrzymie. Wydarzenia na świecie pokazują, jak w sumie niewiele nasza cywilizacja nauczyła się ze swej przeszłości. Dlatego chciałbym przedstawić Wam ludzi, którzy tworzą to Muzeum: konserwatorów, historyków, edukatorów, specjalistów w dziedzinie muzeologii. Od ich zaangażowania, fachowości i oddania zależeć będzie obraz tego Miejsca w najbliższej przyszłości ${ }^{31}$.

Kolejnym znaczącym elementem strategii zarządzania muzeum, który warto poruszyć, odnosząc się do przykładu Miejsca Pamięci i Muzeum Auschwitz-Birkenau, jest budowanie relacji ze zwiedzającym, czy szerzej - z publicznością:

[Dla MPA-B kluczowe jest - przyp. A.P.] budowanie porozumienia między wszystkimi osobami, które mają wpływ na funkcjonowanie muzeum, czyli nie tylko zwiedzającymi, ale i instytucjami wokół, które mogą [nas] wspierać. $\mathrm{W}$ planie strategicznym należy podać, na jakie grupy publiczności muzeum zamierza ukierunkować swoją działalność, w jaki sposób chce to osiągnąć, jakie planuje z myślą o nich zajęcia i wydarzenia. W przypadku większych muzeów w planie strategicznym powinien znaleźć się osobny plan dotyczący komunikacji z odbiorcami oferty muzealnej. W planie strategicznym należy określić, jakie dodatkowe działania mogą posłużyć pozyskaniu większej i bardziej zróżnicowanej publiczności, jakie zajęcia i wydarzenia skłonią ludzi do odwiedzenia muzeum i jak praca na rzecz pozyskania zwiedzających wpisuje się w misję muzeum ${ }^{32}$.

Przykładem tego typu działań jest m.in. włączenie historii KL Auschwitz-Birkenau pod postacią dwóch wirtualnych wystaw w projekt „Google

${ }^{31}$ Sprawozdanie Państwowego Muzeum Auschwitz-Birkenau w Oświęcimiu za rok 2006, s. 4.

${ }^{32}$ Ibidem, s. 44. 
Cultural Institute" (od października 2012 roku). W ramach platformy współpracuje ze sobą siedemnaście instytucji z całego świata, które podjęły się zadania przedstawienia historii XX wieku przy pomocy zdigitalizowanych materiałów archiwalnych. Umożliwia to również bardziej rzetelne przygotowywanie przez uczniów i nauczycieli prezentacji na szkolne zajęcia. Dodatkowym kanałem komunikacji stały się w ostatnich latach fora społecznościowe. Według sprawozdania rocznego za roku 2014, facebookowa strona www.facebook.com/auschwitzmemorial jako pierwszy na świecie serwis o tym profilu przekroczyła liczbę stu tysięcy subskrybentów. W 2016 roku liczba ta wzrosła do dwustu trzydziestu tysięcy. Strona przygotowana w kilkunastu językach dociera do odbiorców na całym świecie. Ponad trzydzieści tysięcy osób obserwuje muzealne konto na Twitterze, a na Instagramie liczba obserwujących sięga dwudziestu dwóch tysięcy. W 2016 roku na stronie www.auschwitz.org odnotowanych zostało ponad czterdzieści trzy miliony odsłon ${ }^{33}$. Nie sposób przy tej okazji nie wspomnieć o platformie e-learningowej skierowanej do osób, które nie są w stanie osobiście pojawić się w Miejscu Pamięci lub po prostu pragną w domowym zaciszu pogłębić wiedzę na temat historii obozu.

Poruszając kwestię relacji ze społeczeństwem i potencjalnym odbiorcą oferty muzealnej, należy wspomnieć o tak zwanych interesariuszach (stakeholders). Pod pojęciem tym mogą kryć się również instytucje, na które Muzeum ma wpływ i które oddziałują zwrotnie na Muzeum. Innymi słowy, istnieje między nimi ścisła relacja (jak na przykład w przypadku stałych partnerstw i współpracy międzyorganizacyjnej). Można wyróżnić cztery kategorie interesariuszy:

- środowisko społeczne, organy administracji publicznej oraz instytucje, $\mathrm{z}$ którymi muzeum utrzymuje kontakty w najszerszym tego słowa znaczeniu ${ }^{34}$;

33 P. Sawicki, op. cit., s. 3.

34 Jako przykład można podać przywoływane już: Międzynarodową Radę Oświęcimską, Centrum Dialogu i Modlitwy, Międzynarodowy Dom Spotkań Młodzieży w Oświęcimiu, Międzynarodowe Centrum Edukacji o Auschwitz i Holocauście, Instytut Pamięci Yad Vashem, Muzeum i Miejsce Pamięci w Terezinie, Centrum Rady Europy, Uniwersytet Jagielloński, Uniwersytet Pedagogiczny w Krakowie i wiele innych. 
- publiczność, składająca się z przedstawicieli grup docelowych, jak i z osób zwiedzających muzeum indywidualnie, uczniów oraz pracowników innych instytucji;

- sponsorzy - instytucje oraz osoby prywatne udzielające wsparcia materialnego (Kapitał Wieczysty, 18 Filarów Pamięci i inni darczyńcy);

- pracownicy muzeum (istnienie muzeum leży w ich interesie, oni także są niezbędni do prawidłowego funkcjonowania placówki) ${ }^{35}$.

Analiza rodzajów interesariuszy może posłużyć do ukazania pozycji, jaką muzeum zajmuje na rynku, oraz poziomu realizacji wzajemnych oczekiwań w relacji muzeum - odbiorca. Tego typu badania wciąż nie są jednak powszechnym elementem w zarządzaniu dziedzictwem i polskimi instytucjami kulturalnymi. Tylko nieliczne muzea mogą np. wskazać poziom rocznej frekwencji w swojej siedzibie:

Obecnie w Polsce uczestnictwo w kulturze nie jest, a powinno być, ważną kategorią. Problemem większości instytucji kultury jest przede wszystkim to, że mają bardzo małą wiedzę na temat tego, kto jest ich klientem i kto korzysta $z$ ich usług. [...] Po pierwsze, w Polsce nieliczne instytucje gromadzą jakiekolwiek badania. Na palcach jednej ręki można wyliczyć te, które z własnej woli tego rodzaju analizy wykonują. [...] Nie ma jakiejkolwiek pogłębionej charakterystyki publiczności, informacji na temat jej potrzeb, oczekiwań, tego, jak ocenia ona działania instytucji $[\ldots]^{36}$.

PMA-B co roku wykonuje szczegółowe badania statystyczne dotyczące odwiedzających - w sprawozdaniu rocznym znajdują się zestawienia osób zwiedzających z wyszczególnieniem kategorii wiekowej czy kraju pochodzenia. Wykorzystanie wiedzy dotyczącej grup docelowych przekłada się m.in. na zmianę sposobu oprowadzania po terenie byłego obozu (od 2012 roku) czy koncepcję zupełnie nowej wystawy głównej, dostosowanej do współczesnego odbiorcy. PMA-B w praktyce wykorzystało również wiedzę na temat odwiedzających np. poprzez udostępnienie wszystkim bezpłatnego autobusu kursującego między Auschwitz I a Birkenau, ustalenie wspomnianego wcześniej nowego regulaminu rezerwacji terminów wizyty oraz wydanie publikacji umożliwiającej przygotowanie do wizyty w miejscu

35 Nowoczesne zarzadzanie muzeum..., op. cit., s. 30-31.

${ }^{36}$ M. Krajewski, op. cit., s. 27. 
pamięci i kierującej uwagę nauczycieli oraz edukatorów na fakt, jak bardzo potrzebna jest rozmowa podsumowująca i porządkująca silne doświadczenia emocjonalne po zakończeniu wizyty w Muzeum ${ }^{37}$.

W 2016 roku Międzynarodowe Centrum Edukacji o Auschwitz i Holocauście po raz pierwszy zrealizowało angielskojęzyczne seminarium Historia - Pamięć - Odpowiedzialność dla grupy zawodowej dziennikarzy. Związane jest to nie tylko $\mathrm{z}$ odpowiedzią na zapotrzebowanie społeczne upowszechniania wiedzy o Zagładzie, ale także $\mathrm{z}$ istotnym elementem zarządzania miejscem pamięci, jakim jest zapobieganie i przeciwdziałanie manipulacji, instrumentalizacji i innym trudnościom związanym ze współpracą $z$ mediami. We wspomnianym seminarium wzięli udział dziennikarze z Australii, Francji, Izraela, Niemiec, Stanów Zjednoczonych, Szwecji i Wielkiej Brytanii. Uczestnikami byli m.in. korespondenci największych światowych agencji prasowych pracujący w Polsce. Jak wiadomo, media są źródłem wielu możliwości dla instytucji kultury, spełniają chociażby funkcję marketingową i popularyzatorską. Bywają jednak również źródłem negacjonizmu czy fałszowania historii poprzez stosowanie hasła „polskie obozy koncentracyjne”. Dobrze zarządzana placówka nie tylko monitoruje sytuację na wielu płaszczyznach świata współczesnego, ale również uczestniczy w dyskursie, nie uchyla się od odpowiedzi i reakcji. Pracownicy PMA-B stworzyli i udostępnili w szesnastu językach aplikację Remember ${ }^{38}$, która wspiera zarówno dziennikarzy, jak i innych zainteresowanych zagadnieniami związanymi z Zagładą, aby nie popełniali powyżej wymienionych, jak i innych błędów. Projekt powstał we współpracy Muzeum i FCB Warsaw oraz przy wsparciu banku PKO BP, Mint Media i Macoscope.

Definicja sformułowana przez Barbarę Czarniawską-Joerges mówi, że organizacje są sieciami zbiorowych działań podejmowanych jako próba kształtowania świata i ludzi. Podążająca tym śladem Katarzyna Barańska podsumowuje, że „zarządzanie to tworzenie więzi”39. Państwowe Muzeum Auschwitz-Birkenau wypracowało z biegiem lat stabilną więź ze światem

37 Przygotowanie do wizyty w Muzeum i Miejscu Pamięci Auschwitz-Birkenau. Pakiet europejski. Wskazówki dla nauczycieli i edukatorów, red. A. Białecka, K. Oleksy, F. Regard, P. Trojański, Oświęcim 2013.

38 correctmistakes.auschwitz.org [dostęp: 11.02.17].

39 K. Barańska, op. cit., s. 168. 
mediów, dowodząc jednocześnie, że miejsce pamięci nie jest przestrzenią martwą, zastygłą w czasie, ale żywą historią, do której wciąż się powraca, historią mającą wpływ na kształtowanie współczesności. Do użytku dziennikarzy z całego świata została oddana strona prasa.auschwitz.org, gdzie poza informacjami związanymi z KL Auschwitz-Birkenau znajdują się wiadomości o aktualnych wydarzeniach czy zasady fotografowania i filmowania w miejscu pamięci. W 2016 roku na terenie Muzeum i Miejsca Pamięci Auschwitz-Birkenau pracowało sto pięćdziesiąt ekip filmowych z całego świata, realizujących m.in. produkcje dokumentalne ${ }^{40}$.

$\mathrm{Na}$ temat strategii zarządzania powstało już wiele publikacji, teorii i badań, jednak skorzystanie $\mathrm{z}$ nich nie jest warunkiem wystarczającym sprawnego kierowania i długofalowego planowania w tak wielowymiarowym miejscu, jakim jest PMB-A. Dyrektor Cywiński podkreśla, że nie można „przyzwyczaić się” do zarządzania miejscami pamięci, nawet jeśli podjęte obowiązki wykonuje się już od wielu lat z równie intensywnym zaangażowaniem:

Auschwitz przerasta. W każdym sensie. Młody człowiek pragnie dorosnąć do tego, co powinien robić, co go czeka, do wyzwań swojego życia. Do Auschwitz nie można dorosnąć. Dojrzeć. [...] Każdy manager ogarnia swym rozeznaniem przestrzeń swojego zarządzania. Mierzy narzędzia na zadanie i wybiera stosowną taktykę. Auschwitz nie da się ogarnąć. Trudno jest zarządzać czymś, czego nigdy się nie ogarnie ${ }^{41}$.

\section{Bibliografia}

Katarzyna Barańska, Muzeum w sieci znaczeń. Zarządzanie z perspektywy nauk humanistycznych, Wydawnictwo Attyka, Kraków 2013.

Piotr M.A. Cywiński, Epitafium... i inne spisane niepokoje, Państwowe Muzeum Auschwitz-Birkenau, Oświęcim 2012.

Dorota Folga-Januszewska, Muzea $w$ Polsce 1989-2008. Stan, zachodzace zmiany i kierunki rozwoju muzeów w Europie oraz rekomendacje dla muzeów w Polsce, MKiDN, Warszawa 2008.

40 Sprawozdanie Państwowego Muzeum Auschwitz-Birkenau w Oświęcimiu za rok 2014, s. 44.

${ }^{41}$ P.M.A. Cywiński, Epitafium..., op. cit., s. 41. 
Alicja Kędziora, Miejsca pamięci w zarządzaniu pamięcią o artyście, „Zarządzanie w Kulturze" 2012, nr 13, z. 2.

Marek Krajewski, Instytucje kultury a uczestnicy kultury. Nowe relacje. Przykład: $M S^{2} w$ Lodzi, [w:] Strategie dla kultury. Kultura dla rozwoju. Zarzadzanie strategiczne instytucja kultury, red. M. Śliwa, Małopolski Instytut Kultury, Kraków 2001.

Nowoczesne zarządzanie muzeum. Współpraca polsko-holenderska w ramach projektu MATRA 1999-2007, red. J. Czaj, B. Ziemnicka-Darnowska, P. Pawlina, Krajowy Ośrodek Badań i Dokumentacji Zabytków, Warszawa 2007.

Edith Penrose, The Theory of the Growth of the Firm, Oxford University Press, Oxford 1959;

Paweł Sawicki, Ponad 2 miliony odwiedzających Miejsce Pamięci Auschwitz-Birkenau w 2016 r., „Oś - Oświęcim - Ludzie - Historia - Kultura” 2017, nr 105.

Ryszard Stocki, Dialog strategiczny w instytucji kultury. Przykład: Wawel i przewodnicy, [w:] Strategie dla kultury. Kultura dla rozwoju. Zarzadzanie strategiczne instytucją kultury, red. M. Śliwa, Małopolski Instytut Kultury, Kraków 2001. Andrzej Szpociński, Miejsca pamięci (lieux de mémoire), „Teksty Drugie” 2008, nr 4. Martyna Śliwa, Zarządzanie strategiczne organizacja, [w:] Strategie dla kultury. Kultura dla rozwoju. Zarzadzanie strategiczne instytucja kultury, red. M. Śliwa, Małopolski Instytut Kultury, Kraków 2001.

\section{Źródła online}

http://auschwitz.org/muzeum/aktualnosci/milion-odwiedzajacych-miejsce-pamieci-w-2015-r-,1741.html.

http://auschwitz.org/muzeum/aktualnosci/nowy-system-rezerwacji-online-w-muzeum-auschwitz,1673.html.

http://auschwitz.org/muzeum/aktualnosci/seminaria-dla-dyrektorow-oraz-wychowawcow-w-zakladach-karnych-i-aresztach-slaska-i-malopolski,1658. html. http://www.fundacja.auschwitz.org/index.php/darczyncy/panstwa. http://www.fundacja.auschwitz.org/index.php/aktualnosci/61-posiedzenie-komitetu-miedzynarodowego-fundacji-auschwitz-birkenau.

www.fundacja.auschwitz.org/index.php/aktualnosci/32-globalny-plan-konserwacji -rozpoczety. 


\section{Strategic Management of the Martyrdom Museum and the Site of Memory - on the Example of the Auschwitz-Birkenau State Museum}

Auschwitz-Birkenau State Museum, located on the territory of the former Nazi's concentration camp, is an example of what a French historian, Pierre Nora, called 'a site of memory' (lieu de mémoire) - a place which serves to commemorate and symbolize the biggest genocide and the tragedy of the twentieth century, that is the Holocaust. Hence, the management of the institution like this has to include both market-based as well as ethical factors. Moreover, since the Museum uses many elements of the original concentration camp's infrastructure, the question arises whether it should aim to preserve the authenticity of this place, or rather follow the main trends in the museology (digitalization, wide multimedia environment etc.). The authoress analyzes the management strategy of the Museum by taking into account the statistical data, its educational offer, as well as the currently realized projects and programs.

Keywords: Auschwitz-Birkenau State Museum, the site of memory, martyrdom museum, cultural management 

ZatącZ्विil

\section{SAMOPUBLIKOWANIE PRAC NAUKOWYCH I LITERATURY PIĘKNEJ}

EWA FRĄCZEK-BIŁAT

Wydział Nauk Humanistycznych UKSW

Faculty of Humanities, Cardinal Stefan Wyszyński University in Warsaw

fraczek_ewa@o2.pl

\section{UWAGI WSTEPNE}

Samopublikowanie to termin względnie nowy, w przeciwieństwie do zjawiska, które - mniej lub bardziej precyzyjnie - opisuje. Pojęcie to, funkcjonujące jako kalka angielskiego „self-publishing”, jest o tyle trudne do uchwycenia jako zamknięta znaczeniowa całość, o ile trudne do precyzyjnego zdefiniowania są w świecie nowych mediów wszelkie terminy dotyczące wydawania - z samą „publikacją” na czele. Najprostsza definicja ujmuje samopublikowanie jako publikowanie bez udziału wydawnictwa. Tak wąskie rozumienie jednak prowadzi do nieporozumień, sugeruje bowiem, że aby mówić o self-publishingu, autor musi samodzielnie dokonać prac redakcyjnych i sam zlecić druk pozycji w określonej liczbie egzemplarzy, słowem: zająć się wszystkim od początku do końca. O wiele częściej natomiast samopublikowanie oznacza wydanie książek drukiem w ramach działalności profesjonalnego wydawnictwa, tyle że w całości lub częściowo finansowane z prywatnych środków autora oraz oddane do druku wyłącznie na skutek jego decyzji ${ }^{1}$. W obydwu przypadkach - a więc przy pełnej lub częściowej samodzielności - ingerencja osób trzecich w tekst, czy to naukowy, czy z zakresu beletrystyki, jest minimalna lub nie istnieje w ogóle.

Wydawnictwa, które wyrażają zgodę na samopublikację autora w ramach swojej komercyjnej działalności, często nie uwzględniają merytorycznego lub artystycznego poziomu oddawanych im tekstów podczas podejmowania

1 P. Nowak, „Samopublikowanie”: stara metoda, nowy sens $w$ dobie e-science, „Biblioteka” 2009, nr 13, s. 91. 
decyzji o podpisaniu umowy z twórcą. Tego rodzaju firmy właściwie nie mogą odmówić świadczenia oferowanych przez siebie usług wydawniczych, czy raczej mogą zrobić to jedynie w przypadku treści naruszających przepisy prawa. Tak działają w Polsce między innymi Poligraf, Warszawska Grupa Wydawnicza, Białe Pióro czy MyBook. Serwisy umożliwiające elektroniczne samopublikowanie (bez druku) to: Wydaje.pl, Publikatornia.pl, Bezkartek.pl oraz Virtualo.pl ${ }^{2}$. Firma Poligraf na swojej stronie w zakładce „o nas” informuje: „Pomagamy Autorom zaistnieć na rynku wydawniczym, ponieważ wierzymy w wolny rynek i w to, że rację mają czytelnicy, którzy głosują swoimi pieniędzmi, kupując dany tytuł. To oni są ostatecznymi jurorami. Wierzymy też, że jest wielu ludzi mających coś ciekawego do powiedzenia światu, którzy nie mieliby szans tego zrobić w tradycyjnym wydawnictwie"3.

W literaturze anglojęzycznej dotyczącej zjawiska self-publishingu pojawia się nawet termin vanity press, podkreślający psychologiczny aspekt wydawania w formie książkowej swoich własnych tekstów, a dokładniej - kwestię próżności autorów, która wykorzystywana jest przez firmy wydawnicze. Pejoratywne określenie ma na celu uwypuklenie roli miłości własnej autora w kontekście jego starań o „bycie wydanym”. Wciąż istnieje bowiem przekonanie, że opublikowanie swojej własnej książki, wydrukowanej i z nadanym numerem ISBN, jest społecznie nobilitujące ${ }^{4}$.

Podczas analizy zjawiska samopublikowania nadmiernym uproszczeniem byłoby jednak założenie, że można ograniczyć chęć „zaprezentowania światu” własnej twórczości do kwestii natury psychologicznej. Choć w dużej mierze potrzeba wydawania pewnych książek (zwłaszcza tomików częstokroć kiepskiej poezji lub spisanych dziejów rodziny, swoich własnych wspomnień itd.) jest faktycznie związana z potrzebą, często bezkrytycznego, zaprezentowania siebie, to jednak wiele form samopublikacji sprawia, że nie sposób jednoznacznie przekreślić tego sposobu promocji twórczości własnej. W szczególności wynika to z wielu aspektów omawianego

2 M. Deja, Elektroniczne samopublikowanie. Ewaluacja jakości i benchmarking internetowych serwisów samopublikawania, Kraków 2016, s. 49.

3 http://wydawnictwopoligraf.pl/oferta.php [dostęp: 23.04.17].

4 A. Glatthorn, Publish or Perish - The Educator's Imperative: Strategies for Writing Effectively for Your Profession and Your School, London - New Delhi Thousand Oaks (CA) 2002, s. 84. 
zjawiska - w innych wymiarach badać można samopublikowanie związane $\mathrm{z}$ działalnością naukową, $\mathrm{w}$ innych wspomniane vanity press; czym innym jest samopublikowanie w mediach elektronicznych, czym innym tradycyjnie wydana książka. Nie do zignorowania w kontekście omawianego tematu jest wreszcie samopublikowanie jako forma reakcji na poczucie bezradności „fundowanej” twórcom przez polskie realia wydawnicze. Z powodu tak szerokiego spektrum problemów self-publishing nie może być po prostu zaetykietowany jako wyraz próżności i oceniony z pobłażliwością.

W tym miejscu warto także wspomnieć, iż opłata uiszczana przez autora za publikację w recenzowanym czasopiśmie naukowym - które umożliwia zdobycie tak zwanych „punktów” - choć kontrowersyjna w pewnym aspekcie, z samopublikowaniem nie ma nic wspólnego. W przypadkach wydawnictw naukowych pobierających określoną kwotę za możliwość umieszczenia swojego artykułu w periodyku mamy bowiem do czynienia z procesem recenzyjnym, generującym swoisty rygor względem treści.

Celem niniejszego artykułu jest przyjrzenie się omawianemu zjawisku także z pozanaukowego punktu widzenia i nie tyle odpowiedź na pytanie, czy jest ono dla jakości piśmiennictwa bądź rynku wydawniczego dobre lub złe, ile raczej zwrócenie uwagi na pewne aspekty pomijane w wąskiej literaturze przedmiotu. $\mathrm{W}$ polskim piśmiennictwie temat samopublikowania poruszony został jedynie w kilku artykułach naukowych i jednej obszerniejszej monografii. Ta ostatnia - Elektroniczne samopublikowanie. Ewaluacja jakości i benchmarking internetowych serwisów samopublikowania autorstwa Marka Dei - choć zawiera typologię terminów związanych z self-publishingiem, to jednak stanowi głównie opis i analizę sprawności marketingowej serwisów oferujących usługę „wspierania autora”. Także nieliczne artykuły (z których za najbardziej szczegółowy można uznać tekst Piotra Nowaka pod tytułem „Samopublikowanie”: stara metoda - nowy sens $w$ dobie e-science opublikowany w czasopiśmie „Biblioteka”) koncentrują się na zagadnieniach wybranych, na przykład związanych z promocją osiągnięć naukowych. Nie do przecenienia w tym kontekście jest także blog Emanuela Kulczyckiego Warsztat badacza (ekulczycki.pl), bardzo często aktualizowany i nad podziw rzetelny, analizujący na bieżąco zarówno przepisy regulujące pracę naukową, jak i śledzący niepokojące zjawiska w obszarze nieprofesjonalnych, z merytorycznego punktu widzenia, konferencji czy kierowanych do pracowników uczelni ofert publikowania artykułów „za punkty”. Self-publishing jest 
w ramach obszarów, które analizuje i komentuje Kulczycki, jednym z kilku aspektów szeroko pojętego „warsztatu badacza”.

Próba odejścia od wąskiego spojrzenia i chęć umieszczenia rozważań także w kontekście szeroko pojętej kultury czytelnictwa i działań wydawnictw w Polsce jest być może karkołomna $z$ uwagi na ogrom związanych z tym obszarem zagadnień, niemniej warto przynajmniej zarysować pewne aspekty, co umożliwi dalsze ich analizy.

\section{SAMOPUBLIKOWANIE A IDEA OTWARTEJ NAUKI}

Jako że temat self-publishingu naukowego był poruszany we wspomnianych powyżej publikacjach Dei i Nowaka, warto zarysować tu jedynie jego główne aspekty, a szczególnie - bezpośrednio związaną z tym zjawiskiem ideę „nauki otwartej”, funkcjonującą w środowisku pod określeniem „Open Access”. Jest to międzynarodowy ruch środowisk akademickich bazujący na założeniu, że treści dydaktyczne i naukowe powinny być dostępne powszechnie, w więc - najlepiej - w wersji elektronicznej, w Internecie, w postaci artykułów opublikowanych w otwartym czasopiśmie elektronicznym ${ }^{5}$.

Jeśli weźmiemy pod uwagę fakt, iż - z punktu widzenia definicji - treść ukazująca się w recenzowanym czasopiśmie self-publishingiem nie jest, temat samopublikacji nieco rozmywa się i komplikuje. Pamiętać należy jednak, że w świecie szeroko pojętej nauki pojawia się - w Polsce od niedawna, na Zachodzie od kilku dekad - postulat demokratyzacji nauki, która to demokratyzacja rozumiana jest nie tylko jako możliwość otwartego dostępu do jej zasobów, ale także jako zminimalizowanie recenzyjnego rygoru i ograniczenia wpływu akademickiej „punktacji” na to, czy specjalista w danej dziedzinie jest poważany w środowisku, czy też w jego ramach ignorowany. Innymi słowy, swoisty „terror zdobywania punktów” - zmuszający często naukowców do uczestnictwa w kuriozalnym procesie, w ramach którego komentarz do toczącej się na łamach recenzowanego czasopisma dyskusji ma większe szanse na publikację niż głoszenie idei nowatorskich - promuje raczej przeciętność niż oryginalność. Co więcej, szczególnie w przypadkach nauk przyrodniczych czy medycznych istotny jest także czas ogłoszenia wyników badań - opóźniany przez powolny system opiniowania, redakcji naukowej, korekty itd. Zgodnie

${ }^{5}$ M. Deja, op. cit., s. 21. 
z opinią jednego z bardziej znanych propagatorów idei Open Access w Polsce, Edwina Bendyka, nauka polska „ciągle tkwi w starym, modernistycznym modelu komunikacyjnym, w którym obowiązywał klarowny podział pracy: uczeni prowadzą badania, których wyniki komunikują za pomocą wyspecjalizowanych kanałów, jak recenzowane czasopisma naukowe i konferencje"6, zaś upowszechnianiem wyników badań zajmują się profesjonalni redaktorzy wspomnianych czasopism, sami będący naukowcami. „Model ten - pisze Bendyk - jest niezwykle trwały. Decydują o tym mechanizmy systemowe (ocena przebiegu kariery polegająca na skrzętnym liczeniu punktów za publikacje i wystąpienia konferencyjne bez rzeczywistego związku z jakością $\mathrm{i}$ istotnością produkcji naukowej) i brak silnego roszczenia społecznego, które zmusiłoby środowisko do większej otwartości komunikacyjnej"7.

Idea nauki demokratycznej pociąga za sobą szereg zjawisk zaliczających się do szeroko pojętego self-publishingu. Naukowcy niekiedy własnym sumptem wydają monografie (starając się o ich recenzowanie przez kogoś z branży lub - rzadziej - pomijając ten etap), często też sięgają do formy znanej, choć wciąż mało popularnej w Polsce (przynajmniej w kontekście nauki), a więc do blogosfery. Treści umieszczane na tego rodzaju witrynach zazwyczaj związane są z aktualnymi obszarami zainteresowań autorów i prezentują ich hipotezy badawcze i najnowsze osiągnięcia. Twórcami należącymi do sieci blogów naukowych są przy tym nie tylko pojedynczy naukowcy (w znaczeniu akademickim) czy reprezentanci instytucji uczelnianych, ale również pasjonaci - osoby zainteresowane nauką lub zajmujące się wdrażaniem osiągnięć z zakresu danej dziedziny wiedzy do praktyki ${ }^{8}$. Jednym z bardziej znanych blogów z tego zakresu jest choćby Piękno neurobiologii (http:// vetulani.wordpress.com), witryna prowadzona przez słynnego i medialnie, i naukowo profesora Jerzego Vetulaniego (zmarłego w kwietniu 2017 roku), który podkreślał, iż zamieszczane w Internecie artykuły stanowią inny obszar tematyczny niż publikacje naukowe w konserwatywno-akademickim rozumieniu.

6 E. Bendyk, Przewodnik po otwartej nauce, Warszawa 2009, s. 13.

7 Ibidem, s. 14.

8 Por. S. Cisek, Weblogi (blogi) - nowe narzędzie komunikacji w nauce, [w:] Zarzadzanie informacja w nauce, red. D. Pietruch-Reizes, Katowice 2008, s. $170-178$. 
$\mathrm{Na}$ marginesie należy podkreślić, że czym innym jest samopublikacja, czym innym zaś - samoarchwizacja, a więc samodzielne umieszczanie w sieci kopii opublikowanych wcześniej artykułów (w tradycyjnych czasopismach lub cyfrowych repozytoriach), najczęściej w formacie PDF. Taka forma popularyzacji własnych dokonań mieści się i w idei nauki otwartej, i w obszarze inwestowania we własną karierę naukową - samoarchiwizacja często prowadzi bowiem do wzrostu cytowalności ${ }^{9}$. Z kolei samopublikowaniem będą artykuły naukowe umieszczane przez autorów chociażby na wspomnianych blogach, ale z pominięciem procesu recenzyjnego.

Samopublikowanie treści naukowych - w formie papierowej lub elektronicznej - spotyka się z krytyką konserwatystów, wskazujących, skądinąd słusznie, na brak kontroli i ryzyko naukowej hochsztaplerki, możliwej do zaistnienia na podatnym na nią internetowym gruncie. Zdaniem wielu naukowców przywiązanych do systemu punktów i recenzji, tylko rygorem akademickim można powstrzymać szerzenie się „pseudonauki”. Z drugiej strony jednak, kontrargumentem wobec takiego myślenia może być słynna „sprawa Sokala”, czyli opublikowanie przez Alana Sokala w renomowanym, punktowanym czasopiśmie „Social Text” - ważnym dla nauk społecznych - artykułu zatytułowanego Transgressing the Boundaries: Towards a Transformative Hermeneutics of Quantum Gravity (Transgresja granic: $k u$ transformatywnej hermeneutyce kwantowej grawitacji), który w rzeczywistości był parodią, zbiorem przemieszanych cytatów słynnych i uznanych akademickich osobistości. Jak twierdzi Tomasz Witkowski, psycholog znany z tego, że sam realizuje misję obnażania nadużyć typowych dla akademickiej psychologii: „w powszechnej opinii żart Sokala funkcjonuje jako przykład ośmieszenia myślicieli, którzy starając się sprawiać wrażenie głębokich, mówią o rzeczach, których nawet sami nie rozumieją"10. Gorzej, że owe pozornie głębokie frazy zyskują często punkty potrzebne do rozwoju kariery naukowej.

Podsumowując, przyjrzenie się temu, jak funkcjonuje świat akademicki nie tylko w Polsce - w dużej mierze prowadzi do smutnej konkluzji, iż nie sposób odróżnić treści wartościowych od bezwartościowych wyłącznie na podstawie (obiektywnych tylko w teorii) kryteriów uniwersyteckich.

9 P. Nowak, op. cit., s. 93.

10 T. Witkowski, Modne bzdury wciąż modne, „Nauka” 2007, nr 4, s. 149. 
Z drugiej strony jednak, samodzielna działalność jest w kontekście uprawiania nauki bardzo trudna - zwłaszcza tam, gdzie niezbędny jest dostęp do sprzętu lub surowców - i ciężka w ocenie. Mimo to coraz więcej osób decyduje się na mniejszą lub większą niezależność wobec ośrodków akademickich (czego wyrazem może być popularyzowanie postaci naukowców dbających o swobodę działania, jak na przykład Gregory'ego Chaitina ${ }^{11}$ ), na krytykę funkcjonowania akademickiego „świata punktów i recenzji” oraz na popularyzowanie idei nauki otwartej - czy to poprzez formę Open Access, czy naukową część blogosfery.

\section{SAMOPUBLIKOWANIE LITERATURY PIĘKNEJ A RYNEK WYDAWNICZY}

Rynek wydawniczy w Polsce rządzi się, jak w większości krajów kapitalistycznych, twardymi prawami. Z jednej strony - z punktu widzenia potencjalnego twórcy - mamy do czynienia z reguła mi ekonomicznej opłacalności zainwestowania kogoś (wydawcy) w nasz produkt, z drugiej, ze spadkiem czytelnictwa i wypieraniem literatury pięknej z księgarni przez poradniki i autobiografie celebrytów, $z$ trzeciej - z koniecznością promocji i przebicia się przez gąszcz tytułów. Nawet wydana książka może bowiem po prostu „zniknąć", jeśli o jej rozgłos nie zadba nie tylko „inwestor”, ale i sam autor.

Po prywatyzacji przemysłu książkowego (od 1989 roku) nastąpił, już w pierwszym dziesięcioleciu XXI wieku, proces konsolidacji, w ramach którego duże koncerny wydawnicze (głównie z dominującym udziałem

${ }^{11}$ Gregory Chaitin to argentyńsko-amerykański matematyk i informatyk, który stworzył algorytmiczną teorię informacji, bazową dla rozwoju informatyki, ale jednocześnie zamiast „odcinać kupony” od uznanych już sukcesów, zajmuje się na własną rękę zupełnie nowatorską (a więc - posługując się żargonem akademickim „niecytowalną”) dziedziną nauki, jaką jest metabiologia (próba matematycznej formalizacji teorii ewolucji). Niezrozumiany przez uniwersytecką rzeczywistość Chaitin walczy o akceptację innowacyjnych teorii właściwie samotnie, a jego zmagania obserwuje pozaakademicki świat - czego wyrazem jest chociażby wydanie w 2016 roku przez „Politykę” filmu Chaitin. Człowiek, który szuka piękna (reż. Karol Jałochowski). Decyzja, aby pozaakademickiego naukowca uczynić bohaterem filmu, pokazuje, że powoli samopublikowanie, czy - szerzej - naukowe działanie na własną rękę, zyskuje rzesze zwolenników. 
kapitału zagranicznego) przejmowały mniejsze wydawnictwa ${ }^{12}$. Na początku aktualnej dekady liczba wydanych tytułów w stosunku do danych z 1990 roku uległa wprawdzie aż potrojeniu (z 10596 tytułów w 1990 do 31515 w roku $2011^{13}$ ), jednak małe nakłady wydawanych dzieł, moda na literaturę mało wyrafinowaną (fenomen książek Dana Browna i Stephenie Meyer czy kilkuletnia „sprzedaż ciągła” utworów Katarzyny Grocholi lub Małgorzaty Kalicińskiej), wysokie ceny i zbyt szybkie zastępowanie jednej książki drugą na półkach $\mathrm{z}$ „hitami” sprawiają, że potencjalny kontakt na linii twórca - wydawca jest bardzo trudny. Największe nakłady osiągają obecnie podręczniki (które z uwagi na wciąż zmieniający się system szkolnictwa pisać - z rynkowego punktu widzenia - warto), na drugim miejscu znajduje się literatura dziecięca, na trzecim - literatura religijna, a dopiero na czwartym - beletrystyka ${ }^{14}$. Co więcej, mimo iż literatura naukowa czy specjalistyczna znajduje się w rankingu liczby nakładów na dalszych pozycjach, to jednak w przypadku jej twórców możliwe jest poszukiwanie dotacji, dofinansowań instytucjonalnych itp. W przypadku literatury pięknej takie zjawiska prawie nie występują, dlatego to w tę właśnie dziedzinę piśmiennictwa wydawcy obawiają się inwestować. Na sukces powieści lub zbioru opowiadań (nie mówiąc już o poezji) składa się zbyt dużo czynników trudnych do przewidzenia, typu sezonowa moda, wydarzenia społeczne, nieprzewidywalne nominacje do nagród literackich itd.

Gdyby pokusić się o uproszczone podzielenie wydawców na tych, którzy zdecydowali się inwestować w literaturę ambitną, i tych promujących twórczość lekką, ale - z literackiego punktu widzenia - średniej jakości, okazałoby się, że dla twórcy przebicie się i u jednych, i u drugich jest... równie ciężkie. Literatura tak zwanych „średnich lotów” rządzi się swoimi prawami, w związku z czym wydawcy wolą albo pracować ze sprawdzonymi twórcami, których książki sprzedają się raczej przeciętnie, ale regularnie,

${ }^{12}$ K. Jagodzińska, Charakterystyka działalności kulturalnej $w$ Polsce po transformacji ustrojowej, [w:] Kultura a rozwój, red. J. Hausner, A. Karwińska, J. Purchla, Warszawa 2013, s. 141.

13 Ibidem, s. 141.

14 Badania przeprowadzone przez Instytut Książki, dostępne na: http://www. instytutksiazki.pl/upload/Files/polish_book_market_2015_PL_popr.pdf [dostęp: 23.04.17]. 
albo inwestować w coś aktualnie modnego, np. poradnik taneczny w momencie rosnącej popularności programu telewizyjnego promującego taniec. Wydawcom stawiającym zaś na szeroko pojętą „dobrą literaturę" zdecydowanie bezpieczniej jest $\mathrm{z}$ kolei publikować znane nazwiska, inwestować w tłumaczenia książek dobrze sprzedających się lub nagrodzonych w innych krajach, albo też - ewentualnie - dać szansę komuś, kto jeszcze nie „zawojował” rynku, ale ma na swoim koncie wygrane konkursy literackie większego kalibru.

Reasumując, najczęściej mało kto jest zainteresowany publikowaniem książek, które twórca uznaje - słusznie lub nie - za warte wydania. Nierzadką sytuację, w której spośród dwudziestu wydawnictw żadne nie wyraziło zainteresowania napisaną już pozycją, utrudnia dodatkowo to, że jedną z cech specyficznych rynku książkowego w Polsce jest nieobecność agencji literackich, które na przykład na rynku amerykańskim doskonale spełniają rolę pośrednika między wydawcą a pisarzem. Twórcy zza oceanu komunikują się z wydawcami właściwie wyłącznie za pośrednictwem agentów, którzy „pełnią funkcję prywatnych sekretarzy autorów oraz oferują im wsparcie zarówno prawne, jak i promocyjne"15. Różnicę łatwo zauważyć, analizując dane liczbowe. W raporcie Instytutu Książki z roku 2013 pojawiła się informacja, że w połowie 2012 roku odnotowano w Polsce 2000-2500 aktywnych wydawnictw, które wydają ponad 10 tytułów rocznie ${ }^{16}$. Jednocześnie na stronie Instytutu znaleźć można informacje o zaledwie... dwunastu agencjach literackich ${ }^{17}$. Powodem takiego stanu rzeczy jest brak tradycji w tym zakresie oraz niewielkie dochody pisarzy, które prowadzą do niechęci dzielenia się zarobionymi środkami z kolejnym - obok wydawcy - pośrednikiem.

W sytuacji napotykania dalszych barier i reakcji odmownych u wydawców oraz wobec braku zaufania do agentów ścieżką dla zdesperowanego twórcy jest samopublikacja. Oczywiście, jak zostało wspomniane, bardzo często twórcy są wobec siebie bezkrytyczni, a ich dążenie do napisania i wydania „prawdziwej książki” wywołuje u profesjonalistów raczej uśmiech pobłażania. Z drugiej strony jednak, może zdarzyć się sytuacja, w której

15 E. Sasin, Agent literacki jako nowy aktor w polskim polu literackim po 1989 roku, „Przegląd Kulturoznawczy” 2015, nr 2, s. 142.

16 Ibidem.

17 Ibidem. 
pisarz ominął ścieżkę tradycyjną ze względów o wiele bardziej złożonych chociażby z uzasadnionego przekonania, że wydawnictwo nie zadba o jego interesy.

Niezależnie od tego, że własnym sumptem w swoim czasie wydawali Mark Twain, Lewis Carroll, Aleksander Fredro czy Edgar Allan Poe, a własne wydawnictwa założyli tak znani pisarze współcześni, jak Stefan Chwin czy Andrzej Stasiuk, self-publishing w wydaniu literackim ma jeszcze gorszy społeczny PR niż self-publishing naukowy. Aby odpowiedzieć na pytanie, dlaczego tak się dzieje, trzeba byłoby pewnie przeprowadzić skomplikowane badania socjologiczno-psychologiczne - na ogół bowiem krytyczni wobec wydawania książki „za swoje” są ci, którzy też piszą, ale mają swojego wydawcę. Dla przeciętnego odbiorcy kultury nazwa wydawnictwa i historia powstania książki są często nieistotne. Faktem pozostaje jednak to, że self-publishing literacki nie może być wsparty ideą analogiczną do idei otwartości nauki. Tym samym działanie na własną rękę wymaga od pisarza pewnego przełamania się. Duży wysiłek finansowy bywa niekiedy lżejszy od związanej z samopublikowaniem konieczności zadbania o autopromocję oraz zmierzenia się z konsekwencjami przekonania $-\mathrm{z}$ niejasnych przyczyn wciąż obecnego w społeczeństwie - że „oficjalnie” równa się „ambitnie”.

\section{PODSUMOWANIE}

Gdyby pokusić się o wypunktowanie plusów i minusów self-publishingu w zakresie literatury naukowej oraz literatury pięknej, po stronie niewątpliwych zalet znalazłaby się - i w jednym, i w drugim przypadku - niezależność od dominujących mód i trendów. Naukowcy, wydając treści własnym sumptem lub elektronicznie, dodatkowo wolni są od nie zawsze uzasadnionych rygorów akademickich. Z kolei pisarz tworzący w obszarze beletrystyki nie jest zmuszony do konsultacji treści z wydawcą - nie licząc korekty i redakcji, za którą uiszcza opłatę. Co więcej, autor, jeśli wydaje sam swoją książkę, może liczyć na 50-70\% sumy każdej sprzedanej kopii, a nie na 5-15\%.

Problematycznych zagadnień związanych z decyzją o samopublikacji jest jednak równie sporo, co zalet tego rozwiązania. Poza dodatkowymi problemami z dystrybucją (w przypadku książki drukowanej; osób publikujących online ten problem nie dotyczy), pisarz i naukowiec muszą często zmagać się z większym krytycyzmem społeczeństwa wciąż zakładającego, że „prawdziwa książka” to taka, za wydanie której zapłacił ktoś, kto dostrzegł 
w nas potencjał (w przypadku beletrystyki), lub taka, która została wnikliwie przeanalizowana przez odpowiednie grono (w przypadku publikacji naukowych).

\section{Bibliografia}

Edwin Bendyk, Przewodnik po otwartej nauce, ICM UW, Warszawa 2009.

Sabina Cisek, Weblogi (blogi) - nowe narzędzie komunikacji w nauce, [w:] Zarzadzanie informacja w nauce, red. D. Pietruch-Reizes, Wydawnictwo UŚ, Katowice 2008.

Marek Deja, Elektroniczne samopublikowanie. Ewaluacja jakości i benchmarking internetowych serwisów samopublikawania, Biblioteka Jagiellońska Uniwersytetu Jagiellońskiego, Kraków 2016.

Allan A. Glatthorn, Publish or Perish - The Educator's Imperative: Strategies for Writing Effectively for Your Profession and Your School, Corwin Press, London - New Delhi - Thousand Oaks (CA) 2002.

Katarzyna Jagodzińska, Charakterystyka działalności kulturalnej w Polsce po transformacji ustrojowej, [w:] Kultura a rozwój, red. J. Hausner, A. Karwińska, J. Purchla. Narodowe Centrum Kultury, Warszawa 2013

Piotr Nowak, „Samopublikowanie”: stara metoda, nowy sens $w$ dobie e-science, „Biblioteka” 2009, nr 13,

Ewelina Sasin, Agent literacki jako nowy aktor w polskim polu literackim po 1989 roku, „Przegląd Kulturoznawczy” 2015, nr 2.

Tomasz Witkowski, Modne bzdury wciąż modne, „Nauka” 2007, nr 4.

\section{Self-publishing of the Academic Literature and of the Fiction}

The article draws attention to the accurate and inaccurate using of the term 'self-publishing'. It shows also the different circumstances that affect the growing popularity of this phenomenon. Essentially the article focuses on the specific difference between the situation in the academic publishing market and the situation faced by writers and publishers of the fiction.

Keywords: self-publishing, vanity press, literary field, publishing market, open access, academic strictness, monographs 

ZatącZ्विil

\section{SZTUKA KULINARNA JAKO \\ NOWY PRZEMYSŁ KREATYWNY ${ }^{1}$}

MAtGORZATA OSZUP-RAWICZ

Wydział Nauk Humanistycznych UKSW

Faculty of Humanities, Cardinal Stefan Wyszyński University

in Warsaw

gosia@bravissimo.pl

\section{DEFINICJA I KLASYFIKACJA PRZEMYSŁÓW KREATYWNYCH. ZWIĄZKI ZE SZTUKĄ KULINARNĄ}

Obserwując współczesne działania, które podejmują utalentowani szefowie kuchni, niejednokrotnie przeżywamy zdumienie. Wojciech Modest Amaro przyrządza pianę z ogórków kiszonych, robi galaretkę $\mathrm{z}$ agaru i wody $\mathrm{z}$ ogórków. Swojego „śledzia XXI wieku” podaje w postaci pomalowanego jadalnym złotem kawałka marynowanej ryby z sałatką z cebuli, zielonego jabłka, szczypiorku i tartego chrzanu z odrobiną oliwy z pestek śliwek. Kucharzowi zależy na wykorzystywaniu awangardowych technik - przy ich pomocy chce pokazać wspaniałą kuchnię polską w jak najbardziej nowoczesny sposób.

Inny znany szef kuchni, Adam Chrząstowski, zalewa czwórniakiem obsmażaną wątróbkę cielęcą z suszoną gruszką. Stając w szranki z kolegami po fachu, Agata Wojda przyrządza bulion grzybowy na gęsinie $z$ wędzoną polską śliwką i gruszką, a do tego ravioli z kaszy gryczanej i gęsiny. Staropolskie tradycje traktuje awangardowo również Karol Okrasa, podając pierożki z pieczoną kaczką i upaloną kaszą gryczaną zatopione w pysznej żurkowo-maślanej emulsji aromatyzowanej majerankiem².

Wspomniany już Adam Chrząstowski, filozof, który został kucharzem, rozważa słowa restauratora Joana Roca. Ten ostatni powiedział, że

1 Artykuł stanowi skróconą i przeredagowaną wersję pracy licencjackiej napisanej pod kierunkiem dr Anny Wróblewskiej i obronionej na Wydziale Nauk Humanistycznych UKSW w 2016 roku.

2 M. Kucia, Kuchnia PL, Warszawa 2011, s. 2-26. 
"gastronomia nie jest sztuką, gdyż w odróżnieniu od niej ma ulotne, nieugruntowane podstawy [...], istnieje bardziej jako przemysł i biznes aniżeli sztuka”. Chrząstowski nie zgadza się z tym stwierdzeniem. Jego zdaniem „sztuka opiera się głównie o kreację”. Autor przekonuje, że „istnieje wiele uznanych dziedzin sztuki, które nie tworzą nic stałego”, i wymienia choćby performans czy rzeźby lodowe. Uważa, że są one sztuką, bo wzbudzają w odbiorcy emocje, i wyraża przekonanie, że podobnie jest z gotowaniem.

Joan Roca porównał kucharzy do złotników, którzy jego zdaniem są rzemieślnikami, a nie artystami. Pracują co prawda na świetnym materiale, tworzą piękne dla oka i wzbudzające emocje przedmioty, ale są rzemieślnikami. Nie zgadzam się. [...] Jeżeli złotnik odbija swój pierścionek od określonej sztancy, którą ma w swoim zakładzie, wtedy jest rzemieślnikiem. Ale jeśli tworzy koncepcję projektu, który finalizuje w postaci unikatowego wyrobu złotniczego, to dla mnie jest ono dziełem sztuki ${ }^{3}$

Autor kulinarnego bloga, a zarazem uznany w branży szef kuchni, przyrównuje gotowanie zarówno do aktu kreacji artystycznej, jak i twórczej interpretacji cudzego dzieła.

Pianista wykonujący koncert Chopinowski jest uznawany za artystę. Nawet jeśli odtwarza go z nut, interpretacja dzieła jest odmienna u każdego artysty. Podobnie jest w kuchni - jeśli nawet gotuję, bazując na klasycznej recepturze Escoffiera, do której jednak dorzucę swoją myśl, to uważam, że to jest moja interpretacja określonego dzieła. I nawet na tym etapie pojawia się aspekt twórczy. [...] Najważniejsza w sztuce jest kreacja, jeśli do niej dochodzi, to nie widzę powodów, dla których gotowanie związane z tworzeniem czegoś nowego, oddziałującego na emocje, nie ma być uważane za sztukę .

Podobnie myśli Agnieszka Kręglicka, ceniona restauratorka i autorka felietonów kulinarnych. Uważa ona, że kucharz zasługuje na miano artysty, „kiedy poprzez smak, działania kulinarne, udaje mu się przekazać więcej treści niż tylko sensualną przyjemność. I są to treści znaczące”. Kręglicka zachwyca się między innymi konsekwencją i spójnością prezentowaną przez

3 A. Chrząstowski, Gotowanie vs sztuka, Blog Adama Chrząstowskiego, http:// adamchrzastowski.natemat.pl/88505,gotowanie-vs-sztuka [dostęp: 8.02.16].

4 Ibidem. 
najbardziej aktualnie podziwianego nie tylko przez fanów sztuki kulinarnej, ale też kulinarnych mistrzów, szefa Restauracji Noma z Kopenhagi, René Redzepiego: „Jego dzieło mówi: moim miejscem jest Skandynawia, jest surowa i piękna, pokażę wam ją moimi oczami, zakochacie się. I tak się dzieje, odkrywamy nowe smaki, czyste i bogate. Bez nadmiarowych dekoracji, bez podpierania się błyskotkami. Ideę Skandynawii oddają wnętrze, współpraca w zespole kucharzy i kelnerów i oczywiście dania"5 - przekonuje znawczyni tematu.

Choć literatura przedmiotu zdaje się całkowicie pomijać klasyfikację kulinariów jako przemysłu kreatywnego, to jednak w niniejszym tekście zastanawiam się, czy pewne aspekty kultury kulinarnej nie pozwalają zaklasyfikować jej jako tego rodzaju przemysłu. Mimo iż terminy „przemysły kultury” i "przemysły kreatywne” stanowią związki słów kojarzonych z dziedzinami do niedawna raczej ze sobą niewiązanymi - przemysłem i kulturą oraz przemysłem i twórczością - obecnie związki takie są uznawane, zatem niewykluczone, że mogą dotyczyć też kulinariów.

W statystyce i naukach ekonomicznych pojęcie przemysłu utożsamiane jest dziś z przetwarzaniem zasobów natury i produkowaniem dóbr o zbliżonych cechach konsumpcyjnych. Z kolei działania kulturowe, według definicji utworzonej w 2006 roku przez Victora Ginsburgha i Davida Throsby'ego, „mogą być wyznaczone przez trzy kryteria: powinny być oparte na pewnej formie kreatywności, powinny odwoływać się do symboliki, a ich produkt powinien wiązać się z pewną, choć dowolną formą własności"6. Wspomniani badacze podają cechy dóbr kulturalnych, pisząc o dobrach doświadczalnych, których preferencja wzrasta w miarę konsumpcji, i takich, które posiadają pewne cechy dóbr publicznych. Dobra kulturalne powinny być związane z pozytywnymi efektami zewnętrznymi i powstawać w wyniku procesów produkcyjnych wymagających kreatywności, wreszcie winny służyć jako nośnik wartości symbolicznych dla tych, którzy je konsumują. Z założenia stanowią własność intelektualną osób, które je wytworzyły, a także

5 K. Lewandowska, Agnieszka Kręglicka: Codzienne gotowanie rzadko bywa sztuka, „Polska Times”, www.polskatimes.pl/artykul/795613, agnieszka-kreglickacodzienne-gotowanie-rzadko-bywa-sztuka,id,t.html [dostęp: 4.09.15].

${ }^{6}$ Cyt. za: P. Lewandowski, J. Mućk, Ł. Skrok, Znaczenie gospodarcze sektora kultury, Warszawa 2010, s. 8. 
ucieleśniają wartości lub sprzyjają wartościom, które nie znajdują pełnego odzwierciedlenia?.

Zastanawiając się nad relacjami ekonomii i kultury, Throsby stawia tezę o zasadniczej różnicy między powodami, dla których podejmowane są działania ekonomiczne, i tymi, które stoją u podstaw aktywności kulturowych. Według tej tezy, z zachowaniami ekonomicznymi wiąże się chęć maksymalizacji indywidualnych korzyści przez konsumenta oraz chęć maksymalizacji - również indywidualnego - zysku u producenta. Działalność kulturowa, zdaniem Throsby'ego, ma natomiast charakter kolektywny, dąży do „doświadczenia grupowego albo zbiorowej produkcji i konsumpcji, które mają wartość wyższą niż prosta suma działań indywidualnych" ". Badacz przekonuje, że przy wycenianiu dóbr kultury wypada odróżnić ich wartość ekonomiczną i wartość kulturową - tę, na którą składają się wartości: estetyczna, duchowa, społeczna, historyczna, symboliczna, a także wartość płynąca $z$ autentyczności. Throsby zauważa, że nawet bezwartościowe, z ekonomicznego punktu widzenia, dobro kultury może dzięki swojej wysokiej wartości kulturowej osiągać niezwykle wysoką cenę?

Do zredefiniowania pojęcia przemysłów kreatywnych doszło w latach 90. ubiegłego stulecia. W 1997 roku w Wielkiej Brytanii powołano Zespół ds. Przemysłów Kreatywnych (Creative Industries Taskforce), mający podejmować „działania, które biorą się z indywidualnej kreatywności i talentu, i które mają zarazem potencjał kreowania bogactwa oraz zatrudniania poprzez wytwarzanie i wykorzystywanie praw własności intelektualnej"10.

Agata Etmantowicz, autorka związana z Ministerstwem Kultury i Dziedzictwa Narodowego, wyraża przekonanie, że brytyjska, nadal powszechnie stosowana definicja jest niedostatecznie spójna i precyzyjna. Podobnie jak inni jej krytycy, autorka podważa zasadność podziału przemysłów kreatywnych na trzynaście sektorów, z uwzględnieniem sektorów

7 Ibidem, s. 8-9.

8 Cyt. za: D. Ilczuk, Ekonomika kultury jako dziedzina badawcza, Warszawa 2015, s. 157.

9 Ibidem s. 157-158.

10 Przemysly kreatywne, Kreatywna Łódź, http://www.kreatywna.lodz.pl [dostęp: 29.07.16]. 
reklamy i oprogramowania, lecz z pominięciem innych istotnych sektorów (jako przykład podaje ona turystykę kulturalną) $)^{11}$.

Zgodnie z definicją ujętą $\mathrm{w}$ raporcie przygotowanym w 2009 roku dla potrzeb polskiego Ministerstwa Gospodarki, przemysły kreatywne to „kreatywne przedsiębiorstwa, które są w szczególności zorientowane na rynek, a zajmują się kreacją, produkcją, dystrybucją i rozprzestrzenianiem kreatywnych dóbr i usług poprzez media"12.

Interesującą, szczegółową charakterystykę przemysłów kreatywnych podaje ekonomista Richard Caves. Do ich cech autor ten zalicza: niemożność przewidzenia i zrozumienia reakcji odbiorcy, nacisk na oryginalność, harmonię i wysoką jakość dóbr i usług. Caves pisze również o zasadzie „wielobarwnej ekipy", mającej zastosowanie przy skomplikowanych kreatywnych projektach (np. filmach), które wymagają szerokiego spektrum czynników produkcji. Produkty przemysłów kultury ma cechować nieskończona różnorodność, nowatorstwo i fachowość artystów, określony czas powstawania oraz trwałość, dzięki której chronione są prawami autorskimi i umożliwiają zarobek swoim twórcom ${ }^{13}$. Jak zauważa A. Etmantowicz: „coraz częściej słychać, że sektor kreatywny jest motorem rozwoju Europy, że jest jednym z największych pracodawców w Europie i że jego obroty przewyższają obroty sektora motoryzacyjnego"14. Caves, oprócz aspektów społecznych i kulturalnych, przypisuje przemysłom kreatywnym znaczną siłę ekonomiczną.

Wobec wielości ujęć i definicji zarówno przemysłów kultury, jak i przemysłów kreatywnych, a także wobec istnienia wielu rozmaitych form działania zaliczanych bądź to do pierwszej, bądź też do drugiej grupy przemysłów, zastanawia brak kulinariów na którejkolwiek z list.

${ }^{11}$ A. Etmantowicz, Co to takiego przemysty kreatywne i przemysty kultury, „Kreatywni samozatrudnieni”, http://www.kreatywnisamozatrudnieni.pl [dostęp: 2.02.16].

${ }_{12}$ Przemysly kreatywne, sektory kreatywne, Słownik Innowacji - Leksykon hasel, http://www.pi.gov.pl/parp [dostęp: 29.07.16].

${ }_{13}$ Analiza potrzeb i rozwoju przemysłów kreatywnych, Raport Ecorys na zlecenie Ministerstwa Gospodarki, Warszawa 2009, http://nck.pl/media/attachments/302357/analiza_potrzeb_i_rozwoju_przemysw_kreatywnych.pdf [dostęp: 2.02.16].

14 A. Etmantowicz, op. cit. 
Najbardziej elastyczna w odniesieniu do postawionej w niniejszym szkicu hipotezy, zgodnie z którą kulinaria można uważać za rodzaj dóbr kreatywnych, a zatem niewykluczone, że również za rodzaj przemysłu kultury, jest definicja z raportu Culture Satellite Account przygotowanego przez fińskie Ministerstwo Edukacji w 2009 roku. Według tej definicji, przemysły kultury powinny „obejmować zarówno tradycyjne, jak i nowe obszary sztuki i kultury, od aktu twórczego w ramach różnych form sztuki, po dystrybucję"15.

Wydaje się, że taka charakterystyka sprzyja uznaniu kreatywności niektórych mistrzów kuchni, ich pomysłom pozwala przypisać znaczenia symboliczne, a w określonych sytuacjach - prawa własności intelektualnej. A jednak autorzy klasyfikacji, poszerzając dotychczasową listę o działalność ogrodów botanicznych i zoologicznych, reklamę, design, fotografię, zabawki oraz gry, parki rozrywki, hazard i gry losowe oraz sport, nie rozszerzają jej o działalność kucharzy i restauratorów. Czy zatem tylko kwestią czasu jest uznanie przemysłu kulinarnego za jeden z przemysłów kreatywnych lub przemysłów kultury? Czy skoro twórczy przepis na nietuzinkową potrawę, a nawet samo danie przyrządzone przez wyjątkowo zdolnego kucharza $\mathrm{w}$ trakcie działań dających się przyrównać do twórczego performansu, mogą stanowić chlubę czy nawet tajemnicę określonej restauracji, to mają szansę - tak przepis, jak i „misterium” gotowania - zyskać status dzieł chronionych prawem autorskim?

Niewykluczone, że kwestia praw autorskich winna być częścią składową sztuki kulinarnej. Zgodnie z Ustawą o prawie autorskim i prawach pokrewnych, ochroną objęty może być wyłącznie sposób wyrażenia, nie są nią natomiast objęte odkrycia, idee, procedury, metody i zasady działania. Jak to rozumieć? Analizując artykuł trzeci tej Ustawy - wedle którego zbiory czy antologie „są przedmiotem prawa autorskiego, nawet jeżeli zawierają niechronione materiały, o ile przyjęty w nich dobór, układ lub zestawienie ma twórczy charakter, bez uszczerbku dla praw do wykorzystanych utworów" - można założyć, że zbiory choćby i tradycyjnych przepisów, podane w kreatywny, nowatorski sposób, mają szansę uchodzić za osobny utwór, a autor zestawienia może zyskać dla swojego dzieła ochronę prawną. Prościej rzecz ujmując: o ile treść przepisu, pomysł na danie czy przedstawiony

${ }_{15}$ P. Lewandowski, J. Mućk, Ł. Skrok, op. cit., s. 10-11. 
sposób jego przygotowania nie mogą być chronione prawami autorskimi, o tyle ochronie będzie podlegać oryginalna i twórcza forma wyrażenia, czyli na przykład prezentacja tego przepisu na blogu kulinarnym czy w książce. Forma wyrażenia przepisu kulinarnego podlega zatem takiej samej ocenie jak każdy inny przejaw twórczej działalności. Należy podkreślić, że w cytowanej Ustawie przyjęto bardzo szerokie pojęcie utworu. Ma nim być rezultat o charakterze kreacyjnym, który odróżnia się od innych, nosi piętno osobowości autora i oryginalny charakter ${ }^{16}$. Wreszcie, czy atmosfera zaprojektowanego z rozmysłem wnętrza, a także sam skład i sposób podania jedzenia mogą - poprzez zdolność wywoływania rozmaitych, niezwiązanych z potrzebą zaspokojenia głodu wyobrażeń - uchodzić za symboliczny wymiar oferty restauracyjnej?

Skoro całe przedsięwzięcie: od pomysłu na nowe danie, poprzez jego przygotowanie, podanie i skonsumowanie, może wymagać kreatywności, skoro twórcy, jako pomysłodawcy i realizatorowi, można w zasadzie przyznać status posiadacza praw autorskich do kulinarnego majstersztyku i skoro zarówno dzieło (tu: twórczość przy przyrządzaniu i samo danie), jak i jego oprawa (piękne wnętrze i muzyka) niosą określone konotacje o charakterze symbolicznym - czy w takim razie można uznać, że zostały spełnione wszystkie trzy wyróżnione przez Throsby'ego warunki przynależności działalności kulinarnej do dóbr kultury? Oto pytania, na które spodziewam się znaleźć odpowiedzi w dalszej części artykułu.

\section{SZTUKA KULINARNA JAKO DZIAŁALNOŚĆ O CHARAKTERZE ARTYSTYCZNYM}

Współcześni mistrzowie kulinarni czerpią inspiracje z różnorodności rozwiązań znanych $\mathrm{z}$ historii oraz tradycji kulinarnych różnych stron świata. Łączenie tradycji, dzięki któremu powstają nowe dania, nosi nazwę kuchni fusion i już w XIX wieku stało się wyzwaniem dla odważnych i ciekawych eksperymentowania kucharzy amerykańskich, a największą popularnością cieszyło się w ostatniej dekadzie wieku ubiegłego. Obecnie, na fali rosnącego zainteresowania dietą wegetariańską i wegańską, styl fusion często stosuje

16 Ustawa z dnia 11 września 2015 r. o zmianie ustawy o prawie autorskim i prawach pokrewnych, http://www.dziennikustaw.gov.pl/du/2015/1639/1 [dostęp: 25.02.16]. 
się w odniesieniu do dań bezmięsnych. Potrawy te mają być przygotowywane i podawane z rozwagą, zaangażowaniem, mają i odżywiać, i leczyć, wykorzystując najciekawsze rozwiązania znane dotąd przede wszystkim lokalnie, a teraz zespalane w nowych i niezwykłych przepisach ${ }^{17}$.

Z kolei kuchnia haute to przede wszystkim wykwintność, prestiż i poszanowanie tradycji, które można by określić mianem kucharskiej kindersztuby. Adepci tego stylu, pobierający nauki w Le Cordon Bleu, jednej z najbardziej prominentnych szkół gotowania mającej swoje oddziały w Stanach Zjednoczonych, Wielkiej Brytanii, Francji i Japonii, obowiązani są „każdego dnia przychodzić do kuchni w swoich białych kucharskich uniformach, odprasowanych spodniach i czapkach kucharskich na głowach, a więc ubrani niemal identycznie jak francuscy kucharze w dziewiętnastym wieku". Jakość haute znajdowała zastosowanie we francuskich zamkach i posiadłościach arystokratów i znamionowała „kuchnię elit”18.

Jak kiedyś „pan na włościach”, także i dziś w eleganckich restauracjach specjalizujących się w stylu haute konsument odgrywa pierwszoplanową rolę, zaś lekkie, oparte na naturalnych smakach i ekskluzywnie podane jedzenie nabiera rangi kulturalnego symbolu i bywa przepustką do społecznych dystynkcji ${ }^{19}$.

Zapewne największe nadzieje na twórczość w kuchni rokuje naturalna kuchnia kreatywna. Wywodzi się ona z kuchni molekularnej, której idę i nazwę ukuli w 1988 roku węgierski fizyk Nicholas Kurti i francuski chemik Hervé This. Według nich, jak i późniejszych propagatorów nowego stylu kulinarnego, na gotowanie składają się aspekty socjologiczne, artystyczne i technologiczne. Kuchnia molekularna wymaga wiedzy naukowej obszerniejszej niż dotąd stosowana przy gotowaniu. Dzięki jej zastosowaniu można otrzymać tak zwane czyste smaki, i to w najbardziej zaskakujących zestawieniach. Za jedną z technik wykorzystujących wiedzę naukową uchodzi metoda sous vide, czyli dosłownie: gotowanie „w próżni”, możliwe dzięki użyciu specjalnych urządzeń i opakowań. Tą metodą przygotowuje się między innymi warzywa, owoce, mięsa, ryby i owoce morza. Mistrzowie

17 M. Reinfeld, B. Rinaldi, Vegan World Fusion Cuisine, Kapaa 2004, s. 6.

18 A.B. Trubeck, Haute Cuisine How the French Invented the Culinary Profession, Philadelphia 2000, s. 3.

19 Ibidem, s. 9. 
kuchni wydobywają niezwykłe smaki, stosując wędzarki umożliwiające wykończenie naturalnym, chłodnym dymem dań i produktów, które nie dają się uwędzić tradycyjnymi metodami, takich jak: masło, surowa ryba, czekolada, napoje, sałatki czy zupy. Ogromne możliwości oferuje technika dekonstrukcji, w której znane składniki tradycyjnych potraw zestawiane są ze sobą w nowy sposób, dzięki czemu nowe danie w niczym nie przypomina z wyglądu potrawy „wyjściowej”, a także techniki emulgacji, piankowania, kompresowania, zagęszczania, żelowania i sferyfikacji. Duże pole do popisu dają również takie substancje, jak suchy lód czy ciekły azot ${ }^{20}$.

W Polsce nowe, popularne przede wszystkim na Zachodzie trendy kulinarne adaptują się sprawnie. Przybywa specjalistów od zaskakiwania smakiem i wyglądem potraw, a także ludzi potrafiących zadbać o szerszy niż dotąd kontekst ich podania. Wśród badanych w 2014 roku młodych ludzi aż cztery osoby na dziesięć planowały częściej jadać w restauracjach i aż $46 \%$ deklarowało, że w nadchodzącym roku rzadziej niż do tej pory będzie odwiedzać lokale oferujące dania typu fast food. „Z jednej strony wzrasta świadomość znaczenia dobrego jedzenia i jego wpływu na nasze życie, szczególnie wśród ludzi młodych. $Z$ drugiej strony lokale gastronomiczne, zwłaszcza restauracje, coraz częściej są miejscem, gdzie Polacy przenoszą część swojego życia społecznego"21 - czytamy w raporcie poświęconym polskiemu rynkowi gastronomicznemu z 2014 roku.

Bardzo modną ostatnio gałęzią przemysłu związanego z kuchnią jest turystyka kulinarna. Polskie trasy wiodące turystów do nowych „odkryć na talerzu" to choćby Szlak Kulinarny Centrum Gdyni czy Iławski Szlak Kulinarny 2010, Małopolski Szlak Owocowy i Szlak Oscypkowy. Zachęcanie konsumentów do podążania owymi szlakami ma niewątpliwie wpływ na budowanie kulinarnej tożsamości miast i regionów, a zatem sytuuje lokalną kuchnię w kręgu znaczeń symbolicznych. $Z$ dużym rozmachem planowane $i$ organizowane są także konkursy i regionalne wydarzenia kulinarne.

${ }^{20}$ M. Misiura, D. Aksamit, Kuchnia molekularna, http://kuchniamolekularna.pl [dostęp: 8.02.16].

${ }^{21}$ Raport 2014. Rynek Gastronomiczny w Polsce, „Nowości Gastronomiczne”, Warszawa 2014, s. 28. 
Imprezy takie bez trudu można przyrównać bądź to do wystaw artystycznych, bądź też plenerów, na których spotykają się twórcy ${ }^{22}$.

Ekonomista Andrzej Klasik, pisząc o sektorze kultury i przemysłach kreatywnych w Aglomeracji Śląskiej, zestawia ze sobą dwa sposoby zarządzania kulturą:

[...] celowe jest zastosowanie dwóch z natury odrębnych [...] systemów prowadzenia działalności kulturalnej. Z jednej strony system non profit, który odnosi się do twórczości artystycznej i działalności kulturalnej eksponującej realizację misji społecznej, autonomię twórczą i korzystających z mecenatu publicznego [...]. Z drugiej strony system for profit, dla którego dzieła o wysokim pierwiastku kreatywności i wartości artystycznej są pierwotnym i pierwszym stadium cyklu kulturalnego, pozwalającym w fazie produkcyjnej na przejście do kreowania sprzedażnego wydarzenia/produktu kulturalnego. [...] Zastosowanie systemu for profit do prowadzenia działalności kulturalnej nie oznacza prostej komercjalizacji dzieł artystycznych i wydarzeń kulturalnych kosztem poziomu twórczości i wartości artystycznej, lecz uruchamia myślenie i działanie impresaryjno-menedżerskie w kategoriach event management - zarządzanie wydarzeniami kulturalnymi, działania marketingowe, sprzedażne i dystrybucyjne, czyli pełny łańcuch podażowy i kreowania wartości ${ }^{23}$.

Co istotne, $\mathrm{w}$ kontekście porównania festiwali kulinarnych $\mathrm{z}$ innymi wydarzeniami dotąd uważanymi za artystyczne Klasik podkreśla, że „w działalności kulturalnej konieczne jest wykorzystanie różnych systemów udostępniania dzieł artystycznych oraz wydarzeń i produktów kulturalnych. Jest to ich udostępnianie na żywo w zaawansowanych technologicznie obiektach kultury, w formie plenerowej [...]"24. Promujące dany region wydarze-

${ }^{22}$ Turystyka kulinarna - czyli przepis na sukces szlaków, imprez i produktów kulinarnych, Kuchnia Plus, www.kuchniaplus.pl/kuchnioteka/artykuly/turystka-kulinarna-czyli-przepis-na-sukces-szlakow-imprez-i-produktow-kulinarnych_336. html [dostęp: 10.02.16].

23 A. Klasik, Sektor kultury i przemysty kreatywne $w$ rozwoju regionu na przykładzie Aglomeracji Górnoślaskiej, s. 3, http://pi.gov.pl/PARPFiles/file/ INNOWACYJNA_FIRMA/R_artykul_prz_kreatywne_agl_gornoslaska.pdf [dostęp: 10.02.16].

${ }^{24}$ Ibidem. 
nia, podczas których można zasmakować specjałów kuchni inspirowanej tradycjami danego zakątka, $\mathrm{z}$ całą pewnością mogą być traktowane jako „wydarzenia i produkty kulturalne”, o których pisze Klasik. Rosnącej popularności tego typu imprez pomaga duże zainteresowanie odbiorców. „Możliwość doświadczania autentyczności miejsca poprzez kontakt z lokalną kuchnią jest unikatowym czynnikiem, który [...] może z wyjazdu tylko »udanego « uczynić wyjazd »doskonały»" - podają autorzy cytowanego wcześniej raportu. Aż 78\% badanych próbuje specjałów lokalnych kuchni podczas wyjazdów, a mając do wyboru szeroką ofertę dań w tej samej cenie, ponad połowa turystów wybrałaby danie kuchni regionalnej, którego jeszcze nigdy nie jadła. Na dodatek jesteśmy wręcz skłonni nadłożyć drogi, by zjeść posiłek w niepowtarzalnym miejscu (aż 72\% badanych ${ }^{25}$.

Poza zmianą polegającą na coraz częstszym traktowaniu restauracji jako miejsc odpowiednich do budowania więzi społecznych, rosnącą otwartością na poznawanie nowych dań i rozwojem nowej formy spędzania czasu, jaką jest turystyka gastronomiczna, mówi się również coraz śmielej o intelektualnej wartości działań kulinarnych. Badając polski rynek gastronomiczny, Edyta Gheribi stwierdza, że do najważniejszych ograniczeń hamujących rozwój przedsiębiorstw gastronomicznych należą ograniczenia kapitałowe. Zaznacza jednak przy tym, że „możliwości rozwojowe ogranicza również mały kapitał intelektualny, co wynika przede wszystkim z mniejszych możliwości korzystania z wiedzy odpowiednich specjalistów"26. Mimo to branża restauracyjna rozwija się, a w ostatnich latach „przychody z działalności gastronomicznej rosną szybciej niż liczba przedsiębiorstw. W latach 2000-2011 ogólna liczba placówek gastronomicznych wzrosła o 19,43\%, natomiast $\mathrm{w}$ tym samym okresie przychody $\mathrm{z}$ działalności gastronomicznej wzrosły o 40,21\%". Z danych zebranych przez GUS wynika, że najwięcej na gastronomię pojmowaną jako ,jedzenie na mieście" wydają gospodarstwa domowe w aglomeracjach zamieszkałych przez pięciuset i więcej mieszkańców ${ }^{27}$.

Jednocześnie „czytając fora internetowe, blogi poświęcone sztuce kulinarnej, można odnieść wrażenie, że gotowanie daje niezwykłe przeżycia, że już samo przygotowywanie potraw jest wielką ucztą, a późniejsza konsumpcja

25 Raport 2014. Rynek Gastronomiczny..., op. cit., s. 28-30.

26 Ibidem, s. 8.

${ }^{27}$ Ibidem, s. 6. 
to już tylko zasłużona nagroda"28, a zatem popularność zyskuje także gotowanie domowe, pojmowane jako atrakcyjna, w dużej mierze angażującą kreatywność forma spędzania czasu.

Podsumowując, istnieje coraz więcej przesłanek ku temu, by działalność kulinarną traktować jako przemysł kreatywny. Opisywana brytyjska klasyfikacja tego przemysłu, w której wyodrębniono tylko trzynaście jego sektorów, coraz częściej krytykowana jest jako nazbyt ograniczająca. Za przykład posłużyć może wywód autorów stworzonego w 2001 roku projektu mającego na celu rozwój kreatywności przemysłowej na pograniczu polsko-litewskim. Twórcy projektu krytykują to, że wykaz nie obejmuje zawodów i specjalności w zakresie przetwórstwa spożywczego i gastronomii. Ich zdaniem, „ponieważ na [...] terenach wiejskich ta sfera działalności ma duże tradycje oraz istotne znaczenie kulturowe i gospodarcze, krzewienie tradycyjnej kultury kulinarnej winno być także przedmiotem zainteresowania decydentów, a zwłaszcza przedstawicieli samorządów. Przedmiotem zainteresowania winny być [...] imprezy o charakterze kulinarnym (święto kindziuka) i promowane lokalne gastronomiczne specjały"29. Upieranie się przy wyjątkowości regionu omawianego w projekcie z pewnością jest bezzasadne, bo także w innych miejscach przemysł napędza wykorzystanie lokalnych tradycji, zestawianie ich $\mathrm{z}$ nowoczesnymi technikami przyrządzania i oferowania dań przez kreatywnych kucharzy i restauratorów. Wszystko wskazuje na to, że wykluczanie sztuki kulinarnej z listy przemysłów kreatywnych okazuje się tylko kwestią niedopatrzenia w literaturze przedmiotu.

\section{ANALIZA PRZYKŁADÓW KUCHNI KREATYWNEJ I ICH ZWIĄZKÓW Z PRZEMYSŁEM KULTURY}

Wyrafinowane gotowanie i serwowanie jedzenia powszechnie uchodzi za działanie kreatywne. Niezliczone tytuły książek łączące słowa „sztuka” z dziedziną kulinariów również przemawiają za tym, że jakkolwiek nie zapatrywalibyśmy się na możliwość tego typu połączeń, mają one swoje miejsce w powszechnej świadomości. I tak Anne Volokh i Mavis Manus

28 Ibidem, s. 24.

29 Wspólna strategia rozwoju kreatywności przemysłowej na pograniczu polsko-litewskim, Olita, Suwałki 2011, s. 10, www.ugpunsk.pl/userfiles/file/Strategia\%20 Rozwoju\%20PK\%20na\%20Pograniczu\%20PL.pdf [dostęp: 10.02.16]. 
piszą o „sztuce kuchni rosyjskiej” (The Art of Russian Cuisine, 1989), a włoscy autorzy - ogólnie o „sztuce gotowania” (The Art of Cooking: The First Modern Cookery Book, 2005). Po polsku możemy przeczytać choćby podręcznik Martina Pola o sztuce gotowania możliwej do uprawiania w codziennym życiu (Sztuka gotowania na co dzień, 1994), jak również o dokonaniach mistrzów kuchni chińskiej (Tradycje i sztuka kulinarna Chin, 2015). Przykłady można mnożyć.

Obok „sztuki kulinarnej” w szeroko rozumianym języku potocznym coraz częściej funkcjonuje również określenie „artysta” stosowane w odniesieniu do utalentowanych kucharzy. Autorzy kulturalnego serwisu internetowego Culture.pl piszą o życiu i twórczości mistrza kuchni, Wojciecha Modesta Amaro. Artykuł poświęcony kucharzowi znajduje się w sekcji „Kuchnia polska”, ta zaś jest jedną ze stworzonych na stronie kategorii tematycznych i występuje obok takich, jak design, muzyka, taniec, architektura, literatura, sztuki wizualne, teatr, komiks, jazz i film. „Wybitnie utalentowany Amaro jest uznawany za kulinarnego artystę" - czytamy. Prowadzona przez niego restauracja nosi nazwę, która odnosi do terminologii z zakresu sztuki - Atelier $\mathrm{Amaro}^{30}$ - i jest jedną z najambitniejszych w Polsce.

$Z$ całą pewnością o miano artysty kulinariów może ubiegać się Marcin Wojtczak, szef kuchni serwujący z niezmiernym polotem i rozmachem szczególnie dania z ryb i owoców morza, takie choćby jak omułki z mascarpone, szafranem i pigwą. Wspominając $\mathrm{w}$ wywiadzie przełomowy moment, w którym świat gotowania otworzył przed nim swoje podwoje, Wojtczak przywołuje swoją pierwszą kulinarną podróż: „Towarzyszyły temu niesamowite okoliczności. [...] Rzecz miała miejsce ponad dwadzieścia lat temu, więc był to czas, kiedy nasza polska gastronomia dopiero co się rodziła i świadomość naszej kulinarnej tożsamości była prawie żadna"3l - wspomina. Zdaniem wytrawnego kucharza, to właśnie bogactwo i różnorodność doświadczeń osób związanych z gastronomią, które poznał podczas wyjazdu, zaimponowały mu tak, że już nie było drogi odwrotu. „Teraz to wiem na pewno, że jako bardzo młody kucharz nie mogłem wymarzyć sobie lepszego bodźca do tego, aby zakochać się w gotowaniu" - zdradza szef

${ }^{30} \mathrm{http} / / /$ culture.pl/pl/tworca/wojciech-modest-amaro [dostęp: 20.03.16].

31 Wszystkie wypowiedzi Wojciecha Marczaka pochodzą z wywiadu, który przeprowadziła autorka artykułu w dniu 27 czerwca 2016 roku. 
kuchni. Z perspektywy dwóch dekad jest już w stanie prześledzić ewolucję własnego podejścia do sztuki kulinarnej. Przyznaje, że aby tego dokonać, potrzebny jest czas i wprawa.

Po dwudziestu latach spędzonych w kuchni z całą pewnością mam możliwość i umiejętność opisania fascynacji, które w danym momencie mi towarzyszyły. Chyba wszystkie etapy mojej ,twórczości” kulinarnej podążały zgodnie z rytmem trendów, jakie objawiały się w tej przestrzeni. Stosowałem nowe techniki, nowe produkty, które otworzyły nowe perspektywy i możliwości, odkrywałem na nowo dawno już zapomniane zioła i warzywa.

Zastanawiając się nad tym, co przede wszystkim charakteryzuje jego obecną receptę na wyśmienite gotowanie, Wojtczak wymienia niezwykłą pieczołowitość w doborze produktów, dbałość o ich jakość i pochodzenie zgodnie $\mathrm{z}$ aktualnym trendem, a zarazem genialną $\mathrm{w}$ jego odczuciu ideą slow food. Łącząc i przetwarzając składniki, Wojtczak chce - w formie gotowego unikatowego dania - przekazać odbiorcy coś więcej niż tylko smak.

Brzmi to bardzo banalnie, kiedy mówimy, że na talerzu pokazujemy samego siebie, ale czyż nie jest tak? Kiedy próbujemy odtworzyć smak z dzieciństwa lub smak, który kojarzy nam się z jakąś miłą, intymną chwilą, czy wtedy nie uzewnętrzniamy swoich uczuć i swego rodzaju tęsknoty? Moim zdaniem tak. Chcę również podzielić się swoją pasją, która daje mi wiele radości i która sprawiła, że jestem tu, gdzie jestem.

Zapytany wprost o własny unikalny styl, artysta $\mathrm{z}$ dużą skromnością przekonuje, że określenie to stanowi termin zarezerwowany dla wielkich prekursorów sztuki, tej kulinarnej również.

Ja nim [artystą - przyp. M.O.-R.] nie jestem, ale uważam, że absolutnie dominującym i modnym nurtem w tej chwili jest ,hołd” dla produktów „,naszych”, regionalnych, które wzrastają blisko nas. [...] Wystarczy krótka podróż za miasto, aby przekonać się o bogactwie jezior, pól, łąk i lasów; to prawdziwe zagłębie naturalnych produktów. Dlatego też spora już część polskich domów i restauracji szczyci się serwowaniem regionalnych produktów. Najbardziej jednak cieszy fakt, że są to miejsca cenione i bardzo popularne.

Rzeczywiście, Marcin Wojtczak w restauracji Villa Foksal, w której jest szefem kuchni, ułożył kartę ukierunkowaną na regionalność, powrót 
do korzeni, odkrywanie zapomnianych smaków polskich warzyw i ziół. Zadziwiającą zdolnością jest umiejętność pogodzenia artystycznych doznań na talerzu dla gościa indywidualnego, jak i utrzymanie wysokiej jakości wspomnianych trendów przy organizacji dużych wydarzeń, nawet dla kilkuset osób.

Wojtczak uważa, że historia naszego kraju miała ogromny wpływ nie tylko na rozwój kultury i sztuki, ale i na to, co znajdowało się - i nadal, niestety, często znajduje - na talerzu.

Pół wieku niewoli skutecznie zabiło w nas istotę i wagę tej dziedziny, zabiło też potrzebę poszukiwania i eksperymentowania. Dziedzictwo wielkich polowań, uczt i wspólnego biesiadowania zostało gdzieś zatracone lub zawłaszczone. Na szczęście, ostatnie dwadzieścia kilka lat transformacji powoli przywraca naszą tożsamość i kulturę jedzenia. W tym kontekście rozwój i przyszłość tej kulinarnej branży widzę bardzo pozytywnie.

Do równie znanych polskich artystów sztuki kulinarnej należą Karol Okrasa i Pascal Brodnicki. Z ich nazwiskami wiąże się działalność przedsiębiorstwa Fabryka Artystyczna, które oferuje nie tylko warsztaty kulinarne i degustacje, ale również widowiska taneczne i iluzjonistyczne, co zbliża tę instytucję do teatru. Z kolei o Michelu Moranie czytamy, że pokazuje on, iż „każdy może być artystą we własnej kuchni” ${ }^{2}$. Innym przykładem „kulinarnego artysty” jest Rafał Hreczaniuk, błyskotliwy pasjonat, który z miłości do gotowania porzucił architekturę i nauczył się swojej nowej sztuki pod okiem mistrzów ze znakomitych restauracji na świecie. W Dublinie pracował z Aidenem i Garrettem Byrne'ami, Rossem Lewisem i Derrym Clarkiem, został też nagrodzony profesjonalnym stażem w słynnej restauracji La Fermata w Mediolanie. Obecnie Rafał Hreczaniuk tworzy autorskie dania w obleganej przez smakoszy restauracji Dyletanci w Warszawie.

Wśród mistrzów kuchni robiących karierę za granicą wymienić też warto Marco Pierre’a White’a współpracującego $\mathrm{z}$ awangardowym twórcą Damienem Hirstem. Znamienna jest swoboda używania określeń z dziedziny sztuki w odniesieniu do działań kucharza i sam fakt wiązania kulinariów i sztuk wizualnych:

${ }^{32}$ E. Kusińska, „Moje smaki”: Michel Moran, Madame Edith, https:// madameedith.com/lifestyle/moje-smaki-michel-moran/ [dostęp: 20.03.16]. 
Gdy energiczny kulinarny geniusz Marco Pierre White połączył siły z l'enfant terrible sztuki awangardowej Damienem Hirstem, musiało dojść do intrygującego, wysokich lotów podwójnego aktu kreacji. White umieścił na talerzach potrawy, dzięki którym wygrywał konkursy kulinarne, a Damien zaznaczył swoją twórczą markę w sferze dekoracji, stosując charakterystyczne dla siebie, bynajmniej nie apetyczne akcenty, takie jak wypreparowane krowie głowy, szkielety [...] i narzędzia chirurgiczne. Jedzenie i sztuka tworzyły w ten sposób mieszankę wybuchową i partnerzy mieli nadzieję, że tym, co przyciągnie tłumy do ich nowej restauracji Quo Vadis, będzie ciekawość $[\ldots]^{33}$.

Jakkolwiek przedsięwzięcie okazało się chybione i ostatecznie White poszedł w kierunku bardziej stonowanych dekoracji, obu twórcom nie można odmówić rozmachu.

Szczególną dbałość o wizualną stronę przyrządzanego przez siebie jedzenia wykazują Holendrzy Lernert Engelberts i Sander Plug. „Artyści ukazują jedzenie w sposób maksymalnie geometryczny i minimalistyczny, krojąc je na idealne kosteczki i ustawiając w równych rzędach. [...] Przypomina to pewną układankę, do której klucz tkwi w estetycznej wizji artysty. Być może tak będą wyglądać dania przyszłości, które aż strach tknąć z obawy przed zaburzeniem pewnej idealnej struktury" - czytamy w artykule omawiającym aktualne trendy rynku i kultury ${ }^{34}$.

Niektórzy kucharze mówią o artystycznym wymiarze swoich działań bez ogródek. „Gotuję od ósmego roku życia, ale jeszcze dwa lata temu nie uważałam się za mistrzynię kuchni. Za to zawsze uważałam się za artystkę [...]. Dorastałam, koncentrując się przede wszystkim na mojej kreatywności i umiejętności przetwarzania pięknych idei w rzeczy namacalne [...]" pisze Colt Taylor w artykule o znamiennym tytule Gotowanie jest sztuka. O tym, co czyni kucharza artystą. Autorka, która wyjątkowo śmiało mówi o wizjonerstwie w kuchni, uważa, że artysta ma jeden jasny cel: użyć swoich talentów, by przekształcić wizję w coś konkretnego. Zauważa również, że:

${ }^{33}$ A lot of people came and were very disappointed with the Damien Hists art collection, „The Guardian” z dnia 17.07.1999 r., www.theguardian.com/theguardian/1999/jun/17/features11.g23 [dostęp: 19.02.16].

34 \#FoodArt, czyli jedzenie do oglądania, F5, http://www.fpiec.pl/post/2015/10/08/ foodartjedzeniedoogladania, [dostęp: 21.02.16]. 
Artysta to nie rzemieślnik, i odwrotnie, jednak znakomity kucharz musi być jednym i drugim. Jego zadaniem jest tworzyć wspaniałe, harmonijne dzieła oddziałujące na każdy z pięciu zmysłów. Jednocześnie mistrz kuchni musi w swojej pracy wykorzystywać zdobycze techniki. [...] By być artystą w kuchni, należy wykorzystać wszystkie bazowe techniki i spleść je z postępowym myśleniem, z gotowością do podjęcia ryzyka ${ }^{35}$.

Podsumowując, Taylor podaje przykłady najznakomitszych mistrzów kuchni nowoczesnego świata: Ferrana Adrię, Granta Aschatza, Michela Brasa i Thomasa Kellera, którzy:

wiedzą, jak przetrzeć nowe szlaki, używając starych, dobrych, wszystkim znanych ingrediencji. Kulinaria jako rodzaj sztuki są na wiele sposobów wyjątkowe. Podczas gdy malowidło angażuje zmysł wzroku, a muzyka słuch, jedzenie, jeśli tylko zająć się nim w najbardziej wyrafinowany sposób, dotyka jednocześnie wszystkich zmysłów. [...] Jako forma sztuki jest jedną z tych przemijających, trwających w swoim czasie. Tworzone talerz po talerzu, osobno dla każdego konsumenta, dopracowane wizualnie tylko po to, by zaraz zniknąć, zostać strawionym ${ }^{36}$.

Głosów w sprawie przyznania kulinariom rangi sztuki pojawia się coraz więcej, bo przybywa realizacji, dzięki którym danie jawi się jako „dzieło sztuki na talerzu”. „Pojęcie »sztuka kulinarna« nabiera dziś nowego znaczenia. Potrawy mają nie tylko zaspokoić głód, ale dostarczyć również przeżyć artystycznych. Przybywa mistrzów kuchni, którzy postanowili spojrzeć na jedzenie od innej strony i nadać mu dodatkowe funkcje" 37 - pisze Elżbieta Bogusławska-Przybysz. Dziennikarka przywołuje znamienny epizod z życia Martiego Guixé, projektanta mebli uznawanego za twórcę idei food designu. Po tym jak Guixé niechcący upuścił na klawiaturę komputera kanapkę z pomidorem, przyprawami i oliwą (miało to miejsce w latach 90.

${ }^{35}$ C. Taylor, Cooking Is An Art: What Makes A Chef An Artist, Craftsman And Visionary, Elite Daily, http://elitedaily.com/life/culture/chef-artist-craftsman-visionary/632690/ [dostęp: 18.02.16].

36 Ibidem.

37 E. Bogusławska-Przybysz, ArtFood - sztuka na talerzu, SPAeden, www. spaeden.pl/kuchnia/kuchenne-trendy/2287-artfood-sztuka-na-talerzu [dostęp: 21.02.16]. 
ubiegłego wieku), doszedł do wniosku, że z tych samych składników można stworzyć szereg rozmaitych, nietypowo prezentujących się potraw. Jak już wspomniano, dziś ideę tę szeroko wykorzystuje się w kuchni molekularnej. Projektowanie jedzenia rozwinęło się. Zarówno za granicą, jak i w Polsce można szkolić się w tym kierunku na uczelniach artystycznych. „Food design obejmuje nie tylko projektowanie żywności, ale też opakowań do niej, naczyń, aranżowanie wnętrz, w których potrawy są spożywane. W założeniach ma dostarczać zabawy i niecodziennych doznań związanych ze spożywaniem posiłków, a także zwrócić uwagę, jak ważne jest świadome jedzenie" 38 .

Wiele projektów ma wymiar społeczny, choćby proekologiczny, czy szerzej: występujący przeciw konsumpcyjnemu trybowi życia. Mariusz Kozak, prowadzący we Wrocławiu Food Art Gallery, ozdabia wnętrza swojej restauracji współczesnymi dziełami sztuki. Dba również o wizualną atrakcyjność samych dań. „Samo naczynie też powinno posłużyć jako inspiracja. Jeśli mamy na nim jakieś wzorki, warto dopasować do nich danie, ułożyć np. dodatkowy szlaczek z pasków marchewki. Warzywa są bardzo wdzięcznymi produktami, bo część z nich to gotowe dzieła sztuki”39 - uważa Kozak.

Tacy twórcy jak on wiedzą, że w nowoczesnej sztuce kulinarnej ograniczeniem jest tylko wyobraźnia i że dziś dużo chętniej degustujemy dania, niż się nimi objadamy. „Dziś wiadomo, że klientowi trzeba dać coś więcej niż tylko zaspokojenie głodu. Specjaliści obliczyli, że o tym, czy sięgniemy po określoną żywność, wcale nie decyduje smak. Aż w 40 procentach przypadków główną rolę odgrywa wrażenie wizualne, 30 procentach - słuchowe, a na pozostałe 30 składają się doznania zapachowe, dotykowe i smakowe"s0 - podaje Bogusławska-Przybysz.

W tym miejscu warto zwrócić uwagę na to, że szczególnie wymagający klient restauracji, jako odbiorca dzieła, które oddziałuje na jego zmysły, spodziewa się jeszcze więcej. Powraca zagadnienie kulinariów jako idei, ich symbolicznych znaczeń. Filozoficzny wymiar sztuki kulinarnej, jakkolwiek dla wielu osób wciąż nieco zaskakujący, ma tak naprawdę tysiącletnią tradycję. Według Chińczyków, „naród, który nie ma kultury, nie umie gotować”.
38 Ibidem.
39 Cyt. za: ibidem.
40 Ibidem. 
$\mathrm{W}$ ich pojęciu gotowanie jest nie tylko sztuką, ma również ścisłe związki ze światem wierzeń. Już Konfucjusz uważał, że „jedzenie jest najważniejszą rzeczą na świecie” oraz że „umysł znajduje się w żołądku”. Dobieranie przypraw to w Chinach cały rytuał. Główną zasadą jest zachowanie wszystkich elementów w równowadze tao ('droga'), z tego powodu każda z potraw powinna zawierać pięć smaków: słodki, gorzki, kwaśny, słony i ostry. Chińskie zupy lecznicze, niegdyś przyrządzane wyłącznie dla cesarzy, bywają gotowane bez przerwy kilka tygodni. Dzięki temu mają one odpowiednią ilość energii życiowej chi i należy je podawać chorym dla wyrównania sił w organizmie, znanych jako yin i yang. Nawet używanie pałeczek ma swój wymiar symboliczny - wywodzi się z wiary w to, że narzędzia takie jak noże mogą służyć do zabijania, a zatem nie powinny być używane przy spożywaniu życiodajnego jedzenia. Pałeczek z kolei nie powinno się stawiać pionowo w misce ryżu, bo wówczas przypominają one kadzidła trzymane przez ludzi podczas pogrzebów ${ }^{41}$. Filozofia konfucjańska wręcz nakazuje, by spożywać posiłki w towarzystwie bliskich osób. Co interesujące, aczkolwiek dziś ma to już posmak ciekawostki folklorystycznej, w Chinach nadal wierzy się, że spożywanie określonej części zwierzęcia wpływa dobroczynnie na podobny organ w ludzkim ciele. Dodatkowo jedne produkty mają wspomagać yin, inne zaś yang, a ponieważ siły te powinny pozostawać w harmonii, w żywieniu niezmiernie istotne jest urozmaicenie. Ma ono znaczenie nie tylko dla zdrowia ciała, ale i dla ogólnej życiowej harmonii ${ }^{42}$.

O równowadze, choć w nieco już bardziej hedonistycznym wydaniu, pisze również Jamie Oliver:

Moja filozofia jedzenia i zdrowego odżywiania zawsze dotyczyła czerpania przyjemności ze wszystkiego, ale w zrównoważony i rozsądny sposób. [...] Więc kiedy mówię o „zdrowym” podejściu do jedzenia i lepszym jedzeniu, to mówię o osiągnięciu tego zmysłu równowagi: mnóstwo wartościowych składników, różnorodność i odrobina rozpusty co jakiś czas ${ }^{43}$.

${ }^{41}$ Kuchnia chińska. Jedzenie $w$ zgodzie z filozofia, www.przyslijprzepis.pl/ artykul/kuchnia-chinska-jedzenie-w-zgodzie-z-filozofia [dostęp: 22.02.16].

${ }^{42}$ G. Mercedes, The Philosophy of Chinese Cooking, SelfGrowth, www.selfgrowth.com/articles/the_philosophy_of_chinese_cooking [dostęp: 22.03.16].

43 Jamie Oliver-filozofia jedzenia, http://przyduzymstole.blogspot.com [dostęp: 22.03.16]. 
Zdaniem Kevina W. Sweeneya, autora jednego z tekstów w książce poświęconej filozofii jedzenia, żyjemy w "czasach kwitnącej gastronomii” (blossoming age of gastronomy). Zainteresowanie kulinariami, innowacjami $\mathrm{w}$ tej sztuce i regionalnymi tradycjami nigdy nie było większe.

Można by sądzić, że jedzenie i radość płynąca z kontemplowania muzyki czy malarstwa to różne rzeczy, bo nie da się porównać naszego apetytu na muzykę czy malarstwo z fizyczną potrzebą [...] odżywania się. [...] Sądzę jednak, że wartości, jakie przyznajemy jedzeniu, odzwierciedlają również potrzeby emocjonalne, kulturalne i osobiste. Większość ludzi potrzebuje czegoś więcej niż odżywczej diety [...] Chcemy twórczych, znakomitych dań, którymi możemy się delektować, nie tylko zaspokajać fizyczny głó ${ }^{44}$.

Warto zwrócić uwagę na relację pomiędzy twórcą - w tym wypadku twórcą dań potrafiącym zarówno przyrządzić, jak i podać je z wyszukanym smakiem - a odbiorcą, czyli konsumentem. Jeśli przyjąć, że każda sztuka, a już z całą pewnością sztuka kulinarna, nie obywa się bez swojego konesera, jako istotna jawi się rola kreatywnych konsumentów, którzy napędzają jej rozwój. Prawdą jest jednak, że „współczesny odbiorca sztuki znajduje się w niespotykanej wcześniej sytuacji, jego status trudno jednoznacznie określić, a on sam może być zdezorientowany w wyniku sprzecznych oddziaływań, którym jest poddawany. [...] W konsekwencji wzajemne relacje elementów triady artysta - dzieło - odbiorca podlegają ciągłym i trudnym do przewidzenia zmianom"45 - uważają redaktorzy monografii poświęconej współczesnemu odbiorowi sztuki.

Jeden z autorów tekstów zamieszczonych w tej publikacji, Grzegorz Dziamski, zastanawiając się, czy sztukę postmodernistyczną można utożsamić z przemysłem artystycznym, czy w epoce ponowoczesnej twórczość artystyczna dołączyła do przemysłów kulturowych, przypomina, że:

lata 80. nie zostaną zapamiętane jako czas neoekspresji czy neokonceptualizmu, lecz jako czas radykalnej zmiany miejsca i roli sztuki w kulturze - czas,

${ }^{44}$ K.W. Sweeney, Hunger is The Best Sauce. The Aesthetics of Food, [w:] The Philosophy of Food, ed. D.M. Kaplan, Los Angeles 2012, s. 52-56.

${ }^{45}$ Co z tym odbiorcą? Wokót zagadnienia odbioru sztuki, red. M. Kędziora, W. Nowak, J. Ryczek, Poznań 2012, s. 7. 
w którym świat sztuki przekształcił się w przemysł artystyczny [...] W latach 80. sztukę zaczęto traktować jak inwestycję. [...] Sztuka stała się częścią współczesnej, postindustrialnej ekonomii, kapitałem kulturowym. Miała przyciągać inwestorów i turystów, tworzyć nowe miejsca pracy, zwiększać dochody miast, przyczyniać się do ekonomicznego rozwoju miast i regionów. [...] Kultura konsumpcyjna wchłonęła świat sztuki do tego stopnia, że artysta nie ma już wyjścia, chcąc tego lub nie, stał się częścią tego zjawiska ${ }^{46}$.

W tym kontekście, przy założeniu, że kucharz może być artystą, warto zauważyć, że o ile malarze, rzeźbiarze czy kompozytorzy mogą przeżywać w związku ze wspomnianą, dokonującą się stale zmianą pewien niepokój, o tyle mistrzowie kuchni problemu takiego nie mieli i nadal nie mają. Tworzenie na sprzedaż, po to, by przekazać swoje dzieło do degustacji kompletnej i totalnej (to znaczy: do spożycia), jest oczywistym elementem ich pracy. Zastanawiając się, co jeszcze we współczesnym świecie może być sztuką, Dziamski konstatuje, że:

sztuka towarzyszyła człowiekowi od zawsze. [...] O ile jednak sztuka jest wieczna, o tyle formy, jakie przybiera, podlegają zmianie w zależności od czasu i miejsca. [...] Ludzka potrzeba poezji, duchowej zabawy, potrzeba wrażeń wywoływanych przez kolory, kształty, dźwięki, słowa czy zapachy jest prawdopodobnie niezmienna, ale nie wynika $z$ tego wcale, żebyśmy zawsze potrzebowali obrazów sztalugowych, utworów symfonicznych czy powieści ${ }^{47}$.

Następnie autor przywołuje siedem cech sztuki wskazanych przez nowozelandzkiego estetyka Denisa Duttona. Są nimi: wirtuozeria, bezinteresowna przyjemność, styl, naśladownictwo, zdolność skupiania uwagi, wzbudzania intensywnych emocji i poczucia wspólnoty, oddziaływanie na wyobraźnię i krytykę. Jak pisze:

Wskazane przez Duttona cechy są na tyle szeroko zdefiniowane, że obejmują nie tylko zjawiska zaliczane w danej kulturze do sztuki, ale także wiele zjawisk pozaartystycznych. Podziw dla mistrzowskiego opanowania jakichś

${ }^{46}$ G. Dziamski, Sztuka i estetyzacja świata, [w:] Co z tym odbiorcą?..., op. cit., s. 11-12.

47 Ibidem, s. 13-14. 
umiejętności rozciąga się na niemal wszystkie ludzkie działania, od gotowania do publicznego przemawiania, od sprzątania domu do prowadzenia samochodu. [...] Nie każde przyrządzanie posiłków jest sztuką, ale takie przyrządzanie, które wymaga wyjątkowych umiejętności i wiedzy, dostarcza przyjemności daleko wykraczającej poza zaspokojenie głodu, skupia uwage swoim kształtem, kolorem, zapachem, przez co działa na wyobraźnię, i ma styl, może być z całą pewnością zaliczone do sztuki - sztuki kulinarnej ${ }^{48}$.

Jakie zatem cechy powinien posiadać „nadawca dzieła”, by można było mówić o gotowaniu jako o sztuce, o kucharzu natomiast - jako o artyście? Pisząc o sztuce w ogólności, a zatem najpewniej o tych jej dziedzinach, które dotychczas „zatwierdzono” jako artystyczne, Bogna Kietlińska stwierdza, że „mniej więcej od połowy XIX wieku spór wokół kompetencji artystycznych przybrał szczególnie na sile i wynikał przede wszystkim ze stopniowego osłabiania więzi między odbiorcą i artystą [...]. Recepcja dzieła jest zatem determinowana przez poziom kompetencji artystycznej odbiorcy, i tak koło się zamyka"49. Czy rzeczywiście? Niewykluczone, że w sytuacji, gdyby poza dziedzinami „wysokimi”, takimi jak malarstwo czy rzeźba, uprawomocnić kreatywne gotowanie jako sztukę, a kompetentne podejście do jej realizacji jako jej odbiór, mogłoby się okazać, że nowa - nowo zatwierdzona - forma sztuki ma się dobrze. Jak już dowodzono, wzrasta liczba wymagających odbiorców (tu: klientów restauracji), ludzi spragnionych doznań wykraczających poza najprostsze potrzeby. Z jednej strony, rosnące oczekiwania konsumentów mobilizują kucharzy, z drugiej zaś, odwrotnie, rosnące wyrafinowanie kucharzy nakłania ich klientów do szukania czegoś wyjątkowego. Przy zaangażowaniu obydwu stron - kucharza-artysty i klienta-konesera można mówić o istnieniu i recepcji sztuki kulinarnej. Szczególnie istotne jest w tym wypadku stałe doskonalenie się kucharzy i restauratorów, bo to dzięki nim następnie sublimują się gusta odbiorców.

Możliwości w dziedzinie rozwoju umiejętności, których wymaga sztuka kulinarna, jest coraz więcej. Określenie food design zyskuje swoje odpowiedniki w wielu językach, po polsku funkcjonuje jako „projektowanie jedzenia”. Dziś nie wystarcza już dobry smak potraw. „Coraz częściej o wyborze danego

48 Ibidem.

49 B. Kietlińska, Znaczenie kompetencji kulturowych i artystycznych $w$ odbiorze sztuki, [w:] Co z tym odbiorca?..., op. cit., s. 96. 
produktu decyduje jego kolor, forma, a czasami nawet dźwięk" - czytamy $\mathrm{w}$ jednym z popularnych kulinarnych serwisów internetowych.

Nowy dokument wyemitowany na antenie Kuchni.tv pt. Jedzenie zaprojektowane przedstawia złożony proces powstania produktów spożywczych i zabiera widzów w świat smaków, przepisów i technik gotowania, które wpływają na ostateczną formę jedzenia. [...] Badania w zakresie psychologii jedzenia mówią o subiektywnych odczuciach dotyczących jedzenia ${ }^{50}$.

Umiejętności w dziedzinie projektowania posiłków coraz częściej można zgłębiać pod okiem specjalistów w tej dziedzinie. Na przykład Akademia Sztuk Pięknych w Łodzi prowadzi podyplomowe studia, na których pasjonaci i poszukiwacze smaku, miłośnicy designu i kulinariów, menadżerowie restauracji, kucharze, dziennikarze i inne osoby, które pragną mieć wpływ na rozwój polskich kulinariów, uczą się twórczych sposobów kreowania i wykorzystania jedzenia. W szerokim kontekście branżowym poznają proces projektowy, szkolą u siebie zdolność kreatywnego myślenia i konsekwencję, której wymaga świadomy, metodyczny rozwój danego projektu ${ }^{51}$.

Konkretne umiejętności kucharskie można zgłębiać, wstępując do niezliczonych szkół gotowania, biorąc udział w tematycznych kursach, warsztatach i oglądając niezmiernie ostatnio popularne programy poświęcone gotowaniu i podawaniu jedzenia ${ }^{52}$.

\section{ZAKOŃCZENIE}

Podsumowując dotychczas zebrane informacje i rozważania, warto określić, jakie cechy klasyfikują kulinaria jako dziedzinę sztuki. Jeśli za Andrzejem Chłopeckim przyjąć, że: „owocem twórczości [...] nie jest coś zwykłego; jakiś jeden $\mathrm{z}$ wielu takich samych, mniej lub bardziej banalnych przedmiotów, zaś twórca to ten, kto wytwarza coś niepowtarzalnego, niezwyczajnego [...],

50 Projektowanie jedzenia, Kuchnia+, http://www.kuchniaplus.pl/kuchnioteka/ artykuly/projektowanie- jedzenia_242.html\#ixzz40q7h0yJy [dostęp: 24.03.16].

${ }^{51}$ Food Design (Projektowanie Kulinariów), Akademia Sztuk Pięknych im. Władysława Strzemińskiego w Łodzi, http://podyplomowe.asp.lodz.pl/ studia-podyplomowe/59-projektowanie-kulinariow [dostęp: 24.03.16].

${ }^{52}$ Kursy Kulinaria, https://www.kursykulinaria.pl/warszawa,37.html [dostęp: 24.03.16]. 
jego działalność nie sprowadza się jedynie do wynajdowania nowości [...], lecz [istnieje] wtedy, gdy tworząc cokolwiek [...], włączy weń elementy zupełnie praktycznie "nieużyteczne«, "niepotrzebne» - dekoracyjne, mające na celu »czystą" estetykę" ${ }^{33}$, to może się okazać, że kulinaria jedynie ocierają się - a nawet nie zawsze - o twórczość, a ich twórcy tylko czasami bywają artystami. Przykład podany przez Chłopeckiego - którego zdaniem „owocem twórczości ogrodnika [...] nie jest zwykła gruszka na pospolitej gruszy; gruszka na wierzbie zaś - o, to już cos'” ${ }^{4}$ - sugeruje, że za twórczy uznać można przede wszystkim akt kreacji podczas wymyślania nowej potrawy, i to tylko wtedy, jeśli jest ona nietuzinkowa, łamiąca konwenanse, jak przysłowiowa gruszka na wierzbie. Autor, jakkolwiek żartobliwie, to jednak bardzo surowo obchodząc się z kryteriami przynależności działań $i$ ich rezultatów do dziedziny sztuki, nie wypowiada się o ewentualnej artystycznej interpretacji wzoru (np. przepisu) już istniejącego.

Większą rolę przyznaje kuchni Arnold Toczyński, pisząc, że jest ona „jednym z fundamentów kultury”, ponieważ „przetwarzanie żywności wpłynęło znacząco na zdolności rozwojowe i adaptacyjne naszego gatunku, jak też zdeterminowało proces budowy kultury i cywilizacji”. Przyznając, że gotowanie i jedzenie jest często formą twórczości, autor ten analizuje społeczne i gospodarcze reperkusje kulinariów: „Bez swobody wyboru tego, co i jak jemy, trudno byłoby sobie wyobrazić kategorię taką, jak wolność, czy system polityczny, jakim jest demokracja. Nie mówiąc już o dzisiejszej globalnej gospodarce, która $\mathrm{w}$ dużej mierze może rozwijać się i rosnąć dzięki temu, że człowiek rozwija się i rośnie jako konsument zasobów i dóbr spożywczych" ${ }^{\text {. }}$.

Bez wątpienia ewolucji sposobów przyrządzania i podawania jedzenia nie sposób odmówić roli kulturotwórczej i wpływu na gospodarkę, o czym słusznie pisze Toczyński. Nie można również zaprzeczyć, że w kuchni częstokroć dochodzi i do konstruowania nowych form (choćby w kuchni molekularnej), i do odtwarzania form wcześniejszych (tu: przepisów stworzonych przez kreatywnych kucharzy). W tym ostatnim wypadku słuszna wydaje się

53 A. Chłopecki, Artystą się bywa, [w:] ...i Ty bądź artysta, Warszawa 1982, s. 9-10. 54 Ibidem.

55 A. Toczyński, „Uczta Babette” - redefinicja dyskursu kulinarnego, www.wydzfilhist.uni.lodz.pl/pub/16.pdf [dostęp: 31.03.16]. 
opinia Adama Chrząstowskiego, który przyrównuje interpretację przepisu do wykonania koncertu Chopinowskiego i uważa ją za twórczą. Analizując wypowiedzi zaangażowanych w swoją pracę mistrzów kuchni i restauratorów, można też przyjąć, że ich działania bywają wyrażaniem przeżyć, a efekty tychże działań mają z założenia zachwycać (wyglądem i smakiem), niekiedy wzruszać (kiedy kojarzą się z czymś ważnym i bliskim).

Na pewno można uznać, że kulinaria są oparte na pewnej formie kreatywności, czyli spełniają pierwszy z wymienianych przez Victora Ginsburgha i Davida Throsby’ego warunków przynależności do działań kulturowych. O tym, że spełniają i drugie kryterium - odwoływania się do symboliki - przekonują rozwiązania znane z kuchni fusion (gdzie oprócz smaków mieszają się szerzej pojęte tradycje $\mathrm{z}$ różnych stron świata) czy praca René Redzepiego, szefa restauracji, której wystrój i dania wyrażają ideę Skandynawii. W świetle cytowanej wcześniej Ustawy o prawie autorskim udowodniono ponadto, że i trzeci warunek Ginsburgha i Throsby'ego, zgodnie z którym dzieła sztuki powinny wiązać się z pewną formą własności, ma swoje zastosowanie w odniesieniu do kulinariów.

Jeśli do cech definiujących daną dziedzinę jako artystyczną dołączyć kwestię recepcji dzieł, jej nieodzowność i niezbywalne miejsce w całym procesie twórczym, to również można wywnioskować, że kulinaria są rodzajem performansu nastawionym na aktywne uczestnictwo odbiorcy. Malarstwo ma swoją widownię, a muzyka swoich słuchaczy - tak też sztuka kulinarna ma swoich smakoszy, których zresztą urzeka nie tylko smakiem. Działając również na pozostałe zmysły: wzroku - poprzez niesamowity niekiedy wygląd dań i wystrój restauracji; słuchu - za pomocą harmonizujących z całą koncepcją dźwięków płynących z odtwarzacza; wreszcie węchu - poprzez porywający zapach, i dotyku - dzięki intrygującej strukturze potraw - jawi się jako dziedzina jedyna w swoim rodzaju, sztuka totalna.

\section{Bibligrafia}

Andrzej Chłopecki, Artystą się bywa, [w:] ...i Ty bądź artysta, Krajowa Agencja Wydawnicza, Warszawa 1982.

Grzegorz Dziamski, Sztuka i estetyzacja świata, [w:] Co z tym odbiorca? Wokót zagadnienia odbioru sztuki, red. M. Kędziora, W. Nowak, J. Ryczek, Wydawnictwo Naukowe Wydziału Nauk Społecznych UAM, Poznań 2012. 
Bogna Kietlińska, Znaczenie kompetencji kulturowych i artystycznych $w$ odbiorze sztuki, [w:] Co z tym odbiorca? Wokół zagadnienia odbioru sztuki, red. M. Kędziora, W. Nowak, J. Ryczek, Wydawnictwo Naukowe Wydziału Nauk Społecznych UAM, Poznań 2012.

Monika Kucia, Kuchnia PL, Ministerstwo Spraw Zagranicznych, Warszawa 2011. Dorota Ilczuk, Ekonomika kultury jako dziedzina badawcza, PWN, Warszawa 2015. Raport 2014: Rynek Gastronomiczny w Polsce, „Nowości Gastronomiczne”, Warszawa 2014.

Mark Reinfeld, Bo Rinaldi, Vegan World Fusion Cuisine, Thousand Petals Publishing, Kapaa 2004.

Kevin W. Sweeney, Hunger is The Best Sauce. The Aesthetics of Food, [w:] The Philosophy of Food, red. D.M. Kaplan, University of California Press, Los Angeles 2012.

Amy B. Trubeck, Haute Cuisine How the French Invented the Culinary Profession, University of Pennsylvania Press, Philadelphia 2000.

\section{Źródła internetowe}

A lot of people came and were very disappointed with the Damien Hirst art collection, „The Guardian” z dnia 17.07.1999 r., www.theguardian.com/theguardian/1999/jun/17/features1l.g23.

Analiza potrzeb i rozwoju przemysłów kreatywnych, Raport Ecorys na zlecenie Ministerstwa Gospodarki, Warszawa 2009, http://nck.pl/media/attachments/302357/analiza_potrzeb_i_rozwoju_przemysw_kreatywnych.pdf. ElżbietaBogusławska-Przybysz, ArtFood - sztuka na talerzu, SPAeden, www.spaeden.pl/kuchnia/kuchenne-trendy/2287-artfood-sztuka-na-talerzu.

Adam Chrząstowski, Gotowanie vs sztuka, Blog Adama Chrząstowskiego, http:// adamchrzastowski.natemat.pl/88505, gotowanie-vs-sztuka.

Agata Etmantowicz, Co to takiego przemysly kreatywne i przemysly kultury, „Kreatywni Samozatrudnieni”, http://www.kreatywnisamozatrudnieni.pl.

Food Design (Projektowanie Kulinariów), Akademia Sztuk Pięknych im. Władysława Strzemińskiego w Łodzi, http://podyplomowe.asp.lodz.pl.

Jamie Oliver - Filozofia jedzenia, „Przy dużym stole”, http://przyduzymstole.blogspot.com.

Magdalena Kasprzyk-Chevriaux, Wojciech Modest Amaro, http://culture.pl/pl/ tworca/wojciech-modest-amaro. 
Andrzej Klasik, Sektor kultury i przemysty kreatywne w rozwoju regionu na przykładzie Aglomeracji Górnoślaskiej, Portal Innowacji, http://pi.gov.pl/PARPFiles/ file/INNOWACYJNA_FIRMA/R_artykul_prz_kreatywne_agl_gornoslaska.pdf.

Kuchnia chińska. Jedzenie w zgodzie z filozofia, „Prześlij przepis!”, www.przyslijprzepis.pl/artykul/kuchnia-chinska-jedzenie-w-zgodzie-z-filozofia.

Edyta Kusińska, „Moje smaki” Michel Moran, „Madame Edith”, https://madameedith.com/lifestyle/moje-smaki-michel-moran/.

Kinga Lewandowska, Agnieszka Kręglicka: Codzienne gotowanie rzadko bywa sztuka, „Polska Times” z dnia 31.03.2013 r., www.polskatimes.pl/artykul/795613,agnieszka-kreglicka-codzienne-gotowanie-rzadko-bywa-sztuka,id,t.html.

Gail Mercedes, The Philosophy of Chinese Cooking, „SelfGrowth”, http://www. selfgrowth.com/articles/the_philosophy_of_chinese_cooking.

Maciej Misiura, Dariusz Aksamit, Kuchnia molekularna, http://kuchniamolekularna.pl.

Projektowanie jedzenia, http://www.kuchniaplus.pl/kuchnioteka/artykuly/projektowanie-jedzenia_242.html.

Colt Taylor, Cooking Is An Art: What Makes A Chef An Artist, Craftsman And Visionary, „Elite Daily”, http://elitedaily.com/life/culture/ chef-artist-craftsman-visionary/632690/.

Arnold Toczyński, „Uczta Babette” - redefinicja dyskursu kulinarnego, www.wydzfilhist.uni.lodz.pl/pub/16.pdf

Turystyka kulinarna - czyli przepis na sukces szlaków, imprez i produktów kulinarnych, www.kuchniaplus.pl/kuchnioteka/artykuly/turystka-kulinarna-czyli-przepis-na-sukces-szlakow-imprez-i-produktow-kulinarnych_336.html. Wspólna strategia rozwoju kreatywności przemysłowej na pograniczu polsko-litewskim, Olita, Suwałki 2011, www.ugpunsk.pl/userfiles/file/Strategia\%20 Rozwoju\%20PK\%20na\%20Pograniczu\%20PL.pdf.

\section{Culinary Arts as a New Creative Industry}

The authoress puts up a thesis that certain ways of preparing, serving and consuming food have the qualities of classifying them as belonging to the sphere of art. Going further in her analysis places culinary amongst the creative industries, in the area where art meets economics. The authoress reaches 
out to various sources and presents a wide variety of theories, opinions as well as facts that support her thesis.

Keywords: culinary, creative industry, cultural management, famous chefs 


\title{
TELEWIZYJNE KANAŁY TEMATYCZNE W POLSCE W KONTEKŚCIE PRZEMIAN TECHNOLOGICZNYCH I DOMINACJI NOWYCH MEDIÓW ${ }^{1}$
}

\author{
ŁUKASZ BAŃBURSKI
}

Wydział Nauk Humanistycznych UKSW

Faculty of Humanities, Cardinal Stefan Wyszyński University in Warsaw

lukaszbanburski@gmail.com

Co to jest kanał tematyczny? Czym różni się od programu tematycznego? Barbara Turowska, Dyrektor Departamentu Monitoringu Krajowej Rady Radiofonii i Telewizji, zauważa, że poprawnymi określeniami są „program telewizyjny” i „program tematyczny”" Faktycznie, w Ustawie o radiofonii i telewizji z dnia 29 grudnia 1992 roku $^{3}$ „program” definiowany jest jako „uporządkowany zestaw audycji, przekazów handlowych lub innych przekazów, rozpowszechniany w całości, w sposób umożliwiający jednoczesny odbiór przez odbiorców w ustalonym przez nadawcę układzie"4; nazewnictwo to nie zostało jednak przyjęte przez środowisko - brakuje na tym polu spójności nawet wśród pracowników wyżej wspomnianej instytucji ${ }^{5}$. Również słowniki branżowe nie są w stanie ostatecznie rozwiązać tego

${ }^{1}$ Artykuł stanowi skróconą i przeredagowaną wersję pracy licencjackiej napisanej pod kierunkiem dr Anny Wróblewskiej i obronionej na Wydziale Nauk Humanistycznych UKSW w 2017 roku.

2 Rozmowa przeprowadzona 15 maja 2017 roku.

3 Dz. U. 1993, nr 7, poz. 34.

4 Ibidem, rozdz. 1, art. 4, p. 6.

5 Za przykład niech posłuży Strategia Regulacyjna na lata 2014-2016, gdzie określenia „kanał” i „program” występują zamiennie. http://www.krrit.gov.pl/ Data/Files/_public/Portals/0/konsultacje/strategia-regulacyjna-krajowej-rady-radiofonii-i-telewizji-na-lata-2014-2016.pdf [dostęp: 3.11.15]. 
problemu: w nowym Słowniku terminologii medialnej ${ }^{6}$ możemy przeczytać, $\mathrm{z}$ jednej strony, że kanał to „standardowo przyjęty zakres częstotliwości, w którym przesyłany jest jeden program telewizyjny", z drugiej zaś, że program to synonim audycji radiowej i telewizyjnej oraz „wyodrębniona jednostka programu radiowego i telewizyjnego", a także „część składowa ramówki”" Zdaje się, że słowo „program” przyjęło się do określania zestawów audycji od tych samych nadawców radiowych (każdy słuchacz radiowej „Trójki” zna slogan „Trójka - Program Trzeci Polskiego Radia”), w kontekście telewizyjnym oznacza już jednak treści nadawane przez dany kanał. Powstaje $\mathrm{w}$ ten sposób schemat, $\mathrm{w}$ którym program nadawany jest przez kanał - na przykład „Wiadomości” nadawane są przez TVP1. Kiedy dodać do tego, że często w publikacjach, szczególnie tych dotyczących oglądalności, stosowany jest kolejny zamiennik - słowo „stacja”, nie trudno zauważyć, że właściwe rozróżnienie może okazać się problematyczne. Na potrzeby tej pracy przyjmę, że obowiązującym określeniem na wydzielone pasmo częstotliwości jest „kanał”, stąd też w tytule niniejszego artykułu znalazły się „kanały tematyczne”, a nie „programy tematyczne”. Również w większości wykorzystanych źródeł figuruje słowo „kanał”, dlatego też właśnie ono wydaje się najodpowiedniejsze i będzie używane w dalszej części wywodu, $\mathrm{z}$ wyłączeniem cytatów.

\section{SPOSOBY KATEGORYZACJI KANAŁÓW TEMATYCZNYCH}

Według raportu miesięcznika „Telekabel” ${ }^{\text {w }}$ kwietniu 2017 roku istniało ponad dwieście czterdzieści polskojęzycznych kanałów telewizyjnych. Część z podziałów czy też prób usystematyzowania rynku, jakie zostaną tu omówione, pochodzić będzie z badań firmy Nielsen. Jest to czołowa na polskim rynku firma o międzynarodowej marce, świadcząca usługi w zakresie pomiarów oglądalności. Nielsen powoli budował swoją pozy-

${ }^{6}$ R. Bartoszcze, Stownik terminologii medialnej, red. W. Pisarek, Kraków 2006.

7 Ibidem, s. 163.

8 Zob. M. Kurdupski, Polsat liderem w sierpniu, TVP1 wyprzedziła TVN. Hitem „M jak miłość", www.wirtualnemedia.pl/artykul/polsat-liderem-w-sierpniu-tvp1-wyprzedzila-tvn-hitem-m-jak-milosc [dostęp: 9.09.15].

9 Tematyczne vs. uniwersalne, „Telekabel” 2017, nr 4, s. 7. 
cję, podpisując umowy z kolejnymi stacjami oraz domami reklamowymi i samymi reklamodawcami, by w roku 2011 wygrać przetarg na współpracę z TVP ${ }^{10}$. Obecnie zbiera dane dla wszystkich najważniejszych podmiotów na naszym rodzimym rynku.

Poniżej podejmuję się zadania podzielenia kanałów tematycznych wedle najważniejszych kryteriów.

\subsection{RODZAJ KONCESJI}

Pierwszym kryterium, wedle którego należy przebadać kanały tematyczne, jest w mojej opinii ich koncesja. Organem odpowiedzialnym w Polsce za wydawanie koncesji jest KRRiT, jednak - jak zauważył dyrektor Departamentu Regulacji tej instytucji, Krzysztof Zalewski - by obecnie publikować sygnał możliwy do odbioru na terenie naszego kraju, nie ma konieczności posiadania polskiej koncesji ${ }^{11}$, wystarczy jej uzyskanie w innym europejskim kraju. Otwarty rynek niestety komplikuje sprawę kontroli. KRRiT nie tylko nie ma realnego wpływu na treści nadawane w tych kanałach czy choćby długość przerw reklamowych ${ }^{12}$, ale także nie może stworzyć pełnego spisu kanałów dostępnych na terenie Polski. Fakt ten pokazuje, jak skomplikowany jest obecnie system regulacji kanałów tematycznych.

Obecnie $^{13} \mathrm{w}$ naszym kraju koncesję posiada dziewięćdziesiąt sześć kanałów nadawanych satelitarnie, a także dwadzieścia trzy naziemnie, czyli łącznie sto dziewiętnaście kanałów. W Wykazie koncesji telewizyjnych ${ }^{14}$ prowadzonym przez KRRiT wyszczególniono dwa typy „charakteru programu": uniwersalny (czyli program ogólny), a także wyspecjalizowany.

10 TVP wymienia TNS OBOP na Nielsen Audience Measurement, www.wirtualnemedia.pl/artykul/tvp-wymienia-tns-obop-na-nielsen-audience-measurement/ [dostęp: 13.03.17].

${ }_{11}$ Wywiad własny z Krzysztofem Zalewskim przeprowadzony 31 maja 2017 roku.

12 J. Sadurski, Polskie kanały telewizyjne nadajace na zagranicznej licencji, http://mediamoje.pl/polskie-kanaly-telewizyjne-nadajace-na-zagranicznej-licencji/ [dostęp: 16.08.17].

13 Stan na 31 maja 2017 roku.

14 Portal Krajowej Rady Radiofonii i Telewizji, http://www.krrit.gov.pl/dlanadawcow-i-operatorow/koncesje/wykaz-koncesji-i-decyzji/ [dostęp: 2.06.17]. 
Ponadto kanały wyspecjalizowane opatrzone są dodatkową charakterystyką, której poszczególne podtypy podaję poniżej zapisane kursywą. Nie istnieje gotowa i zamknięta lista owych typów do wyboru, dzięki czemu każdy nowy program nie musi wpisywać się w już istniejący schemat, może natomiast zaproponować nową kategorię. Krzysztof Zalewski przyznaje, że to do nadawcy należy decyzja, jaki typ specjalizacji zamierza realizowaćc ${ }^{15}$.

W przywołanym powyżej Wykazie figuruje osiemdziesiąt sześć programów wyspecjalizowanych - jedenaście naziemnych oraz siedemdziesiąt pięć cyfrowych. Najpopularniejszą charakterystyką w badanej grupie są kanały muzyczne. Na ten typ zdecydowało się dwanaście stacji, a na pokrewny muzyczno-rozrywkowy - kolejnych pięć. Drugą najczęściej wybieraną charakterystyką jest kanał sportowy (dwanaście kanałów), do której to liczby dodać również trzeba kanał rekreacyjno-rozrywkowo-sportowy, co łącznie daje trzynaście, czyli kilkanaście procent całej puli. Ośmiu wnioskodawców wybrało typ filmowy, a kolejnych czterech zbliżony do niego w formacie typ dokumentalny. Ze względu na znaczącą reprezentację należy w tym miejscu wymienić jeszcze kanały rozrywkowe oraz informacyjno-publicystyczne (po pięć).

Część typów programów adresowanych jest do konkretnych grup ze względu na wiek lub płeć: sześć z nich do dzieci, jeden do dzieci, młodzieży i ich rodziców, a dwa do kobiet. Do tej grupy należy dołączyć również NEXT MAN 3D, którego charakterystyka głosi, że jest programem biznesowym dla mężczyzn, grupa docelowa jest więc w tym przypadku uzupełniona o profil zainteresowań odbiorców, a także Super Polsat - przeznaczony dla osób niepełnosprawnych.

Zwróćmy uwagę, że grupy odbiorców są bardzo rozległe (po połączeniu reprezentują w zasadzie całe społeczeństwo). Warto zadać sobie pytanie, dlaczego zostały nakreślone tak szeroko. Przyglądając się liście charakterystyk, można odnieść wrażenie, że w przypadku tych kanałów nie zostały w pełni wykorzystanie szanse, jakie daje telewizja tematyczna - moglibyśmy się przecież spodziewać lepszej, bardziej konkretnej specyfikacji, chociażby kanału „adresowanego do dzieci w wieku 4-6 lat”. Winna nie jest tu z całą pewnością niewiedza zgłaszających. Daniel Reszka, wiceprezes VIMN,

15 Wywiad własny z Krzysztofem Zalewskim przeprowadzony 31 maja 2017 roku. 
korporacji posiadającej grupę kanałów dla dzieci skupionych wokół marki Nickelodeon, w wypowiedzi dla miesięcznika „Telekabel” stwierdza, że brak takiej kategoryzacji we wniosku dla KRRiT świadczy zapewne tylko (i aż) o tym, że nadawcy nie starają się zbytnio zawężać swoich możliwości ${ }^{16}$. Ostatecznie po wpisaniu do Wykazu należy trzymać się tego, do czego się zobowiązało, i niezmiennie nadawać co najmniej $70 \%{ }^{17}$ treści w ramach obranej charakterystyki, a na tak wypełnionym rynku nikt nie może być pewien powodzenia swoich planów.

\subsection{SEGMENTY TEMATYCZNE}

Badania oglądalności są obecnie kołem napędowym całej branży. Elżbieta Gorajewska, dyrektor zarządzająca Nielsen Audience Measurement, porównuje je do waluty, dzięki której stacje telewizyjne wyceniają wartość swoich usług $^{18}$. W zestawieniu systemów podziału kanałów tematycznych nie może zatem zabraknąć schematu używanego przez tę firmę.

Nielsen dzieli rynek oglądalności na dziesięć segmentów, w których umieszczone są stacje ze względu na ich główny temat (w przypadku dziewięciu segmentów jest to konkretny, sprecyzowany temat, a oprócz tego istnieje również kategoria „uniwersalny”). W corocznym badaniu udziałów tych segmentów w rynku wprowadzone jest dodatkowo rozróżnienie na wszystkich odbiorców powyżej czwartego roku życia (tak zwana grupa 4+) oraz odbiorców telewizji kablowej. Wynik podany jest w zmiennej SHR+, która oznacza średni udział w oglądalności wśród wszystkich odbiorców w określonym odcinku czasu ${ }^{19}$; innymi słowy, wynik oznacza procent oglądających wybrany segment spośród wszystkich ludzi, którzy w określonym czasie znajdowali się przed odbiornikami.

16 D. Reszka, Dodatek „Raport specjalny - kanały dla dzieci”, „Telekabel” 2016, nr 6, s. 12.

17 Art. 4, ustęp 4a Ustawy z dnia 29 grudnia 1992 roku o radiofonii i telewizji (Dz.U.04.253.2531).

18 E. Gorajewska (w rozmowie z A. Marciniakiem), Marzenia o jednym rankingu, „Telekabel” 2016, nr 5, s. 29.

19 Portal Biura Reklamy TVP, www.brtvp.pl/16615065/slownik-tv [dostęp: 18.09.17]. 
Nie można zapominać, że Nielsen nie bada wyłącznie kanałów posiadających koncesję KRRiT. Jak już wskazałem, tych ostatnich w połowie 2017 roku było około stu trzydziestu, natomiast Nielsen już rok wcześniej uwzględnił w swym badaniu o ponad trzydzieści więcej ${ }^{20}$. Pozycja, jaką kanał zajmie w rankingu tej firmy, przekłada się na wyniki finansowe, w związku z czym nadawcy, nawet ci, którzy nie ubiegali się o polską licencję, sami się zgłaszają do udziału w badaniu ${ }^{21}$.

O ile w KRRiT każdy sam może zaproponować własną charakterystykę, o tyle w rankingu Nielsena nie miałoby to żadnego sensu. Aby ułatwić klarowną prezentację wyników, należało podzielić pełen wachlarz kanałów na maksymalnie ograniczoną liczbę segmentów o czytelnej charakterystyce. Powstało ich dziesięć, są to kolejno: serialowe ${ }^{22}$, informacyjne, dziecięce, sportowe, filmowe, podróżniczo-historyczne, muzyczne, rozrywka - lifestyle, kanały nietematyczne (uniwersalne), a także inne. Przyjrzyjmy się, jak zmieniała się ich oglądalność w grupie 4+ na przestrzeni ostatnich lat.

Tab. 1. Udziały segmentów kanałów tematycznych $w$ rynku oglądalności

\begin{tabular}{|c|c|c|c|}
\hline \multicolumn{4}{|c|}{ Udział procentowy segmentów w oglądalności } \\
\hline Nazwa segmentu & $\begin{array}{c}\text { rok } \\
2007\end{array}$ & $\begin{array}{c}\text { rok } \\
2015\end{array}$ & $\begin{array}{c}\text { rok } \\
2017\end{array}$ \\
\hline serialowe & $1,09 \%$ & $3,86 \%$ & $3,92 \%$ \\
\hline informacyjne & $8,05 \%$ & $8,41 \%$ & $8,76 \%$ \\
\hline dziecięce & $2,91 \%$ & $4,69 \%$ & $4,69 \%$ \\
\hline sportowe & $1,23 \%$ & $2,74 \%$ & $1,94 \%$ \\
\hline filmowe & $0,92 \%$ & $3,22 \%$ & $3,62 \%$ \\
\hline podróżniczo-historyczne & $1,64 \%$ & $4,00 \%$ & $4,32 \%$ \\
\hline muzyczne & $0,95 \%$ & $2,25 \%$ & $2,02 \%$ \\
\hline rozrywka - lifestyle & $1,21 \%$ & $5,67 \%$ & $5,94 \%$ \\
\hline nietematyczne & $80,15 \%$ & $61,41 \%$ & $60,51 \%$ \\
\hline inne & $1,85 \%$ & $3,89 \%$ & $4,27 \%$ \\
\hline
\end{tabular}

Źródło: opracowanie własne na podstawie artykułów: Polska przed telewizorem, „Telekabel” 2016, nr 5, s. 19; Nasycony kanałami, „Telekabel” 2017, nr 4, s. 25.

20 E. Gorajewska, op. cit., s. 29.

${ }^{21}$ Ibidem.

22 W raportach za lata 2007 i 2015 ten segment nosi po prostu nazwę „seriale”. 
Wartości w tabeli pokazują ogromny przeskok pomiędzy rokiem 2007, w którym nadawano jeszcze sygnał analogowy, a rokiem 2015, w którym odbiorca mógł już korzystać z naziemnej telewizji cyfrowej. Co jako pierwsze rzuca się w oczy, to ogromny, prawie dwudziestopunktowy spadek oglądalności kanałów nietematycznych (uniwersalnych). Bardzo interesująco wygląda kwestia rozwoju kanałów tematycznych w latach 2015-2017 - zauważmy, że jedyne dwa segmenty tematyczne, które w tym okresie odnotowały spadek oglądalności, to sportowe i muzyczne, a dziecięce utrzymały się na tym samym poziomie. Taki stan rzeczy nie powinien być zaskoczeniem, szczególnie w przypadku kanałów muzycznych. W badaniu przeprowadzonym dla bloga „ScreenLovers”, obejmującym specjalistów - szefów dystrybucji i managerów stacji telewizyjnych, aż jedna czwarta ankietowanych uznała, że kanałów muzycznych jest zbyt wiele ${ }^{23}$. Pozostałych pięć segmentów odnotowało natomiast wzrost oglądalności.

\section{3 ŹRÓDŁO SYGNAŁU TELEWIZYJNEGO}

Choć na co dzień zwykły odbiorca nie zaprząta sobie głowy tym, jak źródło sygnału wpływa na jego obyczaje związane z telewizją, jest to nadal jeden z najważniejszych czynników, który warunkuje kontakt ze „szklanym ekranem”.

Najszerszym, a zarazem najbardziej tradycyjnym podziałem ze względu na źródło sygnału telewizyjnego jest podział na satelitę, sieć kablową oraz telewizję naziemną. Dla zobrazowania procentowych wartości udziału poszczególnych źródeł w Polsce Nielsen AC dzieli rynek na typy gospodarstw, mianowicie na gospodarstwa satelitarne, kablowe oraz eterowe. Oczywiście, coraz częściej mamy do czynienia z sytuacją, w której odbiorca korzysta z wielu źródeł sygnału. Ten stosunkowo prosty schemat pozwala na ukazanie, jak bardzo badania rynku telewizyjnego są obecnie zaawansowane i ustandaryzowane ${ }^{24}$.

W dobie naziemnej telewizji cyfrowej, której sygnał dociera już niemal do całego terytorium kraju, każdy, kto zdecyduje się na zakup telewizji

${ }^{23}$ W. Kowalczyk, Rynek stacji tematycznych jest przesycony, popyt na FTA oraz premium: badanie płatnej TV by ScreenLovers, cz. II, http://screenlovers.pl/ rynek-stacji-tematycznych-jest-przesycony-popyt-na-fta-oraz-premium-badanie -platnej-tv-by-screenlovers-cz-ii/ [dostęp: 6.06.17].

${ }^{24}$ E. Gorajewska, op. cit., s. 29. 
satelitarnej bądź popularnej „kablówki”, staje się odbiorcą kilku źródeł nadawania. Wiele osób otrzymało pakiet telewizyjny przy zakupie Internetu, coraz popularniejsze jest też łączenie kilku rachunków, w tym telewizyjnego, w ramach jednej usługi ${ }^{25}$.

Tab. 2. Typy gospodarstw telewizyjnych $w$ latach 2012-2016

\begin{tabular}{|l|c|c|c|c|c|}
\hline \multirow{2}{*}{$\begin{array}{c}\text { Typ } \\
\text { gospodarstwa }\end{array}$} & \multicolumn{5}{|c|}{ Procentowy udział w rynku } \\
\cline { 2 - 6 } & 2012 & 2013 & 2014 & 2015 & 2016 \\
\hline satelitarne & 37,9 & 36,7 & 35,3 & 36,1 & 35,6 \\
\hline kablowe & 32,6 & 33,0 & 31,0 & 30,1 & 29,6 \\
\hline eterowe & 29,5 & 30,3 & 33,8 & 33,8 & 34,8 \\
\hline
\end{tabular}

Źródło: Nasycony kanałami, „Telekabel” 2017, nr 4, s. 24.

Według badań AC Nielsen w roku 2016 w Polsce 34,8\% spośród wszystkich gospodarstw odbierających sygnał telewizyjnych to gospodarstwa eterowe. Ich liczba wzrasta nieustannie od roku 2012, jednak nadal nie doścignęła liczby gospodarstw satelitarnych, które stanowią 35,6\%. Odbiór satelitarny niezmiennie pozostaje najczęstszym w Polsce, choć jego przewaga nigdy nie była tak mała, jak obecnie. Kwestią otwartą pozostaje, czy w najbliższym czasie nie dojdzie do zmiany lidera. Co prawda duża część ekspertów w prognozach na rok 2017 przewiduje zwiększenie udziału gospodarstw eterowych, to jednak są też i tacy, według których boom związany z nowymi multipleksami już jest za nami i sytuacja na rynku wnet się ustabilizuje ${ }^{26}$. W badaniu najsłabiej wypada odsetek gospodarstw kablowych - dostarczyciele popularnej „kablówki” od czasu uruchomienia w naszym kraju sieci naziemnej telewizji cyfrowej nieustannie tracą względem konkurencji.

${ }^{25}$ Przykładem może być oferta SmartDom, w ramach której można połączyć takie usługi, jak telewizja, telefon, Internet, prąd, ubezpieczenia czy monitoring, by otrzymać dodatkowe rabaty.

26 W. Kowalczyk, Trudny rok TV tematycznych, wzrost UPC i Cyfrowego Polsatu: przyszłość płatnej TV w badaniu ScreenLovers, cz. I, http://screenlovers.pl/trudny -rok-tv-tematycznych-wzrost-upc-i-cyfrowego-polsatu-przyszlosc-platnej-tv-w-badaniu-screenlovers-cz-i/ [dostęp: 11.06.17]. 
Zastanawiające jest, że mimo tak dużych zmian na rynku w ciągu ostatnich kilku lat, łącznie $\mathrm{z}$ rewolucyjnym przejściem na nadawanie cyfrowe, stosowany w badaniach podział wedle typów źródła sygnału, a także procentowe proporcje między konkretnymi rodzajami gospodarstw pozostają utrzymane. Tak jak w roku 2012, tak i dziś każdy ze sposobów odbioru programów ma udział w rynku oscylujący w okolicy jednej trzeciej.

\subsection{GRUPY MEDIALNE}

Choć $\mathrm{z}$ roku na rok następuje rozdrobnienie rynku telewizyjnego, a przedstawiciele stacji już istniejących często muszą przełknąć gorycz płynącą z widoku zmniejszających się słupków oglądalności, to jednak wcale nie oznacza, że posiadanie stacji przestało być opłacalne. Już dawno zdano sobie sprawę, że straty jednego programu można wynagrodzić sobie zyskami z kolejnych. Schemat wygląda następująco: istnieje kanał główny, najczęściej uniwersalny, o długoletniej tradycji, a wokół niego tworzone są programy satelickie, wyspecjalizowane, które pomagają w zbieraniu oglądalności również poprzez łatwiejsze targetowanie. To zjawisko występuje nie tylko w sieciach satelitarnych czy kablowych, ale również w paśmie otwartym, na ogólnodostępnych multipleksach. Jak przyznaje Krzysztof Zalewski:

Taka była polityka Krajowej Rady [Radiofonii i Telewizji - przyp. Ł.B.], by nie uzupełniać oferty kanałami uniwersalnymi, a wyspecjalizowanymi. Te programy tak się dopasowuje, że w jednym są premiery, w drugim powtórki, oczywiście ze względu na koszty. Kanały dzielą się licencjami na wyświetlanie produkcji itp. ${ }^{27}$

W dzisiejszych czasach wyprodukowanie treści telewizyjnych stało się bardzo tanie, stąd tak powszechny proceder tworzenia wciąż nowych programów. Jak opisuje to zjawisko Grzegorz Miecugow:

Robienie programów telewizyjnych jest coraz tańsze, zwłaszcza jeżeli kanały bazują na istniejących zespołach. Taka telewizja jak TVN utrzymuje redakcję

27 Wywiad własny z Krzysztofem Zalewskim przeprowadzony 31 maja 2017 roku. 
pogody, więc wystarczy ją tylko trochę rozbudować i można produkować osobny program - TVN Meteo (dzisiaj Meteo Active, bo to jest bardziej na (zasie) $)^{28}$ :

Wśród kanałów tematycznych posiadających koncesję KRRiT zdecydowana większość należy do ośmiu podmiotów, z których każdy posiada w swojej ofercie przynajmniej trzy kanały. Są to: Telewizja Polsat, ASTRO, ITI Neovision, Kino Polska, Michał Winnicki, Eska TV, Telewizja Polska, a także TVN. Dodajmy, że spośród tych podmiotów zaledwie trzy spełniają wymogi uniwersalnej grupy medialnej, oparte na wskazanym powyżej modelu: kanał uniwersalny plus kanały tematyczne. Należą do nich: Polsat, TVN oraz Telewizja Polska. W roku 2016 kontrolowały one rynek, będąc w posiadaniu udziałów na poziomie 69,34\% ${ }^{29}$, a w lipcu 2017 do ich oferty wchodziło szesnaście spośród dwudziestu pięciu najpopularniejszych kanałów tematycznych ${ }^{30}$, z czego dziewięć znajdowało się w pierwszej dziesiątce rankingu. Wiele wskazuje na to, że pomimo zmian te trzy podmioty nadal będą dominować na rynku w następnych latach, tak jak robiły to do tej pory.

\subsection{SPOSOBY FINANSOWANIA}

Po roku 1989 telewizja w Polsce została przestawiona na tor zmierzający ku wolnemu rynkowi, co oznaczało, że każdy z nadawców (częściowo nawet nadawca publiczny ${ }^{31}$ ) musiał zadbać o swój dalszy byt poprzez utworzenie technik generowania przychodu.

${ }^{28}$ Wywiad własny z Grzegorzem Miecugowem przeprowadzony 4 września 2015 roku. (Pełną treść wywiadu publikujemy w niniejszym numerze „Załącznika Kulturoznawczego" - przyp. red.).

${ }^{29}$ Zmiany w udziałach oglądalności (SHR\%) kanałów należących do wybranych nadawców/dystrybutorów. Porównanie w latach 2015-2016, „Telebabel” 2017, nr 4, s. 30 .

30 M. Kurdupski, TVN24 z najlepszym wynikiem $w$ historii, rosna Nick Jr i Super Polsat (top 25 tematycznych), www.wirtualnemedia.pl/artykul/ogladalnosc-kanalow-tematycznych-lipiec-2017 [dostęp: 2.09.17].

31 Art. 31, ustęp 1 Ustawy z dnia 29 grudnia 1992 roku (Dz.U.04.253.2531) dzieli przypływy nadawcy publicznego na cztery grupy: $\mathrm{z}$ abonamentu, $\mathrm{z}$ obrotu prawami do audycji, z reklam i audycji sponsorowanych, a także z innych źródeł. 
Krzysztof Zalewski zauważa, że tradycyjny model telewizji opiera się na dwóch głównych sposobach finansowania: funduszach $\mathrm{z}$ reklam lub $\mathrm{z}$ opłat od operatorów czy odbiorcó $\mathrm{w}^{32}$. W pierwszym $\mathrm{z}$ nich stacja zarabia, sprzedając swój czas antenowy na potrzeby reklamodawców, w drugim udostępniając przygotowywane przez siebie treści. Jeszcze do niedawna oznaczało to po prostu udostępnienie swojego sygnału któremuś z operatorów sieci kablowych czy satelitarnych, teraz jednak dostępne jest całe spektrum możliwości.

Tym, co zmieniło obecną sytuację, w dużej mierze jest połączenie świata telewizji z Internetem. Dotyczy to przede wszystkim zmiany postrzegania tak zwanego VOD (Video On Demand; wideo na życzenie) i innych tego typu przedsięwzięć przez szeroko rozumianą branżę telewizyjną.

O strategiach stacji telewizyjnych w latach 80 . Derek Compare pisał, iż: "Głównym celem telewizji jest sprzedaż reklamodawcom potencjalnej widowni, a nie sprzedaż konsumentom różnego typu produktów"33. W dobie kaset wideo telewizja nie była zainteresowana wydawaniem swoich największych przebojów, by widzowie mogli je oglądać w dogodnym dla nich czasie. Widz miał, w ich założeniu, czekać na treści, które chciał zobaczyć, przy okazji oglądając również bloki reklamowe, dzięki czemu stacje mogły generować zyski. W wyniku zmiany układu, w procesie przygotowywania i sprzedawania treści telewizyjnych zniknęły jednak stare podziały na producentów i grupy producenckie z jednej oraz sieci dystrybutorów z drugiej strony $^{34}$. Obecnie często są to dwa odrębne działy jednej dużej firmy, która dba o kompleksowe wykorzystanie potencjału produkcji na każdym etapie sprzedaży. Jeśli więc ktoś chciałby obejrzeć kolejny (lub poprzedni) odcinek produkowanego przez daną stację serialu czy też zapoznać się z innymi produkowanymi przez nią treściami, lepiej, by miał do dyspozycji legalne, komfortowe dla niego źródło, a dzięki temu stacja i tak zarobi. Obecnie w USA kilka największych stacji telewizyjnych to gigantyczne konglomeraty,

32 Wywiad własny z Krzysztofem Zalewskim przeprowadzony 31 maja 2017 roku.

33 D. Compare, Publikujac przepływ. Zestawy DVD a zmiana koncepcji telewizji, [w:] Zmierzch telewizji? Przemiany medium, red. T. Bielak, M. Filiciak, G. Ptaszek, Warszawa 2011, s.286.

34 Zob. podrozdział $3.3 \mathrm{w}$ niniejszym tekście. 
skupiające w ramach jednej korporacji firmy zajmujące się filmem, produkcją formatów telewizyjnych, sieciami kablowymi, sprzedażą muzyki, książek, czasopism, nie wspominając o wielu różnych sposobach dystrybucji treści online i na platformach sieciowych. Na polskim rynku również można zaobserwować podobne tendencje. Carlos Ortega, wiceprezes wykonawczy FOX International Channels, twierdzi, że rozwój będzie opierał się na integracji usług, napędzanej przez marki telewizyjne ${ }^{35}$. Dodajmy, że wszystkie trzy spośród wymienionych powyżej największych polskich grup medialnych posiadają swoje serwisy VOD powiązane z platformami cyfrowymi, dzięki czemu mogą one rozbudowywać drogi dotarcia do potencjalnego klienta, przerywając reklamami materiały udostępnione online czy pobierając za możliwość ich oglądania jednorazowe opłaty. Trafnie podsumowuje współczesny biznes telewizyjny Alicja Jaskiernia, która pisze, iż „strumień największych zysków płynie do przedsiębiorstw zajmujących się dostarczaniem treści przekazów medialnych, a nie ich wytwarzaniem"36. Tym samym jasne jest, że obecnie nie można już mówić o dwóch naczelnych sposobach finansowania telewizji. Nowe możliwości idą w parze z każdym kolejnym sposobem odbierania treści telewizyjnych.

\section{OGLĄDALNOŚĆ}

Wskaźnik oglądalności pojedynczych kanałów rozpala wyobraźnię osób odpowiedzialnych za tworzenie treści telewizyjnych, bowiem najłatwiej wywnioskować z niego, czy to, co robią, spotyka się z uznaniem widzów.

$\mathrm{O}$ tym, jak długą drogę przeszły polskie kanały tematyczne w ciągu ostatnich kilku lat, niech świadczy fakt, że zaledwie trzy spośród piętnastu najbardziej popularnych w roku 2007 znalazły się w podobnym zestawieniu za rok 2016. Są to: TVN24, Polsat2 oraz TVN Style.

W poniższej tabeli zaprezentowano po piętnaście najpopularniejszych kanałów tematycznych w roku 2007 i 2016; ciemnym kolorem zaznaczono dodatkowo te, które osiągnęły pułap połowy punktu procentowego oglądalności, natomiast gwiazdki umieszczono przy tych, które dostępne są na multipleksach cyfrowej telewizji naziemnej.

35 C. Ortega, Bogatsza oferta, stagnacja opłat, „Telekabel” 2016, nr 5, s. 29.

36 A. Jaskiernia, Od telewizji masowej do Netflixa. Telewizja w Stanach Zjednoczonych w epoce cyfrowej, Warszawa 2016, s. 73. 
Tab. 3. Ranking 15 najczęściej oglądanych kanałów tematycznych w latach 2007 oraz 2016 wraz z udziałem $w$ rynku

\begin{tabular}{|c|c|c|c|c|}
\hline $\mathrm{Nr}$ & \multicolumn{2}{|l|}{2007} & \multicolumn{2}{|c|}{2016} \\
\hline 1 & TVN24 & $2,98 \%$ & TVN24 & $3,81 \%$ \\
\hline 2 & Jetix & $0,72 \%$ & TVP INFO & $3,26 \%$ \\
\hline 3 & Cartoon Network & $0,63 \%$ & TTV $^{*}$ & $1,60 \%$ \\
\hline 4 & Polsat 2 & $0,61 \%$ & Polsat2 & $1,52 \%$ \\
\hline 5 & MiniMini & $0,61 \%$ & TVP Seriale & $1,48 \%$ \\
\hline 6 & VIVA Polska & $0,53 \%$ & Polsat News & $1,11 \%$ \\
\hline 7 & Eurosport & $0,50 \%$ & TVP Rozrywka* & $1,09 \%$ \\
\hline 8 & Polsat Sport & $0,47 \%$ & Stopklatka TV* & $1,00 \%$ \\
\hline 9 & Discovery Channel & $0,44 \%$ & TVP ABC* & $0,92 \%$ \\
\hline 10 & $\mathrm{AXN}$ & $0,41 \%$ & Polo TV* & $0,83 \%$ \\
\hline 11 & TVN Style & $0,36 \%$ & FOCUS TV* & $0,81 \%$ \\
\hline 12 & TVN Turbo & $0,33 \%$ & Nickelodeon & $0,76 \%$ \\
\hline 13 & MTV Polska & $0,26 \%$ & ATM Rozrywka* & $0,71 \%$ \\
\hline 14 & Animal Planet & $0,23 \%$ & TVN Style & $0,70 \%$ \\
\hline 15 & National Geographic & $0,23 \%$ & TVP Historia* & $0,60 \%$ \\
\hline
\end{tabular}

Źródło: opracowanie własne na podstawie danych Nielsen AC zawartych w: Raport - kanały tematyczne, „Telekabel” 2016, nr 5, s. 20; Raport - kanały tematyczne, „Telekabel” 2017, nr 4, s. 26;.

Jakie wnioski możemy wysnuć $\mathrm{z}$ analizy tabeli? Pierwszym z nich będzie niewątpliwie dominacja TVN24, która to stacja potrafiła utrzymać się u szczytu przez szereg lat. Jest ona pod tym względem jednym z nielicznych wyjątków. Z całą pewnością można docenić również to, jak radzą sobie poszczególne kanały tematyczne na rynku oglądalności. Jeszcze w roku 2007 zaledwie siedem największych miało udziały w rynku powyżej 0,5\%, w roku 2016 było to już dwadzieścia stacji (w tym wszystkie ujęte w tabeli). Udowadnia to tezę, że mimo postępującego rozdrobnienia rynku dobrej jakości program może przebić się do masowego widza i zyskać jego uznanie. Tabela pokazuje również kolejny ważny trend: dużą oglądalność kanałów dostępnych dla każdego w ramach telewizji naziemnej. W roku 2016 aż osiem z topowych piętnastu było obecnych na darmowych multipleksach. Jak już wskazałem, w dalszym ciągu ponad jedna trzecia gospodarstw domowych ma dostęp tylko do tej formy odbioru sygnału; tabela podkreśla zatem, że tej grupy odbiorców w żadnym wypadku nie wolno bagatelizować. 
Ta krótka lista kanałów stanowi również ciekawy przekrój potrzeb odbiorcy: pierwsze dwa miejsca zajmują kanały należące do głównych udziałowców w rynku - TVN oraz TVP, obydwa są informacyjne, a tę dwójkę goni kolejny, określony w koncesji KRRiT jako informacyjno-publicystyczno-edukacyjny ${ }^{37}$, oprócz tego spory odsetek oglądalności osiągnęły kanały filmowe, dla dzieci i rozrywkowe. Czy to właśnie tego oczekują od współczesnej telewizji odbiorcy? Ważnych informacji podanych z dużą ilością rozrywki? Bardzo możliwe.

\section{ROZWÓJ NOWYCH TECHNOLOGII ODBIORU TREŚCI AUDIOWIZUALNYCH}

Zmiany w telewizji są nieuniknione, jeśli nie chce ona zostać jedynie smutnym reliktem przeszłości. Czy telewizja w swojej klasycznej formie, taka, jaką Polacy znali z lat sześćdziesiątych, byłaby dziś konkurencyjnym medium? Oczywiście, że nie. Trafnie opisuje to Grzegorz Miecugow:

Nie wrócą czasy z początków [polskiej - przyp. Ł.B.] telewizji, kiedy ludzie włączali nieliczne telewizory, gromadzili się wokół odbiornika i z nabożeństwem oglądali program dla siedemdziesięciu pięciu procent $\mathrm{z}$ nich kompletnie niezrozumiały, jak np. Kabaret Starszych Panów. Do dzisiaj telewizja publiczna chwali się, że jest to najlepszy program, jaki udało się kiedykolwiek zrobić. Ale gdyby w 1965 roku przeciętny widz miał do wyboru cokolwiek innego, to wybrałby cokolwiek innego, bo tamta rozrywka była po prostu na poziomie nieosiągalnym dla tych trzech czwartych społeczeństwa ${ }^{38}$.

Obecnie nie wystarczy już nadawać „czegokolwiek innego”, ponieważ istnieje spora liczba stacji nadających najrozmaitsze treści w samym tylko paśmie niekodowanym. Nawet telewizja, jaką znamy sprzed zaledwie kilku lat, w której dominowała „wielka czwórka” - TVP1, TVP2, TVN i Polsat - zdobywając co miesiąc ponad połowę udziałów w rynku, a wcale nierzadko dobijając do $75 \%{ }^{39}$, wygląda na archaiczną. Tej zmiany już nie

37 Koncesja KRRiT nr 465/2011-T.

38 Wywiad własny z Grzegorzem Miecugowem przeprowadzony 4 września 2015 roku.

39 TVN w górę, najwięcej traci TVP2, www.wirtualnemedia.pl/artykul/tvn-wgore-najwiecej-traci-tvp2\# [dostęp: 5.08.17]. 
da się cofnąć. Program nie może być „jakikolwiek”, musi trafiać w gusta konkretnych odbiorców, posiadać sprecyzowaną ofertę, stąd rosnąca popularność kanałów tematycznych. Te ostatnie są próbą, jaką podejmują wydawcy w celu zdobycia i przywiązania do siebie widza - widza bardziej świadomego, który ma określone wymagania i chce, by zostały one zaspokojone. Kanały tematyczne nie są jednak jedynym sposobem na pozyskanie cennych odbiorców. Spróbujmy przyjrzeć się innym formom, wybranym z najbardziej powszechnych.

\subsection{MAGNETOWIDY, ODTWARZACZE DVD, SYSTEMY HOME VIDEO}

Próby zdobycia widowni dla swoich treści były podejmowane na szeroko rozumianym Zachodzie już w połowie lat 90 . wraz z pojawieniem się pierwszych magnetowidów (VCR). Na czym polegał ten, często dziś pomijany ${ }^{40}$, rewolucyjny skok techniczny? Oto w domowym zaciszu, o porze dokładnie przez siebie wybranej, każdy posiadacz magnetowidu mógł obejrzeć dokładnie to, na co miał ochotę. Przed wprowadzeniem magnetowidów była to rzecz niemożliwa do osiągnięcia. Radykalnie zmieniła ona też podejście odbiorcy do telewizji - w jej przypadku widz musiał pilnować godzin emisji; faktem była - by użyć stwierdzenia pochodzącego z tego okresu - „całkowita zależność widza od godzinowego układu programu: spóźnisz się - nie obejrzysz" ${ }^{\prime 1}$.

Od tamtego momentu przez kolejne dwie, trzy dekady każdy nowy wynalazek z kategorii home video stanowił już tylko unowocześnienie, lifting tego samego schematu. Najpierw, na pionierskim etapie rozwoju tego segmentu, w użyciu były niewygodne w swojej obsłudze kasety, które mieściły tylko kilkadziesiąt minut programu i trzeba je było przewijać, a po kilkunastu odtworzeniach znacznie traciły na jakości. Następnie pojawił się ogromny, bo wielkości winylowego longplaya, laserdisc, a po nim zbliżone technologicznie, ale o zdecydowanie mniejszych gabarytach - płyty CD, DVD i w końcu Blu-ray.

40 „Mimo swojej wszechobecności i wyjątkowych właściwości, technologia home video została boleśnie zlekceważona przez środowisko akademickie”. D. Compare, op. cit., s. 283.

41 M. Szulczewski, Magia szklanego ekranu, Warszawa 1972, s. 195. 
Ten sposób odbioru treści, choć mocno powiązany z telewizją, długo był głównie „przedłużeniem przemysłu filmowego" ${ }^{\text {, }}$, wykorzystywał bowiem filmowe zaplecze, a nie telewizyjne studia produkcyjne czy stacje nadawcze. Jest to jeden z przykładów tego, jak silnie telewizja powiązana jest z pozatelewizyjnymi sposobami odbioru treści. Połączone ze sobą zostają dwa światy - obieg kinowy i telewizyjny. Początkowo to właśnie świat kina widział duże zagrożenie $\mathrm{w}$ oferowanym przez telewizję prostym dostępie do treści bez konieczności wyjścia na seans. Wyniki oglądalności i frekwencji mówiły jednak same za siebie i doprowadziły do zmiany tego poglądu: „Ostatecznie, poczynając od końca lat osiemdziesiątych, stały się one [stacje telewizyjne - przyp. Ł.B.] najważniejszą dla niego [przemysłu filmowego - przyp. Ł.B.] technologią, która tworzyła nowe rynki zbytu dla jego produktów i generowała większość dochodów ${ }^{43}$.

Telewizyjne treści nie były popularne na rynku home video aż do momentu, kiedy technologia pozwoliła na wydawanie względnie tanich kolekcji dobrej jakości, takich jak chociażby całe sezony seriali na DVD. Od zakupu ulubionego serialu na płycie, aby móc oglądać go wedle uznania, już tylko krok do wykupienia dostępu na platformę, na której odcinki serialu są przechowywane.

Rozwój rynku DVD sprawił, że widz jeszcze ściślej zaczął wiązać się z ulubionymi treściami, mógł „posiąść je na własność, a nie tylko zobaczyć. Model ten, choć teoretycznie odległy od „tradycyjnego" sposobu funkcjonowania telewizji, zaczął przynosić znaczące zyski już na przełomie tysiącleci i z roku na rok zwiększał swój udział w rynku. W tej sytuacji część wydawców postawiła na drogę pośrednią pomiędzy całkowitym „puszczeniem wolno” treści poza obszar kontroli a uniwersalną „ramówką,, w ramach której każdy typ programu ma swojego reprezentanta na falach stacji. Tą drogą pośrednią stały się kanały tematyczne.

42 D. Compare, op. cit., s. 286.

43 Ibidem. 


\subsection{SMART TV, TELEWIZJA HYBRYDOWA, SERWISY NA ŻYCZENIE}

Choć obecnie dwa najważniejsze media - telewizja i Internet - często są przedstawiane jako antagoniści ${ }^{44}$, faktem jest, że i między nimi dochodzi do wymiany idei. Tradycyjni dostawcy treści już dawno dostrzegli w nowych technologiach powiązanych z globalną siecią możliwość zwiększenia swoich stref wpływów. Wejście na nowy poziom udostępniania treści było dla nich korzystne w dwójnasób: po pierwsze, sami mogli dotrzeć do większej liczby odbiorców (w tym do najbardziej cenionych przez reklamodawców grup wiekowych), po drugie - ograniczali miejsce rozwoju nowych podmiotów, które mogłyby potencjalnie stać się ich konkurencją.

Naturalnym krokiem w procesie rozwoju telewizji ${ }^{45}$ było powstanie serwisów i urządzeń połączonych z telewizorami, które jednak nie nadawały programów jedynie $\mathrm{w}$ paśmie ciągłym, według określonej uprzednio ramówki, a oferowały możliwość ich obejrzenia bez możliwości trwałego zapisu plików na fizycznym nośniku, to jest w ramach streamingu. Było to rozwinięcie idei stacjonarnej wypożyczalni ${ }^{46}$.

Warto zaznaczyć, że serwisy VOD dostępne są dla użytkowników na dwa główne sposoby: po pierwsze, jako strona internetowa, możliwa do otworzenia za pomocą przeglądarki w komputerze stacjonarnym lub tablecie $\mathrm{z}$ dostępem do szerokopasmowego łącza, po drugie - jako kolejna funkcja telewizorów (bezpośrednio bądź za pomocą przystawki). Pierwszy z wymienionych sposobów co prawda pomija urządzenie, jakim jest telewizor, jednak nie oznacza to braku możliwości oglądania programów telewizyjnych, które coraz częściej dostępne są również bezpośrednio w sieci ${ }^{47}$. Sposób drugi za-

${ }^{44}$ M. Lemańska, Pojedynek internetu $z$ telewizja nabiera tempa, www.rp.pl/ Media-i-internet/307169928-Pojedynek-internetu-z-telewizja-nabiera-tempa.html [dostęp: 12.07.17].

${ }^{45}$ Odcięcie się od tradycyjnego modelu telewizji pokazywał słynny slogan wykorzystywany przez amerykańskiego giganta - „It's not TV, it’s HBO”.

${ }^{46}$ Chyba najbardziej znany przypadek tego typu firmy to Netflix, który rozpoczął działalność w Internecie dopiero po dziesięciu latach tradycyjnego wypożyczania DVD.

47 A. Kaźmierska, Cyfrowy Polsat GO - dla kogo i w jakiej cenie?, http://satkurier.pl/news/126473/cyfrowy-polsat-go-dla-kogo-i-w-jakiej-cenie.html [dostęp: 26.07.17]. 
kłada dostęp z telewizora do konkretnych aplikacji, takich jak na przykład

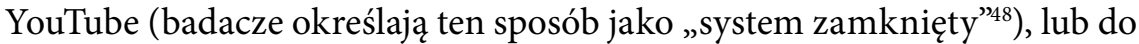
całego bogactwa sieci (mamy wtedy do czynienia z „systemem otwartym”). Ten techniczny podział jest kluczowy do zrozumienia różnicy pomiędzy telewizją hybrydową a Smart TV. Zdaniem EBU (Europejskiej Unii Nadawczej, skupiającej ponad pół setki nadawców publicznych z całego kontynentu) można mówić o telewizji hybrydowej jedynie w przypadku dostępu użytkownika do zasobów całej sieci. Nazwa „Smart TV” zarezerwowana jest dla sprzętu z dostępem do aplikacji telewizyjnych stworzonych konkretnie pod odpowiedni model danego producenta ${ }^{49}$, gdzie za to, co ostatecznie zobaczy użytkownik, odpowiada twórca telewizora ${ }^{50}$.

Początkowo serwisy VOD oferowały treści produkowane przez innych na potrzeby telewizyjnych anten, jednak dość szybko dostrzeżono kierunek, w którym podążać miały kolejne zmiany: Kiedy wreszcie będzie można obejrzeć treści w dowolnym momencie? Kto będzie chciał czekać, aż zaistnieją w „ramówce”? Rozpowszechniła się wtedy opinia, że przyszłość telewizji ograniczy się do tworzenia programów, które wyświetlać będzie już ktoś inny. Jostein Gripsrud na podstawie rozmów z pracownikami Norwegian Broadcasting Corporation stwierdził w 2009 roku, że telewizja „miała zostać przede wszystkim producentem dobrych programów, jej rola dystrybutora i twórcy ramówki programowej miała stracić na znaczeniu"51. Z perspektywy czasu widać, że miał on częściowo rację - faktycznie, obecnie telewizje tworzą więcej treści niż kiedykolwiek, nacisk stawiany jest również na jakość telewizji ${ }^{52}$, jednak rola dystrybutora nadal ma ogromne znaczenie.

48 Zespół ds. Telewizji Hybrydowej KRRiT, Telewizja hybrydowa: szanse, zagrożenia i wyzwania regulacyjne, Warszawa 2013, s. 5.

49 Ibidem, s. 6 i n.

50 Choć przyjęło się określać nazwą „Smart TV” systemy wszystkich producentów, to właściwie jest to nazwa systemu Samsunga. Inni producenci mają podobne systemy, lecz o innych nazwach, nie przebiły się one jednak do świadomości powszechnej.

${ }^{51} \mathrm{~J}$. Gripsrud, Telewizja i nadawanie masowe - prawdopodobieństwo przetrwania w epoce cyfrowej [w:] Zmierzch telewizji?..., op, cit., s. 75-76.

52 Pojęcie telewizji jakościowej (ang. Quality TV) znajduje się w obszarze zainteresowań polskich badaczy. Zob. M. Major, Telewizja jakościowa, www.dwutygodnik.com/artykul/3597-telewizja-jakosciowa.html [dostęp: 26.07.2017]. 
Paradoksalnie, jest to spowodowane spadającą liczbą ludzi zasiadających przed telewizorami - grupy medialne starają się zatrzymać widownię, „nie wypuścić jej" do konkurencji.

Powracając do zagadnienia serwisów „na życzenie”, szybko okazało się, że nie muszą się one ograniczać do roli pośrednika i mogą same tworzyć unikatowe treści, co diametralnie zmieniło sytuację nadawców starego typu. Jedną z pierwszych oznak zmian było wprowadzenie przez HBO nowego produktu do swojej oferty - serwisu HBO On Demand, uruchomionego na terenie USA w 2001 roku, a w Polsce siedem lat później, początkowo pod nazwą HBO Digital. Serwis ten oferował dostęp do treści tworzonych na potrzeby kanałów $\mathrm{HBO}$ oraz Cinemax (należącego do grupy HBO). Nie była to oferta VOD, a sVOD - subskrypcja skierowana tylko do odbiorców zwykłego kanału HBO, dostępna za pośrednictwem dekodera telewizyjnego. Od samego początku można było wybierać pomiędzy dużymi produkcjami HBO - filmami fabularnymi, dokumentami, koncertami, a także serialami dostępnymi po kilka odcinków w pakiecie. Każdego tygodnia na widza czekała około setka programów ${ }^{53}$. Nowy produkt spotkał się z dużym zainteresowaniem. Kierownictwo $\mathrm{HBO}$ poszło więc za ciosem i w sezonie świątecznym 2010 przedstawiło widowni portal HBO GO (warto w tym miejscu dodać, że Polska była drugim na świecie krajem po USA, w którym uruchomiono tę usługę).

Zwróćmy uwagę, że do momentu powstania serwisów, które same tworzyły udostępniane treści, schemat wyglądał następująco: telewizja tworzy program, który następnie jest prezentowany jej odbiorcom $\mathrm{w}$ formie tradycyjnej bądź bardziej nowoczesnej (za pośrednictwem VHS, DVD lub na platformie VOD). Przełomowy okazał się pod tym względem rok 2013, kiedy to Netflix, rywal HBO GO na rynku platform VOD, rozpoczął samodzielne kręcenie seriali o jakości porównywalnej do tych znanych z tradycyjnych telewizji ${ }^{54}$, a nawet wyższej. W Polsce dostawca ten zadebiutował oficjalnie w pierwszych tygodniach roku 2016, z miejsca zdobywając duże

${ }^{53}$ P. Nietrzpiel, Jambox jako pierwszy z HBO Digital, http://satkurier.pl/ news/53868/jambox-jako-pierwszy-z-hbo-digital.html (dostęp: 25.07.17).

54 „House of Cards”, serial Netflixa, zdobył w pierwszym roku nadawania trzy nagrody Emmy, a nominowany był jeszcze w trzech kolejnych kategoriach. 
zainteresowanie ${ }^{55}$ (choć część odbiorców zarzucała serwisowi mocno ograniczoną ofertę w języku polskim). O ile koncern HBO tworzył programy na potrzeby swoich kanałów telewizyjnych, traktując inne sposoby dotarcia do odbiorcy jako wtórne, o tyle Netflix owych kanałów nie posiada. Doszło tu do skrócenia łańcucha pośredników - po co płacić za tworzenie treści, skoro możemy je zrobić samemu? Dążenie do cięcia kosztów i optymalizacji zysków wcześniej wykorzystywane było w drugą stronę - już w roku 2013 zespół KRRiT zauważył, że na naszym rynku dominują serwisy VOD powiązane $\mathrm{z}$ dużymi udziałowcami rynku reklam (głównie z operatorami platform satelitarnych, dużych sieci kablowych oraz z nadawcami telewizji naziemnej) ${ }^{56}$.

Nie można obecnie rozmawiać o telewizji z pominięciem platform pokroju HBO GO czy Netflixa, choć na naszym rynku ich wpływ wciąż nie jest znaczący - z tymi globalnymi graczami konkuruje bowiem cała grupa mniej lub bardziej rodzimych serwisów, w dużej mierze należących do właścicieli stacji telewizyjnych. Krzysztof Zalewski uważa za kluczowe dla zwiększenia udziałów w rynku większe inwestycje w polską produkcję ${ }^{57}$. Polacy bardzo lubią lokalne treści, również te starsze, mające bądź zdobywające miano kultowych, co może jeszcze przez długi czas skłaniać odbiorców do korzystania $z$ usług rodzimych dostawców. Nie każdy duży gracz pomija treści lokalne, jeden $\mathrm{z}$ najmłodszych internetowych serwisów VOD w naszym kraju - Showmax - zdaje się rozumieć, że właśnie dzięki takiej ofercie można przyciągnąć polskiego odbiorcę. Już od samego początku działalności reklamuje się dostępem do satyrycznego „Ucha Prezesa” czy takich filmów jak Pitbull lub Planeta Singli. Choć więc należy do południowoafrykańskiej grupy Naspers, to w planach ma również oferowanie produkcji tworzonych przez Polaków ${ }^{58}$.

${ }_{55}$ K. Kozłowski, Netflix $w$ Polsce - czy warto, jak zaczać, co obejrzeć, http:// antyweb.pl/netflix-w-polsce-czy-warto-jak-zaczac-co-obejrzec/ [dostęp: 26.04.17].

${ }_{56}$ Zespół ds. Telewizji Hybrydowej KRRiT, op. cit., s. 12.

57 Wywiad własny z Krzysztofem Zalewskim przeprowadzony 31 maja 2017 roku.

58 A. Kaźmierska, Jaki serwis VOD z filmami i serialami wybrać?, http://satkurier.pl/news/158093/jaki-serwis-vod-z-filmami-i-serialami-wybrac.html [dostęp: 22.07.17]. 
Jak już zostało wspomniane, obecnie na rynku bardzo mocną pozycję mają serwisy powiązane z kanałami telewizyjnymi. Ipla.tv, która w swojej ofercie ma programy Polsatu, player.pl, który przynależy do Grupy TVN, czy też należący do narodowego nadawcy vod.tvp.pl - to portale posiadające miliony użytkowników ${ }^{59}$. Przynoszą ogromne zyski, a także ułatwiają dotarcie do nowego typu odbiorców, często do tej pory niezainteresowanych telewizją. Dla przykładu, tylko na ipla.tv obok tysięcy programów można uzyskać dostęp do osiemdziesięciu kanałów telewizyjnych. Od dawna nie jest to zatem niszowa forma rozrywki, co coraz częściej wykorzystują nadawcy.

\section{ZAKOŃCZENIE}

Czy połączenie z Internetem będzie stanowić przyszłość telewizji? Jeśli nie nastąpi nic nieprzewidywalnego - zdecydowanie tak. Zmiana sposobu postrzegania telewizji odbywa się na naszych oczach - trudno wymagać, by ktoś, kto od najmłodszych lat ma dostęp do laptopa, tabletu i smartfona, przyzwyczajony jest do przeskakiwania pomiędzy okienkami w poszukiwaniu interesujących treści, zasiadał grzecznie przed telewizorem i czekał na seans. Na przełomie tysiącleci Wiesław Godzic prognozował: „»Nowy« - cyfrowy - sposób kontaktu z telewizją nie jest jeszcze w zupełności rozpoznany i przez długi czas stosować będziemy - mentalnie i behawioralnie - te wzory, które znamy z dotychczasowych kontaktów ze srebrnym ekranem" ${ }^{\text {"60 }}$. Bardzo możliwe, że właśnie skończył się ten czas, o którym mówił polski badacz. $\mathrm{O}$ ile bowiem osoby starsze nadal bardzo dużo czasu poświęcają na oglądanie telewizji w sposób tradycyjny, to znaczy linearny, jak za czasów, kiedy statystyczny telewidz ponad $80 \%$ swojego czasu przed odbiornikiem poświęcał na oglądanie „wielkiej czwórki” ${ }^{\text {, }}$, to już młode pokolenie podchodzi do odbiornika z konkretnymi wymaganiami.

59 T. Wojtas, VoD.pl, Player.pl i WP.tv w dót. Mocno w górę Netflix, ShowMax $z$ 2,6 mln użytkowników (dane serwisów VoD), www.wirtualnemedia.pl/artykul/ serwisy-vod-w-polsce-netflix-shwomax-vod-pl-player-pl-i-wp-tv-w-dol-mocno-wgore-netflix-shwomax-z-2-6-mln-uzytkownikow-dane-serwisow-vod [dostęp: 22.08.17].

60 W. Godzic, Rozumieć telewizję, Kraków 2001, s. 177.

${ }^{61}$ Problematyka kulturalna $w$ programach Polskiej Telewizji Publicznej, red. E. Mikołajczyk, Warszawa 2000, s. 157. 
Jaka przyszłość czeka zatem kanały tematyczne w tej złożonej sytuacji? Jaką odegrają rolę w zagmatwanym schemacie rynku telewizyjnego? Ciężko udzielić jednoznacznej odpowiedzi na te pytania. Bardzo możliwe jednak, że w najbliższym czasie liczba kanałów, obecnie nazbyt „rozdmuchana”, ulegnie radykalnemu zmniejszeniu. Specjaliści nie są zgodni co do ich przyszłości, jedni - tak jak Maciej Mrozowski - twierdzą, że przetrwają one zarówno offline, jak i online ${ }^{62}$, inni - jak choćby prezes Superstacji, Adam Stefanik - upatrują ich szybkiego końca ${ }^{63}$.

\section{Bibliografia}

Roman Bartoszcze, Słownik terminologii medialnej, red. W. Pisarek, Universitas, Kraków 2006.

Derek Compare, Publikujac przepływ. Zestawy DVD a zmiana koncepcji telewizji, [w:] Zmierzch telewizji? Przemiany medium, Wydawnictwo Naukowe „Scholar”, Warszawa 2011.

Wiesław Godzic, Rozumieć telewizję, Rabit, Kraków 2001.

Elżbieta Gorajewska (w rozmowie z A. Marciniakiem), Marzenia o jednym rankingu, „Telekabel” 2016, nr 5.

Jostein Gripsrud, Telewizja i nadawanie masowe - prawdopodobieństwo przetrwania wepoce cyfrowej, [w:] Zmierzch telewizji? Przemiany medium, Wydawnictwo Naukowe „Scholar”, Warszawa 2011.

Alicja Jaskiernia, Od telewizji masowej do Netflixa - Telewizja w Stanach Zjednoczonych w epoce cyfrowej, Oficyna Wydawnicza ASPRA-JR, Warszawa 2016.

\section{Źródła internetowe}

Dziś obchodzimy Światowy Dzień Telewizji. „Telewizja nie zniknie”, www.wirtualnemedia.pl/artykul/dzisiaj-obchodzimy-swiatowy-dzien-telewizji-telewizja-nie-zniknie.

Anita Kaźmierska, Cyfrowy Polsat GO - dla kogo i w jakiej cenie?, http://satkurier. $\mathrm{pl} /$ news/126473/cyfrowy-polsat-go-dla-kogo-i-w-jakiej-cenie.html.

${ }^{62}$ Dziśobchodzimy Światowy Dzień Telewizji. „Telewizja nie zniknie”, www.wirtualnemedia.pl/artykul/dzisiaj-obchodzimy-swiatowy-dzien-telewizji-telewizja-nie -zniknie [dostęp: 19.04.17].

63 Ibidem. 
Anita Kaźmierska, Jaki serwis VOD z filmami i serialami wybrać?, http://satkurier. $\mathrm{pl} /$ news/158093/jaki-serwis-vod-z-filmami-i-serialami-wybrac.html.

Wojciech Kowalczyk, Rynek stacji tematycznych jest przesycony, popyt na FTA oraz premium: badanie płatnej TV by ScreenLovers, cz. II, http://screenlovers.pl/ rynek-stacji-tematycznych-jest-przesycony-popyt-na-fta-oraz-premium-badanie-platnej-tv-by-creenlovers-cz-ii/.

Wojciech Kowalczyk, Trudny rok TV tematycznych, wzrost UPC i Cyfrowego Polsatu: przyszłość płatnej TV w badaniu ScreenLovers, cz. I, http://screenlovers.pl/ trudny-rok-tv-tematycznych-wzrost-upc-i-cyfrowego-polsatu-przyszlosc -platnej-tv-w-badaniu-screenlovers-cz-i/.

Konrad Kozłowski, Netflix w Polsce - czy warto, jak zaczać, co obejrzeć, http:// antyweb.pl/netflix-w-polsce-czy-warto-jak-zaczac-co-obejrzec/.

Portal Krajowej Rady Radiofonii i Telewizji, http://www.krrit.gov.pl/ dla-nadawcow-i-operatorow/koncesje/wykaz-koncesji-i-decyzji/.

Michał Kurdupski, Polsat liderem $w$ sierpniu, TVP1 wyprzedziła TVN. Hitem „M jak miłość”, www.wirtualnemedia.pl/artykul/ polsat-liderem-w-sierpniu-tvpl-wyprzedzila-tvn-hitem-m-jak-milosc.

Michał Kurdupski, TVN24 z najlepszym wynikiem $w$ historii, rosna Nick Jr i Super Polsat (top 25 tematycznych), www.wirtualnemedia.pl/artykul/ ogladalnosc-kanalow-tematycznych-lipiec-2017.

Magdalena Lemańska, Pojedynek internetu $z$ telewizja nabiera tempa, http://www. rp.pl/Media-i-internet/307169928-Pojedynek-internetu-z-telewizja-nabieratempa.html.

Małgorzata Major, Telewizja jakościowa, „Dwutygodnik”, www.dwutygodnik. com/artykul/3597-telewizja-jakosciowa.html.

Paulina Nietrzpiel, Jambox jako pierwszy z HBO Digital, http://satkurier.pl/ news/53868/jambox-jako-pierwszy-z-hbo-digital.html.

Mateusz Nowak, W polskim gospodarstwie domowym jest 6 urządzeń podłączonych do sieci, https://www.spidersweb.pl/2017/04/liczba-urzadzen-podlaczonych -do-internetu.html.

Portal Biura Reklamy TVP, https://www.brtvp.pl/16615065/slownik-tv. TVP rzuca wyzwanie Netflixowi i uruchamia płatny serwis SVoD. „Wsparcie dla wpływów z abonamentu", www.wirtualnemedia.pl/artykul/tvp-uruchomi -platny-serwis-svod-wsparcie-dla-wplywow-z-abonamentu-rtv.

Tomasz Wojtas, VoD.pl, Player.pl i WP.tv w dół. Mocno w górę Netflix, ShowMax z 2,6 mln użytkowników (dane serwisów VoD), www.wirtualnemedia.pl/ 
artykul/serwisy-vod-w-polsce-netflix-shwomax-vod-pl-player-pl-i-wp-tv -w-dol-mocno-w-gore-netflix-shwomax-z-2-6-mln-uzytkownikow-daneserwisow-vod.

\section{Dokumenty źródłowe i akty prawne}

Telewizja Hybrydowa: szanse, zagrożenia i wyzwania regulacyjne, Zespół ds. Telewizji hybrydowej KRRiT, Warszawa 2013.

Ustawa z dnia 29 grudnia 1992 r. o radiofonii i telewizji (Dz.U. $1993 \mathrm{nr} 7$ poz. 34).

\section{Thematic Television Channels in Poland in the Context of Technological Changes and the Domination of New Media}

In the article, a broad topic of thematic channels on the Polish market has been taken up. Thematic channels, increasingly popular and obtaining more and more media coverage, fit well into the landscape of television, gaining a large audience and changing the way television is perceived by Poles.

The author proposes various ways of categorizing thematic channels, because of: the type of concessions, thematic segments, television signal sources, media groups, financing methods. He provides information on viewership of the station. He also focuses on alternative (to traditional television) ways of receiving audio content (videotapes, DVD players, home video systems, smart TVs, hybrid TVs, on-demand services), and defines how they have influenced the shape of contemporary television as well as the development of thematic channels.

Keywords: thematic television channels, TV, Polish television market, media groups, viewership data, viewership, terrestrial television, cable TV, satellite TV 
ZalǫcZnIil

\section{TEATR NA WODZIE. WODNY ŻYWIOL WE WSPÓŁCZESNYM TEATRZE POLSKIM}

MONIKA KOSTASZUK-ROMANOWSKA

Wydział Filologiczny, Uniwersytet w Białymstoku

Faculty of Philology, University of Bialystok

mromanow@poczta.onet.pl

Wprowadzenie na scenę wody z pewnością nie jest często stosowanym zabiegiem teatralnym. I trudno się temu dziwić, bo przecież wykorzystanie tego środka teatralnej ekspresji znacząco podwyższa koszty produkcji przedstawienia. Gdy parę lat temu w Teatrze Wielkim w Warszawie szykowano premierę Latającego Holendra ${ }^{1}$ - słynnej „morskiej” opery Richarda Wagnera - w reżyserii Mariusza Trelińskiego, konieczne okazało się zbudowanie ogromnego basenu o wielkości 26 na 20 metrów. Miała się w nim gromadzić woda (autor scenografii wspominał nawet o 70 tysiącach litrów²), która w trakcie przedstawienia lała się z góry na scenę. Problem stanowiły i gabaryty zbiornika, i jego skuteczna izolacja. Podobno firma, która zaoferowała w przetargu najniższą kwotę, wyceniła wykonanie tej usługi na 900 tysięcy złotych. Ostatecznie basen zbudowano dużo taniej, siłami własnych pracowni ${ }^{3}$.

Z podobnym zadaniem musiała się wcześniej zmierzyć ekipa techniczna Teatru Dramatycznego w Warszawie przy przedstawieniu Krystiana Lupy Niedokończony utwór na aktora ${ }^{4}$. By na scenie pojawiło się zaplanowane przez

1 Premiera Latającego Holendra odbyła się w 2012 roku.

2 Zob. A.S. Dębowska, Wielka ulewa w operze, http://www.e-teatr.pl/pl/artykuly/135257,druk.html [dostęp: 10.02.17].

3 Zob. A.S. Dębowska, Robia niesamowite rzeczy. Poznajcie ludzi Teatru Wielkiego w Warszawie, 2014, http://warszawa.wyborcza.pl/warszawa/1,34889,16779121,Robia_niesamowite_rzeczy__Poznajcie_ludzi_Teatru_ Wielkiego.html [dostęp: 10.02.17].

4 Przedstawienie miało premierę w 2004 roku. 
reżysera jezioro, trzeba było zamówić ekspertyzę oceniającą wytrzymałość podłogi. Najgłębsze miejsce zbiornika (dochodzące do półtora metra) musiało być podtrzymywane przez sześć metalowych słupów ${ }^{5}$. Aktor, który w jednej ze scen miał się w wodzie całkowicie zanurzyć, opowiadał o swoich przeżyciach na próbach tak:

Kiedy jestem w środku przedstawienia, zapominam, że to sztuczny zbiornik wodny. Mam wrażenie, że mamy przyjemny letni wieczór, a ja kąpię się w ciepłym jeziorze. [...] Reżyser chce, aby kąpiel Jakuba [postać $\mathrm{z}$ dramatu przyp. M.K.-R.] w jeziorze nie była tylko ilustracją do tekstu, ale mówiła coś więcej. Żeby pokazała piękno teatru, jego magię, a jednocześnie jego niedoskonałość. Stać nas na to, żeby wyczarować jezioro w teatrze, a jednak nigdy nie będzie to prawdziwe jezioro, najwyżej zalany teatr ${ }^{6}$.

Zacytowałam tę nieco przewrotną wypowiedź, bo dobrze oddaje ambiwalentny charakter wody jako elementu widowiska teatralnego. Woda to bardzo szczególne tworzywo sceniczne. Wydaje się, że w większym stopniu niż inne identyfikuje samą istotę teatralności, która polega przecież na nieustannym oscylowaniu między iluzją a realnością. Fizyczność wprowadzonej na scenę wody nie pozwala zapomnieć o dychotomii sztucznej scenicznej kreacji i materialnej dosłowności tworzywa. Oczywiście, wszystkie postacie wodnych żywiołów - morze, deszcz, burzę - można skutecznie artykułować przy pomocy całej palety ekwiwalentów, czyli światła, barwy czy dźwięku. Takich właśnie środków użył Robert Wilson w zjawiskowym, poetyckim spektaklu Kobieta $z$ morza ${ }^{7}$. Tę liryczną opowieść, wywiedzioną ze skandynawskich legend, reżyser wpisał w wysublimowaną, ascetyczną przestrzeń wypełnioną morskimi odgłosami, efektami świetlnymi i wydobywanymi światłem, zalewającymi scenę kolorami.

A jednak efekt wody, nie tej metaforycznej, lecz prawdziwej - tak bardzo limitowany ograniczeniami technicznymi (o czym była już mowa), i w konsekwencji zawsze jednak do pewnego stopnia sztuczny - ma nad wspomnianymi ekwiwalentami jedną zdecydowaną przewagę. Tą przewagą jest

${ }^{5}$ Zob. D. Wyżyńska, Zalana scena, http://www.e-teatr.pl/pl/artykuly/18758. html [dostęp: 10.02.17].

6 Wypowiedź Michała Sieczkowskiego, [cyt. za:] ibidem.

7 Spektakl miał premierę w Teatrze Dramatycznym w Warszawie w 2005 roku. 

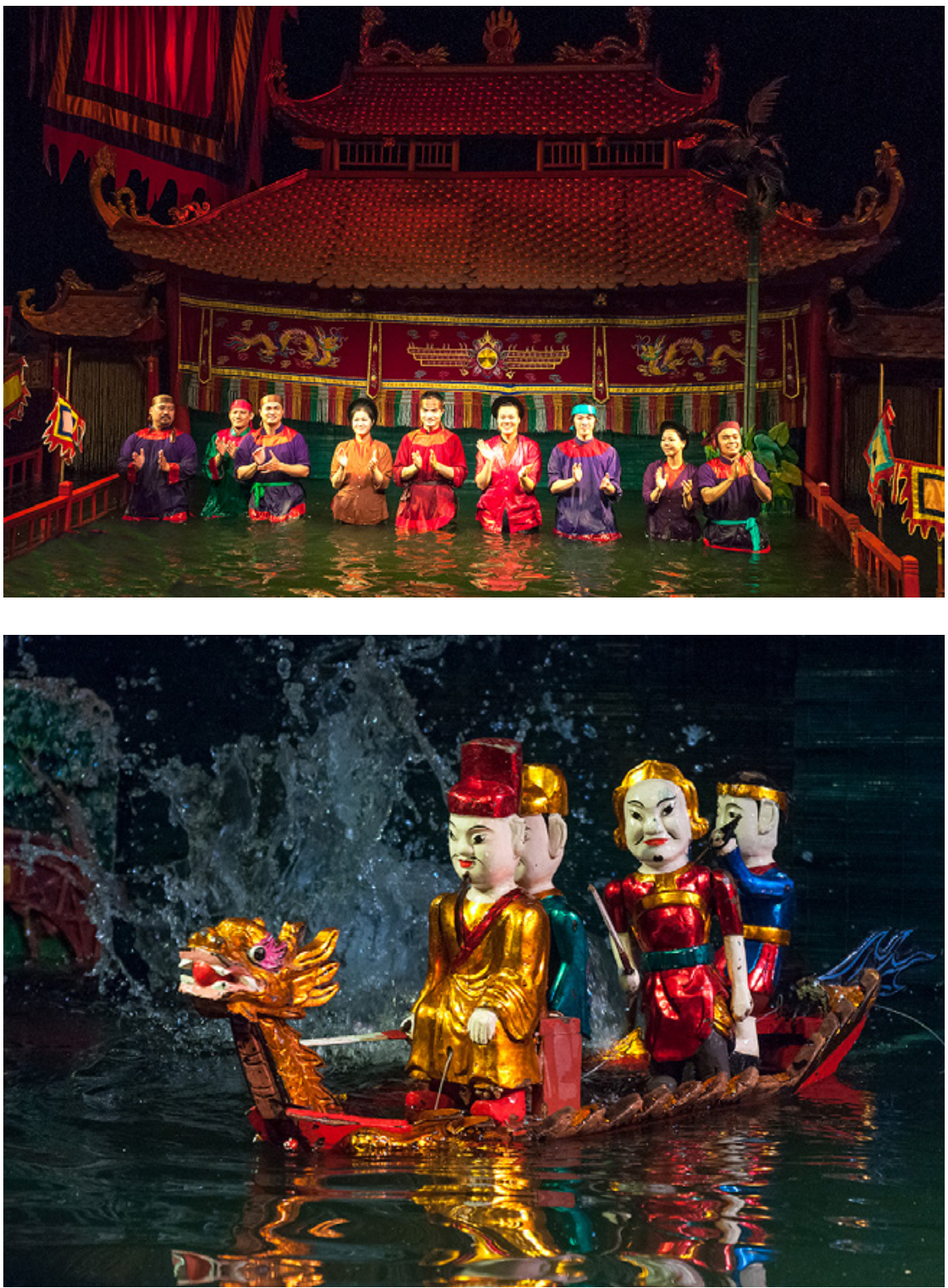

Il. 1-2. Wietnamski teatr lalek na wodzie, fot. Alicja Rapsiewicz (LosWiaheros.pl) 
trudny do zastąpienia potencjał widowiskowy. Można się o nim przekonać, obserwując występy teatrów grających... wyłącznie w/na wodzie, dla których woda to nie tylko środek sceniczny, ale przede wszystkim wyznacznik gatunkowy, świadomie stosowana konwencja. Wykorzystuje ją na przykład tradycyjny wietnamski teatr lalek na wodzie, notabene jedna z głównych atrakcji turystycznych Hanoi. Niezwykłość tych widowisk przybliża opis Đàm Vân Anh:

Już ponad tysiąc lat temu mieszkańcy delty Mekongu, uprawiając [...] ryż, dostrzegli potencjał, jaki tkwił w żywiole wody nie tylko jako podstawy do uprawy, ale również sceny, na której można odtwarzać ludowe opowieści i legendy. [...] Woda świetnie ukrywała ramiona poruszające kukiełkami i umożliwiała stworzenie dodatkowych, ekscytujących efektów jak wzburzone fale i tryskające w górę strumienie. [...] Sceną dla przedstawień wodnego teatru jest obecnie konstrukcja mająca postać basenu o powierzchni około 4 metrów kwadratowych. Za bambusową makietą odzwierciedlającą front typowej wietnamskiej świątyni kryje się nawet do ośmiu aktorów, którzy poruszając specjalnymi prętami, ożywiają lalki do nich przyczepione. [...] Kukiełki pojawiają się na wodnej scenie, wysuwając się z dwóch stron makiety ukrywającej aktorów lub, ku uciesze widzów, witają ich, wynurzając się niespodziewanie $\mathrm{z}$ wody ${ }^{8}$.

Oryginalny gatunek wietnamskiego teatru lalek na wodzie wywodzi się z lokalnej tradycji ludowej sięgającej XI wieku. Przykładem współczesnego modelu widowiska granego w wodzie są natomiast przedstawienia francuskiej grupy Ilotopie. Sami twórcy deklarują, że w ich praktykach „woda jest nową dziedziną współczesnego doświadczenia teatru" ", doświadczenia wykorzystującego swoistą „energię” żywiołu. Polska publiczność miała okazję zobaczyć efektowne spektakle zespołu. W 2001 roku przedstawienie Narcisse quette $\mathrm{z}$ repertuaru Ilotopie włączono do programu XI Międzynarodowego Festiwalu Teatralnego „Malta” w Poznaniu. „Wodną” koncepcję widowiska - nawiązującą do mitologicznej historii Narcyza - reżyserka Dominique

8 Đ. Vân Anh, W wodzie po kostki: wietnamski teatr lalek wodnych, http:// kontynent-warszawa.pl/felietony/kulturalia/762-w-wodzie-po-kostki-wietnamski-teatr-lalek-wodnych [dostęp: 11.02.17].

9 Zob. Spectacles sur l'eau, http://ilotopie.com/spectacles/?lang=fr [dostęp: 12.02.17]. Tłumaczenie własne. 


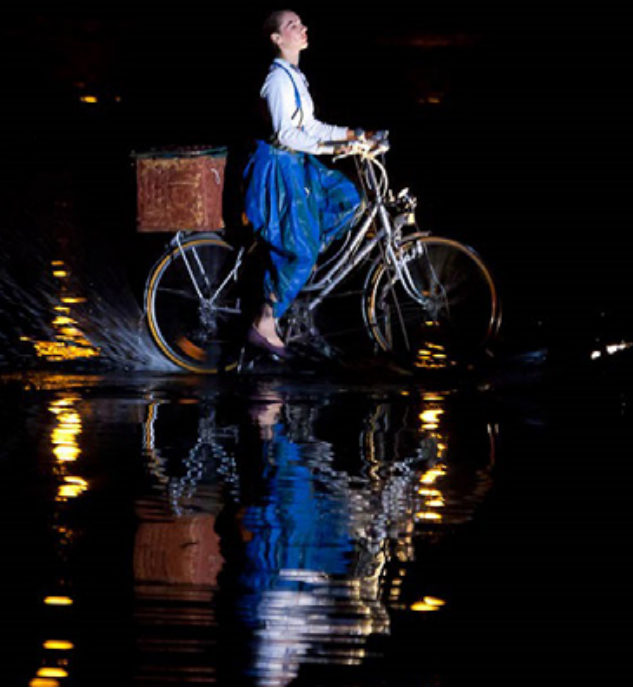

$\frac{1}{8}$
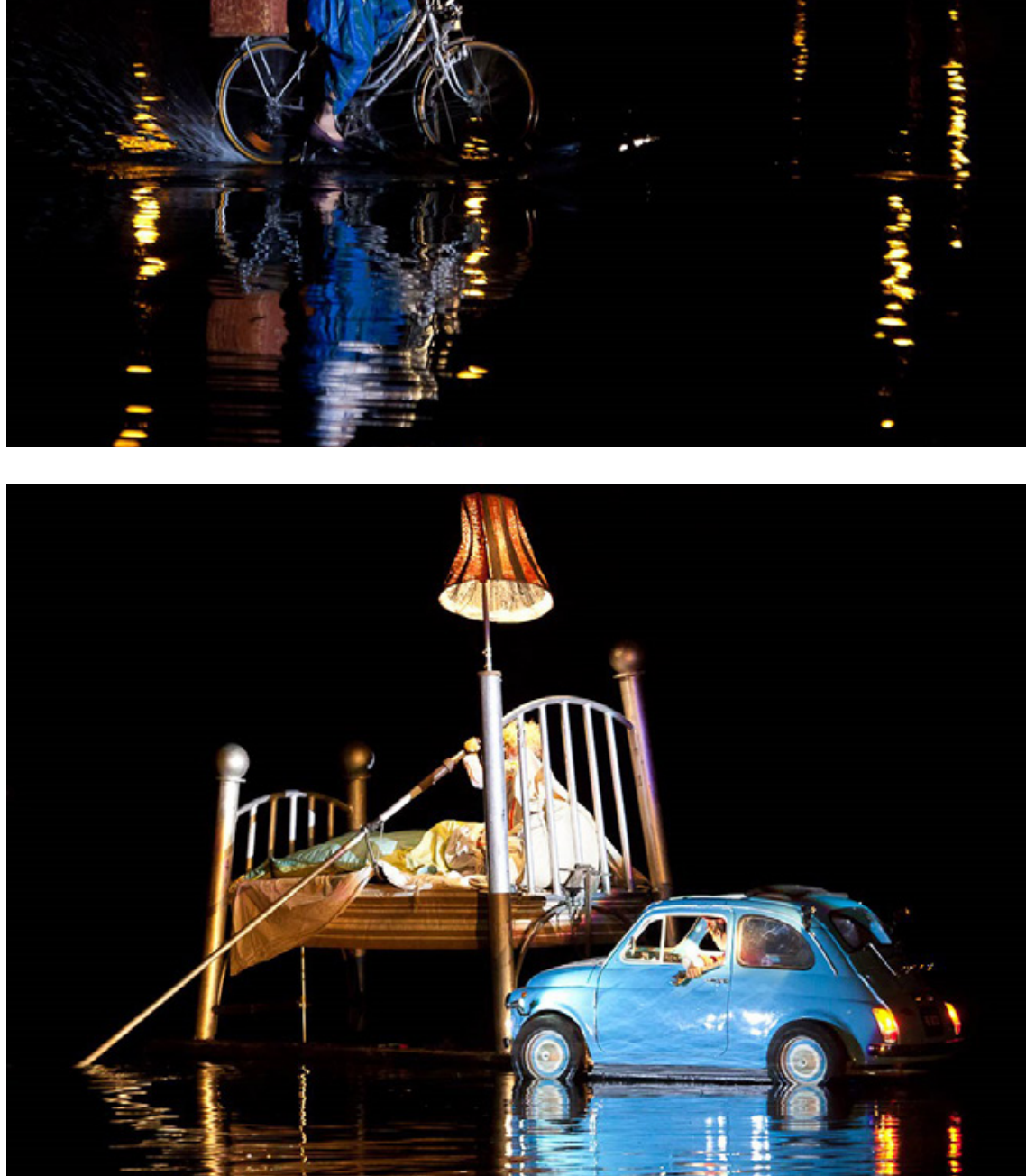

Il. 3-4. Fous de Bassin, Compagnie Ilotopie, fot. Tomasz Tarnowski 
Noël objaśniała następująco: „Pierwszym zwierciadłem człowieka była woda, i dlatego nasze przedstawienie o micie Narcyza chcemy przedstawić na wodzie. Będzie to gra iluzji i odbić lustrzanych"10. Z kolei w trakcie XV edycji Międzynarodowego Festiwalu Teatrów Plenerowych i Ulicznych FETA w Gdańsku w 2011 roku zespół przedstawił spektakl Water fools. Przygotowane $\mathrm{z}$ wielkim rozmachem widowisko było jednym $\mathrm{z}$ najdroższych wśród prezentowanych podczas dotychczasowych edycji festiwalu. Rozpoczynała je scena z przejeżdżającym po wodzie samochodem, potem pojawiał się też pedałujący rowerzysta, „żeglujące” łóżko, płynący po wodzie sprzątacz z miotłą i pojemnikiem na śmieci oraz kobieta z dziecięcym wózkiem. Niezwykła sceneria wydobywała z sekwencji zwykłych, codziennych zachowań nowy, metaforyczny sens. Woda - jak można było przeczytać $\mathrm{w}$ opisie przedstawienia - pełniła w nich rolę „czynnika ujawniającego kruchość ludzkiej kondycji”"11.

Niekwestionowalnym atrybutem wielkich widowisk plenerowych jest możliwość włączenia do spektaklu rzeczywistego akwenu. Stanowią one jednak odrębny, rządzący się własnymi prawami gatunek. W klasycznym teatrze repertuarowym, zlokalizowanym w budynku i niedysponującym taką możliwością, woda pojawia się w odmiennych, ale równie interesujących wariantach i konfiguracjach scenograficznych. Gdyby posłużyć się stricte technicznymi kategoriami ilości i typu źródła, należałoby sklasyfikować trzy najczęściej stosowane odmiany. Pierwsza polega na wykorzystaniu stosunkowo ograniczonej ilości wody wylewanej z kranu, węża lub naczynia. Wariant drugi to umieszczanie na scenie mniejszych i większych zbiorników wodnych lub całych basenów. Ostatni model wprowadza efekt wody spadającej z góry i zalewającej scenę.

W przypadku wariantu pierwszego, wykorzystującego wodę jako pojedynczy znak teatralny, symbolika takiego znaku okazuje się szczególnie gęsta właśnie dlatego, że dotyczy jedynie drobnego komponentu akcji scenicznej.

${ }^{10}$ Cyt. za: „Malta” rusza już XI raz, https://www.wprost.pl/kultura/15837/ Malta-rusza-juz-XI-raz.html [dostęp: 12.02.17].

${ }^{11}$ Zob. «Fous de bassins» na zamknięcie festiwalu FETA w Gdańsku, http://www. institutfrancais.pl/pl/evs/fous-de-bassins-na-zamkniecie-festiwalu-feta-w-gdansku [dostęp: 12.02.17]. 
Trudno więc odmówić mu, istotnego dla znaczeń spektaklu, „wyposażenia” semiotycznego. Jednak w odniesieniu do tego typu zabiegów nie ma zastosowania zasada umownie opisana formułą „teatru na wodzie”. Ponieważ pojedynczy element akwatyczny nie stanowi motywu dominującego, nie może być potraktowany jako strategia - scenograficznie i semantycznie identyfikująca całość komunikatu scenicznego. Ale, co warto zauważyć, tego typu znak teatralny jest z pewnością znakiem szczególnym w tym znaczeniu, że jego sztuczność wydaje się stosunkowo najmniej „sztuczna”. W odbiorze widzów iluzja „prawdziwej” wody, na przykład wylanej z kubka na scenie - w przeciwieństwie choćby do wody wylewanej litrami w postaci deszczu - pozostaje, co oczywiste, iluzją pełną. Nie zakłóca jej wrażenie (opisane w zacytowanej powyżej wypowiedzi aktora z przedstawienia Lupy) obcowania z efektem „sfabrykowanym”, będącym stricte teatralną kreacją.

Przywołam na zasadzie ilustracji tylko dwie takie sceny, pozornie podobne, a jednak w swej wymowie biegunowo przeciwne. Pierwszy przykład to monolog księdza Piotra z przedstawienia Mickiewicz. Dziady. Performance Pawła Wodzińskiego ${ }^{12}$. W scenerii przypominającej raczej noclegownię niż więzienie polskich patriotów chluśnięcie wodą (wylaną prosto $\mathrm{z}$ metalowego kubka) w twarz punktowało wizjonerską opowieść o sądzeniu i dręczeniu Chrystusa, czyli Polski - miało więc mesjański, oczyszczający sens. Z kolei w legendarnej inscenizacji 2007: Macbeth Grzegorza Jarzyny ${ }^{13}$, zrealizowanej w postindustrialnych wnętrzach nieistniejącej już Zakładów Waryńskiego na warszawskiej Woli, mocnym akcentem była scena polewania przez Lady Macbeth wodą ze szlaucha posadzki unurzanej we krwi. U Jarzyny woda zestawiona $\mathrm{z}$ krwią nie była - jak w spektaklu Wodzińskiego - ani cucąca, ani oczyszczająca - została wpisana w krąg zbrodni, intrygi, wojny i śmierci.

Kategoria pierwsza - nazwijmy ją „wariantem minimalistycznym” oznacza zatem kreowanie dosyć wyrazistych (by nie powiedzieć: przewidywalnych) znaków scenicznych. Jednak w kontekście omawianego tematu ważniejsze wydają się realizacje, których twórcy zdecydowali się na rozwiązania „wielkogabarytowe” i wprowadzili na scenę spore ilości wody,

12 Premiera spektaklu odbyła w Teatrze Polskim w Bydgoszczy w 2011 roku.

13 Spektakl wystawiony przez TR Warszawa w 2005 roku. 
organizując przy pomocy tego zabiegu przestrzeń gry najczęściej (i „z konieczności”) w całym spektaklu.

Zacznę od przykładu nietypowego w tym sensie, że wspomniany zbiornik nie musiał być na scenie budowany, gdyż reżyser posłużył się przestrzenią gotową, która takim obiektem dysponowała. W spektaklu $H$. Jana Klaty ${ }^{14}$, bo o nim mowa, zastosowano strategię właściwą wspomnianemu już gatunkowi widowiska plenerowego. Przedstawienie zrealizowano, podobnie jak Macbetha Jarzyny, w scenerii postindustrialnej ${ }^{15}$. Taki „naturalny” plener stanowił teren zrujnowanej Stoczni Gdańskiej. Dopisaną Szekspirowi scenę samobójstwa Ofelii (a właściwie scenę wyławiania jej ciała) rozegrano w basenie portowym. Oczywiście, w teatrze ma znaczenie, czy o śmierci Ofelii widzowie dowiadują się - jak u Szekspira - z wypowiedzi Królowej, czy też sami mogą wejść w rolę ciekawskich gapiów, którzy gromadzą się nad brzegiem basenu i mimo że stoją za policyjną taśmą, to jednak na własne oczy śledzą akcję wyławiania zwłok, a następnie zamykania ich w czarny foliowy worek. Akcję, dodajmy, jakby żywcem przeniesioną z kronik kryminalnych. To właśnie ta stylizacja brutalnie dekonstruowała ewentualne nawiązania do obrazów Eugène’a Delacroix czy Johna Everetta Millaisa, choć przez moment upozowanie martwej Ofelii, nieruchomo leżącej na wodzie, wyraźnie przywodziło skojarzenia z tym drugim dziełem.

Figura Ofelii - topielicy, która „wodzie oddała swoje młode życie” z pewnością natomiast stanowiła inspirację dla autorek innego spektaklu wystawionego w Teatrze Polskim w Bydgoszczy Przyrzecza ${ }^{16}$. Muzyczny monodram osnuto na fragmentach dziennika Virginii Woolf ${ }^{17}$, która, przypomnijmy, popełniła samobójstwo, skacząc do rzeki. Choć przedstawienie zrealizowano „tradycyjnie”, to proponowało ono zdecydowanie „nietrady-

${ }^{14}$ Spektakl według Hamleta przygotowany przez Teatr Wybrzeże w Gdańsku w 2004 roku.

15 Oba spektakle analizowałam w tekście Szekspir postindustrialny zamieszczonym w: Szekspir wśród znaków kultury polskiej, red. E. Łubieniewska, K. Latawiec, J. Waligóra, Kraków 2012.

16 Premiera odbyła się w 2012 roku. Autorkami konceptu przedstawienia były Agata Skwarczyńska, Aneta Jankowska i grająca w spektaklu Karolina Adamczyk.

17 Obok dzienników Virginii Woolf inspiracją dla autorek były też teksty piosenek brytyjskiej wokalistki PJ Harvey. 
cyjne" rozwiązania scenograficzne. W bydgoskiej inscenizacji pojawiało się bowiem duże akwarium o wielofunkcyjnym, jak się okazało, zastosowaniu:

Rewelacyjny pomysł na scenografię - prostopadłościan wypełniony wodą jest dla głównej postaci niezwykle atrakcyjny pod wieloma względami. Raz jest źródłem dźwięków, odwołując się do siły natury tak bliskiej kobiecie, kiedy indziej staje się przestrzenią, do której boi się [ona] wejść, stojąc na krawędzi, przyglądając się ze strachem i zainteresowaniem, przywołującą skojarzenia z próbą samobójczą. Czasem też stanowi miejsce infantylnych zabaw, unaoczniając piękno rozwoju człowieka $\mathrm{z}$ radosnego dziecka po zmysłową kobietę ${ }^{18}$.

„Ogrywanie” elementów scenograficznych zalicza się do podstawowego repertuaru środków aktorskich. W przypadku Przyrzecza dość szczególny obiekt umieszczony w planie gry był jednocześnie wykorzystywanym przez aktorkę instrumentem - instrumentem, dodajmy, także w znaczeniu dosłownym. „Woda kusi i każe ryzykować” - pisał Szymon Spichalski ${ }^{19}$. Bohaterka eksperymentowała więc z materią wody - dotykała jej, wskakiwała do niej, zanurzała się. Dźwięki wydobywane $z$ wody w trakcie tych działań oddawał umieszczony wewnątrz akwarium mikrofon. „Penetracja” wody, już sama w sobie widowiskowa, faktycznie stawała się - co zostało podkreślone w cytowanej wcześniej recenzji - metaforą stanu psychicznego bohaterki. Wśród wielu sensów tej metafory jeden wydawał się szczególnie mroczny. Wyrażał - można to tak ująć - stopniowe zamykanie się bohaterki w neurotycznym świecie własnej psychiki. W nim, jak pod wodą, unieważnione zostaje całe - istniejące ponad taflą - życie. Optycznie zmieniona postać, którą widzowie mogli obserwować przez ściany akwarium, momentami rzeczywiście przypominała topielicę. Jednocześnie wielowymiarowo eksploatowany żywioł wody ostatecznie pozostawał żywiołem nieodgadnionym, dającym możliwość różnych, sprzecznych, ale i komplementarnych, odczytań.

18 P. Blanca, Nie ma historii, jest akcja [recenzja spektaklu „Przyrzecze”], http:// bydgoszcz.naszemiasto.pl/artykul/nie-ma-historii-jest-akcja-recenzja-spektaklu -przyrzecze,3158757,art,t,id,tm.html [dostęp: 14.02.17].

19 S. Spichalski, Adamczyk stapa po wodzie, http://www.e-teatr.pl/pl/artykuly/139203.html [dostęp: 15.02.17]. 
Autorki projektu - zauważyła Agnieszka Serlikowska - wspominały w zapowiedziach o alegorycznym motywie topielicy Ofelii, o podjęciu próby zbadania tajemnicy zatonięcia kobiety. Według mnie rzeka nie musi wiązać się ze śmiercią we wszystkich historiach przedstawionych w spektaklu. Może być także symbolem kobiecego wyzwolenia, poznania świata czy egzystencjalnego spokoju ${ }^{20}$.

Spektakl Przyrzecze stanowił ciekawy przykład teatralnej eksploracji wody - odkrywania jej materialnej faktury, udźwięczniania, pobudzania jej wielozmysłowego potencjału. $Z$ takim efektem mamy do czynienia wówczas, gdy woda w spektaklu pojawia się jako sceniczny partner aktora. To oczywiście tylko jedno z możliwych zastosowań motywu akwatycznego, które sprawdza się zwłaszcza w spektaklach skupionych, kameralnych, próbujących się zmierzyć z tajemnicą ludzkiej psychiki.

Wprowadzanie na scenę obiektów wodnych jest zawsze, co pokazał też spektakl Przyrzecze, działaniem o charakterze proksemicznym. Tafle wody, co oczywiste, nadbudowują plan gry, wyposażają sceniczną przestrzeń w dodatkowy wymiar. Stają się też quasi-naturalnymi ekranami - wchłaniają światła i barwy, odbijają sylwetki postaci. Strukturyzują, a jednocześnie waloryzują plastyczną kompozycję sceny. Tego typu efekt wykorzystano w inscenizacji Szekspirowskiego dramatu Antoniusz i Kleopatra przez Wojciecha Farugę $^{21}$ - dosyć brutalnym spektaklu z interesującą, minimalistyczną scenografią. Jeden z recenzentów, Piotr Olkusz, opisał ją następująco:

Wizualnie to bardzo ładny spektakl. Wielka rampa falujących pagórków schodzi delikatnie w stronę widowni, trafiając po drodze na spory basen z wodą. Patrzymy na czarną Afrykę za morzem. Dosłownie czarną, bo piasek, zamiast skrzyć się złotem, wygląda, jakby próbowano go zasmołować ${ }^{22}$.

Zastosowany przez twórców element wodny faktycznie zdawał się kontrastować z księżycowym krajobrazem lądu. Lecz oba motywy nie budowały prostej opozycji. Martwocie ziemi nie przeciwstawiał się życiodajny żywioł

20 A. Serlikowska, Wodą i dźwiękiem o...?, http://www.e-teatr.pl/pl/artykuly/138640,druk.html [dostęp: 15.02.17].

${ }^{21}$ Spektakl wystawiono w Teatrze im. Stefana Jaracza w Łodzi w 2016 roku.

${ }_{22}$ P. Olkusz, Dlaczego nie po prostu?, http://teatralny.pl/recenzje/dlaczegonie-po-prostu,1389.html [dostęp: 16.02.17]. 

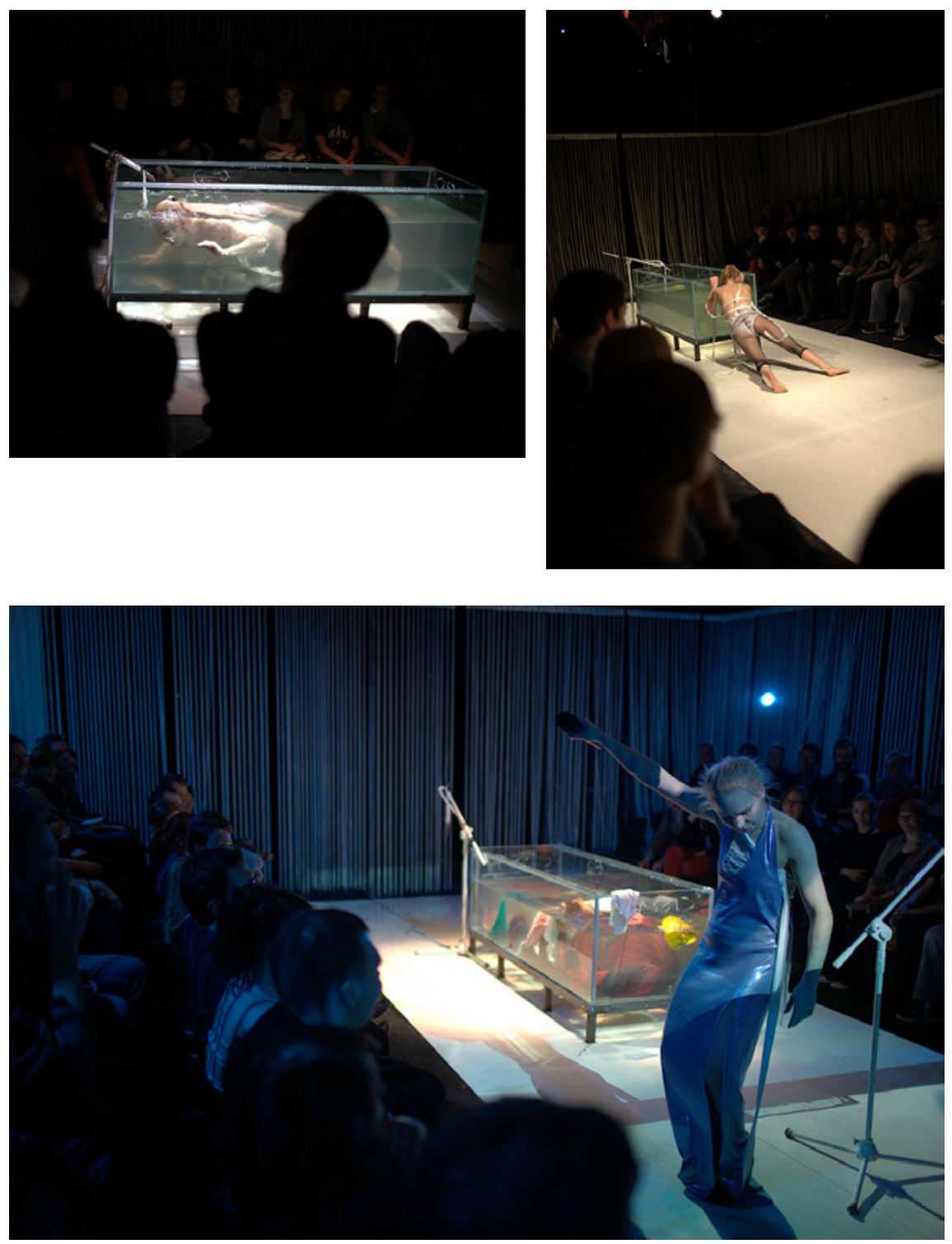

Il. 5-7. Przyrzecze (Teatr Polski im. H. Konieczki w Bydgoszczy, koncept: Agata Skwarczyńska, Aneta Jankowska, Karolina Adamczyk), fot. Paulina Stranz 
wody. Woda na scenie budziła skojarzenia z morzem, ale też z Nilem. Tyle że nie wydawał się on rzeką - co słusznie zauważyła Anna Tomasiewicz „która buntuje się przeciwko własnym brzegom, by dać zalążek nowego życia"23. Element wodny - zrealizowany w postaci długiego, zwieńczającego front sceny, kanału - podkreślał raczej niż negował wrażenie martwoty wpisane w całość wizji scenograficznej. Sugerował, jak przekonywała recenzentka, że „hellenistyczne królestwo to ziemia jałowa” ${ }^{24}$. W pewnym sensie ów symboliczny „Nil” stawał się więc rzeką śmierci. Wskazywała na to zwłaszcza jedna ze scen przedstawiająca metaforyczny obraz bitwy pod Akcjum. Użyto w niej ciekawego rozwiązania polegającego na połączeniu dwóch żywiołów, wody i ognia - po wodzie poruszały się, malowniczo płonąc, podpalone palnikiem tlenowym małe papierowe okręty.

Ruch (wody i w wodzie) - naturalny atrybut żywiołu - w teatrze staje się oczywistym środkiem ekspresji dynamizującym kompozycję przestrzenną. Modelowanie planu scenicznego przy użyciu motywów wodnych ma zatem charakter - jak to określa Jerzy Limon - „chronotypowy”25. Pojęciem tym badacz opisuje jeden $\mathrm{z}$ wariantów kształtowania przestrzeni w spektaklu. Na plan scenografii nakłada się akcja, a wraz z nią ruch sceniczny i gesty wykonywane przez postacie. Zmienność, cechująca dramaturgię opowiadanej w spektaklu historii, nie jest jedynie rozwojem w czasie - może dotyczyć również wymiaru przestrzennego. Nie chodzi tu o oczywisty zabieg zmiany dekoracji, lecz o wpisaną weń, silnie powiązaną z akcją, dynamiczność. Taką zdynamizowaną scenografię określa Limon własnym (a dokładniej: przeniesionym z literaturoznawstwa) terminem „chronografia”:

Za chronografię będę zatem uważał te dzieła sceniczne, w których zmienność kompozycji scenograficznej (również i tej budowanej światłem) jest nie tylko tłem, ale istotnym elementem akcji i odbywa się w obrębie jednej sceny (to znaczy nie tylko jako zmiana dekoracji pomiędzy scenami czy aktami). Ukazywane na oczach widzów zmiany w scenografii (już: chronografii) są powiązane $\mathrm{z}$ wydarzeniami na scenie albo same te wydarzenia tworzą.

23 A. Tomasiewicz, Historia troszkę splamiona nieszczęściem, http://www. teatrdlawas.pl/recenzje/5283-historia-troszke-splamiona-nieszczesciem [dostęp: 16.02.17].

24 Ibidem.

25 Zob. J. Limon, Piąty wymiar teatru, Gdańsk 2006, s. 181. 
Inaczej mówiąc, jest to szczególny wypadek, kiedy scenografia „gra” również w sensie ruchowym ${ }^{26}$.

Wydaje się, że zastosowanie w inscenizacji motywu akwatycznego nie tylko umożliwia, ale wręcz gwarantuje wspomniany efekt. Woda jako żywioł implikuje ruch, zmienność, właściwą jej naturze dynamikę. Woda zgromadzona na scenie - oczywiście, w odpowiednio dużej ilości - z racji samej swej natury dysponuje potencjałem ruchu i zmienności. Oferując możliwość kreowania - z użyciem barwy i światła - coraz to nowych jakości wizualnych (ale przecież też dźwiękowych), tworzy własne przebiegi zdarzeń. A jednocześnie stymuluje właściwą akcję sceniczną. „Gra”, wchodzi w rolę szczególnego nad-aktora, a także prowokuje, wymusza wręcz działania „żywych” aktorów.

I tu pojawia się problem - motyw, który może być atutem inscenizacji, może też okazać się jej słabością. Reżyser, decydując się na wykorzystanie wody w spektaklu, nie zawsze ma dobry pomysł na to, co i dlaczego ma z tą wodą (a częściej: w wodzie) robić aktor. W łódzkim spektaklu woda stanowiła na przykład oczywisty kontekst scen erotycznych. Lecz nie wszystkie „akcje wodne” wydawały się równie przekonująco umotywowane. Wskazuje na to wypowiedź jednej z recenzentek: „ten element scenografii byłby naprawdę dobrym pomysłem, gdyby nie fakt, że większość epizodów z jego wykorzystaniem opiera się na bezcelowym i nieuzasadnionym wskakiwaniu do wody" ${ }^{27}$. Z kolei cytowany już Olkusz kończył swój opis scenografii następującą refleksją: „Obraz ładny. Przypuszczam jednak, że Wojciech Faruga nie reżyserował Antoniusza i Kleopatry po to, by pierwszą rzeczą, która przyjdzie widzowi do głowy na myśl o tym spektaklu, była plastyka"28.

Podobnych zarzutów nie uniknął też spektakl, o którym wspomniałam na początku. Twórcy Latającego Holendra dość precyzyjnie objaśniali koncepcję inscenizacji. Autor scenografii, Boris Kudlička, tłumaczył: „Chodziło mi o stworzenie wrażenia czarnej otchłani, głębiny" ${ }^{29}$. Inspiracją były

${ }^{26}$ Ibidem, s. 256.

27 I. Herłazińska, Na początku i na końcu był chaos, http://www.teatrdlawas. pl/recenzje/4959-na-poczatku-i-na-koncu-byl-chaos [dostęp: 16.02.17].

28 P. Olkusz, op. cit.

${ }^{29}$ Cyt. za: A.S. Dębowska, op. cit. 

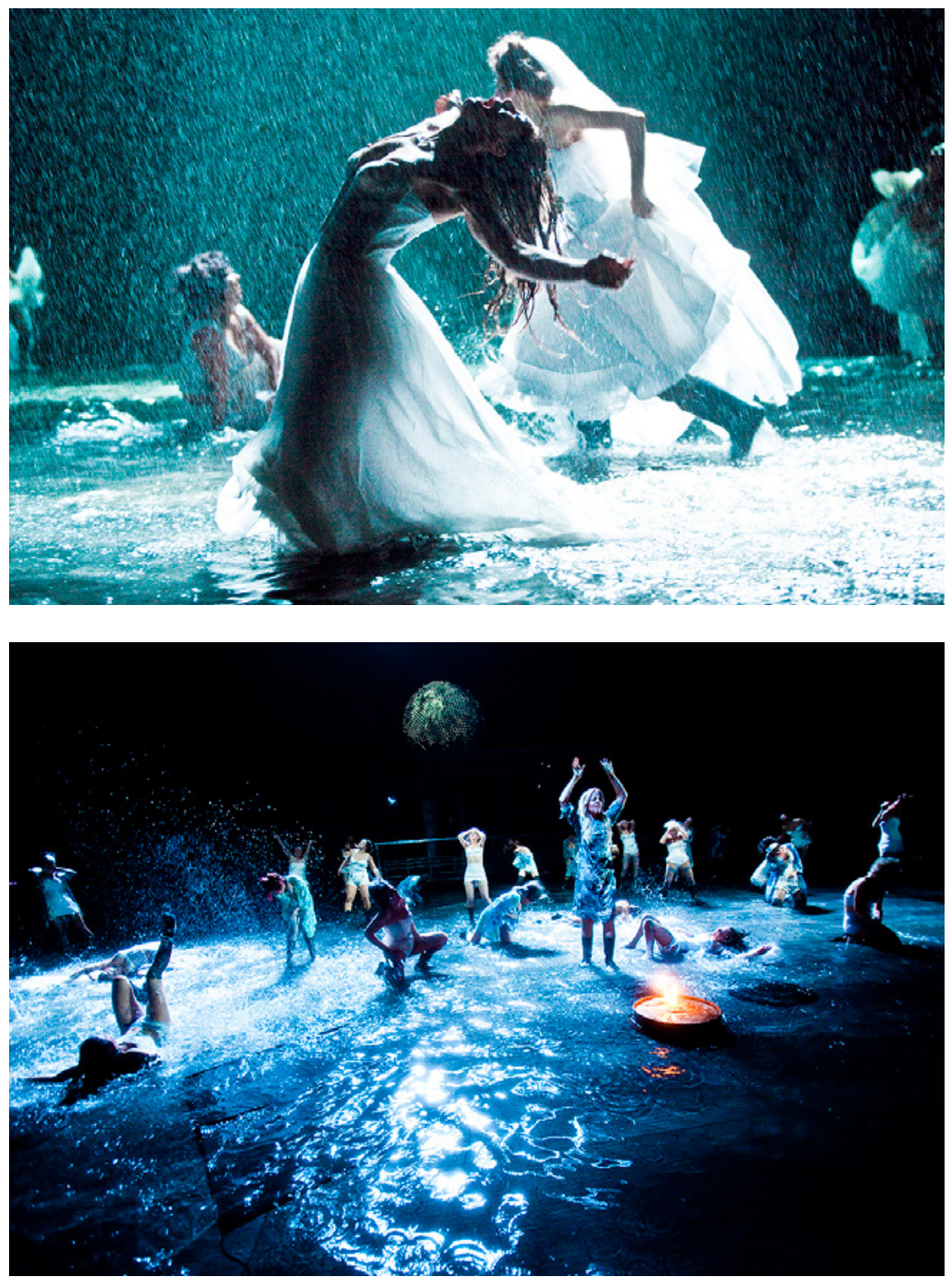

Il. 12-13. Latający Holender (Teatr Wielki - Opera Narodowa, reż. Mariusz Treliński), fot. Krzysztof Bieliński 
autentyczne kataklizmy - tsunami i powodzie ${ }^{30}$. Sam Wagner, jak wiadomo, napisał swoją operę pod wpływem dramatycznego przeżycia - sztormu na Morzu Północnym. Na scenie Teatru Wielkiego faktycznie udało się wyczarować - choć wydawało się to niemal niemożliwe ${ }^{31}$ - wizję bezkresnego oceanu, prawdziwego mare tenebrarum. Wzmacniały ją zwielokrotnione, nakładające się na siebie obrazy wody. Widzowie mogli obserwować przecinające się powierzchnie deszczu, rozbryzgiwane tafle wody i snujące się opary mgły. Mroczna scenografia wyrażała symbolikę samotności, cierpienia i śmierci.

Zjawiskowe obrazy stworzone przez Kudličkę spotkały się z uznaniem krytyków, którzy docenili ich estetyczną maestrię, ekspresyjną siłę i konsekwentnie budowany, metaforyczny przekaz.

To właśnie mrok, światło i woda - podkreślał Olgierd Pisarenko - wspaniale organizują przestrzeń dramatu przez opalizujące, chłodne barwy i ruchome faktury, budowane z mgły, pyłu wodnego, kropli i strug deszczu, rozprysków i odblasków na falującej, czarnej tafli wody. Świat cieśnin i fiordów Północy, wykreowany na scenie Opery Narodowej, wydaje się nieprzytulny, zimny i abstrakcyjny, ale obrazy te mają zarazem fascynującą, nostalgiczną urodę i coś z atmosfery czarno-białych ekspresjonistycznych filmów z lat dwudziestych ${ }^{32}$.

Sam pomysł wprowadzenia na scenę hektolitrów wody w przypadku tego akurat dzieła nie budził wątpliwości. Pojawiły się jednak wypowiedzi kwestionujące nie tyle zasadność użycia „morskiej” scenografii, ile jej rolę w budowaniu dramaturgii spektaklu. Twórcom zarzucano, że nadmiernie poddali się "logistyce wody”33, która - jak pisano - „skradła spektakl”34,

${ }^{30}$ Zob. ibidem.

${ }^{31}$ Sam Kudlička przyznał: „W trakcie realizacji tego pomysłu poruszałem się na granicy możliwości technicznych”. Ibidem.

32 O. Pisarenko, Mokra robota. Latający Holender w Operze Narodowej, http://www. ruchmuzyczny.pl/PelnyArtykul.php?Id=2067 [dostęp: 17.02.17].

33 J. Hawryluk, „Latający Holender” Trelińskiego. Trafiony, zatopiony, http://wyborcza.pl/1,75410,11372269,__Latajacy_Holender_Trelinskiego_Trafiony_zatopiony. html [dostęp: 17.02.17].

34 L. Raś, „Latający Holender” dopłynął do Teatru Wielkiego Opery Narodowej, http://www.wiadomosci24.pl/artykul/latajacy_holender_ 
zdominowała inscenizację, podporządkowała ją sobie, ale nie udźwignęła wszystkich jej sensów. Jacek Hawryluk mówił wręcz o „utopieniu” koncepcji, dodając, że „żaden z elementów scenografii nie wchodzi z wodą w dialog, a jeśli już się stara, to raczej jej "przeszkadza«" ${ }^{35}$. Podobne wrażenia mieli zapewne też inni komentatorzy (zresztą, tak jak Hawryluk, na ogół doceniający walory estetyczne spektaklu). Świadczyły o tym choćby już same tytuły recenzji - Mokra robota, Wodochciejstwo czy Aquapark na scenie ${ }^{36}$.

Inscenizacja Trelińskiego pokazała, że żywioł wody jest w teatrze wyjątkowo atrakcyjnym, ale i skrajnie trudnym tworzywem. Notabene, to właśnie jego atrakcyjność przesądza o jego problematyczności. Niesie bowiem ze sobą ryzyko polegające na zautonomizowaniu motywu, który w spektaklu musi przecież „współpracować” - jak słusznie zauważył Hawryluk $\mathrm{z}$ innymi elementami scenicznego uniwersum. Ustanowiona $\mathrm{w}$ widowisku „przestrzenna przyległość” tych elementów - podkreśla Limon - „powoduje wzajemne przenikanie i zmianę waloru" ${ }^{37}$. Charakterystyczny dla dzieła teatralnego proces semiotyzacji - nadawania znaczeń wszystkiemu, co znajdzie się w planie gry - rodzi zatem konieczność uzgodnienia wielu, ze swej scenicznej natury mobilnych, znaków.

Wniosek wydaje się oczywisty. Woda w teatrze niewątpliwie daje możliwość tworzenia niezwykle spektakularnych, wręcz glamourowych obrazów, lecz jednocześnie wymusza scenograficzną ascezę. Immanentna widowiskowość, oferująca całe instrumentarium niemal "gotowych” efektów, wymaga ogromnej inscenizacyjnej dyscypliny i wielkiej dramaturgicznej precyzji w konstruowaniu całości wizji scenicznej. Bo przecież, mówiąc metaforycznie, w teatrze - podobnie jak w naturze - wodny żywioł może bardzo łatwo wymknąć się spod kontroli.

doplynal_do_teatru_wielkiego_opery_narodowej_228378-2-1-d.html [dostęp: 17.02.17].

${ }^{35}$ J. Hawryluk, op. cit.

36 Zob. O. Pisarenko, op. cit.; H. Milewska, M.Ł. Gołębiowski, Wodochciejstwo, http://www.e-teatr.pl/pl/artykuly/206754.html [dostęp: 17.02.17]; B. Tumiłowicz, Aquapark na scenie, http://www.dziennikteatralny.pl/artykuly/aquapark-na-scenie. html [dostęp: 17.02.17].

37 J. Limon, Między niebem a sceną, Gdańsk 2001, s. 154. 
Ta zasada dotyczy nie tylko estetycznych, ale i semantycznych walorów wyjściowego tworzywa. Twórcy inscenizacji stosujących motywy akwatyczne - zwłaszcza w wersji „na bogato” - za każdym razem muszą dokonać trudnego wyboru, a następnie równie trudnego scenicznego przekładu kulturowych konotacji wody na znaki i symbole konkretnego spektaklu. Repertuar takich konotacji jest - jak dowodzą przywołane spektakle - wyjątkowo duży, lecz jest też naznaczony nieprzezwyciężalną ambiwalencją. Kulturowe tropy wody - rozpięte między biegunowo przeciwnymi sensami życiodajnej, oczyszczającej, wyzwalającej siły i niebezpiecznego, trudnego do okiełznania, śmiertelnego żywiołu, materialnej skończoności i metafizycznej, nieodgadnionej nieskończoności - czynią z niej tworzywo sceniczne naprawdę „wysokiego ryzyka”.

Na koniec warto przywołać jeszcze jedną - wydaje się, wcale nie najmniej istotną - refleksję. Woda w teatrze, tym razem w przeciwieństwie do wody $\mathrm{w}$ naturze, $\mathrm{z}$ czego zapewne zdają sobie sprawę twórcy teatralni, mimo wszystko może się po prostu opatrzyć.

Autorka oraz Redakcja dziękuja Autorkom $i$ Autorom fotografii oraz Teatrom za udostępnienie materiałów wizualnych i zgodę na ich bezpłatne wykorzystanie.

\section{Bibliografia}

Paloma Blanca, Nie ma historii, jest akcja [recenzja spektaklu Przyrzecze], http:// bydgoszcz.naszemiasto.pl/artykul/nie-ma-historii-jest-akcja-recenzja-spektaklu-przyrzecze,3158757,art,t,id,tm.html.

Anna S. Dębowska, Robia niesamowite rzeczy. Poznajcie ludzi Teatru Wielkiego $w$ Warszawie, http://warszawa.wyborcza.pl/warszawa/1,34889,16779121,Robia_niesamowite_rzeczy__Poznajcie_ludzi_Teatru_Wielkiego.html.

Anna S. Dębowska, Wielka ulewa w operze, http://www.e-teatr.pl/pl/artykuly/135257,druk.html.

«Fous de bassins» na zamknięcie festiwalu FETA w Gdańsku, 2011, http://www.institutfrancais.pl/pl/evs/fous-de-bassins-na-zamkniecie-festiwalu-feta-w-gdansku. Jacek Hawryluk, „Latajacy Holender” Trelińskiego. Trafiony, zatopiony, http://wyborcza.pl/1,75410,11372269,_Latajacy_Holender_Trelinskiego_Trafiony_zatopiony.html. 
Iga Herłazińska, Na początku i na końcu był chaos, http://www.teatrdlawas.pl/ recenzje/4959-na-poczatku-i-na-koncu-byl-chaos.

Monika Kostaszuk-Romanowska, Szekspir postindustrialny, [w:] Szekspir wśród znaków kultury polskiej, red. E. Łubieniewska, K. Latawiec, J. Waligóra, Wydawnictwo Naukowe Uniwersytetu Pedagogicznego, Kraków 2012.

Jerzy Limon, Między niebem a sceną, słowo/obraz terytoria, Gdańsk 2001.

Jerzy Limon, Piąty wymiar teatru, słowo/obraz terytoria, Gdańsk 2006. „Malta” rusza już XI raz, www.wprost.pl/kultura/15837/Malta-rusza-juz-XIraz.html.

Hanna Milewska, Maciej Łukasz Gołębiowski, Wodochciejstwo, http://www.e-teatr. $\mathrm{pl} / \mathrm{pl} /$ artykuly/206754.html.

Piotr Olkusz, Dlaczego nie po prostu?, http://teatralny.pl/recenzje/dlaczego-nie-po -prostu,1389.html.

Olgierd Pisarenko, Mokra robota. Latajacy Holender w Operze Narodowej, http://www. ruchmuzyczny.pl/PelnyArtykul.php?Id=2067.

Lidia Raś, „Latający Holender” dopłyną do Teatru Wielkiego Opery Narodowej, http://www.wiadomosci24.pl/artykul/latajacy_holender_doplynal_do_teatru_wielkiego_opery_narodowej_228378-2--1-d.html.

Agnieszka Serlikowska, Wodq̨ i dźwiękiem o...?, http://www.e-teatr.pl/pl/artykuly/138640,druk.html.

Spectacles sur l'eau, http://ilotopie.com/spectacles/?lang=fr.

Szymon Spichalski, Adamczyk stapa po wodzie, http://www.e-teatr.pl/pl/artykuly/139203.html.

Agata Tomasiewicz, Historia troszkę splamiona nieszczęściem, http://www.teatrdlawas.pl/recenzje/5283-historia-troszke-splamiona-nieszczesciem

Bronisław Tumiłowicz, Aquapark na scenie, http://www.dziennikteatralny.pl/artykuly/aquapark-na-scenie.html.

Đàm Vân Anh, W wodzie po kostki: wietnamski teatr lalek wodnych, http://kontynent-warszawa.pl/felietony/kulturalia/762-w-wodzie -po-kostki-wietnamski-teatr-lalek-wodnych.

Dorota Wyżyńska, Zalana scena, http://www.e-teatr.pl/pl/artykuly/18758.html. 


\section{Theatre on the Water. Aquatic Element in Contemporary Polish Theatre}

In view of theatrical performances, water is not only an important cultural trajectory, but also an attractive, though very special, stage material. The authoress draws attention to the ambivalent character of water as an element of the spectacle. Water identifies the very essence of theatricality, which consists of the constant oscillation between illusion and reality. The effect of real water - limited by technical restrictions and in effect artificial to some extent - has an unquestionable spectacle value. The authoress recalls selected performances whose creators have chosen large-scale solutions and introduced a large amount of water to the stage. In this way, she shows how they create the symbolic value of aqua motives, how they use their semantic and sensual potential in the process of translating the cultural connotations of water into signs and meanings of a particular show.

Keywords: water, theatre, spectacle, stage material 

ZatącZnIils

\section{HISTORIA JEDNEGO MOTYWU - RZECZ O ZWIAZZKACH BIŻUTERII Z ARCHITEKTURA}

MAŁGORZATA WRZEŚNIAK
Wydział Nauk Humanistycznych UKSW

Faculty of Humanities, Cardinal Stefan Wyszyński University in Warsaw

m.wrzesniak@uksw.edu.pl

Mówiąc o architekturze w złotnictwie, a zwłaszcza w biżuterii, trzeba najpierw uściślić użyte w tytule niniejszego studium pojęcie motywu, które na potrzeby prowadzonych poniżej analiz należy rozumieć jako różnego rodzaju formy architektoniczne określane terminem „mikroarchitektura”. Mowa zatem o traktowaniu całości budowli jako wzoru dzieła złotniczego, jak w przypadku średniowiecznych relikwiarzy, monstrancji czy trybularzy przybierających formy Niebiańskiego Jeruzalem wyobrażanego pod postacią chrześcijańskiej świątyni ${ }^{1}$, jak również żydowskich pierścieni rytualnych przedstawiających dom lub świątynię jerozolimską. Nie mówimy o mikroarchitekturze jako przedstawieniu rzeczywistej architektury, jak w przypadku relikwiarza pelplińskiego św. Barbary opisanego przez Kingę

${ }^{1}$ Mikroarchitekturę w relikwiarzach wspomina Kinga Szczepkowska-Naliwajek kilkakrotnie w swoich publikacjach na temat złotnictwa. Zob. K. Szczepkowska-Naliwajek, Motywy architektoniczne $w$ złotnictwie średniowiecznym, [w:] De Gustibus. Studia ofiarowane przez przyjaciół Tadeuszowi Stefanowi Jaroszewskiemu z okazji 65 rocznicy urodzin, red. T. Chrzanowski, Warszawa 1996, s. 276-284; eadem, Złotnictwo gotyckie Pomorza Gdańskiego, Ziemi Chełmińskiej $i$ Warmii, Wrocław 1987; eadem, Relikwiarz św. Barbary, „Spotkania z Zabytkami” 2002, nr 6, s. 7-9; eadem, Relikwiarze średniowiecznej Europy od IV do początku XVI wieku: geneza, treści, styl i techniki wykonania, Warszawa 1996. Na temat Niebiańskiej Jerozolimy jako modelu dla złotniczych realizacji średniowiecznych trybularzy zob. S. Kobielus, Niebiańska Jerozolima. Od sacrum miejsca do sacrum modelu, Warszawa 1989; M. Kierczuk-Macieszko, Średniowieczne kadzielnice $w$ Polsce, praca doktorska napisana pod kierunkiem prof. J. Kuczyńskiej (KUL 2011). 
Szczepkowską-Naliwajek (przedstawiającego wieżę - atrybutu świętej), lecz o wzorze rozumianym jako idea artystyczna dla całego obiektu złotniczego, w tym przypadku - biżuterii, zwłaszcza pierścieni.

Ponadto, za formę architektoniczną uznać należy dowolny fragment budowli, także detal architektoniczny, stanowiący podstawę całego dzieła złotniczego. Wykorzystanie tego elementu - detalu lub zdobienia występującego w architekturze danej epoki - w biżuterii czy, ogólniej, w złotnictwie stawia przed badaczem wiele problemów. Najtrudniejsza do rozstrzygnięcia jest kwestia, czy rzeczywiście wzorem dla dzieła złotniczego jest w tym wypadku architektura, czy może jednocześnie obie sztuki - architektura i złotnictwo - przejęły pewne motywy zdobnicze typowe dla określonego czasu. Przykładem tej drugiej sytuacji z pewnością mogą być maswerkowe dekoracje pastorałów gotyckich lub neogotyckie trójliście występujące w żeliwnej biżuterii sentymentalnej powstającej na terenie Niemiec w latach $1800-1860^{2}$.

Wreszcie, z tytułowym określeniem wiązać można różnorakie nawiązania do konstrukcji stosowanych w architekturze. Wydaje się, że we współczesnym rozumieniu - na co wskazują opisy biżuterii wykonywanej w XX i XXI wieku - określenie „architektoniczny” oznacza w jubilerstwie po prostu „budowany”. Odnosi się nie tylko do form wzorowanych na konkretnej architekturze, ale też do prostej, jasnej i przejrzystej konstrukcji danego

2 Biżuteria żeliwna produkowana w pruskich manufakturach w czasach wojen napoleońskich zyskuje symboliczne znaczenie oporu wobec francuskiego najeźdźcy w latach 1815-1816. Jej neoklasyczne formy, obecne w pierwszym dziesięcioleciu XIX wieku, po 1815 zastąpi neogotycka stylistyka maswerkowych wieloliści, czego przykładem są chociażby żeliwne kolczyki z pruskiej manufaktury, datowane na 1820-1830 i przechowywane w Muzeum Wiktorii i Alberta w Londynie (nr. inwentarza: 96C\&D-1906). Zob. E. Dębowska Dziewiętnastowieczna biżuteria żeliwna $z$ Pruskich odlewni królewskich w Berlinie i w Gliwicach, [w:] Biżuteria w Polsce. Materiały $z$ sesji naukowej zorganizowanej przez Muzeum Okregowe w Toruniu oraz Toruński Oddziat Stowarzyszenia Historyków Sztuki 20-21 kwietnia 2001 roku, pod patronatem Krajowej Izby Gospodarczej Jubilersko-Zegarmistrzowskiej, red. K. Kluczwajt, Toruń 2001, s. 107-116; eadem, „Złoto dałam za żelazo” - dziewiętnastowieczna biżuteria żeliwna, http://polskijubiler.com/pokaz.php?id=679 [dostęp: 28.04.16]. 
obiektu. Dotyczy to zwłaszcza biżuterii minimalistycznej, pozbawionej ozdobnego detalu, której zasadą jest forma konstruowana podobnie jak w przypadku dzieła architektury. Jest to, oczywiście, określenie umowne, a może nawet potoczne, które tym samym trudno zdefiniować, gdyż bazuje raczej na odczuciu odbiorcy niż na konkretnych cechach danego przedmiotu. Doskonałym przykładem takiego sposobu wykorzystania form architektury w biżuterii są prace podziwianej w Europie japońskiej artystki Mariko Sumioki, która inspiruje się zarówno tradycyjną architekturą swojego kraju i jej przejrzystą konstrukcją, jak i zróżnicowaniem materiałów ${ }^{3}$.
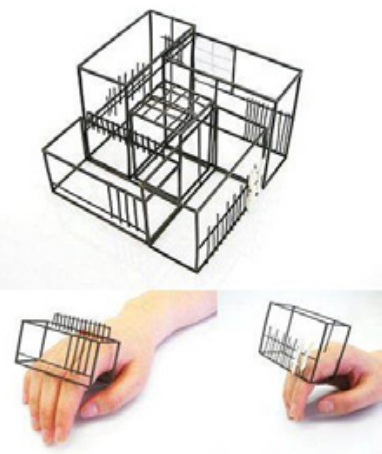

Il. 1. Mariko Sumioka, Pawilon herbaciany, http://glassfiction. blogspot.co.uk/2012/07/mariko-sumioka-samera-afzal.html [dostęp: 6.01.16].

Celem niniejszego studium jest prześledzenie, w jaki sposób wizerunek architektury rzeczywistej (całego dzieła lub jego fragmentu) bądź wyimaginowanej wykorzystywany jest w wyrobach jubilerskich, które od lat 80 . XX wieku uzyskały w Europie ogromną popularność. Nie można jednak prowadzić rozważań na temat współczesnych wyrobów bez przeanalizowania, choćby pobieżnie, historii omawianego zjawiska, które nie jest bynajmniej nowością powstałą w minionym stuleciu. Formy architektoniczne pojawiają się w klejnotach od czasów antycznych. Przede wszystkim wypada wspomnieć o obiektach wzorowanych na fortyfikacjach miejskich: corona muralis i corona vallaris. Korony $\mathrm{z}$ elementem murów miejskich i wież obronnych zdobiły głowy bóstw greckiej Tyche i rzymskiej Kybele, będących między innymi opiekunkami miast. Dlatego też zapewne pojawiają się na skroniach personifikacji państw i miast w Ikonologii Cesarego Ripy (wspomnijmy chociażby o personifikacji Italii, która „głowę ma uwieńczoną

3 www.marikosumioka.com/\#!about/aboutPage [dostęp: 7.01.16]. Zob. C. Ross, QঊA with Mariko Sumioka: ARTS THREAD Talent at MOKSPACE East Meets West: Art \& Design Now! (wywiad z Mairko Sumioka z okazji londyńskiej wystawy w galerii Mokspace: „East Meets West: Art \& Design Now!” 24 kwietnia - 6 maja 2012 roku), www.artsthread.com/blog/qa-mariko-sumioka-arts-thread-talent-mokspace-east-meets-west-art-design-now/ [dostęp 06.01.16]. 

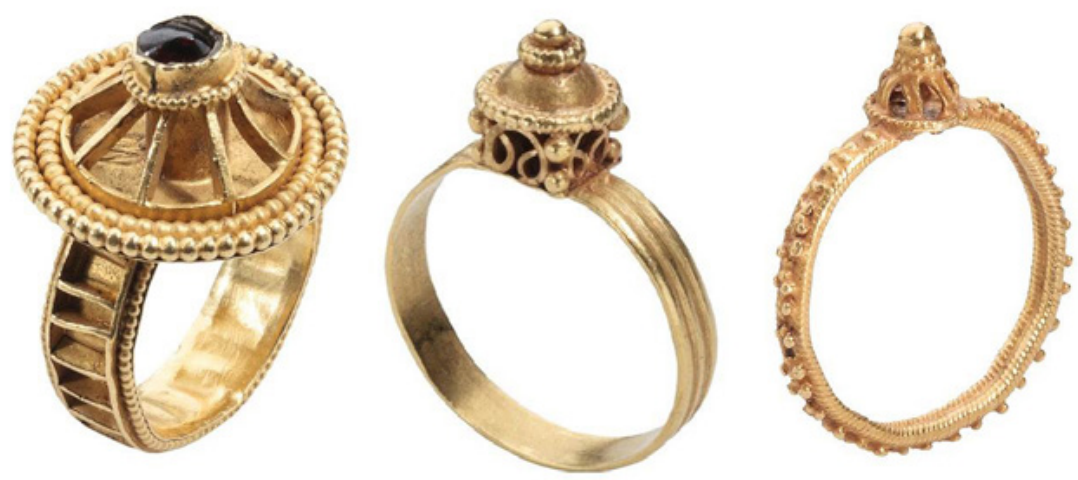

Il. 2. Merowiński pierścień z kolekcji Benjamina Zuckera, ok. 500 r. (pochodzenie: Francja), $w$ depozycie Walters Art Museum, Baltimore, 1985-2013, www.lesenluminures.com/inventory/expo-35291/merovingian-cloisonne-architectural-ring-22770 [dostęp: 02.02.16].

Il. 3. Merowiński pierścień z kolekcji Benjamina Zuckera, koniec VI - początek VII w. (pochodzenie: Francja, Gaul), w depozycie Walters Art Museum, Baltimore, 1985-2013, www.lesenluminures.com/inventory/expo-35291/merovingian-architectural-ring-22771 [dostęp: 02.02.16].

Il. 4. Merowiński pierścień z kolekcji Benjamina Zuckera, koniec VI - początek VII w. (pochodzenie: Francja, Gaul), w depozycie Walters Art Museum, Baltimore, 1985-2013, www.lesenluminures. com/inventory/expo-35291/merovingian-architectural-ring-with-a-beaded-hoop-22778 [dostęp: 02.02.16].

wieżami i murami”", a owa korona - jak podaje dalej autor - wskazywać ma na „ozdobność i dostojność Miast, Krain, Zamków i Miasteczek”5). Corona muralis nie jest przy tym wyłącznie atrybutem bogiń czy personifikacji w starożytnym Rzymie była, obok korony vallaris czy korony castrensis, nagrodą dla oficera legionów, który pierwszy pokonał obwarowania obleganego miasta. Świadectwem tej tradycji są wizerunki rzymskich cesarzy na monetach bitych z okazji odniesionych zwycięstw, na których to monetach występują korony z wieżami i murami obronnymi (muralis) czy palisadą (vallaris).

Formy architektoniczne w damskiej biżuterii pojawią się po raz pierwszy w czasach dynastii merowińskiej (481-751). W wielu muzeach na całym świecie przechowywane są pierścienie odnalezione w grobowcach kobiet,

${ }^{4}$ C. Ripa, Ikonologia, tłum. I. Kania, Kraków 1998, s. 49.

5 Ibidem, s. 51. 
datowane na V-VII wiek, których prosta obrączka dekorowana jest obiektem przypominającym budowlę na planie centralnym. Trzy ciekawe obiekty o różnym stopniu skomplikowania dekoracji znajdują się w prywatnej kolekcji Benjamina Zuckera ${ }^{6}$ prezentowanej w październiku i grudniu 2014 roku w galerii Les Enluminures w Nowym Jorku, Paryżu i Chicago na wystawie pod tytułem Cycles of Life: Rings from the Benjamin Zucker Family Collection.

Autorzy katalogu wystawy wywodzą architektoniczną formę dekoracji prezentowanych artefaktów z kształtu baptysterium lub relikwiarza, choć żaden z merowińskich pierścieni nie ma inskrypcji, które mogłyby potwierdzić ich związek z chrześcijańską symboliką ${ }^{8}$. Cylindryczna forma dekorująca obrączkę nie została do dziś zidentyfikowana w sposób jednoznaczny. Nie udało się też przekonująco uzasadnić jej symbolicznego znaczenia, odczytywanego w kontekście zaślubin jako wyobrażenie domu czy Domu Bożego, podobnie jak w przypadku żydowskich pierścieni zaślubinowych. Niektórzy badacze, na przykład Diana Scarisbrick ${ }^{9}$, uważają, że jest to jedynie rodzaj zdobienia bez żadnej symbolicznej funkcji.

W British Musem znajdują się też dwa późniejsze nieco od merowińskich pierścienie $\mathrm{z}$ wyobrażeniem architektury (British Museum, nr inwentarza: AF.482 i 1872,0604.245), znalezione na terenie Lombardii, których datowanie przypada na VI-VIII wiek. Choć przedstawienie budowli na obrączce tych - prawdopodobnie ostrogockich lub wczesnobizantyńskich - pierścieni wyraźnie kojarzy się z formą świątyni, także i w tym przypadku nie udało się jednoznacznie potwierdzić jej symbolicznego znaczenia.

Pierścienie z wizerunkiem budowli, której funkcja symboliczna nie budzi wątpliwości, zaczynają się pojawiać dopiero od XIII stulecia ${ }^{10}$. Jako pierścienie rytualne służyć one będą społeczności żydowskiej. Najpiękniejszym

${ }^{6}$ www.artstolife.com/arts-to-life/benjaminzucker.php [dostęp: 2.02.15].

7 www.lesenluminures.com/exhibitions/cycles-of-life-rings-from-the-benjamin-zucker-family-collection-22534 [dostęp: 9.02.15].

8 www.lesenluminures.com/inventory/expo-35291/merovingian-architectural-ring-22771 [dostęp: 9.02.15]

9 D. Scarisbrick, Rings. Symbols of Wealth, Power and Affection, London 1993.

10 The Ring: from Antiquity to the Twentieth Century, ed. A. Ward, J. Cherry, C. Gere, B. Cartiridge, London 1981, s. 104. 

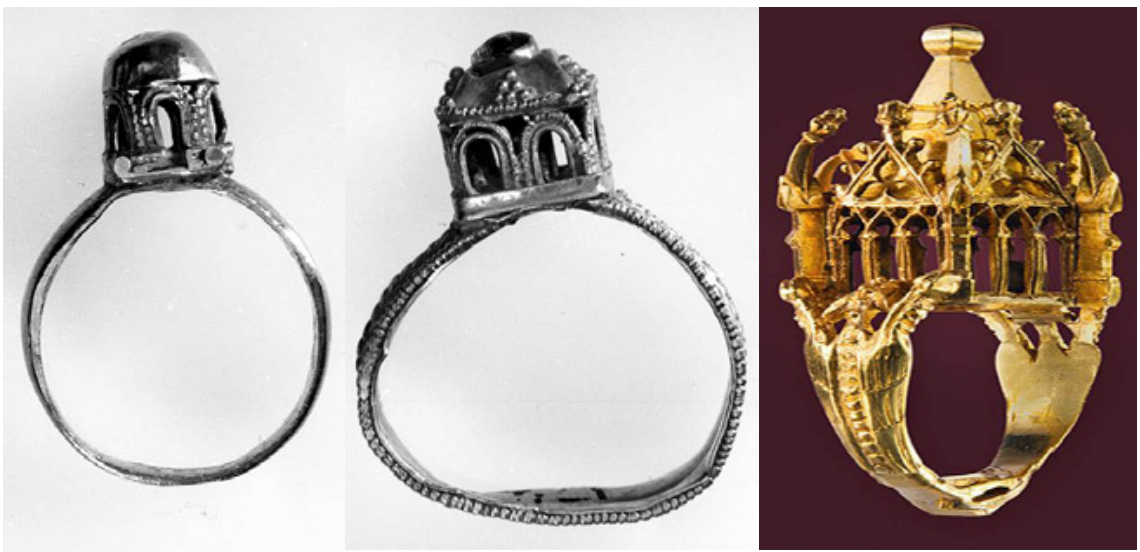

Il. 5. Architektoniczny pierścień lombardzki (?), wczesnobizantyński (?), British Museum, nr inwentarza: 1872,0604.245, VI-VIII w. (miejsce odnalezienia: Lombardia), www.britishmuseum.org/research/collection_online/collection_object_details.aspx?objectId=89912\&par$\mathrm{tId}=1 \&$ searchText $=$ finger+ring\&images $=$ true $\&$ museumno $=1872,0604.245 \&$ page $=1$ [dostęp: 2.02.16].

Il. 6. Architektoniczny pierścień ostrogocki (?), wczesnobizantyński (?), British Museum, nr inwentarza: AF.482, VI-VII w. (miejsce znalezienia: Lombardia, Mediolan), www.britishmuseum.org/research/collection_online/collection_object_details.aspx?objectId=94461\&par$\mathrm{tId}=1 \&$ searchText=finger+ring\&images $=$ true \&museumno $=\mathrm{AF} .482 \&$ page $=1$ [dostęp 2.02.16]. Il. 7. Pierścień rytualny ze skarbu z Erfurtu, sprzed połowy XIV w., http://juedisches-leben. erfurt.de/jl/en/middle-ages/erfurt_treasure/finds/index.html [dostęp: 29.12.12].

przykładem takiego obiektu jest gotycki pierścień odnaleziony w 1998 roku podczas prac archeologicznych w centrum Erfurtu wśród przedmiotów należących do tak zwanego Skarbu Zadżumionych, zakopanego w roku 1349¹1.

Watro wspomnieć, że zaślubinowy pierścień żydowski jest ważnym elementem symbolicznym ceremonii zawarcia związku małżeńskiego w tradycji judaistycznej. Pan młody obdarowuje nim pannę młodą, wypowiadając słowa: „Oto jesteś mi poświęcona tym pierścieniem”. Nałożenie go na wskazujący palec prawej dłoni oblubienicy rozpoczyna obrzęd zaślubin. Kształt pierścienia, nawiązujący do prostego domu lub bogato dekorowanej świątyni, ma dwojakie znaczenie. Po pierwsze, wskazuje na cel zawarcia związku małżeńskiego, którym jest zbudowanie domu, rozumianego jako symbol

${ }^{11}$ M. Campbell, Treasures of the Black Death, ed. C. Descatoire, London 2009. 
więzi rodzinnej (pierścień najczęściej opatruje się inskrypcją z życzeniem szczęścia: „Mazel Tow!”). Po drugie, bogato zdobiona budowla dekorująca pierścień jest też wyobrażeniem świątyni jerozolimskiej, o której, zgodnie z żydowską tradycją, zawsze należy pamiętać.

Pierścienie, o których mowa, noszono od czasów średniowiecznych. Wykonywane były zazwyczaj z materiałów szlachetnych, bez kamieni. Miały mniej lub bardziej rozbudowaną formę, choć niektórzy rabini zalecali prostotę, mającą symbolizować równość wszystkich wobec prawa.

W Muzeum Wiktorii i Alberta w Londynie znajduje się pokaźny zbiór żydowskich pierścieni datowanych od XVI do XIX wieku, a pochodzących z bogatej kolekcji pozyskanej w 1871 roku od Edmunda Watertona. Proweniencja wspomnianych artefaktów nie jest pewna, przypuszczalnie jak podawał właściciel - miejscem ich powstania były Włochy. Niektórzy badacze, analizując cechy ich stylu (bogatą dekorację z barwnej emalii), wskazują na warsztaty weneckie ${ }^{12}$.

Już w XV wieku żydowskie pierścienie zaślubinowe z domem lub świątynią Salomona - jak pierścień z Erfurtu - mają dodany motyw splecionych dłoni pochodzący z dekoracji pierścieni typu fede, obecnych w Europie od czasów starożytnych $^{13}$. Na marginesie warto też zauważyć, że w XIX wieku ich dekoracja zdradza zapożyczenia z biżuterii europejskiej, zwłaszcza sentymentalnej - z zaręczynowych pierścionków z motywem turkusowej niezapominajki, popularnych w wiktoriańskiej Anglii (angielskie forget-me-not).

Sygnalizując jedynie szeroki temat przemian stylowych w pierścieniach żydowskich, nie można nie wspomnieć o jednym z najciekawszych obiektów znajdujących się w Muzeum Wiktorii i Alberta (nr inwentarza: M.35-1939). Pierścień, o którym mowa, zaprojektowany został przez Charlesa Rickettsa (1866-1931), a wykonany przez londyńskiego jubilera Carlo Giuliano (1826-1895) w latach 1899-1903 dla artystki May Morris, córki Williama Morrisa. Dzieło to w niezwykle interesujący sposób łączy stylistykę średniowiecza (obsadzenie kaboszonu z granatu) i rytualnego pierścienia żydowskiego (budowla).

12 The Ring: from Antiquity to the Twentieth Century, op. cit., s. 104.

${ }_{13}$ Na temat pierścieni typu fede zob. M. Wrześniak, Dextrarum iunctio - rzecz o znaczeniu ślubnego pierścienia, „Fides et Ratio” 2015, nr 4(24), s. 12-31, www.stowarzyszeniefidesetratio.pl/kwartlnik24.html [dostęp: 2.02.16]. 

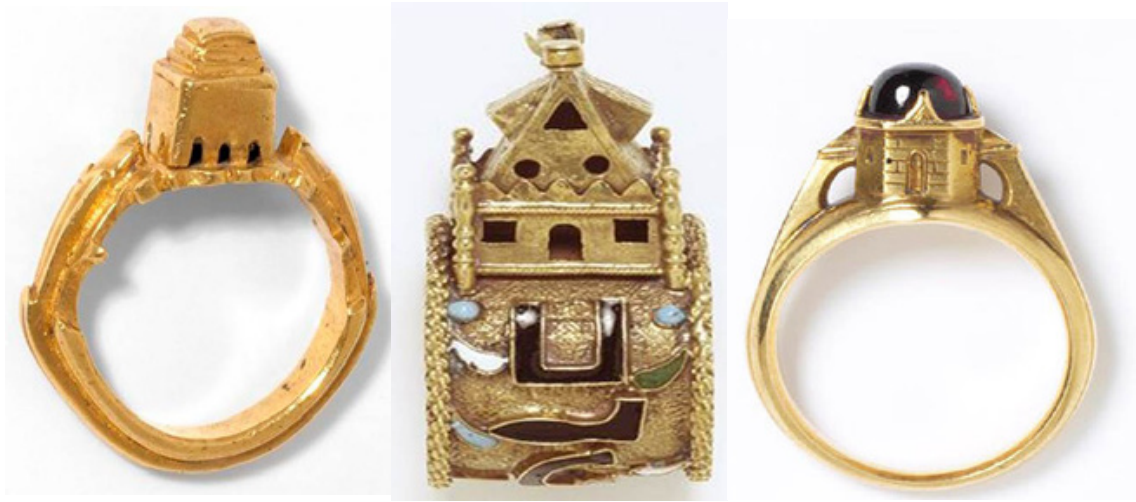

Il. 8. Żydowski pierścień zaślubinowy, VéA Museum, Londyn, nr inwentarza: 863-1871, http://collections.vam.ac.uk/item/O72510/ring-ring/ [dostęp: 2.02.16].

Il. 9. Żydowski pierścień zaślubinowy, VßA Museum, Londyn, nr inwentarza: 866-1871, http:// collections.vam.ac.uk/item/O374198/ring-unknown/ [dostęp: 2.02.16].

Il. 10. Pierścionek May Morris, córki Williama Morrisa, 1899-1903, projekt: Charles Ricketts (1866-1931), złotnik: Carlo Giuliano (1826-1895), nrinwentarza: M.35-1939, http://collections. vam.ac.uk/item/O76591/ring-ricketts-charles-de/ [dostęp: 2.02.16].

Mówiąc o związkach architektury i biżuterii, nie można pominąć znaczącej grupy obiektów wykonanych w technice mosaico minuto romano rzymskiej mikromozaiki, której pojawienie się w biżuterii znawczyni tematu, Maria Grazia Branchetti ${ }^{14}$, datuje na 1775 rok. Wtedy to po raz pierwszy Giacomo Raffelli ${ }^{15}$ zaprezentował w swoim warsztacie w Rzymie

${ }_{14}$ M. Branchetti, L'Arte del mosaico minuto: una technica e il suo tempo, [w:] M. Alfieli, M. Branchetti, G. Corini, Mosaico minuto Romano del 700 e del'800, Roma 1986, s. 21-25. Autorka powołuje się na wydawany w latach 1840-1861 Dizionario di Edudizione Storico-Ecclesiastica Giovanniego Moroni, który podaje rok 1775 jako datę eksponowania pierwszych obiektów biżuterii z mikromozaiką autorstwa Giacoma Rafellego. Zob. G. Moroni, Dizionario di Edudizione Storico-Ecclesiastica, t. 47, Venezia 1846, s. 78.

15 Więcej na temat Giacoma Raffellego, zob. B. Iwaszkiewicz-Wronikowska, Giacomo Raffelli (1753-1836) doradca króla Stanisława Augusta, [w:] Polak we Włoszech, Włoch w Polsce. Sztuka i historia, red. M. Wrześniak, A. Bender, Warszawa 2015, s. 249-256. 
ozdoby dekorowane smalti filati ${ }^{16}$. Mozaiki z mikroskopijnych tesser, których produkcję na wielką skalę rozpoczęły na przełomie XVIII i XIX wieku działające od końca XVI stulecia watykańskie warsztaty, służyły przede wszystkim zdobieniu drobnych przedmiotów użytkowych, takich jak tabakiery, puszki i szkatułki, będące często darami papieża dla znamienitych gości Watykanu ${ }^{17}$. W tym czasie, to jest w XIX stuleciu, zaczęto wykonywać na masową niemal skalę biżuterię złotą, srebrną, a nawet $\mathrm{z}$ metali nieszlachetnych, zdobioną mikromozaiką. Jak podaje Branchetti, ikonografia owych ozdób miała źródła w niedawno podówczas odkrytych freskach pompejańskich i znakomicie wpisywała się w umiłowanie starożytności, jakie cechowało epokę neoklasyczną. Obok tematów mitologicznych, przedstawień zwierząt i roślin, w pierwszej połowie XIX wieku największą popularnością cieszyły się ozdoby dekorowane widokami starożytnych ruin Rzymu. Obiekty te były szczególnie pożądane przez podróżników odwiedzających Wieczne Miasto ${ }^{18}$, którzy zaopatrywali się w pamiątki w warsztatach przy Piazza di Spagna ${ }^{19}$. Biżuteria z mosaico minuto romano stała się - ze względu na niski koszt wykonania - popularną specjalnością rzymską, którą już w 1810 roku prezentowano na wystawie rzemiosła rzymskiego na $K_{\text {Kapitolu }}{ }^{20}$. Właśnie owa popularność wśród podróżników stanie się z czasem - jak twierdzi Massimo Alfieri - przyczyną degradacji tej pracochłonnej techniki i ostatecznego jej upadku z początkiem minionego stulecia ${ }^{21}$.

16 Zob. M. Branchetti, op. cit., s. 21. Na temat techniki mikromozaiki zob. eadem, I mosaici minuti romani dei secoli XVIII e XIX, Roma 1981; The Gilbert Collection. Micromosaics, ed. J.H. Gabriel, London 2000.

${ }_{17}$ M. Branchetti, L'Arte del mosaico..., op. cit., s. 23. Zob. też: Ch. Gere, J. Rudoe, Jewellery in the Age of Queen Victoria. A Mirror to the World, London 2010, s. 409-411.

18 Wspomina o tym zjawisku E. Letkiewicz: Nie tylko Grand Tour. Biżuteryjne pamiątki zXIX wiecznych podróży, [w:] Ciało, strój, biżuteria w kontekście przemian kulturowych, społecznych i politycznych XIX wieku, red. E. Letkiewicz, Lublin 2015, s. 309.

19 M. Branchetti, L'Arte del mosaico..., op. cit., s. 25.

20 Mostra capitolina delle arti e dell'industria romana, „Giornale Giornale del Campidolio" 1810, nr 114, s. 407. Por. M. Branchetti, L'Arte del mosaico... op. cit., s. 25. ${ }_{21} \mathrm{M}$. Alfieli, Il progetto espositivo ed il progetto dell'Alessimento, [w:] M. Alfieli, M. Branchetti, G. Corini, Mosaico minuto Romano del 700 e del'800, Roma 1986, s. 38. 


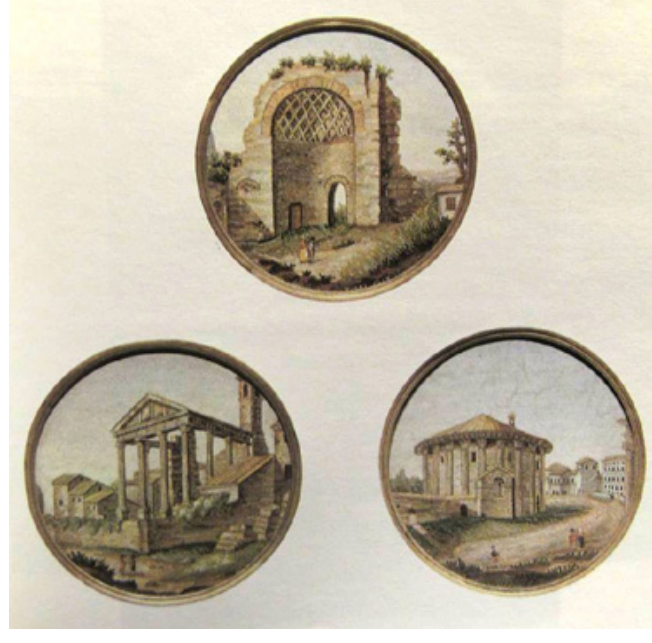

Il. 11. Mikromozaika rzymska (kolekcja prywatna, Rzym). M. Alfieli, M. Branchetti, G. Corini, Mosaico minuto Romano del 700 e del'800, Roma 1986, fig. 130-131, s. 130.

Jak podaje wspomniany autor, biżuteria i drobne przedmioty dekorowane mikromozaiką, nierzadko z wyobrażeniem starożytnej (ruin Forum Romanum, piramidy Cestiusza, Panteonu, Koloseum) lub nowożytnej architektury Wiecznego Miasta (Bazyliki św. Piotra), uosabiającej Romę Pogańską lub Romę Chrześcijańską, w ostatniej ćwierci XIX wieku stają się obiektami bardzo niskiej klasy artystycznej. Brosze, bransolety, naszyjniki czy kolczyki, zdobione wykonywanymi masowo plakietkami z mikromozaiki z coraz większych podłużnych tesser, z czasem utracą swój szeroki (jeszcze w pierwszej połowie XIX wieku) repertuar tematów. W XX stuleciu zostanie on ograniczony tylko do kilku popularnych motywów wykorzystywanych do dziś - przeważnie wizerunków młodej dziewczyny - pracochłonne zaś przedstawienia rzymskiej architektury, które interpretowano jako symbol zwiedzanego miasta, odejdą niemal w niepamięć. Warto zwrócić uwagę na fakt, że to właśnie tym popularnym obiektom zawdzięczamy początek postrzegania biżuterii $z$ wizerunkiem architektury jako symbolu miasta postrzegania i dziś powszechnie obecnego (o czym będzie mowa w dalszej części niniejszego opracowania), jednakże w większości wypadków związki architektury i sztuki jubilerskiej ograniczają się tu wyłącznie do odtworzenia obiektu architektonicznego w dziele złotniczym, bez jego artystycznego, kreatywnego przetworzenia.

W latach 80. XX wieku architektura pojawia się w biżuterii w zupełnie nowej odsłonie. Pierwszym twórcą wykorzystującym tego rodzaju motywy w biżuterii - szczególnie w pierścieniach - był florencki złotnik Alessandro 


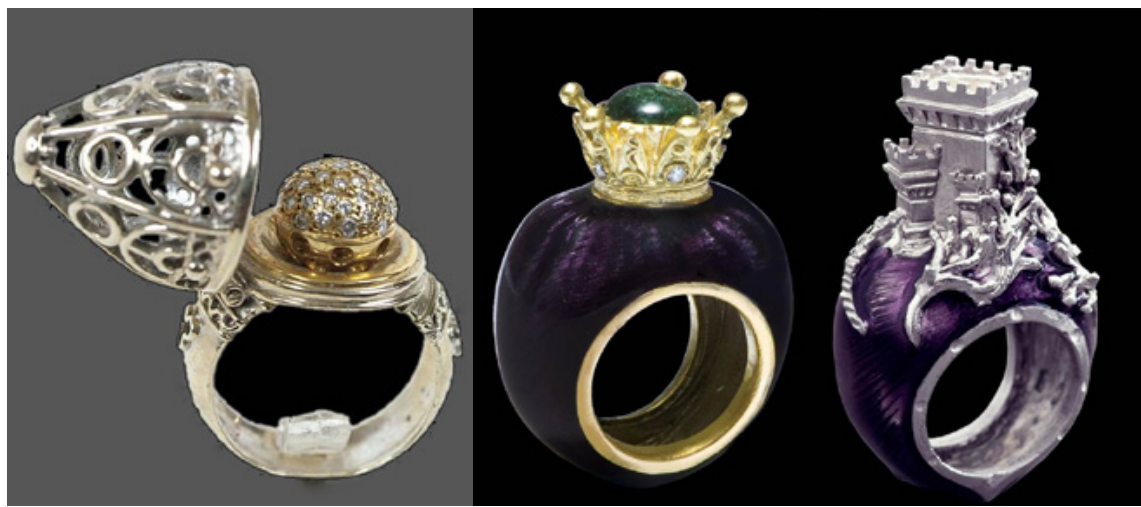

Il. 12. Pierścień Santa Maria del Fiore z kolekcji Kościoły, www.alessandrodari.com/ita-dettaglio-interno.php?idProd=142\&idCat=8 [dostęp: 10.06.15].

Il. 13 i 14. Pierścienie z kolekcji Miłość (korona, symbolizująca pierwiastek duchowy, odnosi się do kobiety; wieża - symbolizuje stabilność mężczyzny), www.alessandrodari.com/ ita-dettaglio.php?idCat=2 [dostęp: 10.06.15].

Dari $^{22}$, który do dzisiaj wykonał ponad dziewięćset prac inspirowanych między innymi architekturą, zwłaszcza z terenów Italii.

W początkowej fazie twórczości, w kolekcjach Korony ${ }^{23}$ i Kościoły artysta posługiwał się zgeometryzowaną i silnie uproszczoną formą stanowiącą syntezę architektury gotyckich kościołów Toskanii. Starał się oddawać istotę danej budowli, wykorzystując tylko jeden z jej elementów. Pojawiały się kopuły, okna i inne detale, które Dari odkrywał w architekturze Veneto (kolekcja Wenecja). W Kościołach budowla sakralna staje się syntezą elegancji, wiary i harmonii. Biżuteria jest dla Dariego symbolem ducha i integralności moralnej, dlatego też na przykład pierścień Santa Maria del Fiore, inspirowany formą florenckiego Duomo, nie wyobraża realnej budowli, lecz jej istotę - najważniejsze symboliczne znaczenie, jakim jest wiara, tutaj sym-

22 Pierwsza publikacja na temat Alessandra Dariego zob. M. Wrześniak, Ukryte treści biżuterii Alessandra Dariego, [w:] O rzeczach pięknych: rzemiosło artystyczne na przestrzeni wieków, red. A. Bender, M. Wrześniak, Lublin 2016.

${ }^{23}$ Od 1991 roku powstaje wspominana już kolekcja Korony. Warto nadmienić, że większość obrączek z tej kolekcji to miniaturowe korony nawiązujące formą do starożytnych koron muralis, vallaris i castensis. 

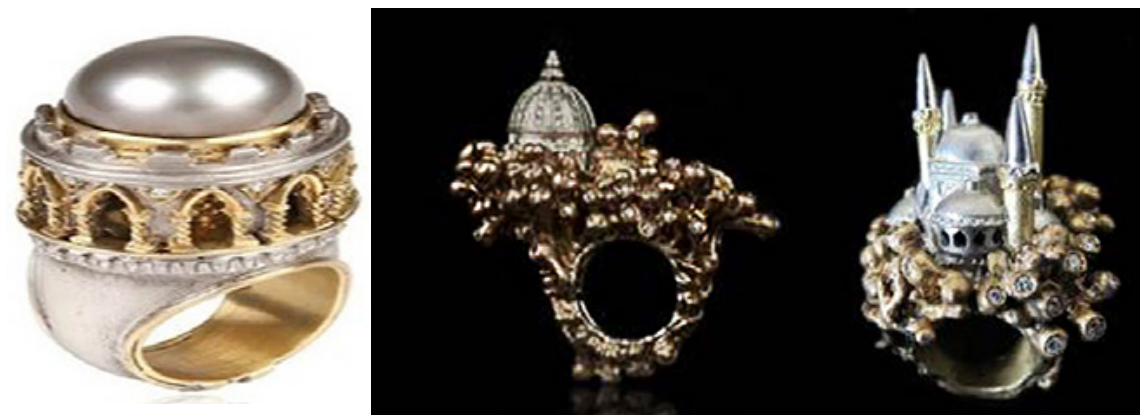

Il. 15. Pierścień Pia de Tolomei z kolekcji Giardino dell'anima, https://pl.pinterest.com/ pin/11681280253221511/ [dostęp: 10.06.15].

Il. 16 i 17. Pierścienie z kolekcji Kościoły (fot. ze zbiorów autorki).

bolizowana przez kameryzowaną brylantami kulę. Kopuła Brunelleschiego stanowi zatem wizualizację kościoła, którego skarbem jest światło wiary, wyrażone przez połyskujące kamienie.

Architektura, zwłaszcza wertykalizm łuku ostrego, oznacza dla Alessandra Dariego duchowy element, pierwiastek świętości. Z kolei w kolekcji Miłość ${ }^{4}$ wieża symbolicznie odnosi się do mężczyzny, oznaczając jego stabilność, siłę i ochronę, jaką zapewnia kobiecie.

Warto wspomnieć ponadto o pierścieniu dedykowanym Pii di Tolomeo wspomnianej w V pieśni Czyśćca z Boskiej komedii Dantego żonie Balda d'Aldobrandino de' Tolomei, właściciela Castel di Pietra w Maremma. Legendarna historia Pii nawiązuje do wydarzenia z końca XIII wieku, którego esencję stanowi splot miłości, zdrady i śmierci. Kobieta miała się zakochać w przechodzącym w pobliżu jej domu mężczyźnie, co stało się powodem wypchnięcia jej przez okno przez niedawno poślubionego małżonka. W pierścieniach dedykowanych Pii Alessandro Dari pod kamieniem lub perłą - stanowiącymi odwołanie do nazwy zamku Balda (wł. pietra 'kamień') - umieszcza rząd gotyckich okien, które symbolizują miłość i śmierć jednocześnie ${ }^{25}$.

${ }^{24}$ Alessandro Dari - Gioielli, www.alessandrodari.com/ita-dettaglio.php?idCat $=2$ [dostęp: 15.05.14].

25 www.alessandrodari.com/ita-dettaglio-interno.php?idProd=111\&idCat=12 [dostęp: 12.02.15]. 
Biżuteria $\mathrm{z}$ formami architektonicznymi, jaka wychodzi spod ręki Alessandra Dariego, nawiązuje do budowli na trzy sposoby. Pierwszy z nich to daleka inspiracja, która owocuje syntetyczną wizją architektury, jak w pierwszej kolekcji Kościoły. Drugi to inspiracja elementem architektury, na przykład gotyckim łukiem ostrym, zwłaszcza w kolekcji Wenecja. Trzeci to symboliczne znaczenie wieży, zamku, warowni jako odzwierciedlenia kobiecości lub męskości. Wreszcie, Dari wykorzystuje arcydzieła światowej architektury jako element dekoracyjny, ale przede wszystkim jako symbol miast, w których się znajdują (żeby wspomnieć tylko dwa przykłady: kopułę św. Piotra na Watykanie i kościół Hagia Sophia w Stambule). Nie jest to jednak tylko naśladownictwo formy architektonicznego obiektu, bowiem połączenie rzeczywistej architektury, ujętej w mikroskali, ze stosowanym często przez artystę koralowcem, który symbolizuje dlań płodność, należy rozumieć jako przedstawienie idei miasta - ośrodka o zdolnościach kreacyjnych, zwłaszcza w sferze kultury.

W latach 80. XX wieku powstała pracownia drugiego wybitnego florenckiego mistrza złotnictwa - Paola Penko, który stworzył bardzo interesującą kolekcję biżuterii nawiązującej do dzieł sztuki (w tym architektury) ${ }^{26}$. Szczególnie ciekawe z perspektywy niniejszego studium realizacje to obiekty $\mathrm{z}$ kolekcji Gioielli nell'Arte (dall'Architettura) ${ }^{27}$. Złotnik inspiruje się ornamentami mozaikowymi fasady kościoła Santa Maria Novella i Tempietto San Sepolcro, które przenosi na ażurowe formy zawieszek, oraz boniowaną fakturą fasad florenckich pałaców: Palazzo Rucellai, Palazzo Medici-Ricardi i Palzzo Pitti. Plakietki-zawieszki Paola Penko, wykorzystującego jeden tylko element architektury, stają się niemal abstrakcyjnymi obiektami, o których urodzie decyduje różnorodność faktury, służące zaś za ich wzór dzieła architektoniczne traktowane są jedynie jako pretekst do powstania interesujących realizacji, niebędących w żadnym razie kopiami budowli już

26 A. Valentini, Penko - Paolo Penko, [w:] Gioiello contemporaneo due, red. O. Casazza, Firenze 2010; dostępne na stronie: www.penkofirenze.it/ita/bottega/ dicono_dinoi.html [dostęp: 28.04.16].

27 Obiekty prezentowane na stronie Paola Penko: www.penkofirenze.it/ita/ collezioni/architettura8.html [dostęp: 27.04.16]. 

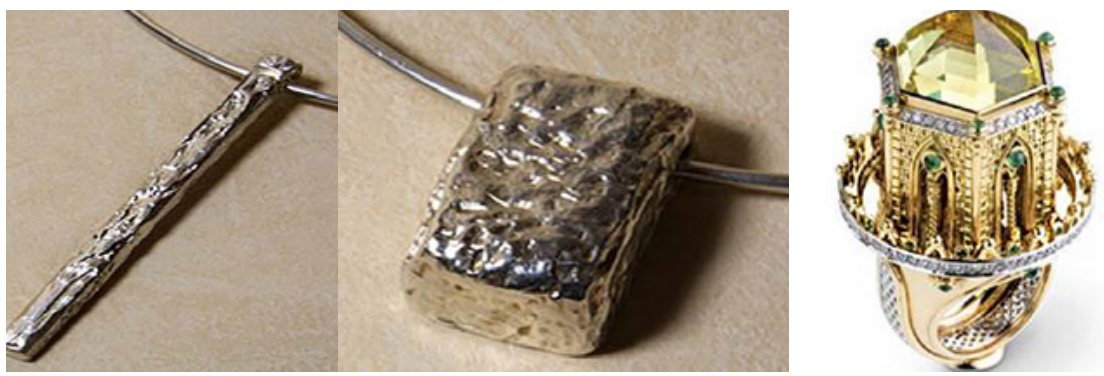

Il. 18 i 19. Paolo Penko, Kamienie z fasady Palazzo Pitti, www.penkofirenze.it/ita/collezioni/ architettura5.html [dostęp: 27.04.16].

Il. 20. Jean Boggio, Ravenna, https://pl.pinterest.com/pin/456833955926779238/ [dostęp: 3.04.17].

istniejących, a źródłem zupełnie nowej jakości ${ }^{28}$. Jest to widoczne zwłaszcza w przypadku kamieni $\mathrm{z}$ fasady Palazzo Pitti, które skopiowane zostały jako prosta, oszczędna w formie zawieszka. Ów minimalizm kryje zaś romantyczną legendę pewnego florenckiego kuriozum. Otóż w fasadzie wspomnianego pałacu znajdują się obok siebie najdłuższy i najkrótszy kamień. Pierwszy, długości blisko 11 metrów, i drugi - 33 centymetrów. Przyjmuje się, że pierwszy właściciel Palazzo Pitti, Luca Pitti, miał nakazać wmurowanie kamieni, których symboliczne znaczenie odnosiło się do niego samego, jako największego pośród florenckiej szlachty, oraz jego wrogów, którzy zostali zmarginalizowani ${ }^{29}$.

Wśród działających poza Florencją artystów, którzy wykorzystują formy architektoniczne we współczesnej biżuterii luksusowej, prym wiodą: działający we Francji Jean Boggio, Brytyjczyk Theo Fennel i pracujący w Istambule Sevan Biçakçi, których realizacje można zaliczyć do wspólnego zbioru bardzo bogatych form nawiązujących do konkretnej architektury, urozmaiconej

${ }^{28}$ Na charakter kreacji Paolo Penko, łączącej dawne techniki i wzory ze współczesną wrażliwością i nowoczesnym, minimalistycznym gustem, zwraca uwagę autorka katalogu wystawy biżuterii współczesnej, Ornella Casazza: Gioiello contemporaneo, op. cit., s. 80.

29 D. Macchiaveli, L'enigma della facciata di Palazzo Pitti, „Firenze Today” z 11 grudnia 2014 r., www.firenzetoday.it/cronaca/enigma-facciata-palazzo-pitti. html [dostęp: 27.04.16]. 
dodatkowymi elementami kreującymi atmosferę baśniowego przepychu. Dzieła pierwszego z nich są wyraźnym zapożyczeniem z twórczości Alessandra Dariego. Niektóre obiekty można by uznać nawet za kopie dzieł Dariego, jak na przykład pierścień Rawenna, stanowiący wyraźne nawiązanie do pierścieni dedykowanych Pii de Tolomei. Jednakże pracujący w Lyonie Boggio ${ }^{30}$ tworzy magiczny, kolorowy świat dekoracji pozbawionych symbolicznego podtekstu (w przeciwieństwie do florenckiego mistrza). Świat zabawny, radosny, wypełniony tańczącymi postaciami, wirującymi karuzelami, błyskotkami i obiektami architektury, które stanowią wyobrażenie bajkowego zamku w cudownym ogrodzie ${ }^{31}$ (pierścienie z serii Ogród rozkoszy). Francuski projektant inspiruje się przy tym często konkretnymi obiektami architektury, nie kopiuje jednak bezpośrednio ich form, oddając jedynie ogólne wrażenie architektonicznej formy budowli (pierścienie $\mathrm{Ca}^{\text {' }}$ d'Oro lub Willa Palladiańska).

Podobne w wyrazie są kreacje Theo Fennella ${ }^{32}$, którego warsztat rozpoczął działalność w Londynie w 1982 roku, by wkrótce otworzyć filie w największych domach towarowych Anglii, nie wyłączając najbardziej ekskluzywnego - Harrodsa. Wśród artystycznych inspiracji angielskiego artysty pojawia się architektura jako - można powiedzieć - baza projektu, który ma kilka odsłon albo warstw znaczeniowych. Pomijając bezpośrednie nawiązania do takich arcydzieł architektury, jak Koloseum czy egipskie piramidy ${ }^{33}$, obiekt architektoniczny, zwłaszcza mur obronny lub warownia, służy artyście do zorganizowania niewielkiego, drogocennego przedmiotu

${ }^{30}$ www.joailliers-createurs.com/joaillier_jean_boggio.html [dostęp: 2.02.15].

${ }^{31}$ Juliet de La Rochefoucauld pisze na ten temat w tekście: Multidisciplinary Artist and Jeweller Jean Boggio Casts a Magic Spell on Everything He Touches, www. thejewelleryeditor.com/2014/09/jean-boggio-artist-and-jeweller-paris/ [dostęp: 12.02.15].

32 Theo Fennell - artysta brytyjski urodzony w Egipcie, studiował w The Byam Shaw (obecnie Central Saint Martin's College of Art and Design); www.theofennell. com/about-tf [dostęp: 28.04.16].

33 Zob. otwierany pierścień-piramidę z sarkofagiem i mumią wewnątrz i pierścień-koloseum z zabitym gladiatorem na arenie: www.theofennell.com/ unique-pieces/masterworks/18ct-yellow-gold-opening-colosseum-ring-with-slaingladiator-bespoke-box-and-magnifying-glass.html [dostęp: 28.04.16]. 

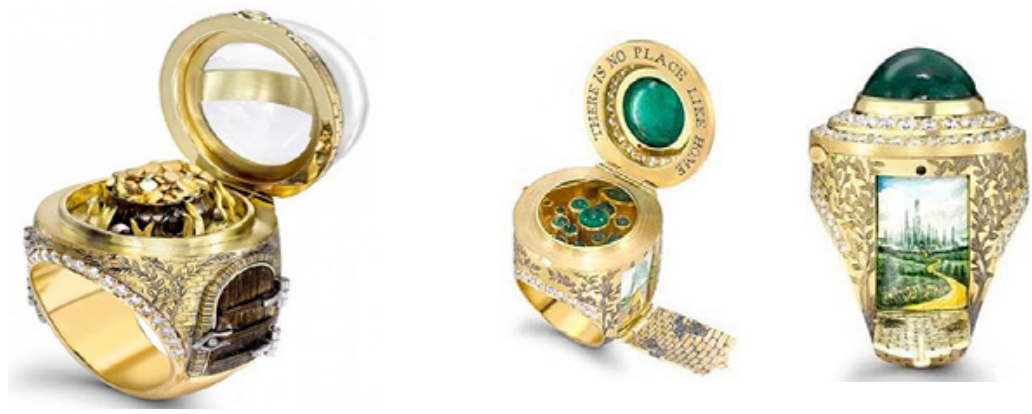

Il. 21. Theo Fennell, Na końcu tęczy, www.theofennell.com/over-the-rainbow-opening-ring. html [dostęp: 28.04.17].

Il. 22 i 23. Theo Fennell, Czarnoksiężnik z Krainy Oz, https://pl.pinterest.com/ pin/423831014908298972/ [dostęp: 28.04.16].

będącego syntezą bogactwa otaczającego nas świata lub świata wyimaginowanego o baśniowym rodowodzie. Artysta w swoich projektach posługuje się najczęściej metaforą muru skrywającego za bramą cudowny ogród. Stałym elementem pierścieni są bramy, wrota, mosty zwodzone, które po otwarciu odsłaniają tajemnicę - ogród, drogę czy jakieś cudowne miejsce. Pod drogim kamieniem, częstokroć dekorującym pokrywę puszki zdobiącej pierścień, znajdują się miniaturowe przedmioty nawiązujące do historii, którą pierścień ilustruje - jak garniec ze złotem w pierścieniu o wdzięcznej nazwie Na końcu tęczy czy szmaragdowy gród w pierścieniu inspirowanym historią Czarnoksiężnika z Krainy Oz. Można powiedzieć, że pierścienie Theo Fennella są mikrokosmosem zamkniętym w miniaturowej warowni lub skrywanym pod czaszą szklanej kuli, natomiast użycie motywów architektonicznych nie jest wyłącznie formalnym zabiegiem organizującym przestrzeń dzieła, ale przede wszystkim symbolicznym obrazem cudownego świata, do którego prowadzą miniaturowe drzwi - przypominające te, które wiodły do tajemniczego ogrodu z powieści Frances Hodgson Burnett (Secret Garden, wydana po raz pierwszy w 1911 roku w Londynie). Wystarczy tylko je otworzyć, aby przenieść się do krainy snów rodem z dziecięcych marzeń. Inspiracją dla brytyjskiego artysty nie jest konkretne dzieło, ale syntetyczna idea tajemniczego zamku, której źródeł należy szukać nie tylko w literaturze dziecięcej, ale i we wspomnieniach z dzieciństwa spędzonego 
przez artystę $\mathrm{w}$ Egipcie, Pakistanie i Singapurze ${ }^{34}$.

Do estetyki cudownego ogrodu rodem z Księgi tysiąca $i$ jednej nocy nawiązują również kreacje Sevana Biçakçiego, tureckiego artysty (z pochodzenia Ormianina) zwanego „jubilerem gwiazd"35. Stosując różne techniki złotnicze, a także zdobienie mikromozaiką, ceramicznymi polichromowanymi tesserami oraz intaglio w półszlachetnych kamieniach ${ }^{36}$, Biçakçi tworzy pierścienie z „zatopionymi” w kaboszonach wizerunkami obiektów sakralnych (szczególnie Hagii Sophii i Błękitnego Meczetu)

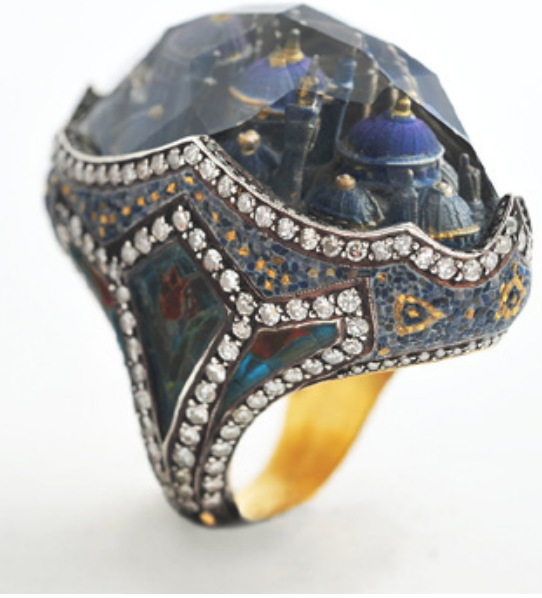

Il. 24. Sevan Biçakçi, Laleli Ring, www.nytimes.com/2014/12/05/style/international/ sevan-bicakcis-jewelry-celebrates-istanbuls -heritage.html?_r=0 [dostęp: 28.04.16]. czy świeckich (Topkapi Sarai)

Stambułu. Architektura jest tutaj tylko jednym z elementów zdobniczych nawiązujących do obecnej w mieście bizantyńskiej lub ottomańskiej spuścizny, która jest nieustającym źródłem inspiracji dla tureckiego jubilera ${ }^{37}$.

Obok tureckiego mistrza, najpopularniejszym artystą jubilerem wykonującym ozdobną mikroarchitekturę jest pracujący w Paryżu Philippe Tournaire $^{38}$, autor pierścieni-symboli miast. Najbardziej twórczymi realizacjami paryskiego artysty są kolekcje Archipolis i Metropolis, w których mia-

34 Biogram artysty zob. www.theofennell.com/about-tf [dostęp: 28.04.16].

35 www.sevanbicakci.com/\#!collection/cfvg [dostęp: 28.04.16].

${ }^{36}$ Sevan Biçakçi drąży w półszlachetnych kaboszonach w technice głębokiego intalio za pomocą dentystycznych wierteł. Zob. S. Fowler, Layers of History in Turkish Artistry. Sevan Bicakci's Jewelry Celebrates Istanbul's Heritage, „The New York Times" z 4 grudnia 2014 r. www.nytimes.com/2014/12/05/style/international/ sevan-bicakcis-jewelry-celebrates-istanbuls-heritage.html?_r=0 [dostęp: 28.04.16].

37 Ibidem.

38 www.philippetournaire.com/The-Tournaire-s-spirit,184.html [dostęp: 2.02.15]. 

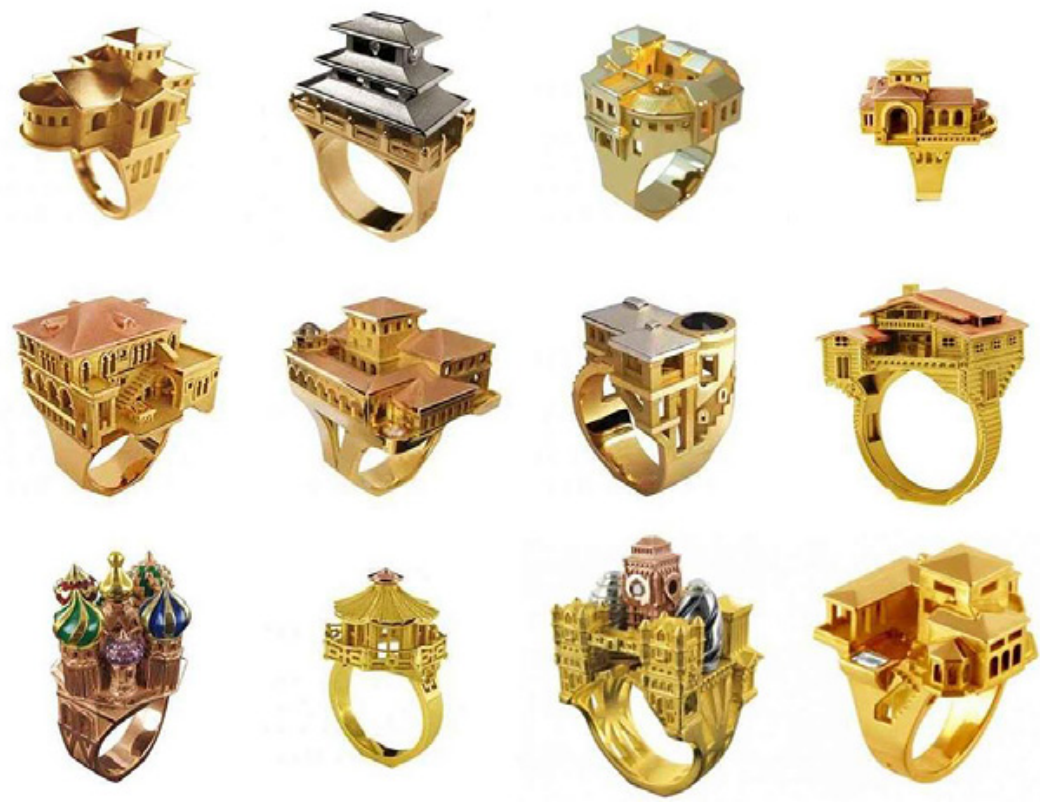

Il. 25. Pierścienie autorstwa Philippe’a Tournaire'a, www.philippetournaire.com [dostęp: 28.04.16].

sto zostało ujęte w syntetyczny obraz różnych budowli wykonanych ze złota i drogich kamieni (nie są to kopie konkretnych miast, lecz raczej synteza miasta, dająca odbiorcy ogólne wrażenie miejskiej aglomeracji w wersji mikro). Równie interesująca i twórcza jest kolekcja Świątynia miłości, w której artysta nawiązuje do form merowińskich pierścionków architektonicznych.

Warto też zwrócić uwagę na pierścionek o wdzięcznej nazwie Francuski pocałunek, w formie nawiązujący do odwróconej wieży Eiffla. Estetyka kreacji Philippe’a Tournaire’a jest oszczędna i prosta w porównaniu z dziełami wspominanych powyżej artystów, formy architektoniczne zaś zredukowane do minimum potrzebnego do rozpoznania obiektu. To ujęcie nowoczesne, bazujące jedynie na skojarzeniu $\mathrm{z}$ dziełem architektury, a pomijające drobne detale. Artysta wykorzystuje architekturę na dwa sposoby: jako element zdobniczy pierścienia symbolizujący miasto, w którym się znajduje, i jako element konstrukcyjny - jak we wspominanym pierścionku zaręczynowym, którego podstawę stanowi odwrócona wieża Eiffla. 

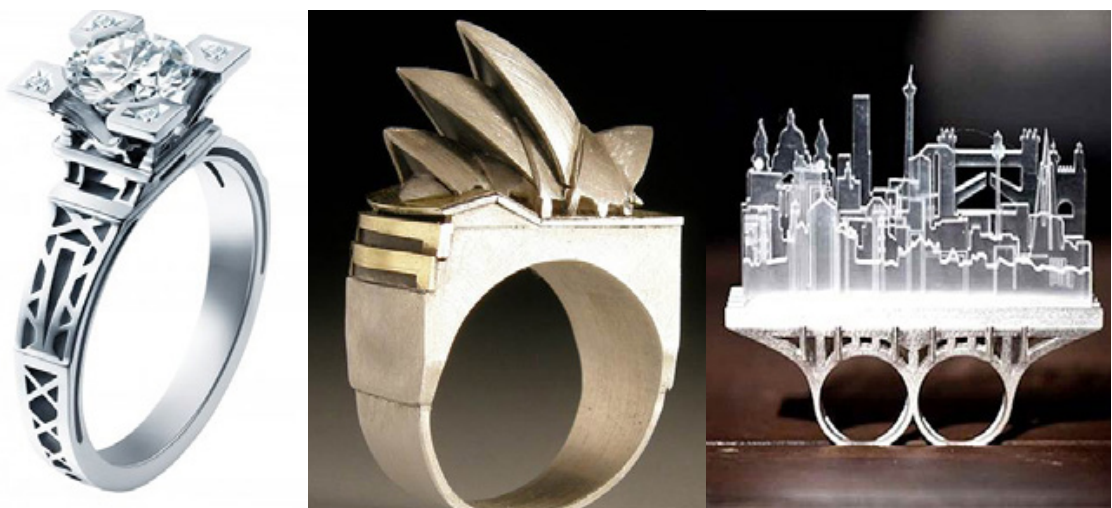

Il. 26. Philippe Tournaire, Francuski pocałunek, www.comitebellecour.fr/en/news/10_ french_kiss.html [dostęp: 28.04.16].

Il. 27. Vicky Ambery Smith, Opera, www.vickiamberysmith.co.uk [dostęp: 28.04.2016]. Il. 28. Bizuteria autorstwa Cristiny Elleni, http://christinaellenicox.com/\#/christinaelleni/ [dostęp: 28.04.16].

Podobne wykorzystanie mikroarchitektury odnajdujemy w biżuterii projektowanej przez brytyjską artystkę Vicky Ambery Smith, której realizacje to przede wszystkim mikrokopie sławnych obiektów. Pierścionki i broszki powstające w jej pracowni złotniczej są jeszcze bardziej oszczędne w formie, bardziej syntetyczne, niemal minimalistyczne. Sprzyja temu fakt, iż Smith chętnie inspiruje się nowoczesną architekturą.

Mikroarchitektura pojawia się obecnie w biżuterii na szeroką skalę, a oprócz konkretnych budowli, artyści chętnie inspirują się całymi ich zespołami. Za oceanem najchętniej wykorzystywanym motywem jest krajobraz miejski, a właściwie nagromadzone w nim obiekty. Wspomnieć należy o dwóch amerykańskich artystkach: Christinie Elleni, która tworzy w San Francisco płaską biżuterię ze srebra i pleksiglasu, wykorzystując kontur budowli charakterystycznych budowli miejskich, i Sharon Massey - amerykańskiej doktor sztuk pracującej na Indiana University of Pennsylvania, której kolekcja Streetview jest wizualizacją miejskich kamienic. Obie artystki interesuje właściwie tkanka miejska, której kontur wyznaczają różnej wysokości budowle, oświetlone bądź pozostające w cieniu. 

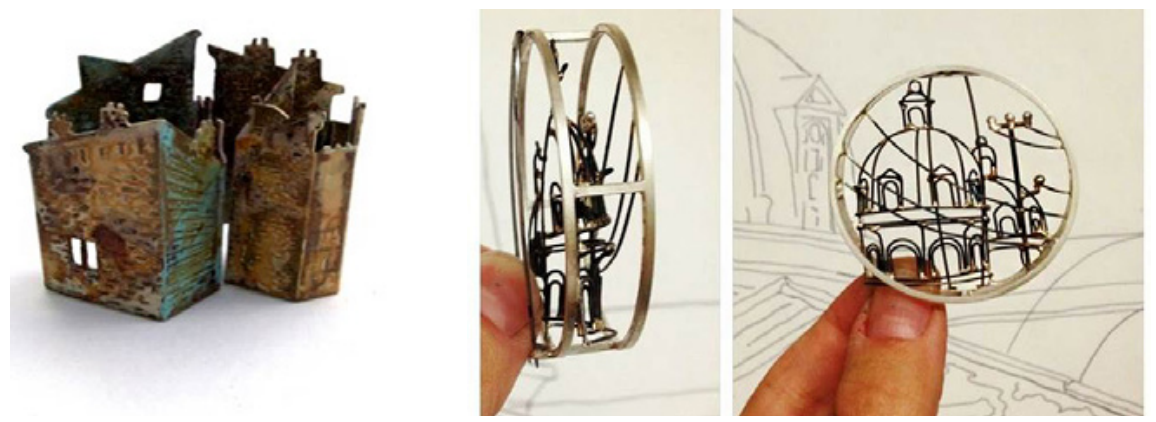

Il. 29. Bizuteria autorstwa Sharon Massey, www.sharon-massey.com/streetview/ [dostęp: 28.04.16].

Il. 30 i 31. Biżuteria autorstwa Caitie Sellers, www.caitiesellers.com/portfolio.html [dostęp: 30.04.16].

Miasto stanowi też inspirację dla prac amerykańskiej artystki Caitie Sellers, która tworzy kolekcje biżuterii z lutowanych drutów metalowych nawiązujących w swych kształtach do szkiców miejskich widoków.

Należy wspomnieć o jeszcze jednym sposobie odwzorowywania architektonicznych form w biżuterii - to użycie detalu architektonicznego w skali mikro, znane choćby z XIX-wiecznej biżuterii żeliwnej, stosowane też przez wspomnianą Caitie Sellers w bransoletach przypominających balustrady czy ogrodzenia. Donna Veverka z Bostonu wykonuje masywną srebrną biżuterię inspirowaną starożytną architekturą (teatrów i amfiteatrów) oraz nowożytnym detalem. Artystka wykonała kolekcję biżuterii dekorowanej miniaturowymi kopiami fragmentów żłobkowanych trzonów kolumn, która nawiązuje do powszechnie występującego w sztuce zjawiska wtórnego wykorzystywania, tak zwanych spoliów.

Detal architektoniczny jest też przedmiotem zainteresowania tworzącego w Baltimore Joshuy Ryana de Monte, który wykorzystując najnowszą technologię, wykonuje biżuterię drukowaną na drukarkach 3D w rozmiarze makro. Biżuteria ta jest właściwie nawiązaniem do siedemnastowiecznej kryzy, która w realizacjach artysty przybiera architektoniczną formę wzorowaną przeważnie na budowlach $\mathrm{z}$ włoskiego gotyku i renesansu. 


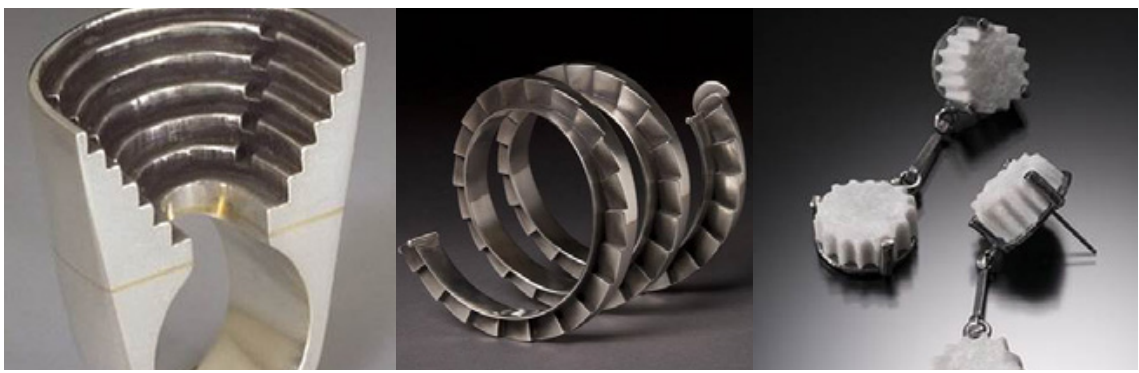

Il. 32, 33 i 34. Biżuteria autorstwa Donny Veverki, www.donnavjewelry.com/one_of_a_kind. html [dostęp: 28.04.16].

Zaprezentowany powyżej pobieżny nawet przegląd pracowni jubilerskich wskazuje, że obecnie artyści-złotnicy chętnie sięgają po znany powszechnie wzorzec, jakim jest dzieło architektoniczne. Kopiują jego wygląd lub kreatywnie go przetwarzają. W ten sposób mikrokopie arcydzieł architektury, obiektów rozpoznawalnych, kojarzonych niemal natychmiastowo z konkretnym miastem, stały się w XX wieku i pozostają do dziś znakomitą pamiątką z podróży. Jak się wydaje, to ostatnie, najprostsze spojrzenie na architekturę, bazujące jedynie na uczuciowym postrzeganiu przedmiotu uznanego za doskonały, jest wspólne wielu artystom współczesnym, takim jak Giampiero Alcozer ${ }^{39}$ czy Giulia Nardi ${ }^{40}$. W XX wieku biżuteria pamiątkowa $\mathrm{z}$ wize-

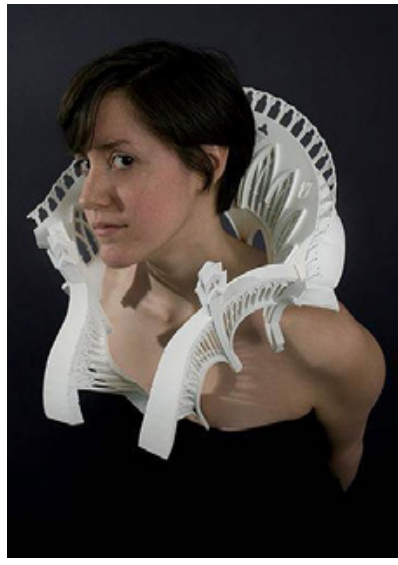

Il. 35. Bizuteria autorstwa Joshuy R. de Monte, www.joshuademonte.com/\#!emotional/clt44 [dostęp: 28.04.16].

runkiem architektury jest w Europie powszechna, zwłaszcza popularne są bransolety $\mathrm{z}$ architekturą Rzymu wykonywane $\mathrm{z}$ połączonych ze sobą kamei

39 www.alcozer.it/ [dostęp: 20.04.16].

40 www.nardi-venezia.com/gioielleria.php [dostęp: 20.04.16]. 
lub metalowych plakiet, ewentualnie łańcuszki z przywieszkami - minireplikami budowli lub rzeźb. Obiekty tego rodzaju pojawiają się stosunkowo często na aukcjach internetowych na portalach Etsy czy eBay, gdzie określane są jako „vintage jewellery from Rome” i datowane przeważne na połowę minionego stulecia. Obok dzieł wysokiej klasy artystycznej powstaje też ogromna liczba przedmiotów produkowanych przez niewielkie manufaktury złotnicze, firmy projektowe, a nawet masowo wytwarzanych przez tak zwane sieciówki, wśród których na rynku europejskim prym wiedzie marka Pandora, produkująca koraliki lub przywieszki o rzekomej wartości kolekcjonerskiej.

Wśród obiektów architektonicznych bez wątpienia najczęściej reprodukowanymi w Europie są złotnicze kopie rzymskiego Koloseum i paryskiej wieży Eiffla. Wizerunek amfiteatru fascynuje wielu jubilerów, którzy - podobnie jak wspomniani już Giampiero Alcozer czy Theo Fennell - wykonują pierścionki z tą najbardziej rozpoznawalną budowlą europejską. Mają ją w swoich kolekcjach nie tylko włoscy jubilerzy (np. Damiano Tacchi ${ }^{41}$ ), ale i pochodzący z Wielkiej Brytanii Donna Veverka, Vicki Ambery Smith czy Zara Simon (kolekcja Metropolis ${ }^{42}$ ). Koloseum, traktowane jako emblemat gladiatora, wykorzystał też australijski jubiler Stewart Hornibrook ${ }^{43}$, wykonujący pierścionki z kopiami starożytnych gemm, często własnej inwencji. Współcześni jubilerzy szczególnie upodobali sobie również obiekty gotyckie, względnie renesansowe, zwłaszcza włoskie - na przykład weneckie palazzo $\mathrm{z}$ ozdobnym gotyckim oknem powtarzane jest $\mathrm{w}$ wielu realizacjach na różne sposoby.

Jubilerzy i projektanci biżuterii w Stanach Zjednoczonych i na Wyspach Brytyjskich chętnie sięgają po wizerunek drapaczy chmur z Manhattanu (także w pojedynczych realizacjach nawiązujących do Chrysler Building czy Brooklyn Bridge), który w silnie uproszczonej, zgeometryzowanej wersji lansowany jest jako idealna biżuteria dla nowoczesnych mieszkanek wielkich aglomeracji miejskich. Warto w tym miejscu wymienić stworzoną

${ }^{41}$ www.gigarte.com/damianotacchi/biografia [dostęp: 28.04.16].

${ }^{42} \mathrm{http}: / /$ zarasimon.com/shop/precious-collection-metropolis.html [dostęp: 28.04.16].

${ }^{43}$ www.facebook.com/profile.php?id=100000470301728\&fref=ts [dostęp: 28.04.16]. 
w 2015 roku kolekcję Urban dimension autorstwa Shlomit Ofir, pracującej w Tel Avivie projektantki, która wykorzystała geometryczne formy drapaczy chmur w zestawie minimalistycznej biżuterii o nazwie Manhattan ${ }^{44}$, oraz proste pierścionki projektu Charlotte Reid ${ }^{45}$.

Wszystkie wspomniane realizacje, czy to w ekskluzywnej, czy popularnej, taniej wersji, jeśli nie niosą ze sobą głębszego ładunku symbolicznego, mają sentymentalny aspekt nawiązujący do podróży - odbytej lub pożądanej, czasem też podróży do wyimaginowanego świata baśni, jak pierścionki Theo Fennella. Ów podróżniczy aspekt biżuterii architektonicznej bardzo chętnie wykorzystywany jest przez projektantów jako marketingowy chwyt bazujący na sławie arcydzieł i chęci posiadania choćby ich repliki. Artyści sięgają po wzornictwo utrwalone, odpowiadające gustom ogółu, powszechnie uznane za dobre. Nawiązania do gloryfikowanej przeszłości, której pozostałością są rzymskie ruiny, nowatorska na początku XX wieku konstrukcja wieży Eiffla, budzące ciekawość i podziw osiągnięcia ludzkiego umysłu, jak na przykład wzniesiona na wodzie Wenecja z koronkową niemal plecionką gotyckich łuków czy nowoczesne budowle będące namacalnym dowodem geniuszu architektów - wszystko to od około dwustu lat jest gwarantem handlowego sukcesu wielkich artystów i drobnych rzemieślników. O tym, jak bardzo skuteczny jest to zabieg, świadczy liczba funkcjonujących na rynku artystów tworzących biżuterię o formach nawiązujących do wyglądu architektury czy całego założenia urbanistycznego, a także stale powstające warsztaty rzemieślnicze szczycące się uprawianiem dawnych technik złotniczych lub produkcją biżuterii, którą można określić za jej pierwszymi twórcami - rzymskimi złotnikami z rodziny Castellanich ${ }^{46}$ jako archeologiczna.

${ }^{44}$ www.shlomitofir.com/collections.aspx\# [dostęp: 28.04.16]. W sklepie Fab znaleźc można podwójny pierścionek z zarysem Manhattanu, zob. http://fab.com/ browse/rings/?ref=subnav\&page $=3$ [dostęp: 28.04.16].

45 www.charlottereid.com/about/ [dostęp: 28.04.16].

${ }^{46} \mathrm{Na}$ temat Castellanich zob. G.C. Munn, Castellani and Giuliano: Revivalist Jewellers of the 19th Century, London 1984; Castellani and Italian Archeological Jewelry, ed. S. Weber Soros, S. Walker, New York 2004; Ch. Gere, J. Rudoe, op. cit., s. 398-411; A. Lipczik, Działalność firmy jubilerskiej Castellanich i jej patriotyczny charakter, [w:] Ciało, strój, biżuteria..., op. cit., s. 281-296, 


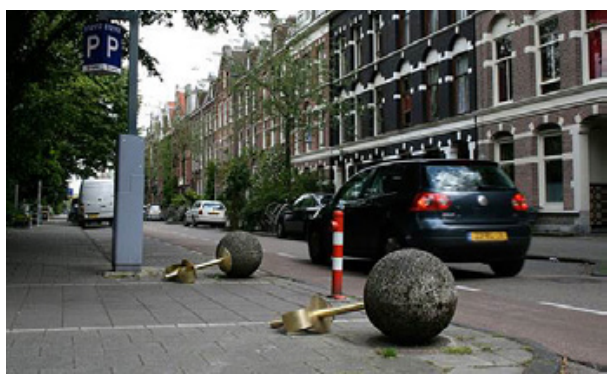

Il. 36. Biżuteria miejska autorstwa Liesbeth Bussche, www.designboom.com/art/liesbeth -bussche-urban-jewelry/ [dostęp: 28.04.2016].

Przedstawiona w niniejszym studium analiza - mająca jednakże charakter wstępny byłaby niepełna, gdyby nie dotknęła jeszcze jednego aspektu jubilerskiej twórczości wykorzystującej architektoniczne motywy - aspektu technicznego, który stanowi niewątpliwe ograniczenie twórców tej interesującej biżuterii. Warto zwrócić uwagę, że artyści poruszają się nieustannie w tym samym ustalonym repertuarze form dopasowanych nie tylko do wymogów technicznych, ale i użytkowych obiektów. W pierścieniach jako element dekoracyjny najczęściej wykorzystywany jest obiekt architektoniczny o planie centralnym; często jest to kopuła dekorowana mikromozaiką lub kamieniem półszlachetnym, nierzadko ruchoma. Wielu artystów tworzy pierścienie $\mathrm{z}$ otwieranymi puszkami (w kształcie obiektu architektonicznego) zawierającymi wewnątrz dodatkowe elementy symboliczne, żeby wspomnieć Alessanda Dariego, Theo Fennella czy Barbarę Walters. W projektach bransolet pojawia się najczęściej architektoniczny detal, płaskie plakiety z wizerunkiem architektury lub przywieszki z budowlami w skali mikro. Wielu artystów, tworząc bransolety, naszyjniki lub broszki, wykorzystuje ciągi kamienic stanowiących odwzorowanie budowli wzniesionych wzdłuż ulicy. W kolczykach - które nie mogą być nazbyt ciężkie - najczęściej pojawia się ażurowe gotyckie okno, rzadko kameryzowane.

A wszystko zaczyna się od obserwacji miasta, od fascynacji urbanistyką, widokiem, architekturą... i wszystko do miasta prowadzi. Kończąc rozważania dotyczące związków architektury i biżuterii, trzeba - odnosząc się do owej fascynacji - wspomnieć o Liesbeth Bussche, działającej, jak się zdaje, na przekór wszystkim omawianym wcześniej twórcom. Anonimowi artyści tworzący biżuterię w czasach Merowingów, rzemieślnicy wykonujący żydowskie pierścienie zaślubinowe czy współcześni złotnicy zapożyczali dzieła architektoniczne lub miejski krajobraz i tworzyli ich miniaturowe modele do noszenia. Natomiast Liesbeth Bussche, artystka streetartowa, „przyodziewa” Amsterdam w biżuterię rozmiaru makro. Analizując jej 
artystyczne działania, można odwoływać się do teorii estetyzacji codzienności: artystka traktuje biżuterię jak dekorację upiększającą miasto - żywy organizm. Dekoruje je wielkimi kolczykami, koralami, łańcuchami. Dziwne, nowe, zaskakujące działanie? Uzasadnione jednak wielowiekową tradycją. Miasto jest w końcu kobietą od czasów starożytnych, zaś wśród personifikacji w Ikonologii Cesarego Ripy - bogato odzianą, z koroną muralis na głowie.

\section{Bibliografia}

Maria Grazia Branchetti, I mosaici minuti romani dei secoli XVIII e XIX, Roma 1981. Maria Grazia Branchetti, L'Arte del mosaico minuto: una technica e il suo tempo, [w:] M. Alfieli, M.G. Branchetti, G. Corini, Mosaico minuto Romano del 700 e del'800, Roma 1986.

Marian Campbell, Treasures of the Black Death, ed. C. Descatoire, Wallace Collection, London 2009.

Castellani and Italian Archeological Jewelry, ed. S. Weber Soros, S. Walker, Bard Graduate Center, New York 2004.

Elżbieta Dębowska Dziewiętnastowieczna biżuteria żeliwna $z$ Pruskich odlewni królewskich $w$ Berlinie i $w$ Gliwicach, [w:] Biżuteria $w$ Polsce. Materiały $z$ sesji naukowej zorganizowanej przez Muzeum Okręgowe w Toruniu oraz Toruński Oddział Stowarzyszenia Historyków Sztuki 20-21 kwietnia 2001 roku, pod patronatem Krajowej Izby Gospodarczej Jubilersko-Zegarmistrzowskiej, red. K. Kluczwajt, Muzeum Okręgowe: TOSHS, Toruń 2001, s. 107-116.

Elżbieta Dębowska, „Złoto dałam za żelazo” - dziewiętnastowieczna biżuteria żeliwna, http://polskijubiler.com/pokaz.php?id=679.

Charlotte Gere, Judy Rudoe, Jewellery in the Age of Queen Victoria. A Mirror to the World, British Museum Press, London 2010.

Bożena Iwaszkiewicz-Wronikowska, Giacomo Raffelli (1753-1836) doradca króla Stanisława Augusta, [w:] Polak we Włoszech, Włoch w Polsce. Sztuka i historia, red. M. Wrześniak, A. Bender, Wydawnictwo UKSW, Warszawa 2015, s. 249-256

Małgorzata Kierczuk-Macieszko, Średniowieczne kadzielnice w Polsce, praca doktorska napisana pod kierunkiem prof. J. Kuczyńskiej (KUL 2011).

Stanisław Kobielus, Niebiańska Jerozolima. Od sacrum miejsca do sacrum modelu, Pallotinum, Warszawa 1989.

Ewa Letkiewicz, Nie tylko Grand Tour. Bizuteryjne pamiątki $z$ XIX wiecznych podróży, [w:] Ciało, strój, biżuteria w kontekście przemian kulturowych, 
społecznych i politycznych XIX wieku, red. E. Letkiewicz, Wydział Artystyczny UMCS, Lublin 2015.

Agata Lipczik, Działalność firmy jubilerskiej Castellanich i jej patriotyczny charakter, [w:] Ciało, strój, biżuteria w kontekście przemian kulturowych, społecznych i politycznych XIX wieku, red. E. Letkiewicz, Wydział Artystyczny UMCS, Lublin 2015.

Giovanni Moroni, Dizionario di Edudizione Storico-Ecclesiastica, t. 47, Venezia 1846. Geoffrey C. Munn, Castellani and Giuliano: Revivalist Jewellers of the 19th Century, Trefoil Books, London 1984

Cesare Ripa, Ikonologia, tłum. I. Kania, Universitas, Kraków 1998.

Kinga Szczepkowska-Naliwajek, Motywy architektoniczne $w$ złotnictwie średniowiecznym, [w:] De Gustibus. Studia ofiarowane przez przyjaciół Tadeuszowi Stefanowi Jaroszewskiemu z okazji 65 rocznicy urodzin, red. T. Chrzanowski, Wydawnictwo Naukowe PWN, Warszawa 1996, s. 276-284.

Kinga Szczepkowska-Naliwajek, Relikwiarzśw. Barbary, „Spotkania z Zabytkami” 2002, nr 6, s. 7-9.

Kinga Szczepkowska-Naliwajek, Relikwiarze średniowiecznej Europy od IV do poczatku XVI wieku: geneza, treści, styl i techniki wykonania, Wydawnictwo Akademii Teologii Katolickiej, Warszawa 1996.

Kinga Szczepkowska-Naliwajek, Złotnictwo gotyckie Pomorza Gdańskiego, Ziemi Chetmińskiej i Warmii, Zakład Narodowy im. Ossolińskich, Wrocław 1987. Diana Scarisbrick, Rings. Symbols of Wealth, Power and Affection, Harry N. Abrams, London 1993.

The Gilbert Collection. Micromosaics, ed. J.H. Gabriel, London 2000.

The Ring: from Antiquity to the Twentieth Century, ed. A. Ward, J. Cherry, C. Gere, B. Cartiridge, Thames \& Hudson Ltd, London 1981.

Małgorzata Wrześniak, Dextrarum iunctio - rzecz o znaczeniu ślubnego pierścienia, „Fides et Ratio” 2015, nr 4(24), s. 12-31.

Małgorzata Wrześniak, Ukryte treści biżuterii Alessandra Dariego, [w:] O rzeczach pięknych: rzemiosło artystyczne na przestrzeni wieków, red. A. Bender, M. Wrześniak, Towarzystwo Naukowe KUL, Lublin 2016.

\section{Źródła internetowe}

http://christinaellenicox.com/\#/christinaelleni/

http://collections.vam.ac.uk/item/O374198/ring-unknown/ http://collections.vam.ac.uk/item/O72510/ring-ring/ 
http://collections.vam.ac.uk/item/O76591/ring-ricketts-charles-de/ http:/glassfiction.blogspot.co.uk/2012/07/mariko-sumioka-samera-afzal.html http://juedisches-leben.erfurt.de/jl/en/middle-ages/erfurt_treasure/finds/index. html

http://zarasimon.com/shop/precious-collection-metropolis.html [dostęp: 28.04.16]. https://pl.pinterest.com/pin/11681280253221511/ https://pl.pinterest.com/pin/423831014908298972/ https://pl.pinterest.com/pin/456833955926779238/ www.alcozer.it/ www.alessandrodari.com/ita-dettaglio.php?idCat $=2$ www.alessandrodari.com/ita-dettaglio.php?idCat=2 www.alessandrodari.com/ita-dettaglio-interno.php?idProd=142\&idCat=8 www.artsthread.com/blog/qa-mariko-sumioka-arts-thread-talent-mokspace-east -meets-west-art-design-now/ www.artstolife.com/arts-to-life/benjaminzucker.php www.britishmuseum.org/research/collection_online/collection_object_details. aspx?objectId=89912\&partId=1\&searchText=finger+ring\&images=true\&museumno $=1872,0604.245 \&$ page $=1$

www.britishmuseum.org/research/collection_online/collection_object_details.aspx?objectId=94461\&partId=1\&searchText=finger+ring\&image$s=$ true\&museumno=AF.482\&page $=1$

www.caitiesellers.com/portfolio.html www.charlottereid.com/about/ www.comitebellecour.fr/en/news/10_french_kiss.html www.designboom.com/art/liesbeth-bussche-urban-jewelry/ www.donnavjewelry.com/one_of_a_kind.html www.facebook.com/profile.php?id=100000470301728\&fref=ts [dostęp: 28.04.16]. www.firenzetoday.it/cronaca/enigma-facciata-palazzo-pitti.html www.gigarte.com/damianotacchi/biografia [dostęp: 28.04.16]. www.joailliers-createurs.com/joaillier_jean_boggio.html www.joshuademonte.com/\#!emotional/clt44 www.lesenluminures.com/exhibitions/cycles-of-life-rings-from-the-benjamin-zucker-family-collection-22534

www.lesenluminures.com/inventory/expo-35291/merovingian-architectural-ring-22771 www.lesenluminures.com/inventory/expo-35291/merovingian-architectu ral-ring-with-a-beaded-hoop-22778 
www.lesenluminures.com/inventory/expo-35291/merovingian-architectu ral-ring-22771

www.lesenluminures.com/inventory/expo-35291/merovingian-cloisonne-architecturalring-22770

www.marikosumioka.com/\#!about/aboutPage

www.nardi-venezia.com/gioielleria.php

www.nytimes.com/2014/12/05/style/international/sevan-bicakcis-jewelry-celebra-

tes-istanbuls-heritage.html?_r=0

www.penkofirenze.it/ita/bottega/dicono_dinoi.html

www.penkofirenze.it/ita/collezioni/architettura5.html

www.philippetournaire.com

www.philippetournaire.com/The-Tournaire-s-spirit,184.html

www.sevanbicakci.com/\#!collection/cfvg

www.sharon-massey.com/streetview/

www.shlomitofir.com/collections.aspx\#

www.thejewelleryeditor.com/2014/09/jean-boggio-artist-and-jeweller-paris/

www.theofennell.com/about-tf

www.theofennell.com/over-the-rainbow-opening-ring.html

www.theofennell.com/unique-pieces/masterworks/18ct-yellow-gold-opening-co-

losseum-ring-with-slain-gladiator-bespoke-box-and-magnifying-glass.html www.vickiamberysmith.co.uk

\section{The History of One Motive - on the Relationship between Jewellery and Architecture}

The hereby text is a short study on the relationship between architecture and jewellery. In the first part, it presents the history of occurrence of architectural forms in jewellery from antiquity to present day in the European culture. The second part delivers the examples of contemporary artefacts, particularly rings with microarchitecture. The analysis of the collected examples proves that architecture - its form, construction and detail - is a motive of decoration willingly used in jewellery design, often of a symbolic meaning related to the household or the temple (wedding rings, ritual rings). Nowadays, especially in the 21st century, microarchitecture in jewellery often emerges with reference to the place of origin, i.e. the famous building 
being, most frequently, the commemoration of a journey, able to bring back the memory of a visited city.

The architectural jewellery, whose meanings and functions are the subject of the hereby study, has undergone many transformations throughout history. Even though it has transitioned from simple to complicated and decorative forms, from precious and rare to cheap and popular objects of mass production presenting the miniature replicas of buildings, the jewellery nearly always symbolises the city. Much less often the jewellery design occurs with reference to the metaphorical meanings of buildings as a representation of permanency (the tower in Alessandro Dari's jewellery) or marital union (the house and the temple in Jewish rings).

Keywords: microarchitecture, architectural jewellery, history of jewellery, ritual ring, symbolic meaning of jewellery, jewellery in culture 



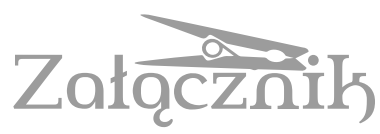

\section{COMPARATIVE ANALYSIS OF MEDIA. THE TRANSFORMATION OF RELATIONS BETWEEN SCRIPT AND IMAGE - FROM ANALOGUE MEDIA TO INTERACTIVE ENVIRONMENT}

AGNIESZKA SMAGA

\begin{abstract}
Wydział Nauk Humanistycznych UKSW
Faculty of Humanities, Cardinal Stefan Wyszyński University in Warsaw

a.smaga@uksw.edu.pl
\end{abstract}

The subject of this comparative analysis is digital imagery and the interplay of script and image within it ${ }^{1}$. These two media are characterised, on the one hand, by a degree of autonomy and different orders of expression (basic elements, methods of binding them), while on the other hand they remain related in terms of similarity and, sporadically, identity. Script and image are treated both as heterogeneous (selectively different) and heteronomous (mutually acting on each other) forms. Therefore, not the finally produced media, but the relationships between them were placed at the centre of the study (Kasperski, 2010: 65-68), as in mathematical category theory ${ }^{2}$.

The specific dependencies of the digital word and image have been described in detail primarily by Jay David Bolter (2001) and Mike Sandbothe (2000). The analyses of these researchers are an important point of reference for this article. Sandbothe acknowledged that forms of communication in the digital hypertext environment that have been separate up to now are changing their specific characteristics and entering into new

1 This article does not discuss the sound aspect of the digital medium.

2 Reasoning in the order of category is distanced from set theory. A collection and its elements cease to be fundamental, autonomous concepts, and move to the background. Heteronomous transformations and interference of the given media are most important. 
arrangements - four digital entanglements: the scriptualisation of speech, the oralisation of writing, the iconisation of script and the scriptualisation of image (Sandbothe, 2000: 217-222). The specified transformations would accentuate the transmedial nature of web pages, where heterogeneous mediums of communication would form an amalgamation of the system, an integrative whole at the level of semiotics and semantics. The subject of this comparative analysis is the relation between script and image, which is why attention has been focused on the last two transmedial processes ${ }^{3}$.

Sandbothe, guided by researcher's intuition, suggested that there is a mechanism common to both media (words and images) that emerges from the pragmatic level, i.e. the functioning of a message. He did not analyse this process, he only suggested its communicative effects, which are based primarily on the introduction of words and images into motion, and binding these media to reality, not only symbolically to its reference, but factually to the real reference, which takes place at the moment of clicking or touching a digital sign (Sandbothe, 2000: 218-219).

Logical reasoning demands that a common mechanism for the functioning of images and words online can be achieved only with the contribution of

3 According to Sandbothe, the iconisation of phonetic script is based on treating text as an image structure in terms of its delivery, and thus its reception. Another manifestation of the process of the iconisation of script was the rehabilitation of non-phonetic scripts (pictograms, ideograms). The researcher found that in the digital environment icons function as further elements of 'pictorial script' and their sequences are becoming an appropriate language of digital communication (Zawojski, 1999: 40-41). The next interference between media identified by Sandbothe was the scriptualisation of the digital image. The author understood it as 'detachment' of the image from the function of imitating reality. An icon, like script, appears in this case as an auto-reference, referring to itself. This means that we 'read' it as a linguistic model, that is, from letter to letter, from word to word, from sentence to sentence, and not as an image by reference to real or unreal non-artistic reality. This process is carried out in graphics programs through 'edit' operations of an image, the same as script, such as changes and deletions. Sandbothe pointed out that digital raster images have these properties due to their technological determinants. However, he did not present the same characteristics in the context of vector graphics, although they are primarily subject to these change procedures, of which there are definitely more than the two mentioned above. 
convergent technology that generates them, further made available at the presentation level. Each of the three levels of digital communication was introduced by one and the same medium (perhaps because of this we should call it a transmedium?), namely, applied graphics, which, as a unified form of transmission, refers only to the presentation layer. On a fundamental level, every digital message is reduced to a numerical representation (Manovich, 2002: 27).

The identification of script and icon signs, which Sandbothe wrote about, rarely occurs at the actual presentation level, because it is not related to an attempt to build a simple relationship of their visual identity. Therefore, it is not subject to processes known from analogue culture. The two transpositions highlighted by the researcher - the iconisation of script and the scriptualisation of image - are not the result of the interdependence of these two categories, rather they are the effect of the overriding action of the trans-mechanism - the graphic code. One should, therefore, speak more about graphicalisation, which introduces the proper procedures for processing both media. This graphical editing constructs the interactions between digital writing and image. The features of flat design constitute to a varying degree the properties of both analogue and digital messages 4 . In the case of the latter, they construct the specificity of presentation and communication in this environment ${ }^{5}$. They introduce multilevel, variable interactions between semiotically varied medial categories.

Graphic code is a variant of an iconic code. That is why the level at which a message is generated is important, i.e. the physical structure of

${ }^{4}$ In research about print media (books, newspapers and other media), graphic media has generally been omitted, because it was 'not seen' or treated as transparent and therefore unimportant. The exception are studies by Philip Meggs (1998), Lewis Blackwell and David Carson (2000).

${ }^{5}$ Graphic mode is understood online as a way of operating an external device, such as a monitor or a printer. In this mode, individual pixels are processed, that is, the individual elements that make up an image on a monitor screen (also in a computer memory). This strategy allows maps, charts, drawings, photographs, films and animations to be processed. The alternative to graphic mode is alphanumeric text - fast in action, but does not support pixels. It defines a method of working in which only characters of a specified code (such as ASCII) are available. 
the substrate, the properties of the tools and the operational and design mechanisms, selected from a broad range of possibilities. Online graphics are an even more complex and complicated service that defines the process of generating, presenting and manipulating scripts, images and sounds. Graphical procedures derive directly from the specifics of mechanical, digital recording of distinct types of data. They take place in the form of zeros and ones stored on a computer's hard disc in the form of bits. This form of notation allows information to be duplicated without loss of quality and to be processed with mathematical algorithms, then graphical rules. Also, TCP/IP-compliant web-based data transmission involves the continuous recovery and processing of encoded characters, and their reproduction regardless of where they are located in space and time.

These mechanisms, which are characteristic of the online environment, shape the tools, procedures, and conventions of digital design. Graphic operations include both single characters and groups of them, as well as page space and finally web space. They have a creative, crafted character ${ }^{6}$ and therefore refer back to the practice of using tools. The choice of graphical instrument for processing material is dictated by the way it is used by the user. For example, edits made in the future on a website can be made using tools such as layers or stacks, selections, paths, shapes, channels, styles, colours, filters, masks, brushes, pencils, sprays, softeners, erasers, scissors, knives, pipettes, paint buckets, calligraphy, shadows, frames, contour pens and many others! With certain programs (Adobe Photoshop, Adobe Illustrator, CorelDRAW, GIMP and others), words and images can be modified and composed in many ways. They are subjected to editorial processes (Sandbothe treats this as one of the forms of scriptualising images), which rarely take place based on text operations only (replacement and deletion in linear form), but more often on the basis of strict graphic editing: reduction, enlargement, duplication, addition, substraction, merging, averaging, transformation (rotation, reversing), scaling, blocking, grouping, hiding and merging layers, filling, framing, metamorphosing, marking (here there is a whole range of possibilities), etc. Saving in digital form allows not

6 'No longer an Analytical Engine, suitable only for crunching numbers, it has become Jacquard's loom - a media synthesizer and manipulator' (Manovich, 2002: 26). 
only straightforward changes to be made, but also multiple units separated from one another to be combined. They are displayed as a heterogeneous whole, but stored in databases as separate, standalone components, so each of them can be individually modified, e.g. through layers, channels, paths and other functions. The variety of tools and operations is a significant determinant of graphic code.

Digitally and design-generated communication components are revealed to recipients through the graphical user interface of web pages and web browsers. The GUI defines a visual representation of information (writing, image and sound) by a computer and interactions with the user by 'drawing' using input (mouse, trackball, touchpad) and input/output (touch screen) devices and the use of controllers and widgets. As can be expected, websites are not static, rather they are dynamic, created on the fly by calling on information. They actually match the needs of their users. Thus, the design of images, sounds, texts and animations that constitute the content of web pages are strongly linked to databases - another relational category - with their indexing and economy of access and the emancipation of the user in terms of information (Belting, 2007: 49-54). This is why graphical editing departs from the convention imposed by paper and creates structures capable primarily of storing and combining many diffuse media. And the functionality of digital graphics is no longer determined by the semantic element, as in analogue design, where the text was treated as a model for describing actions or events, generating complex content that needed to be translated into graphical content, and thus performing its functions. Meanwhile, in the new media environment, design has become

'meta-design'. Today, the designer must create not only a graphic identity, but also information architecture, a navigation system and other structures that will be used by the customer as information carriers. In short, the graphic designer has become an interface designer. (Austin, Doust, 2008: 16-17)

Consequently, utility, alongside the digital recording structure, affects the graphical editing process of text and image. Graphics both build and follow the specifics of the digital environment. They introduce interferences that are themselves the result of interactions between the properties of the material described above, through techniques and choices as well as perceptual and user practices in culture. This produces a continuous 
editing, a dynamic process: on the one hand intermediation between diffuse messages, and on the other hand, hypermediation (Bolter, 2001: 39) - displaying the properties of transmediation. In this way, graphical editing moves from being a finite representation to function primarily as a design interface. As a result of this graphic editing, we get digital graphic presentations, not graphic-icons, but also graphic user interface for mobile, responsive applications and web pages. By the same token, applied graphics and digital communication, existing with its help, require a specific research procedure - one that does away with the search for analogue imaging and writing, image and text prototypes. The new cognitive approach is based on the specifics of digital communication as described above, built from a level of universal communication using a GUI - academic perception 'follows' the expectations and needs of the user of the message, through the perception of the message, to the generated semantics, and further semiotics. Real people are placed at the centre of research interest, as is the case with the design and production of GUI websites ${ }^{8}$. In this way we avoid the discrepancy that Susan

7 Flat design has always oscillated between these two alternatives, placing them closer to the second. From the level of presentation, the imaging it proposes, thanks to far advanced reduction in form, was characterised by a high degree of simplification, the procedure of transition from colour, lightening and formal variety to graphic simplicity. Digital graphics, due to their great diversity, even better reflect the paradox of transparency and opacity that is typical of our Western culture. The graphical interface can take two forms: from apparent transparencye.g. in games - to hypermedia, best seen in web interfaces, especially mobile and responsive interfaces (Weibel, 2008: 5-10).

8 The proposed research path is similar to the order in which websites are created. The first stage is the experience strategy (validation analysis, heuristic analysis, usability tests), then comes market research (targeting users, user profiles, and an interactive shopping map). Websites, before they reach the user, are evaluated for their user-friendliness. For this purpose, they are tested on focus groups, where the time required to perform a particular task is checked, characters seen first are analysed, as well as those that cause most difficulty when performing a task. It turns out that the assumptions of the customer and the designer do not always match the expectations of users. Graphic designers in the design of user-oriented interfaces - like researchers - are accompanied by philosophical thought, according to which design should expand the opportunities - perceptual, educational, 
Sontag talked of between the literal meaning of a message and the actual perception and needs of users. First, we ask 'how and what does graphic code do', and only later 'what does it say' (Sontag, 1966: 13). Then, the goal of comparative analysis can be both practical and theoretical. In the first case, it will help to identify and improve the user experience at the moment of interaction; in the second - it will be connected with the procedure of knowledge acquisition by the recipient. By providing the participant with a variety of tools and procedures for handling communications, the process of constructing meanings and signs is supported.

In practice, the user of a graphical interface of a system, application or web page oscillates between three alternative needs and expectations. The user has a desire to enter a seemingly real, non-mediated world (realistic picture, photography, animation, film). In this case, the user observes the entire range of effects that build the expected illusion of the medium's transparency: geometric perspective, colour, and air, shading, variable scales, colour saturation, and more. On the other hand, there is also a fascination with the possibilities offered by the graphical tools of mediation (personalisation, choice, interaction, linking, change selection, highlighting) ${ }^{9}$. The user, seeing an opaque, graphical interface of a system, application (especially on a smartphone or iPad) or web page feels 'pleasure' in the beginning. Admiring the simplicity of the GUI, combined with the graphical attractiveness of the icons, the user stops understanding them as images that imitate reality. The user also does not read the characters as a text: continuously, linearly, cause-and-effect. He is only delighted by them. Quickly, however, his sight begins to wander, looking for the ability to decode the graphical elements of the GUI or web page content (leading to a specific functionality or tool). In this case, there is a third category of needs and expectations, i.e. practical, there are practical wants, such as finding information, buying, renting, sending, sharing, printing.

cognitive, decision-making and practical - of individuals and societies. Planning understood in this way affects human knowledge, behaviour and attitudes and makes changes within them.

9 'The interface is not a transparent window through which we observe computer data; on the contrary - it modifies it decisively' (Manovich, 2001: 65). 
The three variants of user contact with a message suggested above are available from the graphical interface. For interfaces of operating systems, applications and mobile and responsive web pages, the transition between the first two user needs and the orders of a message is increasingly less visible.

Signs that are initially transparent are eliminated. A blank contact icon can be filled with a photo of a real person. But do we do it? If yes, we take a photo, edit it, cut it to the shape of a square, a circle, a rectangle of a certain size and add it by hand. In this case, the graphic medium has made an enhanced hypermediation and offers an entire range of modification possibilities: from resolution to white balance, contrast, perspective, size, shape and other advanced edits. The interface 'assures' the user of their perfection, suggesting that it will be better than a real photograph, because it offers - by its modification - an introduction to the world that is shown.

However, opaque signs or hypermediating graphical elements, are displayed. In this case, the interface draws users' attention as a pure, constellation form. It stimulates their sense of interaction, combinatorics and creation. For example, the Windows smartphone operating system is built of two-dimensional, simplified, uniformly coloured tiles. The screen settings can be modified (background, leading colour) as well as the start-up screen, by entering pictures from the camera (made by the user or from the library) by selecting the pattern and number of tiles. The position of email, screen lock, internet sharing, application corner and much more can be adjusted. Further applications can be installed and with great satisfaction we can uninstall them if we want to increase operating and mass memory. The enormous variety of tools and associated functions can lead to a communication situation which will not lead to constructing messages referring - through their image or language nature - to the world beyond the interface, but rather they will focus on the modification of the interface itself $^{10}$. Theoretically, we may fall for the magic of the graphic transmedium. But will this actually happen?

10 The ability to manipulate an image with graphical editing pulls an image away from merely being a reflection of reality. An icon can itself become an alternative, virtual, abstract world. It is then treated in terms of technology, aesthetics, and function. 
For the user, an interface's transparency (linked to its image) or opacity (close to written text) is usually not important. Thus, also not important, as suggested at the outset, is the distinction between image and script. For digital communication users, what is more important is the fast and effective performance of tasks such as sending messages, finding specific information, buying, selling, renting, viewing photos, checking weather, bank accounts, shares, email etc. The functionality of an interface is linked, therefore, to a direct, even immediate, response from the recipient. The user's activity is thus a process of mediation occurring with the use of a flat design. Therefore, graphical editing introduces operations on image, text, sound and combinations of these, but not to illustrate, describe or structure meanings, but rather to effectively send and use them (fast, economically and errorfree). At the moment of clicking, or after a user asks a specific question, the multi-semiotic content is downloaded and displayed on the screen according to a previously designed image template. A graphical interface 'treats' script and image on the one hand as standalone units - stored separately in databases in a way that makes them quick and easy to find; on the other hand, it threats them heteronomously, mutually acting, reinforcing each other in the presentation and message. Graphical editing skilfully combines recipients' expectations about the message access: on the one hand in terms of precision (on the model of a script), on the other in terms of a constellation (according to the iconic prototype). It scales in this way two structures of reception, recognised in our culture as different ${ }^{11}$. The user functionality of a message is understood as accurate and synthetic mediation (economic, reductive), which results in analogous features present at the semantic and semiotic level, where the three levels of a message circulate in a feedback loop. In the digital environment, there is no 'implosion' of signifié, or domination and diversity of signifiant, since the correct form is conditioned by effective, mutual communication, creativity and above all usability. This surface explosion exposes the key, primary features of concepts at the expense of their secondary quality. For a GUI, the sign with the greatest value is the one that works fast and accurately, like an arrow fired into an archery target or a missile aimed at a bullseye.

${ }^{11}$ Bolter talks about the opposition of these two reception poetics (Bolter, 2001: 61-66). 
The integrated word-image order of an expression was already a feature of analogue graphics. The tension between the semantic raster, arising from writing, and that associated with image is eliminated from the level of reception. The process of reading and watching was difficult to separate from each other. In the digital version of the procedure, these are combined, and are actually subordinate to their practical application. The graphic conditioning of the digital message, in accordance with its specific application, 'forces' a utility order on text and image.

Mutual dependence at the user, semantic and semiotic levels will continue to evolve in the online environment, as users possess for the first time such an efficient interaction tool, and with it the power of co-operation, co-creation and sharing, which they will certainly not give up when visiting web pages, blogs, as well as in chats, video conferencing, games, simulations, etc. Users will spend more and more time, with increasing pleasure, in the digital world, which they will consume and co-create with the available tools and graphic procedures. Mutual influence between the level of presentation and use means that a visible space is imposed, combined with its destruction, onto the object used, such as a web page, enhancing the relationship between the form and the function of the message. As a result, a 'package' (signifiant) is created at the same time as a 'product' (signifié), which is a kind of means (technique) to stimulate user expectations (Weibel, 2008: 11-28). In the longer perspective, reading/viewing will firstly lead to a redesign of the current level of graphic presentation, including writing and image, and, secondly, it will also define the self-perception of the act of writing and imaging.

\section{Selected bibliography}

Tricia Austin, Richard Doust (2008), Projektowanie dla nowych mediów, trans. A. Garbiński, PWN, Warszawa.

Hans Belting (2007), Antropologia obrazu. Szkice do nauki o obrazie, trans. M. Bryl, Universitas, Kraków.

Jay David Bolter (2001), Writing Space: The Computer, Hypertext, and the Remediation of Print, Lawrence Erlbaum Associates, Mahwah.

Norbert Bolz (1997), Estetyka cyfrowa, trans. J. Ostaszewski, [in:] Pejzaże audiowizualne: telewizja, wideo, komputer, ed. by A. Gwóźdź, Universitas, Kraków. Nicolas Bourriaud (2012), Estetyka relacyjna, trans. Ł. Białkowski, Muzeum Sztuki Współczesnej MOCAK, Kraków. 
Max Bruinsma (2003), Deep Sites, Intelligent Innovation in Contemporary Web Design, Thames \& Hudson, London.

David Carson, Lewis Blackwell (2000), The Other End of Print: David Carson, Graphic Design, and the Aesthetics of Media, Laurens King Publishing, London.

Konrad Chmielecki (2010), Od estetyki intermedialności do estetyki transmedialności. Perspektywy refleksji nad sztuka w kontekście problematyki transgresji mediów i konwergencji kulturowej, [in:] Sztuka w przestrzeni transmedialnej, ed. Tomasz Załuski, Oficyna Drukarska Jacek Chmielecki, Łódź.

Vilém Flusser (2002), Writings, University of Minnesota Press, Minneapolis.

Elisa Giaccardi (2005), Metadesign as an Emergent Design Culture, "Leonardo" vol. 4.

Monika Górska-Olesińska (2009), Słowo w sieci. Elektroniczne dyskursy, Wydawnictwo Uniwersytetu Opolskiego, Opole.

Andrzej Hejmej (2013), Komparatystyka. Studia literackie - studia kulturowe, Universitas, Kraków.

Henry Jenkins (2006), Convergence Culture: Where Old and New Media Collide, New York University Press, New York - London.

Steven Johnson (1999), Interface Culture: How New Technology Transforms the Way We Create and Communicate, Basic Books, New York.

Edward Kasperski (2010), Kategorie komparatystyki, Wydawnictwo UW, Warszawa. Krzysztof Lenk (2011), Krótkie teksty o sztuce projektowania, słowo/obraz terytoria, Gdańsk.

Lev Manovich (2001), The Language of New Media, The MT Press Cambridge, London.

Philip B. Meggs (1998), A History o Graphic Design, Van Nostrand Reinhold, New York.

Richard Poulin (2012), Graphic Design and Architecture, a 20th Century History: A Guide to Type, Image, Symbol, and Visual Storytelling in the Modern World, Rockport Publishers, Beverly (Ma).

Mike Sandbothe (2000), Interactivity - Hypertextuality - Transversality. A MediaPhilosophical Analysis of the Internet, "Journal of Linguistics" vol. 24.

Susan Sontag (1966), 'Against Interpretation' and Other Essays, A Delta Book, New York. 
Peter Weibel (2008), From Data to Images and Back. An Introduction to the Visual Systems of Thorbjørn Lausten, [in:] MAGNET. Thorbjørn Lausten's Visual

Systems, ed. M. Søndergaard, P. Weibel, Kehrer Verlag, Heidelberg.

Widzieć/Wiedzieć, ed. by P. Dębowski, J. Mrowczyk (2011), Wydawnictwo Karakter, Kraków.

Wiek ekranów. Przestrzenie kultury widzenia, ed. by A. Gwoźdź i P. Zawojski (2002). Rabid, Kraków.

Piotr Zawojski (1999), Od obrazów pisma do pisma obrazów, [in:] Słowo w kulturze multimediów, ed. Zbigniew Suszyński, Instytut Filologii Polskiej UwB, Bialystok.

Piotr Zawojski (2012), Sztuka obrazu i obrazowania w epoce nowych mediów, Oficyna Naukowa, Warszawa.

\section{Digital sources}

Elisa Giaccardi Elisa, Gerhard Fisher, Meta-Design: A Framework for the Future of End-User Development, http://13d.cs.colorado.edu/ gerhard/papers/EUDmeta-design-online.pdf.

Piotr Zawojski, Interfejs - sztuka interfejsu - „Interface Culture”, http://www.zawojski. com/2014/04/21/interfejs-sztuka-interfejsu-interface-culture-2/\#more-432.

Piotr Zawojski, Obrazy elektroniczne - eksplozja produkcji, implozja sensu?, http://www.zawojski.com/2006/04/19/obrazy -elektroniczne-\%E2\%80\%93-eksplozja-produkcji-implozja-sensu/.

\section{Comparative Analysis of Media. The Transformation of Relations between Script and Image - from Analogue Media to Interactive Environment}

A digital communiqué operates with GUI not to depict, describe or structure the meanings but, above all, to transfer them. At the moment of clicking, that is, when a specific question is being asked by the user (customer), specific semiotically varied content is downloaded and displayed on the screen in accordance with the pre-designed, graphic template.

Thus, graphical interface treats writing and image on the one hand as heterogeneous units - stored in databases, in a way that makes them quick and easy to find; on the other hand - heteronomous, that is, affecting each other at the level of presentation and manipulation of the message. Graphical 
edition skillfully combines the expectations of recipients concerning the access to the message: on the one hand - precise (along the lines of the language), on the other - economic, reducing (iconic), and it merges in this way two structures of reception, considered in our culture to be different.

Pragmatic functionality of digital message is understood as accurate and synthetic mediation, which results in further analogous features from the level of semiotics and semantics, where the highlighted three planes of the communiqué circulate in the feedback loop.

Keywords: comparative literature, applied graphics, comparative media studies, intermediation, hypermediation, transmediation 

ZałącZnIil

\section{FAUST/YNA.}

\section{W PROMIENIACH ARTURA PAŁYGI}

\author{
JACEK KOPCIŃSKI
}

\author{
Wydział Nauk Humanistycznych UKSW \\ Faculty of Humanities, Cardinal Stefan Wyszyński University \\ in Warsaw \\ jacekkopcinski@o2.pl
}

Pojawianiu się na łamach „Dialogu” nowych polskich dramatów towarzyszy niekiedy rozmowa $\mathrm{z}$ ich autorami, i oto po ostatnich, niezwykłych słowach bohaterki monodramu W promieniach: „Stoję tu, cała w promieniach / I staję się słońcem"', redakcja zamieściła wywiad z Arturem Pałygą zatytułowany Jak zostać Skłodowską. Zaintrygował mnie ten tytuł. Czyżby i dziś, tak jak dziewięćdziesiąt trzy lata temu, uczennice państwowego gimnazjum we Włocławku mogły napisać: „Niejedna z nas chciałaby Cię naśladować, ale za mało w nas geniuszu i tej cierpliwości, którą jesteś tak obdarzona"? ${ }^{2}$ Niewykluczone. Kogo w końcu miałyby podziwiać i z kim się identyfikować współczesne dziewczęta, jeśli zapragnęłyby zostać znanymi na cały świat uczonymi i zdobyć Nagrodę Nobla? Gimnazjalistki z Włocławka obrały sobie Skłodowską za wzór i uczyniły patronką swojej klasy, o czym zawiadomiły ją w liście z 14 czerwca 1924 roku: „Portret Twój, narysowany przez jedną z nas, zawiesiłyśmy w szkole i co dzień, patrząc nań, myślimy o Twojej cichej, bezinteresownej pracy, pełnej poświęceń. I naprawdę słów nie staje i dziwne jakieś uczucia nas ogarniają" ${ }^{3}$. Skłodowska musiała się poczuć nieswojo, czytając to wyznanie, a że zasadniczo nie lubiła szkol-

\footnotetext{
1 A. Pałyga, W promieniach. Zupetnie nieznane listy Marii Skłodowskiej-Curie, „Dialog” 2016, nr 7-8, s. 72.

2 Uczennice V klasy Gimnazjum Państwowego im. Marii Konopnickiej do Marii Skłodowskiej-Curie [Włocławek, 14 czerwca 1924 r.], [w:] Korespondencja polska Marii Skłodowskiej-Curie 1881-1934, oprac. K. Kabazińska, M.H. Malewicz, J. Piskurewicz, J. Róziewicz, Warszawa 1994, s. 244-245.

3 Ibidem. s. 245.
} 
nej instytucji, odpowiedziała krótko: „List Wasz otrzymałam dopiero po wakacjach, pragnę jednak przesłać Wam choć spóźnione podziękowania za serdeczne Wasze słowa, wraz z życzeniami powodzenia w pracy"4. Nie była to odpowiedź wylewna, z pewnością jednak ucieszyła gimnazjalistki. W końcu przemówił do nich ideał z portretu!

Czy więc narysowany przez Pałygę obraz Skłodowskiej, która w finale utworu mówi także: „Chciałabym wyć, jak dzikie zwierzę / Ale nie mogę, bo już jestem popiól"s, może poruszyć wyobraźnię dzisiejszych uczennic? Na pewno, skoro z monodramu „wyłania się portret kobiety radykalnej w swoich dążeniach, bezkompromisowej, bezgranicznie oddanej pracy" - jak zauważa Monika Żółkoś, która zgodnie z nowymi trendami konsekwentnie nazywa noblistkę „naukowczynią”. Pałyga tak o niej nie mówi, choć, jak zaznacza, bardzo go wzruszył list Skłodowskiej do Akademii Noblowskiej, w którym z „godnością”, „gniewem” i „dumą” odpowiedziała na seksistowskie zarzuty formułowane pod jej adresem $\mathrm{z}$ powodu romansu $\mathrm{z}$ żonatym mężczyzną, na dodatek młodszym. Ale $W$ promieniach nie jest literackim przepisem na uczoną feministkę $\mathrm{z}$ charakterem i teatralną partyturą jej buntu. Owszem, uwzględniona w tym utworze podmiotowa narracja rzeczywiście „uwalnia głos ze środka kobiecego doświadczenia”, ale zarazem głos ten i doświadczenie poddaje zaskakującej transformacji. Intrygujący tytuł rozmowy z Pałygą wskazuje przede wszystkim na jego własną postawę twórczą, w której, co tu kryć, tkwi pewien gimnazjalny pierwiastek...

\section{SEANS SPIRYTYSTYCZNY}

Przeczytajmy fragment wspomnianego wywiadu:

Kiedy piszę, próbuję się stać postaciami, które piszę, na ile to możliwe. Nie potrafię pisać inaczej. I nocami, od północy do czwartej, piątej rano, albo czasem w dzień, od dwunastej do siedemnastej, stawałem się Marią. Ale też nie chciałem, żeby z tego niechcący wyszła sztuka o mnie, tylko żeby to był rzetelny monodram biograficzny. Wpadłem na pomysł jej niewysłanych

4 Ibidem, s. 249. Maria Skłodowska-Curie do uczennic V klasy Gimnazjum Państwowego im. Marii Konopnickiej we Włocławku [Paryż, 25 listopada 1924 r.].

5 A. Pałyga, op. cit. s. 72.

6 M. Żółkoś, Dramaty kobiecych historii, „Dialog” 2016, nr 7-8, s. 48.

7 Ibidem. 
listów do siebie, ale to jeszcze nie była ta iskra. Wreszcie siadłem i zacząłem zapalać zapałki, i trzymać je aż do poparzenia palców. I pomyślałem, że ona też tak robiła. I że ten sam ból palców czujemy. I że jest. Przyszło. Sama Skłodowska pewnie by mnie wyśmiała. Wprawdzie łaziła trochę na seanse spirytystyczne razem z Piotrem, ale szybko doszła do wniosku, że to nieporozumienie. Ja też bym nie przesadzał - jej duch mnie nie nawiedził (to już prędzej pisząc o Morrisonie, prosiłem go: „Mów do mnie!”), po prostu starałem się wykonać ćwiczenie i wyobrazić sobie, co bym czuł i myślał jako młoda Marysia czy stara schorowana Maria. W ramach ćwiczeń mało też spałem (śmiech) ${ }^{8}$.

Ciekawe wyznanie, wiele mówiące o wrażliwości tego autora, jego warsztacie i podejściu do dramatu. Pałyga wprawdzie ironizuje swoje artystyczne „ćwiczenia” z wyobraźni, jednak ich nie ukrywa i otwarcie mówi o pragnieniu „stania się Marią”, czyli dążeniu do możliwie pełnej, wręcz intymnej identyfikacji z bohaterką. Ćwiczenia te rzeczywiście przypominają seans spirytystyczny, w którym pisarz odgrywa rolę medium dla postaci dramatycznej: chciałby ją wywołać z niebytu, poczuć w sobie, przemówić jej głosem, być może także doświadczyć jej istnienia w jakimś szczególnym dla niego aspekcie. Oczywiście - w wyobraźni, która wymaga jednak stymulacji nie tylko umysłowej, ale, jak widać, także zmysłowej. Postać taka jak Skłodowska mogła zresztą skłonić Pałygę do większego zainteresowania spirytyzmem, który uczona przez pewien czas traktowała bardzo poważnie. W wywiadzie pisarz trochę bagatelizuje ten wątek jej niezwykłego życia, ale w monodramie już nie. Zanim jednak przejdziemy do lektury $W$ promieniach, posłuchajmy biografistki Marii, Barbary Goldsmith:

Państwo Curie wraz z gronem przyjaciół-naukowców - do których należeli m.in. Crookes, Jean Perrin i jego żona Henrietta, Georges Gouy oraz Paul Langevin - zajmowali się badaniem spirytyzmu, podobnie jak robił to brat Piotra - Jacques, który był jego [spirytyzmu - przyp. J.K.] gorącym zwolennikiem. Piotr i Maria wzięli udział w wielu seansach, zwłaszcza tych, które prowadziła Eusapia Paladino, medium z Włoch. Traktowali te seanse jako „eksperymenty naukowe”, sporządzając naukowe notatki. Historyczka Anna Hurwic napisała, że Curie „uważali za prawdopodobną możliwość

8 Jak zostać Skłodowska [z Arturem Pałygą rozmawia Justyna Jaworska], „Dialog” 2016, nr 7-8, s. 78. 
odkrycia w spirytyzmie źródła jakiejś nieznanej energii, która wyjaśniałaby tajemnicę promieniotwórczości” [...] Na kilka dni przed śmiercią Piotr pisał o swoim ostatnim seansie u Palodino: „Według mnie, w przestrzeni istnieje cała dziedzina zupełnie nowych faktów oraz fizycznych stanów, o których nie mamy jeszcze pojęcia"”.

Goldsmith uważa, że Skłodowska po śmierci Piotra „wyda[wała] się w swym pamiętniku przemawiać do zmarłego męża niczym spirytystka”"10, i rzeczywiście, konwencja rozmowy ze zmarłym zostaje w tym dokumencie przekroczona na rzecz bezpośredniego kontaktu między dwiema osobami. Skłodowska mówi do zmarłego męża i słucha jego odpowiedzi, choć to może tylko rozpacz po stracie najbliższej osoby sprawia, że zachowuje się jak medium. Spirytyzm wyraźnie ją jednak pociągał, zwłaszcza że jego twórca, Hipolit Rivail, sam zajmujący się matematyką, fizyką, chemią, astronomią, fizjologią i anatomią, traktował go jak naukę, a swoje teorie adresował do uczonych, pisząc:

Jak wynalazek mikroskopu odkrył nam świat istot nieskończenie małych, których istnienia nie podejrzewaliśmy, jak teleskop odkrył nam tysiące światów, o których nie mieliśmy pojęcia, tak obcowanie spirytystyczne objawia nam świat niewidzialny, który nas otacza, ociera się o nas nieustannie i bez naszej wiedzy bierze udział we wszystkiem, co czynimy. W niedalekiej przyszłości istnienie tego świata, który nas wszystkich czeka, będzie tak samo niezbicie stwierdzone, jak istnienie świata mikroskopowego i globów, rozsianych w przestworzach. Czyż zaznajomienie nas z tym światem i wtajemniczenie nas w tajniki życia zagrobowego jest niczem? ${ }^{\text {?1 }}$

W Le Livre des Esprits, pierwszym i najważniejszym dziełku Rivaila (wydanym pod pseudonimem Allan Kardec), kursywą ujęto pytania autora, a w cudzysłów wzięto odpowiedzi duchów, pozostałe fragmenty to autorskie komentarze:

9 B. Goldsmith, Geniusz i obsesja. Wewnętrzny świat Marii Curie, tłum. J. Szmołda, Wrocław 2016, s. 130-131.

10 Ibidem, s. 131.

${ }^{11}$ A. Kardec, Księga duchów, tłum. J. Ch., Wisła 1934, s. 214. Pisownia oryginalna. 
Czy duchy maja pewne określone, ograniczone i stale kształty?

„Dla waszych oczu nie, ale dla naszych tak; jest to, jeżeli chcecie, płomień, światłość, lub jakaś iskra eteryczna”.

Czy ten płomień lub ta iskra ma jakie kolory?

„Dla was mieni się od ciemnego aż do blasku rubinu według stopnia oczyszczenia ducha".

Zwyczajnie wyobrażają duchy wyższe z płomieniem lub gwiazdą na czole; jest to symbol, który przypomina naturę istotną Duchów. Umieszczają go nad głową, ponieważ tam jest siedlisko inteligencji.

Czy duchy potrzebuja pewnego czasu do przebycia przestworzy?

„Tak jest, ale mkną tak szybko, jak myśl”.

Czy myśl przenoszaca się nie jest to dusza sama?

„Tam, gdzie jest myśl, jest także dusza, gdyż ona to myśli. Myśl jest własnością duszy"12.

Skłodowska na pewno znała te popularne w kręgu francuskich intelektualistów dialogi, a obraz duchów z płomieniem na czole (jak wyobrażali je sobie głównie okultyści typu Nostradamusa, którego księgi studiował Faust) mógł do niej przemawiać szczególnie. W jednym z młodzieńczych listów pisała przecież o swojej płonącej głowie i dowcipnie porównywała się do zapałki. Pałyga twierdzi nawet, że jako guwernantka w Szczukach („dokąd z Warszawy jechało się trzy godziny koleją i cztery godziny saniami"13) chętnie bawiła się ogniem (pewnie z zimna), ale niczego pewnego na ten temat nie wiemy. Wiemy natomiast, że sam Pałyga, aby przywołać Marię, przypalał sobie palce żywym płomieniem - jakby ujarzmiał żywioł ognia, by wyzwolić $\mathrm{z}$ niego ducha w tajemniczym rytuale... I bardzo uważnie czytał jej korespondencję.

\section{PIERWIASTKOWA POEZJA W DZIAŁANIU}

Podtytuł monodramu Pałygi brzmi: Zupełnie nieznane listy Marii Skłodowskiej-Curie, co prawie dokładnie odpowiada kompozycji utworu, na który złożył się jeszcze Prolog, czyli parafraza pierwszych zdań słynnego wykładu Marii wygłoszonego po objęciu przez nią katedry zmarłego Piotra Curie, a także Wielka improwizacja Marii Skłodowskiej-Curie w dwóch

12 Ibidem, s. 55.

13 K. Kabzińska, Nad listami Marii Skłodowskiej-Curie, [w:] Korespondencja polska Marii Skłodowskiej-Curie..., op. cit., s. XI. 
częściach, będąca przewrotnym i oryginalnym nawiązaniem do improwizacji Konrada z trzeciej części Dziadów. Pozostałe, opatrzone tytułami części utworu mają kształt listów adresowanych do siebie samej, przy czym Skłodowska zwraca się w nich także do Piotra, dwóch córek i nienarodzonego dziecka, jakby nie tylko siebie, ale także ich czworo pragnęła wywołać i wytłumaczyć się przed nimi ze swojego życia. Oczywiście, głównym adresatem tej korespondencji są odbiorcy monodramu, i przyznam, że kiedy przeczytałem „zupełnie nieznane” listy Marii, odczułem ją o wiele silniej niż po lekturze listów „znanych”, naprawdę przez nią napisanych, a po latach zebranych i udostępnionych licznej publiczności. Może dlatego, że podanych do druku tylko we fragmentach? Co kryją te wykropkowane miejsca w listach do ojca, siostry, męża, córek, przyjaciela, kochanka? Żeby to sprawdzić, musiałbym zrezygnować z pośredników - redaktorów, edytorów - i dotrzeć do oryginałów. Wziąć do ręki zapisane kartki i czytać je w nadziei, że nieopracowane i nieocenzurowane przemówią do mnie prawdziwym głosem uczonej. Nie robię tego jednak, za to tekst Pałygi czytam wielokrotnie. Ciekawe, że przeszkadzają mi wydawcy, a nie przeszkadza mi inny pośrednik - pisarz. Do tamtych nie mam zaufania, do niego - owszem, choć przecież podsuwa mi literacki apokryf. Może dlatego, że sam zachowuje się jak medium...

W promieniach nie ma nic wspólnego z okolicznościową kompilacją listów Skłodowskiej ani też ich krytycznym „przepisaniem”. To raczej osobista odpowiedź pisarza na te myśli uczonej, które najbardziej przykuły jego uwagę, i amplifikacja tych motywów obecnych w jej korespondencji, które najsilniej przemówiły do jego wyobraźni. Pałyga czyta listy Marii i dosłownie łapie ją za słowa, nie po to jednak, by jej coś wytknąć, chytrze nicując znaczenie cytowanych fraz: „Ciekawość ludzka jest nieopanowana / Znajdzie, wypatroszy wszystko, a czego nie znajdzie, to sobie dopowie"14 - mówi Maria. Owszem, Pałyga jest jej ciekawy, ale nie w ten sposób. Dopowiada, ale nie to, o czym uczona sama choćby nie napomknęła. Wsłuchuje się w jej głos, by go lepiej usłyszeć, a nie zagłuszyć, choć naśladując nieco staroświecki styl Skłodowskiej, chętnie od niego odchodzi, łamie frazę, modernizuje język i poddaje go zupełnie nowej regule. Jego bohaterka - jak w prawdziwych li-

${ }^{14}$ A. Pałyga, op. cit., s. 56-57. 
stach z końca XIX wieku - często mówi „ładnymi zdaniami”, to znaczy stara się być precyzyjna, logiczna, zrozumiała i jednoznaczna. Tym klarownym stylem wypowiedzi formułowanej na papierze broni się przed „mackami” ludzkiej ciekawości, które „wpychają się” w szczeliny cudzego życia. Ale te „ładne zdania” co i raz zamieniają się w strumień żywej mowy, która brzmi jak poemat dramatyczny:

Nie piszę tego listu.

Wypowiadam go, przecież nic nie ginie.

Słowa promieniują ${ }^{15}$.

„Promieniują” znaczeniami i energią mówiącej. Mowa Marii jest poetycka, bo siłą ukrytych w niej metafor poddaje rzeczywistość zaskakującym transformacjom, a mocą zestawianych ze sobą słów - niczym w awangardowym poemacie - uruchamia nagłe asocjacje: myśli, uczuć, wrażeń. Czy kiedykolwiek zauważyliście, że w zwykłej „radości” kryje się niezwykły, promieniotwórczy „rad” i ostra, kłująca „ość”, którą można się zadławić? Ale monolog Skłodowskiej jest też dramatyczny, to znaczy: pulsuje obecnością mówiącej dziewczyny, a potem kobiety, wyraża jej reakcje, uniesienie, zmęczenie, ból; oddaje dynamikę myśli i gorączkę pragnień; słowem naśladuje działanie, które jest wyjątkowe. Nie znam takiego tekstu, w którym poetyckiej i dramatycznej transformacji podlegałby naukowy eksperyment! Liczby, figury geometryczne, związki chemiczne i zjawiska fizyczne, oczywiście, inspirowały poetów, i gdy Maria „improwizuje” wyodrębnianie polonu, a potem radu, przypominają się poezje futurystyczne Tytusa Czyżewskiego, na przykład jego Poemat liczb z 1920 roku. Ale futuryzm, zafascynowany zarówno nauką, jak i spirytyzmem czy magnetyzmem, to nie jedyne powinowactwo literackie, na które można wskazać. W monologu Marii słyszymy też głos głównego bohatera dramatu Jarosława Marka Rymkiewicza Lekcja anatomii profesora Tulpa: według Rembrandta z 1964 roku, w którym czynnemu opisowi poetyckiemu podlega sekcja zwłok. Oto jak brzmi „pierwiastkowa poezja" Marii w jej w dramatycznym działaniu:

Kwas solny na blendę smolistą.

Kwaśny roztwór.

15 Ibidem, s. 55. 
Na to siarkowodór.

$\mathrm{W}$ roztworze zostają uran i tor.

To, co się wydzieliło z roztworu, uwaga, to co się wydzieliło z roztworu, jest bardziej aktywne niż cały uran i tor.

Czym jest?

Co to jest?

Jeśli uran wymaga śmierci gwiazdy, to czego wymaga to tu?

Co mamy w rękach?

Badam.

To mieszanka siarczków metali: ołowiu, miedzi, bizmutu, arsenu oraz antymonu.

Tyle znamy.

A to nieznane?

[...]

A zatem blenda smolista!

Traktujemy chlorem, i mamy chlorki

$\mathrm{U}, \mathrm{Th}, \mathrm{Pb}, \mathrm{Cu}, \mathrm{As}, \mathrm{Sb}, \mathrm{Bi}$ i X!

Jest osad.

Siarczki.

$\mathrm{Pb}, \mathrm{Cu}, \mathrm{As}, \mathrm{SB}, \mathrm{Bi}$ i X!

$\mathrm{Na}$ to $(\mathrm{NH} 4) 2 \mathrm{~S}$.

Zostają trzy.

$\mathrm{Pb}, \mathrm{Cu}, \mathrm{Bi}$.

I czwarty, jak czwarty muszkieter - X.

$\mathrm{Na}$ to NH3.

I są wodorotlenki $\mathrm{PB}, \mathrm{Bi}$ i X!

$\mathrm{Na}$ to $\mathrm{H} 2 \mathrm{~S}$.

$\mathrm{I}$ jest dalej $\mathrm{Pb}, \mathrm{Bi}, \mathrm{X}$.

Więc nic się nie zmienia.

Zatem sublimacja.

700 Celsjusza.

I jest!

Po jednej stronie odchodzą do nieba PbS1, BiS3, a my do środka piekła. $\mathrm{X}$ !

Nazwijmy go polon! $!^{16}$

16 Ibidem, s. 61. 
Mówiąc na głos, Maria nie tylko bada i tworzy światy, ale też staje się bardziej realna. Powie nam o tym wprost, choć Pałyga sformułuje jej myśl w taki sposób, jakby chodziło nie tylko o bezpośrednie spotkanie $\mathrm{z}$ bohaterką, ale z samą rzeczywistością: „Mówię na głos, żeby przywrócić realność" - oświadcza Maria, i będzie o tę realność walczyć, także wtedy, gdy zgubi wątek... A więc chce „przywrócić realność” i zawiadamia nas o tym, a zaraz potem dodaje tajemniczo: „Wydobyć się z czegoś w rodzaju stawania się czymś”"17. Maria głośno myśli, żeby stać się kimś innym; tak jak podgrzewane przez nią substancje - podlega ciągłej zmianie, która prowadzi do wyodrębniania tego, co w niej najważniejsze. Mówiąc, „wydobywa się z czegoś” i staje się „czymś” na nowo, tak jakby do wewnętrznej przemiany człowieka nie wystarczała sama wola i refleksja, ale potrzebne było jeszcze sprzężone ze słowem działanie. Napisany list będzie tylko martwym wspomnieniem tego tajemniczego procesu, natomiast list wypowiedziany tu i teraz, w czasie realnym, adresowany do kogoś, choćby do siebie samej, list zamieniony w akt żywej i bezpośredniej komunikacji, nadzwyczajnej, bo opartej na słowie podlegającym wytężonej myśli i zaskakującej pracy wyobraźni, list-czynność - jest samym tym procesem. Jest potężnym wehikułem przeżycia zmieniającego osobowość, który może uruchomić - i którego może doświadczyć! - nie tylko aktorka wykonująca monolog Marii, ale także jego czytelnik. Przywołana już w Prologu naczelna definicja radioaktywności - „Radioaktywność to przemiana jednego pierwiastka w inny przez emisję promieniowania” - świetnie wyraża zasadę i cel tego monodramu.

\section{W GĘSTNIEJĄCYM MROKU}

Już wiemy, że powstał on dzięki zapalnej zapałce... W liście do przyjaciółki z 13 marca 1889 roku dwudziestodwuletnia Maria napisała: „Głowa moja tak się pali, tak jest pełna projektów, że sobie rady dać nie mogę. Widzisz, póki życia, Twoja Mania będzie zapałką nad zapałkami!”18. Jak większość dziewczyn z jej pokolenia młoda Maria pochłaniała poezję, tłumaczyła obce wiersze i pisała własne; dowcipna zabawa frazeologizmem nie była więc dla niej niczym szczególnym. Nawet w „ładnie” napisanym liście nie pisze więc o „rozpalonej głowie”, ale o głowie, która się „pali”, a obraz ten momentalnie

17 Ibidem, s. 55.

${ }_{18}$ Korespondencja polska Marii Skłodowskiej-Curie..., op. cit., s. 19. 
skojarzy z płonącą zapałką (bo też ma „główkę”) i... natychmiast się nią stanie. Oczywiście, nie stanie się jakąś zwykłą zapałką, bo przecież w metaforze (inicjującej metamorfozę!) chodzi o myślenie, a Maria chce być uczoną, więc będzie „zapałką nad zapałkami”, wielką, największą, jak biblijna pieśń... Niemniej zapałką - taką do zapalania świecy albo lampy gazowej - a nie pochodnią czy żagwią, która rozpalała wyobraźnię niejednego poety. Pałyga zauważył tę różnicę i uchwycił się tej zapałki, to znaczy - podążył za młodzieńczą, poetycko „nieprzeskalowaną” wyobraźnią Marii, ale pozwolił także działać własnej fantazji, i oto wokół tego motywu powstała w jego utworze kluczowa dla całego monologu sytuacja dramatyczna: „Jestem tu, w gęstniejącym mroku / Jest stolik, kartka, przede mną niezapalona lampka. // Przed lampką zapałka"19 - mówi Maria do siebie samej z przyszłości w pierwszym monologu, zatytułowanym Uwięziona.

Każdy kolejny list wypowiada coraz bardziej dojrzała kobieta; ten mówi osiemnastolatka. Jest znacznie młodsza od historycznej Marii z listu do Przyborowskiej, i właśnie obchodzi swoje urodziny. Samotny listopadowy wieczór jest więc dla niej czasem wyjątkowym, czasem przejścia i zmiany, a także - próby. Dziewczyna osiągnęła dojrzałość i na progu dorosłości przeżywa ten rodzaj egzystencjalnego wstrząsu, którego najważniejszym składnikiem jest poczucie przemijania. „Mania duża”, „Mania w dojrzałości swego owocnego życia” uświadamia sobie „znikomość życia naszego w nieskończoności wszechświata" i zdaje się jej, że już teraz przechyla się w nieistnienie, zaczyna jej ubywać i „znika w tym zmierzchu” ${ }^{20}$. Niesamowity, tajemniczy moment! Maria czuje się samotna, ale i odrębna, nie poszła przecież na zabawę, choć ją zapraszali. Nie chciała trwonić swego krótkiego życia na sprawy nieważne, czemu sprzyja także brak urody, z którego próbuje być nawet dumna: „Jestem brzydka, co uważam sobie za dar, za największym prezent"21.

Samotność Marii, samotność od ludzi, pogłębiona jest przez nieobecność Boga, który zniknął z jej życia z chwilą śmierci siostry, a zaraz potem matki. Dotknięta tą podwójną stratą, religijna dotąd dziewczyna zwątpiła w Bożą dobroć: „Przemodliłam tyle nocy, a miałam wiarę niezachwianą i mocną
19 A. Pałyga, op. cit., s. 72.
20 Ibidem, s. 51.
21 Ibidem, s. 52. 
jak skała, miałam wiarę w - proście, a będzie wam dane. // I umarły dwie”22. A gdy już stała się uczoną, w ogóle wyłączyła Boga z refleksji nad życiem i śmiercią. Ale to potem, teraz, wspominając młodzieńczy dramat, mówi: „pozostała pustka, która domaga się wypełnienia”, i wypełnia ją sobą, bo postanawia pisać listy do siebie samej. Ten zaskakujący pomysł doskonale oddaje najważniejsze rysy osobowości Marii - skupionej, introwertycznej i dumnej, a przez to zamkniętej na innych, ale zarazem szukającej dojrzalszego powiernika, któremu można by powierzyć treści „najwstydliwsze” i „najintymniejsze”. Monolog Marii zamierzył Pałyga jak tego rodzaju wyznanie, które Konrad w Dziadach nazywa „odkrywaniem duszy”23. Maria wprawdzie „nie cierpi romantyzmu”, ale jej listy mają dokładnie taki charakter, choć akurat te dwa fragmenty monodramu, które Pałyga nazwał Wielka improwizacją Marii Skłodowskiej-Curie, poświęcone są zupełnie innemu odkryciu - nie duszy, ale polonu i radu. W przypadku bohaterki chodzi jednak o to samo... Konrad w swoim wyznaniu zwraca się do Boga „po przyjacielsku”, by na Jego milczenie zareagować ostatecznie bluźnierstwem (niewypowiedzianym jednak!). Maria w Boga nie wierzy, ale pragnie obecności kogoś na Jego podobieństwo: „A chcę, potrzebuję bardzo czuć czyjąś obecność, czuć, że ktoś mnie widzi, wie o mnie, rozumie"24.

Gdyby monolog Marii wypowiedziała kiedyś ze sceny aktorka, a stałoby się to w naszej obecności, być może empatia, którą poczulibyśmy wobec dziewczyny, wypełniłaby to jej pragnienie. Ale Maria nie mówi do widowni, mówi do siebie i siebie ustanawia tą drugą, czującą, świadomą i rozumiejącą osobą, przed którą może otworzyć duszę. Jak Henryk w Ślubie, Maria mówi w pustce, którą chciałoby się nazwać metafizyczną, a której znakiem i u Gombrowicza, i u Pałygi jest ciemność: „Jestem tu, w gęstniejącym mroku" - powie dziewczyna, na progu dorosłości doświadczając samotności nowoczesnego intelektualisty, która popycha ją do kreacji sobowtóra. Pisząc do siebie, Maria na niby, ale z prawdziwej wewnętrznej potrzeby ustanawia swoje drugie „ja”, by wobec niego wypowiedzieć siebie, a dokładniej - zbudować się taką, jaką pragnęłaby być. Henryk, „stwarzając” Władzia (a był to akt

${ }^{22}$ Ibidem, s. 62.

23 "Jeszcze po przyjacielsku duszę Ci odkrywam”. A. Mickiewicz, Dziady, cz. III, Warszawa 1974, s. 200.

24 A. Pałyga, op. cit., s. 51. 
nieświadomy, Władzio wyłania się w Ślubie ze snu bohatera), ustanowił kogoś „poniżej” samego siebie, kogoś, nad kim będzie mógł „zapanować”, zmusić go do śmierci samobójczej i stać się (mimowolnym?) tyranem. Maria przeciwnie - marzy o sobie bardziej świadomej, mądrzejszej, większej, nawet nieśmiertelnej! Jej dążenie nie jest jeszcze podminowane poczuciem klęski i wewnętrznego rozbicia, które w połowie XX wieku napełnia dusze tak wielu bohaterów literackich o nihilistycznym światopoglądzie i sercu wypełnionym rozpaczą. Maria należy jeszcze do tej formacji intelektualnej, która na swoich wysoko wzniesionych sztandarach pisze słowo „pozytywizm”, a nie „negacja”, cały idealizm XIX stulecia (religijny, filozoficzny, poetycki) łącząc z realizmem laboratoryjnych eksperymentów i przekuwając go we wzniosły światopogląd naukowy: „Więc pracujmy - woła Maria. - Pracujmy, póki świeci dla nas światło dnia i małe światło w nocy".

Pałyga doskonale uchwycił ten wymiar konstrukcji duchowej Skłodowskiej, wyeksponował go, ale też poddał głębszej, poetyckiej analizie. Przede wszystkim nasycił monologi Marii alchemiczną symboliką, dostrzegając w jej nieugiętej postawie poszukiwacza wiedzy - która tak zafascynowała gimnazjalistki z Włocławka i cały świat - ezoteryczny mit faustyczny. Samo działanie uczonej, jej niekończące się próby rozdzielenia różnych substancji przez ich coraz silniejsze podgrzewanie wpisał zaś w matrycę okultystycznego obrządku, którego artystycznym odwzorowaniem stał się sam monodram. Maria w utworze Pałygi działa nie tylko na materię, ale i na siebie; jej naukowe praktyki mają bezpośredni wpływ na jej kondycję fizyczną i psychiczną - nie tylko poszerzają jej wiedzę, ale także zmieniają światopogląd i kształtują osobowość. W promieniach uświadamia nam, że wbrew pozytywistycznym założeniom badania naukowe kształtują samego badacza, zmieniają jego duchową strukturę, a proces tej wewnętrznej transmutacji jest trudniejszy do prześledzenia, zdefiniowania czy zmierzenia niż przemiana ciał. „Przybiera się cechy tego, co się ukochało, z czym się skleiło życie” - mówi Maria, a potem dodaje: „Jestem radem”. Z każdym słowem wstępuje na wyższy stopień swojej świadomości.

\section{JASNY PROMIEŃ PRAWDY}

A więc jak siebie widzi Maria? Jak siebie rozumie - teraz i w przyszłości? Co ujawnia jej monolog? Jest (będzie) dumna i samotna, jest (będzie) inna i jest (będzie) zdeterminowana. Chce poświęcić się nauce, by wydrzeć światu 
tajemnice, które uczynią ludzi szczęśliwszymi. W ciemności, metafizycznej pustce, rodzi się płomień i rodzi się uczona, która jak Prometeusz gotowa jest wykraść bogom ogień i zanieść go ludziom nawet za cenę męczeństwa. Drażni ją to słowo, ale doświadczenie, które się za nim kryje, wyraźnie ją pociąga. Bierze do ręki zapałkę, analizuje w myślach składniki, z których ją wykonano - drewno i fosfor - zamyślając się nad tym „dziwnym” pierwiastkiem, który niesie tyle zła i tyle dobra; a potem zapala patyk i trzyma go tak długo, aż zgaśnie jej w palcach, gotowa w przyszłości znosić większy ból. „W bólu znikam” - powie - „Jest tylko wola”, i właśnie czystą wolą ponad wszelkimi żywiołami chciałaby się stać, wolą odporną na wszystko, co ją osłabia. Na ból fizyczny i psychiczny, i wszelkie przeciwności jak te, że jest kobietą, a studia w jej epoce są przewidziane dla mężczyzn, że jest Polką, a wiedza w jej kraju to domena Rosjan, że jest biedna, a nauka kosztuje, że musi żyć z ludźmi, którzy zawsze czegoś oczekują... No i jest z ciała, które podlega zmęczeniu, chorobom, starości.

Jak, będąc człowiekiem, nie ulec ludzkim słabościom? Należy się ćwiczyć, zatem Maria wymyśla sobie prywatny „rytuał” ognia... Ale to za mało. Żeby przekroczyć siebie, potrzebny jest silniejszy pomocnik, i Maria wie, że nie wystarczy go sobie wymyślić, żeby wytrwać. Dlatego tamtej nocy, w ciemnym pokoiku, w całkowitej samotności nie tylko ustanawia swoje drugie „ja”, ale także kogoś przyzywa. Dzieje się to zupełnie realnie: cały świat cichnie, zapałka płonie, Maria zbliża do jasnego płomienia koniuszki placów i wtedy słychać czyjś głos:

Płomień mówi do mnie.

Maniu - mówi do mnie.

Jak ktoś bliski, najbliższy, jak członek rodziny, najbliższej rodziny.

Maniu - mówi płomień.

Jestem - mówię.

Jestem.

I boję się.

I czuję, jak narasta strach, panika, którą trzeba stłumić.

I gorąco już w palce.

Chcę.

Mogę.

Proszę.

Żądam. 
Rozkazuję.

Niech tu przede mną.

Stawi się.

Jak przed Faustem.

Dla świata.

Dla ludzkości.

Czy gotowa?

Tak, jestem gotowa.

Czy aby na wszystko?

$\mathrm{Tak}^{25}$.

Maria wie, że kiedy przychodzi ból i zdoła się go wytrzymać, świat (z tymi wszystkimi nieświadomymi ludźmi) odchodzi, a zjawia się - no kto? „Jak przed Faustem” - a więc zrodzony z ognia Duch Ziemi, może sam Mefistofeles? Na jedno wychodzi - cała scena jest faustowska. Pałyga nasyca ją mnóstwem aluzji do pierwszej sceny pierwszej części tragedii Goethego, tej zatytułowanej Noc:

Przygasa lampa!

Jakaś mgła - Czerwony promień drga

Mi wokół głowy - Jakiś powiew

Spływa spod sklepienia

I mnie ogarnia!

Jesteś przy mnie, krążysz, duchu upragniony,

Ja to czuję!

Ukaż mi się!

[...]

Chwyta ksiege i wypowiada tajemniczo znak Ducha. Błyska czerwony płomień, w płomieniu ukazuje się Duch ${ }^{26}$.

Pierwszy monolog W promieniach to noc Marii, noc jej „wyzwolenia”. Podobieństwo zdradzają słowa, przedmioty, obrazy, sama sytuacja rozmowy z płomieniem, która w Fauście jest wyraźnym nawiązaniem do praktyk okultystycznych ${ }^{27}$. Maria zapala zapałkę i zapala myśl, która nagle się od

${ }^{25}$ Ibidem, s. 54.

26 J.W. Goethe, Faust, tłum. J.St. Buras, Kraków 1997, s. 7-8.

27 Konkretnie do tak zwanego „mniejszego wyganiającego rytuału pentagramu”. Zob. A. Abyss, Księga magii i zaklęć, tłum. R. Roczon, Zielona Góra 2007, s. 42. 
niej odrywa i mówi do niej jak przybywający gość. Jej serce, tak jak serce Fausta, „sznuruje” lęk, który musi przezwyciężyć, by uwolnić siebie i nabrać takiej mocy, by „wniknąć stwórczo moją wolną siłą / w żyły natury, jak bogu przystało"28. Właśnie w tę stronę Pałyga poprowadzi dalsze partie monologu Marii, dla której badanie natury będzie jednocześnie stwarzaniem jej nieznanych pierwiastków i wyznaczaniem nieuświadamianych wymiarów. Maria nie ma za sobą lat żmudnych badań, a jej pragnienie nie rodzi się z naukowego rozczarowania; kieruje nią raczej poetycki zapał poznawczy, znany z wierszy Adama Asnyka, które autor W promieniach wplecie w monodram: „Szukajcie prawdy jasnego płomienia! / Szukajcie nowych, nieodkrytych dróg..." recytuje Maria i zaraz trzeźwo dodaje: „I szukam, poparzonymi dłońmi szukam płomienia, tak? / Tylko z tym Bogiem..."29. Kluczowy dla inicjalnej sytuacji faustycznej jest więc ten moment, kiedy Maria zyskuje panowanie nad bólem i lękiem, a siła kierującej nią woli uwalnia nie tylko odważną, buntowniczą, wręcz straceńczą myśl, ale także drugi głos, który wystawia przyszłą uczoną na próbę. Nie, w monodramie Pałygi nie zjawia się Mefisto, choć dojrzała już Maria przywoła jego imię; nikt też - jak celnie zauważa Małgorzata Szpakowska - nie daje dziewczynie żadnych gwarancji, „że się uda, że jej wysiłek nie pójdzie na marne"30. A jednak liczy się wewnętrzna decyzja. Maria jest gotowa na wszystko i zniesie wszystko, „nawet kiedy” - co?

\section{FAUSTOWSKI UKŁAD}

Myśl o „faustowskim układzie” Marii pojawia się także w biografii autorstwa Barbary Goldsmith. Autorka Geniuszu i obsesji wiąże go z drugą Nagrodą Nobla, którą uczona otrzymała za odkrycie polonu i radu, wyodrębnienie czystego radu i badania właściwości pierwiastków promieniotwórczych. Nagroda spopularyzowała nowe pierwiastki, zwłaszcza rad, który uznano za cudowne antidotum na wszelkie choroby, przede wszystkim nowotworowe, a więc te, które w rzeczywistości wywoływał (Maria umarła na białaczkę właśnie z powodu silnego napromieniowania radem). Za światową sławę, która przyniosła jej możliwość dalszych eksperymentów, choć nie przyniosła jej majątku (odkrycie nie zostało przez uczonych opatentowane),

\footnotetext{
${ }^{28}$ J.W. Goethe, op. cit., s. 15.

29 A. Pałyga, op. cit., s. 62.

30 M. Szpakowska, Poparzona, „Dialog” 2016, nr 7-8, s. 81.
} 
zapłaciła zdrowiem i życiem, narażając ponadto wielu innych ludzi. W biografii Goldsmith jak refren powraca motyw naukowej obsesji, która dobro własne Marii i bliskich jej ludzi spycha na dalszy plan codziennego życia. Skłodowska dosłownie zatraca się w pracy, która ściąga na nią ogromne niebezpieczeństwo. Wyodrębniony ze smółki uranowej rad miał być, według jej obliczeń, „kilkaset razy bardziej aktywny od uranu”.

Myliła się jednak. Jedna dziesiąta grama czystego chlorku radu była dziesięć milionów bardziej promieniotwórcza od czystego uranu. Cztery lata później Piotr Curie powiedział, że gdyby wybór należał do niego, nigdy nie podjąłby się zadania wyizolowania radu. Maria nie miała jednak wyboru ${ }^{31}$.

Ostatnie zdanie biografki Skłodowskiej brzmi bardzo złowieszczo, jakby Maria nie była wolna w swoich dążeniach, ale determinacja uczonej, by wyodrębnić rad, miała podstawy czysto naukowe. Teoretyczne odkrycie nowego pierwiastka mogło usatysfakcjonować fizyków, którzy „pracowali z właściwościami promieni" ${ }^{32}$ i potrafili na ich podstawie uznać źródło promieniowania za rzeczywiste. Natomiast chemicy oczekiwali substancji, i Maria postanowił im ją dostarczyć, choć nie miała ku temu odpowiednich warunków. Pracę, którą z pomocą Piotra Curie wykonywała w swoim prymitywnym laboratorium urządzonym w szopie, powinien był wykonywać liczny zespół ludzi wyposażonych w odpowiednią aparaturę. Inna rzecz, że tylko nadzwyczaj zręczna Maria potrafiła dokonać koniecznych pomiarów w trakcie wywoływanych przez nią reakcji. Zmęczenie wywołane wielomiesięcznymi doświadczeniami nie było jedyną ceną, jaką płaciła za miligramy radu wyodrębnione $\mathrm{z}$ wielu ton gliny. Skłodowska cierpiała także na nawracające depresje. Goldsmith sugeruje, że w grudniu 1903 roku uczona nie pojechała do Szwecji odebrać Nagrody Nobla właśnie z powodu depresji, która była następstwem poronienia:

Poprzedniego lata, pomimo tego, że była w piątym miesiącu ciąży, wybrała się z Piotrem, bardzo spragnionym jej towarzystwa, na wyprawę rowerową, niepomna niebezpieczeństwa, jakie może za sobą pociągać tak forsowna podróż. Po trzech tygodniach pedałowania Maria poroniła. Do tej pory,

31 B. Goldsmith, op. cit., s. 85.

32 Ibidem, s. 85. 
gdy tylko mogła, $\mathrm{z}$ zapałem maniaka rzucała się w wir pracy, co pomagało jej przetrwać trudne chwile, lecz teraz okres mozolnej pracy miała już za sobą. Była wyczerpana fizycznie, nie miała też dotąd czasu, aby przywdziać żałobę po utracie ojca oraz swojego nienarodzonego dziecka. W następnym tygodniu rozchorowała się. Niewiele mówiła, mało jadła i ignorowała Irenę, budząc się jedynie po to, by poprowadzić zajęcia w Sevres ${ }^{33}$.

Drugą Nagrodę Nobla w 1912 roku odebrała już osobiście, ale po powrocie ze Sztokholmu trafiła do szpitala z podejrzeniem niewydolności nerek. Choć przeszła operację, przyczyny jej zapaści nie były pewne. Podejrzewano bezobjawową gruźlicę:

Nikt nie wspominał jednak o tym, że wcześniej przeszła całkowite załamanie nerwowe i pogrążyła się w najgłębszej, najczarniejszej depresji swojego życia, która trwała dłużej niż wszystkie dotychczasowe epizody tej choroby razem wzięte. Gdy Ewa była większa, Maria powiedziała jej, że w owym czasie naprawdę chciała się zabić, i rzeczywiście, niektóre jej listy wskazują na to, że planowała popełnić samobójstwo ${ }^{34}$.

Listów tych jednak nie znamy. A może myśli wielkiej uczonej o samobójstwie zostały wykropkowane przez wydawców jej korespondencji? W 1911 roku Maria miała za sobą nie tylko poronienie, ale także tragiczną śmierć Piotra Curie, stratowanego przez powóz konny (głowa uczonego dosłownie została zmiażdżona kołem), oraz wyniszczający psychicznie romans z młodszym od niej Paulem Langevinem, za który była napiętnowana. W „faustowskim układzie” - jeżeli przyjmiemy tę ryzykowaną interpretację losów Skłodowskiej - pojawia się więc także „zakazana” miłość Marii i jej zamach na własne życie, do którego na szczęście nie doszło. Faust także próbował samobójstwa...

\section{UNIECZŁOWIECZENIE}

Serii wielkich naukowych sukcesów Skłodowskiej towarzyszyła więc seria jej osobistych nieszczęść, które przywodzą na myśl Faustowski pakt z diabłem. Maria w opowieści Goldsmith przypomina genialnego kompozytora z powieści Tomasza Manna Doktor Faustus. Tak jak Adrian Leverkühn jest w swojej

33 Ibidem, s. 104.

34 Ibidem, s. 170. 
dziedzinie odkrywcą zupełnie nowych światów i tak jak on cierpi, długie tygodnie swojej fizycznej i psychicznej zapaści spędzając w całkowicie zaciemnionym pokoju, który przypominał grób ${ }^{35}$. Ale to nie jedyny motyw łączący ją $\mathrm{z}$ bohaterem powieści Manna. Największym wstrząsem dla Leverkühna była śmierć dziecka, małego Nepomuka, przez kompozytora i całe jego domowe otoczenie nazywanego Echem ( $w$ domyśle: dawnych czasów, ale także zapomnianej, dziecięcej wiary) i darzonego głębokim uczuciem. Chłopiec modlił się po swojemu za całe stworzenie, zadziwiając i rozczulając Adriana. Jego nagłą śmierć kompozytor odczuł jak kolejny, najstraszniejszy atak Mefistofelesa, z którym - jak mu się zdawało - zawarł pakt. Kreując postać diabła, Mann podążał oczywiście za Goethem, u którego, jak pisze Mircea Eliade:

Mefistolefes nie przeciwstawia się bezpośrednio Bogu, lecz Życiu - Jego głównemu stworzeniu. Zamiast ruchu i Życia stara się narzucić bezruch, odpoczynek, śmierć. Każdy bowiem, kto przestaje się zmieniać, przeobrażać, rozpada się i ginie. Ta „śmierć za życia” objawia się jałowością ducha, jest, koniec końców, równoznaczna z potępieniem. Kto dopuszcza się tego, by w nim samym zginęły korzenie Życia, ten dostaje się pod panowanie Ducha negacji ${ }^{36}$.

Szatańska dialektyka! Mefistofeles stymuluje ludzkie dążenie - poznawcze, twórcze - a jednocześnie jego przeciwieństwem i warunkiem koniecznym czyni śmierć, która na stałe zostaje wpisana w rozwój i postęp, we wszelkie ludzkie działanie. Maria w monodramie Pałygi przyzywa Mefista w chwili swego epokowego odkrycia (performując przed nami proces separacji polonu), i od razu pyta:

Co trzeba poświęcić?

Czego chcesz, Mefisto?

Jeśli życie się swoje poświęca, jest to wybaczalne.

Jeśli się na ołtarzu składa siebie samego, jest to wielkie, jest to ponadludzkie, jest to podziwiane.

A jeśli nie siebie?

Jeśli kogoś?

Jeśli ciebie, dziecko? ${ }^{37}$

35 Ibidem, s. 171.

${ }^{36}$ M. Eliade, Mefistofeles i androgyn, tłum. B. Kupis, Warszawa 1994, s. 80.

37 A. Pałyga, op. cit., s. 66. 
Maria zdaje się mówić o dziecku, które poroniła, a motyw ten każe nam myśleć o dzieciobójczyni Małgorzacie z Fausta i Susannie Margarecie Brandt - pierwowzorze tej postaci, oskarżonej nie tylko o dzieciobójstwo, ale także czary, i ściętej w 1772 roku we Frankfurcie ${ }^{38}$. Najpierw, będąc jeszcze w ciąży, Maria zwraca się do synka, ale potem, gdy poroni, powie: „Popatrz, córeczko!”, bo już zna płeć dziecka. „Córeczko, strasznie bolisz!” - zawoła $\mathrm{w}$ innym momencie, przywołując jakby moment zbliżającego się porodu, choć ból, o którym mówi, może mieć także inną, duchową naturę: „Moje dziecko wyszło z mojego ciała umarłe. / Moja córka. Córeczka. Moje dziecko. Złożone w ofierze”. Ale Maria nie ma zwykłych wyrzutów sumienia. W jej wyjątkowej, transowej nadświadomości (i transowej relacji) śmierć stale miesza się z narodzinami, tworząc jedną rzeczywistość ciągłej zmiany, która nie podlega ocenie moralnej, bo należy do innego, nieludzkiego porządku. Reguła ta dotyczy wszystkich ciał - ożywionych i nieożywionych - zgodnie z wiedzą głoszoną przez dawnych alchemików i współczesnych chemików czy fizyków, a także stojących pomiędzy nimi spirytystów:

Co stanie się z materja i siła życiowa istot organicznych po ich śmierci? „Materja się rozkłada i wchodzi w skład nowych tworów przez wdech, wchłanianie itp.; siła życiowa wraca do swego źródła".

Gdy istota organiczna umiera, następuje nowe ugrupowanie pierwiastków, z których się składała; wchodzą one w skład nowych tworów. Twory te czerpią ze źródła powszechnego siłę życiową, wchłaniają i przyswajają sobie ją, by ją wrócić z powrotem temu samemu źródłu, gdy przestaną żyć ${ }^{39}$.

Tajemnicza „siła życiowa” nazywana jest tu „fluidem”, który Rivail (czyli Kardec) skojarzy z elektrycznością: „Ciała organiczne to również jakby rodzaj bateryj elektrycznych, w których działalność fluidu wywołuje zjawisko życia; ustanie tej działalności powoduje śmierć" ${ }^{\prime 40}$.

W pierwszej części swojej Wielkiej improwizacji... Maria schodzi więc „do środka piekła” i w ogromnej temperaturze, w ogniu, który wszystko niszczy, wyodrębnia polon. W części drugiej sięga po płyny ustrojowe

38 A. Schöne, Sabat czarownic i kult Szatana $w$ „Fauście” Goethego, tłum. A.J. Kopacki, „Literatura na Świecie” 1996, nr 5-6, s. 214.

39 A. Kardec, op. cit., s. 50.

40 Ibidem. 
wydobyte z ciała martwego człowieka i polewa nimi martwą skałę, która spadła z kosmosu, wyodrębniając w ten sposób nowy pierwiastek - rad. Żywe - uśmierca, martwe - ożywia, by na koniec spalić się, spopielić i zamienić w promień... Zanim jednak dojdzie do całopalenia uczonej, w drugiej (Czarownica), trzeciej (Zmęczona), czwartej (Spełniona), a potem piątej i szóstej (Wielka improwizacja...) części monodramu Maria doświadcza wielkiego faustowskiego uniesienia. Duch niczym nieograniczonej woli przemienia materię jej badań i materię jej życia, które mieszają się ze sobą jak glina w kadzi i zupa w garnku, bo Skłodowska, choć zatraca się w pracy, próbuje sprostać powinnościom matki: „Dziecko nakarmić, mieszać, grzać, podgrzewać, gotować"'1.

Za pomocą zaskakujących ciągów metafor Pałyga zrównuje w jej monologu badania naukowe i zwykłą kobiecą codzienność, co wzrusza, ale też daje do myślenia. Materialny, moralny i duchowy aspekt istnienia uczona sprowadza przecież do jednego mianownika, któremu na imię „radioaktywność”: „Co to za światło, które wydzielane jest przez coś w tej kupie?! / Co tu przyszło na świat i dla kogo?"42 - pyta Maria, zaskoczona odkryciem pierwiastka o tak potężnej promieniotwórczości. W jej umyśle polon jest dzieckiem, a dziecko - związkiem pierwiastków, promieniującym tak samo jak blenda smolista, tylko słabiej. Równolegle doświadcza transmutacji siebie samej - zgodnie z przeświadczeniami alchemików, które w XX wieku inspirowały psychologów głębi ${ }^{43}$. Ale konstruując wewnętrzną biografię Marii, Pałyga nie podąża ścieżką Jungowskiej indywiduacji, nie przeprowadza swojej bohaterki przez stacje kolejnych kobiecych archetypów. Interesuje go inny proces, który uczona próbuje nazwać już na początku monodramu, w części Czarownica: „Mam wrażenie, że przechodzę proces unieczłowieczania, nad lub podczłowieczania, nie znam tego nazwy"44 - mówi Maria, a Pałyga szyfruje w jej słowach kwestię Ducha $z$ dramatu Goethego ${ }^{45}$ i to kluczowe pojęcie („Übermensch”), które w wieku XIX wyrażało wyższy etap rozwoju

\footnotetext{
${ }^{41}$ A. Pałyga, op. cit., s. 57.

42 Ibidem, s. 59.

43 Zob. C.G. Jung, Psychologia a alchemia, tłum. R. Reszke, Warszawa 1999.

44 A. Pałyga, op. cit., s. 55.

45 „I oto jestem! - A ty dla mnie masz, / Ty nadczłowieku, tylko lęk żałosny!”. J.W. Goethe, op. cit., s. 8.
} 
człowieka uwolnionego od zobowiązań moralnych ${ }^{46}$. W wieku XX to samo pojęcie stało się już znakiem nowoczesnego nihilizmu, który pozwolił na metodyczną, podpartą naukowymi odkryciami i rozwijającą się technologią eksterminację milionów ludzkich istnień. Pogrążona w badawczym transie Maria nie stawia pytań o biologiczne, społeczne i moralne konsekwencje swoich odkryć, choć sama na sobie ich doświadcza; nie zajmują jej także etyczne granice nauki ${ }^{47}$. Należy jeszcze do tej epoki wielki idealistów, którzy naiwnie głoszą neutralność badań i eksperymentów, a w kieszeniach noszą torebki z radioaktywnymi substancjami, od których rozsypują się im kości ${ }^{48}$. Należy do epoki gorączkowych dążeń naukowych, które otworzyły ludziom oczy na niewidzialne energie, ale zniszczyły im ciała i zabrały dusze, czyli odrębność i wyjątkowość, które zniknęły w kosmosie nieustannie mutujących pierwiastków. Obserwując nocami łunę radową, Maria myśli o niewidzialnej stronie bytu, która dzięki jej pracy wreszcie ukazała się ludzkim zmysłom. Jesteśmy w samym centrum mitu faustowskiego - oto bowiem spełnia się sen uczonego, który zapragnął dotknąć metafizycznej zasady świata:

Założyłam, i to było moje ryzyko, że, wbrew rzeczywistości oraz przekonaniom ludzi, których szanuję i lubię, istnieje coś jeszcze.

Co jest niewidzialne.

Ponieważ nasze zmysły są niedoskonałe.

Ale mamy coś, co dąży do doskonałości, której nie osiągnie, i to jest właśnie doskonałość.

A mianowicie naukę.

Nauka sięgnie tam, gdzie nie sięgają zmysły.

I nie chodzi o duchy.

Niestety, nie chodzi także o ludzi, co najwyżej o ludzkość... Cała pierwsza część Wielkiej improwizacji Marii Curie-Skłodowskiej, ten performowany opis doświadczenia chemicznego, które Pałyga upodabnia do alchemicznego procesu transmutacji pierwiastków, jest $\mathrm{w}$ istocie zapisem faustycznego dążenia do wyodrębnienia „siły z początków świata, przenikającej i obecnej”. Jej wstrząsająco piękną personifikacją - autorowi bardzo zależy na

46 F.W. Nietzsche, Wola mocy, tłum. K. Drzewiecki, S. Frycz, Kraków 2009.

47 Zob. Włodzimierz Galewicz, O etyce badań naukowych, [w:] Etyczne i prawne granice badań naukowych, red. W. Galewicz, Kraków 2013, s. 59-70.

48 B. Goldsmith, op. cit., s. 136. 
podtrzymaniu tej ambiwalencji - staje się na koniec sama Maria. Na wpół ślepa, z poparzonymi wnętrznościami, palcami jak opalone patyki, bezsenna i obolała - staje się jednocześnie słońcem i popiołem. Promieniuje i znika.

\section{SIOSTRA}

W jedenastu mówionych listach Marii Pałyga zapisuje więc wzniosły światopogląd nowoczesnego naukowca, który tak jak Skłodowska mógłby powiedzieć:

Ludzie myślą, że chodzi o dobro i zło, o to, co jest moralne, co jest niemoralne. Nie.

Chodzi o to, żeby nie było błędu ${ }^{49}$.

Światopogląd ten osadza w micie faustycznym i wyobraźni alchemicznej czy spirytystycznej, świetnie wyczuwając, że dla jego opisania nie wystarcza dziś oświeceniowy racjonalizm. Podobną intuicją dwadzieścia lat wcześniej dzielił się Jerzy Jarocki, przygotowując się do teatralnej realizacji dramatu Goethego w nowym przekładzie Jacka Burasa: „wsłuchanie się w Fausta sprawia, że mamy wrażenie, iż jest Coś, co wie, a my wciąż nie wiemy; że ewolucja wiedzy wróciła do punktu wyjścia, i to nie jest już oświeceniowy punkt wyjścia, tkwimy gdzieś indziej" ${ }^{50}$.

Żeby zbliżyć się do owego „Czegoś”, Pałyga cofa wiedzę ku jej magicznym i mitycznym początkom, przywołując imię Fausta i imię Mefista, by w końcu zderzyć tak wymodelowany światopogląd naukowy z mistyką i teologią chrześcijańską. Czyni tak wtedy, gdy monolog Marii komponuje na wzór Hymnu do miłości świętego Pawła. Jeśli słowo „pierwiastek” zastąpimy w nim słowem „człowiek”, a ewangeliczna aluzja sugeruje taką możliwość, w słowach uczonej usłyszymy hymn na cześć nowego boga nauki:

Miłość nie pyta, czy jest pożyteczny, nie oczekuje, że będzie komuś, czemuś służył, nie próbuje wprzęgnąć go w zaprzęg jakichś pragmatycznych sił. Miłość zadowala się jego istnieniem ${ }^{51}$.

49 A. Pałyga, op. cit., s. 54.

50 Das Streben, czyli dążenie. Z Jerzym Jarockim rozmawia Maryla Zielińska, „Literatura na Świecie” 1996, nr 5-6, s. 233.

${ }^{51}$ A. Pałyga, op. cit., s. 56. 
Wobec ideału czystego poznania Maria bierze na siebie całe piękno, ale i cały ciężar swoich odkryć. Niczego nie żałuje i nikogo za nic nie przeprasza. Przebóstwionej nauce składa ofiarę, a za lucyferyczne światło wiedzy gotowa jest się spalić i rozpaść w pył, bo taka jest nadrzędna, „boska” zasada materialnego świata w jego wszystkich wymiarach. Mówiąc o nauce jak o bezinteresownej miłości, tworzy rodzaj świeckiej teologii, która zawiera także pewien projekt człowieczeństwa. Opiera się on na odwadze, wolności i Faustowskim dążeniu, z którego bierze się ludzka ciekawość, pragnienie racjonalnego poznawania i samodzielnego wyjaśniania zjawisk: „To ja, twoja mama, ja to ukazałam. / Niewidzialne zrobiłam widzialnym. / Ja” powie jak Stwórca. Zderzenie dwóch światopoglądów - naukowego i chrześcijańskiego - ma w monodramie także wymiar osobowy i historyczny, bo kiedy Maria powie: „W zasadzie stałam się Faustem, Faustyną wtedy podczas tej przysięgi przecież, prawda? / To było jak cyrograf, jak upuszczenie krwi na ten diabelski pergamin", to w żeńskiej formie imienia Faust zaszyfruje aluzję do zupełnie innej Marii - tej, która najpierw nazywała się Helena Kowalska, a po wstąpieniu do klasztoru przybrała imię Maria Faustyna. Zaskakujące skojarzenie! Kowalska to duchowe przeciwieństwo Skłodowskiej, choć zarazem jakby jej córka... Tak jak ona nie była zbyt ładna, stroniła od ludzi, całkowicie poświęciła się swojej misji i zmarła na nierozpoznaną chorobę. Pisała też listy, a zamiast naukowych odczytów prowadziła Dzienniczek doświadczeń mistycznych, równie niesłychanych jak te, które przeprowadzała Skłodowska w swojej szopie. Obie przez całe lata obcowały z „niewidzialnym”, które ta pierwsza pojmowała jak bezosobową energię (przez spirytystów skojarzoną z duchami) i usiłowała ujrzeć, zbadać, zmierzyć, obliczyć i okiełznać dla dobra wszystkich ludzkich ciał, cierpiących i ostatecznie rozpadających się w pył. Druga natomiast w „niewidzialnym" rozpoznawała osobowego, kochającego Boga, któremu usiłowała odpowiedzieć, poddać się Mu, wielbić Go i wyrazić to dla dobra wszystkich ludzkich dusz, które są wieczne. Wyrazić nie tylko słowem, które nasycone jest chrześcijańską symboliką mistyczną ${ }^{52}$, ale także obrazem, konkretnym

${ }^{52}$ Metafora ognia odgrywa w nim szczególną rolę, jak w Żywym płomieniu miłości świętego Jana od Krzyża. O języku mistycznym świętej Faustyny zob. J. Machniak, Mistyka świętej Faustyny na tle tradycji chrześcijańskiej Zachodu, „Peregrinus Cracoviensis” 2000, nr 9. 
wizerunkiem Jezusa Chrystusa, na którym najważniejsze pozostaje światło w kształcie promieni wydobywających się z jego serca:

Wieczorem, kiedy byłam w celi, ujrzałam Pana Jezusa ubranego w szacie białej. Jedna ręka wzniesiona do błogosławieństwa, a druga dotykała szaty na piersiach. Z uchylenia szaty na piersiach wychodziły dwa wielkie promienie, jeden czerwony, a drugi blady. W milczeniu wpatrywałam się w Pana, dusza moja była przejęta bojaźnią, ale i radością wielką ${ }^{53}$.

Promienie na słynnym obrazie symbolizują Boże miłosierdzie, którego orędowniczką stała się święta Faustyna. Choć przypominają promienie słoneczne, a sama zakonnica pisała w swoim Dzienniczku o „Boskim słońcu” i „słońcu łaski Pana”, nie parzą i nie spopielają. Przeciwnie, w oksymoronicznej wyobraźni mistyczki „tryskają” niczym woda ze źródła, zwilżają, nawadniają, dają życie ${ }^{54}$. W monologu Skłodowskiej przeciwnie - woda (jeżeli nie podlega badaniu) to jedynie wyciekające $z$ trupa płyny ustrojowe albo lód.

Można czytać W promieniach jak apokryf korespondencji Skłodowskiej, można - jak ukryty dialog z zapiskami Marii Faustyny Kowalskiej. Święta w monologu noblistki zjawia się jak Ksiądz Piotr w celi Konrada, ale tylko na zasadzie cienia, niewidocznego dla głównej bohaterki. Dzienniczek siostry Faustyny powstawał w latach 1934-1938, ale jego pierwsze paragrafy mają pamiętnikowy charakter i przenoszą nas do roku 1924, kiedy na zabawie w łódzkim parku Maria doznała swojego pierwszego widzenia. Kilka tygodni wcześniej poprosiła rodziców o zgodę na życie klasztorne i spotkała się z ich stanowczym sprzeciwem. „Głos łaski” starała się zagłuszyć „rozrywkami”, ale nieskutecznie. Zobaczyła umęczonego Jezusa, pobiegła do katedry i tam usłyszała wezwanie: „Jedź natychmiast do Warszawy, wstąpisz do klasztoru". Miała wtedy osiemnaście lat, a więc tyle samo, ile Skłodowska w pierwszym monologu Pałygi. Podobieństwo niektórych motywów biograficznych (ciężkie i surowe życie, choroby czy konflikty z otoczeniem) upodabnia do siebie losy obu kobiet, ale na poziom mitu wynosi je dopiero

53 Bł. M.F. Kowalska, Dzienniczek. Miłosierdzie Boże w duszy mojej, Warszawa 1993, par. 47, s. 36.

${ }^{54}$ „O serce Najświętsze, Źródło Miłosierdzia, z którego tryskają promienie łask niepojętych na cały rodzaj ludzki, błagam Cię o światło dla biednych ludzi”. Ibidem, par. 72, s. 45 . 
pokrewne, choć zarazem zupełnie odmienne dążenie do realizacji celów, którym wszystko podporządkowały. Uczona podąża za swoją genialną intuicją istnienia nieznanych pierwiastków o potężnym promieniowaniu, poświęca życie dla ich odkrycia, a potem wyodrębnienia, a jej największą troską jest poprawność obliczeń, czyli prawda fizycznej realności niewidzialnego. Mistyczka podąża za wizją Jezusa Miłosiernego, wsłuchuje się w jego głos i poświęca życie transmisji jego woli, a jej największą troską jest pewność, czyli prawda metafizycznej realności Boga. Skłodowska boi się błędu i nieraz go popełnia, co ściąga na nią i na innych ludzi niebezpieczeństwo. Ostatecznie jednak jej odkrycia zostaną potwierdzone eksperymentami innych uczonych, a nauka podąży w wyznaczonym przez nią kierunku badań nad promieniotwórczością. „Zamieniam się w promieniowanie. Przenikam, oddziałuje" - powie proroczo w monologu ${ }^{55}$. Kowalska boi się złudzenia i nieraz mu ulega, popadając w duchowe kryzysy, z których wyprowadzają ją spowiednicy. Ostatecznie jednak pozostaje pewna swoich mistycznych doświadczeń, które potwierdzi Kościól, kanonizując Faustynę, a wiernym wyznaczając nową ścieżkę duchowego rozwoju. Obie wreszcie podlegają tajemniczemu procesowi transformacji, który w przypadku mistyczki polega na osobowym zjednoczeniu z Bogiem, a w przypadku uczonej - fizycznym (i fantazmatycznym) przeobrażeniu w kosmiczną energię, rozumianym i odczuwanym jako swoiste unieśmiertelnienie: „Teraz, kiedy już jestem ślepa i spalona, nie ma już czegoś takiego, jak życie, nie-życie” - powie Maria.

Kiedy 22 lutego 1931 roku w celi klasztornej Kowalska dostąpiła swojego najważniejszego objawienia, Skłodowska-Curie zbierała w Ameryce pieniądze na jeden gram radu dla Polski. Rok później przywiozła go do Warszawy i wtedy obie kobiety mogłyby się spotkać, gdyby ich światy, mimo tylu podobieństw, nie były od siebie tak odlegle. W maju 1932 roku otwarto Instytut Radowy, w którym umieszczono radioaktywny pierwiastek Marii. Dwa lata później, w czerwcu 1934 roku, Eugeniusz Kazimirowski skończył malować Obraz Jezusa Miłosiernego, którego kształt podyktowała mu siostra Faustyna (zresztą niezadowolona z rezultatu prac). Skłodowska nigdy go nie zobaczyła. Napromieniowana, 4 lipca umarła we Francji. Tymczasem w Polsce ukazała się właśnie Księga duchów Hipolita Rivaila...

55 A. Pałyga, op. cit., s. 70. 


\section{SKUTKI BEZSENNOŚCI}

Podsumujmy. Napisane przez Pałygę listy Skłodowskiej to nie tyle korespondencja nieznana, ile tajemna, wręcz ezoteryczna, performowana jak okultystyczny obrządek. W promieniach uruchamia w wyobraźni fantazmat alchemicznej przemiany: fizycznej i duchowej. W jego centrum znajduje się mit faustyczny, którego dynamiczna struktura wiąże ze sobą najważniejsze pierwiastki duszy Marii. Rozpacz po śmierci siostry i matki rodzi w niej bunt przeciwko Bogu i pragnienie służenia innej, potężnej sile, którą jest przebóstwiona nauka symbolizowana przez Ducha Ziemi i samego Mefistofelesa. Siłą woli hartowanej w ogniu Skłodowska podporządkowuje nauce całe życie, a w zamian za otrzymaną wiedzę składa ofiarę z siebie i dziecka. Niemal dosłownie spala się na ołtarzu nauki, ale w zamian dostępuje tajemnicy, czyli zaklętej w polonie i radzie potężnej radioaktywności. Ten drugi pierwiastek chemiczny, wydestylowany kosztem ogromnego wysiłku fizycznego Marii i jej psychicznej zapaści, pełni rolę kamienia filozoficznego, a przez świat traktowany jest jak eliksir życia. Uruchomiony $\mathrm{w}$ monodramie mit faustyczny spirytualizuje naukowe badania tej niezwykłej kobiety, a jej dążeniu przydaje cech demonicznych. Skłodowska sama siebie nazywa „czarownicą”, i rzeczywiście - portret narysowany przez uczennice przedwojennego gimnazjum mógłby zawisnąć w muzeum dawnych i współczesnych kacerzy, a więc tych, którzy dla pozyskania boskiej mądrości „wryli się” w księgi, metal, liczbę, trupie ciało - jak napisał Mickiewicz w Improwizacji Konrada. Maria także „improwizuje”, odsłaniając tajniki swojej nad-i podświadomości. Podczas gdy święta Faustyna spala się w ogniu Bożej miłości, stale łaknąc życia, uczona świeci jasnym, fosforycznym płomieniem wiedzy, za którą płaci śmiercią. Jako nowa Faustyna staje się kobiecym symbolem prometejskiego buntu i - nieobecną dotąd w polskim imaginarium - figurą intelektualnego oświecenia. Odważni mogą ją w sobie ożywić, performując niezwykły monodram Pałygi. Doprawdy, zadziwiające są skutki nocnej zabawy zapałkami jednego z najzdolniejszych dramatopisarzy współczesnych...

\section{Bibliografia}

Alan Abyss, Księga magii i zaklęć, tłum. R. Roczon, Kirke, Zielona Góra 2007. Das Streben, czyli dążenie. Z Jerzym Jarockim rozmawia Maryla Zielińska, „Literatura na Świecie” 1996, nr 5-6. 
Mircea Eliade, Mefistofeles i androgyn, tłum. B. Kupis, KR, Warszawa 1994 Włodzimierz Galewicz, O etyce badań naukowych, [w:] Etyczne i prawne granice badań naukowych, red. W. Galewicz, Universitas, Kraków 2013.

Johann Wolfgang von Goethe, Faust, tłum. J.St. Buras, Wydawnictwo Literackie, Kraków 1997.

Barbara Goldsmith, Geniusz i obsesja. Wewnętrzny świat Marii Curie, tłum.

J. Szmołda, Wydawnictwo Dolnośląskie, Wrocław 2016.

Jak zostać Skłodowska [z Arturem Pałygą rozmawia Justyna Jaworska], „Dialog” 2016, $\mathrm{nr}$ 7-8.

Carl Gustav Jung, Psychologia a alchemia, tłum. R. Reszke, Wrota, Warszawa 1999. Allan Kardec, Księga duchów, tłum. J. Ch., nakładem „Hejnału”, Wisła 1934.

Korespondencja polska Marii Skłodowskiej-Curie 1881-1934, oprac. K. Kabazińska,

M.H. Malewicz, J. Piskurewicz, J. Róziewicz, Instytut Historii Nauki PAN,

Polskie Towarzystwo Chemiczne, Warszawa 1994.

Błogosławiona siostra Maria Faustyna Kowalska, Dzienniczek. Miłosierdzie Boże w duszy mojej, Wydawnictwo Księży Marianów, Warszawa 1993.

Jan Machniak, Mistyka świętej Faustyny na tle tradycji chrześcijańskiej Zachodu, „Peregrinus Cracoviensis” 2000, nr 9.

Adam Mickiewicz, Dziady, cz. III, PIW, Warszawa 1974.

Friedrich Wilhelm Nietzsche, Wola mocy, tłum. K. Drzewiecki, S. Frycz, Vis-à-vis/ Etiuda, Kraków 2009

Artur Pałyga, W promieniach. Zupełnie nieznane listy Marii Skłodowskiej-Curie, „Dialog” 2016, nr 7-8.

Albrecht Schöne, Sabat czarownic i kult Szatana w „Fauście” Goethego, tłum.

A. Kopacki, „Literatura na Świecie” 1996, nr 5-6.

Małgorzata Szpakowska, Poparzona, „Dialog” 2016, nr 7-8.

Monika Żółkoś, Dramaty kobiecych historii, „Dialog” 2016, nr 7-8.

\section{Faust/ina. Artur Pałyga's In Radiance}

In this essay, author deals with the interpretation of a very original, new monodrama by Artur Pałyga, entitled In Radiance (2016), whose heroine is Maria Skłodowska-Curie. The author is interested in a poetic and performative dimension of Maria's dozen monologues, which the author described as - completely unknown letters' of the scientist. These monologues reveal the process of Maria's spiritual development from the moment of attaining 
maturity, until her death due to excessive irradiation. Kopciński focuses on the aspects of Maria's consciousness, which Pałyga has brought forth from the myth of Faust, which comprises the foundation of the scientific worldview.

In this monodrama, Skłodowska-Curie is the Polish Faust, who is ready to break the moral rules and pay the price of her and others' life for sheer possibility of revealing the mystery of the universe. Kopciński confronts this original literary image of a scientist with the history of her life and highlights the moments in her biography that can be read as an execution of the 'Faustian bargain'. At the end of his work he compares the character of Skłodowska-Curie, who calls herself Faustina, with the figure of another, extraordinary woman who has also adopted this name - Maria Faustina Kowalska. The comparison of the scientist and the mystic woman allows us to see many similarities in the characters of both, their way of life and their relationships with other people, but also describe fundamental differences in the worldviews they represent. Finally, two Faustinas are two different symbols. The figure of a scientist symbolizes desire for intellectual control over the world, which is constantly changing like elements discovered by Maria Skłodowska. On the other hand, the figure of the mystic symbolizes desire for an inner union with loving God, which involves the sacrifice of one's 'self' to gain eternal life of the immortal soul.

Keywords: In Radiance, Artur Pałyga, monodrama, Maria Skłodowska-Curie, Faust, Faustina Kowalska 


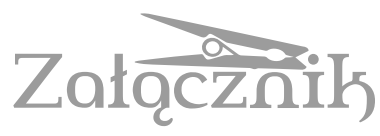

\title{
BETWEEN JOB AND HOMO SOVIETICUS: SERGEY BONDARCHUK'S FATE OF A MAN AS A MASTERPIECE OF PROPAGANDA CINEMA ${ }^{1}$
}

\author{
BRYGIDA PAWŁOWSKA-JĄDRZYK
}

\begin{abstract}
Wydział Nauk Humanistycznych UKSW
Faculty of Humanities, Cardinal Stefan Wyszyński University in Warsaw

brygida.pawlowska@gmail.com
\end{abstract}

\section{1.}

Considering the work of Sergey Bondarchuk (1920-1994) in the context of Old Testament motifs - which will to a large extent be the subject of this article - may seem an extravagant idea. This acclaimed Russian director, an Oscar winner (for two parts of the screen adaptation of Leo Tolstoy's War and Peace, 1965-67), was a favoured filmmaker of the Brezhnev era, and was regarded as the bard of 'socialist humanism'. Thanks to Red Bells (1982), based on John Reed's Ten Days that Shook the World, he became known as the 'epic creator of the revolution'. Bondarchuk's most important films include Fate of a Man (1959), which received the Lenin Prize. The comment below is symptomatic from the point of view of a contemporary assessment of the importance of Bondarchuk's legacy for the development of Soviet cinematography:

This film, however, is very important for understanding Soviet cinema. Immersed in the past, it ran into the future. It combined - relatively harmoniously - the traditions of the former totalitarian cinema of the 1950s, with $[\ldots]$ a new wave and an attempt to refer academically to the Russian classics.

${ }^{1}$ See Polish first edition of this article: Między Hiobem a homo sovieticus. O Losie człowieka Siergieja Bondarczuka w aspekcie transsemiotycznym, „Teksty Drugie" 2010, N$^{\circ}$, p. 200-211. 
This model of cinema would reappear for years in the USSR and then Russia. Whatever you think about him, Bondarchuk was its undisputed champion ${ }^{2}$.

2.

In the opinion of Jerzy Płażewski, Fate of a Man differs from other works of Soviet cinema in that it is a film about suffering (Płażewski 1995: 219). The protagonist of the film, Andrei Sokolov (played by Sergey Bondarchuk), suffers great misfortunes as a young man (his parents and sister died during the famine in 1922), then as a Red Army soldier, a prisoner of war and a prisoner in a concentration camp; finally as the father of the family: Andrei's beloved wife, Irina (Zinaida Kiriyenko), dies with her daughters in the bombing of Voronezh, and - if that weren't enough - his only son Anatoly, a war hero and highly talented mathematician, is killed on the threshold of victory. It is therefore no exaggeration to say that this man, like Job, experienced everything but his own death.

It is difficult to fully agree with the opinion that Soviet cinema had a reluctance to the character of a suffering person: the despair and pain of the individual are, in fact, the subject of excellent films such as Mikhail Kalatozov's The Cranes are Flying (1957), Grigory Chukhray's The Forty-First (1956) and especially Andrei Tarkowski's Ivan's Childhood (1962). Certainly, none of the characters created in them deserve to be called the 'traumatic hero', as Andrei Sokolov. The director showed him not only as a man experiencing extreme existential situations, but also as someone who makes the effort to speak about his tragedy, unknowingly becoming the 'bard of suffering' (cf. Gosk 1998: 113-125).

Sergey Bondarchuk, in line with the literary prototype of the film, used retrospection in his adaptation, which further exacerbated the existential sharpening of the narration by introducing tension between ' $\mathrm{I}$ ' the survivor and 'I' the narrator'. Sokolov tells his story to a driver he meets accidentally waiting to cross the Don. The men meet in early spring, in a scene of awake-

2 Fragment of a sketch by Tomasz Jopkiewicz, which was attached to the DVD publication of Fate of a Man in the Classics of Soviet Cinema series from Epelpol Entertainment 2008.

3 This phenomenon has long been known to theoreticians of prose; see: Stanzel 1980: 267 et seq. 
ning nature, which could be treated as an ironic counterpoint to the hero's personal drama, if not for the images of the river flooding the surrounding orchards carrying destructive connotations ${ }^{4}$. Significantly, the montage of the initial sequence stands in contrast to the images of the sky.

The protagonist of Fate of a Man is therefore the same on the screen as in Mikhail Sholokhov's story: someone who bends under the overwhelming burden of suffering and someone who seeks expression in words for it ${ }^{5}$. Starting his tragic story, he repeats in his mind the eternal question: 'Life, why have you hurt me so? For what is this punishment?' (Sholokhov 1985: 11; underline - B.P.J.) These words, preceded by an image of clouds, come in the prologue of the film, just before the titles, marking them as the film's motto.

\section{3.}

In Bondarchuk's one-hundred-minute film, Sokolov gazes several times up at the sky for a long time (perhaps the most typical gesture of this character), but never once speaks of God's name - Yahweh is replaced in his statements by 'life' and 'fate'. It seems that the character's casting of his own misfortunes in terms of guilt and punishment is primarily rhetorical: it is more a way of expressing a traumatic experience than a search for a cause of his suffering.

However, it must be noted that in the story of Fate of a Man, clear signs of irony can be found. This comes through with particular force in the final parts of the film, when the main character, with his heavy burden of experience, begins to dream of quiet old age at the side of his son that he has found. Sokolov characterises this period with words of reassurance: 'Soon, happiness smiled at me - like the sun after a storm'. The son, with whom Sokolov could have had a hope of healing his pain in the future, dies on the last day of the war. (To emphasise the paternal drama, contrasts were used in the film: shots of the pained face of a mourner were contrasted with the euphoric shouts of cheering Red Army soldiers.) Thus, we find here echoes

4 Water is associated with death and destruction also in other parts of the film: when Sokolov arrives in his home town of Voronezh and sees the ruin of his home and finds out about the death of his closest family, he stumbles through puddles with difficulty. (This scene is not in the original story, in which Andrei learns about the tragedy in a letter from a neighbour.)

${ }^{5}$ In Sholokhov's work, the main narrator is not Sokolov, but his interlocutor. 
of perceptions typical for the nation of Pushkin about the determinant of human existence, which with a little malice turns a defenceless person into a 'game of fate'.

According to studies of Anna Wierzbicka, Russian culture 'bounces' within several essentially untranslatable words: one of them is sud'ba [fate] the most important noun among those by which Russians 'develop their attitude towards life' and through which they communicate with others (its status is evidenced, for example, by the fact that it is extremely common in Russian phrases, sayings, songs and titles; Wierzbicka 2007: 358). The concept of sud'ba is made up primarily of an ancestral inheritance, the fatalistic conviction of man's subordination to an overwhelming force (in the oldest manifestations of these beliefs, it is depicted anthropomorphically), which decides about the unpredictable and often dramatic character of human existence. The idea is linked to the belief that, despite the cruelty of fate, one should accept its judgments without opposition, in an attitude of resignation.

Regardless of the cultural context mentioned above, it would be a gross oversight to underestimate the fact that Sergey Bondarchuk's film, though in a rather perverse way, takes up the Old Testament issue of suffering, including the problem of divine favour, so important in the Book of Job, in the downfall of the most faithful of the faithful. The sequence in the orthodox church is essential for the audio-visual conceptualisation of this issue.

\section{4.}

The only character in Bondarchuk's film who calls out to God is a young man accompanying Sokolov along with dozens of other prisoners on the way to the camp. His creation was satirically redrawn by the director. When the other prisoners are planning to assault the Nazi soldiers escorting the convoy, the man is plagued with fear and whispers to himself: 'God, protect me and have mercy on me, protect me from the enemy'. In the orthodox temple where the prisoners are forced to spend a night, the lonely man still lifts his erratic gaze and performs mechanical gestures that betray as much religious zeal as cowardice and backwardness. (Looking at that caricatured figure, the slogan spread by Soviet propaganda comes to mind: 'Religion the opium of the people'). 
The scene of the death of this nameless character, which takes place against the sound of a violent storm, is tragicomic. The pious man dies because he doesn't allow himself to go to the toilet in a place he regards as sacred:

MAN [Collapsing in pain.]:

- Where to go, where?... They said they won't let us out. What should I do, brothers? I am a believer after all, I am a Christian!

OTHER PRISONERS:

- Do it through the dome, we'll lift you up. [Laughter]

- If you ask nicely, the angels will take you on their wings. [Laughter] MAN:

- I cannot insult this place. I cannot offend it. I am a believer, I am a Christian ... [The man runs, pounds the locked doors of the temple with his fists, shots are fired...]

A deeper understanding of the scene requires us to see the cinematic fusion of elements of different sign systems and open up the imagination to a subtle, trans-semiotic and trans-medial play of meaning ${ }^{6}$. In addition to the dialogue, the mimicry, and the gestures of the actors in this part of the film, acoustic effects and the specific way of handling light play an important role. Their meaning in a given context seems to have a negative character based on enigmatically emerging intertextual relations, including allusions to artistic patterns existing in European culture that present the sacral sphere (in particular literary and artistic conventions).

6 Talk here of trans-semioticity and trans-mediality refers to the situation where 'semiotic or media systems that contribute to the message lose their independence in the creation of meanings. And thus trans-semiotic relationships are, for example, relationships in which images and sound enter film messages; transmedial refers to quotations and paraphrases, such as literary narrative structures or paintings in film. This process is omnidirectional and reversible, which means that in the film, for example, the partial meaning contained in a moving image is reinterpreted by those present in the sound layer and verbal semantics layer, and vice versa - they reinterpret themselves' (Szczęsna 2004: 36). See also: Łotman 1983: 97-101. 


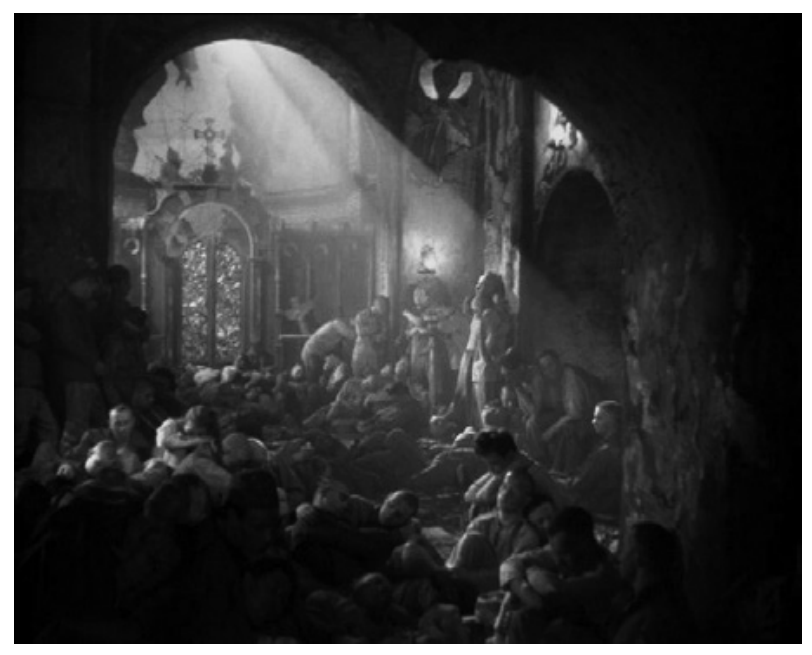

Picture No. 1. S. Bondarchuk's Fate of a Man (1959)

The shameful drama of the man who begs God to intervene is set in a storm ${ }^{7}$. The lightning bolts, connecting heaven to earth, have for centuries played the role of 'tools of transcendence' and symbolic manifestations of the wrath of God in literature (see for example the ancient depictions of Zeus with the thunderbolt or the folk conception of justice referred to in Juliusz Słowacki's Balladyna). In Bondarchuk's work, it is different. Although it is difficult to leave to one side the convention of a film's genre, it is worth mentioning that, under the pressure of new contextual conditions, these motives function as 'signals of absence' of supernatural intervention.

In the church sequence, particularly noteworthy is that the image occurs immediately after the tragic finale of the scene described, because it invokes the apocalyptic vision of religious painters, or artistic portrayals of the descent of the Holy Spirit or other manifestations of divine grace (seen for example in the work of El Greco or Gustav Doré) ${ }^{8}$. We see on the screen the

7 Storms and thunder are traditionally considered to be 'objects of grandeur' (Płuciennik 2002: 14).

8 I have in mind a certain type of artistic composition, not so much a particular artwork. Cf. Obrazy z Biblii z klasycznymi ilustracjami Gustave Doré, comp. G. Davidson, trans. J. Polak, Poznan 2010. 


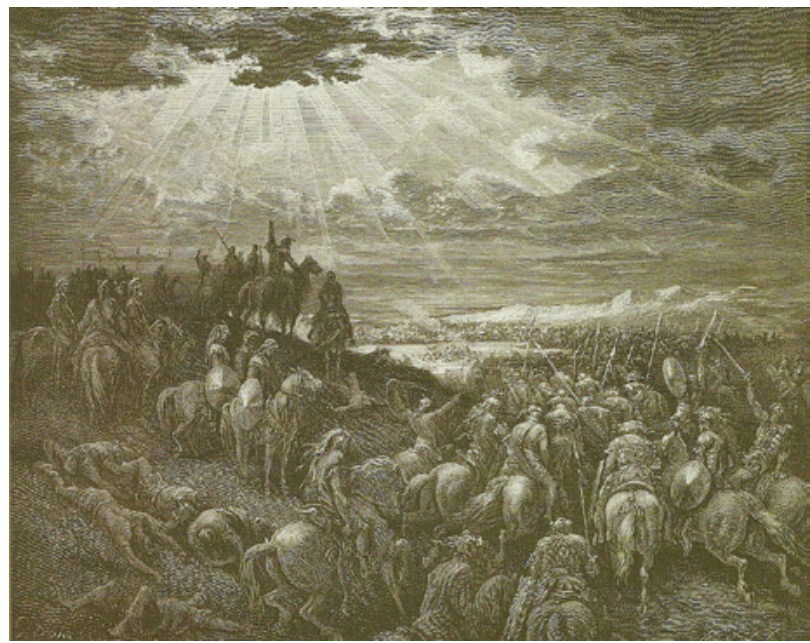

Picture No. 2. Biblical illustration by Gustav Doré

shapeless mass of sleeping prisoners, bathed in splashes of light shining through the vault of the temple; from its frescoed walls, monumental saints look down, over the 'battlefield' of bodies there is a cross, the symbol of salvation (see pictures No. 1 and 2). This image can be considered another manifestation of irony in the film by the Soviet director: this time its plane of reference is the faith of Christians in the providence of almighty God. In view of later events, the shards of afterglow, which evokes associations with embodiments of the idea of sacred emanation, turn out to be, in essence, as banal as ordinary lightning. Themes and compositions accompanying the depictions of the sacred in various cultural texts appear in Sergey Bondarchuk's, but they are subjected to polemical re-evaluation ${ }^{9}$. Their function also changes radically: they simply become signs of transcendental emptiness.

9 Examples of the different functioning of such hidden references to religion can be found in Ingmar Bergman's film Whispers and Screams (Viskningar och rop, 1971). According to experts on the Scandinavian director's work, this film 'fully [...] reflects the meaning of his main metaphor of human destiny as the Passion of Christ' (Szczepanski 2007: 330). 


\section{5.}

It can be said that in Bondarchuk's scene, he 'disposes with' this aspect of the figure of Job that does not fit the Soviet ideal of humanity. On the other hand, according to the director's own words, the film is a polemic against Ashes and Diamonds (1958) by Andrzej Wajda: the Home Army soldier lost and struck by moral indecision is compared here with a 'type of a new socialist man' who, despite the toughest of experiences, does not lose faith in a better future. Although the ending does not seem optimistic (Sokolov reveals his fear of sudden death in a dream), the film is redolent with a faith in human persistence and the sense of solidarity in battling the greatest adversities. With Bondarchuk, the alternative to the 'silent heavens' is the uncompromising and active resistance of a man who does not hesitate to take even the most extreme action, if the good of the cause so requires. This conclusion results, for example, from the logic of the selection and the aftermath of the orthodox church scenes.

After the death of the 'pathetic Christian', the most controversial sequence in the film takes place, although the way that further events are presented largely camouflages their moral burden. Sokolov barely listens to a conversation among two prisoners in which one of them threatens to reveal the next day the identity of the other to the Germans and condemn him to being shot. The frightened commanding officer is a small and delicate man, and the expression of regret to his ruthless companion is the only form of protest that he can muster. (At this point in the film, Bondarchuk, exceptionally, allows himself some ideological bragging, but not that sullies the mouth of the main character. The officer says with bitterness: 'I always suspected that you, Kryzhniev, were a bad man. Especially when you didn't want to join the party, explaining it with your illiteracy'.)

Andrey Sokolov's actions, unlike the actions of Maciek Chełmicki in Ashes and Diamonds, are resolute and ruthless - with his bare hands and voluntarily he suffocates a potential traitor in his sleep. Although the scene of the killing is shown on the screen, it is done in a rather specific way. The camera operator (Vladimir Monachov) used visual metonymy as euphemism: the viewer's attention is focused not on what Sokolov is doing (he leaves the frame), but on the officer, whose role is to hold the legs of the man being suffocated. It lasts a few seconds and then it is over. In Sholokhov's story, immediately after the murder Sokolov feels intense revulsion and 
almost has convulsions, but in the film, he only rubs his hands gently against his clothes, and in the next scene (the cynical execution of randomly chosen prisoners), viewers are allowed to breathe deeply that what happened should have happened. The conclusion proffers itself: Andrei Sokolov is without doubt a hero ${ }^{10}$. The rest of the film, and especially the fact that he adopts an orphan who is wandering alone in the Russian countryside, testifies to him being sensitive to the suffering of others and compassionate.

\section{6.}

In terms of construction, Andrei Sokolov is a hybrid character, although we see him as a distinct personality. It can be said that he consists of several images, several architypes that complement each other. (This kind of construction has a long tradition in Russian culture, for example Prince Myshkin from Fyodor Dostoyevsky's The Idiot, who unites in himself a child, a holy fool, Don Quixote, Christ and Pushkin's 'poor knight'.) The main character of Fate of a Man draws a lot of from the character of Job, but above all, he is also the embodiment of the idealised image of the Russian (Filipowicz 1998: 181-194). As befits a son of Russia, he combines strength of character and hardiness with an unusual sensitivity: he loves his native land, fields of grain, birdsong, and the blue of the Russian sky, and he has warm feelings in his heart for one woman. He is a strong and courageous man, full of dignity and seriousness, he likes to swear and drink, but often makes gestures that show a hidden delicacy. (It is worth noting the scene in which Andrei, stealing from the uniform of an unconscious drunken German, lifts a brick from the ground, not to strike him, but to place it under the head of the enemy soldier as a makeshift 'pillow').

Andrei Sokolov is above all a soldier, the embodiment of the mighty spirit of the nation - nothing shows this better than the respect that prisoner 331 evokes in the enemy. This is the meaning that the famous sequence with the psychopathic camp commandant Müller (Yuri Awierin) has, in which the prisoner, aware of the horror of the situation, prefers to drink for his own destruction instead of in a toast to the victory of the German army.

${ }_{10}$ Examples of the justification and even glorification of violence for ideological purposes were seen in the early years of Soviet cinema, for example the Battleship Potemkin (Bronienosiec Patiomkin, 1925). 
(Incidentally, the film's creators skilfully emphasised the supra-individual dimension of Sokolov through Müller: the Nazi first called him disrespectfully 'Ruski Ivan' twice, and then speaks to him with unmistakable respect, referring to him as 'a true Russian soldier') ${ }^{11}$. This scene also captures the very concrete, and very painful - also for Job - physical dimension of human suffering. Exhausted from starvation, the prisoner is summoned to where German officers are sitting at a table heavily laden (as for wartime) celebrating the alleged successes of Hitler's army. Under these conditions, a refusal to accept the refreshments - here appears Sokolov's famous line 'After a second glass [of vodka] I'm not used to biting' - is not only a manifestation of daring courage but also a heroic manifestation of the dignity of a man who can overcome the humiliating 'coercion' of his own body (cf. the scene in the church).

In the screen adaptation of Fate of a Man, not unlike in the Old Testament ${ }^{12}$, an imagined relationship is established between satisfying hunger and consolation (at times only temporary relief) - in both cases, the symbolic weight of the motives used in this context are diametrically opposite. At the end of his torment, Job finds himself eating bread in his own home with friends, while Sokolov, who has survived a verbal battle with Müller, is rewarded with a loaf of bread (he shares it with his fellow prisoners so that 'everyone is equal'). This theme returns in the final sequences of the film. Sokolov takes the just adopted Vanja (played by Paviel Boriskin) for a meal together. The unlucky widow observes a hungry boy with tenderness and pain: the 'recovered son' tries to satisfy his lengthy hunger by swallowing soup and munching greedily on a lump of bread...

Going beyond the bounds of the actual historical context allows us to discern in the scene with the degenerate commander Müller further discrete analogies with the Book of Job (this time about the motif of the Devil joining

${ }^{11}$ This scene contains an almost comic touch. Müller's skirmishes with the tough prisoner are 'looked over' by Hitler himself; his gaze is directed at Sokolov, and his face seems to express extreme irritation (the protagonists are 'separated' by a portrait of the leader handing slightly behind them). Care was taken to maintain the right proportions - it is certainly no accident that the face of the portrait and the heads of the characters are, roughly speaking, the same size.

12 Eating motifs are reviewed by Aitken 2010: 47-68. 
Job). Sokolov's steadfastness - as a man and a son of the Russian nation - is also tested by the demonic Gestapo officer, and as a consequence he gains a heroic dimension. However, in both cases ideals that are quite different are at stake.

\section{7.}

Bolshevik leaders after Lenin attributed great ideological significance to cinematography (Stalin called cinema 'a powerful means of mass agitation'), which had to have a strong influence on the Soviet Union's cultural policy. Against the background of the obtrusive audio-visual propaganda output of the country, Fate of a Man was received as the herald of change $\mathrm{e}^{13}$. From today's perspective, this assessment may seem overly radical. Bondarchuk's film, being one of the flagship cinematographic achievements of the 'Khrushchev thaw', uses stereotypes, simplified axiological and situational patterns (such as images of infantile German soldiers) and painfully exalted moments. However, it must be admitted that its creator was well aware of the dividing line between art and ideological journalism. This does not change the fact that he was able to smuggle in the most virulent content in an innocent manner. A good example of Bondarchuk's method is a procedure that can be termed 'sound-association insinuation'.

For example, during his stay in the concentration camp, Sokolov sees crowds of people heading to the crematorium; their terrifying procession moves along the road of no return to the sound of a tango. This irritating rhythm appears as a counterpoint also after a brutal fight in a quarry, when Sokolov reluctantly leans over a crag over which the Nazi guard has beaten one of the exhausted prisoners. In a much later scene, an old man (a former neighbour) tries to comfort Sokolov after the loss of his family. To improve his mood, he plays a gramophone record, but this drives the distraught widower into an explosion of uncontrolled anger. Now some time, the rhythm of the hated tango returns, with the only difference that now it is

13 This was how the film was interpreted in the West. To this day in discussions about Fate of a Man, the issue of the 'rehabilitation' by Bondarchuk of Soviet prisoners of war who were treated by Stalin as traitors of the nation is strongly emphasised. 
accompanied by words. The 'criminal melody' is sung in a Germanic language: not in German but in English...

In this way the Soviet director, exploiting the possibilities offered by the poly-semiotic nature of cinema, besmirches the allies of the Red Army: the power of association places them alongside the war criminals.

\section{8.}

The atheistic policy of the Soviet authorities after the October Revolution was twofold: on the one hand, explicit anti-religious persuasion and depredation was used, or simply everything associated with the sacred sphere was ridiculed, and on the other, attempts were made to use the authority of religion for the approved ideology, adapting traditional imagery and related expressions to new needs (cf.: Leinwand 1998: 160-196). A manifestation of the first tendency, for example, is the lithograph of the famous Russian propaganda artist Viktor Deni titled Peasant Mother of God, based on icons depicting the Virgin Mary and the Child. On this poster, probably used by the authorities during parodies of religious processions, the place of images of saints is taken by caricatures of political opponents.

The second tendency is illustrated by the transposition of iconographic images of the bloody battle between Saint George and the dragon (the subject of the fight against good and evil always occupied a prominent place in the Byzantine church and Russian tradition, Leinwand 1998: 171 et seq). For example, on the poster of St. George the Victor, Deni presented Lev Trotsky as a hero who injures the hydra of the counter-revolution with a spear.

According to those who research these issues, religious language was often used in party literature in the Soviet Russia, and post-revolutionary iconography was full of religious motifs and references - 'it was understood that the place of forbidden faith and removed symbols and rites should be occupied by new objects of cult and new saints' (Leinwand 1998: 168). For example: Karl Marx holding Capital in his hand was presented in the midst of clouds, which was supposed to evoke associations of God the Father, and the worker, as a 'martyr of labour', was shown in the image of Christ crucified. Moreover, after 1917, many Soviet political poster artists more or less consciously referred to Russian sacral art (modelled on compositions of icons). The Judeo-Christian tradition was also often combined with patterns typical of the labour movement. Thus, the early Soviet propaganda developed 
ways of adapting Christian tradition for agitation goals. Sergey Bondarchuk's Fate of a Man, contrary to popular opinion, continues this tradition, although it does it in a skilful and balanced manner: emphatically but without agitating ostentation (for this, it fully deserves the title of 'a masterpiece of propaganda cinema'). Perhaps the phenomenon of the film lies precisely in the fact that - although it expresses the content it expresses - it is still art.

Undoubtedly, the world of religious imagery and ideals is an implicit but very important plane of reference for the work of the Soviet director ${ }^{14}$. In Fate of a Man, there are no, and perhaps there couldn't be, any direct references to the Book of Job. Except for the whole series of 'fundamental questions' asked by the main character or implied by the situations in the film, Sokolov's strength of character and his 'charism of suffering' are unmistakeable references to Job. These features, however, are greatly recontextualised in the film. Nevertheless, the great philosophical drama of the Old Testament appears as one of the most important archetypal texts for Sergey Bondarchuk's film (which would be hard to say about Sholokhov's story). It must be remembered, however, that the path connecting the biblical Job with the idealised incarnation of Homo Sovieticus, Andrei Sokolov, is separated by a network of ideological entanglements and cultural mediatizing forms. Therefore, indicators of this relationship (including signals of existence in the polemic relation) must be sought in the sphere of volatile and vague meanings, emerging between gesture, word, sound and image.

\section{Selected bibliography}

James K. Aitken (2010), Job's Diet, [in:] Hiob biblijny. Hiob obecny w kulturze, ed. P. Mitzner, A.M. Szczepan-Wojnarska, Wydawnictwo Uniwersytetu Kardynała Stefana Wyszyńskiego, Warszawa.

Aleksandra Filipowicz (1998), Książę Myszkin - ideał czy idiota?, [in:] Postać literacka. Teoria i historia, ed. E. Kasperski, B. Pawłowska-Jądrzyk, Uniwersytet Warszawski, Warszawa.

${ }^{14}$ Against the background of the cognitive strategies previously described, even the title of Sokolov's son's article seems to be significant: the debut of that talented mathematician is the treatise Current Infinity (its title does not appear in the original story), and the fact that the main character, like Saint Joseph, is a carpenter. 
Hanna Gosk (1998), Bohater traumatyczny w prozie Leo Lipskiego i Henryka Grynberga, [in:] Postać literacka. Teoria i historia, ed. E. Kasperski, B. Pawłowska-Jądrzyk, Uniwersytet Warszawski, Warszawa.

Aleksandra J. Leinwand (1998), Sztuka $w$ stużbie utopii. O funkcjach politycznych i propagandowych sztuk plastycznych $w$ Rosji Radzieckiej lat 1917-1922, Instytut Historii PAN, Warszawa.

Jurij Łotman (1983), Semiotyka filmu, trans. J. Faryno. T. Miczka, Wiedza Powszechna, Warszawa.

Obrazy z Biblii z klasycznymi ilustracjami Gustave Doré (2010), comp. G. Davidson, trans. J. Polak, Vesper, Poznań.

Jerzy Płażewski (1995), Historia filmu, Wydawnictwa Artystyczne i Filmowe, Warszawa.

Jarosław Płuciennik (2002), Figury niewyobrażalnego. Notatki z poetyki wzniosłości w literaturze polskiej, Universitas, Kraków.

Michaił Szołochow (1985), Los człowieka, trans. I. Piotrowska, Wydawnictwa Artystyczne i Filmowe, Warszawa.

Franz Stanzel (1980), Typowe formy powieści, [in:] Teoria form narracyjnych w niemieckim kręgu językowym. Antologia, selection and works R. Handke, Wydawnictwo Literackie, Kraków.

Tadeusz Szczepański (2007), Zwierciadło Bergmana, słowo/ obraz terytoria, Gdansk. Ewa Szczęsna (2004), Wprowadzenie do poetyki intersemiotycznej, [in:] Intersemiotyczność. Literatura wobec innych sztuk/i odwrotnie/, ed. S. Balbus, A. Hejmej, J. Niedźwiedź, Universitas, Kraków.

Anna Wierzbicka (2007), Słowa klucze. Różne języki - różne narody, trans. I. Duraj-Nowosielska, Wydawnictwa Uniwersytetu Warszawskiego, Warszawa [reprint of: eadem, Semantics, Culture and Cognition: Universal Human Concepts in Culture-Specific Configurations, Oxford University Press, New York 1992].

\section{Between Job and Homo Sovieticus: Sergey Bondarchuk's Fate of a Man as a Masterpiece of Propaganda Cinema}

The subject of this article is a famous Soviet war-film, Fate of a Man (1959), directed by Sergey Bondarchuk and based on the short-story written by the Nobel Price winner, Mikhail Sholokhov. The proposed analysis aims at uncovering an essential but hidden context of Bondarchuk's vision of $20^{\text {th }}$ century traumatic human experiences: the Old Testament Book of Job. Focused on 
the subtle meanings being created between gestures, words, sounds and pictures, the author tries to show the presence as well as the function of biblical images in this 'most Soviet of the Soviet movies'. It would be useless to seek such dimensions in the literary version of the same story. Owing to his audiovisual sensibility, Bondarchuk turns out to be a real master of 'soft' adapting of the religious tradition to the needs of the new ideology.

Keywords: Sergey Bondarchuk, Fate of a Man, Soviet cinema, propaganda film, Book of Job, Mikhail Sholokhov, trans-semioticity, trans-mediality, religious references, intertextuality 



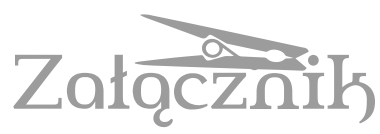

\title{
ROMANS Z ZEGARMISTRZEM
}

\author{
JAN ZIELIŃSKI
}

Wydział Nauk Humanistycznych UKSW

Faculty of Humanities, Cardinal Stefan Wyszyński University in Warsaw

zielinski@gmx.ch

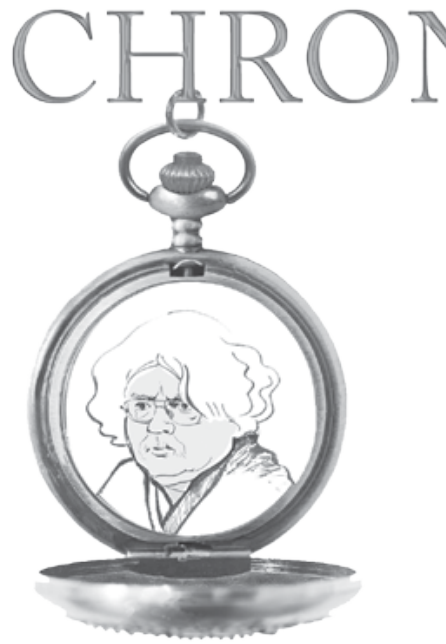

NOME
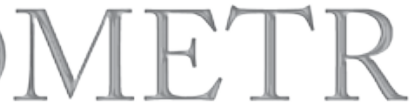

Autorska rubryka prof. UKSW i wykładowcy Uniwersytetu we Fryburgu Jana Zielińskiego. Stopniowa prezentacja wybranych wątków szeroko zakrojonego projektu, który ma przedstawić w układzie chronologicznym obecność motywu czasu

i zegara w kulturze polskiej (na tle międzynarodowym) od średniowiecza do XXI wieku. Punktem wyjścia jest przeważnie tekst literacki, ale odniesienia sięgają różnych dziedzin kultury (łącznie z kulturą materialną), historii, etnografii, filozofii. Poszczególne teksty, zbudowane z segmentów ułożonych na ogół chronologicznie, pokazują odrębne zagadnienie - czasem zaskakujące, czasem wręcz paradoksalne - w różnych jego aspektach.

Pod koniec maja roku 1651 doszło na Kresach do wypadku ukarania żony śmiercią za romans z zegarmistrzem. Mowa o drugiej żonie Bohdana Chmielnickiego, zwanej Heleną z Dzikich Pól (żonie nie całkiem zresztą prawowitej, jako że w chwili, gdy patriarcha jerozolimski Pajsiej udzielał ślubu jej i hetmanowi, żył jeszcze jej mąż, podstarości czehryński Daniel Czapliński). Wiadomość o sprawie dotarła do obozu królewskiego około 9 czerwca, pod tą datą zapisał ją w swym diariuszu Stanisław Oświęcim:

Pod tenże czas o Chmielnickiem i żenie jego przyszła wiadomość, że w pewnym zegarmistrzu, którego sobie od męża za ochmistrza danego miała, 
zakochawszy się, i zwyczajne z niem robieła niecnoty, i mężowi, gdzie mogła, szkodę czynieła. Długo to między niemi in secreto trwało, aż gdy Chmielnicki skarbów swoich pieniężnych (których curam tenże zegarmistrz miał) ruszając ex abscondito dla płacenia Tatarom, baryłki jednej pełnej czerwonych złotych domacać się nie mógł: rozumiał zrazu, że ją syn jego, idąc do Litwy z wojskiem, wziął z sobą. Lecz gdy za pisaniem swojem w tej materyej powziął od syna wiadomość, że jej nie tylko nie brał, ale i nie widział, kazał onego miłego swego podskarbiego tak długo tyranizować, aż poniewolnie musiał się przyznać nie tylko do ukradzenia tej baryłki, uczyniwszy i żonę jego complicem tej kradzieży, ale też i do niecnót i amorów z nią popełnianych. Za tą wiadomością nie długo deliberując Chmielnicki, obróciwszy miłość swoję, którą miał niezwyczajną do niej, w gniew, nie tak dla ukradzionego złota, jako dla zdradzanego łoża, kazał ich oboje, tak jako in actu bywali adulterii, nago związawszy, pospołu obiesić; co nam Król sam przy wieczerzy swojej z uciechą referował'

Albrycht Stanisław Radziwiłł w swych pamiętnikach pod datami 8 i 9 czerwca odnotowuje ujęcie jeńców kozackich, którzy donosili o przemieszczaniu się Chmielnickiego w kierunku Dubna. Na temat romansu „kresowej Heleny” z zegarmistrzem pisze w sumarycznym omówieniu poprzedniego miesiąca: „Ku końcowi tego m[iesią]ca od Chmielnickiego żona wzięta Czaplińskiemu, zmówiła się z zegarmistrzem, którego Chmielnicki był przyzwał ze Lwowa i z nim beczkę złota schowała, i podobno swobodniej z nim postępowała. Tymoszko, syn Chmielnickiego, doniósł to ojcu, który po uczynionej inkwizycyi, doszedł kradzieży i oboje na jednej szubienicy kazał obwiesić"2.

Tymoszko był synem hetmana z pierwszego małżeństwa, który starał się wówczas o rękę córki hospodara mołdawskiego, pięknej Rozandy Lupu; wedle niektórych autorów, jak psychiatra i historyk-amator Antoni J. Rolle, to on miał osobiście wykonać wyrok na swej macosze i jej kochanku: Chmielnicki „za przeniewierstwo i romans z zegarmistrzem kazał ją powiesić, ezgekucyą wykonał sam Tymoszko - pięknie więc wykształcony był ów

1 S. Oświęcim, Dyariusz 1643-1651, wyd. dr Wiktor Czermak, Kraków 1907, s. 298.

2 Albrecht Stanisław ks. Radziwiłł, Pamiętniki ... kanclerza w[ielkiego] litewskiego, wydane z rękopisu przez Edwarda Raczyńskiego, Poznań 1839, s. 437. 
przyszły mąż Lupułłówny”3. Tenże Rolle w opowiadaniu Pod Półksiężycem dośpiewał sobie wygląd i stan zegarmistrza: „Był to panicz rodem ze Lwowa, gładki, wdzięcznego lica, szlacheckich przywyknien'"4.

Trzeba dodać, że w tym czasie królowa, która towarzyszyła Janowi Kazimierzowi w kresowej wyprawie, nagle powróciła do Warszawy, a Jan Kazimierz przejął dziwny list, pisany do niej przez podkanclerzego koronnego Hieronima Radziejowskiego. Historyk Ludwik Kubala w opublikowanej w 1875 roku pracy o procesie Radziejowskiego połączy - niezbyt dokładnie w diariuszach Oświęcimia i Radziwiłła datowane - opowieści i napisze wręcz: „Przypadek zdarzył, że właśnie siedząc przy stole, opowiadał senatorom, jak żona Chmielnickiego z zegarmistrzem uciekła [!], kiedy mu przyniesiono list Radziejowskiego adresowany do królowej"5.

W Ogniem i mieczem Zaćwilichowski w rozmowie ze Skrzetuskim na temat konfliktu Chmielnickiego z Czaplińskim powiada o Helenie z Dzikich Pól: „Mówią przy tym, że żonę starostce bałamucił: starostka mu kochanicę odebrał i z nią się ożenił, a on mu ją za to później bałamucił, a to jest podobna rzecz, bo zwyczajnie... kobieta lekka"', ale wątek zegarmistrza autor Trylogii pominął. Podejmie go natomiast Franciszek Rawita-Gawroński w - opartym na drukowanych i rękopiśmiennych źródłach ukraińskich i polskich - opowiadaniu pod tytułem Weselna tragedia, zamieszczonym w roku 1908 w „Bibliotece Warszawskiej”. Sporo tu drastycznych szczególów, a trup ściele się gęsto: „Kręcił się tam jakiś "zegarmistrz ze Lwowa", człowiek młody, ale goły. [...] Czaplińska zdołała przekupić klucznika i wraz z zegarmistrzem jedną czy dwie beczki ze złotem zdobyła. [...] Zamierzali umknąć w świat. [...] Tymoszko [...] ojca zawiadomił o tym, co się stało. Rozkaz otrzymał krótki: powiesić wszystkich. Tymoszko wykonał polecenie. A tak mu było spieszno rozprawić się z macochą, że nawet szubienicy nie stawił, ale na szerokich wrotach ojcowskiego domu powiesił Imci panią Czaplińską samosiedm - razem ze wszystkimi towarzyszami miłości

3 Dr Antoni J. [Antoni J. Rolle], Zameczki podolskie na kresach multańskich, t. 2, Warszawa 1880, s. 95.

4 Dr Antoni J. [Antoni J. Rolle], Opowiadania historyczne. Pod Półksiężycem. Obrazek z przeszłości. Lwów 1875, s. 91.

5 L. Kubala, Szkice historyczne. Kraków 1896, s. 21.

${ }^{6}$ H. Sienkiewicz, Ogniem i mieczem, t. 1, Warszawa 1901, s. 19. 
i kradzieży”. Chmielnicki miał potem żałować pochopnego wyroku i pić na umór. Rawita-Gawroński dodaje jeszcze na temat zegarmistrza ze Lwowa, że nawet jego „nazwiska dzieje nie zachowały”.

Teodor Tomasz Jeż powieść $Z$ burzliwej chwili (1880-82) kończy wprawdzie sceną powieszenia młodej żony hetmana na bramie $\mathrm{z}$ rozkazu syna Chmielnickiego, ale wątek zegarmistrza pomija. Kobieca bohaterka powieści nosi imię Helena, tak samo jak ta, o którą wybuchła wojna trojańska i rzeczywiście, jest ona obiektem rywalizacji kilku mężczyzn. Bohdanowi Chmielnickiemu przypada tu rola sędziwego, starego Parysa. Jeż powiada: „W tym różnica - różnica, pociągająca za sobą rozchełznanie namiętności, posunięte do stopnia, do jakiego wznieść się nie mogli ani Trojanie, ani Grecy, którym do ręki oręż podawała miłość, ukwiecona urokiem młodości. Tam miłość, tu chuć za podnietę służyła". Znamienne to przeciwstawienie, pojawiające się w połowie drogi między Nietzschem (Narodziny tragedii, 1872; w późniejszym wydaniu opatrzone podtytułem Grecy i pesymizm) a Przybyszewskim, który w roku 1893 napisze Requiem aeternam ze słynnym zdaniem „Na początku była chuc"', i który w 1899 zacznie drukować w „Życiu” pierwsze fragmenty Synagogi szatana, jakby pamiętając z powieści Jeża słowa o tym, że panna Helena „niesiona przez miasto i prowadzona następnie przez ciemności, takim była przejęta uczuciem, jakby się znajdowała we władaniu szatana [...]”10.

Rawita-Gawroński do romansującego z Czaplińską zegarmistrza wraca w kilku szkicach o Tymoszce Chmielnickim, świadczących o swoistej negatywnej fascynacji tą postacią. W Ostatnim Chmielniczence pisze:

Romansowy zegarmistrz na dworze Czehryńskiego hetmana, Czaplińska zwykła nierządnica, przechodząca $\mathrm{z}$ rąk Podstarościego $\mathrm{w}$ ramiona kozackiego hetmana, syn jego Tymoszko, wieszający na wrotach ojcowskiego dworu własną macochę - na rozkaz ojca, wreszcie stary Bohdan, włóczący się z muzyką po „pasiekach”, gdzie go szukać muszą posłowie

7 F. Rawita-Gawroński, Weselna tragedia, t. 2, „Biblioteka Warszawska”, Warszawa 1908, s. 567-568.

8 T.T. Jeż, Z burzliwej chwili. Powieść historyczna, t. 3, Warszawa 1882, s. 269-270.

9 S. Przybyszewski, Requiem aeternam... trzecia księga Pentateuchu. Lwów 1904, s. 5.

10 T.T. Jeż, op. cit., s. 270-271. 
moskiewscy - wszystko to wytwarzało atmosferę chyba niezbyt wysokiej moralności. A jednak w takiej atmosferze wychował się Juraszko ${ }^{11}$.

Ponad sto lat później Jacek Komuda w powieści Bohun (2006) nawiązuje do romansu żony Chmielnickiego z zegarmistrzem ze Lwowa, a skoro ona ma być Heleną Dzikich Pól, jego czyni Kozakiem, ukraińskim odpowiednikiem Parysa spod Troi:

Nie wiadomo, czy przypominał on urodą sławetnego Parysa, pisali jednak o nim, iż fach miał całkiem rozumny - był zegarmistrzem, a przy okazji ochmistrzem hetmana. Helena nie tylko używała sobie z nim w łożnicy, gdy Chmiel wojował z Lachami, ale nawet ukradła z piwnic pod Subotowem baryłkę z czerwonymi złotymi. Kiedy Chmielnicki nie mógł się jej doliczyć, kazał, jak podaje Stanisław Oświęcim, tak długo „tyranizować” ochmistrza, aż pomieniony zegarmistrz przyznał się nie tylko do kradzieży, ale i romansu z Heleną. Dowiedziawszy się o tak podstępnej zdradzie, Chmielnicki nakazał rozebrać kochanków do naga, ułożyć w miłosnej pozycji, związać i razem powiesić12.

Intrygująca poetka olsztyńska Alicja Bykowska-Salczyńska w wierszu Pomnik Bohdana Chmielnickiego w Kowlu z tomu Cno (2016) daje taki obraz:

Na wieszakach kołyszą się

czerwona suknia i czarny garnitur

ciało w ciało nicość w nicość nago powieszeni

piękna Helena z Dzikich pól

niewierna żona $\mathrm{z}$ kochankiem in actu

Narody przemijają, miłość - nigdy

Chmielnicki musi na to patrzeć

Łuszczy się ${ }^{13}$.

Zadziwiająca jest trwałość pewnych motywów. Nie ma tu przecież wprost mowy o zegarmistrzowskim zawodzie kochanka żony Chmielnickiego, ale sentencja „Narody przemijają, miłość - nigdy” mówi o przemijaniu (bądź nieprzemijaniu) i ma zwięzłość gnomy na zegarze słonecznym.

${ }_{11}$ F. Rawita-Gawroński, Ostatni Chmielniczenko. (Zarys monograficzny). 1640-1679, Poznań 1919, s. 145.

12 J. Komuda, Od Autora, [w:] idem, Bohun, Lublin 2006, s. 320.

13 A. Bykowska-Salczyńska, Cno, Olsztyn 2016, s. 44. 



\title{
OD KONKRETU RZECZYWISTOŚCI DO POGRANICZA REALNOŚCI - REFLEKSJA WOKÓŁ WCZESNYCH PRAC STEFANA WOJNECKIEGO ${ }^{1}$
}

WERONIKA KOBYLIŃSKA-BUNSCH

\author{
Instytut Historii Sztuki, Wydział Historyczny, \\ Uniwersytet Warszawski \\ The Institute of Art History, \\ Faculty of History, University of Warsaw \\ w.kobylinska@gmail.com
}

\section{KROK, OD KTÓREGO WSZYSTKO SIĘ ZACZĘŁO'}

Rok 1957, Poznań, salon Polskiego Towarzystwa Fotograficznego. Już w progu siedziby mieszczącej się przy ulicy Paderewskiego pod szczęśliwym numerem siedem wyczuwalna jest atmosfera energicznych przygotowań. Wkroczenie w głąb tej nasyconej artystycznym rozgorączkowaniem przestrzeni oznacza zderzenie $\mathrm{z}$ wyjątkowym nagromadzeniem obrazów. Wokół roztacza się heterogeniczna, czarno-biała mozaika gatunków i możliwości interpretacji „nowoczesnego” idiomu. Pięćset dwadzieścia jeden zdjęć polskich autorów, spośród których należy dokonać selekcji ${ }^{2}$. Krytyczne i wnikliwe oko szybko jednak rozpoznaje, że różnorodność jest tylko pozorna.

1 Niniejszy artykuł nie mógłby powstać, gdyby nie serdeczne wsparcie ze strony Pana Profesora Stefana Wojneckiego, który nie tylko zechciał udzielić mi obszernego wywiadu, ale także przekazał na moje ręce liczne materiały i reprodukcje ze swego prywatnego archiwum. Za niezwykle ciepłe przyjęcie oraz podzielenie się ze mną swą wiedzą, doświadczeniem i wspomnieniami niniejszym składam temu wybitnemu Artyście wyrazy serdecznych podziękowań.

2 Ostatecznie na wystawę Krok $w$ nowoczesność (Poznań, 1957) przyjęto sześćdziesiąt sześć prac trzydziestu dziewięciu polskich autorów. Ponadto, zaprezentowano również dziewięćdziesiąt trzy prace czterdziestu dwóch fotografów reprezentujących jedenaście innych krajów: Austrię, Belgię, Czechosłowację, Francję, Holandię, NRD, RFN, Szwajcarię, Szwecję, Wielką Brytanię i Włochy. Zob. Wystawa fotografii artystycznej „Krok w nowoczesnośc”, Poznań 1957. 
Znakomita większość twórców nie zdecydowała się przekroczyć bezpiecznej, usankcjonowanej w środowisku, piktorialnej ${ }^{3}$ formuły pejzażowej o międzywojennym rodowodzie. Zgłoszono niezliczone sentymentalne widoki natury odbijającej się w taflach wody bądź świetliste impresje przedstawiające kręte polne drogi i aleje, do których tulą się wysokie topole. Zdjęcia te charakteryzowały się celowym zamgleniem konturów, szeroką rozpiętością tonalną i miękkością rysunku. Na tle tych eterycznych, malarskich wizji wyróżniały się dwie prace, które dumnie manifestowały chęć koncentracji na świecie przedmiotów i rzeczywistości konkretu. W przeciwieństwie do znacznej części propozycji przesłanych na ekspozycję Krok $w$ nowoczesność $c^{4}$, prace

3 Piktorializm - kierunek w fotografii artystycznej przeżywający rozkwit pod koniec XIX wieku, którego celem było nadanie zdjęciu charakteru dzieła malarskiego. Zasadniczym postulatem piktorialistów był sprzeciw wobec ostrych, wiernie odwzorowujących rzeczywistość obrazów. W konsekwencji akceptowali oni silną ingerencję w odbitkę fotograficzną, nadającą jej unikatowy charakter. Finalny efekt tej swobodnej wypowiedzi twórczej miał potwierdzać, że fotografia powinna zajmować takie samo miejsce w panteonie sztuki, jak inne dziedziny twórczości plastycznej. W międzywojennej Polsce zapożyczony z Francji piktorializm (w wydaniu propagowanym przez Roberta Demachy'ego czy Constanta Puyo) nabrał szczególnego znaczenia, gdyż stał się istotnym elementem programu sformułowanego przez „ojca polskiej fotografii”, Jana Bułhaka (1876-1950). Koncepcja „fotografii ojczystej” uzyskała zaś w świadomości jemu współczesnych rolę ugruntowanej propozycji teoretycznej. Opiewająca piękno kraju, zaangażowana społecznie fotografia była konsekwentnie popularyzowana $\mathrm{w}$ polskim piśmiennictwie. Solidne podłoże intelektualne zapewniło jej pozycję silniejszą aniżeli ta, która przysługuje (zwykle krótkotrwałej) popularności określonych form stylowych. Szybko postępująca supremacja tego polskiego, „rodzimego” piktorializmu, zasadzającego się na nastrojowo rozmytych wizerunkach pełniących funkcję patriotyczną, nie mogła zostać łatwo przełamana przez obcą, niezaangażowaną fotografię nowoczesną.

4 Wystawa Fotografii Artystycznej Krok w nowoczesność (maj-czerwiec 1957) zorganizowana została przez Polskie Towarzystwo Fotograficzne w Poznaniu i prezentowana była w salonie Polskiego Towarzystwa Fotograficznego (ul. Paderewskiego 7). Funkcję komisarza wystawy pełnił Bronisław Schlabs. W Komisji Kwalifikacyjnej poza Schlabsem zasiadali: Zygmunt Obrąpalski, Fortunata Obrąpalska oraz Janusz Kubanek. 
Stefana Wojneckiego (ur. 1929) cechował brutalny realizm i wyabstrahowanie esencji codzienności. Zaskakująca graficzność, brak operowania miękką plamą walorową, bezprecedensowa dobitność szczegółów - już pierwsze realizacje tego artysty musiały na siebie zwrócić uwagę w środowisku fotograficznym lat 50. XX wieku. Sugestywne, klarowne i wyraziste odbitki wymownie demonstrowały swą tożsamość, zrywając z pokutującym wciąż poczuciem niższości medium fotografii wobec innych dziedzin plastyki. Udział tego wybitnego twórcy w poznańskim fermencie intelektualnym jest nie do przecenienia, gdyż przyczynił się on do krystalizacji postaw awangardowych, tak istotnych dla przemian powojennej polskiej fotografii.

Stefan Wojnecki obalał usankcjonowane sposoby percepcji, w zaskakujący sposób wykorzystując potęgę weryzmu immanentnie wpisanego w medium fotograficzne. Działał zatem na przekór generacji piktorialistów, którzy właśnie precyzjonizm kamery uznawali za bezduszny, automatyczny czynnik wymagający wpierw przezwyciężenia (na przykład za sprawą tak zwanych technik szlachetnych) w celu osiągnięcia obrazu o artystycznym statusie. Odrzucając nastrojowy symbolizm, Wojnecki koncentrował się na odkrywaniu nieoczekiwanych aspektów zwyczajnych przedmiotów. Badał mechanizmy codzienności i penetrował świat rzeczy spowszedniałych. Dwie prezentowane na wystawie Krok w nowoczesność prace jego autorstwa, czyli Grzałka oraz Suwak i kamień, doskonale ilustrują, jak poznański twórca wprawnie żonglował niejednoznacznością kategorii „realizmu”, sięgając po najlepsze tradycje Nowej Rzeczowości (Neue Sachlichkeit). Paradoksalnie, za sprawą bardzo prostych zabiegów, jak choćby odpowiednie zbliżenie soczewki obiektywu do przedmiotów raczej pozbawionych wszelkich metaforycznych konotacji, Wojnecki był w stanie uzyskać wieloznaczne, niemal poetyckie kompozycje.

W przypadku pracy Suwak i kamień Wojnecki wykorzystał swoje fizyczne wykształcenie oraz umiejętności inżyniera, świadomie nadając szklanej kliszy graficznej funkcję negatywu i uzyskując tym samym nadzwyczaj ostry rysunek. Kontury, faktura podłoża, cyfry i oznaczenia - wyłaniają się w sposób ostentacyjny i atakują oko niczym Buñuelowska brzytwa. 


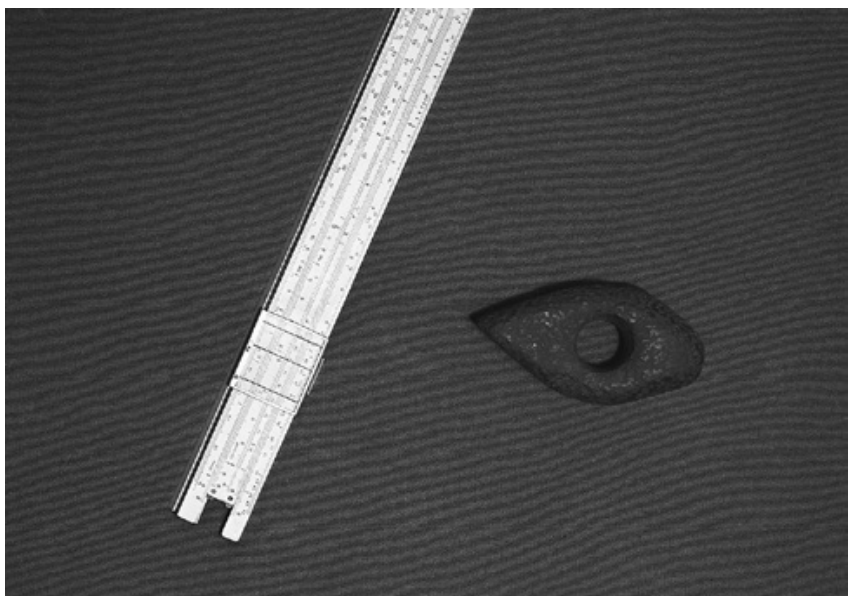

Il. 1. Stefan Wojnecki, Suwak i kamień, 1957 (fotografia-pozytyw) ${ }^{5}$

Z dzisiejszej perspektywy zdjęcie to z pozoru może wydawać się realizacją dokumentacyjną ze względu na szczególny sposób ujęcia: soczewka obiektywu została usytuowana w sposób niemal idealnie równoległy do fotografowanej powierzchni. W rezultacie brak tu przestrzennej głębi, przedmioty statycznie spoczywają na ciemnym tle. W wyobraźni skonfrontowanego z tą pracą odbiorcy uruchamiają się wizje ukazujące pracownię archeologa, który w skrupulatny sposób mierzy i dokumentuje relikt przeszłości. Tymczasem na fotografii tej Wojnecki prehistorycznemu, kamiennemu wytworowi rąk ludzkich przeciwstawił ówcześnie najnowocześniejsze, trudno dostępne narzędzie obliczeniowe - suwak logarytmiczny. Realizuje się tu odwieczny motyw konfrontacji między kulturą, nastawioną na pielęgnowanie tradycji, a nauką - ukierunkowaną na dzień jutrzejszy. Archaiczność spotyka się z symptomem nowoczesności. Zarazem jednak uwidacznia się tu względność wszelkich kategorii odnoszących się do problemu czasu: okazują się one nietrwałe i nieustannie zmienne. Wojnecki problematyzuje jeden $\mathrm{z}$ najdziwniejszych, zdaniem Wisławy Szymborskiej, wyrazów języka. Artysta podziela zdanie polskiej noblistki zawarte w jakże wymownej frazie: „kiedy

5 Wszystkie ilustracje publikujemy dzięki uprzejmości Artysty (przyp. red.). 
wymawiam słowo Przyszłość, pierwsza sylaba odchodzi już do przeszłości"6. Produkt najnowszej technologii wkrótce utraci swą ważność i zostanie wyparty przez bardziej zaawansowane rozwiązania. $Z$ kolei wytwór będący emblematem materialnego dziedzictwa kulturowego stopniowo będzie zyskiwał na wartości ze względu na swój unikatowy charakter świadectwa przemian cywilizacji.

Wykorzystanie ściśle określonych przedmiotów konstytuujących Suwak i kamień - tę nietypową martwą naturę - sugeruje w warstwie narracyjnej możliwość odczytywania tej fotografii przede wszystkim w kontekście opozycji stare - nowe, jednak wątek ów nie wyczerpuje szerokiego wachlarza znaczeń, jaki uruchamia analizowane zdjęcie. Wojnecki demonstruje tu bowiem dojrzały owoc swej refleksji wyrosłej na gruncie dokonań „straży przedniej”, której pierwszym zwiastunem były futurystyczne „słowa na wolności”, stanowiące katalizator rozwoju kolejnych nurtów sztuki XX wieku? Już sam tytuł pracy - w teorii wyłącznie deskryptywny i informacyjny, starający się w neutralny i obojętny sposób opisać przedstawienie - zawiera w sobie pewną awangardową przewrotność ${ }^{8}$. W nazwie tej spotykają się dwa wzajemnie obce i nieprzystające do siebie przedmioty, niczym w owianej legendą dadaistycznej „rozrywce” polegającej na poddawaniu się woli przypadku w zestawianiu ze sobą kolejnych wyrazów czy elementów kolażu9 . Poznański twórca podejmuje $z$ widzem grę i puszcza do niego oko niczym pełni młodzieńczej brawury artyści z kręgu „dada”. W twórczości Wojneckiego wydają się koegzystować różne stylistyki. Artysta podejmuje dialog z awangardą, twórczo reinterpretując będący jej efektem pluralistyczny język obrazowania. Obok dadaistycznej przewrotności można w wypadku tej fotografii również wyczuć echa (przefiltrowanej przez surrealizm) „definicji” piękna autorstwa Comte’a de Lautréamonta, który twierdził, iż piękno to "przypadkowe spotkanie na stole prosektoryjnym maszyny do

${ }^{6}$ W. Szymborska, Trzy słowa najdziwniejsze, [cyt. za:] T. Nyczek, $22 x$ Szymborska, Gdańsk 2000, s. 46.

7 G. Gazda, Awangarda, nowoczesność i tradycja. W kręgu europejskich kierunków literackich pierwszych dziesięcioleci XX w., Łódź 1987, s. 120-125.

8 P. Śliwiński, Poetyckie awangardy. Awangarda przedwojenna, Warszawa 2004, s. 6.

9 H. Richter, Dadaizm, tłum. J. Buras, Warszawa 1986, s. 82-94. 
szycia i parasola"10. Wojnecki podkreśla bowiem nie tylko status i znaczenie poszczególnych przedmiotów, ale przede wszystkim buduje on napięcie między fotografowanymi obiektami, prowokując wyobraźnię widza do odkrywania nieoczekiwanych znaczeń w otaczającej go rzeczywistości. Teza ta rodzi pytanie o to, czy artysta problematyzuje (potwierdzając tezy Petera Bürgera ${ }^{11}$ ), czy może kontynuuje (a raczej - jak ująłby to Stefan Morawski ${ }^{12}$ - dopełnia) działalność ruchów przedwojennych. W niniejszym eseju pozwalam sobie jedynie podkreślić, że Wojnecki podejmuje wątek pewnej nierzeczywistej specyfiki obrazowania; genetyczne związki języka polskiej fotografii powojennej z nurtem surrealizmu stanowią wciąż otwarty i wymagający opracowania rozdział w naszej rodzimej historii sztuki ${ }^{13}$.

Ponadto, przejrzysty świat martwych, pozornie bezwładnie ułożonych przedmiotów nabiera frapującej egzotyki za sprawą pełnej kierunkowych napięć, gruntownie przemyślanej kompozycji. Wzrok odbiorcy rozpoczyna swą wędrówkę $\mathrm{w}$ jednym $\mathrm{z}$ tak zwanych mocnych punktów ${ }^{14}$ fotografii, gdzie usytuowany jest początek jasnego toru matematycznych podziałów i oznaczeń, które diagonalnie przecinają kadr. Scena przypomina migawkowy zapis eterycznego ognia komety, który za chwilę wybrzmi i zniknie, co zapowiada znajdująca się obok kamienna łza. Całość sprawia wrażenie twórczej reinterpretacji symbolu oka o migdałowym wykroju, niepewnie spoglądającego w przyszłość, który to motyw stanowił podstawowy element wizualnej oprawy wzmiankowanej ekspozycji Krok w nowoczesność.

${ }^{10}$ Cyt. za: R. Bréchom, Świat snu, tłum. E. Bieńkowska, „Teksty: Teoria Literatury, Krytyka, Interpretacja” 1973, nr 2, s. 148.

${ }_{11}$ Zob. P. Bürger, Teoria awangardy, tłum. J. Kita-Huber, Kraków 2006.

12 K. Wilkoszewska, W kalejdoskopie awangardowych konstelacji, [w:] Wiek awangardy, red. L. Bieszczad, Kraków 2006, s. 8.

${ }_{13} \mathrm{O}$ inspiracji surrealizmem w dorobku Zdzisława Beksińskiego i Jerzego Lewczyńskiego, którzy - podobnie jak Wojnecki - operowali w latach 50. XX wieku językiem naznaczonym tylko pewnym echem nadrealistycznego rodowodu, pisała między innymi Joanna Kordjak-Piotrowska w szkicu Polska fotografia awangardowa 2. połowy lat 50., [w:] Egzystencje, red. R. Szwander, Warszawa 2005, s. 12.

${ }_{14}$ Zob. informacje o sposobach kształtowania kompozycji w fotografii - podziałach pola obrazu i zasadzie kierunku: P. Wójcik, Kompozycja obrazu fotograficznego, Warszawa 2007, s. 37-41, 64-69. 
Obie prace Stefana Wojneckiego prezentowane na tej jednej z najważniejszych powojennych polskich ekspozycji fotograficznych zasadzały się na antagonistycznych zestawieniach. W przypadku Grzałki elementowi świata techniki artysta przeciwstawił siły natury - dwa podstawowe żywioły. Wijącą się linię błyszczącej przemysłowej konstrukcji otacza bowiem taniec rozedrganych pęcherzyków powietrza, które wibrują „na rozkaz" rosnącej temperatury wody. Bezforemne substancje zostają zmaterializowane na fotografii dzięki wykorzystaniu nieskomplikowanego domowego urządzenia. To, co płynne, bezbarwne i eteryczne, ulega upostaciowieniu; przejrzysta głębia

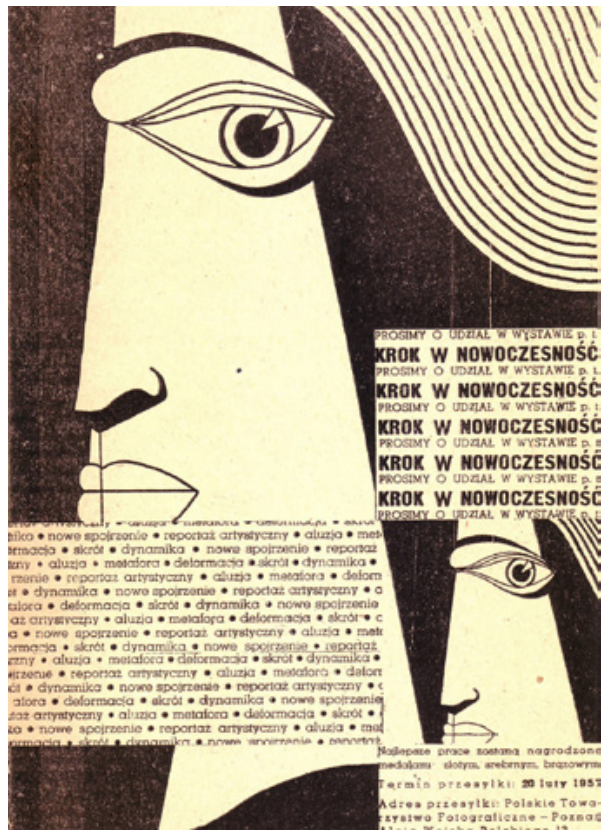

Il. 2. Element identyfikacji wizualnej wystawy Krok w nowoczesność (dzięki uprzejmości Stefana Wojneckiego) nabiera haptyczności. Artyście udaje się ukazać na fotografii wodną przestrzeń i wprawione w ruch powietrze, a zarazem dokonuje on sublimacji znaczenia tytułowej grzałki. Stwarza wizualny poemat na cześć objawu „realności najniższej rangi”15 i w mistrzowski sposób poszerza obszar sztuki fotograficznej o to, co niesłusznie uznawano wcześniej za szpetne czy pozbawione wyrazu. Nieciekawy przedmiot nieoczekiwanie zmienia swój status dzięki gestowi artystycznej legitymizacji. Wojnecki zaciera granice między codziennością a „kulturą wysoką”; wspólnym mianownikiem obydwu opisywanych zdjęć jest potrzeba wykorzystania i przywrócenia znaczenia materii uprzednio zdefiniowanej przez społeczeństwo jako pospolita czy przeciętna.

15 T. Kantor, Teatr śmierci: teksty z lat 1975-1984, oprac. K. Pleśniarewicz, Wrocław - Kraków 2005, s. 17. 


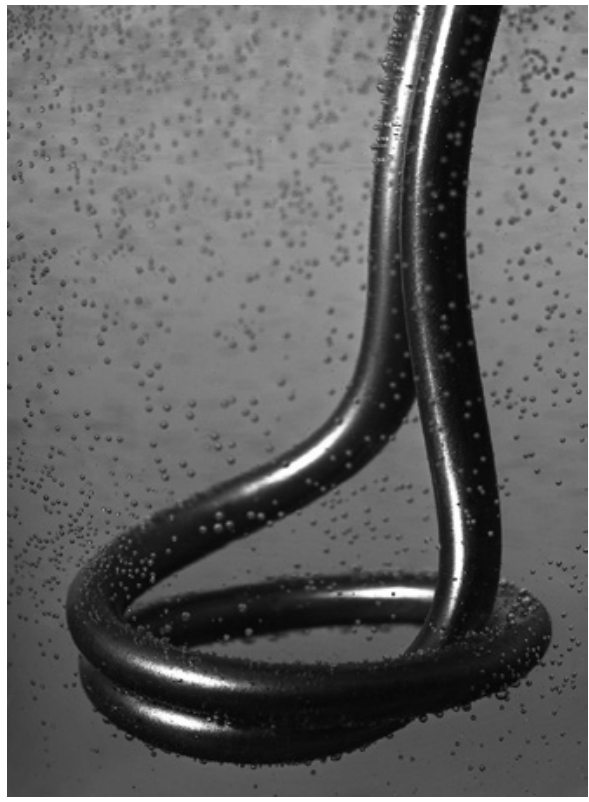

Il. 3. Stefan Wojnecki, Grzałka, 1957 (fotografia-pozytyw)

Fotograf monumentalizuje swój prywatny mikrokosmos, relatywizując nasze percepcyjne przyzwyczajenia. Pozornie nieistotny, błahy i zwykle niezauważalny przedmiot w wizji artysty nieoczekiwanie nabiera dostojeństwa, „mocy sprawczej”, a także może stać się obiektem wizualnego zachwytu. Zacierają się tu granice między strefą $s a$ crum i profanum, podobnie jak w Szarych eminencjach zachwytu Mirona Białoszewskiego. Fotograf podkreśla migotliwą wieloznaczność grzałki, a mistrz pióra - „nieprzecedzonej w bogactwie” łyżki durszlakowej. „Poeta to taki słowiarz, który słowu nie ufa, który atakuje zastane zrosty językowe, rozcina je i organizuje nowe związki słów"16 — słowa Juliana Przybosia dotyczące autora tomu Obroty rzeczy okazują się aktualne także w kontekście śmiałych rozwiązań proponowanych przez Wojneckiego. Artysta „dziwi się” rzeczom, a jego postawa nakierowana jest na zaburzanie apriorycznie pewnych i ustalonych hierarchii, co prowokuje do odwołania się do myśli takich teoretyków, jak np. Bruno Latour - jednostkowe, pozornie nieme obiekty okazują się czynnymi, wywołującymi skutki aktorami sceny społecznej ${ }^{17}$.

\section{ZRYWAJĄC Z KONWENCJAMI}

Pochodząca z 1959 roku praca zatytułowana Drzewo poświadcza, że Wojnecki nie tylko dokonał przewartościowania znaczenia sfery banalnych

16 J. Przyboś, Słowo przedrzeźnione, „Przegląd Kulturalny” 1959, nr 7, s. 8.

17 B. Latour, Przedmioty także posiadaja sprawczość, tłum. A. Derra, [w:] Teoria wiedzy o przeszłości na tle współczesnej humanistyki. Antologia, red. E. Domańska, Poznań 2010, s. 537-539, 549. 
przedmiotów, ale też był w stanie wydobyć nową wizualną jakość z już opatrzonych motywów. Na wzmiankowanym zdjęciu wynurzające się z grubego pnia konary zostają całkowicie wyabstrahowane $\mathrm{z}$ pierwotnie im towarzyszącego kontekstu. Na pozytywie, zdecydowanie większym niż finalnie zamierzony obraz, fotograf za pomocą tuszu ręcznie zamalował (usunął) wszystkie niepotrzebne szczegóły drugiego planu. Dzięki późniejszemu zreprodukowaniu zmodyfikowanej pracy (ale już na mniejszym formacie) artysta świadomie zachował doskonałą jakość, ostrość i wyrazistość form oraz zatarł ślady retuszu. W ten oto sposób fragment natury, dotąd w tak

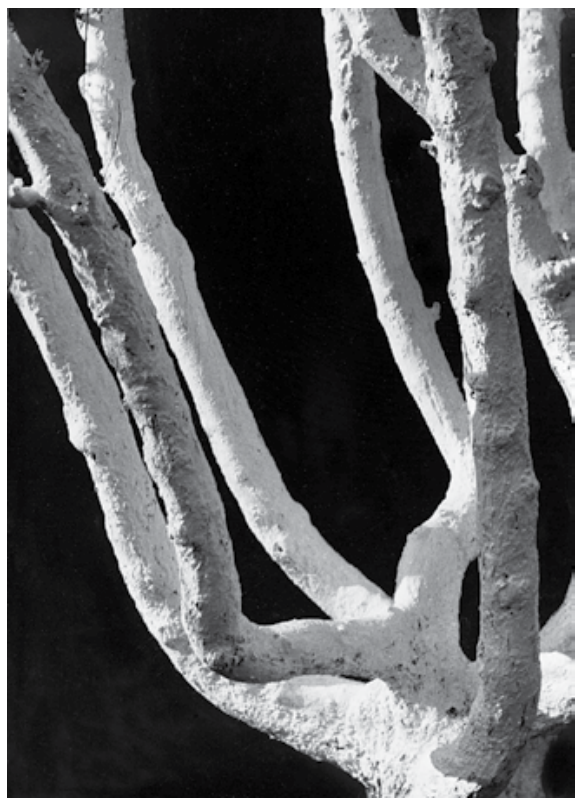

Il. 4. Stefan Wojnecki, Drzewo, 1959 (fotogafia-pozytyw) urokliwy i melancholijny sposób ujmowanej przez polskich fotografików, nabiera przygnębiającego charakteru.

Wojnecki w niezwykle twórczy sposób dokonuje pesymistycznego odwrócenia tradycyjnej symboliki drzewa, zwykle kojarzonego z osią (rozumianą jako źródło i początek) życia ${ }^{18}$. Manualna ingerencja i czarna farba pozwoliły uzyskać silny kontrast pomiędzy głównym motywem a pozbawionym jakichkolwiek informacji tłem, dzięki czemu efekt końcowy stanowi doskonały przykład funkcjonowania tak zwanych obszarów negatywowych - miejsc (pozornie) pustych, niewypełnionych, a jednak niezwykle znaczących dla kreowania plastyki obrazu. Z nicości wynurzają się nagie, bezlistne gałęzie, których kora naznaczona jest szpetnymi wybrzuszeniami. Skonfrontowani z tą wyjątkową wizją przedstawiającą mieszkańca posępnego, pełnego tajemnic lasu, wodzeni niezrozumiałym instynktem - pragniemy dotknąć

18 Zob. M. Eliade, Sacrum, mit, historia, tłum. A. Tatarkiewicz, Warszawa 1974. 


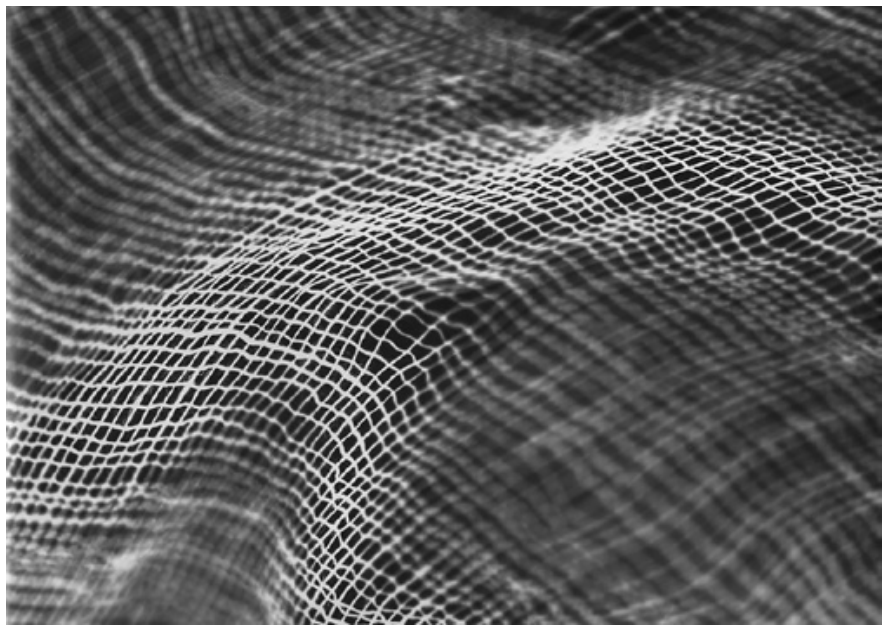

Il. 5. Stefan Wojnecki, Gaza, 1959 (luksografia)

jego szorstkiej faktury. Specyficznie oświetlone, nienaturalnie rozbielone drzewo wydaje się niemal płonąć. Liczne rozgałęzienia winny dawać gwarancję jego żywotności, lecz pozbawione są one przecież kwiecia czy owoców. Najpewniej jest ono już całkowicie uschnięte, niczym wyrzucony na brzeg martwy koralowiec. Czy też może raczej skamieniało ono w bezruchu jak przygarbiony doświadczeniem, sparaliżowany starzec?

Dla wczesnej twórczości Stefana Wojneckiego symptomatyczne wydaje się łączenie awangardowych środków wypowiedzi twórczej z niejednoznaczną symboliką implikującą treści egzystencjalne. Tak rozpatrywać można chociażby pracę Gaza wykonaną w często stosowanej przez artystę non-camerowej technice luksografii (łac. lux - 'światło', gr. gráphein - 'pisać'). W kasetce powiększalnika, zwykle zawierającej negatyw, został zamieszczony tylko fragment materiału, którego obraz był bezpośrednio rzutowany na papier fotograficzny. W ten sposób powstał unikatowy, jednostkowy zapis chwilowego wyglądu przedmiotu - artysta „odcisnął” jego ślad. Obraz został zatem wykreowany bez użycia aparatu, wyłącznie za sprawą manualnych zabiegów i skrupulatnej inscenizacji w ciemni.

Dzięki odpowiedniemu ułożeniu przedmiotu i uzyskaniu małej głębi ostrości fotograf zbudował kilka planów przestrzennych i efektowną 
perspektywę. Wypukłość misternie zagiętej gazy sprawia, że zdaje się ona niemal poruszać czy falować. Wojnecki, rejestrując $\mathrm{w}$ tak niecodzienny sposób kształt pozornie nieefektownego przedmiotu, podejmuje wyrafinowaną polemikę $z$ tradycyjnymi gatunkami fotograficznymi. Penetrowanie włókien, wnikanie w strukturę materiału przywodzi przecież na myśl zbliżenia, w których całość kadru wypełnia naga ludzka skóra ${ }^{19}$. Stanowiące centralny element Gazy wzniesienie przypomina z kolei o typowym dla aktu, subtelnym sposobie pokazywania wyselekcjonowanych, najbardziej pobudzających wyobraźnię aspektów kobiecego ciała. Liryczne ujmowanie nagości na fotografii często prowadziło do wysmakowanego kojarzenia fragmentów anatomicznych z naturalnymi nierównościami terenu Matki Ziemi. Ukazywanie cielesności niejednokrotnie zasadzało się na konotacjach z żeńskim pierwiastkiem ukrytym w panoramicznie ujętym, górzystym pejzażu. Cechujące luksografię odwrócenie naturalnego rozkładu bieli i czerni, a także redukcja półtonów wprowadzają do realizacji Wojneckiego element niepokoju. Przedstawiona przez artystę jasna siatka porów nabiera wanitatywnego charakteru. Zamiast zmysłowej sensualności, Wojnecki z wirtuozerią tworzy metaforyczne odniesienie do ulegającego rozkładowi korpusu. Uczucie to potęguje tytuł pracy, odnoszący się do materiału używanego przede wszystkim w celu tamowaniu krwawień i opatrywania ran. Zawarty w technice luksografii dadaistyczny idiom ${ }^{20}$ zostaje wykorzystany przy uobecnianiu charakterystycznego dla sztuki powojennej wątku biologicznego ${ }^{21}$.

Uzyskane również metodą luksografii Kręgi w bardziej ostentacyjny sposób manifestują swe związki z tematyką dysfunkcyjnego, martwego ludzkiego organizmu. W tej wstrząsającej „lekcji anatomii” człowiek zostaje zredukowany do emblematycznego fragmentu: wewnętrznego miąższu, zwykle ukrytego pod powierzchnią mięśni. Wybrany element kośćca zostaje poddany multiplikacji, przez co tworzy kalejdoskopową feerię form ciasno

19 Zob. np. misterne realizacje Zbigniewa Dłubaka.

20 Metoda ta była znana już w samych początkach fotografii (co potwierdzają prace Williama Foxa Talbota czy Anny Atkins), niemniej dopiero Man Ray w pełni wydobył artystyczny potencjał tej techniki.

${ }^{21}$ Zob. Paris Post War: Art and Existentialism 1944-1954, red. F. Morris, London 1993. 


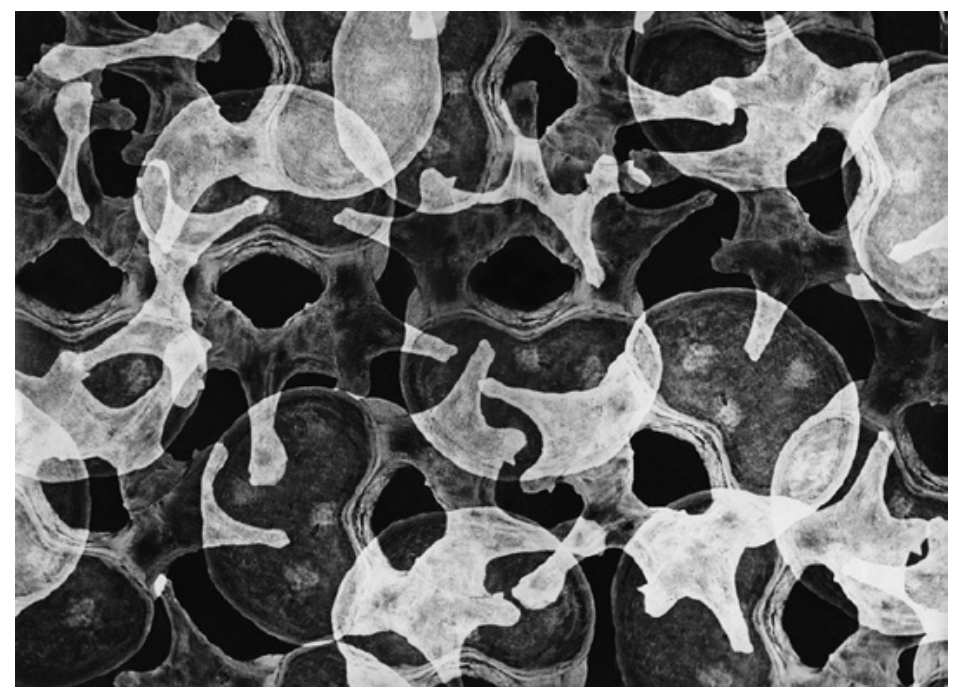

Il. 6. Stefan Wojnecki, Kręgi, 1958 (luksografia)

wypełniających kadr. Ślady ludzkich pozostałości częściowo nakładają się na siebie. Miejsca styku w mniejszym stopniu zostały poddane procesowi naświetlania, i w konsekwencji są one wyraźnie jaśniejsze, przez co niuansują walorowo przedstawienie. Spomiędzy półprzezroczystych tkanek o porowatej strukturze przezierają plamy idealnej czerni zaświetlonego podłoża fotograficznego. Zwielokrotnienie pojedynczego motywu łagodzi „lęk przed pustką".

Łaciński źródłosłów terminu „abstrakcja” (abstractio - 'oderwanie’) nabiera w kontekście tej fotografii szczególnego znaczenia. Kość (mimo że niezaprzeczalnie obarczona biologiczną konkretnością) staje się przyczynkiem do wykreowania wizji zrywającej z tradycyjną kategorią mimesis. Tytułowe kręgi stanowią składową pozbawioną pierwotnego kontekstu, odłączoną - a więc: oderwaną - od człowieka. Niecodzienna konfiguracja spojrzenia kamery niejednokrotnie w historii fotografii była wykorzystywana do tworzenia obrazów nawiązujących do malarstwa nieprzedstawiającego. Za przykład posłużyć mogą choćby dzieła Aarona Siskinda (1903-1991) czy Brassaïa (1899-1984), którzy pokazywali niesamowitość wizualnego potencjału otaczającej człowieka rzeczywistości, sprowadzając 


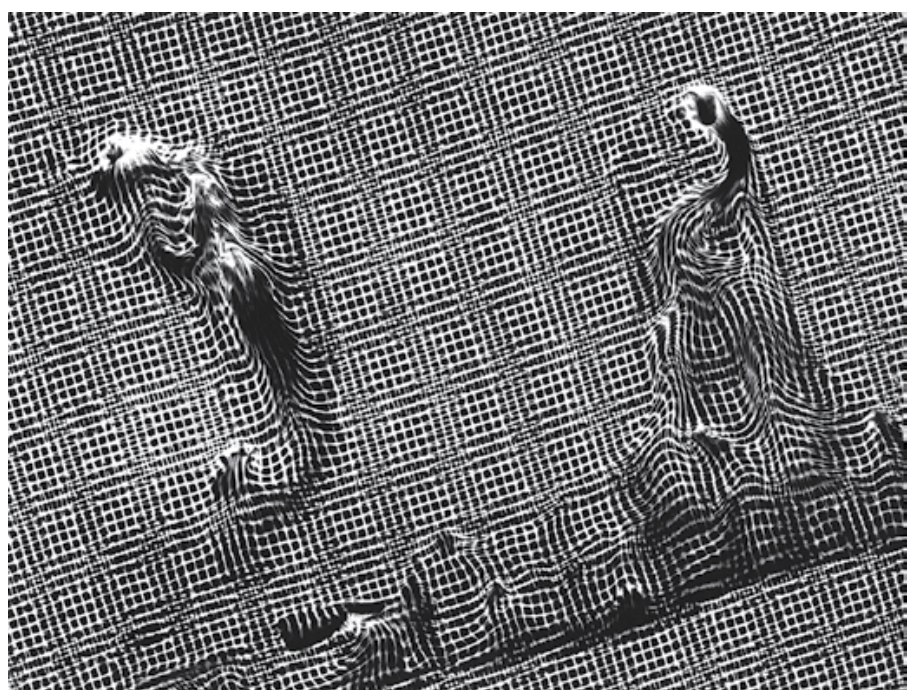

\section{Il. 7. Stefan Wojnecki, Pod powierzchnią, 1958 (fotografia-pozytyw)}

ją do abstrakcyjnego wzoru ${ }^{22}$. Wyraźnie pesymistyczny, egzystencjalny rys tych prac sprawia, iż należą one, pospołu z Kręgami Wojneckiego, do jednej tradycji artystycznej. Siskind i Brassaï, ze znawstwem dobierając i odpowiednio kadrując fragmenty fasad zniszczonych budynków czy pozostałości reklamowych plakatów na płotach, wykorzystywali jednak inne środki wyrazu niż poznański twórca. Wojnecki był bowiem stopniowo coraz bardziej zainteresowany przede wszystkim całkowicie swobodną kreacją obrazu fotograficznego. Dyktowało to wybór luksografii jako metody pracy dla stworzenia tego przejmującego obrazu ludzkich szczątków rozrzuconych na dnie oceanu.

Zdjęcie Pod powierzchnią mogłoby stanowić doskonały przykład transferu i zaadaptowania modernistycznej tradycji abstrakcji ${ }^{23}$ geometrycznej na

22 Do dziś odnajdywanie i wychwytywanie pewnych geometrycznych wzorów z otaczającej rzeczywistości stanowi jedno z klasycznych zadań fotograficznych.

${ }^{23}$ Interpretacje innych prac Wojneckiego operujących tą poetyką, zob. W. Kanicki, Od oscylogramu do estetyki śladu. Abstrakcyjne przypadki w twórczości Stefana Wojneckiego, [w:] Doświadczanie (w) fotografii - Stefan Wojnecki, red. M. Michałowska, M. Piłakowska, Poznań 2015, s. 73-86. 
potrzeby fotografii, gdyż pole obrazu wyraźnie wypełniają misterne, regularne podziały powtarzalnego wzoru. Następuje tu całkowite odstąpienie od reprodukowania otaczającej człowieka rzeczywistości na rzecz unikatowej kreacji alternatywnej kosmogonii. Idealną wizję uporządkowanej, nieomal neoplastycystycznej struktury zakłócają jednak nieregularne rozluźnienia formalnego rygoru, a spektatora niepokoją ekspresyjne wybrzuszenia i wiry. Emulsja szklanego negatywu ze zwielokrotnioną fakturą została miejscowo zwilżona, a następnie podgrzana. Po przechyleniu kliszy substancja ta zaczęła spływać, tworząc nowe, ale jednak kalekie i ułomne organizmy pod powierzchnią tekstury. Manualna ingerencja artysty, polegająca na celowej dezintegracji wykorzystywanego materiału, nosi znamiona autorefleksji nad przebiegiem i charakterem procesu twórczego. Dokonując erozji tradycyjnych metod pracy, twórca stawia pytanie o granice wytrzymałości konwencji samego medium. Wojnecki deklaruje, iż ów wątek w jego twórczości stanowi odpowiedź na autotematyczny nurt sztuki „generatywnej”, poszukującej tożsamości i badającej samą istotę fotografii. Jednocześnie jednak można odważyć się na stwierdzenie, iż poznański fotograf tworzy nową, unikatową dla tego medium ikonografię cierpienia; równie przejmującą jak ta, którą niegdyś wypracował na gruncie plastyki Andrzej Wróblewski za sprawą sugestywnych gwaszy ${ }^{24}$.

Na oczach widza zderzonego z pracą nazwaną przez Wojneckiego Pod powierzchnią rozgrywa się dramatyczny spektakl bez wytłumaczenia. Geneza działania dezintegrującej obraz odśrodkowej siły pozostaje nam nieznana, nie możemy wyczytać jej z samej pracy - liryczne piękno apokalipsy nabiera uniwersalnego charakteru. Statyczny, klarowny język zharmonizowanej geometrii zostaje podważony, a obraz staje się katastroficzną metaforą procesu zniszczenia i destrukcji. Skojarzenie rozedrgania form i ruchu z czynnikiem negatywnym, będącym symptomem zaniku czy rozpadu, widoczne jest również w takich pracach Wojneckiego, jak choćby Nieostrość ruchu (1958), W kosmos (1958) czy Struktura (1962).

24 M. Lachowski, Nowocześni po katastrofie. Sztuka w Polsce w latach 1945-1960, Lublin 2013, s. 238-245. 


\section{PODSUMOWANIE}

Praktyka artystyczna Stefana Wojneckiego przemawia niejako wbrew wykształceniu samego artysty, gdyż odrzuca on postawę racjonalistyczną, którą cechuje przekonanie o sile i możliwościach poznawczych ludzkiego rozumu. Poznański fotograf zdaje się manifestować śmieszność i niewystarczalność precyzyjnych danych naukowych wobec problematyki poznania, wnikania w świat ludzkich emocji. Logika nie jest w stanie sprostać zadaniu wyjaśniania i porządkowania praw funkcjonowania najważniejszych dla człowieczeństwa zjawisk czy kategorii. Wojnecki, dokonując swoistej rewindykacji swobód fotografii, odrzucając wszelkie ograniczenia wolności medium, opisuje świat ludzkich pragnień i niespełnionych nadziei. Jak oswoić i zilustrować tematykę tak trudną, jak sytuacja egzystencjalna jednostki? Wysublimowaną odpowiedzią Stefana Wojneckiego są zdjęcia, które z jednej strony balansują na pograniczu realności, z drugiej natomiast - obierają człowieka i jego emocje za centralny element swej narracji ${ }^{25}$.

\section{Bibliografia}

Robert Bréchom, Świat snu, „Teksty: Teoria Literatury, Krytyka, Interpretacja” 1973, nr 2.

Peter Bürger, Teoria awangardy, tłum. J. Kita-Huber, Polskie Towarzystwo Estetyczne, Universitas, Kraków 2006.

Grzegorz Gazda, Awangarda, nowoczesność i tradycja. W kręu europejskich kierunków literackich pierwszych dziesięcioleci XX w., Wydawnictwo Łódzkie, Łódź 1987.

Mircea Eliade, Sacrum, mit, historia, tłum. A. Tatarkiewicz, PIW, Warszawa 1974. Witold Kanicki, Od oscylogramu do estetyki śladu. Abstrakcyjne przypadki w twórczości Stefana Wojneckiego, [w:] Doświadczanie (w) fotografii - Stefan Wojnecki, red. M. Michałowska, M. Piłakowska, Fundacja 9/11 Art Space, Poznań 2015.

25 Wojnecki problemy te rozwija i prezentuje w nowy sposób w późniejszych pracach konceptualnych, które są głównym przedmiotem zainteresowania badaczy. O przemianach form wizualnych, którymi operował artysta, zob. A. Sobota, Impulsy i pęknięcia, [w:] Stefan Wojnecki - pęknięcia: ku symulacji, oprac. W. Makowiecki, M. Michałowska, M. Pawłowski, Poznań 1999, s. 10-15. 
Tadeusz Kantor, Teatr śmierci: teksty z lat 1975-1984, oprac. K. Pleśniarewicz, Zakład Narodowy im. Ossolińskich, Wrocław - Kraków 2005.

Joanna Kordjak-Piotrowska, Polska fotografia awangardowa 2. połowy lat 50., [w:] Egzystencje, red. R. Szwander, Muzeum Narodowe w Warszawie, Warszawa 2005.

Marcin Lachowski, Nowocześni po katastrofie. Sztuka w Polsce w latach 1945-1960, Wydawnictwo KUL, Lublin 2013.

Bruno Latour, Przedmioty także posiadaja sprawczość, tłum. A. Derra, [w:] Teoria wiedzy o przeszłości na tle współczesnej humanistyki. Antologia, red. E. Domańska, Wydawnictwo Poznańskie, Poznań 2010.

Tadeusz Nyczek, 22 x Szymborska, Tower Press, Gdańsk 2000.

Paris Post War: Art and Existentialism 1944-1954, red. F. Morris, Tate Publishing, London 1993.

Julian Przyboś, Słowo przedrzé́nione, „Przegląd Kulturalny” 1959, nr 7.

Hans Richter, Dadaizm, tłum. J. Buras, Wydawnictwa Artystyczne i Filmowe, Warszawa 1986.

Adam Sobota, Impulsy i pęknięcia, [w:] Stefan Wojnecki - pęknięcia: ku symulacji, oprac. W. Makowiecki, M. Michałowska, M. Pawłowski, Galeria Miejska „Arsenał”, Poznań 1999.

Piotr Śliwiński, Poetyckie awangardy. Awangarda przedwojenna, Wydawnictwo Literackie, Warszawa 2004.

Krystyna Wilkoszewska, W kalejdoskopie awangardowych konstelacji, [w:] Wiek awangardy, red. L. Bieszczad, Universitas, Kraków 2006.

Paweł Wójcik, Kompozycja obrazu fotograficznego, Almapress, Warszawa 2007. Wystawa fotografii artystycznej „Krok w nowoczesnośc”, Spółdzielnia „Grafika”, Poznań 1957.

\section{From Precise Objectivity to the Borderline of Reality - Reflection on Stefan Wojnecki's Early Works}

The main aim of this study is to analyse selected photographs created by Stefan Wojnecki in the 1950s. Chosen materials diversify and enrich the widely accepted image of the artist, who is known primarily for his later conceptual realizations. The essay attempts to characterize those photographs, in which the crucial subject is human individual and his existential 
situation. The basis of the work is primarily the material collected during the interview with the artist himself.

Keywords: neo-avant-garde photography, New Objectivity, New Vision, photogram, photography and metaphor, Polish fine-art photography, post-war photography, Stefan Wojnecki 



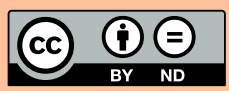

Zatącznik Kulturoznawczy 4/2017

\section{MALUJĘ RZEKE BUG}

STANISŁAW BAJ

Wydział Malarstwa, Akademia Sztuk Pięknych w Warszawie

Faculty of Painting, Academy of Fine Arts in Warsaw

bajstaszek@gmail.com

Bug - zjawisko przyrodnicze, żywioł wody płynącej, naturalna granica podziału Ziemi w aspekcie fizycznym, etnicznym, kulturowym, politycznym, narodowym. Ruch wody rzecznej jest symbolem zmian, przemijania czasu, ludzkiej egzystencji, nieustannego odnawiania. To od wieków ważna arteria komunikacyjna, szczególnie wobec trudnych warunków lądowych. Stąd jej brzegi, bogate w różnego rodzaju ślady obecności człowieka, który osiedlał się, budował osady, tworzył tymczasowe obozowiska podczas wędrówek po rzece. Na brzegach można znaleźć obiekty archeologiczne z najbardziej odległych w czasie kultur. Rzeka Bug jest miejscem przenikania Wschodu i Zachodu, różnych wyznań religijnych, a na obszarze, przez który przepływa, tworzy się odrębny charakter styku kulturowego. Ten potężny żywioł wody, nieokiełznany, dramatyczny i spokojny zarazem, może być przedstawiany w sztuce w sposób romantyczny, liryczny, symboliczny, metafizyczny...

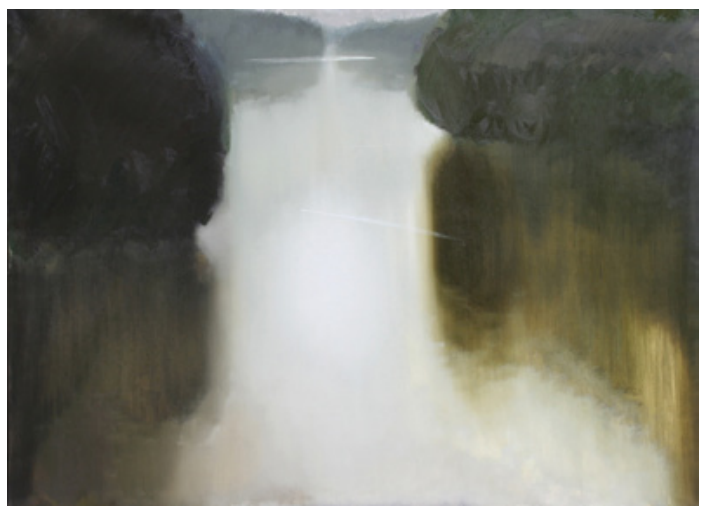

Il. 1. Stanisław Baj, Rzeka Bug, 2009, olej na płótnie, $150 \times 200$ cm 


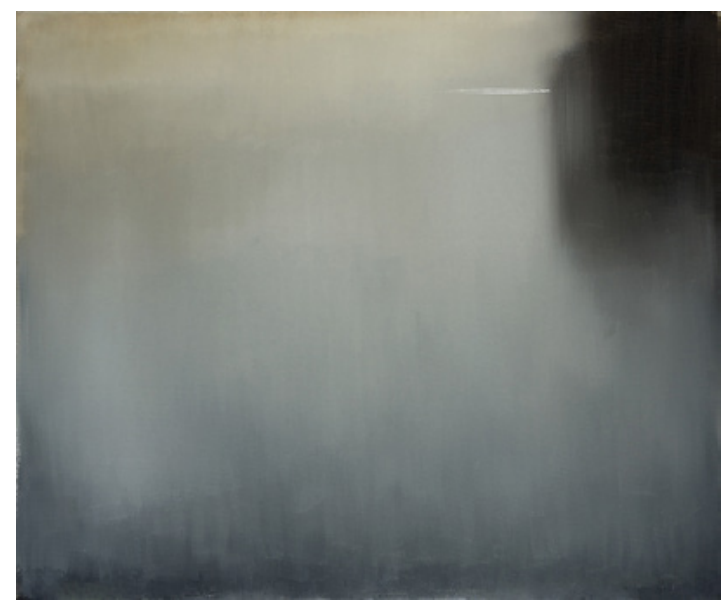

Il. 2. Stanisław Baj, Rzeka Bug, 2015, olej na płótnie, $100 \times 120 \mathrm{~cm}$

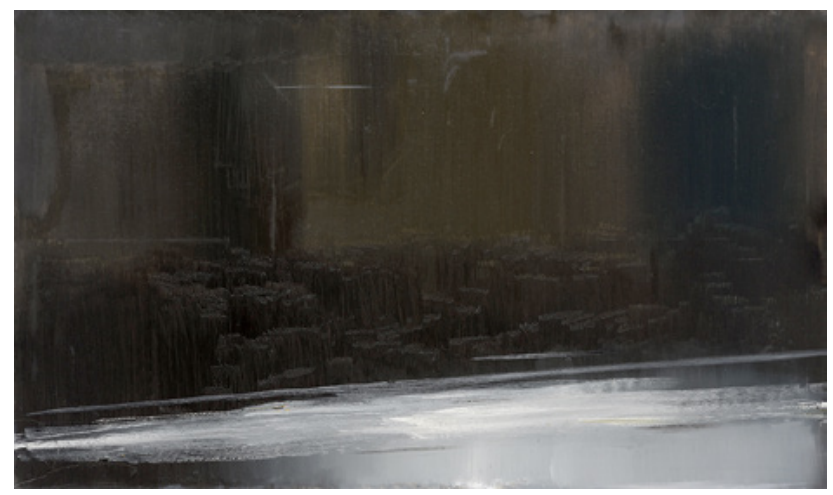

Il. 3. Stanisław Baj, Rzeka Bug, 2015, olej na płótnie, $100 \times 140 \mathrm{~cm}$

Woda płynąca rzeki Bug w niepowtarzalny, charakterystyczny sposób posiada swoje światło i kolor, najczęściej zielono-brunatny, odmienny o różnych porach roku, inaczej intensywny późną jesienią czy wieczorną porą - wówczas osiąga głębię niemal idealnej czerni. Przy nawet najbardziej spokojnej tafli wody powierzchnia jej jest zawsze lekko poruszona, co oznacza ciągły ruch. To delikatne poruszenie, rozmycie - by nie powiedzieć: rozmazanie - odbitych w wodzie form jest odrealnioną rzeczywistością, co 
w zestawieniu z bujną, rozedrganą strukturą brzegowo-roślinną pozwala znaleźć znakomite preteksty malarskie. Rozmyta rzeczna tafla wody zawiera w sobie tajemnicze, ciemne „warkocze” odbić różnych kształtów, na brzegach których zwłaszcza tych ostrych - można zauważyć niezwykłe emanacje światła w dużym natężeniu oraz nieprawdopodobne, delikatne ślady rozproszenia jego działania. Ta nierzeczywista struktura wody ma zawsze pionowe ułożenie. Dla malarza pracującego $\mathrm{w}$ technice olejnej jest to ważna inspiracja, by powtórzyć ów rytm ułożenia wody - ale zupełnie na nowo w odpowiedniej strukturze farby na płótnie, wykorzystując jej konsystencję, grubość, fakturę. Technika olejna jest chyba jedyną,

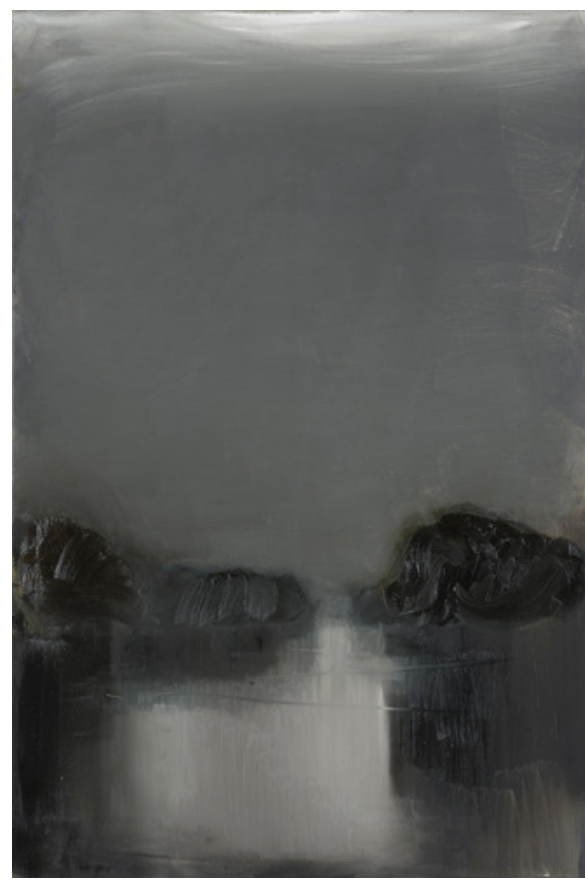

Il. 4. Stanisław Baj, Rzeka Bug, 2015, olej na płótnie, $170 \times 110 \mathrm{~cm}$ dzięki której można uzyskać efekt płynącej wody. Ale owa pionowa struktura namalowanej tafli wody jest tylko częścią końcowego efektu. Najbardziej istotne jest jednak, by na zamalowanym płótnie stworzyć iluzję czy wrażenie ruchu wody. Po wielu latach prób malarskich okazało się, że to "płynięcie” jest ustanawiane przez przeciwstawny kierunek, czyli poziomą zmarszczkę wody, czasem jedną kreskę - ślad zaburzenia ruchu wody spowodowany jakimś niewidocznym zaczepem, konarem.

Lejące się piony miękkich struktur - od głębokiej, przepastnej czerni po jasne smugi światła, przekreślone poziomą kreską w odpowiednim miejscu, ustanawiają płynącą wodę na obrazie, jej malarską istotę. Położenie tej kreski bezwarunkowo musi być świeże, najbardziej pewne, jednorazowe, bez powtórek, jedyne, trafne, w najodpowiedniejszym miejscu kompozycji, $\mathrm{z}$ jednego uderzenia płaskim pędzlem. Jest to najtrudniejszy moment w malowaniu płynącej wody, składa się bowiem na to wiele czynników i oprócz 


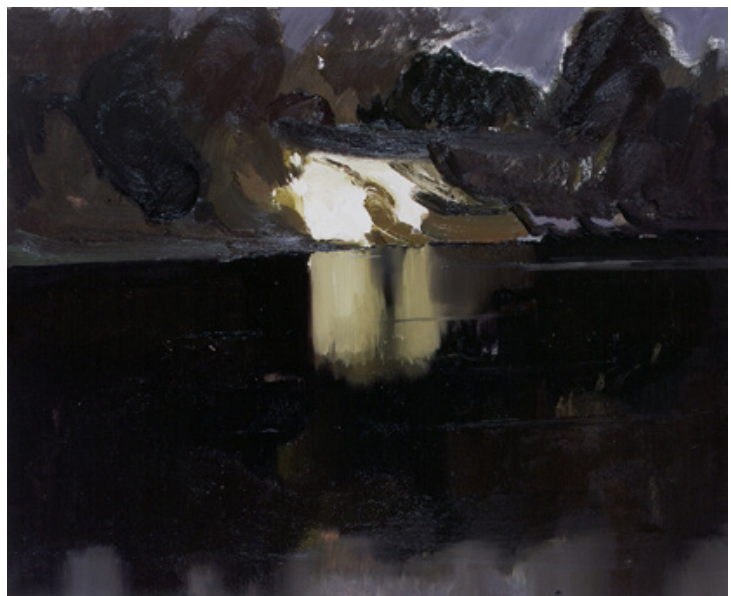

Il. 5. Stanisław Baj, Rzeka Bug, 1998, olej na płótnie, $80 \times 100 \mathrm{~cm}$

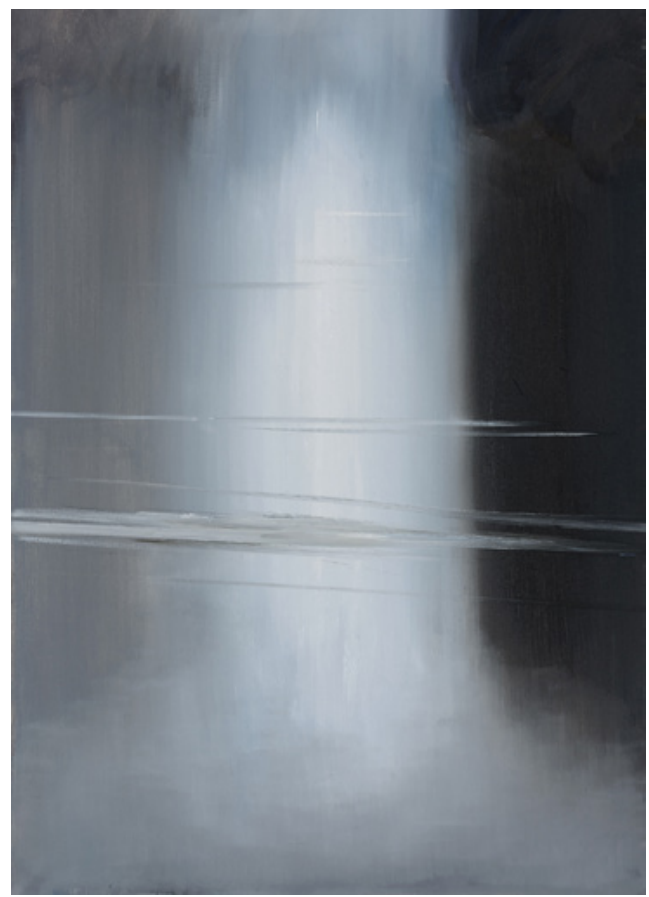

Il. 6. Stanisław Baj, Rzeka Bug, 2015, olej na płótnie, $170 \times 110 \mathrm{~cm}$ 
predyspozycji fizycznych ręki malarza, pewności położenia, doświadczenia, również niezwykle ważna jest koncentracja, skupienie. W tym miejscu spotykają się dwie przeciwstawne struktury: pion i poziom. Jeżeli pozioma kreska powstaje nawet w minimalnie nieodpowiednim miejscu, należy niemal całą powierzchnię struktury obrazu malować od początku. Pozwala na to czasami technika malarstwa olejnego, malowanie przez dłuższy czas „mokre w mokrym”.

Wszystkie te działania są powtarzane wielokrotnie aż do osiągnięcia właściwego rezultatu, nierzadko też kończą się klęską. Ostatecznie chodzi o to, by w portretowaniu płynącej rzeki Bug znaleźć jej najbardziej lapidarny, prosty wyraz, który mógłby znaczyć jak najwięcej, być uniwersalną wartością, własną interpretacją widzenia natury. Ważne są także inspiracje innymi autorami, np. mistrzami akwareli chińskiej, mistrzami pisma znaku i aurą drzeworytów japońskich.

Rzekę Bug znam i noszę w sobie od dzieciństwa. Od przeszło dwudziestu lat próbuję namalować jej wizerunek. Zaczynałem skrupulatnie, odwzorowując jej widok: zakola rzeczne, wodę, odbicia gęstych zarośli. Rzeka na tym odcinku jest granicą między Polską a Białorusią, krańcem Unii Europejskiej i strefy Schengen, dlatego - na szczęście dla niej - nadal pozostaje dzika i nieokiełznana. Ze swej nadrzecznej pracowni przyjeżdżam regularnie nad mój „Styks” o każdej porze roku, o każdej porze dnia, nierzadko wczesnym świtem lub o zmierzchu, i wówczas lubię ją najbardziej - jest wtedy wyciszona, nabrzmiała tajemnicą, poważna, groźna, ponadczasowa. Rzeka najprawdopodobniej nic nie wie o mojej obecności, jestem jej obojętny, jest bezwzględna w swoim istnieniu, a to jej nieujarzmienie pociąga mnie najbardziej.

Rzeka jako płynąca woda, naturalne zjawisko, spełnia wiele funkcji. Bug, jak wiele innych rzek na świecie, np. Ganges, Nil czy Jordan, od najdawniejszej starożytności jest również miejscem symbolicznym, magicznym, przestrzenią kultu religijnego. Nieopodal mojej pracowni w miejscowości Sławatycze każdego roku 19 stycznia odbywa się uroczyste święcenie rzecznej wody, czyli święto Jordanu, agiasma albo wodooswiaszczenije. Barwna procesja z cerkwi przemieszcza się nad rzekę, na której o tej porze roku przeważnie zalega gruby lód. Jest w nim wycięty przerębel w kształcie krzyża z ciemną, żywą wodą jako negatywem, a wyjęty lodowy, dwumetrowej wielkości krzyż zostaje ustawiony centralnie. Obok stoi również lodowy ołtarz. Nad krzyżową 


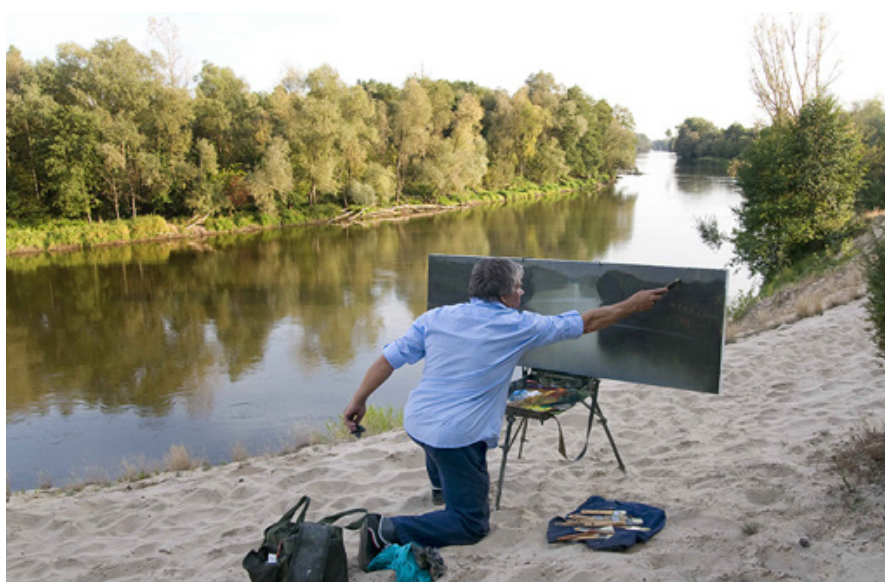

Il. 7. Autor podczas pracy nad Bugiem, 2013 (fot. Marek Szymański)

przeręblą odbywa się obrzęd święcenia wody, który ma niezwykle podniosły charakter i składa się z kilku symbolicznych elementów: modlitwy, trzykrotnego zanurzania krzyża w wodzie, z którego święte krople skapują do naczyń; następnie kapłan wypuszcza białe gołębie jako znak Ducha Świętego, a wierni obmywają lodowatą rzeczną wodą ręce i twarze. Krzyż z lodu stoi potem samotnie przez wiele dni albo nawet tygodni, dopóki nie nastąpi zdecydowana odwilż i nie ruszy kra na rzece. Zdarza się, że krzyż w całkiem wyraźnej jeszcze formie płynie na krze daleko zakolami rzeki Bug.

\section{Paint the Bug River}

This draft is a record of the aesthetic and creative experiences associated with the Bug River. The author, who is a painter himself, proves that the oil technique is unique in terms of the possibility of achieving an effect of a flowing water. In the faint panes of the river you can see unusual emanations of light and improbable, delicate traces of distraction of its action. This unreal water structure of the Bug River is always vertical. For an oil painter, it is an important inspiration to reflect that rhythm of water in a suitable pattern of canvas paint, using its consistency, thickness, texture.

Keywords: Bug river, oil painting, aquatic motifs, aesthetic experience 
ZalǫcZnils

\section{ETYKA PRZERÓBKI. INTERNETOWE REANIMACJE OMRANA DAQNEESHA ${ }^{1}$}

PIOTR JAKUBOWSKI

Wydział Nauk Humanistycznych UKSW

Faculty of Humanities, Cardinal Stefan Wyszyński University in Warsaw

pjakubowski@ymail.com

Tym razem to nie zdjęcie, lecz ujęcie - stopklatka wyabstrahowana z krótkiego nagrania (tzw. footage) autorstwa Mahmouda Raslana, który dokumentował skutki nalotów bombowych na Aleppo, przeprowadzonych 17 sierpnia 2016 roku przez - najpewniej - siły Federacji Rosyjskiej współpracujące z reżimem prezydenta Baszszara al-Asada podczas wojny domowej w Syrii. Ujęcie przedstawia pokrytego niemalże w całości pyłem, wydobytego z gruzowiska chłopca siedzącego we wnętrzu karetki pogotowia. Szarość ciała i ubrania, przełamana plamą zaschniętej krwi pokrywającą lewą połowę twarzy chłopca, kontrastuje $z$ różnymi odcieniami oranżu dominującymi we wnętrzu ambulansu.

W ujęciu tym najmocniej uderza spojrzenie chłopca: zdezorientowane, nieobecne, niepewne, przerażone, pełne trwogi; skierowane jakby w głąb, nie na zewnątrz, nadal utkwione w doświadczonej traumie i nie do końca świadome, że największe zagrożenie najpewniej już minęło, że zostało się ocalonym. Efekt jest tym mocniejszy, że wszystko to - a może znacznie więcej - odnajdujemy tylko w jednym, prawym oku; lewe jest półprzymknięte wskutek opuchlizny, ledwo co widoczne spod ciemniejszej w tym miejscu plamy krwi. Chłopiec, jak się zdaje, siedzi spokojnie, biernie, w pełni poddany temu, co nastąpi; z rozwichrzoną fryzurą, zaciśniętymi ustami i dłońmi złożonymi na udach, z posiniaczonymi nogami wystającymi z krótkich

1 Artykuł powstał w ramach projektu badawczego nr 2016/23/D/HS2/03442 pt. Konstruowanie wizerunku uchodźców w polskim dyskursie publicznym, finansowanego przez Narodowe Centrum Nauki. 
spodenek i bosymi stopami sterczącymi znad siedzenia zbyt dużego („dorosłego") fotela.

Abstrahując na tyle, na ile to możliwe, od etycznej płaszczyzny obrazu od nieuchronnego faktu, że oto znów objawia się nam „widok cudzego cierpienia” - ujęciu temu nie sposób odmówić walorów estetycznych zarówno $\mathrm{w}$ aspekcie kompozycyjnym (idealne wręcz proporcje między punktem centralnym a tłem), jak i kolorystycznym (kontrast szarość - oranże, czerwień plamy krwi na twarzy współgrająca $z$ oliwkowo-bordowym motywem na koszulce - być może obrazkiem przedstawiającym smoka, który w tym kontekście niepokojąco przypomina wnętrzności) ${ }^{2}$. A ponadto doskonały brak jakichkolwiek wyróżników (w kontekście aktualnej isla mofobii ${ }^{3}$ : stygmatów) etnicznych - można rzec, że chłopiec byłby biały, gdyby tylko nie był szary.

Nade wszystko jednak rozpoznajemy topos: „Praktyka przedstawiania okrutnych cierpień jako czegoś, nad czym należy ubolewać i czemu trzeba w miarę możliwości położyć kres, wkracza do historii obrazów wraz ze specyficznym tematem: cierpieniami zadawanymi ludności cywilnej przez zwycięską armię w bitewnym szale”4. Oczywiście, wśród „ludności cywilnej" szczególne miejsce przypada kobietom, dzieciom i starcom, których pozycja dodatkowo eksponuje wynikającą z „cywilności” niewinność i przypadkowość, potęgując tym samym niezgodę, współczucie czy oburzenie na okrucieństwa, których doświadczają, i bezsens wojny. W przypadku trwającego od początków drugiej dekady XXI wieku konfliktu na Bliskim Wschodzie, a także będącego jego konsekwencją tak zwanego kryzysu migracyjnego, fotografie „najbardziej wbijające się w pamięć [...], sprawiające,

2 Zob. A.M. Zarychta, Pozorna lekkość bytu - estetyzacja $w$ fotografii dokumentalnej, [w:] Ciężar i lekkość w kulturze. Estetyka, poetyka, style myślenia, red. B. Pawłowska-Jądrzyk, Warszawa 2016, s. 185-207.

3 Zob. M. Bobako, Islamofobia jako technologia władzy. Studium $z$ antropologii politycznej, Kraków 2017.

${ }^{4}$ S. Sontag, Widok cudzego cierpienia, tłum. S. Magala, Kraków 2010, s. 54.

${ }^{5}$ Choć jego konkretnych źródeł upatrywać należy w interwencji zbrojnej Stanów Zjednoczonych w Afganistanie w ramach ogłoszonej przez administrację George’a W. Busha „wojny z terroryzmem”. Zob. niezwykle wnikliwą dziennikarską analizę zawartą w nagrodzonej Pultizerem książce Joby'ego Warricka Czarne flagi. Geneza Państwa Islamskiego, tłum. T.S. Gałązka, Warszawa 2017. 
że można coś szybko ogarnąć w skompresowanej postaci" ${ }^{\prime}$, przedstawiają dwóch chłopców: trzyletniego Alana Kurdiego oraz pięcioletniego Omrana Daqneesha - owego „chłopca z karetki”, „chłopca z Aleppo”.

Niniejszy szkic stanowi uzupełnienie oraz ciąg dalszy opublikowanego w poprzednim numerze „Załącznika Kulturoznawczego” artykułu poświęconego pierwszemu $\mathrm{z}$ nich ${ }^{7}$. Tu chciałbym pokrótce rozważyć, czy wychwycone przeze mnie strategie retoryk wizualnych, które wykorzystane zostały w internetowych - i nie tylko - przeróbkach, remiksach oraz nawiązaniach do „ikonicznej” fotografii Nilüfer Demir przedstawiającej ciało Alana Kurdiego, pojawiły się także w medialnej cyrkulacji ujęcia prezentującego Omrana Daqneesha w karetce pogotowia (a tym samym czy zaproponowane przeze mnie linie krytyki okażą się zasadne i w tym wypadku).

Zważywszy na fakt, że ani ponadnarodowa „żałoba” po Alanie Kurdim, ani ubolewanie nad losem Omrana Daqneesha nie przełożyły się na zmianę społecznej niechęci wobec uchodźców i migrantów i nie podkopały hegemonistycznego dyskursu antyuchodźczego, już teraz można stwierdzić, że w obydwu tych sytuacjach mieliśmy do czynienia z tym, co Zygmunt Bauman określił jako „karnawały moralności”, czyli „krótkotrwałe [...] wybuchy solidarności i troski, wywołane przez kolejne medialne, spektakularne tragedie w niekończącej się sadze migracyjnej”".

Na początek dwie uwagi ogólne. Po pierwsze, wyszukiwanie za pomocą przeglądarki interneto-

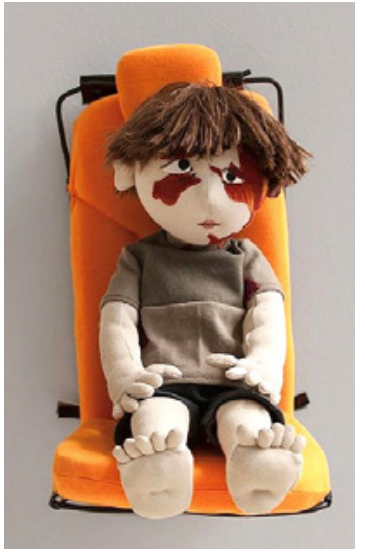

Il. 1. Lalka przedstawiajaca Omrana Daqneesha autorstwa rumuńskiego artysty Dana Cretu, nazwana Sufference Doll („Cierpiąca lalka") $)^{9}$

${ }^{6}$ S. Sontag, op. cit., s. 30.

7 Zob. P. Jakubowski, Nieznośna lekkość pocieszenia, nieznośna miałkość protestu. Internetowe zmartwychwstania Aylana Kurdiego, „Załącznik Kulturoznawczy” 2016, nr 3, s. 300-340.

8 Z. Bauman, Obcy u naszych drzwi, tłum. W. Micner, Warszawa 2016, s. 90.

9 http://www.notey.com/blogs/omran-daqneesh [dostęp: 24.11.17]. Pieniądze ze sprzedaży lalki autor przeznaczył na wsparcie organizacji charytatywnej Save the Children. 
wej Google wskazało na znacznie mniejszą liczbę prosumpcyjnych nawiązań niż w przypadku fotografii Alana Kurdiego. Po drugie, wśród tych, które udało mi się odnaleźć, znacznie więcej stanowiło możliwie „czystą” reprodukcję ujęcia przedstawiającego Omrana Daqneesha, podporządkowaną zasadom odmiennego medium wizualnego (grafika, w tym grafika komputerowa, mural, ale też... lalka dla dzieci).

Choć sam obraz, jak się zdaje, dość łatwo dałoby się przeramować (reframing), np. poprzez przeniesienie chłopca w bezpieczną przestrzeń domu czy placu zabaw ${ }^{10}$, artyści częstokroć decydowali się na odtworzenie pierwotnego ujęcia - a tym samym powielenie jego ram - rezygnując z wyraźnych ingerencji pod postacią dodania czy to odmiennych elementów wizualnych, czy komentarza słownego ${ }^{11}$ (jakby wierni zasadzie, że obraz powinien „mówić sam za siebie").

Wśród odnalezionych przeze mnie grafik parę przedstawiało obydwu chłopców - Alana Kurdiego i Omrana Daqneesha. Już samo umieszczenie

${ }_{10}$ Przykładem takiego przeramowania było zwrócenie uwagi na wizualne podobieństwa między Omranem Daqneeshem a sześcioletnim Alexem (zob. http:// indianexpress.com/article/world/world-news/new-york-kid-offers-home-to-syria-aleppo-omran-daqneesh-3045432/ [dostęp: 24.11.17]), który napisał słynny „wzruszający” list do Baracka Obamy o następującej treści: „Drogi prezydencie Obamo, czy pamięta pan tego chłopca, który został zabrany przez karetkę w Syrii? Czy mógłby pan pojechać i go zabrać, a następnie przywieźć do naszego domu? Zaparkować na podjeździe lub ulicy, a my będziemy na was czekać z flagami, kwiatami i balonami? Będziemy dla niego jak rodzina, a on będzie naszym bratem. Catherine, moja młodsza siostra, będzie dla niego zbierać motyle i świetliki. W szkole mam przyjaciela z Syrii imieniem Omar. Przedstawię go [Omrana przyp. P.J.] Omarowi i będziemy mogli razem się bawić. Będziemy go zapraszać na przyjęcia urodzinowe, a on nauczy nas swojego języka. Skoro nie przywiezie żadnych zabawek, bo ich nie ma, Catherine podzieli się z nim swoim wielkim białym króliczkiem w niebieskie paski. Ja podzielę się z nim swoim rowerem i nauczę go, jak się na nim jeździ. Nauczę go dodawania i odejmowania. [...] Bardzo panu dziękuję, nie mogę się doczekać, kiedy przyjedziecie". https://www.youtube.com/ watch?v=F6rlkbQH8hI [dostęp: 24.11.17] (tłum. własne).

11 Ewentualnie ze zdawkowym, za to dobitnie jednoznacznym komentarzem, np. na muralu przedstawiającym Omrana siedzącego na klockach, które układają się w napis „End war”; https://www.trendhunter.com/trends/antiwar [dostęp: 23.11.17]. 
ich we wspólnych ramach uznać należy za krytyczny gest wskazujący, $z$ jednej strony, na trwałość, permanentność cierpienia, którego końca, jak się zdaję, nie możemy prędko wyczekiwać (przedstawienia te domyślnie otwierają przestrzeń dla kolejnej ofiary), z drugiej - na trwałość obojętności wobec tego cierpienia.

Czy przedstawienia te jednak nie dostarczają zarazem argumentów, których można użyć przeciwko nim samym, skoro (mimochodem) ujawniają również trwała nieskuteczność produkowania i reprodukowania „widoków cudzego cierpienia”? Podejrzenia takie szczególnie mocno nasuwają się w odniesieniu do grafiki Rubena L. Oppenheimera, który obrazek pomstujący na jałowość slacktywizmu ${ }^{12}$ postanowił opublikować na... Twitterze, a tym samym - chcąc, nie chcąc - wygenerował to, przeciw czemu się zwrócił (retweety, polubienia, udostępnienia, aprobujące komentarze etc.) ${ }^{13}$. Z kolei Khalid Albaih, sudański rysownik urodzony w Rumunii, określający siebie mianem „wirtualnego rewolucjonisty" ${ }^{4}$, przedstawił postacie Omrana i Alana, by zobrazować dwa możliwe scenariusze tragicznej alternatywy, przed jaką postawione zostały syryjskie dzieci: co cię spotka, jeśli zostaniesz (Omran Daqneesh), co cię spotka, jeśli uciekniesz (Alan Kurdi). Krytyczny bardziej w rejestrze heartbreaking jest $\mathrm{z}$ kolei obrazek ukazujący Aylana spoczywającego (śpiącego?) na kolanach Omrana, który dodatkowo obejmuje „swojego młodszego braciszka” lewą ręką. Przedstawieniu temu z pewnością daleko do krytykowanej przeze mnie „retoryki pocieszenia” żadnych tu chmurek, aniołków czy ckliwych pasteli, z całości emanuje raczej atmosfera przygnębienia, rezygnacji, pogodzenia się z okrucieństwem świata i rozpaczliwej próby uszczknięcia dla siebie choć odrobiny ciepła, czułego

${ }_{12}$ Czego wyrazem jest zamieszczenie w komiksowym „dymku” oddającym myśli Omrana Daqneesha zwielokrotnionego słowa ‘bla’ wśród logotypów Facebooka i Twittera na tle ciała Alana Kurdiego.

13 Przykładem ataku wymierzonego bezpośrednio we współudział mediów przy powstawaniu globalnej „znieczulicy” jest z kolei grafika autorstwa Saada Hajo przedstawiająca Omrana czytającego gazetę z licznymi ilustracjami ukazującymi... jego samego. Chłopiec rozpaczliwie i z wyrzutem spogląda znad gazety (i z gazety) na widzów. https://mjcob.com/hajo-saadomran-reads-about-omran [dostęp: 20.11.17].

${ }^{14}$ https://www.cartoonmovement.com/p/3310 [dostęp: 18.11.17]. 


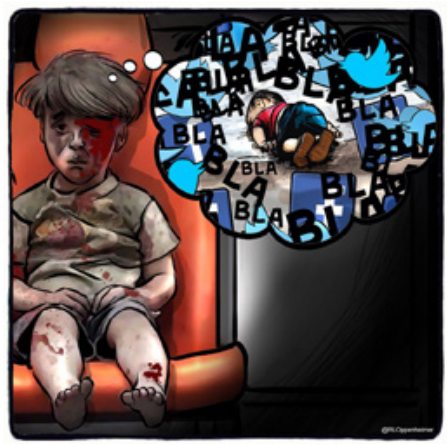

Choices for Syrian children ...

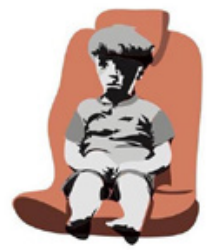

if you stay
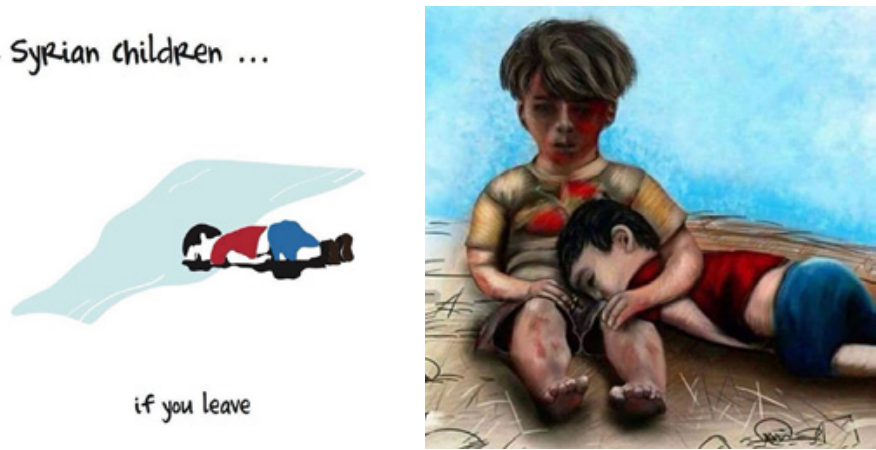

Il. 2, 3 i 4. Omran Daqneesh i Alan Kurdi. Grafiki autorstwa Rubena L. Oppenheimera, Khalida Albaiha oraz anonimowego artysty ${ }^{15}$

dotyku, w tych rozpaczliwych okolicznościach (na marginesie zauważę, że w dwóch ostatnich przytoczonych przykładach obaj chłopcy są doskonale „biali”, co zapewne ułatwić ma empatyczne odruchy wśród zachodniej widowni).

Wśród obrazków przedstawiających samego Omrana odnaleźć można takie, które reprodukują strategię bezpośredniego protestu i oskarżenia (oskarżenia zarówno o obojętność czy przyzwolenie, jak i o - pośrednie sprawstwo), określoną przeze mnie - w nawiązaniu do punkowego protest songu grupy Cool Kids of Death oraz stereotypowych rekwizytów sprzeciwu

15 https://twitter.com/rloppenheimer/status/766923445363802112; https://pbs. twimg.com/media/CqJj31WXEAAVZKI.jpg; https://www.readingthepictures. org/2017/02/omran-daqneesh-visual-culture/ [dostęp: 21.11.17]. 
„ludu” wobec „władzy” - jako „butelki z benzyną i kamienie”. Podobnie jak w przypadku Alana Kurdiego, postać Omrana zostaje wystawiona na pokaz, zaprezentowana „możnym tego świata” jakby z okrzykiem: „Patrzcie, co zrobiliście!”, „Macie krew na rękach!”. Moja uwaga, iż przez to, że „różne grafiki kierują swoje J'accuse w odmienne strony [...], wielość potencjalnych winowajców rozmywa głos wyrzutu i sprzeciwu"16, wydaje się szczególnie zasadna w odniesieniu do obrazka autorstwa tureckiego artysty działającego pod pseudonimem Gundur, na którym widnieje chłopiec w stereotypowym stroju ucznia podczas prezentowania przedstawicielom „ziemskiej władzy” zarówno świeckiej, jak i religijnej ${ }^{17}$ - szkatułki czy laptopa, na którą/który autor dość niezdarnie wkleił fragment ujęcia Omrana z karetki. Kto jednak z przedstawionej ósemki odpowiada za to, co się wydarzyło? I czy wśród nich nie znaleźliby się tacy, którzy nie do końca zasługują na umieszczenie w tym kontekście?

$\mathrm{W}$ analogicznym tonie utrzymana jest ilustracja egipskiego rysownika Sherifa Arafy opublikowana w czasopiśmie „Al-Ittihad”. W tym wypadku jednak Omran jest obiektem kolektywnych drwin ze strony przedstawicieli wielu - skądinąd częstokroć zantagonizowanych ze sobą - sił. Poza prezydentem Baszszarem al-Asadem (jedynym „we własnej osobie”) na obrazku pojawiają się również symbolicznie przedstawione: Rosja (niedźwiedź w czapce „uszatce”), Stany Zjednoczone, świat arabski (w dwóch wydaniach: bardziej „saudyjskim” i bardziej „maghrebskim”), Izrael, ONZ, Unia Europejska, Kościół katolicki (o ile druga osoba z lewej to zakonnica), a wreszcie... terrorysta w pasie szahida, który wykonuje całej grupie zbiorowe selfie za pomocą różowego smartfona (za nimi z kolei, na dalszym tle, widnieje tłum mężczyzn $w$ równie wybornych humorach - to zapewne miałby być „świat”). Upokorzony Omran odwraca wzrok, wpatrując się we własną zakrwawioną dłoń.

16 Zob. P. Jakubowski, op. cit., s. 318.

17 Większość dramatis personae łatwo zidentyfikować, nie wiem tylko, czy mężczyzna stojący obok papieża Franciszka (będącego skądinąd źródłem najbardziej bodajże wyrazistego i jednoznacznego prouchodźczego przekazu na globalnej scenie politycznej) to na pewno Baszszar al-Asad, a także trudno mi stwierdzić, kim jest stojący obok Putina osobnik w stroju „Wuja Sama” - najpewniej „zmiennym desygnatem” określenia „prezydent USA” (z Barackiem Obamą włącznie). 

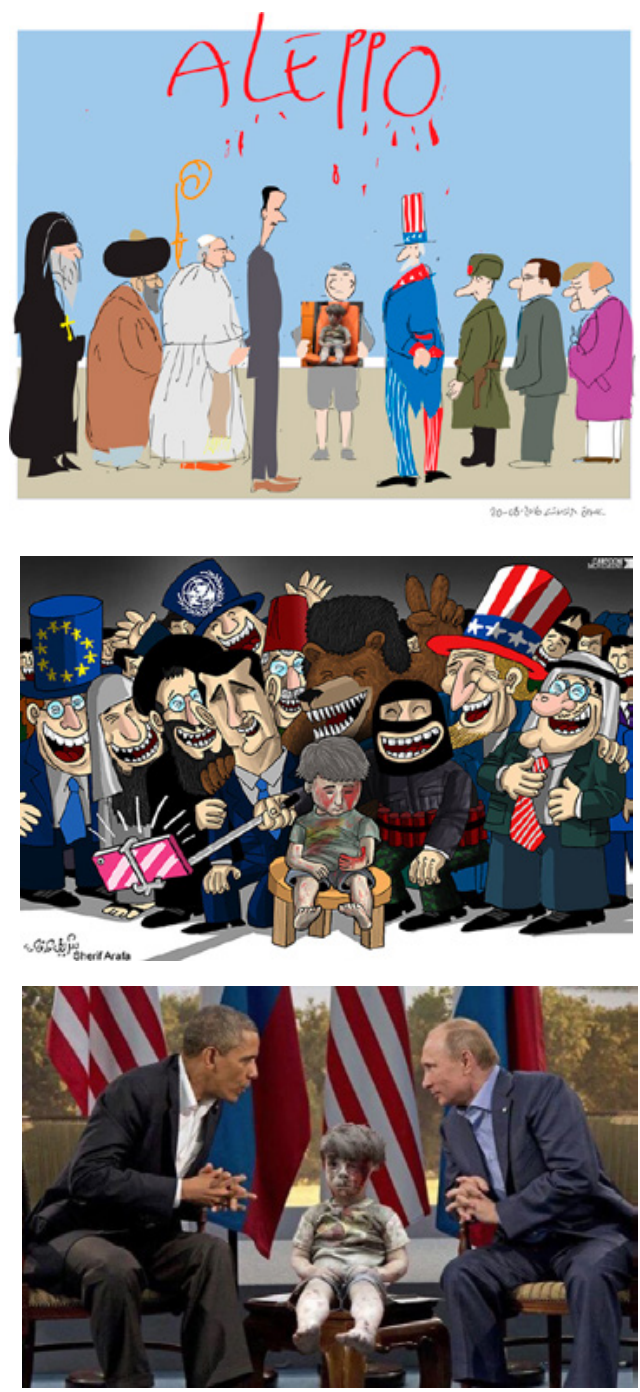

Il. 5, 6 i 7. Omran Daqneesh i „wielcy tego świata”. Grafiki artysty działajacego pod pseudonimem Gungor, Sherifa Arafy oraz fotomontaż nieznanego autora ${ }^{18}$

18 https://www.toonpool.com/cartoons/Omran\%20Daqneesh_276020; http:// blog.cartoonmovement.com/2017/09/sherif-arafa-wins-omran-journalism-award. 
Winni zatem są wszyscy, a więc nikt konkretny, a więc inni; no, może „świat”19 , ewentualnie „Zachód”20, choć przecież nie tylko (odnalazłem trzy obrazki, na których obok Omrana pojawiają się Władimir Putin i Barack Obama; zdekonstruowana retoryka zimnowojenna zachowuje tu swe ramy, orzekając o istnieniu dwóch „mocarstw”, które jednak nie walczą już ze sobą, a kolaborują, czego ofiarą padają inni, w tym właśnie Omran, ale i Alan ${ }^{21}$ ).

Większość analizowanych przeze mnie „internetowych zmartwychwstań” Alana Kurdiego podporządkowanych było temu, co określiłem mianem „retoryki pocieszenia”. Była to dla mnie jednocześnie podstawa do poddania tych przedstawień krytyce jako balansujących na granicy kiczu, w rozumieniu zaproponowanym przez Milana Kunderę („wzruszanie się własnym wzruszeniem”). W przypadku przeróbek obrazu Omrana Daqneesha odnalazłem jedną ${ }^{22}$, za to spektakularną realizację tejże retoryki,

html; https://www.moroccoworldnews.com/2017/01/205712/205712/ [dostęp: 23.11.17].

19 Podobnie jak w przypadku przeróbek fotografii Alana - przedstawiany metaforycznie jako kula ziemska (resp. postać z kulą ziemską w miejscu głowy). Zob. np. https://politicalcartoons.com/?s=omran [dostęp: 23.11.17].

${ }^{20} \mathrm{Na}$ jednej z ilustracji, autorstwa Johna Cole'a, para zapatrzonych w ekrany smartfonów młodych ludzi (na bluzach mają napis „The West”) przechodzi koło Omrana; kobieta pyta: „Hej, nie widziałeś tu może jakichś Pokemonów?”; https:// image.cagle.com/183718/1155/183718.png [dostęp: 21.11.17]

${ }_{21} \mathrm{Na}$ obrazku autorstwa brazylijskiego rysownika Viniego Oliveiry Władimir Putin i Barack Obama, obaj uśmiechnięci i zadowoleni, grają w szachy. Szachownicą jest terytorium Syrii, a pionkami - Alan Kurdi (trzymany za głowę w dłoni prezydenta Rosji) oraz Omran Daqneesh (którym gra były prezydent Stanów Zjednoczonych); https://mjcob.com/vini-oliveira-omran-daqneesh-and-aylan-kurdi-pieces-of-board-of-a-dirty/ [dostęp: 23.11.17].

22 Nikłą obecność wspomnianej retoryki uzasadnić można faktem, iż historia Omrana zakończyła się happy endem - nie trzeba było więc go „dopisywać”, produkując obrazki przedstawiające szczęście chłopca na tamtym/innym świecie - pięciolatek ocalał, a rok później media i Internet obiegły zdjęcia i filmy przedstawiające „całego i zdrowego" Omrana siedzącego w domu wraz z ojcem i rodzeństwem (wówczas wyszła też na jaw informacja, że podczas nalotów bombowych zginął jego dziesięcioletni brat, Ali). Zob. http://www.telegraph.co.uk/news/2017/06/05/ new-photos-emerge-omran-daqneesh-boy-became-symbol-aleppos-suffering/ 
połączoną ze swoistą kanonizacją chłopca ${ }^{23}$ - już nie internetowy remiks, ale obraz olejny autorstwa amerykańskiej malarki Judith Mehr zatytułowany Omran, Angels Are Here („Omranie, anioły są tutaj”), nawiązujący wizualnie do ikony Trójca Święta (ok. 1410-1427) Andrieja Rublowa. Trójka aniołów otaczających siedzącego chłopca ma na aureolach napis: „Radość - Pokój Nadzieja” odpowiednio w języku arabskim, angielskim i łacińskim; całość obramowana jest „arabsko wyglądającym” ornamentem, u góry obrazu

[dostęp: 24.11.17]. Przy tej okazji pojawiły się też liczne kontrowersje. Okazało się bowiem, że ojciec Omrana zadeklarował lojalność dla reżimu prezydenta Baszszara al-Asada, oskarżając media o to, że „Kupczyły jego [Omrana - przyp. P.J.] krwią” (film przedstawiający akcję ratunkową opublikowany został na stronie Aleppo Media Center, grupy opozycyjnych aktywistów walczących z polityką Asada), natomiast sam Omran miał zaprzeczyć, jakoby został ranny po atakach ze strony prorządowej armii syryjskiej (udział Rosjan w nalotach na dzielnice rebelianckie pozostaje wciąż domniemany). Zachodni komentatorzy zwrócili uwagę, że mężczyzna mógł zostać zmuszony do sformułowania owego dement $i$ - rodzina pozostała wszak na terytorium Syrii, a wywiadów udzieliła lojalnym wobec władzy syryjskim i libańskim kanałom telewizyjnym (w tym dziennikarce Kinnanie Alouche z AlSama TV, która swego czasu „zasłynęła” tym, że uśmiechnięta pozowała do selfie na tle martwych ciał opozycyjnych bojowników; zob. https://www.alaraby.co.uk/ english/blog/2016/4/28/selfies-of-death-syrian-journalist-poses-with-dead-rebels [dostęp: 24.11.17]). To nie jedyne kontrowersje związane $\mathrm{z}$ ujęciem przedstawiającym Omrana. Po tym, jak rząd Syrii zrzekł się jakiejkolwiek odpowiedzialności za ofiary nalotów bombowych, cedując winę na stronę rebeliantów, chińska publiczna telewizja CCTV opublikowała viralowy materiał nakręcony w karetce, sugerując, że został on „ustawiony” (przypomnę, że analogiczne podejrzenia, wraz z dowodami inscenizacji, pojawiły się też przy okazji fotografii Alana Kurdiego) i jest częścią zachodniej „wojny propagandowej”, która ma uzasadnić konieczność „humanitarnej” interwencji zbrojnej zmierzającej do zażegnania wojny domowej w Syrii (Unia Europejska i Stany Zjednoczone wielokrotnie krytykowane były za bierność wobec konfliktu oraz skryte wspieranie polityki al-Asada). Zob. http:// www.independent.co.uk/news/world/middle-east/omran-daqneesh-photo-video -aleppo-boy-syria-injured-china-state-media-western-propaganda-war-a7205296. html [dostęp: 24.11.17].

23 Alan Kurdi również został „kanonizowany” poprzez przedstawianie go jako Chrystusa - w stajence betlejemskiej lub spoczywającego na kolanach Maryi, czyli w konwencji piety. 
przerwanym inskrypcją „Pokój z tobą" (w języku arabskim), u dołu - tytułem malowidła (w języku angielskim).

Sama artystka tak opowiada o swoich inspiracjach i intencjach: „Zobaczyłam zdjęcie małego chłopca siedzącego w karetce, wydobytego $\mathrm{z}$ gruzowiska po bombardowaniu Aleppo. Naprawdę chciałam pocieszyć [comfort, sic!] tego chłopca, więc pomyślałam o aniołach - nadciągających, by mu towarzyszyć" 25 . Obraz ten stanowi zatem wizualizację lub „aktualizację" empatycznego odruchu autorki, problematyczna jest jednak jej niewielka samoświa-

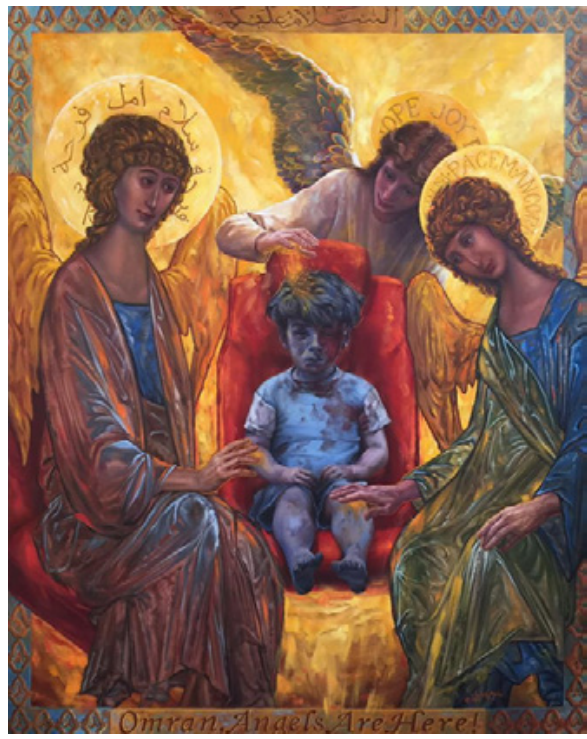

Il. 8. Judith Mehr, Omran, Angels Are Here (2016), obraz olejny na płótnie ${ }^{24}$ domość twórcza. Mehr - z pewnością „na poważnie”, a nie w imię postmodernistycznej gry - połączyła w jedną całość trzy radykalnie odmienne tradycje ustalania relacji między obrazem a sacrum: nieprzedstawiającą (muzułmańską), figuratywną (zachodnią, katolicką) oraz uobecniającą (wschodnią, prawosławną). Co więcej, ikonę, która nie tylko zawiera niezwykle wysublimowaną warstwę symboliczną opartą na głębokiej wiedzy teologicznej ${ }^{26}$, ale i sam proces jej tworzenia (pisania) jest praktyką na poły modlitewną, malarka sprowadziła do samej tylko powierzchni, dążąc wyłącznie do osiągnięcia wizualnego podobieństwa. W efekcie w „ikonie” Mehr nie więcej jest sacrum niż w „ikonce” na pulpicie komputera; wystarczy zestawić jej obraz z dziełami innych współ-

${ }^{24} \mathrm{http} / / /$ judithmehr.com/ [dostęp: 23.11.17].

25 Cyt. za: http://globalworship.tumblr.com/post/154532699735/syria-ancient -christmas-poem-modern-prayers-art [dostęp: 23.11.17] (tłum. własne).

${ }_{26}$ Zob. m.in. P. Evdokimov, Sztuka ikony. Teologia piękna, tłum. M. Żurowska, Warszawa 2006; P. Florenski, Ikonostas i inne szkice, tłum. Z. Podgórzec, Białystok 1997; B. Uspieński, Historia i semiotyka, tłum. B. Żyłko, Gdańsk 1998. 


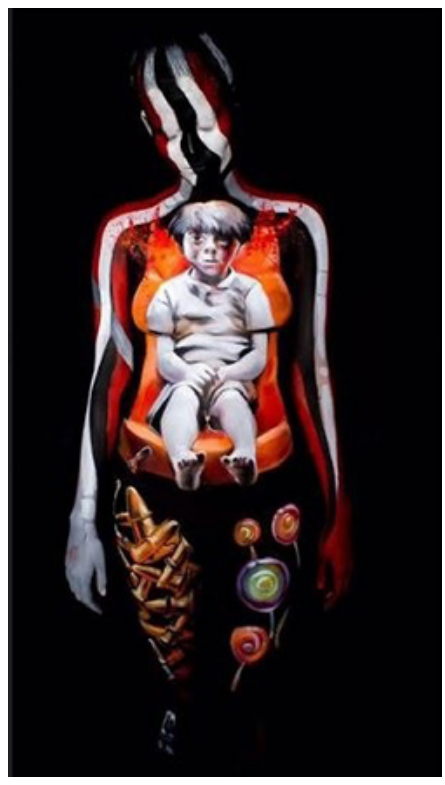

Il. 9. Sanatan Dinda, body painting $z$ Omranem Daqneeshem ${ }^{29}$

czesnych twórców ikon - Jerzego Nowosielskiego czy Jana Berdyszaka ${ }^{27}$ - by dostrzec, $\mathrm{z}$ jakim nadużyciem mamy w tym wypadku do czynienia.

Innym przykładem dość osobliwej przeróbki ujęcia z Omranem Daqneeshem jest dzieło indyjskiego malarza Sanatana Dindy, który postanowił namalować chłopca na... nagim ciele modelki, korzystając z techniki body painting. Opowieść o kontekście narodzin idei malowidła przypomina narrację Mehr, z tą różnicą, że reakcji Dindy bliżej było do sprzeciwu niż konsolacji - „Byłem niezwykle poruszony i zaniepokojony [disturbed], odkąd zobaczyłem to zdjęcie. [...] Nie wiedziałem, co mogę zrobić, by wyrazić swój gniew" - a ponadto artysta poszedł o krok dalej i osadził pierwotne ujęcie w rejestrze symbolicznym: „zdrętwiała [numb] twarz Omrana jest metaforą odrętwienia [numbness], którego doświadcza świat, kiedy musi stanowczo zareagować na problem przesiedlenia [displacement]"28.

Malowidło przedstawia dość bladego (jakby gipsowego) Omrana siedzącego na pomarańczowym fotelu, z którego zagłówka tryskają strugi krwi. Odznaczające się półkola piersi modelki deformują optycznie oparcie krzesła oraz wywołują wrażenie pewnej wklęsłości, jakby chłopiec zapadał się do

27 Zob. R. Rogozińska, Ikona w sztuce XX wieku, Kraków 2009.

${ }_{28}$ Cyt. za: https://timesofindia.indiatimes.com/city/kolkata/I-have-painted-this-boy-to-protest-the-farce-going-on-in-Syria-Dinda/articleshow/53797655.cms [dostęp: 23.11.17] (tłum. własne). Sanatan Dida był również autorem body paintingu przedstawiającego Alana Kurdiego. Zob. http://refugeewatchonline.blogspot. com/2016/07/renowned-artist-from-kolkata-sanatan.html [dostęp: 24.11.17].

${ }^{29} \mathrm{https} / /$ timesofindia.indiatimes.com/city/kolkata/I-have-painted-this-boy-to-protest-the-farce-going-on-in-Syria-Dinda/articleshow/53797655.cms [dostęp: 23.11.17]. 
wnętrza jej ciała. Interpretacyjnie ważnym elementem są uda, w przypadku których Dinda zastosował taktykę - obecną także w przeróbkach fotografii Alana Kurdiego - określoną przeze mnie jako „rozdwojenie ramy”: niewidoczny wskutek wykonania zdjęcia na ciemnym tle prześwit między nogami modelki wprowadza pęknięcie dzielące przedstawienie na „tak jest” (prawe udo, na którym namalowane są bomby i naboje) i „tak powinno być” (noga lewa, na której widnieją kolorowe kręcone lizaki), przez co całość osadzona zostaje w rejestrze utopijnym.

Ostatni przykład, który chciałbym poddać analizie, zachowałem na koniec, gdyż jest jedynym odnalezionym przeze mnie przedstawieniem wliczając w to również przeróbki fotografii Alana Kurdiego - które swą moc krytyczną czerpie z faktu, że problematyzuje (a nawet kwestionuje) swój własny status. Chodzi o zdjęcie autorstwa włoskiego rysownika i aktywisty Gianluki Costantiniego zamieszczone na blogu artysty i przedstawiające przekreślony znakiem „X” rysunek z podobizną Omrana Daqneesha leżący na biurku w towarzystwie przyborów plastycznych i fragmentu jakiejś książki (zapewne albumu $\mathrm{z}$ dawnymi fotografiami). Przedstawienie to jest nie tylko meta-obrazem (fotografią rysunku), ale i foto-opowieścią „w pigułce”30. Chociaż - jak każde zdjęcie - „zamraża” ono czas, to możliwa jest, oparta wnioskowaniu abdukcyjnym, rekonstrukcja historii jego powstania. Sam autor zresztą niejako do tego zachęca, umieszczając siebie w dolnej części fotografii (fragment koszulki i nogawek spodni ujawnia twórcę nachylającego się nad biurkiem, by zrobić zdjęcie).

Otóż zapewne Costantini najpierw chciał wykonać rysunek Omrana - być może motywowany analogicznymi pobudkami co Mehr i Dinda - jednak w pewnym momencie, już po naszkicowaniu figury chłopca i wypełnieniu kolorem (różnymi odcieniami brązu!) odsłoniętych części ciała, porzucił ów pomysł i w akcie złości lub rezygnacji przekreślił nieskończony szkic dwoma pociągnięciami czarnego markera (również widocznego na zdjęciu). Trudno określić, czy dwa napisy - „I don’t exist!” („Nie istnieję!”) oraz ujęty w ramkę - „Aleppo is hell” („Aleppo to piekło”)

30 Zob. M. Michałowska, Foto-teksty. Związki fotografii z narracją, Poznań 2012.

31 Określenia te pojawiają się we wszystkich (kilkunastu) pracach artysty poświęconych bombardowaniom Aleppo, a opublikowanych w czasopiśmie 


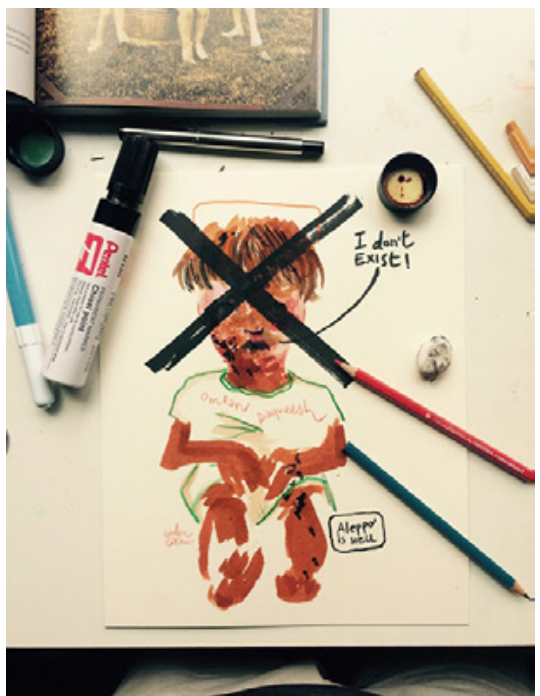

Il. 10. Gianluca Costantini, Omran Daqneesh - I don't Exist!

po przekreśleniu (co ciekawe jednak, rysunek posiada autorską sygnaturę, którą najczęściej składa się dopiero na końcu, po zakończeniu dzieła).

Zastanawiające jest, dlaczego artysta nie zdecydował się na opublikowanie samego (nieudanego?, porzuconego?) rysunku, a zamiast tego wykonał jego zdjęcie na szerszym tle swojego miejsca pracy. Proponuję potraktować to jako sugestię, by bardziej niż samemu obrazkowi przyjrzeć się kontekstowi, w jakim powstał ${ }^{33}$. Kluczowy jest tutaj sam gest przekreślenia (a raczej: ślad tego gestu symboliczny i indeksalny, zgodnie z terminologią Ch.S. Peirce'a, znak „X”). W przeciwieństwie do podarcia czy zgniecenia kartki i wyrzucenia jej do śmietnika, przekreślenie jest jednocześnie negacją obrazu i elementem obrazu, i w tym właśnie podwójnym, aporetycznym charakterze występuje na fotografii Costantiniego (co więcej, zza znaku „X” prześwituje pełne smutku i wyrzutu spojrzenie Omrana).

Gest przekreślenia wzmocniony jest ponadto stwierdzeniem „I don’t exist!”. Półkolista kreska wiodąca od napisu do ust Omrana nakazywałaby konwencjonalnie przypisać je chłopcu, jednakże stwierdzenie

„The New Arab”. Zob. https://www.alaraby.co.uk/english/blog/2016/10/26/gallery-aleppo-is-hell [dostęp: 24.11.17].

32 http://channeldraw.blogspot.com/2016/08/omran-daqneesh-i-dont-exist. html [dostęp: 24.11.17].

${ }^{33}$ Dodajmy, że efekt porzuconego w nieładzie miejsca pracy twórczej jest z pewnością zainscenizowany - na zdjęciu widnieją bowiem przybory, które nie były używane podczas wykonywania rysunku (kredki, ołówek, jasnoniebieski flamaster). Tym samym mamy to do czynienia z potrójną, a właściwie - jak się okaże - poczwórną kreacją artystyczną: stworzeniem rysunku, „twórczym zniszczeniem" rysunku, inscenizacją kompozycji oraz wykonaniem zdjęcia. 
to cechuje performatywna sprzeczność: warunkiem możliwości jakiejkolwiek wypowiedzi jest wszak... istnienie. Jest to przy tym coś więcej kolejne wcielenie Magritte'owskiego Ceci n'est pas une pipe, gdyż rozpoznana „zdradliwość obrazów” jest tu punktem wyjścia, nie dojścia. Ostatecznie jedyną instancją, która może wypowiedzieć owe niemożliwe do wypowiedzenia słowa, jest przekreślony rysunek Omrana Daqneesha - w ramach zasygnalizowanej powyżej aporii zrodzony do istnienia poprzez gest usuwający go $\mathrm{z}$ istnienia, istniejący jako swoja negacja, istniejący. Wprowadzenie perspektywy metapoziomu, czyli obrazu obrazu ${ }^{34}$, umożliwia zakomunikowanie tej aporii (choć bynajmniej jej nie rozwiązuje): przedstawia rysunek jako wewnętrzny - bo będący jego częścią - ale i zewnętrzny - bo będący odrębnym obrazem - element przedstawienia (to trochę jak opowiadanie o Kreteńczyku, który twierdzi, że wszyscy Kreteńczycy kłamią, nie zaś bycie owym Kreteńczykiem i twierdzenie tego).

Amerykański teoretyk kultury wizualnej W.J.T. Mitchell zauważył, odnosząc się do ataków na World Trade Center z 11 września, że „ikonoklazm jest czymś więcej niż niszczeniem obrazów: jest »niszczeniem twórczym«, ponieważ dokładnie w momencie ataku na obraz-»cel« zostaje stworzony kolejny obraz - oszpecania lub unicestwiania" ${ }^{35}$. Zdjęcie Costantiniego jest z pewnością przykładem „twórczego niszczenia” - autor skrywa co prawda przed widzem sam spektakl destrukcji (scenę przekreślenia rysunku możemy sobie jedynie wyobrazić), ale prezentuje jego skutki. Zasadniczy problem $z$ aplikacją kategorii analitycznych zaproponowanych przez Mitchella do kazusu Costantiniego wynika jednak z faktu, że we wszystkich omawianych przez badacza przykładach bałwochwalcy i ikonoklaści do dwie strony sporu, natomiast tu mamy do czynienia z jednym człowiekiem - tym, który (s)tworzył rysunek (idolatra), i tym, który go zniszczył, a następnie zrobił zdjęcie zainscenizowanej sceny owego zniszczenia (ikonoklasta). Konieczna

${ }^{34}$ Ponadto, sam ów rysunek - jako przedstawiający zdjęcie - jest już znakiem drugiego stopnia, co nakazywałoby traktować go jako symulakrum. Zob. J. Baudrillard, Precesja symulakrów, tłum. T. Komendant, [w:] Postmodernizm. Antologia przekładów, red. R. Nycz, Kraków 1997. Fotografia Costantiniego stanowi zatem symulakrum drugiego stopnia - zdjęcie rysunku zdjęcia - z wprowadzonym kluczowym pęknięciem pod postacią znaku „X” - śladu gestu przekreślenia.

35 W.J.T. Mitchell, Czego chca obrazy, tłum. Ł. Zaremba, Warszawa 2015, s. 54-55. 
jest więc jakaś konwersja, metamorfoza, „przed” i „po”. Można powiedzieć, że Costantini w pewnym momencie rysowania Omrana Daqneesha stał się ikonoklastą - stąd też porzucił ten pomysł i zniszczył swój rysunek - a było to możliwe dlatego, że udało mu się zyskać perspektywę (świadomość), dzięki której ujrzał samego siebie jako idolatrę - kogoś, kto wierzył w „fałszywego bożka"36 (który jeszcze do momentu, gdy w niego wierzył, był Bogiem), a potem „przejrzał na oczy”. Jeśli zgodzimy się z tą linią interpretacji, jasne stanie się, dlaczego artysta umieścił na zdjęciu nie tylko sam rysunek, ale i kontekst jego powstania oraz „twórczego zniszczenia” (łącznie ze sobą jako kluczowym elementem owego kontekstu). Co tak naprawdę zobaczył Costantini, gdy „łuski spadły z jego oczu” (Dz 9,18), tego nie wiemy, acz dotychczasowy tok analizy może podszepnąć kilka propozycji: wynikający z „iluzji referencyjnej" (Roland Barthes) fałsz obecny w każdym przedstawieniu rzeczywistości, a szczególnie problematyczny w „widokach cudzego cierpienia”, które nie są i nigdy nie będą cierpieniem, a tym samym nie posiadają mocy, by sprostać prawdzie doświadczenia ${ }^{37}$; nieprzyzwoitą, a jednocześnie nieuchronną estetyczność wszelkich reprezentacji cierpienia, opartych ponadto na powszechnych konwencjach i sztampowych metaforach, które negują jego jednostkowy wymiar; jałowość, niemoc i bezskuteczność, a może nawet szkodliwość prezentowania „widoków cudzego cierpienia” (współudział w powszechnym zobojętnieniu, generowanie narcystycznego slacktywizmu czy pełnych hipokryzji „karnawałów moralności”), etc. „Aleppo is hell!”.

Zdjęcie Costantiniego można zatem uznać za odpowiednik słynnego explicitu Szaleństwa dnia Maurice’a Blanchota. Po odpowiedniej parafrazie brzmiałoby to tak: „Rysunek? Nie, żadnych rysunków. Nigdy więcej”38.

${ }^{36}$ Strukturę fotografii Costantiniego można w tym aspekcie porównać do struktury narracyjnej Wyznań świętego Augustyna, w których obecna jest zasadnicza rozbieżność perspektywy ,ja” opowiadającego i ,ja” opowiadanego. W omawianym wypadku ,ja” opowiadające to ten, który stworzył zdjęcie (i w pewnym momencie zniszczył rysunek), ,ja” opowiadane - ten, który rysował.

$37 \mathrm{~W}$ tym kontekście fotografia ta przedstawiałaby nie tyle nieprzedstawialne, ile samą nieprzedstawialność.

38 „Opowieść? Nie, żadnych opowieści. Nigdy więcej”. M. Blanchot, Szaleństwo dnia, tłum. A. Sosnowski, [w:] idem, Tomasz Mroczny. Szaleństwo dnia, Wrocław 2009, s. 93. 
Przy czym - co szczególnie istotne - nie jest to równoznaczne z wezwaniem do zaniechania tworzenia jakichkolwiek reprezentacji czy świadectw cudzego cierpienia - a wręcz przeciwnie. W sparafrazowanej końcówce opowieści Blanchota wysłyszeć można słynne, przy czym najczęściej wyrwane z kontekstu dictum Theodora W. Adorno: „Pisanie wierszy po Oświęcimiu jest barbarzyństwem”. Jak wskazuje Sidra DeKoven Ezrahi, sformułowanie to „pojawiło się po raz pierwszy w dyskusji, którą autor skończył stwierdzeniem, że »tak wielkiego cierpienia nie wolno zapomnieć«, i nawet jeśli sztuka zawiera w sobie ciągłe ryzyko zdradzenia ofiar, nie istnieje inne miejsce, w którym cierpienie to mogłoby odnaleźć »swój własny głos«"39. Zatem wyjście z aporii jednoczesnej konieczności i niemożności reprezentacji „cudzego cierpienia” wiedzie przez głęboka etyczną odpowiedzialność twórcy ${ }^{40}$, którego głos udźwignąć musi dręczące brzemię protestu-świadectwa ${ }^{41}$, czynionego „W imieniu” i „z upoważnienia” ofiar.

Obawiam się, że ze wszystkich artystów - profesjonalnych i amatorskich - omawianych na przestrzeni obydwu moich tekstów tylko Gianluca Constantini był w stanie uświadomić sobie ów ciężar.

I express my thanks to all artists, who took Omran Daqneesh's tragedy into consideration, for their permission to reprint their works in my essay.

39 S. DeKoven Ezrahi, Holokaust a zmieniajace się granice sztuki i historii, tłum. M. Michalski, „Literatura na Świecie” 2004, nr 1-2, s. 167. Analogicznie Giorgio Agamben stanowczo krytykował tych, którzy „utożsamiając wyjątkowość z niewypowiadalnością, czynią z Auschwitz rzeczywistość całkowicie odrębną od języka”, wskazując, że w ten sposób "powtarzają [oni] bezwiednie gest samych nazistów” dążących do tego, by nikt nie dowiedział się o tragedii, jaka stała się udziałem ofiar Shoah. G. Agamben, Co zostaje z Auschwitz. Archiwum i świadek, tłum. S. Królak, Warszawa 2008, s. 158.

40 W tym także od-twórcy, autora z definicji, zdawałoby się, „niepoważnych” internetowych przeróbek, jeśli tylko podejmuje temat „widoku cudzego cierpienia”,

${ }^{41}$ Jak pisze Paul Ricoeur: „w łacińskim rdzeniu słowa protest jest [...] wyraz testis, świadek - najpierw się pro-testuje, żeby móc zaświadczyć”. Wydobywanie dobra. Z Paulem Ricoeurem rozmawia Brat Emil z Taizé, „Więź” 2001, nr 15, s. 14. 


\section{Bibliografia}

Giorgio Agamben, Co zostaje z Auschwitz. Archiwum i świadek, tłum. S. Królak, Wydawnictwo Sic!, Warszawa 2008.

Jean Baudrillard, Precesja symulakrów, tłum. T. Komendant, [w:] Postmodernizm.

Antologia przekładów, red. R. Nycz, Wydawnictwo Baran i Suszyński, Kraków 1997.

Zygmunt Bauman, Obcy u naszych drzwi, tłum. W. Micner, PWN, Warszawa 2016. Maurice Blanchot, Szaleństwo dnia, tłum. A. Sosnowski, [w:] idem, Tomasz Mroczny. Szaleństwo dnia, Biuro Literackie, Wrocław 2009.

Monika Bobako, Islamofobia jako technologia władzy. Studium $z$ antropologii politycznej, Universitas, Kraków 2017.

Sidra DeKoven Ezrahi, Holokaust a zmieniajace się granice sztuki i historii, tłum.

M. Michalski, „Literatura na Świecie” 2004, nr 1-2.

Paul Evdokimov, Sztuka ikony. Teologia piękna, tłum. M. Żurowska, Wydawnictwo Księży Marianów, Warszawa 2006.

Paweł Florenski, Ikonostas i inne szkice, tłum. Z. Podgórzec, Bractwo Młodzieży Prawosławnej w Polsce, Białystok 1997.

Piotr Jakubowski, Nieznośna lekkość pocieszenia, nieznośna miatkość protestu. Internetowe zmartwychwstania Aylana Kurdiego, „Załącznik Kulturoznawczy" 2016, nr 3.

Marianna Michałowska, Foto-teksty. Związki fotografii z narracja, Wydawnictwo Naukowe UAM, Poznań 2012.

W.J.T. Mitchell, Czego chca obrazy, tłum. Ł. Zaremba, Narodowe Centrum Kultury, Warszawa 2015.

Renata Rogozińska, Ikona w sztuce XX wieku, Wydawnictwo WAM, Kraków 2009 Susan Sontag, Widok cudzego cierpienia, tłum. S. Magala, Karakter, Kraków 2010. Boris Uspieński, Historia i semiotzka, tłum. B. Żyłko, słowo/obraz terytoria, Gdańsk 1998.

Joby Warrick, Czarne flagi. Geneza Państwa Islamskiego, tłum. T.S. Gałązka, Wydawnictwo WAB, Warszawa 2017.

Wydobywanie dobra. Z Paulem Ricoeurem rozmawia Brat Emil z Taizé, „Więź” 2001, nr 15.

Anna M. Zarychta, Pozorna lekkość bytu - estetyzacja $w$ fotografii dokumentalnej, [w:] Ciężar i lekkość w kulturze. Estetyka, poetyka, style myślenia, red. B. Pawłowska-Jądrzyk, Wydawnictwo Naukowe UKSW, Warszawa 2016. 


\section{Źródła internetowe}

http://blog.cartoonmovement.com/2017/09/sherif-arafa-wins-omran-journalism -award.html.

http://channeldraw.blogspot.com/2016/08/omran-daqneesh-i-dont-exist.html.

http://globalworship.tumblr.com/post/154532699735/syria-ancient-christmaspoem-modern-prayers-art.

http://indianexpress.com/article/world/world-news/new-york-kid-offers-home-to-

syria-aleppo-omran-daqneesh-3045432/.

http://judithmehr.com/.

http://refugeewatchonline.blogspot.com/2016/07/renowned-artist-from-kolkatasanatan.html.

http://www.independent.co.uk/news/world/middle-east/omran-daqneesh-pho-

to-video-aleppo-boy-syria-injured-china-state-media-western-propaganda-war-a7205296.html.

http://www.notey.com/blogs/omran-daqneesh.

http://www.telegraph.co.uk/news/2017/06/05/new-photos-emerge-omran-daqne-

esh-boy-became-symbol-aleppos-suffering/.

https://image.cagle.com/183718/1155/183718.png.

https://mjcob.com/hajo-saadomran-reads-about-omran.

https://mjcob.com/vini-oliveira-omran-daqneesh-and-aylan-kurdi-pieces-of-board-of-a-dirty/.

https://pbs.twimg.com/media/CqJj31WXEAAVZKI.jpg.

https://politicalcartoons.com/?s=omran.

https://timesofindia.indiatimes.com/city/kolkata/I-have-painted-this-boy-to-pro-

test-the-farce-going-on-in-Syria-Dinda/articleshow/53797655.cms.

https://twitter.com/rloppenheimer/status/766923445363802112.

https://www.alaraby.co.uk/english/blog/2016/10/26/gallery-aleppo-is-hell.

https://www.alaraby.co.uk/english/blog/2016/4/28/selfies-of -death-syrian-journa

list-poses-with-dead-rebels.

https://www.cartoonmovement.com/p/3310.

https://www.moroccoworldnews.com/2017/01/205712/205712/.

https://www.readingthepictures.org/2017/02/omran-daqneesh-visual-culture/.

https://www.toonpool.com/cartoons/Omran\%20Daqneesh_276020.

https://www.trendhunter.com/trends/antiwar.

https://www.youtube.com/watch?v=F6rlkbQH8hI. 


\section{The Ethics of the Remake. Omran Daqneesh's Online Reanimations}

This article is a follow-up of the essay Aylan Kurdi's Online Resurrections published in the previous issue of the 'Cultural Studies Appendix' (3/2016). This time the author analyzes the remakes of the widely shared shot of Omran Daqneesh - a 5-years old Syrian boy sitting in the ambulance and fully covered by dust with seeable traces of brushes and stains of blood taken from the viral footage which reported damages and sufferings caused by the airstrikes on the Syrian biggest city, Aleppo, during the civil war. For once the author discusses not only the visual rhetoric strategies applied in those remakes, but also their ethical dimensions, especially in reference to the category of 'unrepresentability' connected with the concept of the 'limit situations'.

Keywords: Omran Daqneesh, the pain of the Other, visual culture, convergence culture, civil war in Syria 


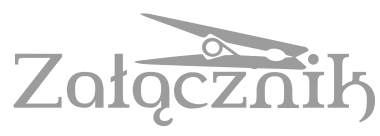

\section{Z ODDALI I Z BLISKA ${ }^{1}$}

\section{Z PROF. TERESĄ KOSTKIEWICZOWA ROZMAWIA MAGDALENA ABRAMCZYK}

TERESA KOSTKIEWICZOWA - literaturoznawczyni, profesor nauk humanistycznych, nauczycielka akademicka. W 1956 roku ukończyła polonistykę na Uniwersytecie Warszawskim. W latach 1956-1971 była zatrudniona w Katedrze Teorii Literatury UW. Następnie, aż do emerytury w 2006 roku, związała się z Instytutem Badań Literackich PAN w Warszawie, gdzie kierowała Pracownią Literatury Oświecenia. Profesor Uniwersytetu Kardynała Stefana Wyszyńskiego w Warszawie oraz członkini m.in. Polskiej Akademii Umiejętności, Rady Naukowej Instytutu Badań Literackich PAN oraz Komitetu Nauk o Literaturze PAN. Była również przewodniczącą Towarzystwa Literackiego im. Adama Mickiewicza, a od 1984 roku przez ponad dwadzieścia pięć lat przewodniczyła Olimpiadzie Literatury i Języka Polskiego. Jedna z największych badaczek polskiego oświecenia, autorka wielu artykułów oraz książek, w tym m.in.: Model liryki sentymentalnej w twórczości Franciszka Karpińskiego (1964), Kniaźnin jako poeta liryczny (1971), Klasycyzm - sentymentalizm - rokoko. Szkice o pradach literackich polskiego Oświecenia (1975), Horyzonty wyobraźni. O języku poezji czasów Oświecenia (1984), Oświecenie. Próg naszej współczesności (1994), $Z$ oddali i $z$ bliska. Studia o wieku Oświecenia (2010). Wielokrotnie wyróżniana za

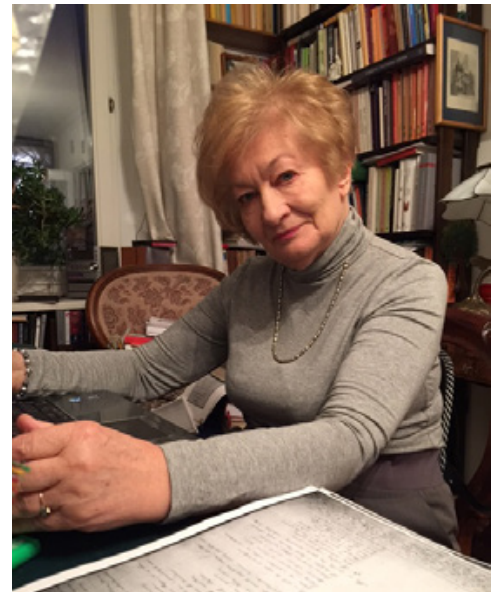

Prof. Teresa Kostkiewiczowa (fot. $z$ archiwum prywatnego)

1 Pod tym samym tytułem w 2010 roku w Warszawie ukazała się książka Pani Profesor: Z oddali i z bliska. Studia o wieku Oświecenia. 
swoją pracę m.in. Krzyżem Kawalerskim Orderu Odrodzenia Polski i Krzyżem Oficerskim Orderu Odrodzenia Polski, nadawanym za wybitne osiągnięcia w pracy naukowo-badawczej w dziedzinie historii literatury, oraz Medalem Komisji Edukacji Narodowej. Otrzymała również tytuł doktora honoris causa Uniwersytetu Warmińsko-Mazurskiego w Olsztynie i Katolickiego Uniwersytetu Lubelskiego Jana Pawła II.

Magdalena Abramczyk: Pani Profesor, bardzo dziękuję za zgodę na spotkanie i udzielenie krótkiego wywiadu. Okazją do rozmowy jest bardzo piękny jubileusz, który Pani Profesor obchodzi w tym roku [wywiad przeprowadzono w 2016 roku - przyp. red.]. I chyba nie da uciec się od tego utartego wyrażenia, że to dobry moment do podsumowań i spojrzenia na wiele kwestii z pewnego dystansu. Zacznę więc może od początku. A właściwie od pytania o początki drogi naukowej Pani Profesor. Kiedy pojawiła się pasja do literatury i to zacięcie teoretyczne? Co zdecydowało o wyborze właśnie takiej drogi zawodowej?

Teresa Kostkiewiczowa: Źródła mojej drogi naukowej sięgają właściwie dzieciństwa. Bardzo wcześnie zainteresowały mnie książki i ich czytanie, a potem pojawiła się potrzeba mówienia o nich, komentowania ich i dzielenia się z innymi tym, co wiązało się z lekturą. Na zadawane mi stereotypowe pytanie: kim chciałabym być, jak dorosnę?, odpowiadałam konsekwentnie: nauczycielką. Duże znaczenie miała zapewne moja pierwsza lektura Pana Tadeusza, którego egzemplarz kupił mi mój tata na ulicznym straganie w Warszawie, chyba latem 1946 roku. Było to najpewniej pierwsze powojenne wydanie poematu, na szorstkim, szarym, prawie pakowym papierze. Po powrocie do domu $\mathrm{z}$ fascynacją czytałam utwór (najczęściej - siedząc na dużym drzewie wiśniowym rosnącym przy naszym ówczesnym domu, żeby mi nikt nie przeszkadzał). Niewiele zapewne rozumiałam, ale byłam zafascynowana tokiem wiersza, jego brzmieniem, obrazami, które rysowały się w mojej wyobraźni. Niestety, ten tak ważny (chyba również z powodu edytorskiej historii utworu) egzemplarz nie zachował się; dostałam później od rodziców piękne pierwsze cztery tomy zbiorowego wydania sejmowego dzieł Mickiewicza (mam je do dziś), dzięki czemu mogłam wczytywać się $\mathrm{w}$ poetę.

Istotny wpływ na rozwój moich pasji i zainteresowań miał później nauczyciel języka polskiego, który był studentem Uniwersytetu Mikołaja 
Kopernika w Toruniu i na trzy dni w tygodniu przyjeżdżał do małego prowincjonalnego miasteczka, by uczyć w szkole. Wykładowcami UMK byli wtedy między innymi tacy wybitni badacze, jak Konrad Górski, Artur Hutnikiewicz czy Czesław Zgorzelski. Otóż nasz nauczyciel robił wykłady na podstawie notatek z zajęć odbytych na uniwersytecie, i to było fascynujące. Jeszcze jako studentka polonistyki, przygotowując referaty, niekiedy korzystałam z zeszytów szkolnych.

Moje studia polonistyczne były okresem raczej trudnym ze względu na wszechobecną indoktrynację ideologiczną i całkowite zdominowanie przez nią wszystkich przedmiotów. Na Wydziale działało jednak - pewnie dzięki jakiemuś niedopatrzeniu władz - niezależne koło naukowe prowadzone przez Janusza Pelca, późniejszego wybitnego badacza kultury staropolskiej, profesora UW i IBL. Tam poznałam rudymenty pracy badawczej i utwierdziłam się w swoim zainteresowaniu literaturą dawną. Kolejny etap to już - nawiązany właśnie dzięki Januszowi Pelcowi - kontakt z profesorem Kazimierzem Budzykiem. To właśnie on rozbudził w gronie skupionych wokół siebie studentów (a potem już asystentów) zainteresowanie metodologią badań literackich i teorią literatury, pokierował zdobywaniem podstawowej wiedzy w tej dziedzinie, a później postawił przed młodymi, uczącymi się dopiero badaczami ambitne zadanie wypracowania podstaw teorii literatury jako obiektu działań badawczych i przedmiotu nauczania uniwersyteckiego - wcześniej teoria literatury nie była wykładana na polonistyce, dopiero po zorganizowaniu przez profesora Budzyka pierwszej uniwersyteckiej Katedry Teorii Literatury na UW zaczęła wkraczać do sal wykładowych na filologii.

Dzięki udziałowi w tych pracach zdałam sobie sprawę, że refleksja teoretyczna jest niezbędnym elementem pracy badacza literatury, ale ciągle bliska mi była literatura dawna, jej poznawanie i historia. Mniej pociągała mnie uogólniająca refleksja teoretyczna, bardziej - stosowanie podejścia teoretycznego dla rozpoznawania zjawisk historycznych. Dlatego - przy akceptacji i wsparciu promotora - podjęłam $\mathrm{w}$ doktoracie temat dotyczący oświecenia i kształtujących się w tej epoce form wypowiedzi poetyckiej, co skądinąd wpisywało się w sformułowany przez profesora Budzyka projekt badawczy dziejów literackich form artystycznych w piśmiennictwie polskim. I tak już pozostało na wiele lat. Jednak łączenie tych dwóch wyraźnie wyodrębnianych obszarów badawczych - historii i teorii literatury - nie zawsze 
było oczywiste, dlatego ciągle sytuowałam się niejako na pograniczu mojego środowiska. Przez wiele lat ci moi koledzy, którzy byli „rasowymi” historykami literatury XVIII wieku, uważali mnie za teoretyka (co wiązało się z pewną podejrzliwością wobec kompetencji erudycyjnych, źródłowych, historycznych), z kolei ci uprawiający „ścisłą” teorię literatury - za historyka literatury. Nie przeszkadzało mi to jednak w uprawianiu nauki o literaturze w sposób mi najbliższy i - jak mi się wydawało - poznawczo ważny.

\section{M.A.: Pamiętam, jak niedawno przysłuchiwałam się rozmowie Pani} Profesor, prof. Małgorzaty Czermińskiej oraz dr Marii Napiontkowej na temat... przyborów do pisania: ołówków, wiecznych piór, długopisów i w końcu klawiatury komputera. Ta $\mathrm{z}$ pozoru niewinna rozmowa dowodziła jednak zupełnie innych metod, innych nawyków przyswajania wiedzy, innego w końcu warsztatu pracy naukowej, niż możemy obecnie obserwować wśród młodego pokolenia ludzi nauki. Czy od czasów, kiedy Pani Profesor stawiała pierwsze kroki na drodze badacza literatury, wiele zmieniło się w podejściu (młodych) ludzi do uprawiania naukowej refleksji nad literaturą? Czy może nadal widać jakieś podobieństwa?

T.K.: Sprawa narzędzi pisarskich to rzeczywiście interesujący temat refleksji. W powojennej szkole (po etapie ołówka, przez który przechodziłam jednak w czasie okupacji, ucząc się w domu) pisało się obsadką ze stalówką, moczoną w kałamarzu umieszczonym w otworze ławki. Problemem były ciągle pojawiające się kleksy - czy słowo to jest jeszcze znane dzisiejszym dzieciom? Po ukończeniu szkoły dostałam od rodziców wieczne pióro - watermana kupionego za spore pieniądze od sąsiadów dostających paczki od rodziny z USA. Długopis był przez długi czas dobrem pożądanym, ale nie zawsze dostępnym, powszechnie używało się zapasowych wkładów. Jeszcze w latach 70. nie było u nas popularnych bicków, przywożono je z zagranicy jako cenne upominki. Ale ja zawsze wolałam wieczne pióro atramentowe; pisałam nim do momentu, kiedy zdecydowałam się na zaprzyjaźnienie z komputerem. Nigdy nie nauczyłam się dobrze pisać na maszynie, przez kilkanaście lat moje rękopisy były przepisywane przez mojego męża, a potem przez panią, która zajmowała się tym zarobkowo. Bardzo długo broniłam się przed przejściem na komputer, wydawało mi się zupełnie niemożliwe jednoczesne myślenie o tym, co chcę napisać, i wykonywanie technicznych czynności na klawiaturze, zwłaszcza że nigdy nie pisałam na maszynie. Widziałam to jako 
wielki, trudny do wykonania skok technologiczny. Ale wiedziałam też, że w dzisiejszym świecie komputer staje się koniecznością, i... przełamałam się. Bardzo się z tego cieszę, bo ułatwienia i pożytki są ogromne.

Ta opowieść jest nie tylko autobiograficznym wspomnieniem. Pokazuje ona, że w ciągu mojego życia dokonało się wręcz kilka rewolucji w technice utrwalania pisma i organizowania warsztatu badawczego. Jest to sprawa tylko pozornie odległa od pytania, które Pani postawiła. Badacze już dawno stwierdzili, że typ narzędzia przekazu wpływa na sposób budowania komunikatu. Jakie są konsekwencje wszystkich tych zmian w sposobie uprawiania badań literackich dzisiaj? Jedno nie zmieniło się na pewno. Aby je podjąć i poważnie prowadzić, potrzebna jest pasja, szczególne zainteresowanie, a także przekonanie - czasem tylko czysto intuicyjne - o społecznej potrzebie i wartości tego typu działalności. To podstawowy warunek wykonywania pracy, która wymaga wielu wysiłków, determinacji, a nawet poświęceń i rezygnacji $z$ różnych codziennych przyjemności (nie pójdę do kina, na koncert, spacer, do przyjaciół, bo muszę - bo chcę - skończyć czytanie tej książki, skoncentrować się na przemyśleniu do końca tego problemu, skończyć pisanie tego tekstu...).

Dziś jednak, dzięki narzędziom elektronicznym i umożliwionej dzięki nim łączności ze światem zewnętrznym, w pracy badawczej jest wiele udogodnień, które młodzi użytkownicy sieci traktują jako coś normalnego i oczywistego. Ale kiedy za pomocą jednego kliknięcia myszki wysyłam mail z pilną wiadomością albo gotowy tekst do czasopisma czy wydawnictwa, czasem myślę sobie, ile materiałów, zabiegów, kosztów i - co najważniejsze - czasu wymagało to jeszcze kilkanaście lat temu. Młodsi nie zawsze są świadomi tej rewolucyjnej zmiany. Internet otwiera szerokie możliwości dostępu do książek znajdujących się na drugiej półkuli, pozwala z domu zamawiać publikacje w wydawnictwach, a nawet w bibliotekach, prowadzić konsultacje, wykłady na odległość - współcześni internauci doskonale znają to wszystko. Można łatwo przenieść na swój dysk publikacje z zasobów archiwów i bibliotek, operować nimi bez odejścia od komputera, ściągać i zapisywać materiały z czasopism online, czytać je przy swoim biurku, znajdować najnowszą literaturę przedmiotu, wystukując odpowiednie hasło. W mojej młodości były to rzeczy sytuujące się w sferze science fiction.

Zapis komputerowy daje też możliwość kształtowania tekstu „na gorąco”, bez utrwalania, przekreślania, zamazywania jego kolejnych wersji i etapów 
powstawania. Badaczom współczesnej poezji trudno więc będzie śledzić warianty i redakcje utworów (chyba że poeta - jak na przykład Różewicz pisze piórem i świadomie traktuje własne rękopisy jako dokument procesu twórczego). Ale i formułowanie tekstu badawczego przebiega inaczej. Zabiegi typu „wytnij” - „wklej”, „kopiuj” - „wstaw” z jednej strony niesłychanie ułatwiają komponowanie wypowiedzi, ale ta łatwość może też prowadzić do pewnej „rozrzutności” cytowań, odwołań, co czasem powoduje niepotrzebną rozwlekłość, zbyteczne dywagacje, brak zwięzłości i koherencji wywodu. Niejednokrotnie obserwuję, na przykład redagując artykuły nadsyłane do redakcji „Wieku Oświecenia”, że łatwość zapisu komputerowego prowadzi do pewnej niestaranności formy, bo zbytnie poleganie na funkcji automatycznej korekty zapisu przez system sprawia, że - niestety - występują błędy literowe i inne, których wykrycie wykracza poza możliwości tego systemu, albo też wprowadza on automatyczne błędne poprawki, które pozostają w tekście, bo najczęściej nie jest on po ukończeniu czytany i poprawiany, skoro mamy zaufanie do możliwości elektronicznego narzędzia.

Łatwiejsza dostępność do literatury przedmiotu niekiedy, paradoksalnie, wręcz osłabia zainteresowanie nią, wywołuje lekceważenie i pomijanie badawczego dorobku poprzedników, a czasem też „wyważanie otwartych drzwi" z powodu jego nieznajomości. Jest to spowodowane między innymi charakterystyczną dla późnej nowoczesności postawą absolutyzowania nowości, lekceważącego traktowania tego, co rzekomo „przestarzałe”, nieaktualne i niepotrzebne. Tymczasem badania literackie - podobnie jak sama literatura - mają charakter kumulacyjny, składają się na pewną całość minionego i obecnego, a od dawnych mistrzów humanistyki można się wiele nauczyć również w zakresie sposobów uprawiania nauki. Występuje też nieustanne poszukiwanie nowych metodologii, ciągłe ogłaszanie „zwrotów”, „przełomów”, nie zawsze prowadzące do odsłaniania ważnej problematyki. Publikacje literaturoznawcze miewają niekiedy charakter nie tyle badawczy i odkrywczy, ile niejako „pretekstowy”, nie są dostatecznie zakorzenione w materiale źródłowym, który w wywodzie przestaje być głównym przedmiotem uwagi. Stają się wówczas nie tyle eksploracją problemu, ile swobodną refleksją autora, snutą wokół jakichś interesujących go spraw. Nie odnoszę się tu do kwestii stylistycznego, bardziej swobodnego czy eseistycznego ukształtowania wywodu badawczego - jego efektowność i językowa uroda są bardzo ważne i mogą przyczynić się między innymi do zainteresowania 
literaturą osób niezwiązanych profesjonalnie z badaniami literackimi. Chodzi mi o niezbędność jasnego formułowania przedmiotu i celów badawczych, o precyzję wypowiedzi i jej intersubiektywną weryfikowalność przez odniesienie do badanego tekstu czy zjawiska. Nie chcę też negować niezbędności poszukiwania nowych dróg i metod badawczych, wszystko to jest potrzebne i ważne dla rozwoju dyscypliny. Trzeba jednak w tych poszukiwaniach zawsze pamiętać, że uprawia się filologię - dyscyplinę o długiej i szacownej tradycji, w której najważniejszy jest tekst źródłowy, jego język, kształt i przekaz, a także historyczna wiedza o jego macierzystym kontekście filozoficzno-estetycznym, światopoglądowym, społecznym. W tej perspektywie bardzo cieszy wzrastające w ostatnich czasach zainteresowanie badaniami tekstologicznymi, edytorstwem, poszukiwaniem i (cyfrowym) zabezpieczaniem materiałów źródłowych. A jest to przecież wracanie do źródeł, do początków dyscypliny ukształtowanej później jako filologia. Warto o tych źródłach pamiętać.

W dzisiejszych czasach zmienił się też charakter i jakość życia naukowego. Dla przykładu, w IBL koniec szóstej dekady i lata 70. ubiegłego stulecia były czasem bujnego rozwoju tego życia i realizacji dużych zbiorowych przedsięwzięć badawczych. Odbywały się fundamentalne dla rozwoju dyscypliny konferencje naukowe, np. o teorii procesu historycznoliterackiego, o problematyce gatunków literackich, o komunikacji literackiej, socjologii literatury, i wiele innych, inspirujących i otwierających nowe obszary badawcze. Skupiały one licznych badaczy ze wszystkich ośrodków akademickich. Propozycje tematów i kandydatury referentów były starannie przemyślane przez organizatorów, ale objętość wystąpień nie była odgórnie określona, a regulowana potrzebą. Zawsze jednak przewidziany był też czas na długie nawet dyskusje, które były równie ważne jak wystąpienia referentów. Dawały one możliwość wymiany myśli, omawiania kontrowersji i prowadzenia sporów, a także nawiązywania kontaktów i planowania wspólnych przedsięwzięć przez ludzi autentycznie zainteresowanych jakąś problematyką.

Od momentu zdominowania życia naukowego przez system grantowy i parametryzacyjny zmienił się charakter takich spotkań. Jest ich nieporównywalnie więcej, bo każda placówka naukowa chce za ich organizację zdobyć punkty do oceny parametrycznej, każdy badacz także ma szansę uzyskać za wystąpienie z referatem cenne punkty, niezależnie od jego jakości i znaczenia. Organizuje się więc często konferencje poświęcone sprawom 
mało istotnym albo wręcz marginalnym, wymyśla się tematy przyciągające efektownością i oryginalnością sformułowań tytułowych, uczestniczy w nich wielka liczba zgłaszających się bez ograniczeń referentów, ale ich wystąpienia mogą trwać zalewie kilkanaście minut, a na dyskusję pozostaje czasu bardzo mało albo wręcz nie ma go wcale. Referenci wygłaszają swoje teksty i, zadowoleni z punktowej zdobyczy, wracają do domu, często nie zamieniwszy z nikim jednego zdania. Wbrew pozorom, skutkuje to atomizacją życia naukowego, a nawet jego marginalizacją.

Również system grantowy nie zawsze spełnia swą założoną rolę motoru rozwojowego badań. Nierzadko uczestniczące w nim osoby, pracujące nad tym samym obszarem problemowym, nie pozostają w autentycznym intelektualnym kontakcie, a ich rola ogranicza się do przygotowania i złożenia tekstu. Zadanie zostaje wykonane, ale nie służy to tworzeniu autentycznego zespołu badawczego, inspiracji i wymianie myśli. Co więcej, młode osoby, które nie znają nieodległych dziejów dyscypliny, uważają, że tak właśnie być powinno, że jest to sytuacja optymalna. Tak więc, rzeczywiście, wiele się zmieniło w nauce od czasu, kiedy rozpoczynała się moja droga akademicka.

\section{M.A.: Ważną potrzebą każdego człowieka jest - a przynajmniej powinno być - znalezienie swojego nauczyciela, mistrza. Celowo staram się nie} używać słowa „autorytet”, dosyć obecnie „podejrzanego”, szczególnie gdy idzie o powtarzane do znudzenia frazy o współczesnym „upadku wszelkich autorytetów”. Kto dla Pani Profesor był takim mentorem?

T.K.: Myślę, że na przebiegu mojej drogi naukowej zaważyło spotkanie kilku ważnych dla mnie uczonych. Pierwszy - to wspomniany już profesor Kazimierz Budzyk, dzięki któremu kształtowały się moje zainteresowania teoretycznoliterackie. To on zarysował perspektywy badawcze w tej dziedzinie, a także, co bardzo ważne, wprowadził mnie w tryb pracy zespołowej, poddawania własnych prac dyskusji w zespole, przyjmowania konstruktywnej krytyki, prowadzącej do doskonalenia pracy i sposobów myślenia. Drugim ważnym wzorem i nauczycielem był dla mnie profesor Czesław Zgorzelski, w tym czasie pracownik Katolickiego Uniwersytetu Lubelskiego. Na jego publikacje zwrócił mi uwagę mój promotor, bo wyrastały one $z$ tej samej tradycji rosyjskiej szkoły formalnej i strukturalnej, na której ukształtowany został w czasach przed drugą wojną światową Kazimierz Budzyk. Książki Zgorzelskiego uczyły mnie tego, co było mi 
najbardziej potrzebne - stosowania instrumentarium teorii literatury do pracy historycznoliterackiej, a nade wszystko pozostawania zawsze blisko tekstu literackiego, traktowanego z wielką uwagą i szacunkiem. Były wzorem wnikliwego czytania, analizowania i interpretacji dzieła zorientowanej na poszukiwanie jego sensów, a także pisania o tym językiem jasnym, precyzyjnym, a zarazem stosownym wobec estetycznej natury dzieła literackiego. Pięknie skomponowane i elegancko napisane publikacje o poezji romantycznej, Mickiewiczu, Słowackim, Norwidzie, ale także o poetach XVIII wieku, były wzorem i wyzwaniem. Wkrótce też nawiązałam bezpośrednie kontakty z profesorem, który zapraszał mnie na spotkania naukowe swojej Katedry, życzliwie towarzyszył swymi radami i dyskusjami mojej pracy. Stał się dla mnie nie tylko mistrzem naukowym, ale też autorytetem życiowym, mądrym w swych wyborach i zawsze wiernym przyjętym zasadom. Korzystałam wielokrotnie $\mathrm{z}$ jego rad i wsparcia nie tylko w sprawach badawczych, ale także innych, związanych z moją działalnością w środowisku.

Można też mówić - jak sądzę - o mistrzach i autorytetach oddziałujących pośrednio, przez lektury i publikacje. Tu sytuacja była dynamiczna, może więc wspomnę jedynie o mojej trwającej od dłuższego czasu fascynacji hermeneutyką, w szczególności Paula Ricoeura i Hansa-Georga Gadamera, $\mathrm{z}$ różnych powodów bardzo mi bliskich.

Spotkanie emanującego życiową i profesjonalną mądrością i otwartą życzliwością mistrza, bezpośredni z nim kontakt, stawiane wymagania oraz wskazówki i rady, a także obserwowanie jego pracy i osoby - wszystko to niezbywalne czynniki dorastania intelektualnego i rozwoju badawczego młodego adepta nauki. To także wielki dar losu, który trzeba zawsze zachować we wdzięcznej pamięci. Pozwala on uniknąć niepowodzeń i rozczarowań, ale uczy też pokory i umiejętności dostrzegania własnych potknięć i przezwyciężania niedoskonałości. Boleję nad tym, że w obecnej sytuacji nauki kwestia relacji mistrz - uczeń nie jest dostatecznie rozumiana i doceniana.

\section{M.A.: Historyk literatury zazwyczaj kojarzy się z samotnikiem, mozolnie studiującym opasłe tomy w zaciszu biblioteki, wytrwale pracującym - jak biolog w laboratorium - nad kolejnym artykułem. Pani Profesor często jednak podkreśla, jak wielką rolę w pracy badacza literatury odgrywa jego środowisko, otoczenie, możliwość interakcji z innymi...}


T.K.: Rzeczywiście, taka postawa ukształtowała się już u początku mojej drogi naukowej. Rozpoczynałam ją właśnie w zespole uczniów i współpracowników profesora Kazimierza Budzyka, wspólnie pracującym nad zarysowanym przezeń projektem badawczym. Trudno przecenić korzyści, jakie płynęły $\mathrm{z}$ funkcjonowania w takim środowisku - zróżnicowanym, skupiającym wyraziste indywidualności, ale zarazem skoncentrowanym na wspólnych celach. Jak już wspomniałam, nasze prace były poddawane zbiorowej dyskusji, która niekiedy bywała ostra, ale nigdy nieprzyjazna czy niemerytoryczna, przeciwnie - zawsze pomocna, cenna, rozwijająca, inspirująca. Uczestnictwo samego profesora, a także profesor Marii Renaty Mayenowej czy zapraszanych profesorów językoznawców, w seminariach prowadzonych dla tej grupy służyło poszerzaniu wiedzy z dziedzin, którymi poszczególne osoby bezpośrednio się nie zajmowały, a była ona potrzebna i poszerzała horyzonty. Wszystkim prowadzącym i uczestnikom tych spotkań zawdzięczam bardzo wiele i zachowuję ich we wdzięcznej pamięci.

Inną formą zbiorowego budowania warsztatów naukowych i prezentacji wyników stały się też organizowane z inicjatywy profesora Budzyka ogólnopolskie konferencje teoretycznoliterackie młodych (ówcześnie) pracowników naukowych polonistyki. Służyły one nie tylko wspólnemu wypracowywaniu formuły nowoczesnej humanistyki, ale też integrowały środowisko, pozwalały uczestnikom wzajemnie się poznać, a często także zaprzyjaźnić, co ułatwiało współpracę i dawało poczucie bliskości osób podobnie widzących przedmiot swojego zainteresowania. To było bardzo ważne doświadczenie. Dlatego w czasach późniejszych, kiedy dane mi było podjąć odpowiedzialność za różne instytucje życia naukowego, zawsze starałam się o zespołowy charakter działań, o dobre relacje osobowe między pracownikami wydziału, katedry czy pracowni, o efektywną współpracę i wspólne poczucie odpowiedzialności za wykonywane zadania. Taka organizacja działań nie jest zagrożeniem dla wybitnych indywidualności, przeciwnie, pozwala im niejako „zabłysnąć” w oczach kolegów, realizować się w roli inspiratorów, a często projektodawców rozwiązań twórczo rozwijających pracę, co zawsze spotyka się z uznaniem zespołu. Wszystkim natomiast daje silniejszą motywację i utwierdza poczucie sensowności wspólnie realizowanych działań, a poza tym buduje zwyczajną ludzką atmosferę współbycia, wzajemnego szacunku, bezinteresowności, życzliwości, niezbędną każdemu jak powietrze. 
Ale godziny samotnej pracy $\mathrm{w}$ bibliotece, $\mathrm{w}$ świetle lampy własnego biurka czy ciszy pokoju, są też niezbędne. Niezastąpione, aby przemyśleć i uwewnętrznić to wszystko, co płynie z zewnątrz, zarówno z czytanych książek, jak i relacji z innymi. A to potrzebne jest nie tylko historykowi literatury.

\section{M.A.: W debacie publicznej niezmiennie od kilku lat dominuje wymóg} użyteczności nauki. Szczególnie deprecjonuje się przy tym nauki humanistyczne, i nie jest to przekonanie tak zwanych zwykłych ludzi, lecz także a może przede wszystkim - osób wyznaczających naukowe i społeczne priorytety. Jaki jest stosunek Pani Profesor do tej sprawy?

T.K.: Wypowiadałam się na ten temat już wiele razy i trochę już jestem zniechęcona i zmęczona nieustannym powtarzaniem tego, co wydaje się oczywiste dla każdego myślącego człowieka. Ostatnia moja szersza wypowiedź na ten temat znajduje się w księdze materiałów Kongresu Dydaktyki Polonistycznej, który odbył się we Krakowie w 2013 roku² $^{2}$. Mówię tam między innymi o tym, że humaniści są w przestrzeni publicznej jedynymi i niezastąpionymi ekspertami w trzech dziedzinach. Są to: język jako narzędzie komunikowania się w życiu zbiorowym i prywatnym; tradycja jako podstawa więzi, bytowego zakorzenienia i poczucia tożsamości osobowej i wspólnotowej; refleksja nad sferą wartości jako busoli i kierunkowskazu wybieranych w sposób świadomy motywacji każdego wyboru. Bez nieustannego doskonalenia tych dziedzin poprzez poszerzanie profesjonalnej i powszechnej wiedzy o nich, inicjowanie i prowadzenie refleksji, a nawet debaty nad nimi, nie może sensownie funkcjonować żadne społeczeństwo ludzi cywilizowanych. Nie trzeba być bardzo spostrzegawczym, żeby zauważyć, że dokonująca się na różne sposoby i w różnych miejscach marginalizacja humanistyki poczyniła już znaczne spustoszenia we wszystkich tych sferach. Przywrócenie w nich równowagi i odbudowanie ich miejsca w życiu zbiorowym jest możliwe tylko poprzez uznanie przez czynniki kierujące życiem społecznym autorytetu humanistów w tej dziedzinie, przyjęcie do wiadomości, że to nie osoby przypadkowe i niekompetentne, ale właśnie

2 T. Kostkiewiczowa, Czy świat potrzebuje humanistów?, [w:] Polonistyka dziś - kształcenie dla jutra, t. 1, red. K. Biedrzycki, W. Bobiński, A. Janus-Sitarz, R. Przybylska, współpraca A. Kania, E. Strawa, Kraków 2014, s. 25-31 (przyp. red.). 
oni, jako eksperci, winni mieć głos decydujący w tych fundamentalnych dla funkcjonowania zbiorowości kwestiach. Niezbędne jest stworzenie humanistom warunków i możliwości do pełnienia funkcji eksperckiej, umożliwienie im pracy nad naprawą tego, co zostało zaprzepaszczone, przede wszystkim w dziedzinie edukacji, oraz budowanie społecznego zrozumienia dla tego, co jest zadaniem humanisty, uznanie jego kompetencji i społecznego autorytetu. Duża rola przypada w tym samemu środowisku humanistycznemu, które powinno także usilnie działać na rzecz spełnienia tych warunków.

M.A.: Niezwykle ważną rolę w działalności Pani Profesor zajmuje dydaktyka. Wbrew pozorom, nieczęste to połączenie - wybitny badacz, który niezwykle wielką wagę przykłada także do swoistej misji dydaktycznej i bardzo użytecznej, czy nawet służebnej, roli wyników swoich dociekań dla społeczeństwa. A sądzę, że w ten sposób można określić działalność Pani Profesor na tym polu. Czy od zawsze widziała Pani kształcenie i edukację jako ważny element swojej pracy? Jak to się zaczęło? Dlaczego było to takie ważne?

T.K.: Jak już wspomniałam, jako małe dziecko konsekwentnie deklarowałam, że chcę być nauczycielką. Skąd to się wzięło? Myślę, że może z mojej sytuacji w dzieciństwie. Przez pierwszych niespełna dziesięć lat życia, w czasie wojny i okupacji żyłam w miejscu dość oddalonym od ludzi, nie miałam rodzeństwa ani kontaktów z rówieśnikami, przebywałam jedynie z rodzicami. Mama moja, która dość wcześnie zaczęła uczyć mnie materiału szkolnego (na terenie Rzeszy, gdzie mieszkaliśmy, nie było szkół polskich, a nauka polskich dzieci była surowo zabroniona), była dla mnie jedynym obserwowalnym uosobieniem roli kobiety. Być może chciałam zachowywać się jak ona? Może podświadomie pragnęłam szerszych kontaktów z rówieśnikami, a także odczuwałam potrzebę dzielenia się z innymi swymi wrażeniami, wymiany myśli i mówienia o tym, co mnie poruszyło i co poznałam? Znałam tylko jeden sposób spełnienia tych utajonych pragnień: uczenie drugiej osoby.

Z biegiem czasu sytuacja stawała się coraz bardziej oczywista. Przemawiały do mnie postaci „siłaczek”, mądrych pań będących autorytetem dla uczniów, idealistycznych Magdalen Brzeskich i bezdomnych Joann, osób poświęcających się studiom, nauce i innym ludziom. Wybór studiów polonistycznych (trochę wbrew planom rodziców, którzy chcieli 
dla mnie bardziej „praktycznego” zawodu) był tylko prostą konsekwencją tych wyobrażeń. Szansa, jaką dał mi kontakt z profesorem Budzykiem i zatrudnienie w uniwersyteckiej Katedrze Teorii Literatury, była spełnieniem marzeń. Rozpoczynałam jednak dydaktykę na polonistyce (pierwsze były ćwiczenia z poetyki) zupełnie nieprzygotowana do takiego zadania, mozolnie zdobywałam więc doświadczenie, któremu towarzyszył wzrastający zapał i radość. Kontakt ze studentami, prowadzenie zajęć, szczególnie typu seminaryjnego i konwersacyjnego, od zawsze było dla mnie ogromnie ważne. Otwierało możliwość dialogu, obserwowania sposobów myślenia młodych ludzi, wskazywania im dróg i sposobów doskonalenia umysłów, zdobywania wiedzy, rozwoju intelektualnego i osobowego. Obserwacja tego rozwoju i dostrzeganie jego efektów to najwspanialsze przeżycie, jakie daje dydaktyka. Nic tak nie cieszy, jak sukcesy uczniów, zarówno pozostające w polu obserwacji nauczyciela, jak i późniejsze, o których niejednokrotnie dowiadujemy się z gazet czy książek. Dotyczy to zresztą wszystkich poziomów kształcenia. Rozmawiam często z moimi koleżankami ze studiów uczącymi w szkołach podstawowych i liceach, które odbierają to tak samo.

Proces dydaktyczny jest jednak zawsze (a z pewnością powinien być) relacją o oddziaływaniu dwustronnym. Dla nauczyciela akademickiego prowadzenie zajęć to czynność wielorako mobilizująca i rozwijająca również jego samego. Wymaga nie tylko - co jest oczywiste - starannego przygotowania, które często, obok spożytkowania na zajęciach, skutkuje nowymi spostrzeżeniami, pomysłami, a nawet publikacjami, ale już sam dialog ze słuchaczami jest intelektualnie owocny, a nawet niezbędny. Pozwala on na gorąco weryfikować jasność i konsekwencję własnego myślenia, zrozumiałość koncepcji, zaś studenckie spostrzeżenia i uwagi niejednokrotnie odsłaniają niedostrzegane wcześniej aspekty spraw, otwierają przysłowiowe „klapki” i pozwalają lepiej widzieć, zrozumieć interesujące problemy. Studenci aktywni, autentycznie zainteresowani przedmiotem, mają także udział w naukowym wzroście swych wykładowców - i to jest piękne. Sama pamiętam sytuacje, w których czyjaś wypowiedź na seminarium stawała się jakby błyskiem, swoistym katalizatorem dokonującym krystalizacji rozproszonych dotąd, niewyraźnych intuicji.

Moje życie układało się tak, że nie zawsze mogłam być w pełni aktywna w dydaktyce akademickiej. Częściowo było to rekompensowane pracą z bardziej zaawansowanymi badaczami przygotowującymi doktoraty, 
ale atmosfera sali seminaryjnej, widok skupionych twarzy kilkudziesięciu osób, wchodzenie z nimi w zbiorowy dialog - wszystko to są niezastąpione doświadczenia, które powodują wzrost aktywności, mobilizują i radują. W jakiś sposób z tej potrzeby wyrastało moje zaangażowanie w prace przy Olimpiadzie Literatury i Języka Polskiego. Szczęśliwie się złożyło, że pod koniec mojej aktywności zawodowej dane mi było jeszcze przez kilkanaście lat prowadzić różne zajęcia na nowo powstałym Wydziale Nauk Humanistycznych UKSW, więc teraz znów - już z oddali - mogę obserwować wzrost naukowy moich dawnych studentów z tego środowiska i cieszyć się ich licznymi i spektakularnymi osiągnięciami.

Dziękuję, Pani Magdo, za wysłuchanie tych bardzo osobistych czasem wspomnień, spostrzeżeń i opinii. Przepraszam też, że tak okropnie się rozgadałam. Wywiad miał być krótki, a rozrósł się niepokojąco. Nie miałam takiego zamiaru, ale skłonił mnie do tego typ Pani pytań - bardzo zasadniczych i obszernie zakrojonych. A poza tym - jak Pani powiedziała na początku - pewne momenty w życiu skłaniają do rozleglejszych refleksji, niech to więc będzie potraktowane jako nieco sprowokowany przez tę sytuację i wymuszony przywilej gadatliwej staruszki. Ale nie chciałabym, żeby był on przykładem znanego powiedzenia: „Wiecie? No to posłuchajcie!”.

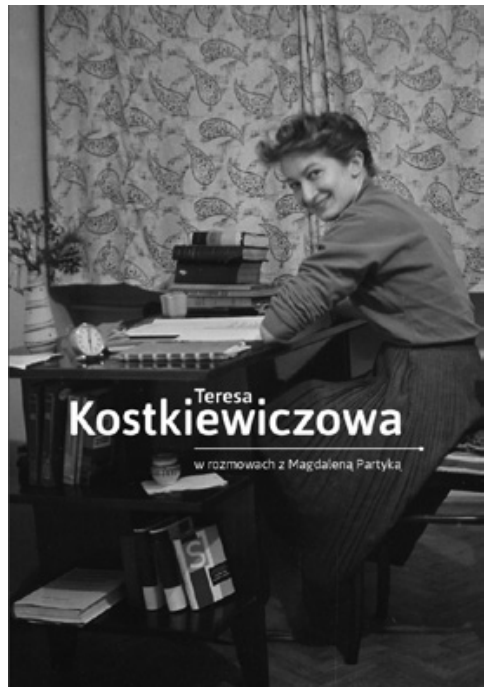

Teresa Kostkiewiczowa w rozmowach z Magdaleną Partyką, Wydawnictwo IBL (w koedycji $z$ Wydawnictwem Naukowym UKSW), Warszawa 2016. 

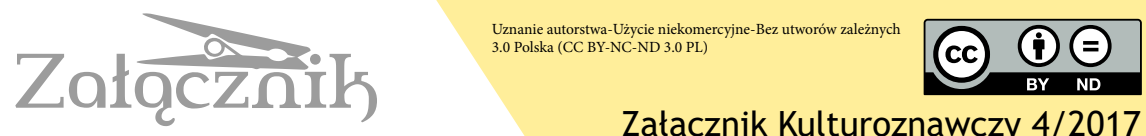

Załącznik Kulturoznawczy 4/2017

\section{ŻYJEMY W ŚWIECIE ROZSYPANYM}

\section{Z GRZEGORZEM MIECUGOWEM}

ROZMAWIA ŁUKASZ BAŃBURSKI ${ }^{1}$

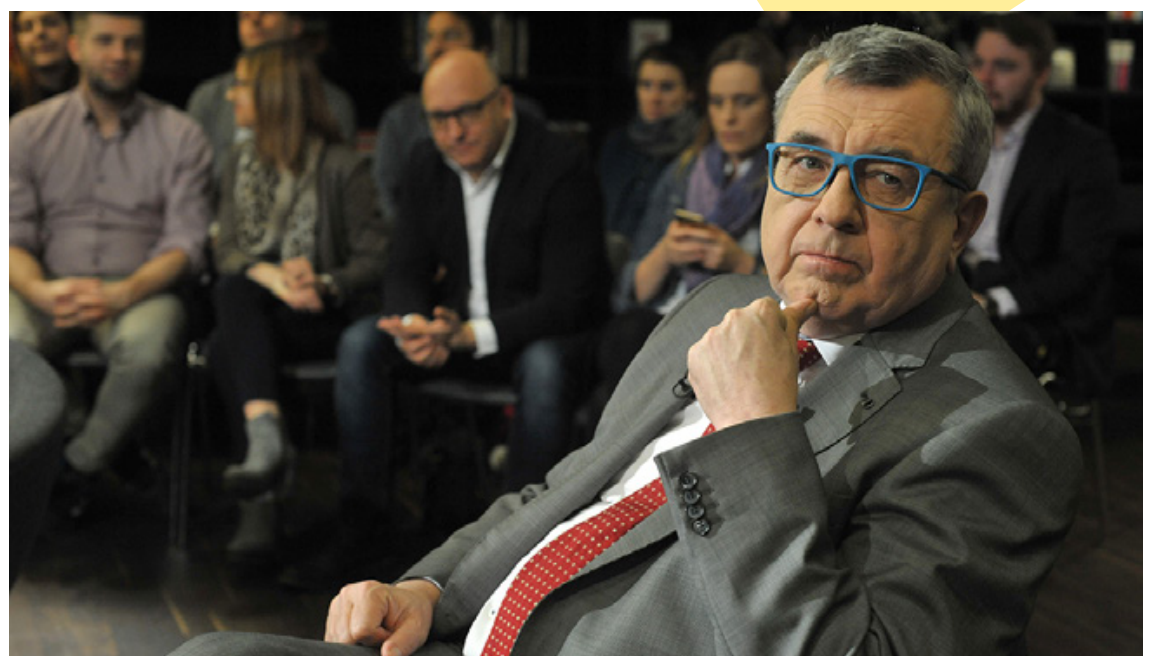

Grzegorz Miecugow (1955-2017), fot. Konrad Kosycarz/KFP

Łukasz Bańburski: Jak doszło do powstania TVN24, pierwszego polskiego kanału informacyjnego?

Grzegorz Miecugow: Prezes Mariusz Walter poprosił mnie o napisanie ramówki dwudziestoczterogodzinnego kanału informacyjnego. Na podstawie tej ramówki Krajowa Rada Radiofonii i Telewizji przydzieliła ITI koncesję Było to blisko dwadzieścia lat temu, ledwie rok po starcie głównego kanału

1 Wywiad przeprowadzony został w 2015 roku na potrzeby pracy licencjackiej Kierunki rozwoju kanałów tematycznych $w$ Polsce, pisanej pod kierunkiem dr Anny Wróblewskiej. Grzegorz Miecugow nie wnosił o autoryzację. Artykuł oparty na pracy licencjackiej Łukasza Bańburskiego publikujemy w niniejszym numerze „Załącznika Kulturoznawczego". 
TVN-u [ogólnopolski kanał TVN powstał w 1997 roku - przyp. red.]. Sądzę, że myśli prezesa biegły w stronę kanału informacyjnego w dużej mierze $\mathrm{z}$ powodu rozczarowania kierunkiem, w jakim pod koniec XX wieku zmierzały telewizje komercyjne. Pierwsza ramówka TVN-owska była bardzo niekomercyjna, wręcz przypominała ramówkę telewizji publicznej. Poniosła porażkę, gdyż wówczas był już na rynku jeden podmiot komercyjny, czyli Polsat. „Grzeczną” ramówką nie wygrywało się tego konkursu. Prezes uznał więc, że musi się dostosować do oczekiwań rynku, nie może narzucać odbiorcy tego, jak ma wyglądać kanał komercyjny. Natomiast właśnie w pomyśle kanału informacyjnego widział szansę stworzenia stacji niekomercyjnej opartej na informacji, przywiązanej do ziemi.

\section{Ł.B.: TVN24 wystartował w 2001 roku. Czy przez te lata zmienił się odbiorca stacji? Czy grupa docelowa widzów TVN24 jest taka sama, czy ulega przemianom?}

G.M.: Przez pierwsze lata TVN24 mogło dyktować warunki, bo było jedyną stacją informacyjną na rynku. Sytuacja zmieniła się w momencie, w którym pojawiła się konkurencja, a było to już w 2002 roku. Wówczas TVP Regionalna zasygnalizowała, że będzie ewoluować w kierunku telewizji informacyjnej. Trwało to jednak kilka lat, gdyż telewizja publiczna jest ociężała, jeśli chodzi o możność samoreformowania się. To poza tym dość skomplikowany proces, telewizja regionalna złożona była przecież z różnych podmiotów usytuowanych w całej Polsce. Ale potem powstał informacyjny kanał Polsatu - i to już była prawdziwa konkurencja.

Czy zmienił się odbiorca? Przede wszystkim odbiorców jest o wiele, wiele więcej. Mniej więcej pięć, sześć lat po starcie zdobyliśmy naprawdę sporo widzów. TVN24 ma w końcu ograniczone możliwości zasięgu, nie pokrywa całego kraju, nie wszystkie gospodarstwa domowe mogą go oglądać. Ale czy zmienił się sam widz? Nie sądzę. Ten widz nie uciekł mimo zmian, a my zmienialiśmy się sukcesywnie. Myślę, że ten widz z 2007 roku, czy ten z samych początków, z 2001 roku, i ten obecny jest ciągle ten sam - troszeczkę zmieniony, bo wszystko wokół nas się zmieniło.

W ostatnich latach pożegnaliśmy erę analogową, zakończył się proces cyfryzacji telewizji naziemnej. Czy w wyniku tego TVN24 straciło nieco widzów? Telewidz stał się chyba trochę bardziej wybredny... Ale nie, nie powiedziałbym. Trzeba spojrzeć tu na sposób nadawania i dystrybuowania 
naszego kanału. To kanał płatny, trzeba za niego komuś zapłacić - operatorowi kablowemu bądź platformom cyfrowym. W 2013 roku na rynek weszły multipleksy cyfrowe, zaprzestano nadawania drogą analogową. Uderzyło to przede wszystkim w stacje otwarte, czyli te odbierane $z$ anten dachowych, bez żadnych innych urządzeń. Ktoś, kto mieszkał w miejscowości, w której miał dostęp do dwóch dobrej jakości ogólnopolskich kanałów telewizyjnych, nagle po wakacjach 2013 roku otrzymywał tych kanałów kilkanaście. Wybór ten dotyczył co prawda telewizji rozrywkowej, ale jednak...

Po 2013 roku widać gwałtowny spadek udziału w rynku największych otwartych stacji telewizyjnych. Nasza sytuacja jednak nie zmieniła się, właśnie dlatego że TVN24 był i jest rozpowszechniany na nośnikach płatnych.

\section{Ł.B.: Porównując sytuację kanałów płatnych z otwartymi, zauważyłem} pewien trend. Kanał nadawany w paśmie otwartym jest jak gdyby próbką kanału płatnego. To przykład otwartego Polsatu Sport News i zamkniętego Polsatu Sport. Co Pan myśli o takim rozwiązaniu? Czy może się to stać trendem powszechnym?

G.M.: Myślę, że tak. Zapłata za produkt, za to, co nas interesuje, jest elementem wyboru. Pay-per-view świetnie działa we wszystkich krajach naszej cywilizacji. Jeżeli stacja wykupi prawa na przykład do ważnej walki bokserskiej i wszyscy chcą to oglądać - i na kanale płatnym, i otwartym - to są to żniwa dla tej stacji. To jest jak najbardziej normalne i stosowane.

\section{Ł.B.: Wróćmy do widza. Społeczeństwo się starzeje, emerytów i rencistów} przybywa, w jaki sposób ta tendencja demograficzna może wpłynąć na rynek? Wśród starszej widowni najpopularniejszą stacją jest TVP1. Czy uważa Pan, że ciężko będzie zdobyć tego odbiorcę ze względu na silną rolę przyzwyczajenia, a może nie jest to atrakcyjny rynek?

G.M.: Badania rynku telewizyjnego zawsze mnie śmieszą, bo grupa docelowa wszystkich telewizji komercyjnych to jest 19-49. Kiedy skończyłem czterdzieści dziewięć lat, powiedziałem: „No! Wypadłem z grupy!”. Zawsze przekonywaliśmy naszych reklamodawców, że mamy specyficzną grupę odbiorców i że u nas grupa docelowa to 19-59. Nie da się ukryć, że starsi ludzie częściej oglądają telewizję. Mają po prostu więcej czasu oraz są mniej podatni na nowe propozycje. W końcówce PRL-u, kiedy zaczęto robić badania widowni, okazało się, że „Teleexpress”, czyli dziennik, który 
był adresowany do młodych, oglądają przede wszystkim emeryci. I tak jest do tej pory. Oczywiste więc, że tak jest, i będzie tak aż do jakiejś śmierci telewizji albo do momentu, kiedy telewizja przestanie być telewizją.

\section{Ł.B.: A jest to możliwe?}

G.M.: Tak. Kiedy będzie można wiele produkcji telewizyjnych oglądać w sieci, w dogodnym dla siebie czasie. Już nawet dzisiaj, jeśli jest się nieźle obeznanym w nowych technologiach, można oderwać się od dyktatu telewizji i oglądać programy w sieci. W tej sytuacji telewizji pozostanie relacjonowanie zawodów sportowych, igrzysk olimpijskich, mistrzostw świata, ponieważ siłą rzeczy na małym ekranie źle się to ogląda, a ponadto jesteśmy przyzwyczajeni do lepszych warunków technologicznych emisji widowisk. W tym sensie telewizja nie zginie, ale zniknie jej forma, jaką znam od czasu mojej młodości: telewizja proponuje program, my siadamy, czasami w gronie rodzinnym, czasami jeszcze sąsiad wpadnie...

\section{Ł.B.: Są badania, z których wynika, że liczba znaków w głównych artyku-} łach „Time’a” spadła w ciągu dwudziestu pięciu lat z 4,5 tysiąca do 2,8 tysiąca. Mówi się, że „Generacja Y” potrafi skupić się tylko na osiem sekund, choć jeszcze pokolenie ich rodziców mogło się skupić przez 42 sekundy. Jaka może być na to odpowiedź twórców programów telewizyjnych?

G.M.: W Stanach Zjednoczonych obraz telewizyjny zaczęto dzielić na kilka okienek. My też robiliśmy takie rzeczy, kiedy na przykład równocześnie trwała wojna w Iraku i obradowała komisja śledcza. Wychodziliśmy z założenia, że jeżeli chodzi o wojnę w Iraku, to ważny jest obraz, jeżeli o komisję śledczą - dźwięk. I to się dało pogodzić. Jednakże widz powinien wiedzieć, gdzie może szukać interesujących go programów. Trzydzieści lat temu widz wiedział, że jeśli włączy o 19.30 telewizor, to obejrzy „Dziennik Telewizyjny” - nie było innych programów. Wiedział też, gdzie ich szukać, wiedział też, jak unikać programu, jeżeli go nie chciał. Kiedy rano wstaję, mam do wyboru: albo włączę telewizję, np. TVN24, albo sprawdzę wyniki nocnych meczy z US Open w Internecie. I wiem, gdzie szukać. Nasz odbiorca musi wiedzieć, gdzie może znaleźć interesujące go treści, i mieć pewność, że jeżeli cokolwiek się zdarzyło, to my nie nawalimy. To jest przyszłość: my wykonujemy swoją pracę, a wy macie pewność, że zawsze z tej pracy możecie korzystać. 
ŁB.: Czy kanały tematycznie nie stanowią zagrożenia dla tradycyjnej telewizji? W kanałach tematycznych wszystko przygotowywane jest pod dyktando widza, podczas gdy w klasycznym wydaniu telewizji udział widza $w$ formowaniu programu był jednak bardzo ograniczony.

G.M.: Nie, nie zgodzę się. W klasycznej telewizji istnieje tak zwana ramówka. Do tej pory utrzymany jest ten relikt dawnych czasów. Słyszymy w mediach na przykład, że „TVN zaprezentuje nową ramówkę na sezon jesienny”. Jeżeli ktoś, tak jak ja, nie jest zainteresowany serialami czy też produkcjami rozrywkowymi którejkolwiek stacji komercyjnej (a do komercyjnych zaliczam również TVP1 i TVP2, bo one też żyją z reklam), to mnie naprawdę ta ramówka nie obchodzi. Ramówka w ogóle obchodzi ludzi coraz mniej. Jeżeli jestem zainteresowany dokumentami, historią, to wybieram National Geographic. Nie znam ramówki National Geographic - z grubsza wiem, co tam jest emitowane, ale tylko z grubsza. Nie pamiętam, więc sprawdzam. Ukazuje mi się informacja, co emitowane jest $\mathrm{w}$ tej chwili i co będzie za godzinę. Jeżeli trwają mistrzostwa świata w lekkoatletyce - a bardzo lubię lekkoatletykę - to muszę tylko wiedzieć, gdzie jej szukać.

\section{Ł.B.: W roku 2014 przybyło kilkanaście nowych kanałów tematycznych,} w tym trzy TVN-u: TVN Fabuła, TVN Meteo Active i ITVN Extra. Łącznie w Polsce jest już ponad dwieście trzydzieści kanałów tematycznych, w tym dwadzieścia cztery naziemne.

G.M.: Telewizja potaniała. Robienie programów telewizyjnych jest coraz tańsze, zwłaszcza jeżeli kanały bazują na istniejących zespołach. Taka telewizja jak TVN utrzymuje redakcję pogody, więc wystarczy ją tylko trochę rozbudować i można produkować osobny program TVN Meteo (dzisiaj Meteo Active, bo to jest bardziej na czasie). Niektóre kanały przygotowywane są pod odbiorcę naziemnego, niektóre pod wielkomiejskiego. Telewizja się dostosowuje. Nie wrócą czasy z początków telewizji, kiedy ludzie włączali nieliczne telewizory, gromadzili się wokół odbiornika i z nabożeństwem oglądali program dla siedemdziesięciu pięciu procent $\mathrm{z}$ nich kompletnie niezrozumiały, jak np. Kabaret Starszych Panów. Do dzisiaj telewizja publiczna chwali się, że jest to najlepszy program, jaki udało się kiedykolwiek zrobić. Ale gdyby w 1965 roku przeciętny widz miał do wyboru cokolwiek innego, to wybrałby cokolwiek innego, bo tamta rozrywka była po prostu na poziomie nieosiągalnym dla tych trzech czwartych społeczeństwa. 


\section{Ł.B.: Uważa Pan, że jedyną szansą na rozwój tych kanałów tematycznych jest jeszcze większa konkretyzacja i szukanie bardzo specyficznych grup docelowych?}

G.M.: Miarą wartości dziennikarza tworzącego newsy jest ich „klikalność” w przypadku sieci, a w przypadku telewizji - oglądalność. Jeśli ktoś produkuje programy, których nikt nie chce oglądać, albo pisze teksty, których nikt nie chce „kliknąć”, to albo wkrótce wyleci z pracy, albo mało zarobi, bo będzie na marginesie. Od telewizji informacyjnej widz oczekuje kciuka w górę, kciuka w dół, i odpowiedzi na pytanie: „Czy mam się bać?” - „Nie, nie masz się bać” lub „Masz się bać”. Dopóki ludzie będą szukali w mediach prostego sygnału „mam się bać / nie mam się bać”, to te media będą funkcjonowały jako przekaźniki takiego sygnału.

Mało kto ogląda stacje biznesowe. W stacjach typu TVN24 jeżeli będzie krach na giełdzie, to widz zainteresowany gospodarką dowie się o nim, a jeżeli jest głęboko zainteresowany, to raczej poszuka w sieci różnych informacji giełdowych, będzie grasował po giełdach z całego świata: z dalekiej Azji, Bliskiego Wschodu czy Londynu. Ma mnóstwo możliwości znalezienia informacji gdzie indziej. W związku z tym program gospodarczy przeznaczony jest dla wąskiej grupy osób, na przykład widzów bardziej niż większość zainteresowanych gospodarką, prowadzących własny interes, $\mathrm{w}$ jakiś sposób powiązanych $\mathrm{z}$ biznesem. Oni sobie obejrzą program stacji biznesowej, ale nie są aż tak wielkimi specjalistami, żeby samodzielnie pozyskać pogłębioną informację w sieci.

W tym rozproszonym, popękanym rynku będzie pełno nisz. Sam kiedyś znalazłem taką niszę. Przez przypadek odkryłem program, który mnie naprawdę zaciekawił. Nie wiedziałem, co to jest - obraz nadawany był z dwóch kamer i nic się nie działo. Tak mnie to wciągnęło i zaintrygowało, że siedziałem i czekałem, żeby się dowiedzieć, co to jest. Przypomniałem sobie, że w pilocie mam taką opcję, iż mogę sprawdzić, jak się nazywa stacja i jaki to program. Okazało się, że oglądam program Wschody słońca. Obraz z dwóch kamer, bodajże Nebraska, 5.48, szaro, stado koni i nic się nie dzieje... Kapitalny program. Niestety, już go nie nadają. Myślę, że jakieś osiemdziesiąt osób w całej Polsce go lubiło. 


\section{Ł.B.: W Izraelu uruchomiono kanał TV specjalnie dla psów...}

G.M.: To chwyt marketingowy. Dla psów oczy nie są podstawowym źródłem informacji o świecie. O wiele więcej dowiadują się za pomocą węchu. Telewizor pachnący elektronami jest nieinteresujący. Jeżeli pies widzi jakiś ruch i zwraca na to uwage, to absolutny przypadek. Kompletna bzdura. O wiele więcej o złożoności rynku telewizyjnego mówi anegdota pochodząca z czasów zjednoczenia Niemiec. Rozbuchane rynki telewizyjne Niemiec Zachodnich zaczęły wkraczać do Niemiec Wschodnich. Mieli łatwiej, nie było bowiem bariery językowej. Pewna stacja zachodnioniemiecka zdecydowała się emitować na terenie Niemiec Wschodnich próbny sygnał. Gdy stacja dostawała prawo emisji na przykład od pierwszego września, to przez cały sierpień w miejscu, gdzie się ten program miał pojawić, nadawano taki sygnał, żeby było można zaprogramować telewizor. Niektóre stacje, chociażby RTL, w nocy po zakończeniu emisji nadawały na przykład kominek. Kominek miał pilnować, żebyś nie zmieniał, człowieku, sygnału. Jedna zachodnioniemiecka stacja wpadła na pomysł, że jako próbny sygnał pokaże akwarium. Przez miesiąc widzowie otrzymali transmisję z życia akwarium. Kiedy stacja wystartowała z programem, oglądalność znacząco spadła. To wiele mówi o rynku telewizji.

\section{Ł.B.: Czy w takim razie uważa Pan, że szansą na rozwój rynku są ciągłe zmiany i wolty poszczególnych graczy?}

G.M.: Wydaje mi się, że cały świat nam się rozsypał. Jeszcze dwadzieścia lat temu, w 1998 roku, producent proszku do prania Pollena 2000 oparł swoją reklamę na założeniu, że wszyscy znają Sienkiewicza. Dwaj bracia Kiemlicze krzyczą do starego Kiemlicza: „Ociec, prać?”. Dzisiaj nikt nie założy, że wszyscy coś znają, bo każdy zna coś innego. Ludzie tworzą wspólnoty ponadregionalne, ponadkrajowe, a czasami nawet ponadkontynentalne. Są grupy, które pasjonują się jakimś zagadnieniem, np. budową motocykla, i w tej grupie dyskusyjnej uczestniczą ludzie od Nowej Zelandii, przez Europę, po Stany Zjednoczone i Afrykę. W połowie lat 90. jeszcze wszyscy oglądali to samo. Po antenach hulała Gala Piosenki Biesiadnej, na której śpiewano piosenki o uginającym się mosteczku i ułanach, którzy przybyli pod okienko. Dzisiaj to jest niemożliwe, dlatego że ludzie w sieci szukają każdy czegoś innego. Ja w wolnej chwili dla rozrywki i dla gimnastyki umysłu gram w Scrabble. Czasami zresztą od Scrabbli sieciowych przechodzę 
do „realu”, grywam w turniejach prawdziwych, ale droga jest raczej inna. „Real” się zamyka, żyjemy w sieci. Ktoś ściąga sobie filmy, ktoś seriale i jest na bieżąco z widzami amerykańskimi, podczas gdy serial w Polsce oficjalnie się pojawi za pół roku. Ma koleżankę, która ogląda to samo. Mają o czym dyskutować, ale do tej dyskusji nie jest dopuszczony nikt z zewnątrz. Są $\mathrm{w}$ innym świecie. Żyjemy w świecie rozsypanym i ten świat rozsypany będzie coraz bardziej. Z punktu widzenia funkcjonowania mediów jest to interesujące, gdyż tradycyjny model mediów na naszych czasach upada. Odczuwają to gazety, radia, telewizje.

Dawniej funkcjonował następujący model: mamy określone medium, chętnie oglądane, czytane lub słuchane. Medium żyje z reklam, a więc z tego, że ma wiele uszu do słuchania czy wiele oczu do oglądania. Reklama musi być droższa tam, gdzie jest tych uszu czy oczu więcej. Następnie medium się specjalizuje, bo zaczyna zadawać sobie pytanie, na przykład: gdzie są ludzie zainteresowani nowymi technologiami? - i pod nich tworzy treści o telefonach i usługach bankowych. Bardzo śmieszny przykład - dziesięć lat temu zrobiono badania, jaki jest najniższy koszt dotarcia do potencjalnego nabywcy sportowego samochodu typu Porsche. Okazało się, że najlepiej jest wykupić reklamę w Cartoon Network. Zasobni tatusiowie, czterdziestolatkowie, jeżeli mają małe dziecko i zostają z nim sami, nie wiedzą, co z nim zrobić. Wówczas włączają Cartoon Network, a reklama tam jest bardzo tania. Są więc realne szanse, że trafi się reklamą Porsche na klienta zasobnego i zainteresowanego; dużo większe niż trafienie na tego gościa w najlepszym czasie reklamowym, np. po wiadomościach.

Dzisiaj problemem jest trafienie do potencjalnego odbiorcy, który jest wybredny, ogląda telewizji niewiele, a jeżeli już, to wybrane elementy. Jak do niego dotrzeć z reklamą środka czystości? Każdy hipster musi czasem coś wyprać, ale nie ma go tam, gdzie był dotychczas.

\section{Ł.B.: Jak w takim razie rozwiązać ten problem, zarządzając mediami? G.M.: Na przykład poprzez inwigilację sieci. Jeżeli wejdzie Pan na reklamę, na przykład, apartamentu w Krakowie, będzie pan dostawał regularnie in- formację, że może wynająć kolejny. To już bardziej skomplikowany model niż ten sprzed dwudziestu lat, kiedy wrzucało się reklamę Polleny 2000 w czasie największej oglądalności. Pan się uśmiechnął, kiedy opowiadałem}


o Pollenie 2000, co oznacza, że Pan jeszcze ją pamięta. Ale już ludzie młodsi od Pana o pięć lat nie będą pamiętali tego rynku.

\section{Ł.B.: Czyli telewizja przetrwa, ale nie w formie, jaką znamy. Zmienią się także jej cele i jej odbiorcy.}

G.M.: Ostatnich piętnaście lat pokazało, jak długą drogę potrafi pokonać telewizja. Piętnaście lat temu wielu moich znajomych wyrzuciło telewizory. Na rynku funkcjonowały cztery duże kanały ogólnopolskie lub ponadregionalne (TVN był wtedy ponadregionalny, a nie ogólnopolski; docierał do $80 \%$ gospodarstw). Mieszkaniec dużego miasta, jeżeli nie miał talerza satelitarnego albo kablówki, miał do wyboru tylko tych kilka stacji. Jeżeli docierał do niego sygnał dystrybuowany w inny sposób, miał dostęp na przykład do Cartoon Network czy Eurosportu, CNN, Euronews. Wówczas kanały, które miały mniejszy udział w rynku niż $1 \%$, nazywano w badaniach „inne”, i te „inne” miały $9 \% \mathrm{w}$ roku 2000 . Teraz mają prawie $40 \%$.

Kiedy ktoś mówi, że w telewizji nie znajduje nic dla siebie, to kłamie. Może inaczej: jeżeli ktoś ma talerz lub kablówkę, to zawsze coś znajdzie, nawet jeżeli jest wymagający. Jeżeli ktoś nie dysponuje telewizją kablową czy satelitarną, to przyjdzie mu to $\mathrm{z}$ większą trudnością. Ale za kilka lat, czyli już za chwileczkę, ten sam widz będzie miał w przestrzeni otwartej nie kilkanaście, a kilkadziesiąt kanałów. Wówczas znajdzie na pewno.

\section{Ł.B.: Dziękuję za rozmowę.}





\section{HUMANIŚCI I TEORIA. NA MARGINESIE KSIAZŻKI EDWARDA KASPERSKIEGO METODY I METODOLOGIA ${ }^{1}$}

AGNIESZKA WNUK

Wydział Polonistyki Uniwersytetu Warszawskiego

Faculty of Polish Philology, Warsaw University agnieszka.wnuk@o2.pl

Pierwszy raz w pełni świadomie zdałam sobie sprawę z potrzeby teoretycznego wprowadzenia do tego, czym są metody i metodologie w naukach humanistycznych, po przeczytaniu kilka lat temu pracy rocznej jednego z moich studentów. Tekst dotyczył ballady Adama Mickiewicza Romantyczność, więc z pewną dozą przesady pozwolę sobie stwierdzić, że raczej nie mógł wnieść wiele nowego do badań - oczywiście do badań nad literaturą polskiego romantyzmu, ale do refleksji nad sensem i celem metodologii dla mnie prywatnie wnosił wiele, choć w przewrotny sposób. Autor pracy zastosował bowiem do interpretacji „modną” metodę psychoanalityczną i dowodził, że Karusia, bohaterka ballady, pod wpływem ducha zmarłego Jasieńka doświadcza „napięcia seksualnego”... Potężna maszyneria terminologiczna, w połączeniu ze zgrabnym stylem autora, nie przyniosła dobrego rezultatu. Badany tekst nie pasował do przyjętej tezy, która - owszem - została podparta argumentami, ale tych z kolei już się nie udało zilustrować przekonującymi cytatami z utworu. Drogi teorii i analizowanego przedmiotu okazały się rozbieżne.

Ów błąd popełniony przez studenta to w zasadzie modelowy przykład bezkrytycznego podejścia do metody. Stanowi ono nieodłączny etap edukacji, oczywiście pod warunkiem, że się w owym stanie naiwnego zapatrzenia $\mathrm{w}$ analityczną procedurę, którą dana metoda wyznacza, nie będzie trwało

1 Zob. E. Kasperski, Metody i metodologia (metodologia ogólna, nauki humanistyczne, wiedza o literaturze). Podręcznik akademicki, red. Ż. Nalewajk, Warszawa 2017. 
wiecznie. Absurdalne i czysto mechaniczne posługiwanie się metodami w naukach humanistycznych wyśmiali już zresztą w latach dziewięćdziesiątych XX wieku Alan Sokal i Jean Bricman w książce Modne bzdury. O nadużywaniu pojęć z zakresu nauk ścisłych przez postmodernistycznych intelektualistów (polskie tłumaczenie pochodzi z roku 2004)2. Rzecz jest jednak bardziej skomplikowana, by sprowadzać ją jedynie do kategorii żartu. Różnicy między naukami humanistycznymi a ścisłymi nie da się przecież zniwelować (te pierwsze, jak zauważa Edward Kasperski, odnoszą się do rzeczywistości wtórnej, znakowej, te drugie zaś - do przedmiotów jako takich, które same w sobie nie generują żadnych wtórnych znaczeńn ${ }^{3}$ ), i na ten fakt zwraca między innymi uwagę kontrowersyjna publikacja Sokala i Bricmana.

Wspomniana przeze mnie praca roczna uzmysłowiła mi coś jeszcze pewną lukę w nauczaniu akademickim, którą dostrzegałam już w trakcie swoich lat studenckich, ale której wtedy jeszcze nie traktowałam jako coś, co mogłoby zatrząść podstawami humanistyki. Nie jest to jednak słabość właściwa jedynie studiom polonistycznym, czy szerzej: literaturoznawczym, ale naukom humanistycznym w ogóle (kulturoznawstwu, filmoznawstwu, historii sztuki, rozmaitym filologiom, historii, filozofii itd.). Mam tu na myśli nieprzystawalność teorii i praktycznego czytania wszelkich tekstów (kultury), która sprawia, że adepci kierunków humanistycznych osobno a przy tym, można rzec, „na sucho” - poznają metody badawcze (a w zasadzie - ich historię), osobno zaś przedmiot tych badań (obyczaje, dzieła filmowe i teatralne, języki obce, utwory literackie itp.).

Czy tając książkę Edwarda Kasperskiego Metody i metodologia, przypomniałam sobie zarówno te nieudane próby „pożenienia” teorii z praktyką, jak i pracę roczną jednego z moich studentów. Takiej publikacji, która uświadamiałaby rolę metodologii jako narzędzia analizowania tekstu kultury i w przejrzysty sposób tłumaczyła różnicę między metodą a metodologią, a także podsumowywała osiągnięcia humanistyki jako nauki, wskazywała ważkie problemy i kreśliła perspektywy na przyszłość, z pewnością brakowało.

2 Zob. A. Sokal, J. Bricman, Modne bzdury. O nadużywaniu pojęć z zakresu nauk ścistych przez postmodernistycznych intelektualistów, tłum. P. Amsterdamski, A. Lewańska, Warszawa 2004.

3 Zob. E. Kasperski, op. cit., s. 108. 
W tym miejscu pozwolę sobie rozwinąć wątek, który wydał mi się szczególnie interesujący - pojęcie metodologii jako stylu (badań). Jak zauważył bowiem autor książki, metodologia stała się we współczesnej humanistyce „częścią tej rzeczywistości, którą bada, i [...] w "przedmiocie« rozpoznaje ona samą siebie"4; jest rodzajem indywidualnego stylu badacza, a nie uniwersalną i dostępną dla każdego ścieżką umożliwiającą obiektywne poznanie określonego dzieła czy zjawiska. Tak rozumiana metodologia oznacza modne, nowoczesne podejście do tekstów kultury, gdzie osoba badacza liczy się bardziej niż badany przedmiot. To z kolei prowadzi do niebezpiecznego zatarcia różnicy między interpretacją, reinterpretacją a nadinterpretacją ; radykał stwierdziłby może, że nawet zachęca do nierzetelnego prowadzenia badań. W tym kontekście taka kategoria jak „docieranie do prawdy o przedmiocie badań” brzmi anachronicznie, a wręcz naiwnie. Oczywiście, nie postuluję tutaj, by wracać do metod, których czas zdążył już przeminąć (jak metoda historyczno-genetyczna czy strukturalna), ale mimo to nie potrafię uwolnić się od wrażenia, że coraz więcej prac z zakresu nauk humanistycznych stanowi twórczość samą w sobie i z tej przyczyny kwalifikuje się jako obiekt analiz literaturo- lub kulturoznawczych.

Zapewne zdążyliśmy się przyzwyczaić do tego, że rozważania o metodach $\mathrm{w}$ badaniach humanistycznych niemal zawsze wiążą się z diagnozą samej dyscypliny, i to co najmniej od lat 60. ubiegłego wieku, kiedy krytyce poddano między innymi metodę porównawczą jako narzędzie zbyt nieprecyzyjne, subiektywne i przypadkowe, by mogło stanowić atrakcyjną alternatywę dla innych ówczesnych metod, z których każda ujawniała z czasem jakieś swoje słabostki. Mimo niekończących się sporów metoda porównawcza przeżywa dziś swój renesans. Dowodzi tego zarówno rosnąca liczba prac komparatystycznych, jak i rozbudowa struktur akademickich, w ramach których powstają kolejne pracownie, zakłady, katedry komparatystyki na wydziałach humanistycznych w całej Polsce (co ciekawe, jest to trend ogólnoświatowy). Choć wydawane publikacje jasno wskazują na to, że w kręgu zainteresowań coraz liczniejszych komparatystów wciąż pozostaje głównie komparatystyka literacka lub literaturocentryczna (czyli taka, której jednym

${ }^{4}$ Ibidem, s. 31.

5 Ten interesujący problem został ostatnio poruszony m.in. na łamach kwartalnika „Tekstualia” 2017, nr 1(48). 
z przedmiotów porównania jest literatura), to właśnie metodę porównawczą wskazuje Kasperski jako współcześnie najbardziej ożywczą poznawczo, i to dla całej humanistyki. Niewątpliwe zalety tej metody to przede wszystkim możliwość równorzędnego badania niejednorodnych tekstów i zjawisk kultury, przykładowo: dzieła sztuki i tekstu literackiego, praktyk kulturowych oraz struktur językowych danej społeczności.

Metoda porównawcza to znak naszych czasów - w wielokulturowym świecie, w którym dzięki ultraszybkiemu transferowi informacji mamy w zasadzie nieograniczony dostęp do wszelkich dóbr kultury nawet $\mathrm{z}$ najdalszych zakątków globu, pozwala ona nie tylko uporządkować i zrozumieć nowe zjawiska, lecz także dostrzec ukryte powiązania i nierzadko jedynie subtelne różnice między tym, co wydawało się już dobrze znane i zbadane. Niejako z samej swej natury zachęca ona zarówno do analizowania interakcji między zjawiskami kultury materialnej i niematerialnej, jak i do wchodzenia w rozmaite interakcje, do niezamykania się w wąskiej, wyspecjalizowanej ścieżce badań, do czerpania z całego dorobku ludzkości. To perspektywa bardzo szeroka i obiecująca wiele. Czy rzeczywiście jednak metoda porównawcza okaże się panmetodą jednoczącą wszystkie odnogi humanistyki, pewnie pokaże czas. Niewykluczone, że w przyszłości i ona podzieli los fenomenologii, strukturalizmu czy psychoanalizy albo utoruje drogę jakiemuś innemu, nowemu narzędziu. Póki co pozwala czerpać garściami z tygla kultury, i pod tym względem wydaje się metodą szczególnie atrakcyjną dla kulturoznawców.

\section{Humanists and Theory. In the Margin of Edward Kasperski's Metody i metodologia [Methods and Methodology]}

The text discusses some aspects of Edward Kasperski's last book entitled Metody i metodologia [Methods and Methodology]. The author refers to the idea of methodology as a research style and points out the advantages and disadvantages of comparative method in contemporary cultural studies.

Keywords: research methods, methodology, humanities, comparative method, contemporary cultural studies, cultural text analysis 


\title{
PROMENADE ABROAD WITH BRUNO SCHULZ
}

\author{
BRIAN R. BANKS
}

brianbanks@gmail.com

I wish here to share an excursion in the footsteps of Bruno Schulz, seen from abroad and 15 years of study that included Muse \& Messiah: The Life, Imagination and Legacy of Bruno Schulz published by the Inkermen Press in England. He has been translated into 33 languages and counting, so interest is global in spite of the disappointing dissonance of rarely finding a Schulz section in bookshops here, a widespread trend of course in this marketing age. Today's route might have its signposts obscured by foliage and thorns: this discussion is fact-based observing not criticising, with a hope for debate.

Western historians, rightly or wrongly, consistently believe that Polish literary Modernism had its richest harvest during the 1930s with Witkacy (1885-1939), Bruno Schulz (1892-1942) and the younger Witold Gombrowicz (1904-1969), a galloping troika of kindred spirits that was never actually a cohesive group or movement. Gombrowicz and Witkacy disliked each other when Schulz introduced them at Witkacy's Bracka Street apartment in Warsaw, but they shared a mutual strategy: recognition of Polish culture and its situation in a 'fluctuating borderland between Russia and western Europe' (as Joseph Conrad's once-famous father described it) within the developing European vanguard of artistic experimentation.

Added to this interest in this century is the narrative of Jewish historians, perhaps because of what Norman Finkelstein calls 'the holocaust industry' (the website of Prague's Kafka Society is sponsored by a Holocaust Foundation, though the German-speaking Austrian citizen died 15 years before the war). Perhaps it is nostalgia for a vanished life, the cosmos of the Ostjuden similar to what East Germans now call ostalgia. It is, however, noticeably selective in its choices, e.g. not Wat, Leśmian, Tuwim, which can isolate subjects from their Polish reality. All these forms of nostalgia - perhaps Poland too? - certainly involve a 'here' and 'somewhere else' simultaneously, and 
Schulz embodied characteristics of the 'other' all his difficult life, in art, literature, and as a teacher.

This is also the background concerning the clandestine removal of Schulz's frescoes in Drohobycz at the start of this century, undertaken said Yad Vashem's statement because of the 'indifference of Poland and Ukraine' to be eventually displayed in Israel as by a Jewish, not Polish-Jewish, artist. This act is still debated and protested internationally, raising the fundamental question of self-identity during his lifetime. Sadly, it seems the circumstances of a tragic death motivate interest in the work - but less in the life that was lived - seeking to fit a theory backwards, so to speak. Lucian wrote 1900 years ago, 'History should be written [...] with truthfulness and hopes for the future rather than flattery to please today's recipients of praise' (Lucian 1982: 63) and this is valid today. Those who should be helping travellers - 'the public' - regain routes, have crumpled and transposed the map upside down for their own purposes: perhaps Schulz wrote it originally in invisible ink?

This raises an emotive point, a central axis involving the subject's worldview, what did he seek to achieve and how did he want to be seen and remembered: How Jewish was Schulz? According to Jewish criteria, it is questionable. It seems he did not undertake bar mitzvah or eat kosher, may possibly have crossed himself in Catholic churches with his students, was critical (memoirs say) of what he called the 'anachronism' of local Hasidic Jewry, posted a notice in the local press that he was no longer of the Judaic faith when trying to marry Józefina Szelińska (a convert from Judaism to Catholicism), and didn't attend the Orthodox Synagogue (his ex-students, and sister of his friend, told me) though his father did. He didn't speak Hebrew or Yiddish. All opinions are of course valid, but surely no agenda can hold more weight than facts and the imagination of the subject rather than the theorist's sheen and veneer polished with their own instruments.

As a respecter of faiths he may have visited the Progressive Synagogue of course, though this choice had tensions then. There is, however, no evidence at all that he spoke of Palestine: unlike Kafka, Bruno Schulz looked west for inspiration - like his country in its problematic geo-linguistic position and dreamed of living in Paris or a western city according to his family. They named him in western style, as was their earlier choice of a German surname, after the Polish (but not Rome's) Catholic name day of Saint Bruno 
of Querfurt, a martyred missionary working in Poland, Lithuania and Kiev Rus. His cultural choice for identity was Polish aided by German in the Austrian form like Kafka, and wide, even 'ecumenical' reading-ancient classics, mythology, Mickiewicz, Gide, Huxley, Aragon, Marx-but those who prefer to label a Judaic view as somehow primary are leaving far too much out of the equation. As my writings and lectures (Leuven, Berlin etc.) seek to show, there is far more European influence as with Witkacy or Gombrowicz's with France than that of Hasidic or Yiddish literature.

Out of the terrible debris came 29 stories, a few essays and reviews along with 160 letters so far in the public domain. For John Keats, who lived exactly half Schulz's span, 300 letters exist; Rilke wrote 10,000, the first edition of Proust's correspondence (he lived a year longer than Bruno) extends to 21 volumes; Chekhov lived several years less yet there are 8 volumes. Bruno Schulz's life-work has more loss and absence than presence, a mosaic composed of fragmented shards. We are stumbling among ruins with lighted torches hoping to find signs and even migration routes among later detritus. Terrible times, with so much lost. It is a fact that in the cultural meltingpot of Drohobycz, Lwów and Warsaw, after his mother read to him Goethe in the original (they spoke that language at home, as was on their sign on their shop), his principal literary lights all wrote in German: Rilke, Kafka and Thomas Mann. His inner world was a complex amalgam underpinned by Mann's Magic Mountain and Joseph and His Brothers, Kafka's Trial and Metamorphosis, and Rilke's Notebooks of Malte Laurids Brigge with poetry based on his theory of Inwardness, i.e. the writer's creativity returning the things of the world back to it through art. Like them, he questioned the religions of their upbringings but not God, as every writer chooses a commonwealth of fellow-travellers reflecting their self-image.

The Austrian Habsburg Empire that annexed Schulz's region during his formative years, a regime that Karl Kraus called 'solitary confinement with permission to scream', collapsed in 1918. It may be significant that two of his favourite authors, Kafka and Rilke, both died not long after from illness, at the time Schulz turned to writing almost a decade before his debut book. It was also when a close-friend and literary collaborator, W. Riff, died young from the same illness, an event so traumatic that Schulz avoided talking of the subject in later correspondence. First an artist, it seems that he additionally turned to writing - away from exhibitions for example; he said 
that he could only charge the rich not poor for his work - because it was a more private domain, safer within the covers of a book.

The deeply-Polish author read and respected the work of compatriots. Recent memoirs confirm that he met writers (in some cases memorised their work) as diverse as Wat, Wittlin, Jastrun and Zegadłowicz. (The latter's family showed us two of Schulz's drawings that they still retain). He telephoned Gombrowicz and they walked in Warsaw together, exchanged several telegrams a day about the manuscript of Ferdydurke, which Schulz illustrated. Zofia Nałkowska's Journal strongly suggests a far more intimate relationship of several months with Schulz than his first biographer discusses, before her marriage to a husband who, significantly, wouldn't allow the writer to meet her alone and burnt his gift of a special unique copy of his book. This relationship was undervalued by Jerzy Ficowski; when I interviewed him twice he refused to discuss it. Such subjects are surely of interest to readers wanting the most complete and vital portrait possible.

This tapestry includes Schulz's sporadic travels involving art studies, followed by promotion of his work, a crucial element of his life confirmed by a last surviving - though distant - relative, a grand-nephew, from the family's oral tradition. For reasons too many to discuss here, Ficowski preferred to ignore this and maintain only one visit to Vienna: Bruno Schulz's attendance at its art academy in 1917-18, exactly ten years after his earliest known artwork (survived many decades later in a suitcase). He stayed with relatives, who unlike Kafka's have eluded research, without a stipend from his local Jewish community which further points to an outsider status (Maurycy Gottlieb and others did receive assistance from Drohobycz).

But superb research by Paolo Caneppele in Vienna found that the artist was there several times. This was known by heirs but omitted by Polish biographers. At least four earlier visits than the school year, between November 1916 and August 1917, are recorded in Austrian visa documents. This strongly suggests he travelled south of Drohobycz (not via Warsaw), as the stated visa border town was in Hungary, now in east Slovakia. It's plausible that he was there for most or even all of the war because visa dates overlap. He may have passed Franz Kafka on a boulevard or station platform, where the Prague writer's friends, Milena Jesenska and Ernst Pollak, were discussing him in the famous cafés that were even advertised on Drohobycz's post-office documents. Rilke also did war service there. Such factors are 
interesting, because it was the place and moment for Expressionism that shows partial reflection in his art, when the bohemian world was rocked by the funerals of Gustav Klimt, Egon Schiele (their art was collected by oil-rich Jewish families in Drohobycz) and Frank Wedekind, a controversial competitor of Przybyszewski in most of Europe's capitals. Their plays, novels and art, I have observed, hold (more subtle) threads in his own work as a writer-artist very much of his epoch. Coinciding with his first-known visa was the funeral there of the Habsburg Emperor, Franz Joseph, also featured in Schulz's stories twenty years later.

A never-discussed personal possibility arises, which theoretically impacts in his prose. The time in Vienna may coincide with the unemployed student, if he travelled earlier, being away from home when his father died in 1915. The family also stayed there, e.g. his mother - six months after her husband's death, during what was traditionally a year-long mourning period. His brother, Izydor had three visas in the years 1915-1919 when he was an Austrian army officer, accompanied by his wife, present in the stories. (Bruno wasn't conscripted into the army because his school year wasn't called up). One of their children was also born in Vienna, in 1915. Oddly absent from the stories, Izydor was an entrepreneur and the only one in the close family who had a job, which saved the family from penury when their textile shop closed.

Jerzy Ficowski tells us that the shop was burned down in the war, without explanation. My research found a declassified government report about the circumstances, discussed in my book. The more general background is further confirmed in Stefan Zweig's (2013) autobiography The World of Yesterday when he visited at the time and discusses local Jewish trade and absence of war damage to the town centre. Bruno Schulz visited Vienna at least twice more in the 1920s during longer-period visas. We also know, from his earliest surviving letter of May 1921, that the 29-year old was at least in Warsaw looking for a job, armed with a portfolio of his art.

Scholars in Israel found a letter by Charlotte Richman, daughter of the writer's cousin on his mother's side, which is undated but said to be 1920-1921, stating that he visited them in Berlin with his Idolatrous Booke series, which reflects the decadence of Weimar Berlin and late Habsburg Vienna, then being discussed in cafés and periodicals there. He lived off Wilmersdorfer Strasse, in the newly-incorporated Charlottenburg city district, since 
disappeared. Muse \& Messiah discusses the culture and events he could have been exposed to (prior to becoming a teacher, where he' $\mathrm{d}$ been a pupil two decades earlier), as well as new information about his friends.

More frequented cultural centres were Lwów and Warsaw, rather than the Kraków of post-Romantic Young Poland that embraced Jungendstil/ Art Nouveau. Visits were made to Witkacy in Zakopane, made famous for foreigners by Henryk Sienkiewicz in the 1890s and later Joseph Conrad. In the 30 s he went to Paris and Stockholm to make contacts, as well as sending letters to an Italian editor and translators in Paris that included Joseph Roth, a mutual friend of the Lwów-based Wittlin, whose daughter's American-published memoirs describes a visit by Schulz.

Yet Drohobycz, with its neighbouring spa-resort of Truskawiec, formed the chromosomes of his blood, an internalised republic that could never be relinquished like Adam Mickiewicz's borderlands. It was needed like a drug or infusion, with creativity the one potent antidote against despair after temporary, dearly-won travels. Is not his mantra-like prose comparable to an induced trance-like state confessing an odyssey? Through the motifs of dusk, dawn, night, seasons, storms, sleep, dream and reverie, the transformation of people and nature in a realm of isolated introversion, their short-term effect fed the art of a cultural cosmopolitan as mytho-poesis: poetic interpretation of life and its events via symbol, metaphor, allegory and emblem. Mythology forms on an assumption that an event literally happened, in some reality (however obscure it may seem later), but because we cannot perceive the world's meaning, humans need to create it. This was also the stimulus for the similar contemporary European style of Magical Realism.

Bruno Schulz created as a heresiarch or demiurge, in Ficowski's wonderful terms, to counter the fracture between myth - life's interpretation - and presented reality within a space-time province called a Republic of Dreams, geographically north of the Carpathians in a self-created age of innocence. Like Kleist's 'backdoor of Paradise' (another space in which potential essence is tantalisingly just out of reach), a route was sought behind reality which seems somehow always just round the corner, over the fence, beyond the toll-gates that then marked the borderlines of place like those at Truskawiec. Schulz was less ill-at-ease in provincial life, like Gide, but worse in the nerve-wracking, crowded capital; he was not a ruralist like Léautaud, Francis Jammes, Ivan Franko, or Thomas Hardy. 
He doesn't propose a philosophy for life, it isn't existential except in the sense of living his own authentic life: he rather portrays a psyche during and in the immediate aftermath of something as inexplicable as life itself. For that lover of mathematics it was a vector of overlapping spheres, not set in the restrictive nostalgia-template of the Romantics that Norwid questioned, but hidden enchantment kept alive awaiting 'maturity into childhood', like Proust's Times Past or Yeats' Isle of the Blessed concepts, and his thwarted love relationships resonate with Alain-Fournier's lost domain.

Schulz, who wrote a now-lost Die Heimkehr (The Home-Coming) in German, seems to see his region as a land of ancestors. His 'Fatherland' (rather than the Polish macierz, motherland) is not like the word's standard meaning, but the feelings of a traveller returning to a home-town; the title suggests the life he had once known was in the land of the father. The patriarch (the same Latin root as homeland, patriot) is a dividing line of life (and the other life) before and after his devastating demise, which may be a key to his tales, especially Sanatorium Under the Sign of the Hourglass (1937). There is an absence of the mother, who once briefly appears like a phantom yet pampered him, locals said. Is the imbalance of the father's presence among the family due to the author's guilt of absence from his last days, perhaps, or not fulfilling his commercial life like the brother?

Bruno Schulz's mindless murder by a Nazi, who was never caught, took place only 200 metres from the shop he was born above, across one plot from his childhood's courtyard. His world actually encompassed only a very small area of the town. From there to the school he attended and worked in, to where he painted frescoes to stay alive (situated on the same side of the road as his last home), were within barely 15 minutes walk. Only the famous Street of Crocodiles, the main shopping street (opposite their shop) next to the town's bazaar, was on the other side of the Square, near the (unmentioned) neo-Renaissance Great Synagogue. His Drohobycz was smaller than the map co-ordinates, just as his world was vaster than Galicia...

For readers, posthumous reputation is initially shaped by biographers of course - without their hard work it's debatable if there would be a scaffold let alone a structure - but the true primary witnesses are those who met the subject (Ficowski regrettably didn't meet Schulz but Artur Sandauer did, who he failed to interview along with other friends such as Nałkowska, Ola 
Wat etc). These three interlocking elements - influences, personal contacts, biographers - are a confused, often unquestioned sequence by Schulz's commentators today, but aren't normally so regarding a creative life. The circumstances of Kafka and Brod, Norwid and Miriam, or Wat and Miłosz, are clear and without similar confusion.

Before this century and wider interest, the usual portal for non-Polish readers was translation. Jerzy Ficowski, who didn't speak English, signed an agreement allowing (!) the first English translation of Schulz's work. A re-issue of it by Penguin Books was one of the last business agreements by Schulz's heir before copyright expired in 2012. These actions were unfortunate, because the English text is one of the worst possible! It is full of spelling errors, additions (e.g. a place name changed to Drohobycz; even the book's title from Cinnamon Shops to The Street of Crocodiles!), and deletions (adjectives, nouns and lines) because the translator says in the Introduction that English cannot sustain the Polish original.

Not only are English readers not exactly reading Bruno Schulz, but it's now possible that that false version will be used for other translations. In this age of Google translate, western publishers tell me they use spell-andgrammar-check instead of proof-readers - but techno-tools are as fallible as their loader, adding to the chaotic mess. Until this century and Yale Press, Gombrowicz was translated not from Polish but Spanish editions. Several years ago a new translation of Schulz was heralded loudly in the Polish national press, when the commissioned American translator wrote to me asking about Schulz because she said she didn't know much about him and usually translated Holocaust studies. To date, no book has been published. A more faithful translation is on the web by John Curran Davis.

This is an era when major art by such as Żechowski and Beksiński are declined by museums because of 'no space' even when donated, and the fees for lending Schulz's art are so high that Amsterdam and Barcelona can't pay. The keepers and guardians of artistic culture seem to be confused about their role. The Mickiewicz Institute has never exhibited or published the very important Artur Sandauer Archive that was generously donated by his son Adam Sandauer, who most kindly showed me the contract of the 1980s. They also have a decorated lacquer box given to the family by the son of Schulz's Nazi 'protector' Landau, but this has only been seen when donated. 
A recent book by Agata Tuszyńska (2015), Narzeczona Schulza about Józefina Szelińska, surely breaks basic academic or even journalistic protocols. We do not know in the text when the subject or the writer is talking: the personal pronoun 'I' is used throughout, like in a novel, even when an educated teacher like the subject is (supposed to be) speaking. Why? Serious collectors of the subject tell me they expected more, so they don't put the quasi-novel into their Schulz section. Jerzy Ficowski was not allowed by her to use her name so he only used initials. Perhaps she was traumatised by the failure of marriage plans but also, I am guessing, because Schulz's publisher, Rój, would only publish their translation of Kafka under his more saleable name, an error continued by schools today; a Schulz letter says he helped correct the manuscript. Her family still does not allow the public to see Schulz's letters while their walls show his art including what may be only the second surviving example of his oil painting. The author ignores this rather odd situation, although it's a quarter of a century after the love of Schulz's life passed away in Gdańsk, unmarried and after more than one suicide attempt.

The public-funded Institute of Books in Kraków uses on its website a Chronology of Schulz that is in fact decades out of date. It is based on Ficowski, they told me, so ignores new factual discoveries (just as he sometimes did regarding Polish sources) by an Italian, Austrian, Ukrainian, Israeli, and Englishmen among others. The last time I looked, it ignores a great recent Polish find: a review of Schulz's debut in the daily Łódź newspaper 'Głos Poranny'. The www.culture.pl website, in their 20 facts section, says Schulz was 'thrown out' of the Jewish community (was that after he published a notice that he wasn't in it anyway?!). A few years ago a National Museum exhibition of Polish interwar art completely ignored Schulz, while 'Gazeta Wyborcza' championed another show's 'new drawing by Schulz' that wasn't one of his subjects or in any of his known styles. Perhaps it was by fellow-Drohobyczian E.Lilien but that's not news... Absurd false statements are common there: a pupil of the writer was 'his last surviving student' etc.

So both the Polish and foreign situations regarding Schulzology remain oddly at variance. Abroad, generally, a couple of other contemporaries have been noticed before, for example Wat and Leśmian in America in the 1960s, Stefan Grabinski and Stanisław Przybyszewski (as a German!!) more recently, 
but national classics such as Tuwim and the Nobel laureates, Sienkiewicz and Reymont, elude wider research (Reymont's one American biography completely ignores his Paris period and novel based on it, Wampir 1911). Witkacy and Gombrowicz first established their reputations in France in the 1920s and 1960s respectively, while Schulz first entered the world pantheon at this later time due to a flurry of translations in England, America, then France, Germany, Japan, Israel, South America and Taiwan.

Some worldwide writers - as diverse as Bohumil Hrabal, Danilo Kiš, David Grossman, V.S. Pritchett and John Updike - have registered homage to the shy, hyper-sensitive teacher who attempted foreign recognition in his lifetime. This notice has its lowest point when Schulz's painstakingly beautiful short stories, more accurately prose poems, were cut up and repasted by Jonathan Foer (Tree of Codes, 2010), without respect for the original author's intentions and art. (It was a popular hobby for schoolgirls with The Beatles' books in 1968 too). He was proud, in an interview, that the book didn't take him long to do and was only a question of what words to leave out! There is a market for this nowadays, while I am told by Polish publishers who prefer books on bonsai trees or Nazis that there is no market for Bruno Schulz. One of Poland's leading publishers, S.K., officially wrote to me that there are too many foreign names in my book for Polish readers.

Present time, in cultural terms, seems to this author to have validity if it retains the lived past as its source, a natural mine shaft just as memory as experience is for living writers. Schulz's past was of course his family (that's why central new facts are in my book to be revealed, should a new edition be published) but also the borderland he inhabited. From the farthest eastern frontier of Poland and Europe, the reader is invited into the world of a Polish-European-Jewish-Galician witnessing the end of a way of life despatched from a far outpost. The vivid experience of the first artistic son in his genealogy, with attempts to comprehend it, is now of universal interest which transcends upbringing, creed and, ultimately, borders that were arbitrarily imposed without the agreement of those who were there.

And so, by logical inference when remembering his region and work, this universality excludes nationalism, what Aldous Huxley called 'Molochtheology' (Schulz reviewed him favourably) and Tolstoy dismissed as 'meaning nothing at all' regarding literature. Goethe said the same to Eckermann in 1827 and André Gide in his Journal in May 1912. A 'national icon' like 
Mickiewicz is seen differently in Lithuania, and first discussed in France by Victor Hugo, Mérimée and Lautréamont as an internationalist before his fame in Poland. Status and approach is subjective, a re-drawn image that all too often ignores history or contexts, like a hologram presented to another viewer. Do lecturers boldly stating that Schulz was a masochist because of (some of) the art he did in the 1920s only (Gombrowicz spoke in his diary of Schulz's artistic character), or that he would have been a Zionist if Israel had existed during his lifetime, or that he was hiding a love of his racial background secretly in his texts - when Polish readers knew he was Jewish anyway! - really think they know his character? 'This is a city of careerists [where] people don't study for knowledge but for a position and celebrity, acquired through social contacts, women, parties...I know genuine scholars, even men of genius, brought to a sudden halt in their development, who have taken to giving lessons or writing popular articles which no one reads or, if they do, fail to understand'. Is this still true for the capital or Schulzology? When was it written? In 1890 - by Bolesław Prus in Lalka (1996: 627).

Everyone who met the bi-lingual cosmopolitan intellectual, including his students I interviewed, recall that international (including Polish) culture was his motivation and stimulus. Gombrowicz, who only missed the Nobel prize by one vote in spite of being supported by Sartre, wrote in his Memories for February 1961: 'Among us [Schulz] was the most European writer, with the right to take his place amongst the greatest intellectual and artistic aristocracy of Europe' (Gombrowicz 1997: 111). Is the trusting reader today, new to the subject, allowed to distinguish between fact and interpretation of his life-work which forms a cohesive unity, a carefully created personal philosophy?

It isn't journalism or the latest sensation, nor is it bestowed for puerile cut-and-paste. Schulz, like Goethe in his way, was trying to understand or come to terms with living not dead forms, by exploring their worlds for truths applied to culture within social contexts, navigating with a compass that in his last years was no longer allowed to hold its magnetism. If you will pardon the unfashionable lyricism (although he himself said that the plastercasts like fossils should be cast off), culture has never been historically about ownership of the plot but cultivating the seed so it may flourish in an organic way, a rich garden whose blooms are more interesting than the portal or fence around it while first ornamenting them there. All true art is timeless 
after first grounded in its period and primary sources 'over there', which it transcends so to speak, to hopefully be an inspiration for wanderers and fellow-explorers today wherever they be. The legacy of Bruno Schulz has fulfilled his own dream.

\section{Muse \& Messiah}

The Life,

Imagination \& Legacy

of

Bruno Schulz

$(1892-1942)$

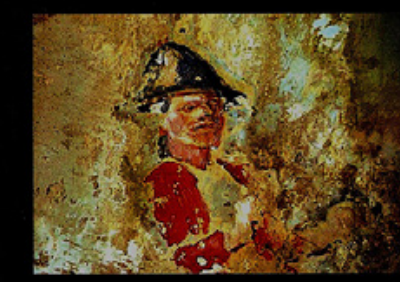

Brian R. Banks
Brian R. Banks, The Muse \& Messiah: The Life, Imagination and Legacy of Bruno Schulz (1892-1942), Inkerman Press, London 2006.

\section{Selected bibliography}

Jonathan Safran Foer (2010), The Tree of Codes, Visual Editions, London.

Witold Gombrowicz (1977), Wspomnienia polskie. Wędrówki po Argentynie, Instytut Literacki, Paryż.

Lucian (1982), How to Write History, [in:] idem, A Selection, trans. M.D. Mcleod, Duckworth, London.

Bolesław Prus (1996), The Doll, trans. D. Welsch, introd. by S. Barańczak, Central European University Press, Budapest - London - New York.

Bruno Schulz (1979), The Street of Crocodiles, trans. C. Wieniewska, introd. by J. Ficowski, Penguin Books, New York.

Bruno Schulz (1987), Sanatorium Under the Sign of the Hourglass, trans. C. Wieniewska, introd. by J. Updike, Penguin Books, New York. 
Bruno Schulz (1990), The Booke of Idolatry, ed. by J. Ficowski, trans. B. Piotrowska, „Interpress”, Warszawa.

Agata Tuszyńska (2015), Narzeczona Schulza. Apokryf, Wydawnictwo Literackie, Kraków.

Stefan Zweig (2013), The World of Yesterday, Plunkett Lake Press, Lexington (MA).

\section{Promenade Abroad with Bruno Schulz}

The article depicts ethnic, religious, as well as cultural and literary background of Bruno Schulz and his work. The author argues with some Schulz's biographers and commentators in order to differentiate between facts and 'myths' or interpretations of writer's life. Moreover, the author traces the main lines of Schulz's foreign reception and addresses some critical remarks about translations of his work into English, as well as about the other examples of reading and popularizing Schulz's legacy and heritage, especially in Anglophone cultural contexts.

Keywords: Bruno Schulz, heritage, literary criticism, translation 



\title{
MUZYKA JAKO ŚRODEK NARRACJI W WYBRANYCH FILMACH MICHAELA HANEKEGO'
}

MACIEJ WOŹNIAK

Wydział Nauk Humanistycznych UKSW

Faculty of Humanities, Cardinal Stefan Wyszyński University in Warsaw

maciekwozniak@poczta.onet.pl

\section{WSTĘP: O SEYSZALNYM KRAJOBRAZIE KINA}

\author{
„O, ty, przemiano \\ uczuć w co? - w słyszalny krajobraz”
}

Rainer Maria Rilke, Do muzyki (tłum. A. Lam)

Kiedy Georges, jeden z bohaterów Miłości Michaela Hanekego, usiłuje złapać gołębia - ulicznego intruza we wzorcowo urządzonym mieszczańskim mieszkaniu - przez dobrych kilka minut widz zostaje sam na sam z trzepoczącym ptakiem i zadyszanym staruszkiem. W eseju Gołębie zagrażają kinu Zygmunt Kałużyński, wspominając o niemal sto lat wcześniejsze pionierskie lata filmu dźwiękowego, napisał: „Na szklanym dachu atelier siadywały gołębie, których gruchanie przerywało dialogi: specjalni funkcjonariusze dyżurowali tam, by przepędzać ptactwo kijami"2. Skojarzenie tych dwóch punktów w historii kina - leżących na dwóch biegunach filmu dźwiękowego - pozwala dostrzec w Hanekem nie tylko reżysera od „wstrząsają-

1 Artykuł stanowi przeredagowaną wersję rozprawy magisterskiej napisanej pod kierunkiem dr hab. Katarzyny Taras i obronionej na Wydziale Nauk Humanistycznych UKSW w 2016 roku.

2 Z. Kałużyński, Gołębie zagrażają kinu, [w:] idem, Buntownik bywalec, Warszawa 1998, s. 87. 
cych widzem" historii czy dyżurnego moralistę, ale też artystę organicznie związanego z rozwojem kina i jego środków wyrazu. Jeden z tych środków to dźwięk, zaś jego odmianą szczególną - a w przypadku filmów Michaela Hanekego wyjątkowo godną uwagi - jest muzyka.

Pozostańmy jeszcze na moment przy - zupełnie pozbawionej muzyki scenie $z$ gołębiem, ponieważ pozwala ona spojrzeć na sposoby narracji u Hanekego z perspektywy metody, czyli użytego „chwytu”3. Scena jest prowokująca, zarówno formalnie (sprawia wrażenie, że wypada z rytmu filmu, jest tak nieproporcjonalnie rozciągnięta w stosunku do całości, że może wzbudzić w widzu irytację oraz zniecierpliwienie ${ }^{4}$ ), jak i pod względem treściowym (zastawia pułapkę przymusu interpretacyjnego, czyli tak zwanego trybu symbolicznego ${ }^{5}$, w którą wpadł chociażby Tadeusz Sobolewski, cokolwiek zbyt łatwo sugerujący związek gołębia z symboliką chrześcijańską ${ }^{6}$ ). Skuteczność prowokacji jest tym większa, że do Hanekego przylgnęła nie tylko łatka perfekcjonisty, który każdą sekundę taśmy nagrywa $\mathrm{z}$ premedytacją, ale także reżysera, u którego gra z widzem nie zakłada równoprawności obu stron, tylko intelektualną oraz emocjonalną przewagę jednej z nich - czyli po prostu reżyserską manipulację widzem. Owszem, część filmów Hanekego, w tym Funny Games, może potwierdzać opinię „manipulatora”, ale takie obrazy jak Pianistka czy Miłość - czego dowodem

3 W. Szkłowski, Sztuka jako chwyt, tłum. R. Łużny, [w:] Teoria badań literackich za granica, t. 2, cz. 3, wyb. S. Skwarczyńska, Kraków 1986, s. 10-28.

4 „Najgorsze były długie, wręcz wlokące się sceny, które zamiast zachwycać, strasznie nużyły. Apogeum mojego zniecierpliwienia nastąpiło w momencie, kiedy Georges zaczął nie wiadomo po co polować na gołębia”; M. Piechocka, A. Kortus, http://inlovewithmovie.blogspot.com/2013/03/miosc-amour.html [dostęp: 20.08.16].

5 U. Eco, Tryb symboliczny, tłum. M. Woźniak, [w:] Teorie literatury XX wieku. Antologia, red. A. Burzyńska i M.P. Markowski, Kraków 2006, s. 304-353.

6 „Obijanie się gołębia o ściany paryskiego mieszkania symbolizuje również szamotaninę duchową współczesnego człowieka po utracie dawnej religijnej busoli"; T. Sobolewski Haneke z Miłościa, ale bez litości, „Gazeta Wyborcza” 2012, nr 256.

7 „Doskonała znajomość tego, czego spodziewa się publiczność, pozwala twórcy na manipulowanie jej uczuciami i reakcjami, sprawianie, że jej nadzieje momentalnie rozsypują się jak domek z kart”; J. Dudkiewicz, „Funny games” czyli po co to ogladasz? - analiza filmu Michaela Hanekego, http://film.org.pl/a/analiza/ 
choćby skrajne rozbieżności w ich ocenie ${ }^{8}$ - pokazują, że bywa także inaczej: wydarzenia i bohaterowie uwalniają się spod ścisłej reżyserskiej kontroli, co pozwala im na samostanowienie, widzowi zaś - na konfrontację z filmowym światem na tyle wielowymiarowym, że nie mieści się w ramach standardowo pojmowanego „niepokoju moralnego” czy przesłania zgodnego z obowiązującą „pedagogiką społeczną".

To osiągnięcie wolności przez filmowe wydarzenia i bohaterów odbywa się w dużej mierze dzięki wybitnym aktorom (których silne osobowości i bogate zawodowe życiorysy wykluczają pokorne posłuszeństwo dyrektywom oraz pozbycie się „własnych” emocji), a także dzięki wybranej do filmów muzyce. Chodzi tu przede wszystkim o tak zwaną muzykę klasyczną, czyli napisaną $\mathrm{w}$ poprzednich epokach, potem wykonywaną w określonych okolicznościach oraz kontekstach historycznych lub społecznych (można by ją określić, ze współczesnej perspektywy, jako „muzykę po przejściach” - i do tego sformułowania jeszcze wrócę, ponieważ uchyla ważną interpretacyjną furtkę). Emancypacja muzyki w kolejnych filmach austriackiego reżysera, jej coraz mniej schematyczne użycie, coraz odważniejsze „wchodzenie w buty” narratora, komentatora czy analityka ekranowych wydarzeń, potwierdzają choćby i to, że nie ma jednego - zasuszonego jak liść między stronicami

funny-games-czyli-po-co-to-ogladasz-analiza-filmu-michaela-hanekego-36176/ [dostęp: 1.03.16].

8 „Haneke nakręcił jeden z najpiękniejszych filmów o śmierci, ale i o tytułowej miłości”; R. Błaszczak, Miłość, http://kafeteria.pl/kultura/milosc-michael-haneke-a_5375 [dostęp: 1.04.16]. „Wybaczcie krnąbrność, ale uważam, że ten film jest festiwalem bezpłciowych oczywistości ubranym w grubą warstwę pseudoambitności, dodatkowo okryty nieprzekonującą symboliką. Niedomówienia scenariusza nie stawiają pytań, których byśmy nie znali. Decyzje bohaterów nie dają odpowiedzi, które mogłyby prowokować do szczerych i nowych przemyśleń"; P. Rezmer, Miłość, http:// stacjakultura.pl/4,21,29422,Milosc_recenzja_filmu,artykul.html [dostęp: 1.04.16].

9 „- Ale nie chcę przez to powiedzieć, że mój film jest jakiegoś rodzaju przesłaniem. Przesyłki nadajemy na poczcie, a nie na ekranie kina (śmiech).

- Broni się Pan przed określeniem »moralista«.

- Moralista to nudziarz, nauczyciel, któremu się wydaje, że wszystko wie lepiej”. Era Wilków [z Michaelem Hanekem rozmawiają Anna Chorostecka i Jan Niedziela], „Gazeta Wyborcza” 2001, nr 278. 
filmowej encyklopedii - Michaela Hanekego. Jest za to żywy artysta kina, który zmienia się i ewoluuje, podobnie jak sztuka, którą uprawia.

W niniejszej pracy chcę przeanalizować rolę muzyki w filmach Hanekego oraz wykazać, jak i dlaczego przejmuje ona rolę narratora wobec przedstawianych wydarzeń. Czyniąc to albo równolegle z tradycyjnym kinowym narratorem, czyli obrazem, albo samodzielnie, ujawnia ona te aspekty historii, których oko kamery nie dostrzega. Na początku w skrócie prześledzę historię muzyki w kinie, wychwytując momenty pozostawiające zauważalny ślad w filmach Hanekego. Przegląd jest nader skrótowy i skupiony na wczesnych dekadach rozwoju kina - wszystko to, by pokazać, jak głęboko biją źródła muzycznej narracji u Hanekego. Śledząc zdobycze kina pod kątem muzycznej narracji, pokażę, że artystyczna droga Hanekego, jego zmieniający się punkt widzenia (czy raczej, w tym przypadku, „punkt słyszenia”), nawiązuje do różnic w spojrzeniu na narrację w filmie i sposoby jej budowania u najwybitniejszych reżyserów sprzed lat (vide opinia Tarkowskiego o Eisensteinie, którą zacytuję).

W kolejnych rozdziałach omawiam dokładniej - z perspektywy muzycznej narracji - trzy filmy Hanekego: Funny Games (1997), Pianistkę (2001) i Miłość (2012). Charakter mojej pracy, pisanej z punktu widzenia kulturoznawcy, sprawia, że skupiam się bardziej na opowiadaniu filmowej historii za pomocą utworów muzycznych w kontekście obecności tych kompozycji we wspólnej przestrzeni kulturowej niż na teoretycznej analizie filmoznawczej (z jej historią pojęć określających sposób istnienia muzyki w filmie, począwszy od klasycznej pracy Siegfrieda Kracauera i jego terminów „muzyka komentująca” czy „muzyka funkcjonalna” ${ }^{10}$ ). Zadowalam się zatem względnie prostszym podziałem na sferę diegetyczną i niediegetyczną ${ }^{11}$, nie podążam

${ }^{10}$ S. Kracauer, Teoria filmu. Wyzwolenie materialnej rzeczywistości, tłum. W. Wertenstein, Gdańsk 1975, s. 174-177 i 178-186.

${ }^{11}$ „Diegeza - pojęcie diegesis, oznaczające w języku greckim »opowiadanie«, $\mathrm{w}$ tradycji retorycznej [...] było przeciwstawiane pojęciu mimesis, czyli »naśladowania«. [...] W odniesieniu do filmu termin upowszechnił E. Souriau [...]. Souriau rozróżnia przestrzeń ekranową (daną bezpośrednio na ekranie) i przestrzeń diegetyczną (pomyślaną przez twórców filmu i rekonstruowaną przez widza w trakcie oglądania filmu). [...] Do świata diegetycznego należy zarówno przestrzeń (i czas) bezpośrednio przedstawione na ekranie, jak i przestrzeń (i czas) domniemane jako niezbędne dopełnienie tego, co w filmie jest pokazywane. Dźwiękiem diegetycznym 
natomiast za proponowanym przez Jerzego Płażewskiego podziałem na muzykę immanentną i transcendentną. Będę przy tym korzystał z rozpoznań Płażewskiego, tyle że bez szczegółowego trzymania się jego terminologii ${ }^{12}$.

Wybieram akurat te trzy filmy Hanekego dlatego, po pierwsze, że reżyser używa w nich wielu muzycznych chwytów narracyjnych (których rozpoznanie sprzyja lepszemu wglądowi w opowiadaną na ekranie historię, a także pogłębionej interpretacji filmu), po drugie dlatego, że ukazują one, jak na przestrzeni kilkunastu lat zmieniała się narracyjna rola muzyki u Hanekego: ku coraz wnikliwszemu wglądowi pod podszewkę wydarzeń, coraz bogatszemu (intelektualnie, emocjonalnie, duchowo) komentarzowi do akcji filmu, a wreszcie - ku wyzwoleniu kina spod wizualnego nadzoru kamery. Dzieje się tak po to, by film (wraz z bohaterami, ich historiami, poruszonymi problemami) mógł - tak jak wiersz u Andrzeja Sosnowskiego ${ }^{13}$ „wyjść z domu”, czyli wyrwać się spod kurateli twórcy, zamiast jedynie instrumentalnie służyć (idei, przesłaniu, przestrodze itd.).

Zamierzam przeanalizować, w jaki sposób stopniowa emancypacja muzyki w omówionych przeze mnie filmach wpływa na emancypację bohaterów i wydarzeń (bo ścieżka dźwiękowa przestaje jedynie „ilustrować tezy” czy

w filmie jest dialog postaci widocznych w kadrze lub muzyka płynąca ze źródła, które jest obecne w obrazie albo którego obecność zakładamy (np. radia samochodowe w American Graffiti G. Lucasa z 1973 r.), dźwiękiem niediegetycznym jest muzyka ilustracyjna towarzysząca zdarzeniom i postaciom. Komedie M. Brooksa zawierają żarty na temat dźwięku niediegetycznego, który okazuje się dźwiękiem diegetycznym (w Płonących siodłach z 1974 r. szeryfowi Bartowi w drodze do Rock Ridge przygrywa zespół Counta Basiego, koncertujący właśnie na prerii, zaś w Lęku wysokości z 1977 r. w scenie jazdy autostradą "źródłem « ilustracyjnego akompaniamentu jest autobus z grającą orkiestrą Johna Morrisa)". J. Ostaszewski, hasło: Diegeza, [w:] Słownik filmu, cz. 1, red. R. Syska, Kraków 2010.

12 Jerzy Płażewski wyróżnia: (1) muzykę immanentną (źródło w kadrze), (2) muzykę transcendentną (źródło poza kadrem). Trzy funkcje muzyki immanentnej: (a) muzyka jako element akcji, (b) muzyka jako ilustracja, (c) muzyka jako żart. Trzy funkcje muzyki transcendentnej: (a) muzyka imitatorska, (b) muzyka ilustratorska, (c) muzyka samoistna. Przytaczam za: J. Płażewski, Język filmu, Warszawa 2008, s. 341-352.

13 „Wiersz wychodzi z domu i nigdy nie wraca”. A. Sosnowski Wiersz (Trackless), [w:] idem, Taki, Wrocław 2003. 
tė̇ „ukazywać postawy”). Czasami wsłuchanie się w muzycznego narratora potrafi nawet zmienić nastawienie do całego filmu. Możliwość takiej sytuacji zasugeruję na przykładzie Funny Games (choć udział muzyki w tym filmie jest objętościowo niewielki, ograniczony prawie wyłącznie do pierwszych scen), w którym analiza pojawiających się na początku utworów - pod kątem kulturowego porządku, jaki reprezentują - umożliwia zmianę nastawienia do dalszej części filmu. Właśnie muzyka doprowadzi mnie do wniosku, że poddana przemocy rodzina wcale nie jest taka „niewinna”, jak zwykło się przyjmować w omówieniach Funny Games, zaś terror, który ją spotyka, wcale nie jest „anonimowo” totalitarny, ponieważ jego źródło bije niepokojąco blisko takich instytucji, jak opera czy filharmonia. Jeszcze bardziej złożone zmiany perspektywy w odbiorze filmu chcę pokazać na przykładzie muzyki z Pianistki oraz Miłości - tak samo zwracając uwagę na znamienny fakt, że decydując się na użycie tak zwanej muzyki klasycznej, czyli istniejącej od stuleci i wrośniętej w tkankę kultury Zachodu (a nie komponowanej specjalnie do filmu), Haneke pozbawia się dużej części władzy nad filmem i jego możliwymi interpretacjami.

Przy okazji omawiania skutków wykorzystywania kompozycji historycznie „używanych”, a więc siłą rzeczy uwikłanych w zmiany społeczne i kulturowe napięcia, chcę zwrócić uwagę na podobną - jak w przypadku muzyki - rolę znanych i mocno osadzonych w historii kina aktorów występujących u Hanekego. Ten przykład posłuży mi do pełniejszego uzasadnienia tezy, że elementy budujące filmową narrację - niezależnie od pierwotnych intencji reżysera - wnoszą do konkretnego filmu dużo więcej niż swoją estetyczną formę. Barokowa i postromantyczna muzyka w Funny Games czy też kompozycje z epoki muzycznego romantyzmu w Pianistce pozostawiają znacznie mocniejsze „echo semantyczne"14 niż ich czysto brzmieniowa obecność w filmach. To „echo”, niosące rozbudowane sensy i znaczenia, może być dla odbiorcy filmu jeszcze ciekawsze, kiedy Michael Haneke używa muzyki niejako wbrew jej pierwotnemu charakterowi, na przekór narzucającemu się kontekstowi, w tym także na przekór stereotypowym, utrwalonym regułom użycia kompozycji muzycznych w kinie komercyjnym ${ }^{15}$ (tak robi np.

${ }^{14}$ Z. Lissa, Czy muzyka jest sztuką asemantyczną?, „Myśl Współczesna” 1948, nr 10 .

15 „[Wojciech Kilar:] Za obrzydliwą formę muzyki filmowej uważam tę, która pozornie towarzyszy filmowi, dublując inne jego elementy i czerpiąc siłę 
z utworem Johna Zorna, zagłuszającym operowe arie w Funny Games, albo z kompozycją Schuberta, brzmiącą na tle kabiny sex shopu w Pianistce). Dzięki temu Haneke, niejako przy okazji, uszlachetnia swoje dzieła, przenosząc je na wyższe piętra sztuki filmowej.

W niniejszej pracy spróbuję wykazać, dlaczego muzyczna narracja u Michaela Hanekego ma decydujący wpływ na artystyczną rangę jego filmów. Zaryzykuję przy tym hipotezę, że tyle, ile arbitralnej władzy traci reżyser, tyle zyskuje film - na podmiotowości jego bohaterów i głębi opowiadanej historii. Nie dotyczy to zresztą tylko reżysera, ponieważ nawet kompozytor nie jest w stanie kontrolować wszystkich sensów generowanych przez stworzoną przez niego muzykę, tym bardziej że po procesie montażu i ostatecznym spotkaniu dźwięku z obrazem tworzą się nowe poziomy znaczeń (Wojciech Kilar mówił w tym kontekście o nieświadomym i niezamierzonym $z$ góry, a nader istotnym wpływie muzyki na akcję filmu ${ }^{16}$ ). Według Michela Foucaulta, nowoczesna podmiotowość (nowoczesne „ja”) zrodziła się z wizualnego ujarzmienia, z ciągłej obserwacji, jakiej każdy jest poddany ${ }^{17}$. Smutne skutki takiego stanu rzeczy pokazują filmy Hanekego, ale równocześnie muzyka, jaka się w nich pojawia - czasem niezgodna z punktem widzenia kamery, a czasem wręcz „spiskująca” przeciwko niej pełni rolę buntowniczą, rebeliancką wobec nadzorującego film oka. Michael Haneke odżegnuje się od publicznej interpretacji swoich filmów, pozwalając im żyć własnym życiem - życiem dzieł artystycznych, otwartych. W mojej pracy chcę pokazać, że jednym z jego sojuszników w tej strategii jest użyta w filmach muzyka i że jej emancypacja pociąga za sobą emancypację bohaterów i całej filmowej rzeczywistości. Z zamknięcia w kadrze ku otwarciu na świat.

W eseju o filmie Miłość nawet zdradzający niekiedy skłonność do światopoglądowego szufladkowania reżyserskich intencji Tadeusz Sobolewski

z konkretnych, fizycznych wydarzeń ekranowych. To znaczy, że jeśli galop konia - to rytmy na ten temat; jeśli wzburzone morze - to glissanda harfy; jeśli scena miłosna, to obowiązkowo skrzypce". J. Cegiełła, Szkice do autoportretu polskiej muzyki współczesnej. Rozmowy z kompozytorami, Kraków 1976, s. 82-83.

16 Zob. L. Polony, Kilar. Żywioł i modlitwa, Kraków 2005.

17 Zob. M. Foucault, Nadzorować i karać. Narodziny więzienia, tłum. T. Komendant, Warszawa 1998. 
w końcu przyznaje, że „obecna w filmie delikatna symbolika jest przezroczysta, wywiedziona z konkretnych sytuacji"18. Dalej idzie Jakub Majmurek, który na trzeźwej ocenie, że „gołąb jest tu na szczęście tylko gołębiem, nie symbolem ducha świętego czy jakiejkolwiek innej zbłąkanej transcendencji”, opiera sugestię, iż „ta w gruncie rzeczy komiczna, "nic nieznacząca scena« pojawiająca się tuż po najbardziej dramatycznym momencie w filmie, daje poczucie obcowania $z$ wielkim kinem, dotykającym prawdy być może nieuchwytnej w jakimkolwiek innym medium"19. Wniosek Majmurka - nawiązujący mimochodem do uwagi Szkłowskiego, że „chwyt” w sztuce nie ułatwia nam „zrozumienia” przedmiotu, lecz jego „percepcję, ma służyć nie „poznawaniu”, lecz „widzeniu”20 - sporo mówi o podejściu do filmowych środków wyrazu, które czynią z filmów Hanekego rodzaj dzieła otwartego ${ }^{21}$, a więc wymykającego się jednoznacznej interpretacji czy zamknięciu w wygodnym schemacie.

Jeżeli wrócimy teraz znowu na drugi biegun dziejów kina dźwiękowego - do czasów, kiedy z gołębiami zmagali się nie aktorzy, lecz pracownicy techniczni, którzy „wypędzali je poza obszar filmowej diegezy” - będziemy mogli prześledzić (w dość radykalnym skrócie) drogę, jaką pokonała muzyka w filmie, by jego „słyszalny krajobraz” mógł zabrzmieć tak, jak to się dzieje w filmach Michaela Hanekego.

\section{SKĄD SIĘ WZIĘŁA MUZYCZNA NARRACJA U HANEKEGO}

Historycy filmu w dużej mierze zgadzają się, że u zarania kina muzyka pojawiła się w celu zagłuszenia hałaśliwych aparatów projekcyjnych, a dopiero później zauważono, że potrafi istotnie uzupełniać przekaz wizualny ${ }^{22}$.

18 T. Sobolewski, op. cit.

19 J Majmurek, I to jest ta cała miłość?, „Krytyka Polityczna”, www.krytykapolityczna.pl/Blogfilmowy/MajmurekItojesttacalamilosc/menuid-85.html [dostęp: 1.01.16].

20 W. Szkłowski, op. cit. s. 10-28.

${ }^{21}$ Zob. U. Eco, Dzieło otwarte: Forma i nieokreśloność w poetykach współczesnych, tłum. L. Eustachiewicz, Warszawa 2008.

22 I. Sowińska, hasło: Dźwięk w kinie, [w:] Encyklopedia kina, red. T. Lubelski, Kraków 2003, s. 272. 
Z filmoznawcami nie zgadzają się natomiast niektórzy antropolodzy kultury, którzy twierdzą, że muzyka leży w samej „naturze” kina, a jej rytmiczne czy harmoniczne struktury, albo nawet właściwości określonych gatunków muzycznych, są ukryte w filmowych kadrach ${ }^{23}$. Ta różnica poglądów wydaje się mniej istotna z punktu widzenia historycznego, natomiast sygnalizuję ją, ponieważ ma znaczenie dla niniejszej pracy, w której podejście kulturoznawcze czy interdyscyplinarne (szukające związków z innymi dziedzinami sztuki) do filmów Michaela Hanekego bierze górę nad analizą czysto filmoznawczą. Filmy Hanekego, analizowane od strony muzycznej (dziejów muzyki, kontekstów związanych z poszczególnymi utworami i ich obecnością w kulturze), potrafią ujawnić swoje niedostrzegalne dotąd znaczenia, którym „skąpiono uwagi”24, ponieważ twórczość reżysera zwykło się omawiać według stereotypowych kluczy (moralista, skandalista itp.). Aby znaleźć dla muzyki w filmach Hanekego tak głębokie konteksty, na jakie zasługuje, wypada zacząć od początku.

W moim krótkim przeglądzie dziejów muzyki w filmie będę podążał dwiema ścieżkami: prześledzę rozwój sztuki filmowej w kontekście historycznym, koncentrując uwagę na pierwszym półwieczu kina (tutaj oprę się w dużej mierze na dwóch tomach Historii kina pod redakcją Tadeusza Lubelskiego, Iwony Sowińskiej i Rafała Syski ${ }^{25}$ ), oraz przyjrzę się z osobna wybranym klasycznym dziełom filmowym, w których użyto muzyki w sposób przełomowy, a pomysły muzyczne w nich wykorzystane znajdują po latach swoje echo w filmach Michaela Hanekego (tu skorzystam głównie z pierwszych tomów Kina, wehikułu magicznego Adama Garbicza ${ }^{26}$ ).

${ }^{23}$ „Kino jest ze swej natury muzyczne, tak jak opera, choć widzowie nie zdają sobie z tego sprawy”. E. Morin, Kino i wyobraźnia, tłum. K. Eberhardt, Warszawa 1975, s. 110.

${ }^{24}$ „Za pośrednictwem muzyki film otwiera się na kulturowy (a nawet: cywilizacyjny) kontekst w sposób wyjątkowy i zasługujący na uwagę, której dotąd mu skąpiono". I. Sowińska, Polska muzyka filmowa 1945-1968, Katowice 2006.

25 Historia kina, t. I: Kino nieme, red. T. Lubelski, I. Sowińska, R. Syska, Kraków 2009; Historia kina, t. II: Kino klasyczne, red. T. Lubelski, I. Sowińska, R. Syska, Kraków 2012.

26 A. Garbicz, J. Klinowski, Kino, wehikuł magiczny. Przewodnik osiąnięć filmu fabularnego. Podróż pierwsza 1913-1949, Kraków 1981; A. Garbicz, Kino, wehikut 
Do mniej więcej 1905 roku muzykę w kinie odtwarzano głównie z urządzeń typu patefon czy pianola, a taperzy - czyli akompaniujący filmowi pianiści - pojawili się początkowo po to, by zmniejszyć wrażenie „mechaniczności kina” jako medium (jak sugeruje Iwona Sowińska: „dlatego t.[aper] zawsze pozostawał w polu widzenia publiczności stanowiąc dodatkową atrakcję"27). Rola tapera zmieniła się w drugiej dekadzie XX wieku, kiedy produkcję kinową zdominowały filmy fabularne, a samo kino zaczęło udowadniać, że chce być czymś więcej niż „jarmarczną" rozrywką lub sposobem dokumentalizowania rzeczywistości. Wtedy rozpoczęła się także stopniowa emancypacja muzyki w filmie. Taperzy albo improwizowali, uważnie śledząc rozwój fabuły i nadążając za zmianami przekazu emocjonalnego, albo korzystali z kartotek przygotowanych zawczasu utworów (niekiedy dedykowanych konkretnemu filmowi), uwzględniających - i wypełniających stosownym motywem - nawet przerwy na zmianę rolki w projektorze. O rosnącym poziomie taperów i ich biegłości nie tylko w odtwórczym, czysto pianistycznym rzemiośle, najlepiej świadczy fakt, że od tego fachu zaczynał karierę wybitny kompozytor Dymitr Szostakowicz.

Badając początki obecności muzyki w filmie, trzeba od razu oddzielić pojęcie „muzyki w filmie” i „muzyki filmowej”, ponieważ ta pierwsza pojawiała się u samych początków kina (potocznie określanego jako „kino nieme”, które jednak nigdy nie było kinem „bezdźwiękowym”), ta druga zaś upowszechniła się kilkanaście lat później pod postacią kompozycji pisanych specjalnie do kinowych produkcji (na spory dystans czasowy między tymi dwoma formami zwraca uwagę Alicja Helman ${ }^{28}$ ). Niezależnie od innych dźwięków, zarówno utwory muzyczne wzięte skądinąd, jak i utwory pisane na potrzeby rodzącego się przemysłu kinowego były obecne przez większość okresu znanego jako „kino przeddźwiękowe” (czyli przez pierwsze trzy dekady rozwoju kina - do roku 1927) ${ }^{29}$.

Warto przy tym zauważyć, że choć na Zachodzie brak dźwięku w filmie od początku wydawał się problemem technicznym, z którym należało się

magiczny. Przewodnik osiagnięć filmu fabularnego. Podróż czwarta 1967-1973, Kraków 2000.

27 I. Sowińska, Przełom dźwiękowy, [w:] Historia kina, t. 2, op. cit.

28 Zob. A. Helman, Na ścieżce dźwiękowej: o muzyce w filmie, Kraków 1968.

29 Zob. Z. Lissa, Estetyka muzyki filmowej, Kraków 1964. 
uporać, to $\mathrm{w}$ Japonii niemym filmom towarzyszył narrator, zwany benshi, który na żywo opisywał akcję filmu oraz interpretował dialogi. Benshi przypominali raczej aktorów teatralnych niż lektorów, a ich rodowód sięgał tradycyjnego teatru kabuki. Tymczasem jednak w Europie i Ameryce potrzeba wzbogacenia muzycznego komentarza zaowocowała rozwinięciem instrumentarium: taperom zaczęli towarzyszyć skrzypkowie, a potem zespoły muzyczne. Równolegle zaczęto instalować w kinach tak zwane organy Wurlitzera, czyli instrument, który potrafił naśladować brzmienie orkiestry, a także rozmaite naturalne odgłosy.

Bogatsze kina mogły sobie pozwolić na angażowanie regularnych, „żywych" orkiestr, a jedną z pierwszych, które wniosły do kina symfoniczny sznyt i ambicje muzyki poważnej, była London Symphony Orchestra. Pierwszym kompozytorem o nazwisku uznanym wcześniej w filharmoniach, który zdecydował się na debiut w kinie, był Camille Saint-Saëns, który z 1908 roku skomponował muzykę do Zabójstwa księcia Gwizjusza Charlesa le Bargy i André Calmettesa - filmu przełomowego pod wieloma względami: po raz pierwszy opatrzonego listą nazwisk twórców i aktorów, a także cieszącego się opinią pierwszego filmu artystycznego (muzyka w nim „składała się ze wstępu oraz pięciu części; kompozytor operował orkiestrą smyczkową, fortepianem i fisharmonią"30). Kolejny wstrząs estetyczny otwierający muzyce w filmie ogromne perspektywy - wywołał niezwykły rozmach orkiestrowej partytury napisanej przez Josepha Carla Breila do Narodzin narodu Davida W. Griffitha z 1915 roku. Taki rozwój wydarzeń zaczął przyciągać do kina kolejnych klasycznie wykształconych kompozytorów. Niektórzy - jak wcześniej wspomniany Dymitr Szostakowicz - w filmie rozpoczynali karierę, zatem od początku mieli szansę docenić możliwości muzyki filmowej. Innych - jak Siergieja Prokofiewa - film zachęcił gwałtownym rozwojem środków artystycznych (nie było to jednak regułą, bo na przykład Igor Strawińki przejawiał do idei komponowania muzyki do filmu daleko idącą estetyczną niechęćs1).

30 A. Helman, op. cit., s. 10.

31 „Stosunek muzyki do akcji dramatycznej jest taki sam, jak muzyki w restauracji do rozmowy przy stoliku. Nie mogę tego uznać za muzykę". I. Dahl, Igor Strawiński on Film Music, [cyt. za:] S. Kracauer, op. cit., s. 4. 
Pojawienie się na przełomie lat 20. i 30. filmu dźwiękowego nie tylko związku kompozytorów z kinem nie unieważniło, ale wręcz wzmocniło, otwierając przed muzyką - która mogła być teraz nagrywana w studiu, a podczas montażu precyzyjnie dopasowywana do scen - niesłychanie szerokie perspektywy.

\subsection{OD SZANSONISTKI Z KABARETU DO PIANISTKI Z KONSERWATORIUM}

Za pierwszy pełnoprawny film dźwiękowy powszechnie uznawany jest Śpiewak jazzbandu w reżyserii Alana Croslanda z 1927 roku, choć wcześniej miało premierę kilka filmów z mniej lub bardziej zaawansowanymi próbami synchronizacji obrazu z muzyką (np. ambitny pod tym względem Don Juan tegoż Croslanda z roku 1926). W Śpiewaku także nie wszystko było udźwiękowione, niekiedy pojawiły się jeszcze kadry z napisami zamiast dialogów. Aktorzy (od)zyskali mowę w rok późniejszych Światłach Nowego Jorku Boba Foya. Początkowo pojawienie się dźwięku w filmach zostało przez artystów kina przyjęte bez entuzjazmu: dla reżyserów oznaczało to odejście od doskonalonych przez lata $\operatorname{metod}^{32}$, zaś dla aktorów - rezygnację ze specyficznie nadekspresyjnego stylu, który wielu z nich uczynił gwiazdami ${ }^{33}$. Aby ten stan rzeczy mógł się zmienić, trzeba było poczekać na pierwsze filmy, w których muzyka, i w ogóle warstwa dźwiękowa, pojawiły się nie dlatego, że była już taka technologiczna możliwość, tylko dlatego, że stanowiły artystycznie przemyślaną część dzieła, poszerzającą pole jego środków wyrazu. Za pierwsze filmy, w których muzyka jest równoprawnym partnerem obrazu i decyduje o emocjonalnej sile utworu i głębi jego przekazu, uznaje się Dusze czarnych Kinga Vidora z 1930 roku oraz Błękitnego anioła Josefa von Sternberga z 1931 roku.

W filmie Vidora uderza, z jednej strony, autentyzm użytych motywów (akcja dzieje się w Alabamie, w środowisku afroamerykanów - stąd muzyka

32 „Filmowcy wielkiego formatu nie mogli się wewnętrznie pogodzić z koniecznością przewartościowania tak wyśmienicie już wypracowanej stylistyki filmu bez głosu”. Dusze Czarnych, [w:] A. Garbicz, J. Klinowski, op. cit., s. 157.

${ }^{33} \mathrm{O}$ dramatycznym aspekcie przełomu dźwiękowego w dziejach kina w niezrównany sposób opowiada film Bulwar Zachodzącego Słońca Billy’ego Wildera z 1950 roku. 
bluesowa, soulowa, negro spirituals) i ich organiczny związek z fabułą (pełne wewnętrznego żaru „czarne” songi stają się równoległą do obrazu narracją o niszczącej sile erotycznej namiętności), a z drugiej strony - równie nowatorskie potraktowanie ciszy, która pozwala na niezwykle sugestywne wprowadzenie dźwięków naturalnych albo na podnoszenie poziomu emocji w momentach, kiedy widz raptem sam musi sobie dopowiedzieć, co się stało. Traf chciał, że drugi film z pierwszej pary dźwiękowych arcydzieł kina, czyli Błękitny anioł, także opowiada o fatalnym seksualnym zauroczeniu, muzyka zaś z podobną brawurą (choć tym razem zamiast autentycznego folkloru mamy piosenki skomponowane specjalnie do filmu ${ }^{34}$, a zamiast głosów reprezentujących całą afroamerykańską tradycję muzyczną - głos jednej jedynej Marleny Dietrich) wkracza w świat ludzkiej świadomości i podświadomości, portretując go równolegle z obrazem.

Warto zatrzymać się dłużej przy tym drugim filmie, co pozwoli skojarzyć kilka zasadniczych wątków i metod twórczych obecnych u von Sternberga z wątkami i metodami twórczymi, które siedemdziesiąt lat później pojawią się u Michaela Hanekego, a także zauważyć, że ich nośnikiem jest muzyka u obu reżyserów wykorzystana (czy raczej: nadająca filmowi niebywale intensywne życie) w podobny sposób. Urodzony w stolicy Austrii Josef von Sternberg jako dziecko wyjechał do Stanów Zjednoczonych, lecz po kilku dekadach, już jako uznany filmowiec, wrócił do Europy (na zaproszenie niemieckiej wytwórni UFA). Wrócił, by zrobić film nie tylko zbyt śmiały obyczajowo jak na ówczesne amerykańskie standardy, ale też mierzący się z psychologicznymi i społecznymi problemami z ducha ,europejskimi”, a już szczególnie związanymi $\mathrm{z}$ atmosferą Niemiec i Austrii, które to państwa poddaje reżyser (w końcu - pochodzący z Wiednia) swoistej psychoanalizie ${ }^{35}$.

${ }^{34}$ Piosenki śpiewane przez Marlenę Dietrich skomponował Friedrich Holländer. Wywodził się on ze znanej rodziny zamieszkałej w Głubczycach, a zanim zrobił karierę w Hollywood, od osiemnastego roku życia pisał przeboje dla berlińskich kabaretów, więc z mistrzostwem potrafił oddać atmosferę pełną erotycznych podtekstów, zajrzeć za pomocą muzyki w mrok ludzkiej podświadomości; chętnie sięgał w tym celu do formy walca jako muzycznego motywu miłosnego.

${ }_{35}$ „W jego dziele chodzi o ukazane $\mathrm{z}$ wielką przenikliwością duchowe wnętrze Niemiec. Rygor porządku prowadzi tu do niepohamowanego wyładowania wszystkich niszczycielskich instynktów, kiedy tylko nadarzy sie ku temu okazja; 
Poszukiwaczem podobnych (i mających zbliżone źródła) zbiorowych traum jest Michael Haneke, który urodził się co prawda w niemieckiej Bawarii, ale w Wiedniu spędził młodość i zdobył wykształcenie. Efektem tego jest pokrewieństwo ideowe oraz artystyczne obu twórców, szczególnie widoczne, jeżeli porównać Błękitnego anioła i Pianistkę - w jednym i drugim filmie obserwujemy zmagania „kultury wysokiej” z „niskimi pobudkami”, „kulturalnej” moralności, dyscypliny społecznej, sztuki - z „naturalnym”, nagim istnieniem. Przy czym w obu filmach muzyka dochodzi do uszu widza wcale nie zza kadru czy z tła wydarzeń (jako ich ilustracja czy komentarz), tylko $\mathrm{z}$ centrum filmowej diegezy, tętniąc w samym sercu konfliktu.

Jeden z najbardziej sugestywnych efektów von Sternberg osiąga, kiedy zderza pieśń o tradycyjnych wartościach, płynącą z zegara w miejskim ratuszu, z kabaretowym songiem ku chwale fizycznej miłości, zmysłowej i nieokiełznanej - i słychać w tym zderzeniu całą kolizję wartości, jaką zgotował przełom XIX i XX stulecia (winowajcy krachu wartości tworzą nader szacowną ławę oskarżonych, na czele z Darwinem, Freudem, Einsteinem i Nietzschem). Przełom XX i XXI stulecia okazuje się dla ludzkiego ciała i duszy niewiele łaskawszy - o czym donosi Michael Haneke, zderzając uduchowione kompozycje klasyków i szlachetne wnętrza filharmonii z podłą atmosferą sex shopów i porno-klubów, których tyleż potajemnym, co regularnym gościem jest szacowna pianistka. Haneke donosi o tym wszystkim nieuprzejmie, czyniąc bohaterkę - wyrafinowaną koneserkę Bacha i Schuberta - osobą uzależnioną od ostrej pornografii i sadomasochistycznego seksu.

Obydwa filmy łączy także odwaga reżyserów we wkraczaniu na zakazane w kinie mainstreamowym obszary, „zarezerwowane” choćby dla kina pornograficznego - i w obu przypadkach ich filmy okazują się na tyle wybitne, by wykraczać daleko poza wymiar obyczajowego „skandalu”. Pianistka zawiera sceny pod względem seksualnym drastyczne, nawet jak na liberalną współczesną Europę (Błękitny Anioł w purytańskiej atmosferze przedwojennej Ameryki budził porównywalne zgorszenie), ale ich obecność

rygor surowej mieszczańskiej moralności przynosi klęskę i upadek jednostce, którą namiętność zmusiła do sprzeniewierzenia się ideałom: tak oto brak wolności prowadzi do zwyrodnienia”. Błękitny Anioł, [w:] A. Garbicz, J. Klinowski, op. cit., s. 169. 
dodaje do filmu Hanekego nowe piętra znaczeń i sensów (także w kontekście emocji, jakie wywołuje u widza, oraz pytania: kto właściwie jest bohaterem pianistki? - które zadam przy okazji analizy filmu i towarzyszących mu reakcji $)^{36}$.

Oczywiście, odpowiednikiem „treściowym” tytułowej bohaterki Pianistki, Eriki - akademickiej wykładowczyni fortepianu, wcale nie jest w Błękitnym Aniele Lola - kabaretowa szansonistka, tylko uwiedziony przez nią, szanowany i pryncypialny nauczyciel, profesor Rath. Jednak można dopatrzeć się kilku „formalnych” analogii w sposobie kreślenia za pomocą muzyki portretów obu kobiet i obrazów ich relacji ze światem. $Z$ jedną wszakże zasadniczą różnicą. Wykreowana przez Marlenę Dietrich Lola stała się - w dużej mierze dzięki walorom wokalnym - jedną z ikon kobiecej seksualności, co spowodowało przejęcie tego wizerunku przez kulturę masową i wpłynęło na ewolucję wzorca kobiecości w XX wieku. Natomiast zagraną przez Isabelle Hupert Erikę - której neurotyczną urodę wzmacnia makijaż fortepianowej klasyki - można uznać za antybohaterkę kultury, zepchniętą na ciemną stronę. Erika jest rewersem tej samej „kobiecości”, której awersem jest Lola.

\subsection{OD FABRYKI MARZEŃ DO MANUFAKTURY KOSZMARÓW}

Wróćmy jednak do przerwanego wcześniej wątku - czyli do lat 30. ubiegłego wieku. W okresie upowszechniania się filmu dźwiękowego pojawiło się pokolenie kompozytorów, których można już nazwać filmowymi, ponieważ kino stało się dla nich najważniejszym polem działania oraz źródłem dochodów. Obok takich nazwisk, jak Maurice Jaubert, Joseph Kosma, Alfred Newman, Miklós Rózsa, Max Steiner, Herbert Stothart czy Dmitri Tiomkin, można jednym tchem wymienić pochodzącego z Polski Bronisława Kapera (laureata Oscara za muzykę do filmu Lili). Twórcy ci osiągnęli dojrzałość twórczą w tak zwanej Złotej Erze Hollywood, trwającej - według jednych

${ }^{36}$ „Sztandarowe książki Lindy Williams czy Montgomery'ego Hyde’a [socjolodzy zajmujący się historią pornografii i jej miejscem w kulturze - przyp. M.W.] lokują dosadne reprezentacje seksualności w kontekście historii sztuki, socjologii, antropologii, sposobów reprezentacji, dyskursów nad kobiecością, studiów filmoznawczych itd.”. P. Sołodki, Rubieże przyjemności. Seksualna niesubordynacja na obrzeżach amerykańskiej kinematografii, Gdańsk 2015, s. 467. 
historyków kina - do końca lat 40. (czyli do wyroku Sądu Najwyższego USA, który zakończył działalność monopolistycznego sytemu kin studyjnych podporządkowanych wielkim wytwórniom), zaś według innych badaczy aż do połowy lat 60. i przełomu kontrkulturowego, co może sugerować, że cały okres da się zamknąć w latach wprowadzenia i uchylenia cenzorskiego kodeksu Haysa ${ }^{37}$. Podstawowe cechy muzyki filmowej z okresu „Golden Age” to odwołania do XIX-wiecznego neoromantyzmu (Max Steiner był uczniem klasycznych kompozytorów - Johanesa Brahmsa i Gustava Mahlera), potężne składy symfonicznych orkiestr, a także zachowawczość w trzymaniu się określonych - oczekiwanych przez widza i nienaruszających zastanych kanonów - środków wyrazu.

Pozostańmy jeszcze przez chwilę w trzeciej dekadzie XX stulecia, kiedy równolegle z rozkwitem Hollywood oraz wytwórni niemieckich - nastąpił gwałtowny rozwój kinematografii rosyjskiej. Podwaliny pod tak zwaną rosyjską szkołę montażu położyli z jednej strony Lew Kuleszow i Wsiewołod Pudowkin (swym słynnym eksperymentem $z$ twarzą, którą sfilmowali w trzech różnych kontekstach za pomocą trików montażowych, co spowodowało trzy różne reakcje widzów), z drugiej zaś strony Siergiej Eisenstein,

37 „Gdy w 1922 r. szefowie wielkich wytwórni filmowych powołali Motion Pictures Producers and Distributors Association, kierowanie nim zaproponowali ówczesnemu amerykańskiemu Generalnemu Poczmistrzowi. Funkcję tę pełnił William Harrison Hays, prominentny polityk, działacz rządzącej Partii Republikańskiej. Nie dość, że cieszył się zaufaniem i poparciem Białego Domu, to jeszcze był dostojnikiem Kościoła prezbiteriańskiego. [...] W 1934 r. prawem przewidującym kary stał się kodeks, który przeszedł do historii jako »Kodeks Haysa«. [...] Tak powstał dziwaczny, szczegółowy zbiór komicznie dziś brzmiących nakazów, które ogólnie sprowadzały się do zasady, iż »sympatia widzów nigdy nie powinna być po stronie zbrodni, zła i grzechu«. [...] Wpływ zmian społecznych i obyczajowych, decyzje Sądu Najwyższego oraz działania organizacji na rzecz swobód obywatelskich wymusiły znaczne złagodzenie kodeksu w 1966 r. Co prawda nadal kładł on nacisk na cnotę i potępiał grzech, ale jeśli chodzi o seks, nie zakazywał go, a jedynie zalecał umiar w podejmowaniu tego tematu. $Z$ drugiej strony zwracał baczniejszą uwagę na sceny przemocy. W $1968 \mathrm{r}$. kodeks został zastąpiony przez system klasyfikujący filmy wedle wieku, jaki widz powinien mieć, by je oglądać”. Ł. Dziatkiewicz, Narodziny filmowej cenzury, „Dziennik”, dodatek „Weekend” z dnia 31.05.2014 r. 
który opublikował słynny artykuł Montaż atrakcji. Jego tekst (zamieszczony w czasopiśmie awangardystów) stawiał fundamentalną dla rozwoju kina tezę, że zestawienie dwóch obrazów (z czego niedaleko do wniosku, że także: obrazu i muzyki) nie jest ich sumą, ale całkiem nową jakością. Czyli w efekcie podawał definicję filmowej metafory.

W tym samym okresie Dżiga Wiertow, absolwent psychoneurologii, który kręcił w latach 1917-25 szereg kronik filmowych, stworzył manifest „Kino-Oko", w którym głosił wierność rzeczywistości, ale zakładał opisywanie jej za pomoca języka-montażu. Co prawda u Pudowkina i Wiertowa ów język pozostał jeszcze wyłącznie na poziomie wizualnym ${ }^{38}$, ale już Eisenstein który dał pierwszy popis wizualnego montażu w filmie Październik z 1929 roku - do pracy nad Aleksandrem Newskim z 1938 roku zaprosił Siergieja Prokofiewa, co zaowocowało arcydziełem harmonii „obraz-muzyka”. Dla reżysera najistotniejsze były metafora i kontrapunkt: to nad tymi środkami, podczas niezwykle długiego i precyzyjnego procesu montażu, pracowali z kompozytorem, którego rola dalece wykraczała poza samo napisanie muzycznej partytury ${ }^{39}$. Eisenstein od początku odrzucał ideę ilustracyjności muzyki czy też jej jakkolwiek „mimetycznej” funkcji wobec pokazywanego obrazu (w czym zaczął się właśnie specjalizować Hollywood, za pomocą ścieżki dźwiękowej ujednolicając i ujednoznaczniając przekaz wizualny).

Wcześniej jednak do głosu - w sensie dosłownym - doszli także inni rosyjscy filmowcy. Siergiej Rutkiewicz i Fridrich Ermler zamówili u Dymitra

38 Pudowkin zachwyca rytmem zmiennych kadrów w Burzy nad Azja z 1928 roku, natomiast Wiertow oszałamia dynamiką obrazów w rok późniejszym Człowieku z kamerą.

39 „Nad Aleksandrem Newskim twórcy pracowali w niesłychanym tempie. Przeglądając w nocy nakręcony materiał, już przed południem Prokofiew przynosił napisaną muzykę, od której Eisenstein uzależniał ostateczny kształt sceny. O współpracy tej reżyser pisał: »Są sceny o obrazie zmontowanym według muzyki uprzednio nagranej na taśmie dźwiękowej. Są sceny, do których ilustracja muzyczna została skomponowana na podstawie obrazu oglądanego w ostatecznej wersji montażowej. Są sceny realizowane w najrozmaitszych wariantach. [...] Z Prokofiewem zawsze się długo targujemy, kto pierwszy. A spieramy się dlatego, że pierwszemu przypada w udziale zasadniczy twórczy trud: ustalić odpowiedni rytm sceny«". A. Helman, op. cit., s. 75. 
Szostakowicza pierwszą stricte filmową suitę orkiestrową, którą dopasowali potem do scen swojego filmu Turbina $50000 \mathrm{z}$ roku 1932. Bardziej spektakularne rezultaty włączenia muzyki w strukturę montażową osiągnięto w filmie My z Kronsztadu Jefima Dzigana z 1932 roku. Utwory napisane do filmu przez Nikołaja Krukowa organicznie wrastają w tkankę wydarzeń, w dźwięki otaczające bohaterów, zaś śpiewana w jednej ze scen Międzynarodówka jest tak wpisana w dramaturgię filmu, że działa jednocześnie na poziomie realistycznym (śpiew w bitewnym zgiełku) i symbolicznym ${ }^{40}$.

Wszystko to było oczywiście podporządkowane komunistycznej ideologii i budzeniu w widzu odpowiedniej świadomości (co zresztą skończyło się, kiedy tylko Stalin umocnił się u władzy). Mimo to trzeba podkreślić, że $\mathrm{w}$ porównaniu $\mathrm{z}$ wyrafinowaniem środków użytych przez rosyjskich reżyserów, przemysłowa wytwórczość „marzeń”, których fabrykami były studia w Hollywood, ograniczała się (przy podobnym zamiarze: sformatowania emocji widza) głównie do utwierdzania estetycznych schematów przy unikaniu artystycznego ryzyka. Symbolem hollywoodzkiego stylu (ścieżek dźwiękowych balansujących między dętym patosem a ckliwym smyczkowym liryzmem) może być urodzony w 1901 roku Alfred Newmann, który napisał muzykę do ponad trzystu filmów i był - w co trudno uwierzyć - czterdzieści pięć razy nominowany do Oscara (statuetkę odebrał skromne dziewięć razy). Na szczęście każda reguła wymaga istnienia wyjątków. U takich hollywoodzkich kompozytorów jak Jerry Fielding i Elmer Bernstein (obaj urodzeni w 1922 roku) noworomantyczna symfonika bywała często przełamywana: a to motywami z folkloru meksykańskiego (Bernstein w Siedmiu wspaniałych Johna Sturgesa, Fielding w Dzikiej bandzie Sama Peckinpaha), a to śmiałymi i chwytliwymi tematami nie tyle komentującymi, ile napędzającymi akcję (Bernstein w marszu wojskowym z Wielkiej ucieczki Sturgesa, Fielding w sugestywnie mrocznych motywach z Dajcie mi głowę Alfredo Garcii Peckinpaha).

Współpraca Jerry’ego Fieldinga z Samem Peckinpahem przywodzi na myśl inne wybitne duety kompozytorsko-reżyserskie, w których muzyka nie ograniczała się do ilustracji scen, na przykład tandem Bernard Herrmann Alfred Hitchcock, współpracujący ze sobą dobrych kilkanaście lat, choć

${ }^{40}$ My z Kronsztadu, [w:] A. Garbicz, J. Klinowski, op. cit., s. 256. 
stał tu na przeszkodzie skrajnie trudny charakter obu artystów. Co ciekawe, mimo sukcesów z Hitchcockiem (choćby w Psychozie, gdzie surowa oszczędność muzycznych motywów tym mocniej spaja je $\mathrm{z}$ akcją), bodaj jeszcze wspanialsze rezultaty osiągnął Herrmann przedtem i potem, czyli na samym początku i u kresu kariery kompozytora filmowego. Jego debiutem w kinie była muzyka do Obywatela Kane’a Orsona Wellesa, w której pojawiły się - analogiczne do zniekształceń obrazu - dysonanse i zawirowania, natomiast ostatnim filmem, do którego napisał ścieżkę dźwiękową (i którego premiery, niestety, już nie dożył), był Taksówkarz Martina Scorsese, gdzie motywy miękko zorkiestrowane symfonicznie raptem ustępują, zgodnie z przyspieszającym pulsem filmu, przed improwizacjami jazzowymi (co ma metaforyzować nie tylko wydarzenia przedstawione w samym filmie, ale także rzeczywistość lat 70.).

Taksówkarz miał premierę w 1974 roku, ale żeby w ogóle doszło do jego nakręcenia (tudzież do powstania całego nurtu mrocznych i gwałtownych filmów z lat 70., których twórcy, obserwując rzeczywistość od innej niż dotychczas strony, wypracowali nowe sposoby widzenia i słyszenia), konieczna była o kilka lat wcześniejsza rewolta w łonie całej zachodniej kultury. W połowie lat 60. amerykańscy twórcy śmielej otworzyli muzykę filmową na jazz (np. wspomniany już Elmer Bernstein) czy rytmiczną muzykę pop (np. Lalo Schifrin, autor przebojowego motywu z Mission Impossible). Miejsce masywnych i mieszczańsko sytych motywów orkiestrowych zajęły kapryśnie synkopujące melodie i chwytliwe piosenki (choćby duetu Simon i Garfunkel w filmie Absolwent - jednym z symboli kontrkultury), zaś w aranżacjach przybyło ironii i stylistycznej przewrotności.

Specjalistą od tych ostatnich był Ennio Morricone, który tworzył wraz z Sergio Leone jeden ze słynnych duetów reżysersko-kompozytorskich. Obaj zaczynali od serii tak zwanych spaghetti-westernów z lat 60., których znaczenie dla sztuki filmowej zaczęto doceniać dopiero kilka dekad później. Morricone włączył do partytur filmowych dźwięki naturalne (strzały, gwizd, odgłosy zwierząt, łamanie patyków), szacowne brzmienie rodem z filharmonii zderzał z efektami psychodelicznymi czy industrialnymi (zgrzyt pociągu, chwiejący się na wietrze metalowy szyld), regularnie sięgał po rzadko spotykane instrumenty (harmonijka ustna, okaryna, drumla), a podniosłe melodie „ku pokrzepieniu serc” zastąpił zawadiackimi tematami sławiącymi raczej męską dzielność i zaradność niż stojące za nimi intencje (niekiedy 
nader ambiwalentne moralnie). W późniejszej twórczości Morricone nieco się ustatkowal, ale motyw fletni pana z Dawno temu w Ameryce Sergio Leone, kolizja melodyjnego tematu ze złowrogim motywem niby rozstrojonej orkiestry we Franticu Romana Polańskiego czy przemyślne kontrapunkty europejskiej symfoniki z indiańskim folklorem w Misji Rolanda Joffé mają swoje estetyczne źródła w cyklu na pozór błahych filmów o przemocy, zachłanności i podłości.

Rozmaite moralne i estetyczne niepokoje filmu lat 70. uległy stopniowej komercjalizacji (jak przypominają co przytomniejsi: kina nie wymyślili artyści, ale inżynierowie i przemysłowcy), ale cieszące się jak zwykle największą popularnością kino gatunkowe pozostało nimi zainfekowane. Na polu muzyki filmowej upowszechnił się np. model action score (czyli po prostu muzyka kina akcji), który ma dynamizować przebieg wydarzeń (znakomite okazują się synkopujące motywy jazzowe), podtrzymywać napięcie (wszak nowoczesne kino akcji to jedno z dzieci klasycznego thrillera, tyle że źródłem nerwowego pulsu bywa skromniejsze instrumentarium) i pozostawiać widza w poczuciu zagrożenia i niepewności, także tej wykraczającej poza salę kinową (tu nieoceniona jest elektronika, także ta najsurowsza, bliska muzyce industrialnej - utwory Vangelisa do Łowcy Androidów Ridleya Scotta to jeden z najbardziej spektakularnych przykładów jej zrośnięcia się z filmowym obrazem).

Pamiętając o nominacji do Oscara za rok 2015 dla Johna Williamsa za muzykę do siódmej już części cyklu Gwiezdne wojny, warto cofnąć się o dwie dekady i przypomnieć tło, na jakim powstała ścieżka dźwiękowa do pierwszej części cyklu - z 1977 roku. Wtedy - w otoczeniu muzyki kina lat 70., wspomnianej w kilku poprzednich akapitach - taki powrót nie tylko do symfoniczności, z jej gestem melodycznym i patetycznym nastrojem (motyw z czołówki, marsz imperium), ale w ogóle do atmosfery „złotego wieku” Hollywood, miał w sobie odświeżającą siłę, wartą choćby Oscara (którego Williams wówczas dostał). Natomiast przyczyną nominacji w roku 2016 nie jest ani muzyczna wartość nowych utworów zasłużonego kompozytora, ani w jakikolwiek sposób zaskakujące czy przewrotne ich użycie, lecz skłonność Hollywood do pewnej estetyki - a żadnej estetyki nie oderwiemy od światopoglądu czy hierarchii wartości.

Kiedy w scenie otwierającej Funny Games Michaela Hanekego kulturalna mieszczańska rodzina słucha $\mathrm{z}$ samochodowego odtwarzacza tradycyjnej 
muzyki klasycznej, którą przerywają ataki gwałtownego noise’u granego przez zespół Johna Zorna, można odebrać to jako zapowiedź, skrót czy nawet diagnozę mających nastąpić dramatycznych wydarzeń. Ale można też umieścić tę scenę w szerszym kontekście muzyki filmowej, która tkwiąc korzeniami w XIX-wiecznej tradycji symfonicznej (i stojącym za nią modelu życia), na przemian zrywała i powracała do tych inspiracji.

Zgiełk zespołu Naked City, wybuchający w rodzinnym aucie i brzmieniowo miażdżący arie z klasycznych oper, jest na tyle gwałtowny, że przebija się nie tylko ku dalszej części filmu - przez kruchą karoserię chronologicznego przebiegu wypadków - ale wydostaje się w ogóle na zewnątrz dzieła Hanekego. Jego pogłos (czyli wspomniane już „echo semantyczne”) słychać w długim na stulecie hallu historii kina.

\subsection{OD NATURALNOŚCI DO DOSKONAŁOŚCI. I Z POWROTEM}

Oczywiście, historia muzyki w kinie nie ogranicza się do naprzemiennej dominacji stylu rodem z Hollywood i „nadgryzania” go przez wpływy z Europy. Linie podziałów i różnic są dużo bardziej zawiłe. Odrębną, niezależną drogę wybrał w latach 30. René Clair, u którego dochodzi do swoistego „mocowania się” obrazu z dźwiękiem ${ }^{41}$. Świat filmów Claira tętni życiem zarówno w sferze wizualnej (nadaktywni bohaterowie w komediowych sytuacjach o Chaplinowskim odcieniu, ale w realiach miasteczkowej Francji), jak i audialnej (wszechobecna gadatliwość, krzątanina w domach, hałas ulic i jarmarków). Niby jest to muzyka kreśląca obyczajowe pejzaże i serdeczne portrety ludzkie, lecz kiedy przysłuchać się uważniej, okazuje się, że często kontrapunktuje lub nawet zaprzecza widzianym na ekranie wypadkom przez swoje groteskowe przerysowanie albo zgoła metafilmowe zabiegi typu wyciemnianie kadru, mimo że wydarzenia toczą się dalej, wyciszanie dialogu, choć rozmawiający aktorzy pozostają widoczni na ekranie, albo mylenie tropów, które wątki muzyczne należą do sfery wewnątrzkadrowej,

${ }^{41}$ „W myśl koncepcji Claira obraz ma za zadanie przytłaczać dźwięk, przy czym fonia - i tu zasadnicze odstępstwo od poglądów Chaplina - winna odpłacać się pięknym za nadobne. Obie płaszczyzny filmowego spektaklu, po równo obdarzone impulsywnością, są świadomie skłócone i toczą ze sobą zaciętą walkę o dominację". T. Wojciechowski Dźwięk w kinie, cz. 4 - komedie René Claira, http://film.org. pl/a/artykul/dzwiek-w-filmie-cz-4-komedie-rene-claira-32764/ [dostęp: 1.01.16]. 
a które już nie ${ }^{42}$. Zaprzecza to opinii o „poczciwości” filmów Claira (który wszak w młodości był śmiałym awangardzistą, a zamiłowanie do przewrotnych wolt pozostało mu na zawsze), ale z drugiej strony stoi u źródła wrażenia, które Adam Garbicz, analizując klasyczne Pod dachami Paryża,

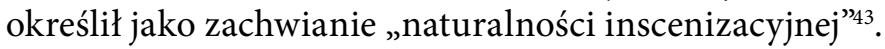

Właśnie z ową "naturalnością" zmagali się francuscy spadkobiercy Claira, np. reżyserzy Nouvelle Vague, którzy z jednej strony chcieli uchwycić samo życie w jego szorstkości i „niefilmowości”, ale z drugiej - brnęli w pozakadrowe, literackie komentarze, odczytywane nadto skrupulatnie „strumienie świadomości" bohatera. Jean Luc Godard wyreżyserował, oprócz kilku sztandarowych dzieł Nowej Fali w rodzaju Do utraty tchu, także paradoksalnie nowofalowy musical Kobieta jest kobietą, w którym aktorom zdarza się (pytanie: „naturalnie”, czyli jakby mimochodem, czy raczej „sztucznie”, z powodów artystycznych?) nucić motywy z muzyki pochodzącej ze sfery niediegetycznej, dobiegające ewidentnie spoza kadru. Niezależnie od odpowiedzi na to pytanie, Godardowi udało się przerzucić tym filmem co najmniej dwa efektowne pomosty. Jeden w przestrzeni: między awangardowym kinem europejskim a komercyjną amerykańską formą musicalu. Drugi zaś w czasie: między Pod dachami Paryża (1930) a Parasolkami z Cherbourga $(1964)^{44}$.

Na dylemat "naturalności” (wynikającej z filmowej prostoty podglądania ludzkich zachowań przez kamerę) i „sztuczności” (wynikającej z artystycznego aspektu kina, coraz bogatszego w środki formalne) warto spojrzeć z zewnątrz, spoza Europy i USA - czyli choćby z perspektywy Dalekiego Wschodu. Akira Kurosawa mówił o świadomym niedopełnieniu obrazu, pozostawieniu przez reżysera celowych luk, które ma zapełnić dźwięk, a ideę tę świetnie realizował Masaru Satô, współpracujący z nim przy tak

${ }^{42}$ „W scenie barowej bójki z Pod dachami Paryża grzmiąca z gramofonu uwertura do Wilhelma Tella Rossiniego powoduje konfuzję przyglądającego się starciu dwójki przyjaciół pijaka, który surrealistyczny obrazek uznaje za przejaw delirium. Zaskoczony dowcipem widz sam już nie wie, czy muzyka rzeczywiście dobiega $\mathrm{z}$ winylowej płyty, czy jest wytworem umysłu wstawionego jegomościa”. Ibidem.

${ }^{43}$ Pod dachami Paryża, [w:] A. Garbicz i J. Klinowski, op. cit., s. 171.

44 Film w reżyserii Jacquesa Demy z muzyką Michela Legranda, w którym wszystkie partie, nawet kwestie dialogowe, są śpiewane. 
znakomitych filmach, jak Ukryta forteca czy Straż przyboczna. Do jeszcze ciekawszych rezultatów doszedł Fumio Hayasaka, pracujący z reżyserem przy Siedmiu samurajach z 1954 roku. W filmie tym dźwięk wkracza znacznie śmielej w strukturę sceny, na pozór zaburza ją (np. gwałtowny rytm zakłócający kontemplację olśniewającej przyrody w scenie przed bitwą), ale $\mathrm{w}$ istocie poszerza jej panoramę, tyle że o elementy niewidoczne (rosnące przed walką napięcie $)^{45}$. W dodatku muzyczny komentarz zdaje się nadążać za chwilowymi zmianami akcji, ale tej synchronizacji ruchu wewnątrzkadrowego z muzyką (np. werblem kojarzącym się z biciem serca) bliżej do jazzowej improwizacji - która nie wyklucza przecież precyzyjnego zgrania instrumentów - niż do kontroli, jaką chciał uzyskać kilkanaście lat wcześniej Siergiej Eisenstein.

Montażowa skrupulatność - efekt wytężonych godzin współpracy Eisensteina z Prokofiewem - powoduje, że wiele scen z Aleksandra Newskiego sprawia wrażenie ożywiania czy też sklejania ze sobą „martwych” (przez swoje posłuszeństwo) wycinków rzeczywistości, przyszpilania motyli do maty. Mamy zatem w filmie rosyjskiego reżysera „ciąg rzutów przestrzennych" ${ }^{\text {"46 }}$ zamiast rozwijania się w czasie (dylemat, którego istotę ujmuje paradoks lecącej strzały, ukuty przez Zenona z Elei). Bardzo ta skrupulatność i kontrola irytowały Andrieja Tarkowskiego, który w jednym z tekstów krytycznych napisał, że: „u Eisensteina nie czuje się w poszczególnych ujęciach prawdy czasu - są one zupełnie statyczne i anemiczne. Wynika to oczywiście ze sprzeczności istniejącej między zewnętrzną zawartością ujęcia, która nie utrwala żadnego czasu, a szybkością postępowania po sobie całkowicie nienaturalnych połączeń - narzuconych z zewnątrz i obojętnych wobec płynącego w ujęciach czasu" ${ }^{\prime 47}$. Słowa te sporo mówią nie tylko o różnym u obu znakomitych reżyserów podejściu do materii filmowej, ale także o panującym w Związku Radzieckim ustroju, którego jednym z podstawowych elementów było pragnienie podporządkowania trywialnego życia

${ }^{45}$ Piotr Sawicki, Czas i energia. Kurosawa a muzyka, [w:] Akira Kurosawatwórca japoński, twórca światowy, red. W. Laskowska-Smoczyńska, P. Kletowski, Kraków 2011, s. 69.

${ }^{46}$ T. Wojciechowski, Dźwięk w kinie, cz. 6 - Aleksander Newski, http://film. org.pl/a/analiza/dzwiek-w-kinie-cz-5-aleksander-newski-36801/ [dostęp: 1.01.16].

47 Ibidem. 
wzniosłej idei, a także totalitarna kontrola najdrobniejszych nawet tegoż życia elementów.

Nie odnosząc się już bezpośrednio do Eisensteina, ale w ogóle do kina jako sztuki, Tarkowski daje wyraz podejściu bliskiemu Kurosawie, pisząc: „Prawdziwą muzykę kina tworzy starannie zorganizowany w filmie i muzyczny w swojej istocie świat dźwięków. [...] Dźwięki otaczającego nas świata są tak piękne, że jeśli nauczylibyśmy się ich słuchać z należytą uwagą, muzyka nie byłaby kinu potrzebna"48. Jeżeli przyjrzymy się różnicy w podejściu Hanekego do muzyki w Funny Games (gdzie jest użyta dość instrumentalnie, by zapowiedzieć wydarzenia, zwięźle scharakteryzować nawet nie postacie, ale psychologiczne typy bohaterów oraz ich status społeczny czy kulturowy) i w Miłości (gdzie towarzyszy bohaterom tak, jak towarzyszą im inne dźwięki powszedniej codzienności), możemy zaryzykować tezę, że Haneke przeszedł między tymi filmami drogę od Eisensteina do Tarkowskiego.

\section{JAK I O CZYM MÓWI MUZYKA W FILMACH HANEKEGO}

„Panicznie boję się przemocy fizycznej, chociaż nigdy nie zostałem nawet uderzony" - powiedział Haneke w dokumentalnym filmie 24 rzeczywistości na sekundę $e^{49}$. W innym dokumencie, Michael Haneke: Moje życie, aktorka Juliette Binoche jednym tchem wymienia kolejne obsesyjne lęki reżysera: „Śmierć, choroba, cierpienie, strach przed odrzuceniem, byciem niedostrzeganym, niesłyszanym" ${ }^{50}$. Z drugiej strony, mamy wspomnienie austriackiego reżysera o oglądanym na studiach Tomie Jonesie Tony'ego Richardsona i metafilmowym geście bohatera - niespodziewanym odwróceniu się wprost do kamery, by powiedzieć „Mam nadzieję, że mnie nie złapią” - który wstrząsnął Hanekem i był, według słów reżysera: „totalnym

48 A. Tarkowski, Czas utrwalony, tłum. S. Kuśmierczyk, Warszawa 2007.

4924 Realities per Second: A Documentary on Michael Haneke, reż. N. Kusturica i E. Testor, [cyt. za:] M. Sadowska, Michael Haneke: cichy włamywacz, „Newsweek” z dnia 31.10.2012 r., www.newsweek.pl/kultura/film/michael-haneke--cichy-wlamywacz,97712,1,1.html [dostęp: 30.05.16].

50 Michael Haneke: My life, reż. Felix i Gero von Boehm, [cyt. za:] M. Sadowska, op. cit. 
odczarowaniem, pozwalającym zrozumieć, czym jest iluzja"51 . Warto wspomnieć, że podobne traumatyczne wspomnienia są udziałem Elfriede Jelinek, autorki powieści Pianistka, która w wywiadzie dla „Teleramy” wyznała: "Zaczęłam uczyć się gry na pianinie, mając lat siedem, później doszły jeszcze skrzypce. To była destrukcja mojej młodości i mojego życia. Bo kiedy traci się młodość, to na całe życie"52.

Powyższe konteksty pozwalają przypuszczać, że powtarzane jak mantra w recenzjach filmów Hanekego określenie "gra z widzem”"53 (oznaczające tyleż grę z masowymi oczekiwaniami publiczności, co w ogóle z kulturą popularną i jej regułami), dotyczy gry, którą reżyser prowadzi także - a może: przede wszystkim - sam ze sobą. Nie chodzi jednak o to, by tą drogą dojść do wniosku, że Haneke funduje sobie autoterapię (w Funny Games przez skonfrontowanie własnego „panicznego lęku” z przemocą czystą, manichejskim Złem, w Pianistce poprzez swoisty seans sadomasochistyczny, zaś w Miłości przez bezpośredni kontakt ze śmiercią), albo że dokonuje osobistej zemsty za własne „odczarowanie” (nagłe zwrócenie się z pytaniem w stronę widza czy też metafilmowe cofnięcie taśmy przez jednego z oprawców w Funny Games to oczywiście ponure echa gestu Toma Jonesa).

Stawka wydaje się większa niż jedno - nawet tak ważne, bo reżyserskie - życie. Mało zabawne "games” uprawiane przez Hanekego, igraszki z diabłem traum i lęków, są nie tylko dalekie od chwytów znanych z kinowego mainstreamu ${ }^{54}$, ale także od czysto formalnego filmowego ekspery-

${ }^{51} 24$ Realities per Second..., [cyt. za:] M. Sadowska, op. cit.

52 Cyt. za: G. Arata, Dla Isabelle, „Kino” 2011, nr 11.

53 „Gra, którą Paul i Peter prowadzą z zastraszoną rodziną, nie jest jedyną rozgrywką w filmie, a wręcz jest znacznie mniej istotna niż gra, którą reżyser prowadzi $\mathrm{z}$ widzem. Niemal przez cały czas trwania projekcji zadaje jedno, proste pytanie: »Po co to oglądasz?«. Wie doskonale, czego oczekuje publiczność, i wykorzystuje tę wiedzę, by irytować, manipulować odbiorcą, a w konsekwencji spróbować zmusić go do zastanowienia się nad samym sobą. [...] Haneke walczy nie tyle z ramą gatunku, w którym się porusza, czyli thrillerem, a raczej z tym, czego oczekuje od niego widz". J. Dudkiewicz, op. cit.

54 „Większość reżyserów próbuje w swoich filmach osiągnąć mniej więcej te same cele: zdiagnozować pewien problem, odpowiedzieć na pytania »dlaczego tak jest« i »jak z tej sytuacji wyjśćc, wreszcie z sympatii do własnych bohaterów 
mentu (choć przy okazji dochodzi tu do postmodernistycznego zamachu na świętość gatunków filmowych, np. kryminalnego thrillera w Funny Games czy melodramatu w Pianistce). Wkraczamy zatem do swoistego kinowego laboratorium, czy może do pokoju kolekcjonera z przyszpilonymi egzemplarzami - nosicielami ludzkich przypadłości. Pytanie, jak uruchomić filmową narrację, której korzenie sięgną głębiej niż oko kamery, zaś ramy będą szersze niż filmowy kadr? Jak wnieść żywą historię do gabinetu figur wymodelowanych do przesady ostro i wyraziście?55

W tym miejscu rozważań musi pojawić się kwestia swoistego programowania czy modelowania aktorów. W analizach filmów austriackiego reżysera pojawia się wątek pokrewieństwa modeli aktorskich u Michaela Hanekego i Roberta Bressona ${ }^{56}$ (choć istnieje zasadnicza różnica: Bresson pracował z naturszczykami, a Haneke czyni to $z$ wytrawnymi zawodowcami ${ }^{57}$ ). Obaj reżyserzy zgadzają się co do kwestii życia wewnętrznego swoich bohaterów (Bresson: „Żadnej psychologii”; Haneke: „Nie uważam psychologii za czynnik konieczny"), i w tym kontekście należy odebrać pochwalną ocenę austriackiego reżysera skierowaną pod adresem jego protagonistki, Isabelle

okazać im litość i zafundować happy end lub przynajmniej nadzieję na lepsze życie. Słowem: dać oglądającemu widzowi poczucie katharsis, oczyścić atmosferę tak, aby po wyjściu z kina poczuł się on wzbogacony o nowe doświadczenie. [...] Michael Haneke jest inny”. Blog „Filmowe konkret-słowo”, https://xmuza.wordpress.com/2012/06/11/la-pianiste-2001-michael-haneke [dostęp: 25.04.15].

55 „Klauni-kaci z Funny Games są równie sterylni w swoich białych rękawiczkach, jak Erika, tytułowa Pianistka, w swoim przeżywaniu seksualności, zdominowanym przez jej wyobrażenie cudzych fantazji i przez wymiary pożądania zwykle umieszczane bezpiecznie w dziale "pornografia«". I. Kurz, Potworność. O Michaelu Hanekem, „Dwutygodnik” 2012, nr 11/96, www.dwutygodnik.com/ artykul/4135-potwornosc-o-michaelu-hanekem.html [dostęp: 25.04.15].

${ }^{56}$ „W podejściu do aktorstwa Hanekemu z pewnością najbliżej do Bressona i jego automatycznych modeli, wypranych z uczuć". J. Topolski, 27 fragmentów socjologii przypadku: haneke, „Odra” 2010, nr 1.

${ }^{57}$ „Przypomina się imperatyw Bressona: Być (modele) zamiast pozorować (aktorzy). Paradoks polega na tym, że Hanekemu udaje się uzyskać za sprawą profesjonalnych aktorów efekt, który Bresson osiągał, »używając « aktorów niezawodowych, czyli »modeli«”. P. Zawojski Przypisy do „Ukrytego" Michaela Hanekego, „Opcje” 2006, nr 4. 
Hupert: „potrafi ona zagrać wszystko, nie angażując uczucia, tylko je genialnie naśladując". Jeżeli do takich słów artysty (jakże ambarasujących: aktorstwo jako mimikra?, gdzie Stanisławski?, gdzie Grotowski?, gdzie Lee Strasberg i Metoda?) dodamy opinię jednego z recenzentów jego sztuki zgodnie z którą „kamera patrzy na bohaterów okiem mądrego patologa” 58 - siłą rzeczy wypada zadać pytanie o życie w filmach Michaela Hanekego.

\subsection{MUZYKA PO PRZEJŚCIACH, AKTORZY Z PRZESZŁOŚCIĄ}

Funny Games pod wieloma względami ogląda się jeszcze jak „wczesnego Hanekego": precyzyjnie skonstruowany filmowy mechanizm, zaprogramowany na osiągnięcie konkretnych efektów ${ }^{59}$, oraz ścisła kontrola nad widzem i jego emocjami ${ }^{60}$. Wykonawcy głównych ról (Susanne Lothar i Ulrich Mühe jako sterroryzowane małżeństwo, a także Arno Frish i Frank Giering jako ich prześladowcy) to niewątpliwie aktorzy warsztatowo znakomici, ale względnie młodzi i znani z kina niemieckiego, a więc niekojarzeni z międzynarodowym kanonem filmowym. Ścieżka dźwiękowa do filmu prezentuje się równie skromnie, towarzyszy jedynie napisom początkowym i na pozór wygląda jedynie na wprowadzenie w fabularną sytuację (ale - o czym napiszę dalej - nawet tych kilka niepozornych minut, $\mathrm{z}$ utworami trafiającymi do nieprzygotowanego, dopiero moszczącego się w kinowym fotelu widza, okazuje się dla filmu niezwykle istotne).

Inaczej jest w filmach Pianistka i Miłość, które w sferze znaczeń znacznie dalej wykraczają poza obszar prostych interpretacji i odpowiedzi na pytanie „co artysta miał na myśli?”61. W Pianistce tytułową rolę gra francuska

58 T. Sobolewski, Ból wolności - ekranizacja „Pianistki”, http://wiadomosci. gazeta.pl/wiadomosci/1,114873,2328011.html [dostęp: 30.05.16].

59 „Haneke używa Paula i Petera (w pewnym sensie swoich przedstawicieli, pomagających mu w kontakcie z publicznością), by pokazać, że ludzie chcą oglądać takich bohaterów". J. Dudkiewicz, op. cit.

${ }^{60}$ „Haneke. Ten facet wie, gdzie bić. Manipuluje, prowadzi widza wydeptaną ścieżką na rzeź, pokazuje mu środkowy palec". D. Arest, Haneke: Not so funny, „Gazeta Wyborcza”, http://wyborcza.pl/1,76842,5547054,Haneke__Not_so_funny. html\#ixzz45QDzJu8w [dostęp: 1.04.16].

61 „Doceniając wszystkie wcześniejsze filmy Michaela Hanekego, zżymałem się niekiedy na wyraziście stawiane przezeń tezy, formułowane w stylu tak 
aktorka Isabelle Huppert, znana od początku lat 70. z występów u najsłynniejszych reżyserów (jak Jean-Luc Godard, Michael Cimino, James Losey) i szczególnie ceniona za sugestywne kreacje bohaterek skrajnie wrażliwych, których uwikłanie w dramaty kobiecości wiąże się z realiami społecznymi i obyczajowymi (np. w filmach Koronczarka Claude'a Goretty czy Pani Bovary Claude’a Chabrola). Z kolei w Miłości wystąpił duet aktorów, których można nazwać - bez nadużywanej często egzaltowanej przesady - legendami kina $^{62}$. Emmanuelle Riva zasłynęła debiutancką rolą w filmie Hirosima, moja miłość Alana Resnais'go, uznawanym za jeden z najważniejszych filmów $\mathrm{w}$ historii kina. Jego awangardowa forma jest nie tylko eksperymentem artystycznym, ale zarazem rodzajem wyzwania rzuconego mieszczańskim stereotypom lat 50. ubiegłego stulecia i równie skostniałej narracji historycznej. Natomiast Jean-Louis Trintignant to jeden $z$ kanonicznych kinowych amantów (sztandarowa rola w filmie Kobieta i mężczyzna Claude'a Leloucha), znany jednak również z filmów, których kulturowy wymiar jest znacznie szerszy, zarówno pod względem społeczno-obyczajowym (I Bóg stworzyt kobietę Jeana-Luca Godarda, Konformista Bernardo Bertolucciego) czy psychologicznym (Trzy kolory: Czerwony Krzysztofa Kieślowskiego), jak i czysto artystycznym (Pustynia Tatarów Valerio Zurliniego).

Cała trójka aktorów niejako „w pakiecie” wnosi do filmów, w których gra, nie tylko historię kina czy w ogóle historię kultury z jej przemianami i konfliktami, ale także zaufanie widza, zdobyte już wcześniej dzięki wielowymiarowości kreowanych przez nich postaci ${ }^{63}$. W tym kontekście godne

gwałtownym, że właściwie niedopuszczającym odrębnego zdania. W Miłości reżyser stępił pazur doktrynera”. Ł. Maciejewski, Miłość to bohaterstwo przez rezygnację, http://film.dziennik.pl/recenzje/artykuly/409314,milosc-to-bohaterstwo-przez-rezygnacje.html [dostęp: 1.04.16].

${ }^{62}{ } \mathrm{Na}$ ekranie dwie legendy francuskiego kina - Emmanuelle Riva, młoda kochanka z Hiroshimy, mojej miłości Alaina Resnais'go, oraz Jean-Louis Trintignant, który dla Hanekego po kilkunastu latach przerwy wraca do kina". M. Grochowska, Miłość ponad wszystko, www.filmweb.pl/reviews/ Mi\%C5\%82o\%C5\%9B\%C4\%87+ponad+wszystko-12843 [dostęp: 1.04.16].

63 „To rezultat postawienia przed kamerę wykonawców tak wiarygodnych jak Riva i Trintignant. U których możemy ujrzeć aktorską maestrię, a w grze Rivy być może nawet kobietę potrafiącą unieść całą emocjonalną siłę Hiroszimy, mojej miłości 
uwagi jest upodobanie austriackiego reżysera do tych samych imion (w produkcjach niemieckich: Anna i Georg, w produkcjach francuskich: Anne i Georges) nadawanych parom głównych bohaterów w różnych filmach. Nie chodzi o to, że coś łączy filmowe historie, chodzi o sugestię, że ich bohaterowie zachowują pewną ciągłość charakterologiczną oraz zbierany film za filmem (paradoksalnie, bo - jak wiadomo - u Hanekego nie z każdego filmu „da się ujść z życiem”) bagaż doświadczeń. Swoiste „podwójne życia” Anny i Jerzego pozwalają im podejmować różne wybory, zmieniać pewne cechy charakteru, ale w obrębie pewnej kulturowo określonej tożsamości dla widza rozpoznawalnej i wiarygodnej. W Funny Games Anna i Georg są melomanami znającymi na wyrywki muzyczną klasykę, włącznie z konkretnymi wykonaniami utworów, ale zawodowo zajmują się czymś innym; natomiast w Miłości (2011) Anne i Georges są nauczycielami muzyki, a Anne wychowuje nawet prawdziwych wirtuozów. W Siódmym kontynencie z 1989 roku Anna i Georg zamykają się przed światem na cztery spusty, by popełnić wstrząsające rodzinne samobójstwo, natomiast Anne i Georges z Miłości równie zgodnie izolują się $\mathrm{w}$ mieszkaniu, by razem walczyć $\mathrm{z}$ nieuleczalną chorobą kobiety ${ }^{64}$.

Podobnie u Hanekego rzecz ma się z muzyką, tym bardziej że reżyser wykorzystuje w swoich filmach głównie utwory skomponowane w XVIII i XIX wieku, a następnie wielokrotnie reinterpretowane (zgodnie ze zmieniającymi się kanonami), a zatem głęboko zanurzone w kulturowej i społecznej rzeczywistości. Poza tym Austriak pozostaje wierny kompozytorom z bliskiego sobie kręgu, szczególnie Franzowi Schubertowi i Ludwigowi van Beethovenowi (obaj dużą część życia spędzili w Wiedniu), do których

Alaina Resnais'go”. R. Gilbey, „Amour” and the Music of Time, www.newstatesman. com/culture/2012/11/michael-hanekes-amour-and-music-time [dostęp: 30.05.16].

64 „Ta cicha aprobata nie nosi jednak znamion ostentacji, wydaje się naturalnym przedłużeniem małżeńskiego doświadczenia Anne i Goerges’a. Ich wspólnej przeszłości Haneke nigdy co prawda nie opowiada, sugeruje ją jednak na płaszczyźnie pozafabularnej - głównych bohaterów grają tu legendy francuskiego kina, a ich poprzednie ekranowe wcielenia ciągle żyją w pamięci widza; w pewnym sensie dopowiadają widzowi, co mogło się dziać między tą dwójką w minionych latach". G. Fortuna, Delikatność, http://film.org.pl/r/recenzje/milosc-17041/ [dostęp: 30.05.16]. 
można dodać także obecnych nie tyle poprzez konkretne kompozycje, co raczej „duchem” - Roberta Schumanna czy Fryderyka Chopina. Wszyscy ci kompozytorzy funkcjonują w kulturowej pamięci tyleż dzięki swoim utworom, ile poprzez biografie, w których burzliwe fakty i niedyskretne domysły zrosły się na prawach wciąż budzącego emocje mitu. Można zatem powiedzieć, że w Pianistce i Miłości „aktorom z przeszłością” towarzyszy „muzyka po przejściach”.

Umiejętny dobór muzyki sprawia, że narracja w filmach Hanekego uruchamia się niejako sama ${ }^{65}$, a historię zastajemy już rozpoczętą, dziejącą się $^{66}$, rozpędzoną na tyle, że reżyser nie musi (ach!, jakże by tego nie chciał) niczego tłumaczyć ${ }^{67}$. Wyjątkowo efektownie udaje się to w czołówce Funny Games - z rodziną słuchającą kompozycji z samochodowego odtwarzacza. Ledwie przemkną napisy początkowe, widz wie już całkiem sporo nie tylko o bohaterach i ich statecznym, dostatnim żywocie, ale także o kruchości tej sielanki (wystarczy zmienić radiowy kanał czy płytę); nie tylko o przeszłości (nie tyle osobistej, ile kulturowej), ale także o przyszłych wydarzeniach; nie tylko o nagich faktach, ale także o symbolicznym porządku, w którym te fakty są zanurzone. Każde zanurzenie powoduje - co wiadomo od czasów

65 „Całą historię Funny Games skraca czołówka. Rodzinka jedzie samochodem i bawi się w operowe zagadki. Słyszymy Mozarta, Pucciniego, Macagniego. Za oknem sielskie pejzaże. Nagle wybucha heavy metal. I tytuł na czerwonym tle. To zespół Naked City, na saksofonie drze się John Zorn. Oczywiście nie chodzi o banalne przeciwstawienie mieszczaństwa i agresji, lecz o efekt trzęsienia i thrillu”. J. Topolski, 27 fragmentów..., op. cit.

66 „Sam Haneke jest muzycznym erudytą, co wykazał, kompilując utwory do kolejnego filmu. Stłamszona przez matkę i pognębiona przez system Klavierspielerin (tytuł oryginalny) musi pracować jako Piano Teacher (angielski tytuł książki). Świątynia tradycji, konserwatorium, okazuje się piekłem na ziemi, pełnym frustratów i Przegranych (Bernhard). Jak aktualnie brzmi tu spór między klasyką a moderną, czyli hierarchiczną tonalnością a swobodną atonalnością". Ibidem.

67 „Lojalnie uprzedzałem, że nie odpowiem na żadne pytanie, które dotyczyć będzie interpretacji moich filmów". Wrzątek podany na zimno [z Michaelem Hanekem rozmawia Paweł Felis], „Gazeta Wyborcza”, http://wyborcza.pl/piatekekstra/1,129155,14799325,Wrzatek_podany_na_zimno.html [dostęp: 30.05.16]. 
Archimedesa - efekt wyparcia, i być może właśnie o tym, co wyparte, jest cała reszta filmu.

\section{FUNNY GAMES, CZYLI MUZYKA JAKO TOWARZYSTWO UBEZPIECZENIOWE}

Czego zatem słuchają Anna i Georg, bohaterowie Funny Games, czyli małżeństwo jadące wraz z synem Schorsim na swoją działkę nad jeziorem? $\mathrm{Z}$ odtwarzacza płyną najklasyczniejsze $\mathrm{z}$ klasycznych operowe arie: wystawnie barokowa Care selve z opery Atalanta Georga Friedricha Haendla oraz zorkiestrowana na bujną XIX-wieczną modłę Tu qui santuzza z opery Rycerskość wieśniacza Pietro Mascagniego ${ }^{68}$. Pomiędzy kwiecistym patosem Haendla a postromantyczną manierą Mascagniego lokuje się - słyszany w filmie przez moment - utwór nieco skromniejszy w wyrazie: Kwintet klarnetowy A-dur Wolfganga Amadeusza Mozarta, którego wyrafinowana melodyka także nawiązuje do operowej tradycji śpiewaczej ${ }^{69}$ i całej związanej z nią historii europejskiej sztuki.

Oczywiście, jeżeli przyjrzymy się dokładniej muzyce Haendla i Mascagniego (a można założyć, że uprawiający swoje „zabawne gry” w zagadki Anna i Georg mają sporą wiedzę na ten temat), to znajdziemy w nich dużo więcej niż estetyczny urok. Stosunkowo mniej znany, poza środowiskiem wielbicieli oper, Pietro Mascagni jest uznawany za jednego z pierwszych przedstawicieli tak zwanego weryzmu, czyli kierunku w sztuce przełomu XIX i XX wieku, który był kontynuacją naturalizmu i dążył do ukazywania, w „naturalnym” stanie, rzeczywistości społecznej z towarzyszącymi jej napięciami i problemami. Po pierwsze jednak, ciążyła na włoskim kompozytorze, tak jak na wielu innych kompozytorach uprawiających weryzm (można do nich zaliczyć także autora Halki, Stanisława Moniuszkę), pewna powierzchowność oraz skłonność do protekcjonalizmu, z jakim artysta pochyla się ze swoich wyżyn nad losem „prostego ludu”. Po drugie, weryzm u Mascagniego był dość powierzchowny i dotyczył raczej

68 „Rycerskość wieśniacza błyskawicznie stała się przebojem sal operowych całego świata”. M. Rye, 1001 albumów muzyki klasycznej, tłum. A. Fulińska, Poznań 2003, s. 460

${ }^{69}$ „Mozart w pełni wykorzystał aksamitne brzmienie klarnetu [...], pisząc na ten instrument długie, przypominające arie melodie”. Ibidem, s. 180. 
zawartości libretta niż struktury kompozycji, która nie wykraczała poza gatunkowe schematy z poprzedniej epoki muzycznej i miała zdecydowanie inne ambicje niż uchwycenie jakiegokolwiek społecznego realizmu ${ }^{70}$. Po trzecie wreszcie, opera Mascagniego miała nieszczęście do ogromnej liczby wykonań epatujących stereotypowym wdziękiem „przebojów muzyki klasycznej"71, co ma znaczenie dla jej usytuowania na symbolicznej mapie kultury.

Wynika z tego, że rodzinnym samochodem jadą spadkobiercy trzech stuleci kultury europejskiej, a gdyby przyjrzeć się im uważnie (drogie auto holujące przyczepkę z jachtem, które zmierza ku działce $\mathrm{z}$ domem nad górskim jeziorem) i bardziej krytycznie, można by rzec, że to beneficjanci burżuazyjnej kultury konsumpcji i społecznej zachowawczości. Ich muzyczna erudycja (małżonkowie grają w zagadki dotyczące wykonań poszczególnych utworów) nie zmienia faktu, że poruszają się po bezpiecznym terenie sztuki oswojonej do granic banału i że taka sztuka pełni dla nich rolę estetycznego przewodnika.

Owa gra w muzyczne zagadki podsuwa jedną z kilku możliwych interpretacji tytułu filmu. Zabawa przebiega w atmosferze wesołych przepychanek słownych i obrazuje sielankę serdecznej rodzinności połączoną z ekonomicznym dobrostanem. Właśnie wtedy jednak następuje moment przełomowy: jakby czyjaś ręka zmieniła utwór w odtwarzaczu, raptem z głośników uderza kakofoniczny zgiełk utworu Bonehead zespołu Naked City, zawieszony pomiędzy heavy metalem, muzyką noise i free-jazzem. Wejście tej muzyki jest tak nagłe i gwałtowne, jakby było fizycznym uderzeniem, ale jej wymiar jest znacznie głębszy niż dźwiękowa agresja.

70 „U Mascagniego realistyczne dążenia przejawiają się niemal wyłącznie w treści i w charakterze dramatycznej akcji; od strony muzycznej bowiem utrzymuje się na ogół Rycerskosśc wieśniacza w tradycyjnych konwencjach włoskiej opery”. J. Kański, Przewodnik operowy, Kraków 1985, s. 203.

${ }^{71}$ „Być może był to lepszy kompozytor, niż się to dziś powszechnie uważa: jego najbardziej popularna opera Rycerskość wieśniacza obciążona jest rzeczywiście dosyć powierzchownymi tradycjami wykonawczymi i chętnie się ją wskazuje jako przykład marnego gustu i operowej sztampy". J. Łętowski, Muzyka klasyczna na płytach kompaktowych, Warszawa 1997, s. 136-137. 
Liderem grupy Naked City jest saksofonista John Zorn, eksplorujący cały obszar muzyki współczesnej, bez podziału na style i gatunki ${ }^{72}$, a w kilku projektach, którymi kieruje (m.in. w grupie Masada), podkreślający także własne żydowskie pochodzenie (rzecz jasna, z jego bagażem historycznym). Trudno w takim kontekście zadowolić się prostą interpretacją, że nawet jeżeli nie chodzi tu o „przeciwstawienie mieszczaństwa i agresji”, to po prostu o efekt „trzęsienia i thrillu”" Z Zestawienie radykalnej artystycznej filozofii Zorna (synteza rozmaitych wątków muzycznej tradycji i skrajnie nowoczesnych środków wyrazu) z dość sztampowymi „przebojami muzyki klasycznej" (symbolizującymi określony ład panujący w Europie od kilku stuleci) może sugerować kolizję uporządkowanej egzystencji pod medialno-konsumenckim kloszem - z inną rzeczywistością, obnażoną niczym miasto w nazwie zespołu Zorna. Pojawiająca się za sprawą muzyki rysa - zarówno na społeczno-ekonomicznym fundamencie Europy, jak i na tożsamości jej mieszkańców, ufundowanej przez racjonalny gest Kartezjusza - w dalszych scenach filmu zmieni się w rujnujące pęknięcie.

Gwałtowne zmiany nastroju i „kierunku” muzycznej narracji są zresztą jedną z zasadniczych cech twórczości Zorna. Muzyk powołuje się tu na inspirację motywami Carla Stallinga, komponowanymi do popularnych kreskówek z serii „Zwariowane melodie” ze studia Warner Bros (ich bohaterowie to m.in. Królik Bugs, Kaczor Duffy, Struś Pędziwiatr). Te animowane filmiki swoją niesamowitą witalność, narracyjną jędrność i ponadczasowy humor zawdzięczają w dużej mierze muzyce Stallinga, opartej na skrajnych kontrastach tempa i dynamiki. Zostały one gładko przyswojone przez kulturę masową jeszcze w pierwszej połowie XX wieku, ponieważ pasowały do groteskowego, pełnego czarnego humoru świata kreskówek. Przewrotność stylistyczna nie była zresztą dla Stallinga celem samym w sobie, a tylko środkiem do jego osiągnięcia, ponieważ wszystko zaczęło się od tego, że na potrzeby szybkiej, przemysłowej produkcji kompozytor wymyślił

72 „Mój świat muzyczny jest jak niewielki pryzmat. Patrzysz przezeń, a on rozprasza się ku milionom różnorodnych kierunków. Ponieważ każdy gatunek muzyki jest tym samym, wszyscy muzycy zasługują na jednakowy szacunek". Słowa Johna Zorna, [cyt. za:] K. Niweliński, Zorn, John - Naked City, http://artrock.pl/ recenzje/51397/zorn_john_naked_city.html [dostęp: 30.05.16].

73 J. Topolski, 27 fragmentów..., op. cit. 
urządzenie pozwalające zmieniać tempo nagrania w trakcie montażu filmu (aby rysownicy i muzycy mogli pracować niezależnie). Zorn, inspirując się kompozycjami Stallinga, przenosi jego - jak to ujął dziennikarz magazynu „Rolling Stone” - „zawracające z piskiem opon schizofreniczne motywy”74 z bezpiecznej krainy animowanej groteski w świat niebezpiecznie bliski ludzkiej codzienności. Pokazuje, jak dobrze pasują do otaczającego nas mechanicznego zgiełku oraz informacyjnego chaosu.

W gwałtownym zwrocie akcji muzycznej na początku Funny Games możemy zatem doświadczyć, jak z gruntu filmowa technika kompozytorska - która najpierw została przez Zorna „wyniesiona” poza obszar kina, a potem „przywrócona” przez Hanekego tam, skąd się pierwotnie wzięła ujawnia swój głębszy aspekt, czyli zmienia muzykę w swoisty „komentarz socjologiczny".

Sam Haneke, zapytany bezpośrednio o muzykę Johna Zorna, kieruje nas ku jeszcze innemu - parodystycznemu, ironicznemu - kontekstowi twórczości tego artysty (według Hanekego, okazuje się on rodzajem „nad-heavymetalowca”, z całym nietzscheańskim bagażem tego neologizmu), której „przeakcentowanie”, hałaśliwe „przeegzaltowanie”, odpowiada formie Funny Games jako ekstremalnie przesadzonego thrillera ${ }^{75}$. Wykorzystane w filmie utwory Zorna są zresztą opatrzone tytułami, w których można się dopatrywać ironii czy pastiszu heavymetalowej konwencji (Bonehead, Hellraiser). Pamiętając o namaszczonej powadze, z jaką kultura mieszczańska celebruje muzykę klasyczną - a według Hanekego, wręcz ją zawłaszcza, uzurpując sobie przesadne zasługi w historii kultury ${ }^{76}$ - możemy usłyszeć w muzyce Zorna dźwięk siarczystego policzka wymierzanego „sytym burżujom”.

${ }^{74}$ www.rollingstone.com/music/lists/the-100-greatest-metal-albums-of-all-time-w486923/naked-city-torture-garden-1990-w487068 [dostęp: 30.05.16].

75 „Odbieram Johna Zorna jako rodzaj nad-heavy metalu [über-heavy metal], ironiczne przeakcentowanie pewnej formy, która - jako film - staje się ekstremalnie przegiętą odmianą thrillera". The World That Is Known [Michael Haneke w rozmowie z Christopherem Sharrettem], www.kinoeye.org/04/01/interview01.php [dostęp: 30.05.16].

76 „Oczywiście, trudno nie patrzeć ironicznie na to, jak mieszczaństwo sytuuje samo siebie w historii kultury”. Ibidem. 
Jeżeli przyjrzymy się uważnie początkowej sekwencji filmu, widzimy jednak, że utwór Johna Zorna - w przeciwieństwie do Mascagniego i Haendla - nie mieści się w sferze diegetycznej (czyli słyszy go tylko widz, nie bohaterowie), tak samo jak niekoniecznie mieści się w ekranowej diegesis kilka późniejszych działań dwójki morderców (pytania kierowane bezpośrednio do widza czy cofnięcie akcji filmu za pomocą telewizyjnego pilota). A skoro rodzina nie posłuchała pierwszego wezwania do opamiętania się, reżyser wysyła im drugie upomnienie - w postaci dwójki morderców. Ironia Michaela Hanekego okazuje się - wbrew „moralistycznym” pozorom - podobna do ironii Quentina Tarantino, który także nie waha się „argumentować” za pomocą ludzkich zwłok.

Jeżeli potraktujemy początkowe, wzbogacone muzyką sekwencje Funny Games jako swoistą uwerturę do filmu - pamiętając, że od XVIII wieku uwertura zawierała krótkie motywy wzięte z następującej po niej opery, dzięki czemu miała wprowadzać w atmosferę zasadniczego dzieła - widzimy, że to, co w skrótowej formie dzieje się przez pierwsze kilka minut filmu, potem rozegra się raz jeszcze, już w pełnym, półtoragodzinnym wymiarze. „Uwerturowy” charakter wstępnej, opatrzonej muzyką części filmu pozwala zadać pytanie, na ile cała jego reszta jest realistyczna (nawet jeśli miałby to być folderowy weryzm jak z Mascagniego), a na ile bezceremonialnie "operowa” (a wtedy wystudiowaną brutalność filmu można skojarzyć z brutalnością rodem z westernowych „końskich oper” Sergio Leone)? Sztucznie przerysowane - zarówno pod względem stroju, jak i zachowania - postacie dwójki morderców, ujrzane w kontekście „operowym” okażą się jak najbardziej na miejscu. Zaś ich dialogi - rozpisane niczym arie, w których chodzi raczej o harmonie czy kontrasty niż o realny sens napędzający akcję - zaczniemy podejrzewać o celowe kwestionowanie realizmu filmu (tak jak kwestionują ów realizm kunsztownie absurdalne dialogi pary morderców, Vincenta i Julesa, z Pulp Fiction Tarantino).

Potwierdzenie intencji zamachu na realistyczność filmowej rzeczywistości Funny Games przychodzi z przeciwległego krańca filmu, kiedy w jednej z końcowych scen, na łódce, tuż przed zabójstwem ostatniej ze swoich ofiar, psychopatyczni agresorzy toczą ze sobą znamienną rozmowę:

Paul: Czyż fikcja nie jest realna?

Peter: Dlaczego? 
Paul: No przecież widzisz ją w filmie, prawda?

Peter: Oczywiście!

Można spojrzeć na ten dialog z kilku perspektyw. Po pierwsze, jako na gorzki metafilmowy żart Hanekego ${ }^{77}$, który przez cały czas gra $\mathrm{z}$ konwencjami filmowymi (sensacyjnego thrillera o bandyckim napadzie, horroru - z zagęszczającą się atmosferą prowadzącą do nieuniknionej masakry, ale także filmu dokumentalnego czy programu w konwencji reality, gdzie w nudny, skrupulatny sposób analizuje się przebieg zbrodniczych wydarzeń $^{78}$ ), i w tym momencie rozmowa daje do zrozumienia, że jako widzowie ulegamy regułom medialnego spektaklu w momencie kontaktu $\mathrm{z}$ nim, skoro przekaźnik - zgodnie ze słynną maksymą Marshalla McLuhana - sam w sobie jest przekazem. Istotny przy tym okazuje się podział dokonany przez Kanadyjczyka: na media „gorące” (które łatwiej zawłaszczają i kontrolują emocje odbiorcy) i „zimne” (które nie mają mocy, by uczynić to samodzielnie). McLuhan bowiem zalicza film do mediów "gorących” - łączących się z ludzkimi zmysłami z „wysoką rozdzielczością” (czyli tak, jak robi to rzeczywistość pozafilmowa). Według McLuhana: „oddziaływanie techniki nie ujawnia się na poziomie opinii lub koncepcji, ale trwale, nie napotykając na żaden opór, zmienia proporcje zmysłów lub wzorce percepcji"79.

Ten kontekst pozwala jeszcze śmielej interpretować absurdalny dialog morderców, ponieważ w takim samym jak kino złudzeniu „realności” utrzymuje mieszkańca cywilizacji tak zwanego Zachodu jej obraz tworzony przez kulturę (nie tylko tę masową - sugeruje reżyser za pośrednictwem prezentowanego na wstępie Haendla czy Mozarta). Dobrze pokazuje ów stan zarówno początek filmu (rodzinny samochód jest wysokiej klasy, wygląda na zaopatrzony w zabezpieczenia typu poduszki powietrzne czy system ABS),

77 „Film antygatunkowy, parodia. Akcja toczy się jak akcja thrillera, ma strukturę thrillera, ale w tym samym czasie film komentuje sam siebie". Michael Haneke $\mathrm{w}$ rozmowie $\mathrm{z}$ Sergem Toubianą, $\mathrm{www} . y 0 u$ ube.com/watch?gl=PL\&hl=pl\&v=roOl9PvEPjs [dostęp: 30.05.16].

78 Przykładem może być magazyn kryminalny 997 emitowany w Telewizji Polskiej od 1986 do 2010 roku i cieszący się przez te dwadzieścia cztery lata dużą popularnością.

79 Zob. M. McLuhan, Zrozumieć media: Przedłużenia człowieka, tłum. N. Szczucka-Kubisz, Warszawa 2004. 
jak i sposób, w jaki reżyser rozwija akcję, co chwila dając widzowi nadzieję, że bohaterowie wywiną się z opresji - korzystając przy tym ze schematów, na których opiera się kino gatunkowe. Bohaterowie także wierzą w swoje bezpieczeństwo, bo wierzą w trwałość i szczelność struktury, w jakiej się wychowali - czyli w tę kulturę, której symbolem i szczytowym osiągnięciem jest muzyka Haendla czy Mozarta.

Podobnie dzieje się z widzem: wierzy w możliwość uratowania bohaterów z rąk psychopatycznej pary, bo wierzy w strukturę filmowej konwencji, a szerzej - w strukturę kultury, jaka go otacza. W jej - jak to metaforycznie ujął Peter Sloterdijk - „kryształowy pałac”, który zyskał ostatnio nowy wymiar: globalizację ${ }^{80}$. Dzięki filmowej konwencji nawet w najkrwawszych horrorach zazwyczaj jednemu z bohaterów udaje się ujść z życiem (w tym przypadku byłaby to Anna, która na łódce podejmuje ostatnią próbę ocalenia - ale reżyser przecina i tę nitkę nadziei). Konwencja zatem obiecuje gwarancję na życie, a trzymanie się utartych schematów to - i dla bohatera, i dla utożsamiającego się z nim widza - licencja na przeżywanie (wykupione ubezpieczenie doczekało się obiegowej nazwy: happy end). W Funny Games Haneke pokazuje, że to ubezpieczenie jest podwójne: o tym, że wszystko jest w porządku, utwierdzają widza schematy gatunkowe, ale także sfera muzyczna - reprezentowana przez sztandarowe utwory muzyki klasycznej, a więc głos wysoce autorytatywny.

Można powiedzieć, że muzyka słuchana przez bohaterów rozszerza fałszywą gwarancję bezpieczeństwa i niezawodności: nie chodzi jedynie o fałsz filmowych konwencji, bez których szybko stajemy się bezradni (o emocjonalnej i intelektualnej bezradności widza po zanegowaniu tych konwencji sugestywnie świadczą opinie na temat Funny Games zamieszczane na portalach filmowych ${ }^{81}$ ), chodzi o fałsz całej współczesnej kultury - z jej iluzją powszechnego bezpieczeństwa i coraz wyższą ceną, jaką za to bezpieczeń-

${ }^{80}$ Zob. P. Sloterdijk, Kryształowy pałac, O filozoficzna teorię globalizacji, tłum. B. Cymbrowski, Warszawa 2011.

${ }^{81}$ „Jestem wrażliwą osobą i jakoś nie skłonił mnie do refleksji, film jest płaski, pozbawiony emocji, a dlaczego, bo jest tak głupi, że aż boli. Dwójka psycholi bawi się $\mathrm{z}$ widzem i robi z nich durnia, śmiejąc mu się w twarz. Moje przemyślenia? Gniot, na którym ktoś chciał naszukać kasy i pewnie naszukał, najwięcej na małolatach i pseudointelektualistach, chciał zrobić dramat, a wyszła mu parodia thrillera". 
stwo trzeba płacić. Argumentów uzasadniających konieczność transakcji i podwyższenia stawki opłat dostarczają na bieżąco media, pełne doniesień o wszelkich możliwych zamachach, kataklizmach i kryzysach ${ }^{82}$.

Do konstruowania podwójnego ubezpieczenia, dublowania poczucia asekuracji autorytarnością tonu, szczególnie predysponowana jest muzyka barokowa czy postromantyczna. Bywa ona oparta na stosunkowo łatwych do wychwycenia schematach (harmonicznych, melodycznych) i czytelnych napięciach adresowanych do konkretnych emocji (patos, melancholia, radość, rozpacz), stąd jej lawinowo rosnąca popularność w ostatnich dziesięcioleciach, w epoce dominacji kultury lekkostrawnej i mającej służyć rozrywce. Znamienne, że bohaterowie Funny Games nie słuchają w samochodzie klasycznej muzyki współczesnej - wymagającej od widza więcej intelektualnego zaangażowania, mocniej napiętej uwagi, ale też zawierającej elementy oporu wobec sytej, konsumenckiej rzeczywistości - tylko właśnie utworów sprzed dwóch stuleci, zalecających się do słuchacza swym estetycznym urokiem, a co ważniejsze, łudzących łatwą przyswajalnością oraz kulturową swojskością ${ }^{83}$.

W tym kontekście możemy spróbować inaczej spojrzeć nie tylko na ofiary (których wina okazuje się „odziedziczona” po stuleciach zachodniej cywilizacji, grzech natomiast jest niejako „pierworodny”, niezmyty żadnym chrztem ani autentycznym rytuałem przejścia), lecz także na parę

Opinia internauty zamieszczona na: www.twojefilmy.pl/funny-games/ [dostęp: 30.05.16].

82 „Przy okazji premiery Funny Games reżyser przestrzegał przed fałszywym obrazem świata, jaki prezentują media, obwiniał je za kreowanie, a nie opisywanie rzeczywistości, tworzenie uproszczeń, generalizowanie i relatywizowanie. Szczególnie niebezpieczne wydawało mu się to przy okazji kwestii związanych z przemocą, która dzięki telewizji stała się tematem o walorach rozrywkowych". K. Wolanin, Zrozumieć Michaela Haneke, http://liberte.pl/zrozumiec-michaela -haneke/ [dostęp: 30.05.16].

83 „Na początku filmu klasyczna muzyka w wykonaniu Gigliego i Tebaldiego zostaje użyta do zasygnalizowania stanu świadomości trójki protagonistów, wprowadzając w nastrój filmu. Muzyka, rozwijająca się równolegle z pięknem krajobrazu w ujęciu otwierającym film, usypia czujność widzów, dając im fałszywe poczucia bezpieczeństwa”. Sounds In Haneke's „Funny Games”, www.academia. edu/14328396/Sound_in_Hanekes_Funny_Games_U.S [dostęp: 30.05.16]. 
morderców. I wtedy okaże się, że wcale nie są oni wysłannikami z zewnątrz, pozbawionymi cech ludzkich funkcjonariuszami terroru, którego źródeł nie mamy szans poznać. Wbrew regułom thrillera czy horroru, widz nie może poczuć się niewinną ofiarą przemocy, emocjonalnie utożsamić się z rodziną w śmiertelnym niebezpieczeństwie, ponieważ ma też cechy upodabniające go do pary zbrodniarzy. Aseptyczną schludność Petera i Paula można odbierać jako odbite w krzywym zwierciadle zamiłowanie do ładu i porządku (oto perfekcyjni panowie domu dwaj), dyktowane nam, rzecz jasna, przez media i wzorce kulturowe.

Haneke twierdzi, że jako widzowie, użytkownicy Internetu, pensjonariusze portali społecznościowych, nie grzeszymy jedynie biernością i zaniedbaniem, ale przede wszystkim zgodą na fałsz i strukturalne złudzenie, które przynosi świat elektronicznych mediów. Nieuchronne ujawnienie fałszu i pęknięcie złudzenia rodzi agresję - tym powszechniejszą, im media są bardziej masowe, utrzymującą się tym bardziej permanentnie (jako stały stan cichej irytacji czy frustracji), im bardziej media stają się częścią naszej codzienności. W wywiadzie dla kinowego magazynu „Kinoeye” reżyser powiedział o tym - jak na niego - wyjątkowo wprost:

Nowe technologie, którymi posługują się zarówno media, jak i świat polityki, wywołują wielkie zniszczenia swoim niepohamowanym wzrostem i szybkością rozprzestrzeniania się. Media przyczyniają się do tworzenia dość niepokojącej iluzji, że w danej chwili jesteśmy informowani o wszystkim, co się właśnie dzieje, każda informacja ma status nagłej. Żyjemy w otoczeniu pozwalającym nam myśleć, że dowiadujemy się o wszystkim szybciej, kiedy tak naprawdę nie wiemy nic. To rodzi straszne konflikty wewnętrzne, one powodują złość, która znowu przemienia się $\mathrm{w}$ agresję, a ta prowadzi do aktów przemocy ${ }^{84}$.

Jeżeli do słów reżysera dodamy, zapowiadającą pojawienie się dwójki morderców, gwałtowną muzykę Johna Zorna, która drążąc mroki ludzkiego „ja”, rozrywa tkankę muzycznej iluzji dobrostanu i harmonii zmysłów (w ten sposób podświadomość raptownie przebija się przez świadomość), to wtedy może się okazać, że Peter i Paul są wysłannikami naszego skonfliktowanego

${ }^{84}$ Cyt. za: J. Topolski, 27 fragmentów..., op. cit. 
wnętrza (które przybywa, by zrobić porządek z bałaganem na zewnątrz), emisariuszami frustracji i złości ogarniającej całe społeczeństwa. Czyli że reprezentują właśnie nas, widzów, a nie jakąś zewnętrzną rzeczywistość terroru i horroru ${ }^{85}$. Cień rzucany przez Petera i Paula - tak jak cień rzucany na Mozarta i Haendla przez gitarowo-saksofonowy jazgot Johna Zorna - jest cieniem padającym od wewnątrz, a nie z zewnątrz.

Haneke niby pozwala publiczności solidaryzować się z ofiarami (by koniec końców zakpić sobie $\mathrm{z}$ widza i jego nadziei), ale jeżeli konsekwentnie pójść za tym, czego reżyser oczekuje (czyli przełamania stereotypowego oglądu - i sztuki filmowej, i rzeczywistości), a także za tym, co sugeruje wprowadzająca nas w filmowe zdarzenia muzyka (że jako użytkownicy kultury przychodzimy na świat z jej grzechem pierworodnym i że nie jest to grzech bezkarny), może się to skończyć paradoksalnym zrozumieniem dla poczynań dwójki morderców. Poczynania te bowiem okazują się nie aż tak psychopatycznie irracjonalne, jak mogłoby się zdawać. Cały film wypada wtedy obejrzeć raz jeszcze.

Wróćmy zatem do pierwszej sceny Funny Games i zauważmy, że kamera towarzyszy samochodowi, który jedzie przez pełną naturalnego piękna okolicę, obserwując go wysoko z góry, podobnie jak w słynnym początkowym ujęciu ze Lśnienia Stanleya Kubricka. Podobieństwo wygląda na nieprzypadkowe, aczkolwiek film Kubricka - także rozsadzający ramy gatunku, do którego teoretycznie należy - daje szersze możliwości interpretacyjne zarówno na poziomie konkretnych faktów (w jego symbolice doszukiwano się aluzji do zagłady Indian północnoamerykańskich, a także sugestii kwestionujących autentyczność pierwszego lądowania astronautów na Księżycu ${ }^{86}$ ), jak i na płaszczyźnie ogólniejszej, która obejmuje sięgające w Jungowską zbiorową podświadomość fundamenty całej współczesnej kultury $^{87}$. Jest to związane z odmiennym - niż w Funny Games - użyciem przez

85 „Publiczność staje się wspólnikiem zabójców”. Michael Haneke w rozmowie z Sergem Toubianą, op. cit.

${ }^{86}$ Rodney Ascher nakręcił dokument Pokój 237, film w całości poświęcony tropom interpretacyjnym i narracyjnym w Lśnieniu Kubricka i stanowiący nader rzetelny katalog tych rozlicznych wątków.

${ }^{87}$ „King musiał zrozumieć, że jego opowieść psychosocjologiczną [...] Kubrick zmienił w antropologiczną, przedstawiając przyczyny i objawy rozpadu 
Kubricka muzyki, która staje się nie tylko wyrafinowanym komentatorem ekranowych wydarzeń, ale także aktywnym czynnikiem sprawczym, równie ważnym dla zsumowanego efektu artystycznego (czyli gotowego filmu), jak aktorzy czy scenariusz ${ }^{88}$. Na czysto technicznym poziomie synchronizacji, Funny Games - ze swoim wręcz prowokującym oddzieleniem symbolicznie „muzycznej” czołówki od „pozamuzycznej” właściwej akcji - jest oczywiście zamierzonym przeciwieństwem metody Kubricka (znanego ze swoich iście zegarmistrzowskich operacji montażowych oraz emancypacji muzyki w filmie aż do osiągnięcia przez nią znaczenia równego grze aktorów $\left.{ }^{89}\right)$. Jednak ostateczny efekt pozwala zobaczyć w pomyśle z czołówką Funny Games raczej błyskotliwy filmowy greps niż pomysł artystyczny, który porusza naprawdę głęboko. Gdyby nie kontrast między cokolwiek tarantinowskimi manierami morderców (i takimiż dialogami między nimi) a grającymi $\mathrm{w}$ zupełnie inny, momentami skrajnie naturalistyczny sposób aktorami wcielającymi się członków terroryzowanej rodziny, można by zadać pytanie: czy Hanekemu nie jest aby w tym filmie bliżej do Quentina Tarantino niż choćby do Sama Peckinpaha?

Warto w tym kontekście przyjrzeć się bliżej powołanym do filmowego życia mordercom o chłopięcym wdzięku i nienagannych manierach. Z całą pewnością (co ucieszyłoby Michaela Hanekego) nie sprawiają oni wrażenia urodzonych morderców - są reżyserskim konstruktem (w dodatku nieco

uporządkowanego bytu i regresu człowieczeństwa”. Lśnienie, [w:] A. Garbicz, Kino, wehikuł magiczny. Podróż piąta 1974-1981, Kraków 2009, s. 496.

${ }_{88}$ J. Topolski, Kino/Muzyka. Zbliżenia. Gambit Kubricka, „Ruch Muzyczny” 2009, nr 8; idem, Muzyka w filmach Stanleya Kubricka, http://stopklatka.pl/news/ muzyka-w-filmach-stanleya-kubricka [dostęp: 30.05.16].

${ }^{89}$ „Obsesja synchronizacji - [...] na przykładzie z Lśnienia - ma na celu maksymalne przybliżenie utworu muzycznego do postaci. Jeśli Kubrick posuwał się do odtwarzania muzyki na planie zdjęciowym, to znaczy, że dążył do uzyskania efektu pełnej tożsamości pomiędzy grą aktorską a ścieżką muzyczną. Traktował tę drugą jako niezbędne dopełnienie pierwszej. Wydaje mi się, że linia przebiegająca pomiędzy kreacją aktorską a muzyką jest jedną z najważniejszych osi, wokół których Kubrick buduje swoje filmy". A. Łazarkiewicz, Muzyka z podświadomości. Praktyczne i teoretyczne aspekty wykorzystania muzyki w filmie na podstawie analizy „Lśnienia” Stanleya Kubricka, „Glissando” 2007, nr 10/11. 
„operowym” w swym sztucznym przerysowaniu). Pomysł uczynienia z nich nosicieli symbolicznego zła (zagnieżdżonego gdzieś w utajonym sercu kultury i - jak przystało na jej przymioty: „masowa”, „globalna”, „elektroniczna” - błyskawicznie roznoszonego przez cyfrowy krwiobieg ${ }^{90}$ ), jest nośny jedynie na poziomie służebnym wobec ideowego przesłania filmu. Poza nim Peter i Paul okazują się postaciami marionetkowymi, animowanymi sztucznie i w ściśle pragmatycznym celu. Używane przez parę morderców białe, aseptyczne rękawiczki okazują się rękawiczkami na dłoniach samego reżysera.

Za porównanie może posłużyć podobna para - tyle że tym razem morderczyń, a nie morderców - uśmiercająca stateczną, mieszczańską rodzinę w filmie Clauda Chabrola Ceremonia. Lista podobieństw między filmami Hanekego i Chabrola jest zresztą znacznie dłuższa: u francuskiego reżysera zamordowana rodzina jest co najmniej tak samo dobrze sytuowana $\mathrm{i}$ - to bardzo znamienne pokrewieństwo - co najmniej tak samo rozmiłowana w muzycznej klasyce, która towarzyszy kulminacyjnej scenie filmu. W Ceremonii jednak bohaterki są jak najbardziej realne: mają wyraziste, wiarygodnie sportretowane osobowości, a zarówno ich początkowa, dziecinna wręcz niefrasobliwość, jak i stopniowo narastająca frustracja są bystro podpatrzone u rzeczywistych ludzi, choć ukazane na ekranie nader powściągliwie i z wiarą w inteligencję widza, szczególnie tę emocjonalną.

Oczywiście, Haneke celowo jest wyraziście alegoryczny (tak jak alegoryczna jest scena ze słuchaniem muzyki na początku filmu: Haendel, Mascagni - dobro i bezpieczeństwo, Zorn - zło i groza), natomiast Chabrol, w zgodzie z uprawianym od lat stylem, wybiera dyskretną metonimię. Bohaterki Ceremonii, Sophie i Jeanne, pochodzą z niższej klasy społecznej. Ich morderczy uczynek na tle anielsko harmonijnej, ale i złowrogiej muzyki Mozarta (rodzina słucha opery Don Giovanni), odniesiony do całych grup społecznych ukazuje destrukcyjną siłę „buntu mas” (czyli przewidzianego przez José Ortegę y Gasseta stanu „triumfu hiperdemokracji”"1). Niezależnie

${ }_{90}$ Z przebiegu wypadków łatwo orientujemy się, że trwająca półtorej ekranowej godziny egzekucja trzyosobowej rodziny jest tylko epizodem, bo chłopcy mordują jedną rodzinę za drugą, a czas wakacji i sceneria pustkowia nad jeziorem pozwalają widzieć w nich prawdziwych morderców-pracoholików.

91 „Masy działają bezpośrednio, nie zważając na normy prawne, za pomocą nacisku fizycznego i materialnego, narzucając wszystkim swoje aspiracje 
od metaprzesłania obu filmów, na tle precyzyjnie szkicowanej osobowości bohaterów oraz bystrego postrzegania przez Chabrola niuansów i półcieni w społecznych relacjach (Jakub Majmurek pisał o „subtelnych narzędziach krytyki społecznej" u francuskiego reżysera ${ }^{92}$ ), pomysły Hanekego z Funny Games zakrawają na reżyserskie efekciarstwo.

Z drugiej strony, trzeba pamiętać, że pełny tytuł opery Mozarta brzmi Il dissoluto punito ossia il Don Giovanni, co po polsku oznacza: „Rozpustnik ukarany, czyli Don Giovanni”, więc i Chabrolowi - który wymierza wywyższającym się burżujom karę przez rozstrzelanie - można by tu zarzucić zbyt grubo ciosaną metaforykę. Natomiast jeżeli chodzi o Hanekego, to ten już niedługo (Funny Games i Pianistkę dzielą cztery lata) pokaże, że potrafi udzielić muzyce w filmie znacznie szerszych, narracyjnych kompetencji. Zmiana ta nie oznaczała odcięcia się od przeszłości, ponieważ reżyser wcale nie porzucił błyskotliwych na granicy brawury pomysłów w rodzaju tego z Funny Games. W ostatecznym rozrachunku jednak potrafił nadać muzyce - lub pozwolić, by ona sama go sobie nadała - dużo istotniejszy wymiar.

\section{PIANISTKA, CZYLI MUZYKA JAKO WOLA I PRZEDSTAWIENIE}

Zupełnie inaczej niż w Funny Games, początek Pianistki oglądamy w całkowitej ciszy i ciemności, a pierwsze sceny (mocno wyodrębniony prolog

i upodobania”. J. Ortega y Gasset, Bunt mas, tłum. P. Niklewicz i H. Woźniakowski, Warszawa 2008, s. 12.

92 „Dom zamożnej, pełnej pretensji, prowincjonalnej, mieszczańskiej rodziny obserwujemy tu z punktu widzenia niepiśmiennej służącej (Sandrine Bonnaire). Chabrol doskonale pokazuje tu, że mieszczańska kultura opiera się na dystynkcji i wykluczeniu; mieszczańskie wartości kulturalne są wartościami tylko o tyle, o ile zostaną przeciwstawione komuś, kto jest wykluczony z udziału w nich (służba, ale także proletariat, czy nielegalny imigrant). Służąca zaprzyjaźnia się z odrzuconą przez pana domu kochanką, prowadzącą dość hipisowski styl życia pracownicą poczty. Na końcu obie kobiety biorą rewanż na świecie, który ich odrzucił, i przy pomocy drogiego sprzętu myśliwskiego mordują rodzinę pracodawców, gdy ta ogląda w telewizji inscenizację Don Giovanniego Mozarta”. J. Majmurek, Claude Chabrol (1930-2010) cyniczny (a)moralista, „Dwutygodnik” 2010, nr 10(40), www.dwutygodnik.com/artykul/1486-claude-chabrol-1930-2010-cyniczny-amoralista.html [dostęp: 30.05.16]. 
ukazujący fundamentalny problem filmu - patologiczną relację bohaterki z matką) obywają się bez muzyki, co jest tym bardziej zaskakujące w kontekście tytułu. Ten zaś pojawia się dopiero po siedmioipółminutowym wstępie. I dopiero wtedy - niejako poprzedzona dramatyczną, emocjonalną i fizyczną szarpaniną między bohaterkami - wybucha na ekranie, romantycznymi frazami Fantazji f-moll Fryderyka Chopina, muzyka fortepianowa. Mogłoby to sugerować, że reżyser zrobił dokładnie na odwrót, niż uczynił wcześniej: muzyka nie będzie tym razem antycypowała dalszego rozwoju akcji, lecz prowadziła kronikę wydarzeń (w dużej mierze miłosnych). Jednak sposób prezentacji kolejnych utworów świadczy o tym, że ich miejsce w dramaturgicznej tkance filmu nie jest określone na stałe. Kompozycje raz będą komentarzem, innym razem głębszą analizą. Raz - wprowadzą prosty kontrast, innym razem - złożony kontrapunkt.

Podobnie stało się z budowaniem filmowych postaci. Wstępna scena zwięźle i dobitnie zapoznająca widza $\mathrm{z}$ patologicznymi relacjami między bohaterką (graną przez Isabelle Hupert) a jej matką (w tej roli Anne Girardot) oraz ukazująca rodzinny dom jako piekło emocjonalnego terroru (Haneke, jak wiadomo skądinąd, dość zdecydowanie postrzega rodzinę jako źródło cierpien ${ }^{93}$ ) - wydaje się komentowana muzycznie dopiero później. Komentowana - podkreślmy - za pomocą dzieł kompozytorów po rodzinnych przejściach. Owi kompozytorzy to: Franz Schubert, którego ukochana, decyzją rodziny, wyszła za mąż za piekarza; Robert Schumann, który jako piętnastolatek doświadczył samobójczej śmierci siostry, a później został przez matkę zmuszony, wbrew aspiracjom muzycznym, do podjęcia studiów prawniczych; Ludwig van Beethoven, którego liczne choroby i cierpienia mogła, według badaczy, spowodować tak zwana kiła wrodzona, czyli otrzymana w spadku genetycznym.

Celowo przytaczam fakty z biografii kompozytorów romantycznych, których muzyka buduje akcję filmu równolegle ze zdarzeniami z życia jego bohaterów, ponieważ jednym z zasadniczych wątków jest właśnie hipotetycznie sugerowana współzależność, symboliczna więź pomiędzy skomplikowaną psychiką artystki (tytułowej pianistki) a żyjącymi dwa stulecia

93 „Chciałbym przede wszystkim [...] stwierdzić, że rodzina to wylęgarnia konfliktów, [...] codzienna wojna w rodzinie jest swego rodzaju mordowaniem się, a to rodziców i dzieci, a to żon i mężów”. The World That Is Known, op. cit. 
wcześniej kompozytorami muzyki, którą owa artystka wykonuje ${ }^{94}$. Taka perspektywa pozwala zrezygnować $\mathrm{z}$ traktowania relacji „filmowe wydarzenia - komentarz muzyczny" z perspektywy czasowego następstwa czy związku przyczynowo-skutkowego, a zacząć widzieć między akcją filmu i muzyką podobny związek, jaki istnieje między semantyką i syntaktyką. Muzyka z Pianistki może być zatem „gramatyką", która staje wobec „słownika" zdarzeń czy emocji bohaterów. I dopiero razem wzięte, tworzą giętki język tego niezwykłego filmu, w którym rozgrywa się niby współczesny, a w istocie stary jak ludzkość dramat samotności, dominacji, niespełnienia, którego schematy zostały wpisane w nuty muzyki romantycznej.

Po takim wstępnym rozpoznaniu przyjrzyjmy się bliżej, w jaki sposób muzyka z Pianistki towarzyszy rozwojowi akcji filmu albo wchodzi w relacje z poszczególnymi wydarzeniami. Jako pierwszy utwór - pojawiający się pod palcami grającego pianisty ćwiczącego w konserwatorium, gdzie profesorką fortepianu jest Erika Kohut, tytułowa bohaterka filmu - słyszymy Fantazje f-moll Fryderyka Chopina, czyli utwór, którego powstanie w październiku 1841 roku zostało spuentowane listem kompozytora do Juliana Fontany ze słynnym fragmentem: „Dziś skończyłem Fantazję - i niebo piękne, smutno mi na sercu - ale to nic nie szkodzi. Żeby inaczej było, może by moja egzystencja nikomu na nic się nie przydała. Schowajmy się na po śmierci" I choć Michael Haneke wybrał fragment tego utworu raczej ze względu na jego typowy dla epoki romantyzmu charakter, a nie biograficzne czy muzykologiczne niuanse, to w kontekście rozwoju akcji Pianistki (o kryzysowej sytuacji w domu rodzinnym już wiemy, za chwilę dowiemy się o mrocznych kulisach pracy w konserwatorium oraz perwersyjnym życiu erotycznym bohaterki) okazuje się on znamienny. W ten sposób użyta w filmie muzyka przemawia niezależnie od zamierzeń reżysera.

Istotny dla filmu okazuje się bowiem i chopinowski „smutek na sercu” (Erika Kohut też okazuje się pogrążona w chronicznej depresji, niezbyt obecna ciałem: nawet podczas kontaktu seksualnego jej ręce wiszą bezwładnie jak u kukły), i melancholijne zdanie: „żeby inaczej było, może by

94 „Trudno określić, na ile istnieje korelacja między neurozą Eriki Kohut a tym, co można by nazwać "psychogramem« wielkiego kompozytora, jakim był Schubert". Ibidem.

${ }^{95} \mathrm{http}: / /$ pl.chopin.nifc.pl/chopin/genre/detail/id/21 [dostęp: 30.05.16]. 


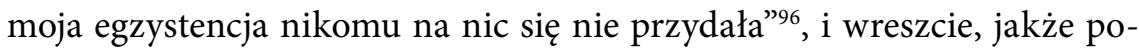
etycka fraza: „schowajmy się na po śmierci”. Jak dowiemy się już wkrótce, Erika - ukrywając przed matką, kolegami z konserwatorium oraz kręgami wiedeńskich melomanów nadzwyczaj istotną część swojej osobowości (czyli upodobanie do praktyk sadomasochistycznych, drastyczny voyeuryzm, znajdowanie erotycznej rozkoszy w upokarzających formach kontaktu) $\mathrm{w}$ istocie chowa to, co dla niej najważniejsze (ukryte pod warstwą perwersji zwyczajne pragnienie miłości). Pianistka ukrywa przed otoczeniem swoją prawdziwą osobowość, prawdziwe życie. A w życiu, które wiedzie oficjalnie, w zgodzie z obowiązującymi normami społecznymi, na wszystko robi się dramatycznie za późno.

Jeżeli zajrzymy pod podszewkę Chopinowskiej Fantazji f-moll nie od strony biografii kompozytora, lecz formy utworu, także natrafimy na istotne dla wydarzeń z filmu Hanekego fakty (szczególnie w kontekście rozwichrzonej, wymykającej się normom budowy kompozycji ${ }^{97}$, której Fantazja zawdzięcza swoją witalną energię i organiczną siłę). Osobowość Eriki również zbudowana jest na sprzecznościach (wykonawczyni uduchowionej muzyki Jana Sebastiana Bacha okazuje się wielbicielką brutalnego seksu; autoryta-

${ }^{96}$ Jak sugerują bystro podpatrzone w Pianistce scenki rodzajowe z wiedeńskiego konserwatorium, warunkiem osiągnięcia muzycznej doskonałości jest mozolna, pełna cierpień i represji droga per aspera ad astra; źródłem pianistycznego talentu bohaterki także nie jest z całą pewnością radość życia. Sam reżyser stwierdza, że: „Wiedeń jest stolicą muzyki klasycznej i w związku z tym jest centrum wszelkiej nadzwyczajności. Muzyka jest bardzo piękna, lecz tak jak towarzyszące jej okoliczności, może stać się narzędziem represji”. The World That Is Known, op. cit.

97 „Interpretatorzy muzykologiczni utworu, którym nie była znana ta właśnie zasada gatunku, nie umieli sobie długo poradzić z kształtem Fantazji f-moll. Niecks znalazł w Fantazji »zniewalającą dziwność i »chimeryczność" formy. Leichtentritt odczytał formę utworu jako »niejasną", cierpiącą na »brak logiki i ciągłości w budowie«. Dla jednych była jedynie »serią oszołamiających obrazów « prezentowanych "w wielkim uniesieniu«, "przesuwających się przed wyobraźnią słuchacza z szaloną szybkością«. Dla innych przekształconą, swoiście zdeformowaną formą tzw. sonatowego allegra, ronda, lub wynikiem skrzyżowania obu tych form”. M. Tomaszewski, Fryderyka Chopina Dzieła Wszystkie, audycja w Programie II Polskiego Radia, [cyt. za:] http://pl.chopin.nifc.pl/chopin/composition/detail/id/112 [dostęp: 30.05.16]. 
tywna wykładowczyni konserwatorium po powrocie do domu zmienia się w córeczkę ukrywającą przed surową matką występki i przewinienia), zaś na pozór wykluczające się cechy jej charakteru sięgają przeciwnych biegunów nie tylko zawodowej, ale i ludzkiej moralności (imponujące kompetencje profesorki gry na fortepianie sąsiadują ze skłonnością do brutalnej złośliwości, cynicznego szyderstwa, a nawet aktów okaleczającej przemocy). Dzieje się tak wskutek wewnętrznych konfliktów, które targają Eriką od tak dawna, że w zasadzie stały się nieusuwalną częścią jej psychiki i cielesności. Co nie zmienia faktu, że ta neurotyczna czterdziestoparolatka, uzależniona od ostrej pornografii i zatrzymana przez matczyny terror na emocjonalnym poziomie krnąbrnej gimnazjalistki, pozostaje - w dużej mierze dzięki kreacji Isabelle Huppert - fascynującą kobietą. Huppert wniknęła w swoją bohaterkę na tyle głęboko, żeby w wywiadzie dać jej sugestywnie zwięzłą charakterystykę: „Erika to ktoś, kto neguje swe ciało, ale jej ciało budzi się wbrew jej woli. To, w pewnym sensie, kobieta, która ucieka i przecieka. I przecieka wszystkim: krwią, moczem, wymiotami. Jest to jednocześnie ciało zamknięte w gorsecie i ciało otwarte na oścież. Ta dwoistość intrygu$\mathrm{je}^{\text {"98. }}$. Na podobnej dialektyce formy (między innymi sonatowej) i jej negacji Chopin oparł swoją Fantazję f-moll.

Celowo poświęcam tak dużo uwagi utworowi, który pojawia się w Pianistce zaledwie na kilkanaście sekund i w zasadzie nie ma znaczenia dla powierzchniowej warstwy fabuły filmu. Po pierwsze, chcę zwrócić uwagę, jak poważne implikacje - niezależne od intencji reżysera - pociąga za sobą wykorzystanie romantycznej „muzyki po przejściach”, po drugie zaś, chcę pokazać, jak mogą zmieniać się niuanse w odbiorze filmu Hanekego w zależności od kraju, gdzie jest oglądany: polski widz będzie z natury rzeczy mocniej „obciążony” muzyką Chopina (z całym jej muzyczno-biograficzno-kulturowym bogactwem ${ }^{99}$ ), natomiast widz austriacki będzie mocniej

98 Cyt. za: G. Arata, op. cit.

99 „Chopin nie operował w Fantazji f-moll cytatem. Ani dosłownym - jak niegdyś w Fantazji A-dur na tematy polskie, ani przybliżonym, jak to uczynił w Scherzu h-moll z kolędą Lulajże Jezuniu lub w Mazurku e-moll, "palmejskim", $\mathrm{z}$ pieśnią Tam na błoniu błyszczy kwiecie. Litwinka zaistniała w Fantazji f-moll poprzez działanie nie cytatem, a aluzją. Jest w utworze obecna, lecz na sposób dyskretny. Trzeba ją w nim wysłyszeć”. M. Tomaszewski, op. cit. 
„obciążony” muzyką kompozytorów wiedeńskich - Schuberta i Beethovena (z całą aurą ewokowaną przez to miasto ${ }^{100}$ ). To drugie "genetyczne obciążenie" dotyczy także samego Hanekego, więc tym istotniejsze wydają się wszystkie konteksty, które muzyka z Pianistki ujawnia nie tyle zgodnie czy wbrew, ile po prostu poza zasadą reżyserskiej wszechmocności.

Skoro pokazałem schemat, według jakiego muzyka współdziała z filmem (czyniąc z niego „dzieło otwarte”, nieustannie gotowe na reinterpretacje), kolejne fragmenty, w których istotną rolę pełni muzyka, omówię już w bardziej bezpośrednim związku z akcją filmu. Pierwszą sceną z muzyką towarzyszącą bohaterom przez dłuższy czas jest scena domowego koncertu, na którym Erika Kohut poznaje swojego przyszłego ucznia, Waltera Klemmera (całkiem sympatyczny charakter postaci Waltera to element, w którym film najbardziej różni się od powieści Elfriede Jelinek ${ }^{101}$ ). Erika w duecie $\mathrm{z}$ innym pianistą odgrywa przed gośćmi Fugę z Koncertu C-dur na dwa klawesyny Jana Sebastiana Bacha. Ten pełen entuzjastycznej energii utwór dobrze oddaje nastrój koncertu (aura snobizmu nie wyklucza tu wzajemnej serdeczności i autentycznej miłości do muzyki), a także staje się lustrem odbijającym pierwszą rozmowę Eriki z Walterem.

Szarmanckie powitanie („Pozwolę sobie ucałować dłoń, która gra Bacha w takim stylu") znajduje kontynuację w rozmowie, w której muzyczna erudycja obydwojga tworzy między bohaterami nić porozumienia (Walter mówi o muzyce „nad wyraz dojrzale”, a fakt, że jest studentem politechniki, nie pozbawia go szacunku dla „tradycji prywatnych recitali”; Erika natomiast potrafi podjąć ironiczną konwencję, daleką od sztywnych kanonów filharmonii), ale także od razu sugeruje istotne różnice. Walter zdradza

100 „Owszem, można uznać, że muzyka funkcjonuje w ten sposób, lecz dodatkowo trzeba mieć świadomość, że w filmie oglądamy specyficznie austriackie realia". The World That Is Known, op. cit.

101 „Christopher Sharrett: Walter Klemmer wydaje się bohaterem filmu, aż nagle staje się potworem. Michael Haneke: Niech pan to powie Elfriede Jelinek [śmiech]. No, ale żarty na bok. Jego charakter jest ukazany w książce dużo bardziej negatywnie niż w filmie. Książka jest napisana w nader cynicznej manierze, opisuje przemianę infantylnego kretyna w faszystowskiego dupka. Mój film próbuje uczynić go postacią trochę ciekawszą i atrakcyjniejszą". The World That Is Known, op. cit. 
skłonność do prowokacyjnej dezynwoltury i łamania konwencji („Dziś tylko akademicy stepują w rytm słoni Brucknera”), Erika zaś preferuje mocniejsze stąpanie po ziemi oraz bardziej skrupulatną uniwersytecką wiedzę („Czytał pan esej Adorna o Fantazji C-dur Schumanna?”), choć przy okazji sugeruje, jakie mogą być ciemne źródła jej patologicznej sytuacji rodzinnej (Erika: „To Schumann tuż przed utratą zmysłów. Wie, że traci głowę. Ma świadomość bliskiej katastrofy, całkowitego zatracenia”. Walter: „Mówi pani o tym jak o własnym życiu”. Erika: „Uwielbiam Schuberta i Schumanna. Mój ojciec zwariował i zmarł w szpitalu w Steinhof. Dlatego łatwo mi mówić o zmierzchu duszy").

Choć podteksty tych wyznań wydają się niepokojące, to cała scena utrzymana jest w serdecznej atmosferze - dokładnie takiej, jak odegrana Fuga z Koncertu Bacha. Tę pogodną atmosferę, skontrastowaną z potencjalnie mrocznymi treściami, można odnieść do podstawowych różnic między Bachem a Schubertem czy Schumannem - zarówno na poziomie muzyki, jak i biografii tych kompozytorów. Życie Jana Sebastiana Bacha, stosunkowo długie i dostatnie, było życiem kompozytora, owszem, rzuconego przez los na prowincję, ale spełnionego męża i ojca, człowieka o mocnym charakterze, stabilnej psychice, którego muzyczny geniusz nie kazał płacić za siebie tak horrendalnej ceny, jak w przypadku kompozytorów muzycznego romantyzmu. Skrajnie odmienne było życie Franza Schuberta czy Roberta Schumanna. Schubert cierpiał biedę spowodowaną ogólną niezaradnością życiową, musiał zrezygnować ze związku z ukochaną kobietą (rodzina znalazła jej solidniejszą małżeńską partię), jego jedyny publiczny koncert został powszechnie zignorowany, bo w Wiedniu występował akurat słynny skrzypek Nicolo Paganini, zaś na domiar nieszczęścia, podczas krótkiej wizyty z domu publicznym zaraził się kiłą, która - wespół z wyniszczającym leczeniem rtęcią - spowodowała jego śmierć $\mathrm{w}$ wieku zaledwie 31 lat. Schumann żył, jak na romantyka, dość długo - 46 lat, ale przez większą część życia zmagał się z narastającą chorobą psychiczną (słyszał głosy w głowie, aż do schizofrenicznego rozdwojenia jaźni), która miała traumatyczne źródła w dzieciństwie (samobójcza śmierć starszej siostry, nagły zgon ojca) i skończyła się drastyczną próbą samobójczą, po której trafił dożywotnio do szpitala psychiatrycznego. Dodatkowo na drodze do życiowego spełnienia stanęła Schumannowi matka, która wbrew artystycznym aspiracjom syna 
zmusiła go do studiów prawniczych - leczył więc frustrację alkoholem i przygodnym seksem.

Z premedytacją przytaczam te biogramy w wersji uproszczonej, aby pokazać „mityczną” obecność kompozytorów w zachodniej tradycji i kulturze. Ów „mit” znajduje wszakże sugestywne oparcie w muzyce (u Bacha w dużej części jasnej i klarownej; u Schuberta czy Schumanna - skłonnej do ciemnego liryzmu i neurotycznego rozedrgania), a w filmie Hanekego ogarnia bohaterów (zanurzonych po uszy w środowisku muzycznym Wiednia) swoim kulturowym cieniem. Jak się wkrótce okaże, życiowe dramaty Eriki oscylują wokół problemów rodzinnych i uczuciowo-seksualnych, podobnie jak życiowe dramaty kompozy torów otoczonych „romantycznym” nimbem. Na razie Walter o tym nie wie, ale jest wyraźnie poruszony osobowością Eriki, a kiedy okazuje się, że on także (zaskakująco uzdolniony muzycznie jak na studenta kierunków ścisłych) ma swój występ podczas koncertu, podejmuje znaczącą decyzję - zamiast zacząć grać zaplanowaną miniaturę fortepianową Schönberga, oświadcza: „Zagram mój ulubiony utwór Schuberta - Scherzo z Sonaty A-dur".

Widzimy już, na jak różne sposoby muzyka towarzyszy bohaterom filmu zarówno bezpośrednio (uprzedzając lub komentując ich poszczególne kroki), jak i z kulturowego dystansu, czyniąc aluzje skierowane bezpośrednio do widza (który najpierw pomyśli o „mitycznym” Wiedniu - mieście Beethovena i Freuda, ale także Wolfganga Přiklopila - a potem dokona już własnych porównań i syntez ${ }^{102}$ ). Ta zmienność muzycznej perspektywy narracyjnej (szczególnie w pierwszej połowie filmu, bo w drugiej Haneke więcej inicjatywy oddaje kamerze) oraz swoboda w przechodzeniu na rozmaite poziomy, z jakich odzywa się muzyka jako narrator (dotyczy to zarówno chronologii zdarzeń, jak i wiwisekcji osobowości), czynią z Pianistki dzieło pod względem muzycznej narracji zupełnie wyjątkowe.

Chyba najbardziej podobny efekt do tego z Funny Games - czyli radykalnego skrótu, a przy okazji uderzającego widza kontrastu - reżyser osiąga w scenie, kiedy liryczny temat Andante z Tria fortepianowego Es-dur

102 „W założeniu twórcy Pianistka jest prowokacyjnym oskarżeniem pod adresem wiedeńskiej burżuazji. Podejmuje jednak kwestie bardziej uniwersalne. Film kręcony w dzielnicach i mieszkaniach wiedeńskich elit mógłby równie dobrze dziać się w Warszawie lub Tokio". G. Arata, op. cit. 
Schuberta towarzyszy wizycie Eriki Kohut w sex shopie. Znamiennym prologiem do tej sceny jest telefon od matki, pełny surowych napomnień adresowanych w stronę córki. Po chwili widzimy, jak utwór Schuberta jest ćwiczony na próbie przez trójkę skupionych muzyków (na fortepianie gra bohaterka filmu), po czym subtelna linia melodyczna - bez cięcia montażowego w sferze audio, a jedynie po cięciu w sferze obrazu - pozostaje z bohaterką, kiedy ta wybiera filmy w pełnym mężczyzn wiedeńskim sex shopie, by obejrzeć je w kabinie wideo. Wyrafinowany liryzm skrzypiec, wiolonczeli i fortepianu zderza się najpierw z wyrazami twarzy mężczyzn obserwujących jedyną w sex shopie kobietę, a później z jękami i okrzykami aktorów pornograficznego filmu oglądanego przez Erikę - dopiero wtedy Andante cichnie, ustępując pod naporem kontrastujących z nim dźwięków.

Scena jest zmontowana nadzwyczaj płynnie - ze świetnym wyczuciem czasu i rytmu poszczególnych ujęć - dzięki czemu melodia Schuberta w przewrotny estetycznie sposób komentuje dwoistość osobowości Eriki ${ }^{103}$ (a także w ogóle dualizm człowieka, w którym natura i kultura raz toczą ze sobą walkę, a innym razem tworzą zgodną w sprzecznościach hybrydę, gdzie to, co wzniosłe i szlachetne, zrasta się z trywialnym i obscenicznym ${ }^{104}$ ). W tym momencie warto raz jeszcze zwrócić uwagę na podobieństwa i różnice między filmem Hanekego a książką Jelinek, ale tym razem w najbardziej interesującym nas kontekście - wykorzystania utworów muzycznych w narracji. U obydwojga artystów nastrój czy emocjonalna wymowa kompozycji współgrają nie tylko z treścią ich dzieł, ale także z formą: u Hanekego - ze sposobem montażu ujęć i scen, natomiast u Jelinek - z rytmem języka i tym, jak „wchodzi” on w głowę bohaterów. Książka ma narrację trzecioosobową,

${ }^{103}$ „Wyższe uczucia są u niej zapośredniczone w patologicznym związku z matką, w muzyce oraz w pornografii. Wysokie i niskie, wzniosłe i patologiczne - jest w niej nierozdzielnie splecione". T. Sobolewski, Haneke. Wściekły i podstępny, "Gazeta Wyborcza” z dnia 20.11.2009 r., dodatek „Duży Format”, http://wyborcza. pl/duzyformat/1,127291,7267426,Haneke__Wsciekly_i_podstepny.html [dostęp: 30.05.16].

104 „Przejście prosto z koncertu, wciąż na tle romantycznej muzyki, do sex-shopu sprawia, że widz, chcąc nie chcąc, musi przyjąć punkt widzenia Eriki, zobaczyć pornografię jako wirtualny rytuał miłosny. Próba prawdziwej miłości przyniesie Erice nieszczęście, ale również świadomość, kim naprawdę jest”. Ibidem. 
narrator okazuje się nader szyderczym pełnomocnikiem autorki, opisy zmagań bohaterów z losem i własnymi uczuciami są przedstawiane tonem bezlitosnej kpiny, ale między innymi dzięki obecności muzyki dostrzegamy także ich wrażliwość. Oto przykład takiej „napędzanej” muzyką Schuberta i Schumana mieszanki czułości i szyderstwa: „Teraz we dwójkę wędrują zwiewnie przez luźno usypany pył pośrednich tonów, światów i dziedzin, bo na tym zna się warstwa średnia. Mroczniejący niepostrzeżenie Schubert otwiera cały korowód, czy też, jak pisze Adorno, mrocznienie w Fantazji C-dur Schumanna. I płynie w dal, w nicość, ale bez przeradzania się w apoteozę świadomego gaśnięcia!"105.

Haneke ma dla bohaterki na pewno więcej czułości niż szyderstwa, o czym świadczy już decyzja obsadowa (obdarzona subtelną urodą Isabelle Hupert gra w filmie kobietę, która w książce jest określona jako „ten nieforemny zezwłok, ta nauczycielka gry na fortepianie, na której dokładnie znać profesję [...]. Ta chorobliwie powykręcana, trzymająca się ideału dziwaczna istota"106), ale dla niniejszej pracy istotniejsze jest podejście do muzyki, a trzeba zauważyć, że i Haneke, i Jelinek wykorzystują sposób obecności klasycznych kompozycji w kulturze i społeczne mity związane z kompozytorami. U Hanekego mamy subtelnie lirycznego Schuberta rozbrzmiewającego w sex shopie (i burzliwe reakcje kinowej publiczności na drastyczny realizm dalszej części tej sceny, kiedy Erika wącha chusteczki zużyte przez masturbujących się mężczyzn), natomiast u Jelinek pojawia się kontrast między powszechnym zdrowiem społecznym (którym wszak cieszą się zarówno wielbiciele literatury, jak i kinomani - tak samo skłonni do wystawiania moralnych cenzurek) a przypadłościami ciała i ducha artystów. Spójrzmy na przykład na ten fragment: „To dogasanie światełka życia Schuberta i Schumanna to przecież skrajne przeciwieństwo tego, co sądzą zdrowe masy, kiedy tradycję nazywają zdrową i tarzają się w niej z lubością. Zdrowie - diabła tam. Zdrowie to uwznioślenie tego, co jest. Pismaki zapełniające programy koncertów filharmonicznych, aż wierzyć się nie chce, czynią ze zdrowia główne kryterium znaczącej muzyki"107.

\footnotetext{
105 E. Jelinek, Pianistka, tłum. R. Turczyn, Warszawa 2004, s. 89.

106 Ibidem, s. 83.

107 Ibidem, s. 90.
} 
Wróćmy jednak do filmu, ponieważ muzyczna narracja w tej jego części wyraźnie się zagęszcza. Podczas wizyty Eriki w sex shopie Andante Schuberta po kilku minutach milknie, ale muzyka opuszcza filmową akcję tylko na chwilę, ponieważ zanim jeszcze Erika opuści jedną z kabin porno, przez głosy i jęki z filmu zaczyna przebijać się inny utwór Schuberta pieśn Im Dorfe, zaś po przejściu montażowym okazuje się, że śpiewa ją jeden ze studentów podczas lekcji z Eriką. Z sex shopu wracamy zatem do konserwatorium równie płynnie, jak wcześniej wyszliśmy z granego tam koncertu (Haneke wyraźnie intensyfikuje w tym momencie filmu obrazowo-muzyczną metaforykę, nadchodzi bowiem moment wprowadzenia nas w sedno opowiadanej historii). Charakterystycznym motywem dźwiękowym w Im Dorfe są głucho dudniące akordy fortepianu akompaniującego śpiewowi tenora, i to dudnienie zostaje połączone - kolejny, tym razem drobny, ale treściowo wydajny zabieg reżysera - z pukaniem do drzwi. Lekcja zostaje raptem przerwana i wchodzi Walter, który mimo reprymendy Eriki („W szkole muzycznej nie przerywa się zajęć!”) oświadcza, że chciałby zostać jej studentem. Jest to jeden $\mathrm{z}$ głównych punktów zwrotnych $\mathrm{w}$ filmie.

Od tego momentu akcja filmu rozdziela się dwa wątki. W jednym widz poznaje kolejne epizody z tajemnego życia erotycznego Eriki Kohut (wizyty w samochodowym kinie drive-in, gdzie masturbując się, podgląda pary; a także akty samookaleczania swoich części intymnych), które łączy jedno: dojmująca samotnośćc ${ }^{10}$. W drugim natomiast możemy obserwować Waltera i jego kolejne kroki, by zbliżyć się do fascynującej go kobiety. To uczucie może być dla Eriki ostatnią szansą na wyrwanie się z sadomasochistycznej pułapki oraz chorobliwej zależności od matki, ale wiemy już, jak wiele będzie ją kosztowało ewentualne otwarcie się na miłość. Temu wszystkiemu - czyli wydarzeniom, które możemy oglądać, oraz ukrytym myślom i uczuciom bohaterów - uważnie asystuje muzyka.

Scena egzaminu wstępnego Waltera do konserwatorium znakomicie ukazuje całe zniuansowanie sytuacji. Młody Klemmer prezentuje komisji, w której jest też pani Kohut, kilka kompozycji - w filmie zostają one

108 „Erika nie znosi bliskości i fizycznego kontaktu, ulgę przynosi jej podglądanie innych i rytuały sadomasochizmu. Największe wrażenie robi scena, w której pani profesor siada nad brzegiem wanny, aby "zabawić się« w przecinanie żyletką warg sromowych, podczas gdy jej matka krząta się za ścianą przy kolacji”. G. Arata, op. cit. 
montażowo połączone w jeden utwór, na tle którego rozgrywa się dramat wahania Eriki (wie ona, że przyjęcie Waltera będzie oznaczało dalsze kontakty z chłopakiem). Klemmer zaczyna od utworu Arnolda Schönberga (jest to Klavierstücke op. 33b, który miał zagrać na domowym recitalu, ale po rozmowie $z$ Eriką zmienił zdanie), a racjonalnie wykoncypowana, jak najdalsza od romantycznej egzaltacji struktura tej kompozycji dobrze oddaje charakter Waltera. Potem Klavierstücke płynnie - i dla kogoś, kto nie zna tych utworów, w zasadzie niedostrzegalnie - przechodzi w Preludium nr 5 Sergiusza Rachmaninowa, który choć był rówieśnikiem Schönberga, muzycznie reprezentował raczej poprzednią epokę z jej postromantycznym bagażem patosu i sentymentu. Kamera obserwuje na początku naprzemiennie grającego Waltera i słuchającą Erikę, lecz od rozpoczęcia utworu Rachmaninowa skupia się głównie na twarzy Eriki - jakby jej mimika była swoistą partyturą muzyki, którą słyszymy. Kiedy chłopak przechodzi (znów bez cięcia taśmy, jakby to była jedna kompozycja) do trzeciego utworu, czyli do Scherza z Sonaty A-dur Franza Schuberta, emocje widoczne na twarzy pianistki są tak silne, że nie budzą wątpliwości co do dwóch rzeczy: po pierwsze, że Walter gra znakomicie, a po drugie, że utwór porusza Erikę Kohut znacznie głębiej, niż mogłyby sięgnąć techniczne zagadnienia wykonawcze lub zasady kompozycyjne.

Chwilę później odbywa się narada komisji i wszyscy członkowie wyrażają zachwyt grą Klemmera - poza Eriką, która się sprzeciwia, uporczywie mnożąc zastrzeżenia natury technicznej („fanfaronada” łamiąca akademickie reguły gry) oraz ze zjadliwą ironią komentując decyzję o wstąpieniu do konserwatorium („Nie wzbogacę artystycznej natury ani wirtuozerii pana Klemmera"). Wiemy oczywiście, że opór Eriki wynika z innych przyczyn (gra chłopaka niewątpliwie znalazła jej uznanie), więc kiedy w końcu dostrzegamy na wywieszonej kartce $\mathrm{z}$ nazwiskami przyjętych kandydatów nazwisko „Walter Klemmer” - kamera długo odwleka tę chwilę, celebruje najazd na drzwi sekretariatu - jest to oznaka kapitulacji Eriki. Zapowiedź eskalacji jej napięcia i lęku, ale także budzenia się nadziei na miłosne spełnienie.

To burzliwe skonfliktowanie erotycznego pragnienia ze strachem i poczuciem winy dochodzi do głosu w kilku momentach filmu, owocując albo odruchami masochistycznymi, albo agresją wyładowywaną na innych. Ten drugi przypadek widzimy, kiedy Erika przyłapuje jednego ze swoich uczniów na oglądaniu z kolegami czasopism pornograficznych w kiosku, 
po czym „mści się” na nim (i poniekąd także na sobie samej) podczas lekcji w konserwatorium. Pretekst i fundament do wyrażenia moralnego oburzenia pianistka znajduje w zasadach muzycznych. Zaczyna od wytykania uczniowi błędów w grze („Nie eksponuj nut drugoplanowych! Trzymaj się głównej linii!”), a potem przekierowuje swój gniew, łącząc oba wątki muzyczny z seksualnym („Co cię pchnęło do muzyki? Twój malutki talent? Zapewniam cię, że nie warto. Przygrywaj striptizerce i nie marnuj mojego czasu”). Jednak z szyderstw wynika, że nawet taki przypływ „moralnego niepokoju” nie uwalnia Eriki od poczucia własnej winy („A może kobiety to świnie, bo robią świnię z ciebie?").

Widzimy zatem, że muzyka pełni w życiu Eriki Kohut rolę specyficznej ostoi moralnej czy też etycznej przeciwwagi dla grzesznych uczynków. Ale to nie wszystko, ponieważ wydaje się ogarniać sobą każdy poziom życia pianistki. Kiedy Erika słucha Schuberta granego przez ucznia, słyszymy jej komentarz do wykonywanego akurat fragmentu partytury („Śnią o niezdobytym, upajają się dobrem i złem, a nazajutrz wszystko znika - tu pojawia się ironia!”) i wiemy, że zarówno utwór, jak i interpretacyjne wskazówki dotyczą jej własnego życia. Kiedy za moment słyszymy harmoniczną zmianę w utworze, też towarzyszy jej czujnie wychwycona interpretacja („To rytm upartego mieszczanina"), za którą stoi własne życie wykładowczyni gry na fortepianie, tkwiące w kleszczach sztywnego, wiedeńskiego mieszczaństwa.

Muzyka ma aż taką moc, więc czasem działa jako strażnik moralności (na pierwszej lekcji Walter słyszy stanowcze: „Żadnego Schuberta, tylko Schönberg!”, wypowiedziane tonem, jakim dziewczyna broni się przez rozbieraniem na pierwszej randce), ale czasem jej obosieczne ostrze tnie $\mathrm{w}$ przeciwną stronę. Pokazuje to jedna $\mathrm{z}$ najważniejszych scen filmu - ta, w której Erika zakrada się do szatni i wsypuje do kieszeni swojej uczennicy szkło z potłuczonej szklanki, by okaleczona dziewczyna nie mogła grać, choć zbliża się najważniejszy występ w jej karierze. Na auli konserwatorium młoda pianistka ma akompaniować tenorowi śpiewającemu pieśni Franza Schuberta, ktoś musi przewracać jej nuty i wypada (niestety!) na Waltera, który wykonuje wobec dziewczyny serdeczny gest pomocy. Gest ten jest na tyle mało znaczący, że dostrzegają go tylko jedne $\mathrm{z}$ obecnych na auli par oczu - oczy Eriki Kohut. Para studentów zaczyna wykonywać utwór. Walter przewraca kartki, wszyscy słuchają, ale są na auli uszy, dla których muzyka Schuberta znaczy coś więcej niż dla innych - uszy Eriki Kohut. 
Kamera zatrzymuje się na twarzy Eriki w długim ujęciu (Haneke z premedytacją stosuje statyczne ujęcia, wyzwalając u widza inny rodzaj skupienia niż ten wymagany przez telewizję czy popularne kino hollywoodzkie ${ }^{109}$ ). Emocje narastają w delikatnych drgnieniach jej ust tyleż silnie, co niemal niedostrzegalnie (Grażyna Arata uchwyciła paradoksy kreacji Isabelle Hupert, pisząc o „szokującej subtelności jej ekranowej interpretacji”"110), kiedy równocześnie widzi siedzącego obok dziewczyny Waltera (jeszcze nie wie, czy go kocha, ale już jest o niego zazdrosna, jakby zazdrość była forpocztą miłości) i słyszy pieśń Der Wegweiser Franza Schuberta (której narrator, wędrując nieuczęszczaną ścieżką w rytm naśladującego zmęczone kroki fortepianu, trafia na zaśnieżone, górskie bezdroża i tam, pogrążony w rozpaczy, pragnie samotnie umrzeć). To połączenie - nadziei na spełnienie z Walterem, zagrożonej w tym momencie przez inną kobietę, oraz dramatycznej pieśni o osuwaniu się w samotność - działa jak zapalnik: Erika nagle wychodzi z sali. Potem jest sama, patrzy na nią tylko kamera, więc w szatni może dopuścić się skrajnej podłości, która jest aktem zazdrości i zemsty, ale też dowodem siły sprawczej muzyki.

Kiedy Erika wraca do auli, tenor śpiewa już kolejną pieśń Schuberta ćwiczone wcześniej na lekcji Im Dorfe, w którym bohater, idąc nocą przez wieś i słuchając szczekania psów na łańcuchach, szydzi z marzeń i snów mieszkańców mijanych domów, ponieważ dobrze wie, jak bardzo te marzenia są płonne. Większość studentów na auli mogła nie znać tekstu pieśni

109 „Christopher Sharrett: Sprawia pan wrażenie wielbiciela długich ujęć. Jest mnóstwo statycznych kadrów w pańskich filmach [...] i wiele takich ujęć twarzy Eriki [...]. Michael Haneke: Możliwe, że ma to związek z przekazem telewizyjnym. Telewizja zmienia nasz sposób oglądania. Przyspiesza przyswajanie obrazów. Na przykład reklamy w tym medium. A im szybciej coś jest pokazywane, tym mniej jesteśmy zdolni dostrzec przedmioty w ich fizycznej realności i tym bardziej stają się one uwodzicielskie. Im mniej realny jest obraz, tym szybciej kupujemy towar, jaki nam prezentuje. Oczywiście, ten typ estetyki zyskał wyższą rangę w kinie komercyjnym. Telewizja przyspiesza nasze doświadczenia, a my potrzebujemy czasu, by pojąć to, co widzimy. Ale współczesne media do tego nie dopuszczają". The World That Is Known, op. cit.

110 G. Arata, op. cit. 
Schuberta i słuchać go nieuważnie, ale przynajmniej jedna osoba znała te słowa świetnie i odbierała je nader osobiście - Erika Kohut.

Dochodzimy w ten sposób do kwestii miejsca i znaczenia w Pianistce cyklu pieśni Franza Schuberta Podróż zimowa. Schubert skomponował te dwadzieścia cztery utwory do wierszy niemieckiego poety Wilhelma Müllera. Właśnie stamtąd pochodzą obie śpiewane w filmie pieśni, a całość zakorzeniona w kulturze jako fundamentalne dzieło o samotności i poszukiwaniu własnej życiowej drogi ${ }^{111}$ - została w pewien sposób „nałożona”, niczym siatka kartograficzna, na mapę filmowych wydarzeń (do sposobu owego „nałożenia” jeszcze w powrócę). Aczkolwiek należy podkreślić, że Haneke pozostaje ironiczny i ostrożny w tym zabiegu, dzięki czemu ani znajomość cyklu, ani wiedza o tej korelacji nie jest przy oglądaniu filmu niezbędna ${ }^{112}$. Tu wracamy do - sygnalizowanej w pierwszej rozmowie Eriki i Waltera (kiedy to przy opowieści o Schumannie padły słowa: „Mówi pani o tym jak o własnym życiu") - do możliwości ponadczasowego duchowego pokrewieństwa między kompozytorami nieżyjącymi od dwóch stuleci a współczesnymi artystami, czyli do nałożenia typów psychicznych, czy wręcz indywidualnych cech charakteru Schuberta albo Beethovena (obaj dużą część życia spędzili w Wiedniu) na bohaterów Pianistki ${ }^{113}$.

W tym miejscu po raz kolejny przydatny okazuje się wątek polski, a mianowicie tom wierszy Stanisława Barańczaka zatytułowany Podróż zimowa

111 Rozliczne nawiązania do Winterreise odnajdziemy w dziełach sztuki z XIX i XX wieku, zarówno w literaturze (Czarodziejska góra Tomasza Manna), jak i w kinie (W obecności klowna Ingmara Bergmana).

${ }^{112}$ „Christopher Sharrett: Podróż zimowa Schuberta zajmuje centralne miejsce w Pianistce. Niektórzy dowodzą, że istnieje ścisły związek między Eriką a Schubertowskim wędrowcem $\mathrm{z}$ tego cyklu. I tu powraca ogólniejsze pytanie, na ile muzyka wyraża zdrową część świadomości Eriki, a na ile wzmacnia w niej procesy wyparcia. Michael Haneke: Niewątpliwie siedemnasta pieśń z cyklu jest w samym sercu filmowych wydarzeń i można ją widzieć jako motto - i życia Eriki, i tego filmu. Cały cykl wyraża ideę kroczenia nieuczęszczaną przez nikogo ścieżką - co wprowadza w film, jak sądzę, ironiczny kontekst”. The World That Is Known, op. cit.

113 „Rozpacz u Schuberta jest bardzo istotna i to rzutuje na nastrój filmu. Ktoś o tak ogromnych problemach jak Erika może czuć się jakby miał schubertowsko skomplikowaną artystyczną wrażliwość”. Ibidem. 
(wydany w 1994 roku), w którym poeta poddał pieśni z Schubertowskiego cyklu zabiegowi polegającemu na dopisaniu nowych tekstów do istniejącej muzyki; ściśle trzymał się przy tym jej schematów melodyczno-rytmicznych, ale treściowo stworzył całkiem nową jakośćl14. Koncepcja wybiega daleko poza parafrazę, mimo bogatej sieci nawiązań do oryginalnych tekstów, ponieważ w sferze poetyckiej Barańczak tworzy całkiem nową jakość. W oryginale ku tułaczce pchnęła bohatera pieśni nieszczęśliwa miłość (co było bliskie osobistemu doświadczeniu Schuberta), natomiast u Barańczaka motywy wędrówki są raczej religijne (jest koniec XX wieku, lecz chociaż Bóg - jak obwieścił Nietzsche - jest martwy, zaś jego obowiązki - jak ustalił Freud - przejęło superego, to wciąż nie przestaje być potrzebny). Dosłowna u Müllera zima, przez której realne śniegi brnie narrator, u polskiego poety staje się metaforą, a jej trzaskający mróz może być mrozem - do wyboru - egzystencjalnym lub politycznym (wszak komunizm w Polsce, w momencie publikacji tomu, dopiero co się skończył). Zabieg dokonany przez Barańczaka - i skonfrontowany z odbiorcą literackim, a później także muzycznym ${ }^{115}$ - bywa nazywany współcześnie „stylizacją intersemiotyczną” (jako że muzyka i literatura to dwa odrębne systemy znaków) ${ }^{116}$ albo w zgodzie $\mathrm{z}$ nazewnictwem ukutym jeszcze w XIX wieku - kontrafakturą ${ }^{117}$,

114 „Wiersze zawarte w tym zbiorze są, z jednym wyjątkiem, utworami oryginalnymi - n i e przekładami liryków romantycznego poety Wilhelma Müllera [...]. Choć związek między moimi utworami a muzyką Schuberta jest bardziej intymny i ścisły, moją ambicją było napisanie takich tekstów, które można byłoby zaśpiewać do określonej melodii, a zarazem - przeczytać można również w oderwaniu od muzyki, jako samodzielne wiersze". www.wydawnictwoa5.pl/Podroz-zimowaWiersze-do-muzyki-Franza-Schuberta;s,karta,id,174 [dostęp: 30.05.16].

115 Cykl wierszy wykonali w 1994 roku w formie regularnych, zaaranżowanych na głos i fortepian pieśni (odśpiewanych z szacunkiem dla schubertowskiej tradycji wykonawczej) Jerzy Artysz i Katarzyna Jankowska w sali koncertowej Polskiego Radia w Warszawie. Część z utworów trafiła potem na płytę opublikowaną przez magazyn „Studio”.

116 A. Hejmej, Stuchać i czytać: dwa źródła jednej strategii interpretacyjnej. „Podróż zimowa” Stanisława Barańczaka, „Pamiętnik Literacki” 1999, z. 2.

117 M. Poprawski, Muzykologiczne aspekty interpretacji „Podróży zimowej” Stanisława Barańczaka, www.demusica.pl/cmsimple/images/file/poprawski_muzykalia_5_1.pdf [dostęp: 30.05.16]. 
czyli dopisaniem nowego tekstu do wcześniej istniejącej muzyki (co było popularną praktyką u artystów średniowiecznych i renesansowych).

Trzymając się tej drugiej definicji i jej historycznych uwarunkowań, warto przypomnieć, że - przy zachowaniu całkowitej integralności muzyki i wierności jej zapisowi - kontrafaktura pozwalała na zmianę sposobu ekspresji oraz aury utworu, co w realiach średniowiecza czy renesansu pozwalało na przenoszenie go ze sfery sacrum do sfery profanum lub w przeciwną stronę. Służyło to twórcom do podejmowania wyrafinowanej gry z konwencjami artystycznymi, społecznymi czy religijnymi, co często kończyło się wzburzeniem publiczności i skandalem.

Tom Barańczaka nawiązuje także do tych cech kontrafaktury, ponieważ zachowując pozory uwspółcześnionej, ale spolegliwej wobec oryginału parafrazy ${ }^{118}$, po pierwsze, kwestionuje rozmaite stereotypy dotyczące podejścia do dawnych dzieł (w tym - nienaruszalności ich charakteru), po drugie natomiast, traktując $\mathrm{z}$ atencją kompozycje Schuberta, podejmuje ironiczny spór z romantyczną poezją Müllera, a więc poniekąd z samym duchem romantyzmu (który po stu pięćdziesięciu latach wciąż pozostaje niepokojąco żywy w powszechnym odbiorze literatury). Jak zauważył Marcin Poprawski: „Podróż zimowa przenosi muzykę Schuberta ze sfery profanum do sacrum, jako że w wierszach Barańczaka wyraźnie ujawnia się kluczowy ton modlitwy, którego prawie nie ma u Müllera" ${ }^{\prime 19}$. Z drugiej strony, ktoś słusznie może zwrócić uwagę, że możemy rzecz rozumieć odwrotnie: muzyka Schuberta, traktowana przez koneserów jak świętość, zostaje poprzez „wykreślenie” niemieckiego tekstu wewnętrznie rozbita i ulega swoiście rozumianej profanacji.

Oczywiście, Pianistka nie jest tak rozumianą kontrafakturą (choć film jako gatunek jest niewątpliwie systemem znaków, więc umożliwia taki zabieg $\left.^{120}\right)$. Jednak intersemiotyczny charakter dzieła Hanekego wynika

118 „[Barańczak] rozsiewa różne aluzje tematyczne na przestrzeni całego cyklu, czyniąc z nich odniesienia ogólnie pasujące do aury i nastroju Müllerowskiego cyklu”. Ibidem.

119 „Zgodność ta jest łatwo dostrzegalna, ale zarazem tylko powierzchniowa, jako że podszyta Barańczakową ironią, polemiką, sprzeciwem i niską oceną wartości poezji Müllera! A podobieństwa wcale nie służą tu afirmacji”. Ibidem.

120 „Kinematografia, podobnie jak inne sztuki, jest szczególnym systemem znaków". B. Eichenbaum, Problemy stylistyki filmowej, [w:] Estetyka i film, red. A. Helman, Warszawa 1972, s. 60. 
z wykorzystania jej elementów. Film zawiera niektóre cechy kontrafaktury: zmianę tonacji, wielopoziomowy dialog z oryginałem czy wreszcie godzącą w społeczne zasady nieobyczajną naturę, która pociąga za sobą skandaliczną aurę. W przypadku Pianistki ta aura powstała wokół obscenicznych upodobań i zachowań bohaterki, których ocena - dominująca zarówno w spontanicznych reakcjach publiczności ${ }^{121}$, jak i w wielu recenzjach i dyskusjach krytyków ${ }^{122}$ - po pierwsze, spychała na dalszy plan inne problemy poruszone przez film, po drugie natomiast, kierowała dyskusję w kierunku stereotypowej dychotomii kultura/natura, ludzkie/zwierzęce ${ }^{123}$.

Wyrazy oburzenia albo skwapliwie umoralniający ton wielu recenzji świadczą o tym, że w Pianistce zostały dobrze uchwycone (czy też: zachowały się) prowokujące i wywrotowe właściwości kontrafaktury. Chociaż można by pozostawić obronę filmu oraz uzasadnienie drastycznych scen samemu reżyserowi (który wielokrotnie i do znudzenia, także własnego, opowiadał w wywiadach o swoim stosunku do pornografii, między innymi o niszczącym ludzką psychikę wpływie masowych mediów, o utowarowieniu obsceniczności czy pornografizacji przemocy ${ }^{124}$ ), to zdecydowanie lepiej poszukać uzasadnienia wewnątrz, a nie na zewnątrz filmu, czyli pozwolić dziełu, by broniło się samo. I właśnie tak się stanie, jeżeli przede wszystkim przyjrzymy się (i przysłuchamy) Pianistce jako celowemu zetknięciu dwóch systemów znaków, czyli „nadpisaniu” współczesnych kinowych obrazów

121 „On jest chory! - usłyszałem po festiwalowym seansie”. T. Sobolewski, Haneke. Wściekły i podstępny, op. cit. „Dla zaszokowania widzów i zainteresowania ich problemem postanowił nie unikać obsceniczności, ukazując z odpowiednią dosadnością sadomasochistyczne skłonności Eriki”. K. Wolanin, op. cit.

122 „Ale to nie jest rafinada, to jest zejście do rynsztoka!”. Z. Kałużyński, T. Raczek, Pojedynek z seksem, „Wprost” 2001, nr 47.

123 „To jest problem bohaterki: przepaść między kulturą, która jest jej światem, a zwierzęcością, bydlęcością, ohydnością seksu. [...] To jest konflikt między tym, co w człowieku duchowe, i tym, co zwierzęce. Bo człowiek jest potworem, panie Tomaszu". Ibidem.

124 „Pornografia sama w sobie nie jest dla mnie interesująca, nie mam ochoty jej atakować, szkoda by mi było czasu, żeby robić film przeciwko niej. Zgodnie z moją definicją pornografii: Pianistka może być odebrana jako film antypornograficzny, ale Funny Games jest w takim razie o wiele bardziej antypornograficzny!”. Era wilków, op. cit. 
oraz skrajnie drastycznej historii na powstałą półtora wieku wcześniej muzykę. Muzyka ta jest świadectwem epoki, której moralno-społeczny gorset był ciaśniejszy niż dziś, a jednak nostalgia za owym „dawnym” porządkiem (klasycznie zdyscyplinowanym jak muzyka, która go reprezentuje) wciąż pozostaje żywa i powszechna.

Takie spojrzenie pozwala zobaczyć w filmie nie obraz patologicznych relacji - rodzinnych i damsko-męskich - na tle opresyjnego austriackiego mieszczaństwa (znamienne są różnice między filmem, znajdującym osobliwe zrozumienie $^{125}$ dla najgorszych nawet cech bohaterów, a pełną oskarżycielskiej furii powieścią Elfriede Jelinek) oraz nie opowieść o melodramacie w obscenicznych realiach (choć jeśli jest to obscena w znaczeniu zaproponowanym Jeana Baudrillarda, to rzuca ona istotne światło w mroki duszy bohaterów filmu ${ }^{126}$ ). Zamiast tego Haneke pokazuje przede wszystkim historię ujawniania się indywidualnej ludzkiej prawdy, która napotyka na opór społeczny (tym bardziej jeżeli jest to prawda o kobiecie). Bez względu na to, czy będziemy w XIX-wiecznym Wiedniu, czy we współczesnej liberalnej Europie.

Wykorzystanie muzyki sprzed dwóch stuleci i specyficznie „kontrafakturowe" dopisanie do niej nowej historii, celowo drastycznej i bulwersującej, pokazuje, że z prawdą Eriki nie godzą się, po kolei: jej matka (traktująca kobietę jak nastolatkę), Walter (który na śmiałe odsłonięcie się Eriki reaguje agresją i pogardą) i wreszcie sam widz (wobec czego zasadne staje się pytanie, czy nie jest on - tak jak w przypadku Funny Games - właściwym bohaterem filmu).

Bohaterka Pianistki, prowadzona przez muzykę z całkiem innej epoki, błąka się po hałaśliwych ulicach Wiednia (między opresyjnym domem, rygorami konserwatorium a perwersyjnym światem sex shopów) niczym wędrowiec z Podróży zimowej - raptem przeniesiony z wystudiowanych romantycznych realiów w trywialną współczesność. U obojga trauma odrzucenia

125 Zasłyszane przez Tadeusza Sobolewskiego w kinowej sali „On jest chory!” jest spowodowane poniekąd właśnie podejściem Hanekego, dalekim od moralnego osądzania.

126 „Obsceniczność zawiera element transgresji, prowokacji czy perwersji. Igra z wyparciem za pomocą fantazji, których tematem jest przemoc.” J. Baudrillard, O uwodzeniu, tłum. J. Margański Warszawa 2005, s. 32; zob. też: P. Zawojski, op. cit. 
graniczy z pewnością, że to odrzucenie będzie się powtarzać: zawsze znajdzie się jakiś mistrz piekarski (za którego wyszła ukochana Franza Schuberta) albo normalna dziewczyna (którą na pewno szybko znajdzie sobie Walter). Jednak w filmie - do połowy seansu - owa granica pewności jeszcze nie zostaje przekroczona.

Przyjrzyjmy się w tym kontekście scenom dwóch pierwszej lekcji, które Walter bierze u nowej profesorki fortepianu. $\mathrm{Na}$ „dzień dobry” wygłasza ona stanowczy komunikat: „Żadnego Schuberta, tylko Schönberg”, co niesie dwojakie znaczenie: po pierwsze, ma utemperować „romantyczne” gesty chłopaka skierowane ku niej, po drugie natomiast, skierować jej własne myśli na tory raczej „schönbergowskie” - intelektualne, skrupulatne, ustrukturyzowane jasno i klarownie - niż „schubertowskie”, czyli emocjonalne i niosące nazbyt wiele biograficzno-miłosnych podtekstów. Jednak próba oczyszczenia ich relacji, zaprowadzenia porządku uczeń - nauczyciel, okazuje się nieskuteczna.

Ta muzyczna alternatywa - albo Schönberg, albo Schubert - okazuje się symbolicznym rdzeniem filmowych wydarzeń. Niedługo później dochodzi bowiem do kolejnego zwrotu akcji: pierwszego fizycznego zbliżenia między Eriką i Walterem w toalecie konserwatorium. Jest to jedna z przełomowych scen filmu, o dużej intensywności emocjonalnej ${ }^{127}$ (na plakat promujący film trafił kadr z kompulsywnym pocałunkiem na podłodze). Walter dąży do „normalnego” seksualnego kontaktu, ale Erika nie potrafi się przełamać i ulec standardowym w takiej sytuacji emocjom, rzec można: „schubertowskim” (z całym romantycznym bagażem stereotypów idących za muzyką Schuberta), pozostającym w kręgu społecznie akceptowanej „seksualnej tonalności”'28. Kobieta została przeprogramowana (przez długo-

127 „Świadomość okaleczonego losu, ukrywana za cynizmem i samotną konsumpcją seksualnych podniet, wybucha w filmie kilka razy, działając na zasadzie dynamitu". G. Arata, op. cit.

128 „Tonalność, muzyka tonalna - termin opisujący konwencje harmoniczne większości zachodniej muzyki [...] od wieku osiemnastego do teraz. Muzyka tonalna jest zorganizowana wokół centrum nazywanego toniką i skali, której tonika jest podstawą. Nazywa się ją również »harmoniką funkcyjną lub »harmonią klasyczną"”. Kultura dźwięku. Teksty o muzyce nowoczesnej, red. Ch. Cox i D. Warner, tłum. J. Kutyła, Gdańsk 2010, s. 510. 
trwałe oddawanie się perwersyjnym praktykom) na skrajnie wyrafinowany tryb doświadczenia seksualnego, związany z kontrolą, bólem, dominacją, wykraczający poza utrwaloną „tonalność” relacji erotycznych - a zatem swoiście „schönbergowski” (jako że Schönberg to jeden z prekursorów atonalności w muzyce ${ }^{129}$ ).

Złożona psychika Eriki Kohut i jej skrajnie nietypowe potrzeby (zamiast standartowego seksualnego zbliżenia, nakłania Waltera do poddania się aktowi dominacyjnej masturbacji) to produkt nie tylko pornoedukacji oraz sadomasochistycznych praktyk odreagowywania samotności i upokorzenia ${ }^{130}$, ale być może także rodzaj „skrzywienia zawodowego”, czyli efekt lat pracy nad wyrafinowanym materiałem muzycznym i wpajania go uczniom w skrajnie chłodny, intelektualny sposób. W słynnej scenie z Pianistki jesteśmy zatem świadkami nie tylko nieudanej rozbieranej randki prostego studenta politechniki („od recitalu utkwiła mi pani w głowie jak śruba w nakrętce - przepraszam za to techniczne porównanie”) z profesorką muzyki, zanurzoną w świecie fortepianowych arcydzieł (bez odtrutki w postaci spełnionej kariery wykonawczej ${ }^{131}$ ), ale także symbolicznego spotkania akceptowanej społecznie kulturowej tradycji z awangardą, która ujawnia swoją „bulwersującą” moc. Tak czy owak, pragnienia Eriki zostały po raz pierwszy ujawnione - puszka Pandory została otwarta.

Podczas drugiej lekcji Waltera u Eriki - już po zbliżeniu w toalecie, ale przed jakąkolwiek werbalną kodyfikacją ich związku - na tle lirycznych

129 „Atonalność, muzyka atonalna - termin ten opisuje szerokie spektrum stylów kompozycyjnych, które nie opierają się na konwencjach harmonii tonalnej, a zwłaszcza nie organizują wysokości dźwięków wokół ośrodka tonalnego”. Ibidem, s. 501.

130 „Seks w La Pianiste ma formę kuriozalną i bolesną, zdecydowanie antykonformistyczną i daleką od jakichkolwiek śladów romantyzmu. Jest odbiciem i kompensacją wewnętrznych frustracji i afektywnego okaleczenia bohaterki, u której zduszono potrzebę ciepła i czułości, zastępując je strukturami dominacji”. G. Arata, op. cit.

${ }^{131}$ „A może, panie Zygmuncie, ona poszukuje w seksie tego stopnia wyrafinowania, który osiąga w sztuce, w muzyce? Może jest niezdolna do zwykłego seksu w rodzaju - kocham cię, pocałuj mnie, chodźmy do łóżka”. Z. Kałużyński, T. Raczek, op. cit. 
dźwięków Andantina z Sonaty A-dur Schuberta (a zatem Schönberg przegrał w symbolicznym pojedynku) obserwujemy walkę, jaką Erika toczy ze swoimi pragnieniami. Walczy, przywołując na pomoc fachową wiedzę („Wskazówki Schuberta idą od szeptu do krzyku”), a także inspirowaną przez muzykę intuicję $\mathrm{w}$ drążeniu zakamarków kompozytorskich dusz („Brahms napisałby con intimissimo sentimento"). Ma także inną broń: wsparte wiedzą szyderstwo („Jak pan wie, Schubert był dość brzydki, a pana chroni ładna buźka"). W końcu jednak Erika wręcza Walterowi skrupulatny wykaz jej miłosnych życzeń (w istocie jest to bulwersujący katalog sadomasochistycznych czynności), który chłopak ma otworzyć dopiero, kiedy będzie sam. W takim sposobie rozegrania miłosnej partii znowu spotykają się dwie osobowości Eriki Kohut. Jedna to wykładowczyni w konserwatorium, zagrzebana w katalogach opusów, ściśle przestrzeganych muzycznych tempach i nastrojach (allegro, largo, cantabile), zaś druga to wielbicielka pornografii z jej niezmordowanym katalogowaniem ludzkich zachowań seksualnych, aby każde pragnienie mogło trafić na odpowiednią sklepową półkę (BDSM, pissing, dogging). Erika przenosi cechy obydwu swoich osobowości na miłosną relację z Walterem, przekazując mu listę precyzyjną jak zapisy w partyturze i wypunktowaną jak handlowe zamówienie.

Walter czuje, że gardło Eriki ściskają emocje, lecz pianistka mówi stanowczo: „Zrozum, że ja nie mam uczuć. Nigdy nie zatriumfowałyby nad moją inteligencją". Do pewnego stopnia jest to prawda, ponieważ potrzeba zdystansowanej kontroli (także w rzekomo czysto emocjonalnej grze w uwodzenie ${ }^{132}$ ) i narzucania skodyfikowanych rygorów (choćby samemu miało się nim boleśnie ulegaćl ${ }^{133}$ ) jest u niej silniejsza niż jakiekolwiek spontaniczne uczucia. Na zakończenie tej sceny Erika nakazuje: „A teraz zabierz się za Schuberta - tylko to wolno ci w tym pokoju", zaś Walter wraca do Andantino, którego subtelna

132 „Przede wszystkim muszę uświadomić samemu sobie to, że cała ta historia jest fikcyjną grą". S. Kirkegaard, Dziennik uwodziciela, tłum. S. Lack, M. Bienenstock, Warszawa 2009, s. 430.

133 „Osobnik perwersyjny jest skrajnie podejrzliwie nastawiony do uwodzenia i stara się je skodyfikować. Stara się ustalić jego reguły, sformalizować je w tekst, wyrazić je w pakcie. W ten sposób łamie podstawową regułę, regułę tajemnicy". J. Baudrillard, op. cit., s. 124. 
melodia jest przeciwstawiona obserwowanej przez kamerę kopercie z ukrytymi pragnieniami.

Co ciekawe, jest to ostatni moment, kiedy muzyka w Pianistce tak efektywnie angażuje się w filmową narrację - do sceny erotycznego zbliżenia a potem, kiedy wypadki toczą się już siłą emocjonalnej bezwładności (ku klęsce bohaterki, ukazaniu się odmiennego oblicza Waltera i krachowi ich uczucia), kompozycje odchodzą na drugi plan, w tło wydarzeń. Ostatniej scenie filmu (kolejnemu statycznemu ujęciu) towarzyszy jedynie szum ulicznego ruchu otaczający wiedeńskie konserwatorium.

O tym, dlaczego muzyka milknie, Michael Haneke opowie w innym filmie.

\section{MIŁOŚĆ, CZYLI DLACZEGO MUZYKA MILKNIE}

Jeszcze dłuższe, pozbawione muzyki, statyczne ujęcie rozpoczyna film Miłość. Przez kilka minut kamera obserwuje w filharmonii publiczność czekającą na fortepianowy recital, a pary głównych bohaterów - choć grają ich znani, świetnie rozpoznawalni aktorzy - przy pierwszym oglądaniu filmu widz może w ogóle nie wychwycić. Jest to typowe dla Hanekego, wystawiające cierpliwość widza na próbę, szerokokadrowe ujęcie ${ }^{134}$, symulujące nieobecność reżysera: kamera sprawia wrażenie postawionej naprzeciwko widowni na stałe. W warstwie audio jest tak samo - wypełniają ją naturalne szmery, stuknięcia, strzępy głosów, których przedłużająca się (zdecydowanie ponad komercyjną filmową miarę) obecność pozwala tym dobitniej zabrzmieć pierwszym akordom Impromptu c-moll nr 1 Franza Schuberta.

Początkowo Impromptu brzmi w rzeczywistości diegetycznej: słuchane przez publiczność podczas koncertu. Charakterystyczny temat na początku utworu (łatwo wpadający w ucho niekoniecznie uzbrojone w muzyczną wiedzę) znakomicie pełni przy tym funkcję motywu otwierającego film. Po „antyromantycznym” szumie w prologu, słuchamy „romantycznej” melodii zapowiadającej późniejszy przebieg akcji. Niesie to za sobą także głębszy

134 „Scena otwierająca film (ze znakiem firmowym Hanekego - szerokokadrowym ujęciem zachęcającym widza, by zaczął analizować to, co widzi, w ten sam sposób, w jaki analizuje treść całego filmu) ukazuje parę w sali Théâtre des Champs Elysées na fortepianowym recitalu”. http://framescourer.blogspot.com/2012/11/ music-in-amour-2012.html [dostęp: 30.05.16]. 
sens, ponieważ - jak pamiętamy - w pierwszym ujęciu kamera w ogóle „nie dostrzega" bohaterów - są tylko statystyczną parą ludzi w tłumie (dwoma zajętymi krzesłami na sali, dwoma zakupionymi biletami, dwiema pozycjami w remanencie kasy po koncercie), a dopiero wypadki, które nastąpią, zaczną ukazywać Anne i Georges'a w coraz bliższej perspektywie - aż do tej najbardziej osobistej, najintymniejszej.

Ta intymność dotyczy zresztą tyleż samo rzeczywistości wewnątrz filmu (przez dwie godziny będziemy się z bliska przyglądać postępującej ciężkiej chorobie Anne, która po udarze będzie miała sparaliżowaną prawą część ciała i zacznie ulegać stopniowej psychicznej i fizycznej degradacji, ale także codziennemu poświęceniu Georges’a, który mimo podeszłego wieku zaopiekuje się żoną), co kontekstom pozafilmowym. Miłość jest bowiem zainspirowana losami 92-letniej ciotki reżysera, która dotknięta nieuleczalną chorobą, prosiła o odebranie jej życia ${ }^{135}$. Emocjonalne zaangażowanie Hanekego potwierdza fakt, że część sprzętów i obrazów z paryskiego lokum pary bohaterów to rzeczy prywatne, należące do reżysera, zaś urządzenie mieszkania jest wzorowane, miejscami z detaliczną precyzją, na mieszkaniu jego rodziców. Choć, oczywiście, przełożenie życia na dzieło nie jest aż takie proste ${ }^{136}$.

Otwierająca Miłość fortepianowa kompozycja Schuberta sięga jednak nie tylko w przyszłość, lecz także w przeszłość bohaterów. Najpierw mamy znany już chwyt z cięciem montażowym w warstwie obrazu, bez cięcia taśmy z dźwiękiem: Impromptu c-moll na koncercie trwa dalej, choć bohaterowie wracają już do domu, a frazy fortepianu są niezwykle płynnie

135 „Powiedziałem jej, że nie mogę jej pomóc, bo po pierwsze, poszedłbym do więzienia, a po drugie, nie byłbym w stanie tego zrobić - opowiada reżyser. - Potem ciotka próbowała popełnić samobójstwo, ale w porę zawiozłem ją do szpitala. Była na mnie zła. Dlaczego mi to zrobiłeś? - pytała. Dwa lata później udało jej się, odebrała sobie życie. Miłość to film dla niej”. Michael Haneke dedykuje "Miłość" ciotce, www.canalplus.pl/film/news-michael-haneke-dedykuje-milosc-ciotce_40195 [dostęp: 30.05.16].

${ }^{136}$ „Nie ukrywał, że inspiracją dla Miłości były zdarzenia z jego życia. Ale choć w paryskim studiu odtworzył mieszkanie swoich rodziców (z detalami, jak meble z lat 50., stereo $z$ lat 60.), podkreśla, że nie opowiada o doświadczeniach związanych $\mathrm{z}$ ich odchodzeniem". M. Sadowska, op. cit. 
zharmonizowane z kołysaniem autobusu i ruchem sylwetek pasażerów w kadrze. Scena jest zmontowana z podobną realizacyjną zręcznością jak ta $\mathrm{z}$ Pianistki, gdzie grane na próbie w konserwatorium Schubertowskie Andante towarzyszy bohaterce później w sex shopie, tyle że tu zostaje użyta o wiele dyskretniej, bez ambicji radykalnie metaforycznych, chociaż dla filmu znaczy równie wiele. W kilka chwil zostaje nam zasugerowane, jak głęboko może tkwić muzyka w świadomości Anny i Georges’a oraz jak ważną rolę będzie pełnić w dalszych wydarzeniach.

Po powrocie do domu odegrany na koncercie utwór dalej absorbuje uwage bohaterów, choć z punktu widzenia widza nie istnieje już w formie dźwiękowej (film wraca do realistycznej sfery i słyszymy, z detalami, odgłosy domowej krzątaniny). Anne, pomiędzy banalnym zdjęciem płaszcza i zrobieniem czegoś w kuchni, wyraźnie ożywionym głosem mówi: „Szesnastki w presto były nadzwyczajne - co za finezja! Nie sądzisz?” (dzięki temu dowiadujemy się, że bohaterowie nie są tylko parą starszych melomanów, ale mają znacznie więcej wspólnego z muzyką), na co Georges odpowiada retorycznym wobec entuzjazmu w głosie żony - pytaniem: „Jesteś z niego dumna?” (co wskazuje na więź łączącą Anne z młodym pianistą na koncercie). Tak samo jak w Pianistce, widzimy zatem, że Haneke prowadzi narrację za pomocą muzyki na dwa sposoby: po pierwsze, za pomocą jej „fizycznej” obecności, czyli słyszalności przez widza, po drugie zaś, za pomocą rozmaitych kontekstów, które dotyczą utworów, a które można umieści w sferze obrazu, dialogów, albo nawet w sferze domyślnej - ufając kulturowej wiedzy widza.

Jest wszakże też istotna różnica: pierwsza rozmowa o muzyce w Pianistce kiedy Erika opowiada Walterowi o losach Schumanna, nawiązując do własnych doświadczeń - niesie ze sobą bagaż „romantycznych” kontekstów (zawartych w słowach: „utrata zmysłów”, „katastrofa”, „zatracenie”, czy w końcu „zmierzch duszy”), które, jak wiemy, mają się niejako „powtórzyć” w filmowym „tu i teraz”, czyli w dramatycznym romansie, jaki wkrótce nawiążą bohaterowie. Natomiast pierwsza rozmowa o muzyce w Miłości w ogóle nie nawiązuje do „romantycznych” korzeni utworu Schuberta (słyszymy słowa „szesnastki” i „presto”, których suchy aspekt techniczno-wykonawczy jest zrównoważony nacechowanym uczuciowo słowem „finezja”) i odbywa się nie podczas iskrzącej wzajemną fascynacją rozmowy erotomanki z przystojnym studentem, lecz w banalnych pieleszach $\mathrm{u}$ pary starszych mieszczan. 
Co równie znamienne, w Pianistce po scenie domowego recitalu, na którym słyszymy granego na dwóch fortepianach Bacha, muzyka zaczyna coraz śmielej przejmować narrację, rozbrzmiewając często i asystując rozwojowi akcji szczególnie przez pierwszą godzinę filmu. Tymczasem w Miłości po odegranym na początku Impromtu Schuberta muzyka na prawie godzinę czyli niemal pół filmu - milknie.

Muzyka milknie, lecz to wcale nie znaczy, że reżyser zwalnia ją z narracyjnych obowiązków. Działanie muzyki, wskutek fizycznej, dźwiękowej „nieobecności”, staje bardziej dyskretne, subtelniejsze, dalekie od kinowych schematów (tak jak tytułowa miłość okazuje się daleka od powszechnych wyobrażeń). Pojawia się na przykład pod postacią przedmiotów (sprzętu stereo ulokowanego tak, że stanowi naturalne tło dla kilku kluczowych scen w filmie, albo książki o dyrygencie Nicolasie Harnoncourcie, który w latach 60. ubiegłego wieku - a więc w latach twórczej młodości obojga bohaterów - zrewolucjonizował myślenie o muzyce). Nawet fakt, że ucznia Anne gra autentyczny pianista, Alexandre Tharaud, potrafi nabrać metafilmowego znaczenia, jeżeli wiemy, że to Tharaud nagrał utwory na ścieżkę dźwiękową do Miłości. A soundtrack to szczególny, ponieważ - inaczej niż w komercyjnych produkcjach - na płytę nie trafiły całe utwory, ale ich urywki - dokładnie takie, jakie słyszymy w trakcie seansu ${ }^{137}$. Jest to przypadek zepsutej świadomie radości słuchania, aby doświadczenie nagłego ucichnięcia muzyki - która przecież nie znika wtedy z głowy - można było osiągnąć także po powrocie z kina do domu. Wtedy okazuje się, że jesteśmy blisko rozważań Carla Dahlhausa nad fenomenologicznymi aspektami trwania i odbierania muzyki, a także jego - istotnego z punktu widzenia niniejszej pracy - przeświadczenia o wielopoziomowości muzyki, skutkującej wielopoziomowością odbioru i interpretacji ${ }^{138}$. Pierwotnie wymyślony

137 „Kto zakupi soundtrack do Miłości Michaela Hanekego przed obejrzeniem filmu, może mieć wrażenie zabawnej pomyłki, jeżeli chodzi o podejście reżysera do muzyki. Nie w tym rzecz, że lista utworów jest niekompletna, bo mamy tu i Schuberta, i wybór bagateli Beethovena. Tyle że każdy utwór na płycie jest przerwany po krótkim czasie - nagłym cięciem albo słowami: »Wyłącz to«. (W roboczej wersji film miał tytuł Kiedy muzyka milknie)". Ryan Gilbey, op. cit.

138 „Dahlhaus rozważa także problem muzyki jako fenomenu audytywnego, przemijającego w czasie, ujmowanego w kategoriach fenomenologii. Podejmuje 
przez Michaela Hanekego tytuł dla filmu - Kiedy muzyka milknie - ma zatem konsekwencje wykraczające daleko poza fabułę.

Sposób, w jaki muzyka działa wewnątrz filmu, odpowiada, jak się zdaje, podejściu samego reżysera ${ }^{139}$. Miłość pod wieloma względami oglądamy jak film, który nie wyszedł spod ręki Hanekego: częściowo pozostały tu elementy jego stylu, ale przy znamiennym braku niektórych efektów, do jakich nas przyzwyczai1 ${ }^{140}$. Ta zmiana stylu Hanekego w Miłości - nieco podobna do wolty Davida Lyncha, kiedy wbrew postmodernistycznemu emploi nakręcił Prosta historię - ma oczywiście prawo budzić nieufność (wszak reżyser to podstępny gracz na emocjach widza, wytrawny szuler tasujący to, co widzialne i ukryte $\left.{ }^{141}\right)$, lecz potrafi też uwiarygodnić reżysera, który nie potrzebował, w chwili premiery Miłości, potwierdzać ani swojej

m.in. krytyczną dyskusję z koncepcją Romana Ingardena, podważając jego tezę o jednowarstwowej strukturze muzyki i twierdząc, że "Tak jak bezowocna jest próba policzenia warstw - nie da się zaprzeczyć, że zdanie o jednowarstwowości jest błędne«". A. Jarzębska, Dialektyczny dyskurs Dahlhausa, „Ruch Muzyczny” 2009 , nr 6.

139 „Nieprzypadkowo film nosi tytuł Miłość, ale odkrycie prawdziwego znaczenia tego słowa u niejednego widza wywoła uczucie dyskomfortu, będzie zaskoczeniem, a dla wielu - szokiem. Haneke jest czulszy niż zwykle, ale bynajmniej nie sentymentalny". M. Sadowska, op. cit.

140 „Miłość wygląda jak film Hanekego - tak pod względem kompozycji długich, w większości statycznych kadrów, jak i sensu opowieści - ale nie ogląda się jej jak filmu Hanekego. Austriacki reżyser zawsze stosował pewnego rodzaju brutalizm, forsował przyjętą przez siebie tezę w taki sposób, jakby był przekonany o jej słuszności, nie znosząc choćby cienia sprzeciwu. Często wymierzał widzowi precyzyjnie wycelowane kopniaki, zwykle za pomocą przepełnionych przemocą scen, z góry zaplanowanych jako szokujące. Miłość pozbawiona jest tego typu zagrań, pozbawiona jest też pewnego rodzaju napuszenia”. G. Fortuna, op. cit.

${ }^{141}$ „Ja sama do Miłości podchodzę nieufnie, może dlatego, że nie spodziewałam się takiego filmu po twórcy Ukrytych, Wideo Benny'ego, Pianistki. [...] Zaskakująco łagodnego wobec widzów i bohaterów, choć czyniącego tematem śmierć. Do tego ów gołąb, jak skradający się przez okno kicz (»Gołębi puch - perfidny kicz« śpiewał kiedyś nie bez racji Lombard)”. M. Sadowska, Martwa natura. Z gołębiem, www.canalplus.pl/film/blog-malgorzata-sadowska-martwa-natura-zgolebiem_961_11 [dostęp: 30.05.16]. 
wirtuozerii technicznej, ani błyskotliwej erudycji na polu artystycznym czy filozoficznym, natomiast wielu odbiorców jego filmów odpychała reżyserska maniera uparcie pesymistycznego moralizatora, a zatem w istocie - filmowego doktrynera ${ }^{142}$.

Co ciekawe, niektóre muzyczne wątki w Miłości wydają się nawiązywać do wydarzeń z poprzednich filmów reżysera (i ukazywać podobne sytuacje czy stany, acz w nieco innym świetle). Na przykład kiedy Anne i Georges’a odwiedza ich córka, Eva, słyszymy - przy okazji opowieści o tournée, na którym wykonują z mężem muzykę Johna Dowlanda - historię artystyczno-erotycznych perturbacji w ich związku. Dzieje burzliwego romansu męża ze skrzypaczką, zwieńczone próbą samobójczą kochanki, można odebrać jako cień kroniki wypadków miłosnych z Pianistki (tym bardziej że w roli Evy reżyser obsadził Isabelle Huppert - pytanie: ile w tym typowej dla Hanekego ironii?). Tymczasem Georges słucha opowieści córki ze stoickim spokojem, równie daleki od zdziwienia czy wzburzenia takim obrotem spraw w „artystycznym” małżeństwie, co od jakiejkolwiek oceny moralnej.

Wiemy, że Eva także jest muzykiem, ale poza tym jej relacje z rodzicami (a konkretnie z Georges'em, bo Anne leży już chora w łóżku) są raczej chłodne, pełne stonowanego dystansu zamiast spontanicznej serdeczności. Spora część krytyków, jakby wciąż tęskniąca za „dawnym” Hanekem, przedstawia to jako dowód, że reżyserowi nie stępił się pazur krytyki społecznej ${ }^{143}$

142 „Doceniając wszystkie wcześniejsze filmy Michaela Hanekego, zżymałem się niekiedy na wyraziście stawiane przezeń tezy, formułowane w stylu tak gwałtownym, że właściwie niedopuszczającym odrębnego zdania”. Ł. Maciejewski, op. cit. „Miłość Michaela Hanekego jest najlepszym filmem w karierze reżysera, którego rzemiosło doceniałem zawsze, ale którego moralizatorstwo często budziło moje wątpliwości (także na tych łamach). Tym razem efekciarskiego czarnowidztwa nie ma prawie wcale - zamiast niego Haneke staje twarzą w twarz z umieraniem jako ostateczną potwarzą natury rzuconą pod adresem ludzkiej godności”. M. Oleszczyk, Miłość, „Dwutygodnik” 2013, nr 2(101), www.dwutygodnik.com/artykul/4067-milosc-rez-michael-haneke.html [dostęp: 30.05.16].

${ }^{143}$ „Córka starszej pary także nie zna już sztuki włáciwego zachowania. Kiedy przychodzi do rodziców (a pojawia się nieczęsto), zaznacza swoją obecność wybuchami narcystycznego cierpienia. Epatuje zmęczonego ojca pełną wyrzutu, 
i nie wygasła pasja demaskatora mieszczańskiej obłudy ${ }^{144}$, ale można też dostrzec w rozmowie ojca $z$ córką coś wręcz przeciwnego: skryte za dystansem zaufanie (takie samo jak w relacji Georges’a i Anne), owocujące szczerością i spokojną otwartością ${ }^{145}$ - czyli relację stanowiącą zaprzeczenie charakteru związku Eriki z jej matką w Pianistce. Te dwie bohaterki reżyser pokazywał z bezlitosną przenikliwością, zupełnie inaczej niż w Miłości portretuje Evę i jej ojca ${ }^{146}$. Być może dlatego, że Haneke patrzy na nią oczami Georges’a, a ten $z$ kolei patrzy na córkę mądrymi oczami Jean-Louisa Trintignanta (którego wpływ na kształt filmu był znacznie większy niż tylko znakomita kreacja aktorska ${ }^{147}$ ), siedzącego w fotelu, za którym stoi staroświecki, ale markowy sprzęt do odtwarzania muzyki.

Sprzęt stereo, czyli odtwarzacz CD, gramofon i wzmacniacz (z charakterystycznymi wychylającymi się wskazówkami poziomu dynamiki) to w zasadzie jeden z głównych bohaterów filmu: jego zaawansowany wiek (pochodzi mniej więcej z lat 60. ubiegłego stulecia) świadczy, że pamięta młodość pary bohaterów, a więc rozkwit ich miłości (wspominanej przez córkę) i ich kariery jako muzyków (być może nie tylko nauczycieli). Natomiast fakt, że jest

opuchniętą od łez twarzą”. K. Świrek, „Miłość” według najlepszych zasad. O regułach w filmach Michaela Hanekego, „Kultura Liberalna” 2012, nr 46, http://kulturaliberalna.pl/2012/11/13/swirek-milosc-wedlug-najlepszych-zasad-o-regulach-w-filmach-michaela-hanekego-esej/ [dostęp: 30.05.16].

144 „Myślę o momentach, w których czuję największy fałsz - o relacjach z córką, po hanekowsku zimnych, formalnych, nasyconych obcością i utrzymanych w ryzach konwencji przy pozorach wzajemnej otwartości”. M. Sadowska, Martwa natura..., op. cit.

145 „Haneke w ładny sposób daje do zrozumienia już na początku, jak ważna była w ich życiu fizyczna bliskość - odgłosy z sypialni rodziców wspomina w rozmowie z ojcem córka”. K. Frankowska, „Miłość” Hanekego - przerwany chorał Bacha, www.tvp. info/8968512/milosc-hanekego-przerwany-choral-bacha [dostęp: 30.05.16].

146 „Córka - domagająca się od ojca "poważnej rozmowy« o zdrowiu matki, a jednocześnie znacząco milknąca na dźwięk jego ironicznego pytania: »To co, zabierzesz mamę do siebie...?«. Jest miarą wielkiej pokory tego wybitnego filmu, że Haneke nie ulega pokusie krytykowania Evy za jej niezdolność udzielenia prawdziwej pomocy". M. Oleszczyk, Miłość, op. cit.

147 „Tytuł wymyślił Trintignant. Reżyser spełnił prośbę aktora, dla którego - jak deklaruje - wymyślił rolę Georges'a”. K. Frankowska, op. cit. 
wciąż sprawny, pozwala przeplatać za jego pomocą wątki minione i współczesne, przeszłość i teraźniejszość, pamięć i rzeczywistość. Znakomicie wykorzystano to w scenie, kiedy Alexander przysyła swojej nauczycielce płytę z nagraniami. Album rozpoczyna znane już nam Impromptu c-moll Schuberta, jednak po kilku pierwszych fortepianowych frazach Anne mówi do Georges’a stanowczo: „Wyłącz!”.

Jest to być może scena-klucz do całego filmu. Może chodzi o to, że włączając nagranie, Georges zaczął czytać list od Alexandra, w którym ten pisze o swoim współczuciu wobec strasznej choroby Anne - a kobieta nie chciała mieszać tych dwóch porządków, pragnęła cała oddać się muzyce i związanym z nią wspomnieniom. Może chodzi o to, że dźwięki dobrze znanej kompozycji (pewnie to nauczycielka jako pierwsza prezentowała ją swemu wychowankowi) uświadomiły Anne, że w obecnym stanie (wylew i związany z nim paraliż prawej strony ciała) nie jest już tak naprawdę tą samą osobą, która kiedyś grała ją na fortepianie. A może w ogóle chodzi o dotkliwość i przenikliwość muzyki, która dotyka nas tak mocno, jak nie są w stanie dotknąć ani słowa, ani fizyczne cierpienie. Tak czy owak, ważniejsze dla filmu od brzmiącej jedynie przez moment muzyki jest jej nagłe zastopowanie i następujące po nim ujęcie (modelowy przykład efektu, który Siegfried Kracauer określa jako „cisza naładowana napięciem” ${ }^{148}$ ). Ujęcie oczywiście długie i statyczne - pokazuje, jak Anne i Georges siedzą nieruchomo przy wyłączonym odtwarzaczu CD. Bardzo starzy oboje.

Milknący nagle utwór Schuberta pojawia się mniej więcej w połowie filmu (co również może sugerować, że jest jego osią), ale powrót muzyki jako fizycznie obecnego muzycznego narratora odbywa się kilka minut wcześniej, przy okazji wizyty, jaką Anne i Georges’owi składa Alexander. Artysta, mniej więcej rówieśnik młodego bohatera z Pianistki, podobnie jak Walter uwielbia muzykę Franza Schuberta („Moje życie kręci się obecnie wokół Schuberta”), ale choć mówi o niej z pewną egzaltacją, to ma jednak więcej pokory („Miałbym ochotę zagrać wszystkie sonaty. Ale ostatnie powinny chyba jeszcze poczekać”). Tak jak większość późnych dzieł wielkich mistrzów (np. Die Kunst der Fuge Bacha czy ostatnie Kwartety smyczkowe Beethovena), także schyłkowe sonaty Schuberta cieszą się wyjątkową estymą

148 „Efekt potęguje się, gdy muzyka nagle urywa się w momencie największego napięcia, pozostawiając nas sam na sam z obrazem”. S. Kracauer, op. cit. 
tyleż jako nadzwyczaj dojrzałe dzieła muzyczne, ile jako filozoficzne medytacje nad istotą muzyki i ludzkiego życia - a zatem wręcz nie wypada, by brał się za nie młody, dopiero debiutujący wykonawca. Jakby na potwierdzenie tej zasady, Anne prosi Alexandra o zagranie utworu, który wykonywał na jej lekcji, kiedy był dwunastoletnim chłopcem, czyli Bagateli d-moll Ludwiga van Beethovena.

Ta stosunkowo prosta, pogodna kompozycja pełni w filmowej narracji dwie funkcje. Po pierwsze, pozwala Anne odbyć podróż w czasie do momentu, gdy była jeszcze w pełni sił witalnych i artystycznych (Haneke pozostaje wierny sobie: żadnego sentymentalizmu; jest zwięzły i lakoniczny, pozostawiając widza z oceną, kiedy i jakie emocje odzywają się w bohaterach filmu ${ }^{149}$ ), po drugie zaś, utwór swoją lekkością i bezpretensjonalnością zdejmuje z całej sceny ciężar, który niewątpliwie podkreśliłby jakiś „późniejszy” (filozoficznie medytujący nad istnieniem) utwór Beethovena lub Schuberta. Tymczasem Haneke rozgrywa dramat Anne inaczej: dźwięk fortepianu w Beethovenowskiej Bagateli płynnie przechodzi w szum elektrycznego wózka inwalidzkiego, którym kobieta uczy się jeździć w następnej scenie, a montaż ujęć jest celowo ułamek sekundy spóźniony względem muzyki. Po chwili ten sam zabieg - przeplatania się dźwięków z porządku sztuki i porządku życia, płynnego przechodzenia tego, co artystycznie wzniosłe, w to, co trywialnie przyziemne - zostaje powtórzony, tyle że w odwrotną stronę, i szum wózka na korytarzu mieszkania przechodzi w dźwięk fortepianu, na którym gra Georges, siedząc samotnie w salonie. Jednak odgrywane frazy są już zupełnie inne: zamiast pełnej wigoru Bagateli słyszymy fortepianową przeróbkę pełnego powagi i zadumy preludium chorałowego Jana Sebastiana Bacha Ich ruf zu Dir, Herr Jesus Christ.

Tytuł „Wołam do Ciebie, Panie Jezu Chryste” wiele mówi o nastroju i przesłaniu kompozycji, natomiast fakt, że gra ją Georges - niezdradzający przez cały film żadnych przejawów wiary religijnej - świadczy zarówno o głębokości zakorzenienia utworu Bacha w kulturze, jak i o nader nieoczywistej pozycji, jaką film Hanekego zajmuje względem religii chrześcijańskiej

149 Podejście bohaterki do przeszłości - a przy okazji „antymelancholijne” w swej lakoniczności podejście reżysera - świetnie ukazuje krótki (trzywyrazowy) dialog starego i, jak się okazuje, dobrego małżeństwa nad albumem ze zdjęciami: „Anne: Piękne. Georges: Co? Anne: Życie”. 
i związanymi z nią ideami. Aby pojąć wieloznaczność tej sceny, musimy uzbroić się w wiedzę o zakończeniu filmu, w którym Georges, w obliczu zupełnej zapaści Anne (przykuta do łóżka kobieta traci kontakt ze światem i przestaje przyjmować pokarmy), dusi żonę poduszką. Po zabójstwie Georges urządza dla Anne symboliczną i przejmującą w swojej intymności ceremonię pogrzebową, po czym kładzie się na łóżku, by popełnić rozłożone w czasie samobójstwo przez zagłodzenie się. Obserwując te działania (z wyjątkiem sceny z poduszką pełne raczej spokojnej metodyczności niż wyrazistego dramatyzmu), warto pamiętać o jednej ze scen, rozgrywającej się zaraz po stwierdzeniu choroby u Anne, kiedy prosi ona męża, aby w razie pogorszenia się jej stanu zdrowia nie opuszczał jej (czyli np. nie oddawał do hospicjum), ponieważ z tym kontekście uczynki Georges’a zyskują wymiar dotrzymania obietnicy. Nie tylko tej z początku filmu, ale i tej dużo wcześniejszej, z czasów sprzed filmowych wydarzeń - o wierności i nieopuszczaniu aż do śmierci.

Wróćmy teraz do preludium chorałowego Bacha i wątku religijnego w filmie. Jeżeli odrzucimy interpretacje skrajne - zarówno zarzuty o radykalną antyreligijność (głównie dość powierzchowne oskarżenia ${ }^{150}$, w których często pada nacechowane ideologicznie słowo „eutanazja”), jak i nazbyt skwapliwe konotacje z symboliką chrześcijańską (jak ta łącząca gołębia i „religijną busolę”, wspomniana przeze mnie we wstępie tej pracy), pozostaje do rozważenia całkiem spory obszar „pomiędzy”. Najbardziej intrygujące $\mathrm{w}$ nim wydają się sugerowane ślady mocnych i tajemnych więzi religii ze sztuką (która niejako wzięła na siebie dawne obowiązki teologii i filozofii religijnej ${ }^{151}$ ), a także spostrzeżenia na temat miłości, w których aspekt

150 „W zakresie formy i środków realizacji film Michaela Haneke Miłość jest bardzo prosty. W sferze emocjonalnej - to tortura. W sferze przesłania - prawdziwa bomba, którą wypada nazwać antychrześcijańską do szpiku kości”. P. Gociek, Chory film o miłości, http://wpolityce.pl/kultura/246542-premiera-kinowa-michaela-haneke-chory-film-o-milosci-nasza-recenzja [dostęp: 30.05.16].

151 „Nie zamierzam dowodzić, że Haneke podejmuje w swoim filmie treści teologiczne - nawet jeśli niektórzy je w nim odnajdą, to artysta zapewne ich tam nie umieścił. Uprawia on jednak sztukę na tak wysokim poziomie, tak bezkompromisowo poszukuje prawdy o człowieku, że najistotniejsze kwestie natury filozoficznej czy teologicznej pojawiają się w jego dziełach w sposób samoistny. Nie stanowią 
chrześcijański pojawia się od zupełnie niedoktrynalnej strony ${ }^{152}$. Nie w tym rzecz, czy taka była pierwotna intencja Michaela Hanekego (który pytania dziennikarzy o metafizyczne aspekty w swoich filmach raczej zbywa ${ }^{153}$, choć od wysokich aspiracji muzyki bynajmniej się nie odżegnuje ${ }^{154}$ ), ale w tym, że użycie preludium chorałowego Bacha (tak jak wcześniej Podróży zimowej Schuberta) przenosi film w tak szeroką sferę kontekstów, na szachownicę $\mathrm{z}$ tak wieloma figurami kulturowych tropów i toposów, że austriacki reżyser, przy całej swojej erudycji, nie byłby w stanie wszystkich przewidzieć i świadomie wciągnąć w filmową grę.

Co najmniej równie ważny, jak samo użycie w filmie Ich ruf $z u$ Dir, Herr Jesus Christ, jest sposób, w jaki utwór wpływa na rozwój wydarzeń. Fortepianowa transkrypcja utworu Bacha (skomponowanego na organy) dokonana przez Ferruccio Busoniego bywa chętnie wykorzystywana w muzycznej edukacji, więc Georges mógł ją kiedyś grywać niejako zawodowo - tym razem jednak okoliczności są zgoła inne. Może mieć to wpływ na grę, która - jakby zdziwiona samą sobą, czyli swoim nieoczekiwanym rysem medytacyjnym (bo nazwać go "modlitewnym”, tego byłoby już dla Hanekego zbyt wiele) - nagle się urywa. Nie wiemy, czy Georges jest zawstydzony utworem,

one jednak wykładni konkretnej doktryny religijnej czy kierunku filozofii”. Miłość, czyli rana, [Katarzyna Jabłońska w rozmowie z ks. Andrzej Lutrem], „Więź” 2012, nr 10 .

152 „Jego Miłość to śmiała propozycja wejścia w samo centrum miłości, czyli... w ranę. Bo »Prawdziwa miłość - jak mówi Wiesław Myśliwski w Traktacie o łuskaniu fasoli - jest raną. I tylko tak ją można odnaleźć w sobie, gdy czyjś ból boli człowieka jako jego ból«. Może więc uprawniona jest nadzieja, że jeśli czyjś ból boli mnie tak jak tego, który cierpi, to staje się rodzajem mostu, prowadzącego nas do siebie nawzajem?”. Ibidem.

153 „Gołąb jest stamtąd, pojawia się niczym nieobecny dotąd u tego reżysera mistyczny ornament, znak do zinterpretowania, niepokojący dla jednych, irytujący dla drugich. Pytany o niego, sam Haneke odpowiada po prostu: »W Paryżu jest mnóstwo gołębi«". M. Sadowska, Martwa natura z gołębiem, op. cit.

154 „Wielka muzyka wynosi współczucie ponad konkretne przypadki. Podró $z$ zimowa wynosi nawet ludzką marność na poziom wyjątkowego opisu. Wszelkie fundamentalne dzieła, szczególnie te, które koncentrują się na ciemnych stronach istnienia, wbrew całej rozpaczy, wynoszą nieszczęsną treść na wyżyny swej formy”. The World That Is Known, op. cit. 
po jaki sięgnął (intensywnie nacechowanym religijnie), czy też nagle zrozpaczony - bo oto ujrzał w muzycznym lustrze sprzed wieków dwie twarze: swoją i śmiertelnie chorej Anne. Wiemy tylko tyle, że utwór milknie. Znowu zapada „cisza naładowana napięciem”, ale tym razem kamera - inaczej niż w modelowym przykładzie Siegfrieda Kracauera - jest gdzie indziej: w sypialni żony, proszącej, aby grał dalej. Jej wołanie pozostaje jednak bez odpowiedzi.

Scena jest ważna dla filmu na dwóch poziomach. Tym „metafizycznym”, o jakim wspomniałem w poprzednich akapitach, i tym - dla kontrastu całkiem przyziemnym, dotyczącym banalnej codzienności bohaterów. Otóż wydaje się, że do momentu choroby to Anna była w tym małżeństwie związku na pewno wykraczającym daleko poza domową krzątaninę i społeczne konwenanse ${ }^{155}$ - stroną aktywniejszą i bardziej dominującą. Widać to $\mathrm{w}$ drobiazgach, tonie głosu czy gestach, ale niektóre $\mathrm{z}$ tych drobiazgów łączą się z najważniejszymi motywami filmu - na przykład z poleceniem natychmiastowego wyłączenia odtwarzacza z płytą Alexandra albo napomnieniem, by Georges wziął płaszcz, w finałowej, metaforycznej scenie filmu (kiedy obydwoje już nie żyją, co przejawia się tym, że po prostu wychodzą z mieszkania, ale przecież wychodzą tacy, jacy byli wcześniej, przed nadejściem choroby). Od pewnego momentu jednak, po wylewie Anne, to jej mąż przejmuje prawo do mentalnej dominacji i stopniowo zaczyna przejawiać inicjatywę nie tylko w sprawach bezpośrednio związanych $\mathrm{z}$ opieką. Urwany - mimo protestów żony - chorał Bacha może być zatem wyrazem emancypacji mężczyzny, wcześniej trochę „pantoflarza”, który coraz wyraźniej zdaje sobie sprawę nie tylko z powagi obecnej sytuacji (bierze więc na siebie coraz więcej odpowiedzialności - aż do ostatecznej granicy pod koniec filmu), ale także, patrząc wstecz, z charakteru całego trwającego pięć dekad związku.

Przemianę Georges'a może sugerować kolejna z najważniejszych scen filmu. Oto mężczyzna słucha, jak siedząca naprzeciw przy fortepianie Anne gra Impromptu Ges-dur Schuberta. Utwór jest pełen radosnej energii, a zatem mocno kontrastuje $\mathrm{z}$ wydarzeniami, które oglądaliśmy ledwie

155 „Są jak jeden organizm, co widać, gdy tylko pojawiają się w kadrze. Po raz pierwszy oglądamy ich w dalekim planie, w filharmonii. Siedzą w tłumie innych widzów, a jednak się wyróżniają. Nie ma wątpliwości, że są razem, nawet wtedy, gdy na siebie nie patrzą". K. Frankowska, op. cit. 
chwilę wcześniej. Lecz raptem Georges odwraca się, wyłącza stający za fotelem odtwarzacz - i wtedy muzyka milknie, a żona znika. Pozostajemy na dłuższą chwilę sam na sam $\mathrm{z}$ mężczyzną wpatrzonym w samotnie stojący fortepian (przejmująca twarz Jeana-Louisa Trintignanta zdaje się mówić: żadnych sentymentów). Scena jest wyrazista i efektowna, ale choć można ją porównać do sceny z jazgotem Johna Zorna zagłuszającym szacowną klasykę w Funny Games albo z Andantinem Schuberta, przeniesionym przez bohaterkę Pianistki z wysokich progów konserwatorium w wulgarne realia sex shopu, to została nakręcona $\mathrm{z}$ tak sugestywnym umiarem, przejmującą lakonicznością środków wyrazu, że pozostajemy z wrażeniem, iż nie tylko Georges się zmienił. Zmienił się także sam Haneke ${ }^{156}$.

Oprócz podstawowych znaczeń (świetnie uchwycone działanie mechanizmów pamięci czy też wyraz „antymelancholijnego” przesłania filmu Hanekego), nagle milknące Impromptu Schuberta można odebrać jako dowód, że to Georges ma teraz inicjatywę, czy nawet władzę w tym domu ${ }^{157}$. I zbiera się na odwagę, by przerwać żonie grę. Jest za późno, by zrobić to realnie, w rzeczywistym świecie - gdzie Anne już nie rusza się z łóżka, pogrążona w majaczeniach - więc Georges wyobraża ją sobie na tle grającej płyty. Warto w tym kontekście przypomnieć, że w tym samym czasie co Miłość trafił na ekrany film Wulkan islandzkiego reżysera Rúnara Rúnarssona,

156 „Swoistą cechą poprzednich filmów Hanekego była ich dosadność, która przeradzała się w pewnego rodzaju atrakcyjność. [...] W Miłości Haneke tylko raz pozwala sobie na scenę, która miałaby wywołać w widzu z góry określoną reakcję. Pod koniec filmu obserwujemy, jak Anne gra na fortepianie. Kilka sekund później kamera pokazuje siedzącego w tym samym pokoju Georges'a, obserwującego żonę. Po chwili mężczyzna wyłącza stojący za nim odtwarzacz, a muzyka momentalnie ucicha. Tak prosta, kumulująca emocje, ale - co świadczy o niezwykłej sprawności austriackiego reżysera - pozbawiona sentymentalizmu scena robi o wiele większe wrażenie niż tysiąc obrazów powolnej agonii, za pomocą których można by tę historię przedstawić”. G. Fortuna, op. cit.

157 „Ze wszystkich relacji miłosnych w jego filmach ta wydaje się najbardziej »ludzka«, pozbawiona egoizmu, oparta na wzajemnym oddaniu. Ale i tu wkrada się coś mrocznego. Czy w poświęceniu Georges’a nie ma czegoś ukrycie sadystycznego? Jakiejś okrutnej nadwyżki? Odmawiając oddania Anny do hospicjum [...], czyni ją całkowicie zależną od swojej pomocy i opieki. Anna jest w jego władzy”. J. Majmurek, op. cit. 
opowiadający zaskakująco podobną historię o samotnym mężczyźnie, który opiekuje się chorą żoną po wylewie (podobieństwo obu wątków jest tak duże, że tylko fakt, iż filmy były kręcone równolegle, zdejmuje z Hanekego cień podejrzenia o plagiat). W Wulkanie jednak to właśnie kwestia władzy, jaką uzyskuje nad żoną stary rybak Hannes, wysuwa się zdecydowanie na pierwszy plan i prowadzi do dramatycznych konsekwencji ${ }^{158}$.

Wracając do filmu Hanekego, trudno wyrokować, czy wyłączenie przez Georges’a odtwarzacza to bardziej wyraz przejęcia władzy (nie tyle może nad Anne, co nad bezlitosną pamięcią), czy skromniej - deklaracja niepodległości (znów: nie wobec drugiego człowieka, ale wobec własnej melancholii). Natomiast wolno sądzić, że ten stanowczy gest mieści się nie tylko wewnątrz rzeczywistości filmu - jest także gestem wobec widza, który dopóki brzmiała muzyka, nie zdawał sobie sprawy, że widzi przy fortepianie tylko wyobrażoną Annę. Nagła cisza jest jak gwałtowne rozwianie złudzenia. Demaskowanie fantazmatów i złudzeń zarówno filmowych bohaterów, jak i kinowych widzów zawsze było spécialité de la maison Hanekego, rzadko jednak robił to w sposób tak artystycznie wyrafinowany ${ }^{159}$.

Zatrzymajmy się jeszcze przez moment na wyraźnie widocznym w tej scenie, wspomnianym już przeze mnie „antymelancholijnym” charakterze filmu Hanekego. $Z$ całą pewnością reżyser nie podchodzi cynicznie do duchowej siły wspomnień czy narracyjnych zdolności ludzkiej pamięci o czym przekonuje chociażby scena, kiedy Georges mówi Anne o filmie, który jako dziecko oglądał, a jakiś czas potem opowiadał, wzruszony wtedy filmową historią jeszcze bardziej („Kiedy opowiadałem, łzy wracały, silniejsze niż podczas seansu"). Podejście Hanekego - wymierzone

158 „Hannesowi zostają tylko dwie wierne towarzyszki - żona i rybacka łajba. Kiedy ta druga niemal idzie na dno, mężczyzna chce poświęcić czas i pieniądze na jej naprawę. Podobnego "zabiegu« nie jest w stanie przeprowadzić na żonie, która rażona wylewem krwi do mózgu, nagle przewraca się na podłogę. Odtąd będzie wegetować pod opieką męża, który pod pretekstem zadośćuczynienia za dotychczasową nieczułość nie odda jej do domu opieki. Na ile jednak Hannes naprawdę się zmienił?". www.nowehoryzonty.pl/film.do?id=5286\&ind=page\%3d0\%26typ\%3ddz\%26edycjaFest\%3d11\%26czas\%3d15\%253a45\%26dzien\%3d26 [dostęp: 30.05.16].

159 „Nie wiem, czy Miłość jest najlepszym filmem Hanekego, na pewno jest jednak najbardziej subtelnym z nich”. G. Fortuna, op. cit. 
choćby przeciwko światopoglądowi Larsa von Triera, wyrażonemu w filmie Melacholia - dobrze oddaje scena, kiedy Georges po powrocie z pogrzebu przyjaciela opowiada anegdotyczną historię o puszczonym podczas ceremonii Yesterday Beatlesów, na które żałobnicy zareagowali „atakami śmiechu". Nie w tym rzecz, czy uczestnicy pogrzebu albo Anne z Georges'em lubią tę słynną piosenkę (i jaki mają ci akademiccy melomani stosunek do muzyki popularnej). Chodzi o odcięcie się od wszelkiego sentymentalizmu czy rozczulania się nad przemijaniem ${ }^{160}$, na które - w innym momencie filmu - Georges reaguje tak stanowczo, że nawet Anne oraz pełne energii Schubertowskie Impromtu muszą zniknąć z pola widzenia i słyszenia.

Takie odczytanie tej sceny to oczywiście tylko kolejna $\mathrm{z}$ wielu możliwych wersji. Interpretacyjne furtki, które pozostawia muzyczna narracja w Miłości, zawierają się w niedomówieniach i sugestiach. Dzieje się tak dlatego, że film - inaczej niż choćby Pianistka - opiera się na wygrywaniu kontrastów między muzyką a milczeniem, na dialektyce dźwięku i ciszy (według Carla Dahlhausa, dla muzyki niezwykle istotnej ${ }^{161}$ ), którą Haneke zręcznie umieścił w pospolitych realiach ${ }^{162}$. Pozwala to widzowi (bo sama historia jest zaiste „prosta”) dociekać kolejnych znaczeń zarówno „wewnątrz”

160 „Kiedy Anna jest już po operacji, Georges jedzie na pogrzeb, na którym, jak potem opowiada, ktoś puszcza $z$ taśmy piosenkę The Beatles Yesterday. Owszem, to żenada. Która ma potwierdzić fakt, że sam film z pewnością nie jest nostalgiczny. Nie pojawia się najmniejsza sugestia, jakoby wczoraj w życiu Anny i Georges'a, podobnie jak w piosence Beatlesów, wszystkie kłopoty wydawały się takie odległe". R. Gilbey, op. cit.

${ }^{161}$ „Myślą przewodnią wszystkich jego rozważań było głębokie przekonanie, iż konkretny problem widzimy naprawdę dopiero wówczas, gdy ujęty jest w przeciwieństwach”. A. Jarzębska, op. cit.

162 „Taka jest cała muzyka w filmie, ta wykonywana przez bohaterów jest raptownie przerywana, zaś ta, którą wykonuje ktoś inny, jest wyciszana przez wyłączenie odtwarzacza. Muzyka milknie, w zgodzie z intencjami bohaterów, a nie w zgodzie z logiką filmowej narracji. Takie realizacyjne wyrachowanie, jego naga brutalność, jest zgodna z emocjonalnym nastrojem filmu. Rozpoznajemy tu typową dla Hanekego przyjemność w zawodzeniu oczekiwań widza poprzez bełtanie klarownej narracji i diegezy, ale także zgoła metafizyczną inklinację, by sens ukazywał się raczej w wyniku swoistej iluminacji niż konkretnie, czarno na białym". http:// framescourer.blogspot.com/2012/11/music-in-amour-2012.html [dostęp: 30.05.16]. 
opowiadanej historii (w wydarzeniach i zachowaniach bohaterów), jak i „na zewnątrz" - w odnajdywanych tropach kulturowych.

Jeżeli chodzi o tę drugą, metafilmową sferę, to nader ciekawy jest fakt, że po to samo Bachowskie preludium chorałowe Ich ruf zu Dir, Herr Jesus Christ sięgnął Andriej Tarkowski w filmie Solaris ${ }^{163}$, nakręconym na motywach powieści Stanisława Lema. Pierwsze skojarzenie to myśl o hołdzie złożonym rosyjskiemu reżyserowi, którego podejście do montażu muzyki w filmie (jej „naturalna” obecność - jako dźwięku ze świata, treściowej esencji wydarzeń, a nie ich formalnej ramy) $\mathrm{z}$ pewnością wpłynęło na Hanekego.

Kiedy jednak przyjrzymy się tym filmom uważniej, to okazuje się, że w obydwu kluczowe są motywy tracenia ukochanej osoby (w Solaris już się ono dokonało - astronauta Kelvin trafia na obcą planetę po śmierci swej żony, Harey, natomiast w Miłości dzieje się to na naszych oczach) oraz jej nadnaturalnego - powrotu. U Tarkowskiego sprawcą wskrzeszenia Harey, a właściwie jej cielesnego hologramu, jest Ocean, zajmujący całą planetę Solaris i przejawiający zgoła boskie kompetencje. U Hanekego „wskrzeszenie" Anne dokonuje się za sprawą muzyki Schuberta - której podprogowe fale mają dostęp do pamięci i wyobraźni Georges’a. Co ciekawe, obaj - Kelvin i Georges - nie godzą się na takie rozwiązanie: niszczą to, co wydaje się wybawieniem od śmierci, czyli podsunięte im fantazmaty Harey i Anne. Obaj wiedzą, że ich wyrwane z objęć śmierci ukochane są atrapami, wytworami tęsknot i wspomnień, a nie realnymi kobietami. Śmierć potwierdziła prawdę ich życia - nieodwracalnie. I w tym miejscu pojawia się Bach z całym chrześcijańskim zapleczem i jego centralną postacią - Jezusem Chrystusem, który umarł, aby żyć. Kelvin w Solaris mówi: „Kochamy tylko to, co możemy utracić”; Georges w Miłości wyłącza muzykę, aby nieprawdziwa Anne znikła.

Preludium chorałowe Bacha u Tarkowskiego pojawia się w różnych miejscach filmu, nawet jako tło dla napisów, i jest grane w pierwotnej aranżacji na organy, a więc brzmi dostojnie i wzniośle, wypełnia przestrzeń szczelnie. Wrażenie szczelności wzmaga sugestywna aranżacja dokonana przez Edwarda Artemiewa, w której tło dla organów stanowią elektroniczne efekty

163 „Oto więc znaczenie Ich ruf zu dir, Herr Jesu Christ (BWV 639) J.S. Bacha granego przez Georges’a ze złamanym przez ból sercem: to muzyka religijna, której trzeba słuchać koniecznie w kontekście medytacji Tarkowskiego nad miłością i utratą w Solaris (1972)". Ibidem. 
dźwiękowe. Ich specyficzne zagęszczenie ewokuje atmosferę metafizycznej tajemnicy (dodatkowo wzmocnione zdjęciami, szczególnie w scenach, kiedy główny bohater powraca do domu nad stawem, a swojskie ziemskie krajobrazy zdają się zrzucać maskę realności i wkraczać w sferę symboliczną), co pomaga dostrzec $\mathrm{w}$ dziele Tarkowskiego tropy teologiczne albo wręcz gnostyckie. Owszem, można doszukiwać się takich motywów także w powieści Lema ${ }^{164}$, ale styl pisarza, mimo konwencji science-fiction, jest w Solaris bliski raczej stylowi powieści psychologicznej. Natomiast użycie chorału Bacha przez Tarkowskiego - w dodatku chorału spreparowanego przez Artemiewa tak, by pobrzmiewał "mistycznie” - jest nie tylko radykalnym wyłamaniem się z Lemowskiej konwencji (lista zarzutów polskiego pisarza wobec rosyjskiego reżysera była zresztą długa), ale także porzuceniem skromnego realizmu psychologicznego - nawet wobec „cudów” dokonywanych przez solaryjski ocean - na rzecz wzniosłego uduchowienia.

$\mathrm{Na}$ tym tle fortepianowa przeróbka Bachowskiego chorału w filmie Hanekego okazuje się tym bardziej dyskretna, zaś fakt, że dźwięki nie płyną zza kadru, tylko wydostają się - w efemerycznej, kruchej postaci - spod palców bohatera, świadczy tyleż o zupełnie innej pozycji filmu wobec religijno-filozoficznej tradycji, ile o innym języku, który austriacki reżyser wybiera.

Haneke niby składa Tarkowskiemu hołd, ale jednak go kwestionuje. Niby nie dociera w Miłości do takiej sublimacji duchowych przeżyć jak rosyjski reżyser, ale w istocie dociera być może jeszcze dalej - tam, gdzie arbitralny ton prawd wiary czy epokowych dzieł sztuki milknie wobec pojedynczej i skromnej prawdy ludzkiej. Preludium chorałowe Bacha opowiada nam w Miłości to samo, co w Solaris, a jednocześnie - za sprawą znaczących korekt reżyserskich - odzywa się z innego źródła, innym językiem.

164 „Jak zatem jawi się im solariański Ocean na nowo? Jako zalążek Boga ułomnego lub kalekiego, którego możliwości, zdolności przerastają jego świadomość i rozumność. Albo jako Bóg o wielkim potencjale, lecz psychice małego dziecka; dziecka, które ma wszelkie dane ku temu, by dorosnąć. Widać zatem, że nowe rozumienie Oceanu wydostało się już poza schemat ściśle naukowy. Jest on pojmowany jako istota z dwóch paradygmatów: przyrodniczego i teologicznego zarazem”. M. Dobkowski, Solaris. Gnoza i optymizm technologiczny, www.gnosis.art.pl/e_gnosis/ksiazki_stare_i_nowe/dobkowski_solaris.htm [dostęp: 28.03.16] 
Tym językiem mówi też muzyka w scenie, w której osiąga przejmująco ludzki wymiar: kiedy Georges śpiewa z żoną piosenkę Sur le Pont d’Avignon. Głos tracącej zmysły i dotkniętej afazją kobiety ledwie potrafi uchwycić melodię piosenki, łamiąc się w niemal dosłownym sensie, ale na twarzy Anne widzimy, po raz ostatni, błysk radości. To jej ostatni kontakt z rzeczywistością: melodia dziecięcej piosenki o tańczeniu na moście, który - całkiem jak ludzkie życie - urywa się nagle na środku rzeki ${ }^{165}$.

Do końca filmu zostaje - po scenie ze wspólnym śpiewaniem - jeszcze pół godziny. Ale nie usłyszymy już ani Schuberta, ani Beethovena. Zamilknie fortepian w salonie i staroświecki sprzęt $h i-f i$ za fotelem. Michael Haneke mimowolnie postępuje dokładnie według credo Krzysztofa Komedy, zgodnie z którym muzyki w filmie powinno być raczej za mało niż za dużo ${ }^{166}$. Dziecięca piosenka to ostatnia rzecz, jaką muzyka w Miłości ma do powiedzenia.

\section{ZAKOŃCZENIE: O WZAJEMNOŚCI}

„kiedy nas wnętrze otacza jak najdoskonalsza dal"

Rainer Maria Rilke, Do muzyki (tłum. A. Lam)

Jak wynika z mojej analizy, muzykę w filmach Michaela Hanekego można rozpatrywać w trzech podstawowych kontekstach. Są to:

1) Związki muzyki w danym filmie z przedstawionymi w nim wydarzeniami i wyrażonymi ideami.

2) Związki między muzyką z różnych filmów austriackiego reżysera.

3) Związki między muzyką u Hanekego a muzyką w filmach innych reżyserów.

165 Pont Saint-Bénézet (pol. Most św. Benedykta), znany także jako Pont d'Avignon - średniowieczny most nad rzeką Rodan w Awinionie (Prowansja, Francja), zachowany częściowo. Według jednej z tradycji most nie został ukończony i nigdy nie sięgnął do drugiego brzegu. http://pl.wikipedia.org/wiki/Pont_Saint-Benezet [dostęp: 28.03.15].

166 K. Komeda, Ankieta: Rola muzyki w dziele filmowym, „Kwartalnik Filmowy” 1961, nr 2. 
W każdym z omówionych przeze mnie filmów te trzy relacje zachodzą $\mathrm{w}$ różnym stopniu, zawsze jednak poszerzając ramy interpretacyjne oraz inspirując widza do aktywnego, zaangażowanego intelektualnie odbioru dzieła. Obserwując zmiany w użyciu utworów między poszczególnymi filmami, można wnioskować, że i sam reżyser był przez muzykę (która towarzyszyła mu od dzieciństwa i była pierwszym wyborem edukacyjnym ${ }^{167}$ ) inspirowany do zmian, jakie na przestrzeni kariery zachodziły w jego stylu czy podejściu do materii filmowej, w tym także do kompozycji, po jakie sięgał ${ }^{168}$. Zmiany te są widoczne na wszystkich trzech poziomach obecności muzyki w jego filmach. Zreasumujmy je pokrótce.

Jeżeli chodzi o związki muzyki z filmem, w którym ją słyszymy, to w Funny Games muzyka została pomyślana jako swego rodzaju uwertura (zapowiadająca przebieg wydarzeń, zwięźle portretująca bohaterów oraz sugerująca istotne założenia wstępne). W Pianistce towarzyszy, blisko i wytrwale, rozwojowi wydarzeń (dla których bywa albo dopowiadającym komentarzem, albo kontrapunktem pozwalającym widzowi na inne spojrzenie) oraz czujnie asystuje bohaterom (pogłębiając wgląd w ich motywacje i działania). Natomiast w Miłości pozostaje stale obecna w filmie, tyle że jest to obecność szczególna: mniej „ciałem”, czyli słyszanym dźwiękiem (który nader często milknie), a bardziej „duchem”, czyli ciszą po urwanym dźwięku (która okazuje się milczeniem nader znaczącym).

Jeżeli chodzi o relacje między tymi trzema filmami, to z perspektywy muzyki wyraźnie daje się zauważyć, jak Haneke zmienia podejście do tworzonego przez siebie filmu (na poziomie opowiadanej historii, a także wglądu w psychikę bohaterów), rezygnując z nadmiaru arbitralności i reżyserskiej

167 „Zawsze chciałem być muzykiem, najlepiej kompozytorem albo dyrygentem. Nie starczyło mi talentu". Wrzątek podany na zimno, op. cit.

168 „Widać, że od jakiegoś czasu [Haneke - przyp. M.W.] szuka nowych środków wyrazu, boi się, że jego styl zakrzepnie w manierę. Było to już bardzo widoczne w Białej wstążce. Miłość to najbardziej »klasyczny« film Hanekego. Nie ma tu znanych z poprzednich obrazów technik »strategicznej dezorientacji widza«. Od początku kamera jasno zakreśla przestrzeń akcji (mieszczański apartament) i precyzyjnie opisuje postacie. Dominują statyczne kadry kręcone nieruchomą kamerą, montaż na zasadzie ujęcie-przeciwujęcie, środki pozwalające »wybrzmieć" aktorom, odtwarzanym przez nie postaciom i ich emocjom”. J. Majmurek, op. cit. 
władzy. O ile muzyka na początku Funny Games - nagłe zburzenie przez Johna Zorna bezpieczeństwa zbudowanego przez Haendla i Mascagniego skutkuje gwałtownym przebiegiem późniejszej akcji i niejako „zaostrza” obyczaje (bohaterów-morderców oraz reżysera znęcającego się nad widzem), to muzyka w Pianistce - choćby Schubertowskie Andantino, towarzyszące bohaterce w kabinie porno - przebieg akcji i obyczaje łagodzi. Przy okazji znika także dawne - obecne $\mathrm{w}$ jeszcze wcześniejszych filmach reżysera wyniosłe spojrzenie prokuratora (znajdującego winę) czy chirurga (znajdującego zwyrodnienie) ${ }^{169}$, ponieważ przestaje być możliwe w tak szerokim polu skojarzeń i emocji, jak to, które otwiera muzyka Schuberta czy Chopina. W muzyce zapisana została „romantyczna” matryca zachowań Eriki Kohut, jej skłócona $\mathrm{z}$ życiem osobowość - i w tym sensie muzyka jest jednym z głównych bohaterów Pianistki $i^{170}$.

Jeszcze wyraźniej uniezależnienie się muzyki od reżysera-demiurga widać w Miłości, gdzie utwory klasycznych kompozytorów - jakby w kontraście czy wręcz w polemice z Pianistka - pojawiają się znacznie rzadziej. Zarówno ulotna obecność, jak i wieloznaczne milczenie muzyki w tym filmie sugeruje przeniesienie opowiadanej historii ponad wymiar służebny wobec jakiegokolwiek z góry przyjętego pomysłu czy przesłania ${ }^{171}$. Haneke tak samo nie próbował „reżyserować" naturalnych zmarszczek starości na twarzy czy przygarbionych sylwetek Emmanuelle Rivy i Jean-Louisa Trintignanta, jak i obecności chorałowego preludium Bacha. W fizycznej

169 „Haneke zawsze sytuuje się ponad własnymi postaciami, wygrywając ich dewiacje, lęki bądź okrucieństwa nie po to, by swych bohaterów lepiej poznać, ale po to, by udowodnić widzowi, że już dawno przejrzał ich wszystkich na wylot i że nie pomylił się w swojej ponurej diagnozie”. M. Oleszczyk, Biała wstążka, „Dwutygodnik” 2009, nr 11, www.dwutygodnik.com/artykul/595-biala-wstazka -rez-michael-haneke.html [dostęp: 28.03.15].

${ }^{170}$ „W filmie Hanekego muzyka nie jest wyłącznie ilustracją fabuły, jest rzeczywistym podmiotem historii”. G. Arata, op. cit.

171 „Haneke jest mistrzem podskórnej sugestii, która czasami (jak w Białej wstążce) puchnie w wątpliwą historiozofię, ale w Miłości służy trzeźwemu zasugerowaniu, iż oglądamy parę z własną przeszłością, z pewnym zestawem wspomnień, ran i prowizorycznie zażegnanych pretensji, bez których nie ma mowy o żadnym współistnieniu”. M. Oleszczyk, Miłość, op. cit. 
(czyli słyszalnej) przestrzeni filmu pojawia się ono ledwie na kilkanaście sekund, ale na głębszym poziomie „brzmi” dalej. Zakończenie Miłości, podobnie jak finałowa scena Pianistki, obywa się w ogóle bez tła muzycznego, jednak zbieranie się dwojga - już nieżyjących - bohaterów do wyjścia z mieszkania, banalne zmywanie ostatnich naczyń, by zostawić porządek, czy sięganie po płaszcze z wieszaka niesie w sobie szczególne „znaczeniowe echo" muzyki, którą słyszeliśmy wcześniej.

To, co „słyszeliśmy wcześniej”, okazuje się w twórczości Hanekego ważne nie tylko w obrębie konkretnego filmu czy poprzednich obrazów reżysera, ale też w kontekście klasycznych dzieł kina światowego. Preludium chorałowe Bacha w Miłości to rodzaj „korespondencji pośmiertnej” Michaela Hanekego z Andriejem Tarkowskim, który użył tego utworu w Solaris. Solaris to pod wieloma względami film chybiony technicznie i adaptacyjnie $^{172}$, co nie zmienia faktu, że znając konteksty użycia przez Tarkowskiego kompozycji Bacha, możemy lepiej zrozumieć motywacje Hanekego: scjentystyczna rzeczywistość stacji kosmicznej tak samo „nie powinna” dopuszczać metafizyki, jak mieszkanie pary bohaterów Miłości, typowych mieszkańców zachodnioeuropejskich wielkich miast - agnostyków lub ludzi obojętnych religijnie. Poza tym Solaris Tarkowskiego był kręconym pod okiem wrogiego religii radzieckiego reżimu, więc bachowskie Ich rufzu Dir, Herr Jesus Christ osiąga w nim wymiar metafory także metafilmowej. Słysząc to samo preludium chorałowe w Miłości Hanekego, warto pamiętać, jak bardzo jest to muzyka „po przejściach”.

Szukając formalnego klucza, dzięki któremu muzyka może przenikać w głąb filmu, zwróciłem w niniejszej pracy uwagę na cechy upodabniające Pianistkę do kontrafaktury (czyli pewnego rodzaju „tłumaczenia” muzyki na język filmu). Są one zauważalne, kiedy muzyka podąża za myślami i uczuciami bohaterów lub za zmieniającą się dramaturgią wydarzeń (podobnie

${ }^{172}$ „Tarkowski [...], lekceważąc jednak protesty Lema, które sprowadzał do niezrozumienia istoty filmowości i twórczego przetwarzania, nie był w stanie zauważyć, że ekranowa wersja Solaris oznacza - na poziomie logiki inscenizacyjnej i odczytania bezpośredniego - intelektualną kompromitację adaptatora, przy czym nic tu nie mają do rzeczy wygłaszane maksymy w rodzaju »klarowność nie jest rzeczą najważniejsząu". Solaris [w:] A. Garbicz, Kino, wehikuł magiczny. Podróż czwarta 1967-1973, Kraków 2000, s. 488. 
jak np. w Amadeuszu Miloša Formana, z jego posępniejącym gwałtownie zakończeniem, odkąd Mozart dostaje zlecenie na napisanie Requiem), ale także kiedy wprowadza elementy kontrastu i ironii (jak np. w Kontrakcie rysownika Petera Greenawaya, gdzie reżyser pozostaje wierny realiom dawnej epoki, a uderza w nie pastiszem barokowej muzyki skomponowanym przez Michaela Nymana).

Inaczej jest w Miłości, gdzie większość formalnych środków wyrazu zmniejsza natężenie, a reżyser zamienia warsztatową błyskotliwość na dyskrecję (być może staje się po prostu błyskotliwie dyskretny). Muzyka pojawia się tu wyłącznie jako organiczny element filmowej diegezy, wpleciona między wydarzenia, czynności, przedmioty tak bardzo, że żaden utwór nie ma możliwości „satysfakcjonująco” wybrzmieć. Taka strategia Hanekego w interesujący sposób koresponduje z tezą Bohdana Pocieja, że dzięki muzyce film zbliża się do swojej „natury”, którą - według autora jest „ciążenie w dół, ku naturalizmowi, do poziomu [...] przed-sztuki” ${ }^{173}$. Za swoje ujmująco naturalne życie kompozycje płacą tym, czym się zwykle płaci za życie - kruchą śmiertelnością.

Losy bohaterów Miłości poznajemy z perspektywy kamery pokazującej $\mathrm{z}$ bliska ich codzienność, ale także z perspektywy utworów Beethovena czy Schuberta, które - inaczej niż kamera i cały filmowy warsztat - nie są elementami zewnętrznymi ani wobec filmowej historii (skorą brzmią „tam”, w paryskim mieszkaniu lub w pamięci bohaterów), ani wobec widza (skoro przez te dwa stulecie zdążyły przeniknąć w tkankę kulturową i społeczną, więc „mamy je w głowie”). To, co przychodzi z daleka, z dziejów muzyki, odzywa się w myślach i emocjach kinowego widza, a to, co widz uznaje za własne, osobiste, okazuje się obecne w dalekich nutach, napisanych dawno temu. Austriacki reżyser na pewno zna traktujący o tym wiersz austriackiego poety Rainera Marii Rilkego.

Michael Haneke w trzech omówionych przeze mnie filmach stopniowo emancypuje muzykę z pozycji narratora działającego wewnątrz filmu na pozycję metanarratora odzywającego się na zewnątrz: we wspólnej pamięci kulturowej i w głowie każdego widza. Reżyser za pomocą muzyki ożywia filmową historię, nadaje jej naturalność prawdziwego życia, ale robi też

${ }_{173}$ B. Pociej, Uwagi o muzyce filmowej, „Kwartalnik Filmowy” 1994, nr 6. 
na odwrót: za pomocą sztuki filmowej ożywia kompozycje sprzed stuleci, uruchamia ich kreacyjne możliwości, sprawczą moc. Jak zauważył Carl Dahlhaus: „Historia oddziaływania muzyki [...] nie jest wobec samych dzieł »zewnętrzna«, lecz przenika ich istotę, którą należy zatem pojmować jako historycznie zmienną"174. Haneke, niedoszły muzyk, który jako reżyser szczęśliwie wraca do partytur i instrumentów, dobrze o tym wie. Ta spełniona, serdeczna wzajemność - sztuki muzycznej i filmowej - jest być może największym osiągnięciem Michaela Hanekego.

\section{Bibliografia}

Charles Altman, W stronę teorii gatunku filmowego, [brak tłumacza], „Kino” 1987, nr 6.

Stanisław Barańczak, Podróż zimowa. Wiersze do Muzyki Franza Schuberta, Wydawnictwo a5, Warszawa 1994.

Jean Baudrillard O uwodzeniu, tłum. J. Margański, Wydawnictwo Sic!, Warszawa 2005.

Iwona Cegiełkówna, Miłość, „Kino” 2012, nr 11.

Iwona Cegiełkówna, Pianistka, „Cinema Polska” 2001, nr 11.

Janusz Cegiełła, Szkice do autoportretu polskiej muzyki współczesnej. Rozmowy z kompozytorami, Polskie Wydawnictwo Muzyczne, Kraków 1976.

Michel Chion, Audio-wizja. Dźwięk i obraz w kinie, tłum. K. Szydłowski, Ha!art, Warszawa - Kraków 2012.

Carl Dahlhaus, Estetyka muzyki, tłum. Z. Skowron, Wydawnictwo Uniwersytetu Warszawskiego, Warszawa 2007.

Carl Dahlhaus, „Rozumienie” muzyki i język analizy muzycznej, [w:] idem, Idea muzyki absolutnej i inne studia, tłum. A. Buchner, Polskie Wydawnictwo Muzyczne, Kraków 1988.

Piotr Dumała, Anioły śmierci w krótkich spodniach, „Kino” 1998, nr 5.

Łukasz Dziatkiewicz, Narodziny filmowej cenzury, „Dziennik”, dodatek „Weekend” $\mathrm{z}$ dn. 31.05.2014 r.

Umberto Eco, Dzieło otwarte. Forma i nieokreśloność w poetykach wspótczesnych, tłum. L. Eustachiewicz, W.A.B., Warszawa 2008.

${ }_{174}$ C. Dahlhaus, „Rozumienie” muzyki i język analizy muzycznej, [w:] idem, Idea muzyki absolutnej i inne studia, tłum. A. Buchner, Kraków 1988, s. 283. 
Umberto Eco, Tryb symboliczny, [w:] Teorie literatury XX wieku. Antologia, red. A. Burzyńska i M.P. Markowski, Znak, Kraków 2006.

Borys Eichenbaum, Problemy stylistyki filmowej, [w:] Estetyka ifilm, red. A. Helman,

Wydawnictwa Artystyczne i Filmowe, Warszawa 1972.

Alfred Einstein, Muzyka w epoce romantyzmu, tłum. M. Jarocińska, S. Jarociński,

Państwowe Wydawnictwo Muzyczne, Kraków 1983.

Encyklopedia kina, red. T. Lubelski, Wydawnictwo Biały Kruk, Kraków 2003.

Era Wilków [z Michaelem Hanekem rozmawiają Anna Chorestecka i Jan Niedziela],

„Gazeta Wyborcza” 2001, nr 278.

Fabryka zapomnienia [wywiad z Michaelem Hanekem], (przedruk z „Die Zeit”), „Forum” 2006, nr 6.

Paweł T. Felis, Czy fikcja jest prawdziwa?, „Gazeta Wyborcza” 2008, nr 296.

Paweł T. Felis, Haneke w Łodzi: Tematy same mnie znajduja, „Gazeta Wyborcza” 2013, nr 240.

Paweł T. Felis, Skandal śmierci, „Przekrój” 2012, nr 44.

Michel Foucault, Nadzorować i karać. Narodziny więzienia, tłum. T. Komendant, Aletheia, Warszawa 1998.

Adam Garbicz, Jacek Klinowski, Kino, wehikuł magiczny. Podróż pierwsza 1913-1949, Wydawnictwo Literackie, Kraków 1981.

Adam Garbicz, Kino, wehikuł magiczny. Podróż czwarta 1967-1973, Wydawnictwo Literackie, Kraków 2000.

Adam Garbicz, Kino. Wehikuł magiczny. Podróż piąta 1974-1981, Wydawnictwo Literackie, Kraków 2009.

Andrzej Hejmej, Słuchać i czytać: Dwa źródła jednej strategii interpretacyjnej. „Podróż zimowa” Stanisława Barańczaka, „Pamiętnik Literacki” 1999, z. 2. Alicja Helman, Funkcja muzyki i słowa w przekazie filmowym, [w:] Z zagadnień semiotyki sztuk masowych, red. A. Helman, M. Hopfinger, H. Książek-Konicka, Ossolineum, Wrocław - Kraków - Gdańsk 1977.

Alicja Helman, Na ścieżce dźwiękowej: o muzyce w filmie, Polskie Wydawnictwo Muzyczne, Kraków 1968.

Alicja Helman, Jacek Ostaszewski, Historia myśli filmowej, słowo/obraz terytoria, Gdańsk 2007.

Historia kina, t. I: Kino nieme, red. T. Lubelski, I. Sowińska, R. Syska, Universitas, Kraków 2009

Historia kina, t. II: Kino klasyczne, red. T. Lubelski, I. Sowińska, R. Syska, Universitas, Kraków 2012. 
Barbara Hollender, Za granica normalności, „Rzeczpospolita” 2001, nr 252. Barbara Hollender, Okrutna „Pianistka”, „Rzeczpospolita” 2004, nr 237. Alicja Jarzębska, Dialektyczny dyskurs Dahlhausa, „Ruch Muzyczny” 2009, nr 6. Elfriede Jelinek, Pianistka, tłum. R. Turczyn, Wydawnictwo W.A.B., Warszawa 2004.

Tomasz Jopkiewicz, Funny Games, „Film” 1999, nr 9.

Zygmunt Kałużyński, Buntownik bywalec, Wydawnictwo Ars, Warszawa 1998.

Zygmunt Kałużyński, Duch zezwierzęcony, „Polityka” 2001, nr 49.

Zygmunt Kałużyński, Weekend z mordercami, „Polityka” 1998, nr 14.

Zygmunt Kałużyński i Tomasz Raczek, Pojedynek z seksem, „Wprost” 2001, nr 47. Józef Kański, Przewodnik operowy, Polskie Wydawnictwo Muzyczne, Kraków 1985. Søren Kirkegaard, Dziennik uwodziciela, tłum. S. Lack, M. Bienenstock, Hachette, Warszawa 2009.

Piotr Kletowski, Filmowy (?) świat Markiza De Sade, „Ha!art” 2007, nr 2/3.

Krzysztof Kłopotowski, Zawód: artysta sadomasochista, „Rzeczpospolita” 2013, nr 138.

Jaga Kolawa, Bartosz Żurawiecki, DV Drama. Pianistka, „Świat Filmu” 2002, nr 2. Siegfried Kracauer, Teoria filmu. Wyzwolenie materialnej rzeczywistości, tłum.

W. Wertenstein, słowo/obraz terytoria, Gdańsk 2008.

Beata Kosińska-Krippner, „Funny Games”, czyli przemoc w białych rękawiczkach, „Kwartalnik Filmowy” 1998, nr 21/22.

Kultura dźwięku. Teksty o muzyce nowoczesnej, red. Ch. Cox, D. Warner, tłum. J. Kutyła, słowo/obraz terytoria, Gdańsk 2010.

Wojciech Kuczok, Pokątne pragnienia, „Tygodnik Powszechny” 2001, nr 50.

Krzysztof Kwiatkowski, Bez ckliwości, „Wprost” 2012, nr 44.

Zofia Lissa, Czy muzyka jest sztuką asemantyczną?, „Myśl Współczesna” 1948, nr 10.

Zofia Lissa, Estetyka muzyki filmowej, Polskie Wydawnictwo Muzyczne Kraków 1964.

Tadeusz Lubelski, Drzwi zamknięte, drzwi otwarte, „Ekrany” 2012, nr 6.

Tadeusz Lubelski, Rytuały powszechne, „Tygodnik Powszechny” 1998, nr 15.

Antoni Łazarkiewicz, Muzyka z podświadomości. Praktyczne i teoretyczne aspekty wykorzystania muzyki w filmie na podstawie analizy „Lśnienia” Stanleya Kubricka, „Glissando” 2007, nr 10.

Janusz Łętowski, Muzyka klasyczna na płytach kompaktowych, Twój Styl, Warszawa 1997.

Tadeusz Marek, Schubert, Państwowe Wydawnictwo Muzyczne, Kraków 1988. 
Marshall McLuhan, Zrozumieć media. Przedłużenia człowieka, tłum. N. Szczucka, Wydawnictwa Naukowo-Techniczne, Warszawa 2004.

Łukasz Maciejewski, Bohaterstwo przez rezygnacje, „Dziennik. Gazeta Prawna” $\mathrm{z}$ dn. 11.02.2012 r.

Ewa Mazierska, Bez litości, „Film” 2002, nr 4.

Magdalena Michalska, Bezlitosny świat Michaela Hanekego, „Dziennik” 2009, nr 171.

Miłość aż po grób [z Emmanuelle Rivą rozmawia Krzysztof Kwiatkowski], „Wysokie Obcasy" 2012, nr 44.

Miłość, czyli rana [z ks. Andrzejem Luterem rozmawia Katarzyna Jabłońska], „Więź" 2012, nr 10.

„Miłość, jakkolwiek by było [z Michaelem Hanekem rozmawia Tadeusz Sobolewski], „Gazeta Wyborcza” 2012, nr 123.

Edgar Morin, Kino i wyobraźnia, tłum. K. Eberhardt, Państwowy Instytut Wydawniczy, Warszawa 1975.

Nie chcę nikogo pouczać [z Michaelam Hanekem rozmawia Joanna Grabiańska], „Kino” 1995, nr 12.

Nie ma szczęścia bez bólu [z Jeanem-Louisem Trintignantem rozmawia Barbara Hollender], „Rzeczpospolita” 2012, nr 255.

Jan Olszewski, Kto to lubi?, „Film” 1998, nr 5.

José Ortega y Gasset, Bunt mas, tłum. P. Niklewicz, Wydawnictwo Muza, Warszawa 2008.

Jacek Ostaszewski, Słownik filmu, Krakowskie Wydawnictwo Naukowe, Kraków 2010.

Karolina Pasternak, Czuły barbarzyńca, „Newsweek Polska” 2012, nr 23.

Zdzisław Pietrasik, Pornografia bez porno, „Polityka” 2001, nr 44.

Anita Piotrowska, Nigdy nie ustaje, „Tygodnik Powszechny” 2012, nr 45.

Łukasz Plesnar, Semiotyka filmu, Wydawnictwo Uniwersytetu Jagiellońskiego, Kraków 1990.

Jerzy Płażewski, Język filmu, Książka i Wiedza, Warszawa 2008.

Jerzy Płażewski, Prośba o cztery jajka, „Kino” 1998, nr 3.

Bohdan Pociej, Uwagi o muzyce filmowej, „Kwartalnik Filmowy” 1994, nr 6.

Leszek Polony, Kilar. Żywioł i modlitwa, Polskie Wydawnictwo Muzyczne, Kraków 2005.

Adam Poprawa, Drogowskazy muzyki. O trasach zimowej podróży Schuberta, Müllera oraz Barańczaka, „Warsztaty Polonistyczne” 1995, nr 1. 
Adriana Prodeus, Miłość, „Film” 2010, nr 10.

Rola muzyki w dziele filmowym (ankieta), „Kwartalnik Filmowy” 1961, nr 2.

Umberto Rossi, Haneke atakuje, tłum. J. Płażewski, „Kino” 2001, nr 9.

Matthew Rye, 1001 albumów muzyki klasycznej, tłum. A. Fulińska, Wydawnictwo Elipsa, Poznań 2003.

Małgorzata Sadowska, Michael Haneke: cichy włamywacz, „Newsweek” 2012, nr 44. Piotr Sawicki, Czas i energia. Kurosawa a muzyka, [w:] Akira Kurosawa - twórca japoński, twórca światowy, red. W. Laskowska-Smoczyńska, P. Kletowski, Centrum Sztuki i Techniki Japońskiej Mangha, Kraków 2011.

Bogusław Schaeffer, Dzieje muzyki, WSiP, Warszawa 1985.

Bogusław Schaeffer, Dzieje kultury muzycznej, WSiP, Warszawa 1987.

Sławomir Sikora, O miłości Michaela Hanekego trochę inaczej, „Kwartalnik Filmowy" 2013, nr 83-84.

Peter Sloterdijk, Kryształowy pałac. O filozoficzna teorię globalizacji, tłum. B. Cymbrowski, Wydawnictwo Krytyki Politycznej, Warszawa 2011.

Tadeusz Sobolewski, Haneke. Wściekły i podstępny, „Gazeta Wyborcza”, dodatek „Duży Format” 2009, nr 45.

Tadeusz Sobolewski, Haneke z miłościa, ale bez litości, „Gazeta Wyborcza” 2012, nr 256.

Tadeusz Sobolewski, Mistrz okrutnych ciosów, „Gazeta Wyborcza” 2013, nr 244.

Tadeusz Sobolewski, Porno-Schubert, „Gazeta Wyborcza” 2001, nr 254.

Paweł Sołodki, Rubieże przyjemności. Seksualna niesubordynacja na obrzeżach amerykańskiej kinematografii, Wydawnictwo Naukowe Katedra, Gdańsk 2015.

Susan Sontag, Duchowy styl filmów Roberta Bressona, „Film na Świecie” 1999, nr 400.

Andrzej Sosnowski, Taxi, Biuro Literackie, Wrocław 2003.

Iwona Sowińska, Polska muzyka filmowa 1945-1968, Wydawnictwo Uniwersytetu Śląskiego, Katowice 2006.

Iwona Sowińska, Dźwięki i obrazy. O słuchaniu filmów, Wydawnictwo Śląsk, Katowice 2001.

Iwona Sowińska, Kilka trudności z historią muzyki filmowej, „Kwartalnik Filmowy” 2003, nr 44.

Jacek Szczerba, Cztery razy miłość, „Gazeta Wyborcza” 2012, nr 282.

Agnieszka Szeffel, Zobaczone, przeczytane, „Zeszyty Literackie” 1999, z. 1.

Wiktor Szkłowski, Sztuka jako chwyt, tłum. R. Łużny, [w:] Teoria badań literackich za granica: Antologia, t. 2: Od przełomu antypozytywistycznego do 
roku 1945, cz. 3: Od formalizmu do strukturalizmu, wyb. S. Skwarczyńska, Wydawnictwo Literackie, Kraków 1986.

Kamil Śmiałkowski, Niezabawne gry, „Wprost” 2004, nr 22.

Andriej Tarkowski, Czas utrwalony, tłum. S. Kuśmierczyk, Wydawnictwo Świat Literacki, Warszawa 2007.

Jan Topolski, Kino/Muzyka. Zbliżenia. Gambit Kubricka, „Ruch Muzyczny” 2009, nr 8.

Jan Topolski, 27 fragmentów socjologii przypadku: haneke, „Odra” 2010, nr 1.

Emilia Walczak, Od Brechta do Jelinek. Michael Haneke - antyspektakularna trauma Realnego, „Kwartalnik Filmowy” 2008, nr 64.

Alan Williams, Historyczne i teoretyczne problemy wprowadzenia do kina ścieżki dźwiękowej, „Kwartalnik Filmowy” 2004, nr 44.

Piotr Wojciechowski, Pani od gry..., „Film” 2001, nr 11.

Janusz Wróblewski, Okrutne gry, „Polityka” 2004, nr 22.

Wrzątek podany na zimno [z Michaelem Hanekem rozmawia Paweł Felis], „Gazeta Wyborcza" 2013, nr 244.

Wszystkie moje filmy sq obsceniczne [z Michaelem Hanekem rozmawia Joanna Grabiańska], „Kino” 2002, nr 1.

Ernest Zavarsky, J.S. Bach, tłum. M. Erhardt-Gronowska, Polskie Wydawnictwo Muzyczne, Kraków 1985.

Piotr Zawojski, Przypisy do „Ukrytego” Michaela Hanekego, „Opcje” 2006, nr 4. Jacek Ziemek, Wiedeń - Schubert - Seks, „Przekrój” 2001, nr 48.

Jerzy Ziomek, Kontrafaktura, [w:] Między tekstami. Intertekstualność jako problem poetyki historycznej, red. J. Ziomek, J. Sławiński, W. Bolecki, PWN, Warszawa 1992.

Łukasz Ziomek, Hymn L’Amour?, „Kino” 2013, nr 1.

\section{Źródła internetowe}

Darek Arest, Haneke, not so funny, http://wyborcza.pl/1,91947,5547054,Haneke Not_so_funny.html\#ixzz0z3EHXFv7.

Rafał Błaszczak, Miłość, http://kafeteria.pl/kultura/milosc-michael-haneke-a_5375. Jędrzej Dudkiewicz „Funny Games” czyli po co to oglądasz? - analiza filmu Michaela Hanekego, http://film.org.pl/a/analiza/funny-games-czyli-po-co-to-ogladasz -analiza-filmu-michaela-hanekego-36176/.

Kinga Dunin, Kobiece marzenie o dobrej śmierci, www.krytykapolityczna.pl/ felietony/20122407/kobiece-marzenie-o-dobrej-smierci. 
Katarzyna Frankowska, „,Miłość” Hanekego - przerwany chorał Bacha, http://www. tvp.info/8968512/milosc-hanekego-przerwany-choral-bacha.

Funny Games (recenzja), www.twojefilmy.pl/funny-games/.

Ryan Gilbey, "Amour” and the music of time, www.newstatesman.com/ culture/2012/11/michael-hanekes-amour-and-music-time.

Piotr Gociek, Chory film o miłości, http://wpolityce.pl/kultura/246542-premiera -kinowa-michaela-haneke-chory-film-o-milosci-nasza-recenzja.

Malwina Grochowska, Miłość ponad wszystko, www.filmweb.pl/reviews/ Mi\%C5\%820\%C5\%9B\%C4\%87+ponad+wszystko-12843.

Michael Haneke w rozmowie z Sergem Toubianą, https://www.youtube.com/ watch?gl=PL\&hl=pl\&v=roOl9PvEPjs.

Lamos Ignoramus, Michael Haneke's „Funny Games” and the Lie of Reality, http:// filmslie.com/michael-hanekes-funny-games-lie-reality/.

Iwona Kurz, Potworność. O Michaelu Hanekem, www.dwutygodnik.com/artykul/ 4135-potwornosc-o-michaelu-hanekem.html.

Jakub Majmurek, Claude Chabrol (1930-2010) cyniczny (a)moralista, www.dwutygodnik.com/artykul/1486-claude-chabrol-1930-2010-cyniczny-amoralista. html.

Jakub Majmurek, I to jest ta cała miłość?, www.krytykapolityczna.pl/Blogfilmowy/ MajmurekItojesttacalamilosc/menuid-85.html.

Michael Haneke dedykuje „Miłość” ciotce, www.canalplus.pl/film/ news-michael-haneke-dedykuje-milosc-ciotce_40195.

Music in „Amour”, http://framescourer.blogspot.com/2012/11/music-in-amour-2012. html.

Narodowy Instytut Fryderyka Chopina, http://pl.chopin.nifc.pl/chopin/genre/ detail/id/21 oraz http://pl.chopin.nifc.pl/chopin/composition/detail/id/112.

Krzysztof Niweliński, Zorn, John - Naked City, http://artrock.pl/recenzje/51397/ zorn_john_naked_city.html.

Michał Oleszczyk, Biała wstążka, http://www.dwutygodnik.com/artykul/595-biala-wstazka-rez-michael-haneke.html.

Michał Oleszczyk, Miłość, http://www.dwutygodnik.com/artykul/4067-milosc-rez-michael-haneke.html.

Pianistka (recenzja), https://xmuza.wordpress.com/2012/06/11/la-pianiste-2001 -michael-haneke.

Monika Piechocka i Agata Kortus, filmowy blog „inlovewithmovie”, http://inlovewithmovie.blogspot.com/2013/03/miosc-amour.html. 
Podróż zimowa. Wiersze do Muzyki Franza Schuberta, www.wydawnictwoa5.pl/

Podroz-zimowa-Wiersze-do-muzyki-Franza-Schuberta;s,karta,id,174.

Marcin Poprawski, Muzykologiczne aspekty interpretacji „Podróży zimowej”

Stanisława Barańczaka, www.demusica.pl/cmsimple/images/file/poprawski_muzykalia_5_1.pdf.

Paweł Rezmer, Miłość, http://stacjakultura.pl/4,21,29422,Milosc_recenzja_filmu,artykul.html.

Małgorzata Sadowska, Martwa natura. Z gołęiem, www.canalplus.pl/film/ blog-malgorzata-sadowska-martwa-natura-z-golebiem_961_11.

Tadeusz Sobolewski, Ból wolności - ekranizacja „Pianistki”, http://wiadomosci. gazeta.pl/wiadomosci/1,114873,2328011.html.

Krzysztof Świrek „Miłość" według najlepszych zasad. O regułach w filmach Michaela Hanekego, http://kulturaliberalna.pl/2012/11/13/swirek-milosc-wedlug-najlepszych-zasad-o-regulach-w-filmach-michaela-hanekego-esej/.

Jan Topolski, Muzyka w filmach Stanleya Kubricka, http://stopklatka.pl/news/ muzyka-w-filmach-stanleya-kubricka.

Tymoteusz Wojciechowski, Dźwięk w kinie, http://film.org.pl/a/artykul/dzwiek -w-filmie-cz-3-dusze-czarne-32371/; http://film.org.pl/a/artykul/dzwiek -w-filmie-cz-4-komedie-rene-claira-32764/; http://film.org.pl/a/analiza/ dzwiek-w-kinie-cz-5-aleksander-newski-36801/; http://film.org.pl/a/artykul/ dzwiek-w-kinie-cz-5-jean-luc-godard-34204/.

Katarzyna Wolanin, Zrozumieć Michaela Haneke, http://liberte.pl/zrozumiec -michaela-haneke/.

The World That Is Known [Michael Haneke $\mathrm{w}$ rozmowie z Christopherem Sharrettem], http://www.kinoeye.org/04/01/interview01.php.

Artur Zaborski [o filmie Wulkan w reż. Rúnara Rúnarssona], www.nowehoryzonty. $\mathrm{pl} /$ film.do?id=5286\&ind=page\%3d0\%26typ\%3ddz\%26edycjaFest $\% 3 \mathrm{~d} 11 \%$ 26czas\%3d15\%253a45\%26dzien\%3d26 [dostęp: 30.05.2016].

Dominika Zielińska, Antyhumanizm Michaela Hanekego, http://bad-taste.pl/ antyhumanizm-michaela-hanekego.

\section{Filmografia}

24 Realities per Second: A Documentary on Michael Haneke, reż. N. Kusturica i E Testor, 2005.

Amadeusz, reż. Miloš Forman, 1984.

Aleksander Newski, reż. Siergiej Eisenstein, 1938. 
Błękitny anioł, reż. Josef von Sternberg, 1931.

Bulwar Zachodzącego Stońca, reż. Billy Wilder, 1950.

Burza nad Azja, reż. Wsiewołod Pudowkin, 1928.

Ceremonia, reż. Claude Chabrol, 1995.

Człowiek z kamerą, reż. Dżiga Wiertow, 1929.

Dajcie mi głowę Alfredo Garcii, reż. Sam Peckinpah, 1974.

Dawno temu w Ameryce, reż. Sergio Leone, 1984.

Don Juan, reż. Alan Crosland, 1926.

Dusze czarnych, reż. King Vidor, 1930.

Dzika banda, reż. Sam Peckinpah, 1969.

Frantic, reż. Roman Polański, 1988.

Funny Games, reż. Michael Haneke, 1997.

Gwiezdne wojny, reż. George Lucas, 1977.

Gwiezdne wojny: Przebudzenie mocy, reż. J.J. Abrams, 2015.

Hiroshima, moja miłość, reż. Alain Rensais, 1959.

Kobieta i mężczyzna, reż. Claude Lelouch, 1966.

Kobieta jest kobieta, reż. Jean Luc Godard, 1960.

Koronczarka, reż. Claude Goretta, 1977.

Kontrakt rysownika, reż. Peter Greenaway, 1982.

Lśnienie, reż. Stanley Kubrick, 1980.

Łowca Androidów, reż. Ridley Scott, 1982.

Michael Haneke: My life, reż. Felix i Gero von Boehm, 2009.

Miłość, reż. Michael Haneke, 2012.

Misja, reż. Roland Joffé, 1986.

My z Kronsztadu, reż. Jefim Dzigan, 1932.

Narodziny narodu, reż. David W. Griffith, 1915.

Obywatel Kane, reż. Orson Welles, 1941.

Pani Bovary, reż. Claude Chabrol, 1991.

Parasolki z Cherbourga, reż. Jacques Demy, 1964.

Październik, reż. Siergiej Eisenstein, 1929.

Pianistka, reż. Michael Haneke, 2001.

Pod dachami Paryża, reż. René Clair, 1930.

Pokój 237, reż. Rodney Ascher, 2012.

Psychoza, reż. Alfred Hitchcock, 1960.

Pulp Fiction, reż. Quentin Tarantino, 1994.

Pustynia Tatarów, reż. Valerio Zurlini, 1976. 
Siedmiu samurajów, reż. Akira Kurosawa, 1954.

Siedmiu wspaniałych, reż. John Sturges, 1960.

Siódmy kontynent, reż. Michael Haneke, 1989.

Solaris, reż. Andriej Tarkowski, 1972.

Straż Przyboczna, reż. Akira Kurosawa, 1961.

Śpiewak jazzbandu, reż. Alan Crosland, 1927.

Światła Nowego Jorku, reż. Bob Foy, 1928.

Taksówkarz, reż. Martin Scorsese, 1974.

Trzy kolory. Czerwony, reż. Krzysztof Kieślowski, 1994.

Turbina 50 000, reż. Siergiej Rutkiewicz i Fridrich Ermler, 1932.

Ukryta forteca, reż. Akira Kurosawa, 1958.

Wielka ucieczka, reż. John Sturges, 1963.

Zabójstwo księcia Gwizjusza, reż. Charles le Bargy i André Calmettes, 1908.

\section{Music as a Narrative Resource in Selected Films of Michael Haneke}

The author of the article analyzes the narrative role of music in Michael Haneke's films. In terms of content, three movies are discussed: Funny Games (1997), The Piano Teacher (2001) and Amour (2012).

The selection of films was made on the basis of diversed musical plot devices used there. Additionally, these films show how role of music evolve over the years into more profound view inside events horizon, full-bodied commentary to film's action and liberation from optical invigilation of camera.

The goal of this paper is to show why narrative resource has crucial impact on artistic weight of Haneke's films. The director renounces interpretation of his films by giving them their own life - the life of the open work. The article rises the argument that music supports the strategy of director. Moreover, it indicates that emancipation of the music entails the emancipation of heroes and diegetic reality.

Keywords: Michael Haneke, Funny Games, The Piano Teacher, Amour, film score, film narrative 